UNIVERSIDADE DE SÃO PAULO

ESCOLA DE COMUNICAÇÃO E ARTES

PROGRAMA DE PÓS-GRADUAÇÃO EM CIÊNCIAS DA COMUNICAÇÃO

MARIANA MARQUES DE LIMA PINHEIRO

\title{
A Crítica de Telenovela como Operação de Circulação de Sentidos
}

São Paulo 


\section{A Crítica de Telenovela como Operação de Circulação de Sentidos}

Tese apresentada junto ao programa de Pósgraduação em Comunicação da Escola de Comunicação, Área de Concentração em Ciências da Comunicação, Linha de Pesquisa: Comunicação, redes e linguagens: objetos teóricos e empíricos, da Escola de Comunicação e Artes da Universidade de São Paulo como exigência para a obtenção do título de Doutora em Ciências da Comunicação.

Orientadora: Prof ${ }^{a}$ Dr $^{a}$ Maria Immacolata Vassallo de Lopes

São Paulo 
Autorizo a reprodução e divulgação total ou parcial deste trabalho, por qualquer meio convencional ou eletrônico, para fins de estudo e pesquisa, desde que citada a fonte.

Catalogação na Publicação

Serviço de Biblioteca e Documentação

Escola de Comunicações e Artes da Universidade de São Paulo

Dados inseridos pelo(a) autor(a)

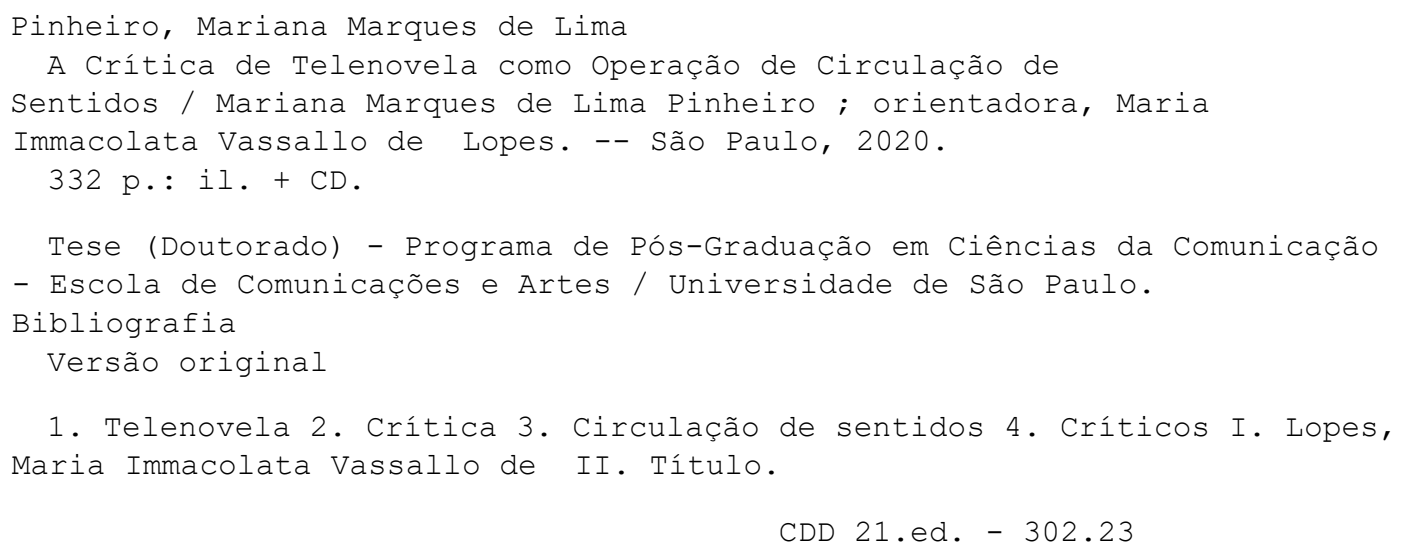

CDD 21.ed. -302.23 


\section{Mariana Marques de Lima Pinheiro}

A Crítica de Telenovela como Operação de Circulação de Sentidos

\section{Banca Examinadora}

Presidente:

$\operatorname{Prof}^{\mathrm{a}} \mathrm{Dr}^{\mathrm{a}}$ Maria Immacolata Vassallo de Lopes

Membros:

São Paulo, de de 2020 
Dedico este trabalho à minha família, fonte de amor, suporte e compreensão 


\section{AGRADECIMENTOS}

Esta tese, sem dúvida, se configura como o final de uma etapa e o início de um novo ciclo. Neste processo de idas e vindas, familiares, amigos e colegas foram essenciais para que, nos inúmeros percalços que apareceram nestes quatro anos, eu pudesse finalizar esta pesquisa.

Agradeço à minha família, a quem eu dedico inteiramente esta tese, pelo apoio incondicional em todos os projetos pessoais e acadêmicos. E por sempre acreditarem na minha capacidade e conhecimento nos piores momentos de dúvidas. Meu mais amoroso reconhecimento e gratidão à minha mãe Letícia, minha avó Cecília, tia Maria Goreti, tio Miguel Júnior, meus irmãos Lucas e Laís, minha prima Ana Clara e meu padrasto Francisco, muito obrigada por tudo. E mesmo pela distância de alguns deles, vocês foram meu abrigo seguro que me manteve firme.

Sou grata aos críticos Cristina Padiglione, Maurício Stycer, Nilson Xavier e Patrícia Kogut, pela paciência e prontidão em me receber, e ao carinho por aceitarem serem casos de estudo para este trabalho.

A Maria Immacolata Vassallo de Lopes, minha orientadora, sou grata pela oportunidade de ter sido sua orientanda. E pelas incontáveis tardes de reuniões, nas quais soube repassar grandes ensinamentos que repercutirão em minha carreira, como o comprometimento pela ciência, pela pesquisa, pela metodologia, e, principalmente, sobre telenovela.

O processo de escrita de uma pesquisa de doutorado, normalmente, é descrito como solitário, porém, graças aos meus colegas do CETVN, permaneço com a lembrança da amizade, da solidariedade, das trocas de referências e explicações conceituais e do acolhimento nos momentos alegres e difíceis do doutorado. A vocês, pesquisadores Lucas Martins Néia, Tissiana Pereira, Andreza Almeida, Larissa Leda, Daniela Ortega, Ligia Maria Prezia Lemos, Clarice Greco, Fernanda Castilho, muito obrigada. Também agradeço aos bolsistas Rafael Crema, Anésio, Eduardo, Vital, Letícia e Gustavo e muito outros que passaram pelo centro.

Agradeço enormemente à minha amiga Tissi pela companhia nas tardes de terçafeira, quando promovíamos a cada semana uma verdadeira força-tarefa para finalizar esta 
tese. Esses momentos de companheirismo e ensinamentos foi engrandecedor e deixou o processo de escrita menos solitário.

Agradeço ao Lucas Martins Néia pela amizade, pelo apoio, pelos conselhos e pela sabedoria ao lidar com os meandros da academia.

Aos amigos Flávia Barros, Ana Catarina França, Alberto Cavalcante, Bruno Barbosa, Carlos Augusto e Jorge Abrão, meu profundo agradecimento. Vocês souberam lidar com as minhas ansiedades e frustrações com palavras sempre carinhosas de incentivo.

Agradeço aos professores e funcionários do programa de Pós-Graduação da Escola de Comunicação e Artes da Universidade de São Paulo, pela assistência e pelas experiências enriquecedoras tanto nas salas de aula quanto na própria instituição.

Aos meus médicos e fisioterapeutas, que, devido à quebra do meu braço no meio do último ano de doutorado, possibilitaram, com muita persistência e paciência, que pudesse utilizar minha mão direita para escrever as páginas seguintes.

Agradeço aos professores da Banca, por aceitarem participar da Comissão Examinadora desta pesquisa.

Agradeço à Capes pela bolsa de estudos, primordial neste processo.

Muito Obrigada. 


\section{LISTA DE FIGURAS}

Figura 01 - Helena Silveira vê TV 89

Figura 02 - Helena Silveira vê TV 90

Figura 03 - Revista Amiga 93

Figura 04-O Globo, Segundo Caderno 95

$\begin{array}{ll}\text { Figura } 05 \text { - Desenho da Pesquisa } & 100\end{array}$

Figura 06 - Primeiro Mapa Metodológico das Mediações 116

Figura 07 - Segundo Mapa Metodológico das Mediações 117

Figura 08 - Terceiro Mapa Metodológico das Mediações 120

Figura 09 - Quarta Mapa Metodológico das Mediações 123

Figura 10 - Fusão dos Mapas Metodológicos das Mediações 128

Figura 11 - Página do site de Nilson Xavier 141

Figura 12 - Página do site de Maurício Stycer 142

Figura 13 - Página do site de Cristina Padiglione 144

Figura 14 - Página do site de Patrícia Kogut 145

Figura 15 - Mapa dos Códigos 163

Figura 16 - Nuvem de Palavras 164

Figura 17 - Social TV para TV aberta em $2018 \quad 195$

Figura 18 - Habilidades Cognitivas na TV Social 221

Figura 19 - Retrato da Entrevista - Cristina Padiglione 225

Figura 20 - Retrato das Críticas - Cristina Padiglione 225

Figura 21 - Retrato da Entrevista - Maurício Stycer 233

Figura 22 - Retrato das Críticas - Maurício Stycer 233

Figura 23 - Retrato da Entrevista - Patrícia Kogut 242

Figura 24 - Retrato das Críticas - Patrícia Kogut 242

Figura 25 - Retrato da Entrevista - Nilson Xavier 249

Figura 26 - Retrato das Críticas - Nilson Xavier 249 


\section{LISTA DE TABELAS}

Tabela 01 - Telenovela das 21horas da TV Globo e Rating de 2012 - 2018

Tabela 02 - Cinco Telenovelas com maior número de ratings

Tabela 03 - Principais Críticos de Telenovela

Tabela 04 - Críticos selecionados para a análise

Tabela 05 - Números de críticas realizadas por crítico

Tabela 06 - Críticas de Avenida Brasil

Tabela 07 - Críticas de Salve Jorge

Tabela 08 - Críticas de Amor à Vida

Tabela 09 - Críticas de A Força do Querer

Tabela 10 - Críticas de O Outro Lado do Paraíso

Tabela 11 - Categorias Empíricas e Teóricas

\section{LISTA DE GRÁFICOS}

Gráfico 01 - Modelo Metodológico de Pesquisa

Gráfico 02 - Quantidade de Críticas publicadas 2012 e 2018

Gráfico 03 - Produtividade dos Críticos de 2012 - 2018 
PINHEIRO, Mariana Marques de Lima. A Crítica de Telenovela como Operação de Circulação de Sentidos. 2020. 332f. Tese (Doutorado em Ciências da Comunicação) Escola de Comunicações e Artes, Universidade de São Paulo, São Paulo, 2020.

\section{RESUMO:}

Esta pesquisa tem como finalidade entender como se configura a crítica de telenovela veiculada no ambiente digital. Nosso objetivo principal é apreender a função dessa crítica de telenovela contemporânea difundida em sites e blogs, compreendendo suas características no cenário brasileiro e sua circulação de sentidos. Assim, percebemos a circulação da telenovela em diferentes ambientes como um emaranhado de forças que levam à construção de sentidos e às reconfigurações do campo discursivo. Como formadores de opinião - e devido ao crescimento dos profissionais -, percebemos uma complexa interligação entre o que se fala sobre telenovelas no âmbito popular (casa, trabalho, redes sociais) com o que é discutido nas críticas, isto é, as análises se apresentam como mediadoras do falar empírico. Para os objetivos deste trabalho, a técnica de coleta de dados empíricos consiste em entrevistas com os críticos jornalistas. Os dados primários são compostos pelos artigos das críticas sobre telenovelas. $\mathrm{O}$ universo de observação é formado pelas críticas realizadas pelos jornalistas das cinco ficções de maior audiência pertencentes ao prime time da Rede Globo, entre os anos de 2012 e 2018 . A faixa horária escolhida se deve à relevância discursiva e a pertencerem ao horário nobre da televisão. Quanto à emissora selecionada, as narrativas da TV Globo são as que mais se destacam em termos de discursividade, além de serem as que conseguem as maiores audiências da televisão no País. A seleção da pesquisa para a abordagem qualitativa compreenderá os críticos Maurício Stycer; Nilson Xavier; Patrícia Kogut e Cristina Padiglione. Esse elenco se destaca pela sua relevância nos escritos sobre o tema, pelo tempo de trabalho na mesma atividade de crítico, além de realizarem suas críticas on-line, o que propicia uma dinâmica maior na circulação de seus conteúdos e a facilidade de reunir e analisar os artigos. A fundamentação teórica se baseia em Martín-Barbero (2015 [1987]), a partir da teoria das mediações; Benjamin (2018) pelos Fragmentos da crítica literária, e por meio de Verón (1987), com a semiose social. Baccega (2000), Bucci (2004), Pignatari (1984) trazem apontamentos iniciais sobre a crítica da televisão brasileira. Como principais resultados, percebemos - pelas leituras e acompanhamento das críticas - , análises de caráter estético, nas quais discussões acerca do roteiro, verossimilhança, temáticas sociais são ressaltadas; e ainda notamos reflexões sobre as características da telenovela brasileira e a função da crítica. Além destas noções, percebemos uma pauta de valores, em que emergem os elementos políticos e uma demanda para questões sociais apresentadas nas ficções, evidenciando uma crítica que incide e dialoga com as questões da sociedade.

Palavras-chave: Telenovela. Crítica. Circulação de sentidos. Críticos. 
PINHEIRO, Mariana Marques de Lima. The Telenovela Criticism as a Circulation of Senses Operation. 2020. 332f. Thesis (PhD in Communication Sciences) - School of Communications and Arts, University of São Paulo, São Paulo, 2020.

\begin{abstract}
:
This research aims to understand how the telenovela criticism in the digital environment is configured. Our main objective is to apprehend the function of this critique of contemporary telenovelas spread on websites and blogs, understanding its characteristics in the Brazilian scenario and its circulation of meanings. Thus, we perceive the circulation of the telenovela in different environments as a tangle of forces that lead to the construction of meanings and the reconfigurations of the discursive field. As opinion makers - and due to the growth of professionals - we perceive a complex interconnection between what is said about telenovelas in the popular sphere (home, work, social networks) with what is discussed in the criticisms, that is, the analyzes are presented as mediators of empirical speech. For the purposes of this work, the empirical data collection technique consists of interviews with critical journalists. The primary data is made up of criticism articles about telenovelas. The observation universe is formed by the criticisms made by the journalists of the five most watched fictions belonging to the prime time of Rede Globo, between the years 2012 and 2018. The time slot chosen is due to the discursive relevance and belonging to the prime time of television. As for the selected broadcaster, TV Globo's narratives are the ones that stand out the most in terms of discourse, in addition to being the ones that reach the largest television audiences in the country. The selection of the research for the qualitative approach will include the critics Maurício Stycer; Nilson Xavier; Patrícia Kogut and Cristina Padiglione. This cast stands out for its relevance in the writings on the subject, for the time spent working in the same activity as a critic, in addition to conducting their criticisms online, which provides greater dynamics in the circulation of their content and the ease of gathering and analyzing the articles. The theoretical foundation is based on Martín-Barbero (2015 [1987]), based on the theory of mediations; Benjamin (2018) for Fragments of Literary Criticism, and through Verón (1987), with social semiosis. Baccega (2000), Bucci (2004), Pignatari (1984) bring initial notes on the criticism of Brazilian television. As main results, we perceive - through the readings and follow-up of the criticisms -, analyzes of aesthetic character, in which discussions about the script, verisimilitude, social themes are highlighted; and we still notice reflections on the characteristics of the Brazilian telenovela and the role of the critic. In addition to these notions, we perceive an agenda of values, in which the political elements and a demand for social issues presented in the fictions emerge, showing a criticism that affects and dialogues with the issues of society.
\end{abstract}

Keywords: Telenovela. Criticism. Circulation of senses. Critics. 
PINHEIRO, Mariana Marques de Lima. La critique de Telenovela comme opération de circulation des sens. 2020. 332f. Thèse (Doctorat en Sciences de la Communication) - École des Communications et des Arts, Université de São Paulo, São Paulo, 2020.

\section{RESUMÉE :}

Cette recherche vise à comprendre comment la critique du feuilleton dans l'environnement numérique est configurée. Notre objectif principal est d'appréhender la fonction de cette critique des telenovelas contemporains diffusés sur les sites Internet et les blogs, en comprenant ses caractéristiques dans le scénario brésilien et sa circulation des significations. Ainsi, nous percevons la circulation du feuilleton dans différents environnements comme un enchevêtrement de forces qui conduisent à la construction de significations et aux reconfigurations du champ discursif. En tant que faiseurs d'opinion - et en raison de la croissance des professionnels - nous percevons une interconnexion complexe entre ce qui est dit sur les feuilletons dans la sphère populaire (maison, travail, réseaux sociaux) avec ce qui est discuté dans les critiques, c'est-à-dire que les analyses sont présentées comme médiateurs du discours empirique. Aux fins de ce travail, la technique de collecte de données empiriques consiste en des entretiens avec des journalistes critiques. Les données primaires sont constituées d'articles de critique sur les feuilletons. L'univers d'observation est formé par les critiques faites par les journalistes des cinq fictions les plus regardées appartenant au prime time de Rede Globo, entre les années 2012 et 2018. Le créneau horaire choisi est dû à la pertinence discursive et à l'appartenance au prime time de la télévision. En ce qui concerne le diffuseur sélectionné, les récits de TV Globo sont ceux qui se démarquent le plus en termes de discours, en plus d'être ceux qui atteignent le plus grand public de télévision du pays. La sélection de la recherche pour l'approche qualitative comprendra les critiques Maurício Stycer; Nilson Xavier; Patrícia Kogut et Cristina Padiglione. Cette distribution se distingue par sa pertinence dans les écrits sur le sujet, pour le temps passé à travailler dans la même activité qu'un critique, en plus de mener ses critiques en ligne, ce qui offre une plus grande dynamique dans la circulation de leur contenu et la facilité de collecte et d'analyse les articles. Le fondement théorique est basé sur Martín-Barbero (2015 [1987]), basé sur la théorie des médiations ; Benjamin (2018) pour Fragments of Literary Criticism, et through Verón (1987), with social semiosis. Baccega (2000), Bucci (2004), Pignatari (1984) apportent des premières notes sur la critique de la télévision brésilienne. Comme principaux résultats, nous percevons - à travers les lectures et le suivi des critiques -, des analyses de caractère esthétique, dans lesquelles les discussions sur le scénario, la vraisemblance, les thèmes sociaux sont mises en évidence; et nous avons également remarqué des réflexions sur les caractéristiques de la telenovela brésilienne et le rôle du critique. En plus de ces notions, nous percevons un agenda de valeurs, dans lequel émergent les éléments politiques et une demande d'enjeux sociaux présentés dans les fictions, montrant une critique qui affecte et dialogue avec les enjeux de société.

Mots-clés : Telenovela. Critique. Circulation des sens. Les critiques. 


\section{SUMÁRIO}

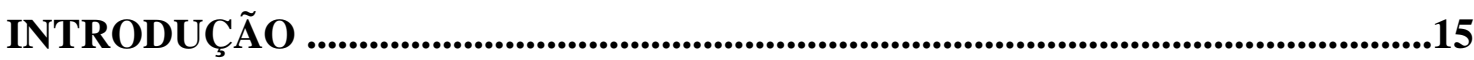

1. O desenho do objeto empírico e recorte do corpus de pesquisa ...............................16

2. A crítica como objeto de estudo: objeto teórico, objetivos e hipóteses de pesquisa e

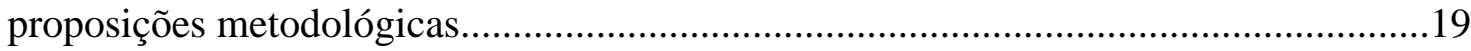

3. Problema de Pesquisa e Hipóteses.........................................................................20

4. Proposições metodológicas: desenho do objeto empírico e recorte do corpus de

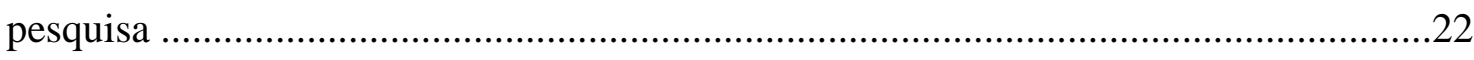

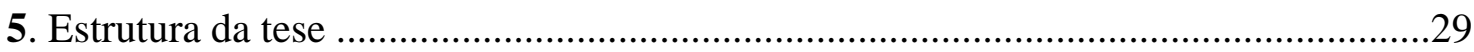

\section{PARTE 1}

Capítulo 1 - O Panorama televisivo.............................................................................. 33

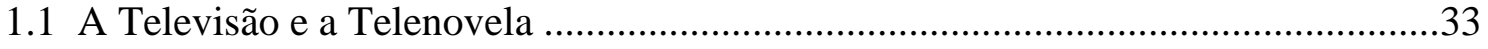

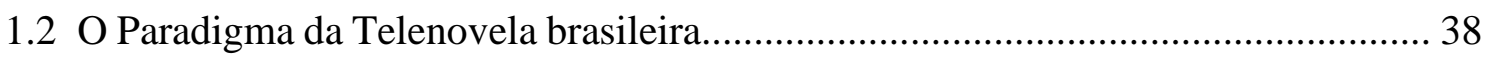

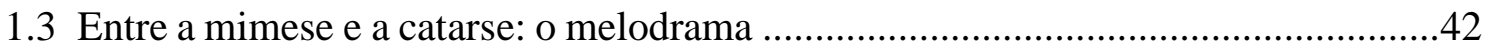

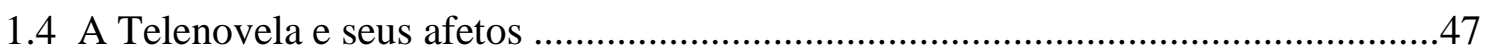

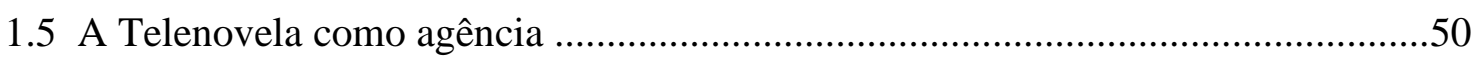

1.6 A Telenovela e o pacto de recepção ......................................................................62

Capítulo 2 - Entre critérios e repertórios: o fazer da crítica..................................73

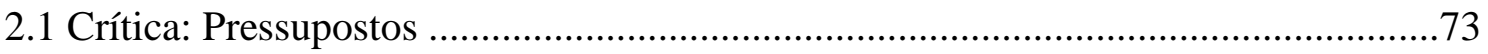

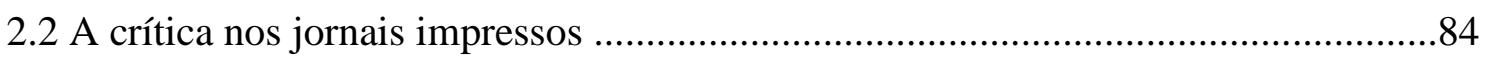

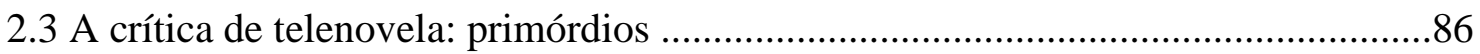

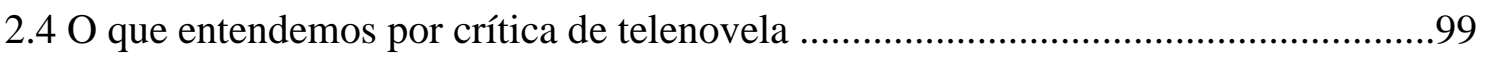

Capítulo 3 - Os Mapas e as críticas: um olhar teórico-metodológico......................108

3.1 A Telenovela, as críticas e os mapas das mediações .............................................108

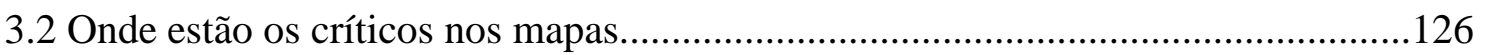

\section{PARTE 2}

Capítulo 4 - Universo da Pesquisa: detalhamento da metodologia de análise.......133

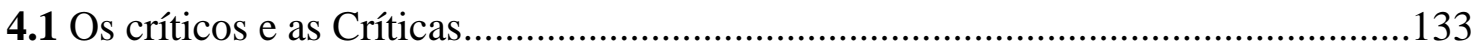

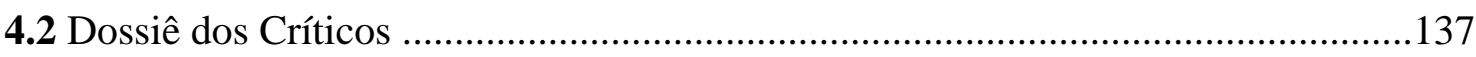

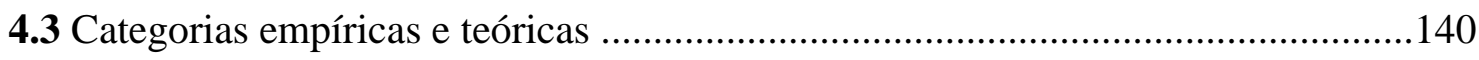

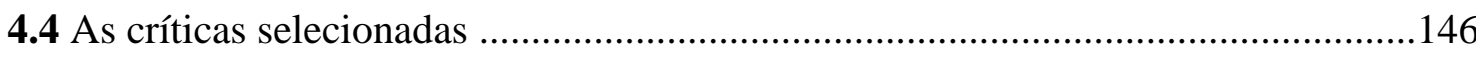

4.5 Análise qualitativa: utilização do Maxqda ........................................................151

Capítulo 5 - As Categorias Empíricas e teóricas .................................................161 


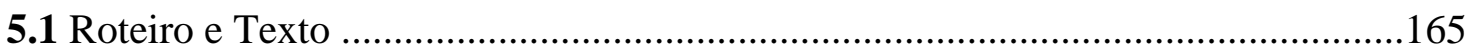

5.2 Reflexões sobre Telenovela ………………………………………………......171

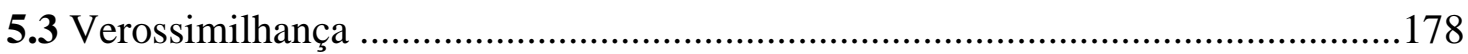

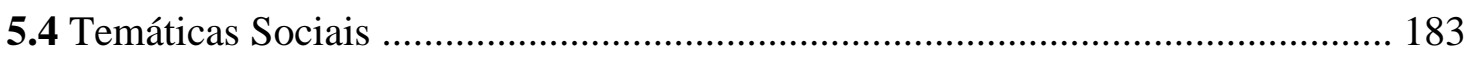

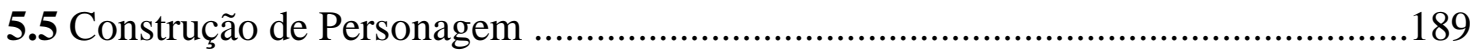

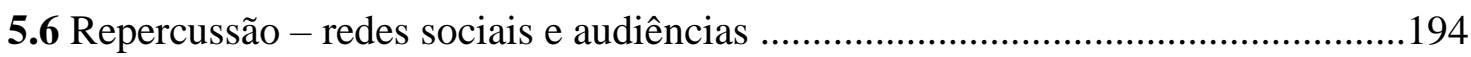

5.7 Atuação e desempenho da Atriz/Ator .................................................................197

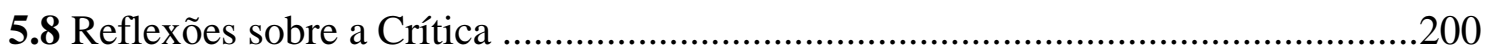

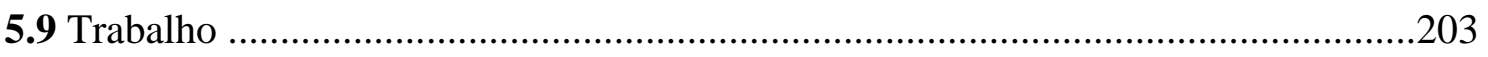

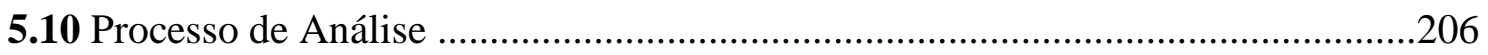

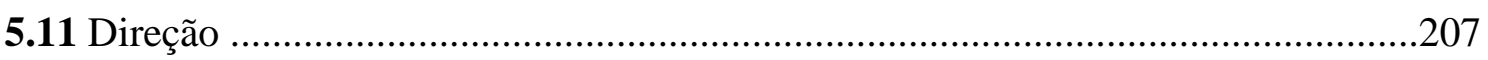

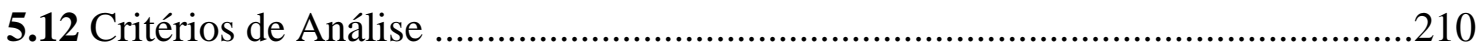

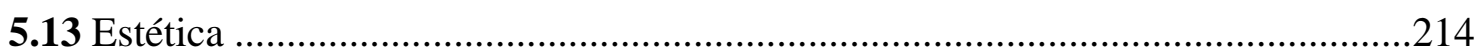

5.14 Relação com a Telenovela ............................................................................216

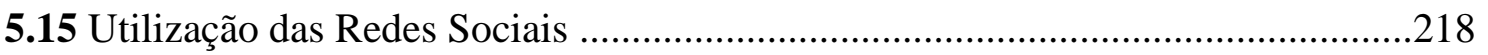

Capítulo 6 - Entre entrevistas e críticas ...............................................................223

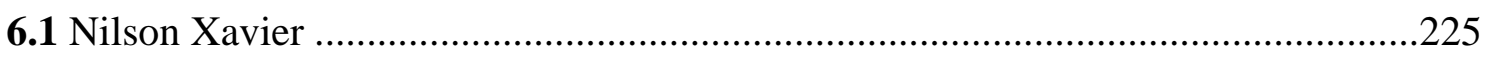

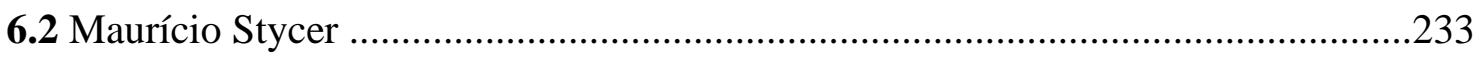

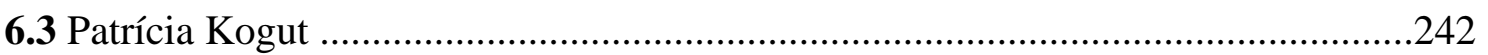

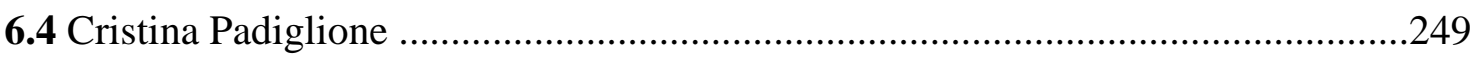

6.5 O Conjunto dos códigos analisados ...............................................................256

CONSIDERAÇÕES FINAIS .............................................................................264

REFERÊNCIAS _..................................................................................................................274

ANEXOS: Apresentação...............................................................................................286

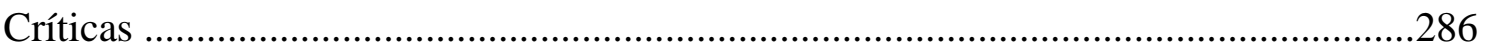

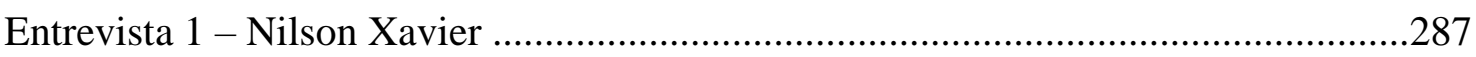

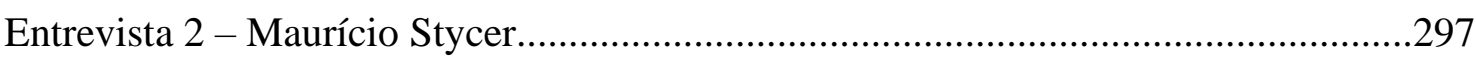

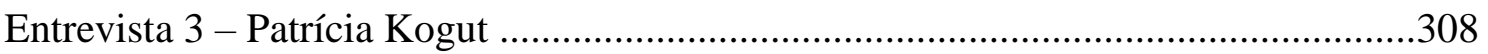

Entrevista 4 - Cristina Padiglione .................................................................................. 314 


\section{INTRODUÇÃO}

"Tem uma tradição no Brasil da novela se tornar um assunto
fora da novela, e isso é uma das coisas mais interessantes que
tem na maneira brasileira de fazer o folhetim televisivo."
Maurício Stycer

A necessidade de estudar a crítica de telenovela e sua circulação de sentidos perpassa inúmeras escolhas que envolveram minha experiência com o campo da comunicação. Acredito que essa reflexão ajuda a compreensão do ajustamento entre o objeto e o investigador, tão necessário em uma pesquisa e essencial para enfrentar os percalços tanto objetivos como subjetivos que se apresentaram ao longo deste trabalho. Logo, um breve histórico de minha trajetória acadêmica ajudará a aclarar as minhas escolhas diante da pesquisa.

Nascida e criada em Belém, no Pará, desde cedo me debrucei na televisão. Desse interesse ainda prematuro, posso dizer que veio meu empenho e o entusiasmo pela comunicação e o jornalismo. O interesse latente na área da comunicação me fez cursar a graduação de Comunicação Social, com habilitação em Jornalismo. E, sempre interessada nos fenômenos comunicacionais, eu ainda não encontrava na televisão meu mote para estender-me em possíveis pesquisas. Dessa forma, enquanto cursava Jornalismo, por um tempo dediquei-me ao jornalismo impresso, tendo em vista meu interesse pela escrita e a rotina como repórter. Ao fim da graduação, realizando o TCC, trabalhei a temática sobre dois blogs de política de jornalistas paraenses, a partir da perspectiva teórica de rede e cibercultura, em seus tópicos relativos a um escândalo político e a utilização dos blogs para as discussões políticas no Estado do Pará.

Com o término do curso e um título de jornalista, mudei-me para São Paulo, com o intuito de continuar minha formação, dessa vez, por meio de uma especialização em Jornalismo Internacional na PUC-SP. Nesse ínterim, instigada a continuar estudando, porém em projetos mais complexos, passei no mestrado também na PUC, no Programa de Comunicação e Semiótica. Com um pré-projeto bastante incipiente e tateando os meandros da academia, me vi em meio às aulas, orientações e discussões, que iriam me auxiliar a formar meu projeto final sobre televisão. Apoiada pelo meu orientador, prof. Dr. Rogério da Costa, passei a ter um olhar crítico sobre a grade de programação da 
televisão aberta brasileira. Pude ver as possibilidades de estudo naquilo que a maioria dos brasileiros utiliza de forma constante, mas que, como alertam Martín-Barbero e Rey (2004, p. 23), ainda é tratado na academia através do "mau-olhado dos intelectuais". Busquei a compreensão dos encadeamentos dos hábitos e costumes propagados através das imagens e sons em movimento, a nova rotina de ver TV, as outras experiências de consumo, assim como os ângulos de análises já existentes sobre a grade de programação.

Minhas inquietações teóricas me levaram a esse objeto tão amplo, complexo e cambiável devido a seu contexto. E decidi seguir com a pesquisa para o doutorado dando ênfase às forças de circulação da telenovela, os circuitos sociais que ela atravessa com os assuntos abordados e a sua crítica. Como se nota, a telenovela não é somente exibida, ela é também comentada, comparada e interpretada. As opiniões populares e a análise especializada, realizada por jornalistas que fazem a crítica de telenovela, veem gerar sentidos, produtos midiáticos, campos de discussões, ao criar circuitos de discursos, de falas acerca da narrativa.

Esses circuitos de discurso mostram como a telenovela cria imaginários, organiza os discursos de uma sociedade, como Lopes (2009) expressa através do conceito narrativa da nação. Tendo em vista ainda minha entrada no grupo de pesquisa do Centro de Estudos de Telenovela - CETVN e do Observatório Ibero Americano de Ficção Televisiva - OBITEL, estive em constante aprendizado acerca do contexto televisivo brasileiro e, em particular, das especificidades e transformações das telenovelas. Em síntese, credito meu contínuo e renovado interesse pelo objeto a esses fatores que, cada vez mais, impulsionam-me à sua compreensão.

Acredito ser válido pensar que uma tese seja relevante para o campo ao qual está sendo produzida, assim, quanto à relevância ao campo da comunicação, a pesquisa em si se detém nas análises das discursividades, apostando numa contribuição densa ao entendimento dos vínculos que a telenovela estabelece com seu espectador, pois, como menciona Lauro César Muniz, “TV é povo" (1998, p. 07). E adiantamos que, desse vínculo, sobressaem questões que concernem às narrativas e às relações subjetivas com seu público.

\section{O desenho do objeto empírico e recorte do corpus de pesquisa}


Nesta pesquisa, compreende-se a circulação da telenovela em diferentes ambientes como um emaranhado de forças que levam à construção de sentidos e a reconfigurações do campo discursivo acerca da telenovela. De maneira geral, levando em consideração a ideia de recepção e consumo, a circulação envolve diferentes percepções em que os produtos midiáticos são circundados ao/pelo receptor. Em um cenário de alargamento das paisagens televisivas, da fragmentação do olhar do telespectador, em que as ações dos receptores estendem as discussões sobre as próprias produções endereçando sentidos, reconhecemos que muitas forças enunciativas atuam na disseminação da telenovela, designando-lhe atributos e nos levando ao que Lopes (2009, p. 29) conceitua como pacto de recepção e espaço de debate de sentidos.

Enfim, o objeto em si é bastante complexo. Graças à linguagem e ao avanço da tecnologia, a circulação revela um intrincado de significados, sendo ressignificados pelos públicos em diferentes ambiências que serão listadas a seguir. Todavia, ressaltamos que tanto o produtor quanto o receptor são partícipes essenciais na manutenção dessas relações, realizando uma retroalimentação de sentidos.

A experiência comunicativa no ato de assistência da ficção desencadeia conversas, relatos escritos, vídeos, discussões referentes à telenovela. Como uma obra aberta, tais forças de circulação de sentido originam inúmeras discussões em variados cenários midiáticos, que levam a um sentimento de pertencimento na trama. A proximidade entre o telespectador e a obra prestigiada se tornou mais curta, confirmando e criando os sentidos que percorrem a narrativa. Essa nova experiência cognitiva possibilitada pelas novas telas nos leva a pensar em uma "nova economia da atenção" (SANTAELLA, 2010), onde se nota a disputa pelos olhares e a "sobrecarga de estímulos e de informação, fragmentação do tempo nas novas formas de vida social cibercentrada” (p. 303).

Ressaltamos que as mudanças nas lógicas de produção em que o processo abaixo está inserido podem levar a uma compreensão mercadológica do que consiste a circulação e, consequentemente, dos processos de distribuição dos produtos e das métricas que expressam os efeitos apontados para tais produtos. Longe dessa percepção, Jenkins, Ford e Green (2014) acreditam na circulação como um processo mais heterogêneo, desvinculado de práticas comerciais, amparado em um modelo participativo e de envolvimento com o produto. A que acrescentamos a definição de Fausto Neto (2009, p. 08), para quem circulação é "o modo como produtores e receptores se encontram em 
jogos de ofertas e, respectivamente, de exposição e composição de mensagem”. Ele adverte para sua natureza como dispositivo midiático, onde se encontram as relações de trabalho de negociação de apropriação de sentidos, que se dão segundo postulados que apontam para divergências e não linearidades.

Reconhecer as forças de circulação que permeiam a telenovela no Brasil implica um exercício de observação etnográfica do cotidiano, tendo em vista os anos em que as narrativas teleficcionais têm sido produzidas (desde 1963 em capítulos diários), em diversos canais e em variados horários da grade de programação. Sendo assim, durante esta fase de observação preliminar e como a escolha do objeto é, em si, uma operação teórica, selecionamos os circuitos, o universo de circulação da telenovela como sendo:

a) o ambiente familiar, logo a casa, lugar antropológico no qual a televisão se constitui como um dos principais meios de informação e entretenimento;

b) o ambiente de trabalho, onde também se constatam discussões sobre a telenovela;

c) os produtos midiáticos, como mídias impressas - jornais e revistas -, a própria televisão, em seus programas de comentários sobre telenovelas e seus atores;

\section{d) a crítica de telenovela;}

e) as discussões em redes sociais.

Os pontos elencados combinam diferentes espaços e, logo, o universo plural de sentidos da circulação. Em meio ao cenário onde o olhar é a mercadoria mais cobiçada (SANTAELLA, 2010, p. 302), vemos que a telenovela continua a ser o foco do olhar da nação em termos de ficção, sua pungência propicia e fomenta que esse universo de sentidos esteja intrínseco ao comportamento brasileiro. Até por sua característica dialógica, as ficções se veem no centro de variadas discussões.

É fato que no campo da comunicação o objeto é mutável e dinâmico, devendo tais características a seu caráter histórico. Os fatores históricos, como os discursos científicos de um determinado momento, podem vir a ser ultrapassados e a provocar uma tensão nas verdades estabelecidas. Nesse intuito, percebemos a necessidade de recortar uma das forças elencadas acima para melhor compreensão dos sentidos da circulação na realidade histórica que é a contemporaneidade. É a crítica de telenovela - tão feita e tão vista - em 
sites e em blogs que sobressai como uma forma heurística de expressar as discussões que na atualidade permeiam as telenovelas.

\section{A crítica como objeto de estudo: objetivos, hipóteses de pesquisa e proposições metodológicas}

A escolha da análise da crítica de telenovela como objeto desta pesquisa doutoral se deve por revelar um dos circuitos mais notáveis de circulação dos sentidos da telenovela. Como formadores de opinião, e devido ao crescimento dos jornalistas que tomam para si o trabalho de realizar e difundir discursos sobre as produções televisivas, percebemos uma complexa interligação entre o que se fala sobre telenovelas no âmbito popular (casa, trabalho, redes sociais) com o que é discutido nas críticas, levando em consideração o emaranhado de discursos que circulam. Pensamos que a crítica, em um primeiro momento, mostra-se uma medida do falar empírico. O que se comenta, o que diz, o se faz sobre/pelas produções, até dados de audiência, que permitem um paralelo entre o que se fala, discute e consome. Outra característica que se destaca são os levantamentos e reflexões feitas por esses críticos ao longo das telenovelas emitidas, questões relativas, por exemplo, à estética, à narrativa, aos números de audiência, às polêmicas, às linguagens, isto é, a uma coleção de tópicos nos quais o telespectador parece se amparar.

A crítica vem sendo, nos últimos anos, realizada especialmente por jornalistas, que não somente se debruçam em entender os rumos e assuntos das tramas, mas também abordam as principais mudanças que ocorrem na televisão como um todo. Assim sendo, a pesquisa irá se pautar pela crítica jornalística e no trabalho de quatro críticos referidos na metodologia abaixo, buscando pontos de confluência e divergência na circulação de sentidos das telenovelas e na própria função e ofício dos críticos.

A relação entre a crítica e o leitor e a consequente produção de sentidos evidencia o que Soares e Serelle (2013) denominam de caráter relacional da crítica; característica constitutiva desses discursos que requer de seu construtor, ou seja, o crítico, um repertório amplo sobre o que se está analisando. Como os autores afirmam:

O caráter relacional aponta para a dimensão comunicativa da crítica, uma espécie de mediação entre obra e leitor, ponto de convergência dos valores e repertórios por ela acionados. Definido enquanto um conjunto de elementos metodicamente dispostos, o repertório não se limita a um conteúdo rigorosamente organizado, mas refere-se, também, a um 
conjunto de conhecimentos que, na origem latina do termo, engendra o sentido de descoberta, produzindo algo novo a partir de suas combinatórias. Ao ser reconhecido como dotado de valor, um objeto passaria a integrar esse inventário; por sua vez, os elementos constantes dessa coleção, ao serem rearticulados, fazem surgir outros valores. (SOARES e SERELLE, 2013, p. 6)

Em vista disso, vemos que a produção de sentido é intrínseca ao discurso (VÉRON, 1980), e o discurso como uma ponte entre a linguagem e a ideologia, no sentido de entendermos como a linguagem apresenta a ideologia (FIORIN, 1998). Será no estudo da crítica da ficção televisiva o locus de sistematização de questões teóricas e práticas que permearam esta tese.

\section{Objetivos}

\section{Objetivo Geral}

O objetivo geral da pesquisa é entender o desenvolvimento da crítica de telenovela no Brasil e em como se configura essa crítica contemporânea, realizada em sites e blogs, percebendo sua articulação nos discursos das e sobre as telenovelas ao explicitar as operações de circulação de sentidos.

\section{Objetivos Específicos}

1) Compreender o papel do crítico de telenovela em meio às forças da circulação de seus sentidos.

2) Entender a função dessa crítica contemporânea.

3) Observar quais os critérios utilizados na crítica de telenovela; apreender as características compartilhadas entre os críticos.

4) Contribuir com noções e categorias teóricas que possam contribuir para um protocolo de análise da crítica de ficção televisiva.

5) Entender o andamento histórico da crítica de televisão/telenovela desde a década de 1970 aos dias atuais.

\section{Problema de Pesquisa e Hipóteses}

A pergunta principal que impulsionou esta pesquisa foi: Como se configura essa crítica de ficção televisiva contemporânea, realizada em sites e blogs, e de que forma 
ela explicita as operações de circulação de sentidos? A partir da observação e dos textos estudados sobre a temática da pesquisa, além da experiência abarcada com o CETVN e o OBITEL, foi possível estabelecer pontos em que algumas conjecturas puderam ser efetuadas sobre a crítica e as forças de circulação das telenovelas. Dessa forma, neste trabalho, seguimos duas hipóteses, a saber:

A hipótese de caráter epistemológico antecipa que a crítica de telenovela veiculada nas mídias digitais atua como expositor e disseminador das questões dos públicos, delimitando os temas que considera mais interessantes e relevantes por meio dos termômetros das redes sociais e dos dados da audiência. Com isso, a crítica desnuda a estrutura televisiva a seu leitor, a percebe e discute a estrutura da telenovela. Uma metalinguagem (BARTHES, 2007), no sentido de abordar uma obra já existente. Isto posto, a crítica de telenovela articula o texto televisivo com a sociedade onde está inserido, e, como a ficção brasileira opera com características próprias, tais críticos devem “relacionar a obra com um contexto, deve-se compreender seu 'funcionamento'. Somente assim será possível desenvolver uma 'teoria da articulação' entre o texto e a sociedade onde ele surge (MAINGUENEAU, 2001, p. 14), ou seja, como os circuitos de circulação, levando em consideração os lugares enunciativos, articulam as condições de reconhecimento (HONNETH, 2009; FRASER, 2007) por meio da oferta de discurso estimulando a criação de conteúdos sobre as produções, e em como as ficções trabalham a questão do reconhecimento e ativam os elementos de representatividade. Portanto, as ficções tratam das demandas de reconhecimento por meio de suas temáticas sociais (merchandising social), que implicam discussões políticas evidentes na sociedade.

A hipótese de caráter prático prevê os dados obtidos por meio da análise das 76 críticas e das quatro entrevistas. De maneira geral, as críticas se traduzem como a leitura de seu tempo, apontando para a abrangência da televisão, a relevância dos temas abordados e o caráter da telenovela como um produto da indústria cultural brasileira. A ida do espaço da crítica dos jornais impressos para o ambiente digital demonstra a transformação do papel e espaço da crítica nas empresas de comunicação no país, sabendo que esse espaço sofreu modificações tanto espaciais como simbólicas, devido à participação ativa do leitor/espectador. Por conseguinte, a crítica nesse ambiente digital acentua as características do diálogo, onde se configurou um território comum de discussão; da democratização, na qual opiniões são constantemente pulverizadas; e da interação, espaço para comentários, lugar estabelecido para a avaliação dos usuários sobre 
determinado texto. O que percebemos também é que a crítica de televisão é assimilada como inferior comparada a outras artes, e o aspecto sempre levantado é o argumento da baixa qualidade e da telenovela ser um produto popular. Desse modo, é preciso entrever a função dessa crítica de TV para a efetivação da crítica voltada para a telenovela, entendendo as estruturas e regras do paradigma da telenovela brasileira.

\section{Proposições metodológicas: desenho do objeto empírico e recorte do corpus de pesquisa}

O modelo metodológico da pesquisa empírica de comunicação proposto por Lopes (2014) será utilizado de referência para o entendimento do que foi realizado. Logo, a montagem estratégica da tese perpassa por inúmeras opções e decisões que serão explicitadas a seguir.

\section{Gráfico 01 - Modelo Metodológico de Pesquisa}

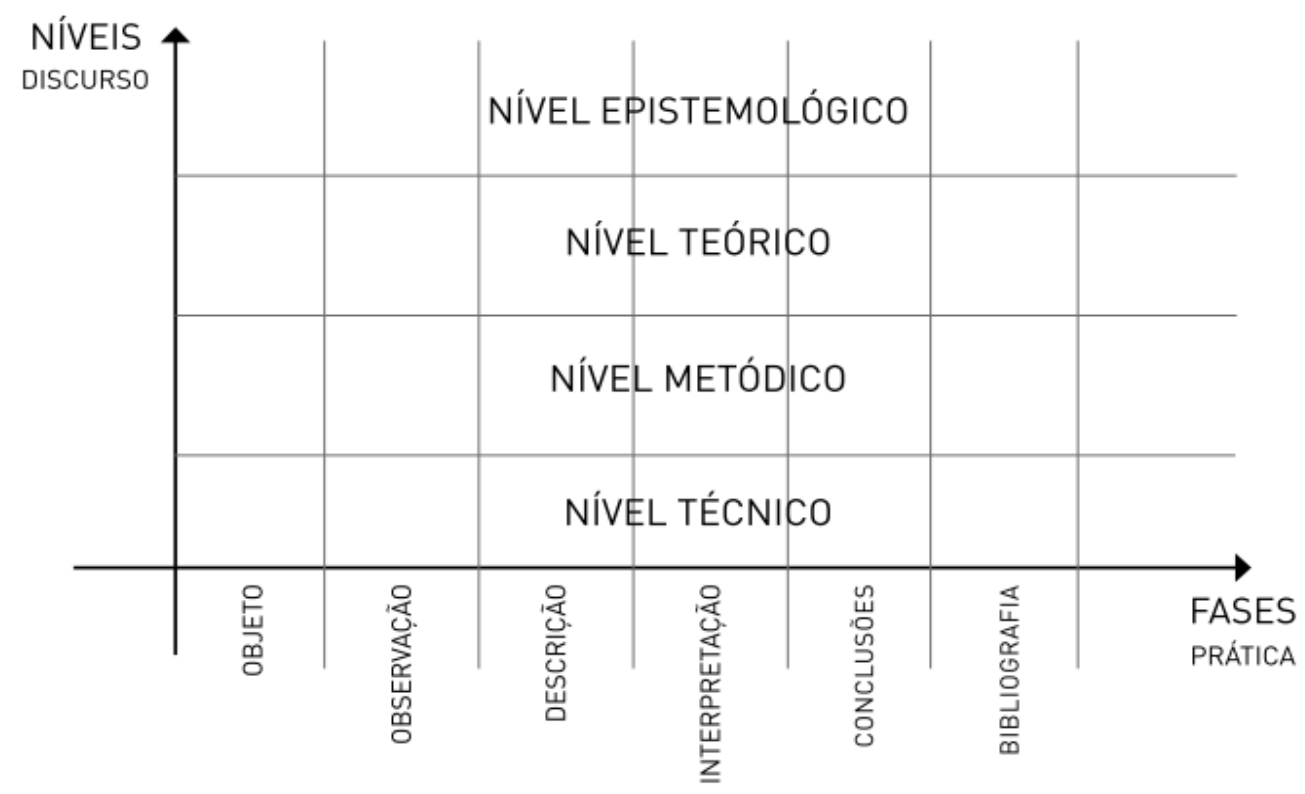

Fonte: Lopes, 2014, p. 156

No eixo paradigmático, portanto o vertical, estão dispostos os quatro níveis que compreendem toda a pesquisa. São eles o nível epistemológico, o teórico, o metódico e o técnico. O nível sintagmático, horizontal, é composto por fases, a saber: a definição do objeto, a observação, a descrição e a interpretação dos dados. Vale ressaltar, segundo 
Lopes, que cada fase é perpassada por cada nível e trabalha em função de cada uma das fases.

Tendo isso em vista, nesta pesquisa, no nível epistemológico, temos a definição do objeto se configurando como a crítica de telenovela em meio à circulação de sentidos dessas narrativas. Em um primeiro momento, percebendo toda a rede de sentidos no qual a telenovela está inserida, delimitamos a pesquisa na compreensão dessa crítica e seus atores e em como ela é realizada e divulgada nos meios digitais. Posteriormente, fomos desenvolvendo esse objeto por meio das leituras subjacentes ao tema, o que nos leva ao nível teórico na busca de uma explicitação teórica desse objeto, e assim à ruptura epistemológica ${ }^{1}$ entre o objeto em si e em como chegamos à construção do objeto científico.

Em seguida, passamos ao nível metódico, onde a exposição desses discursos será trabalhada, e um momento em que também podemos inferir certas causas. O nível técnico é marcado pela observação, a seleção e operacionalização desses dados, que podem ser primários ou secundários. Este nível incide na elaboração do objeto científico e nos procedimentos de coleta de dados, além das informações referentes à problemática. Lopes (2014) comenta que, para a operação desse nível, é necessário que se atenha para diversos fatos que proporcionam a adequação do campo teórico e da formulação dos fatos científicos. Dessa forma, percebemos que a ação mais importante visa à constituição dos dados que permitem, consequentemente, a construção do objeto científico.

A crítica, em si, é um objeto vasto e complexo. A crítica do audiovisual encontrou no cinema um extenso campo de trabalho, que vem se perpetuando desde o nascimento da sétima arte. A TV, em sua pouca trajetória, apresenta uma crítica que vai se constituindo ao longo do próprio processo de desenvolvimento da plataforma. Como cada televisão abarca um contexto próprio, notamos que, para a constituição do objeto científico, foi necessário visualizar e elencar os campos de discussão acerca da telenovela para daí passarmos para o estudo da crítica das ficções. Esses campos de discussão elencados acima permitem um olhar singular para a capacidade dialógica das narrativas em nosso contexto. Entretanto, para os objetivos da pesquisa e atendendo à fase de

\footnotetext{
${ }^{1}$ No sentido abordado por Lopes (2014), a ruptura epistemológica consiste na quebra entre o objeto científico e o real; ela exige, também, uma crítica metódica as categorias, aos esquemas e aos problemas entre a linguagem científica e a linguagem comum.
} 
construção desse objeto, optamos pela escolha dessa crítica, que ainda se mostra prematura, mas que caminha para se solidificar.

Neste último nível podemos enquadrar a identificação desses críticos que serão analisados na pesquisa, observando sua movimentação em seus blogs/sites e na postagem das críticas. A crítica de televisão, incluindo a telenovela, tem seu advento nos cadernos de cultura dos jornais impressos. Hoje, notamos que ela tem maior aderência em páginas on-line, na qual a interação com seus leitores se mostra mais proveitosa. Diante da observação dos conteúdos publicados, identificamos os críticos que se destacam na análise das telenovelas, e que, em sua maioria, se autodenominam como jornalistas e críticos de televisão. As fases da pesquisa correspondem a passos em que um projeto deve se pautar para a culminação de uma pesquisa científica. As fases têm um caráter mais prático, buscam explicitar as interações e ações a serem estabelecidas para se chegar a uma conclusão.

\section{Método}

Temos firmado teoricamente que a crítica de telenovela é uma das mediações centrais entre a produção e a recepção das ficções, além de ser um campo discursivo que permite à telenovela ir além de sua transmissão. Elas acompanham o ritmo das tramas e apresentam ao público argumentos e análises que determinado jornalista atribui a uma obra. Logo, nossa leitura das críticas foi feita de maneira constante, tendo em vista a facilidade de seu acompanhamento, via celular e/ou computador, o que vai de acordo com a proposta metodológica apresentada.

A técnica de coleta de dados empíricos consistirá em entrevistas com os críticos jornalistas. Os dados primários serão compostos pelos artigos das críticas sobre telenovelas e por dados estatísticos concernentes à temática. O universo de observação serão as críticas realizadas pelos jornalistas das telenovelas pertencentes ao prime time da TV Globo, entre os anos de 2012 e 2018. Desse período, selecionaremos cinco telenovelas de maior audiência ${ }^{2}$, para, então, fazermos a análise.

A faixa horária escolhida se deve pela relevância discursiva e por estar em pleno horário nobre da televisão. Quanto à emissora selecionada, as telenovelas da TV Globo são as que mais se destacam em termos de discursividade, além de serem as que

\footnotetext{
${ }^{2}$ Dados confirmados pelo monitoramento anual realizado pelo OBITEL, e disponíveis em obitel.net.
} 
conseguem as maiores audiências da televisão no país ${ }^{3}$. Já o recorte temporal foi devido ao tempo de atuação dos críticos elencados no meio digital, sendo que, em 2012, todos atuavam em suas páginas on-line.

A seleção para a abordagem qualitativa compreenderá quatro profissionais que escrevem crítica de telenovela:

1) Maurício Stycer (Blog do Mauricio Stycer - Uol - formato blog);

2) Nilson Xavier (Blog do Nilson Xavier - Uol- formato blog);

3) Patrícia Kogut (Patrícia Kogut - O Globo; edição digital- formato site);

4) Cristina Padiglione (TelePadi - Folha de S. Paulo; edição digital - formato site).

Esses críticos selecionados se destacam pela sua relevância nos escritos sobre o tema, pelo tempo de trabalho na mesma atividade ou ofício de crítico e por fazerem críticas em páginas on-line (em formatos site ou blog), o que propicia uma dinâmica maior na circulação de seus conteúdos e a facilidade de reunir e analisar os artigos dispostos em arquivos e pastas. Portanto, os critérios de seleção da amostra dos críticos são biografia profissional especializada, levando consideração suas trajetórias com a escrita sobre televisão; verificação e análise dos posts a serem trabalhados, levando em consideração o panorama televisivo.

A análise de conteúdo incidiu sobre um corpus constituído por posts produzidos pelos críticos sobre as ficções. Para isso, criamos uma ficha onde constam o nome da telenovela, a data, a autoria da crítica e o título da crítica (presente no capítulo 4). Esse levantamento permitiu a escolha das críticas sobre as quais faremos a análise de conteúdo, bem como a observação dos críticos quanto à constância da escrita, ao estilo, ao acompanhamento da ficção e a outros elementos que podem emergir da análise proposta.

O levantamento foi realizado com cada crítico, sendo as críticas divididas por telenovela. Conforme Daniel Filho (2001, p. 179), a estrutura da telenovela é composta majoritariamente por quatro partes, a saber: o início, que se prolonga até o capítulo 30; em seguida vai para a primeira grande virada (plot twits), iniciada no capítulo 50; passa então para a barriga, que se configura pela repetição de certos assuntos, uma estagnação na trama; logo segue para a segunda virada, no capítulo 110; e, posteriormente, segue para seu fim a partir do capítulo 130.

\footnotetext{
${ }^{3}$ Dado confirmado pelo monitoramento feito anualmente pelo OBITEL.
} 
Levando em consideração essa estrutura apresentada, iremos separá-las em três tomos: 1) as realizadas na primeira semana da telenovela, 2) as feitas no meio das tramas, e 3) as feitas no momento da barriga, e, por fim (4), as realizadas ao fim da trama, isto é, as que ofertam um balanço geral de toda a obra. Isso permitirá a observação e análise de quais os critérios utilizados na crítica de telenovela, bem como apreender as características compartilhadas entre eles.

Sintetizando, temos quatro críticos, cinco telenovelas selecionadas e quatro críticas para cada telenovela. Portanto chegamos ao número total de 80 críticas para análise das telenovelas Avenida Brasil (2012), Salve Jorge (2012-2013), Amor à Vida (2013 - 2014), A Força do Querer (2017), e O Outro Lado do Paraíso (2017 - 2018). Logo, temos o levantamento do total de críticas realizadas pelos quatro críticos no período analisado:

Gráfico 02 - Quantidade de Críticas publicadas 2012 e 2018

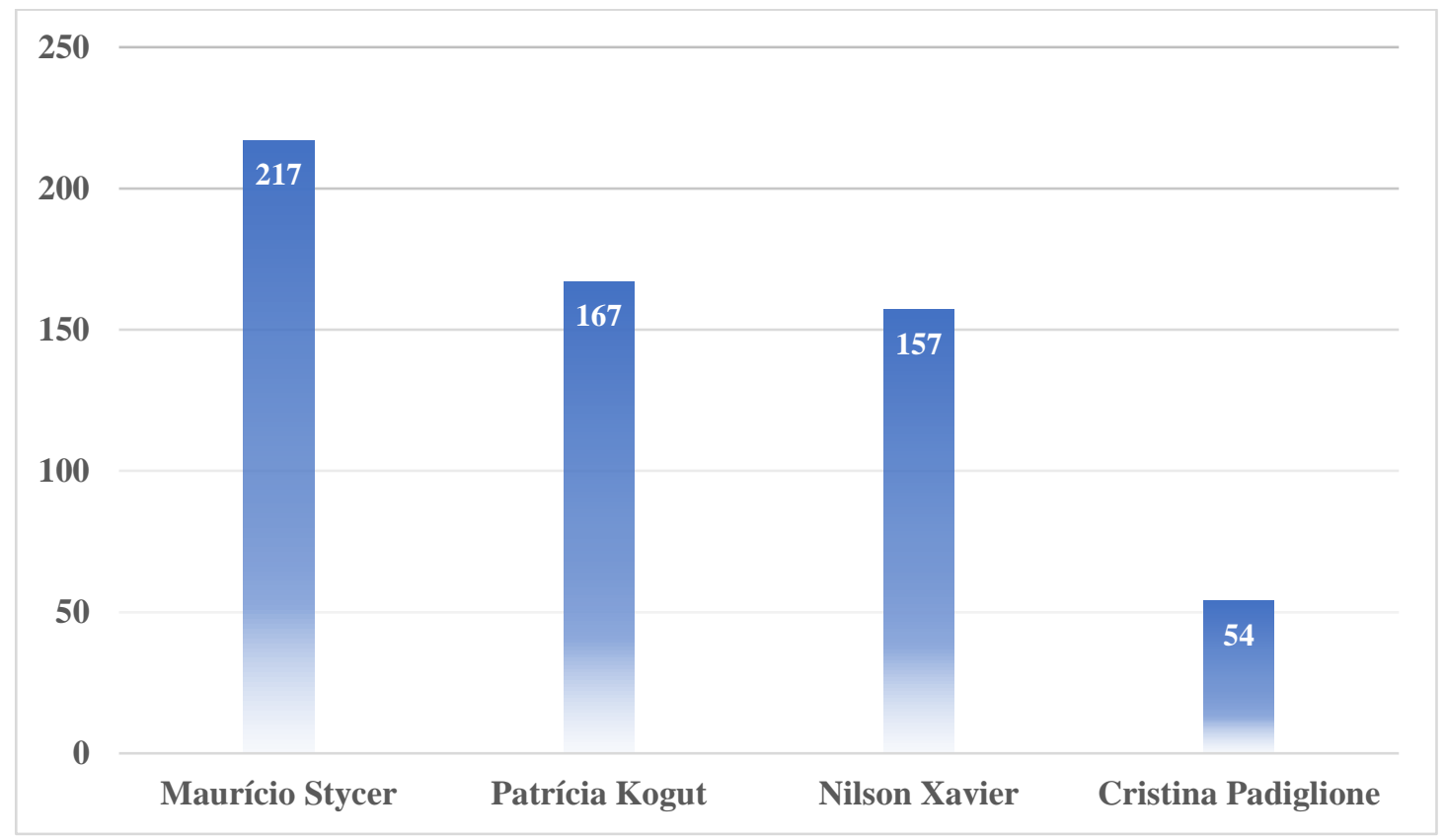

Fonte: Levantamento realizado pela autora

Os números acima são referentes a todas as críticas feitas pelos críticos elencados no período de 2012 a 218 de todas as novelas do horário nobre. Então, foram 14 telenovelas que se passaram neste período, contando duas ficções de gênero bíblico da Record TV. Dentre essas 14, identificamos cinco ficções de maior audiência, por meio dos dados do Obitel e, portanto, selecionamos quatro críticas de cada telenovela. 


\section{Organograma do processo metodológico da pesquisa}

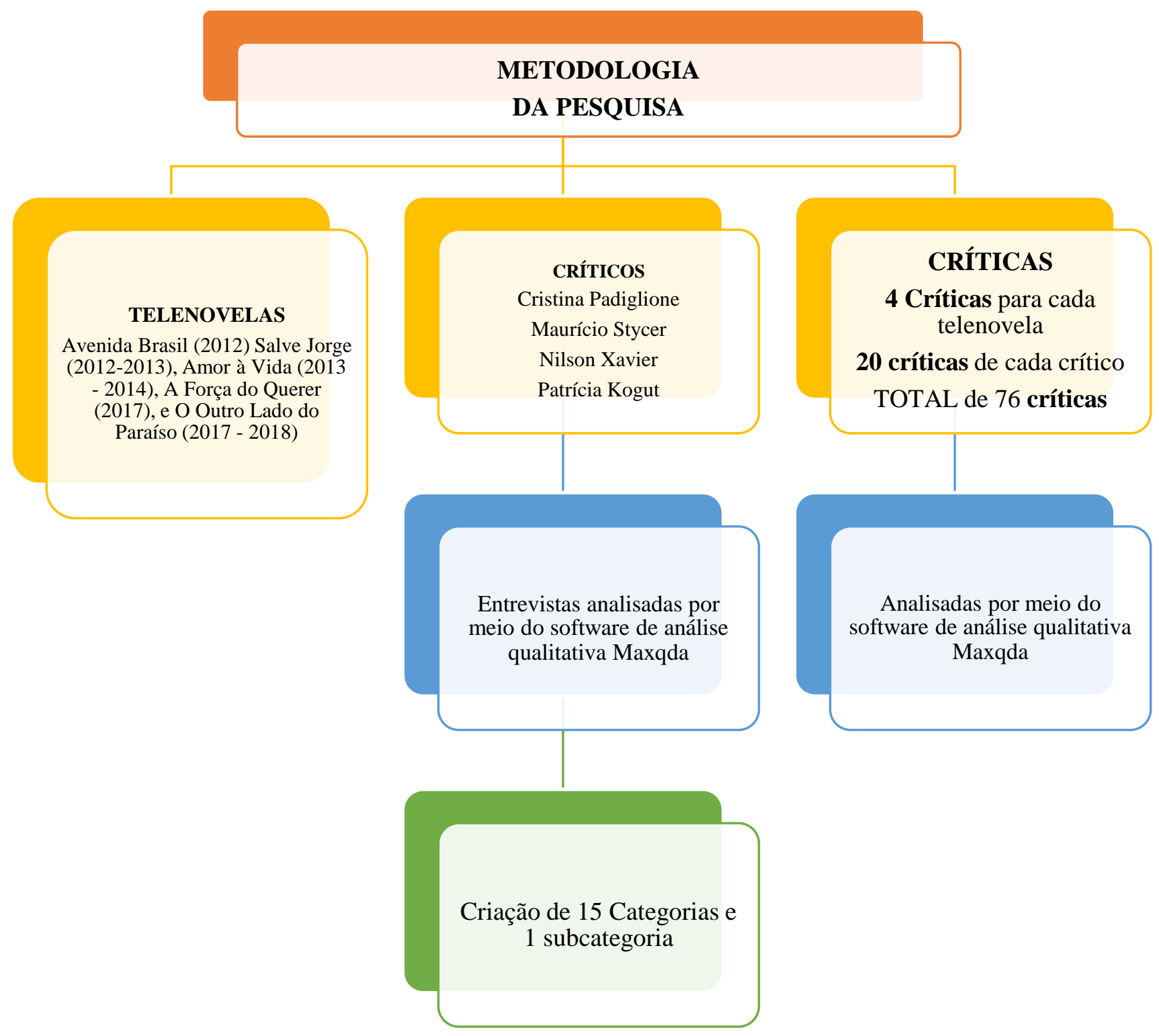

Fonte: Elaborado pela autora

\section{Entrevista com os críticos}

O seguinte passo da pesquisa visa à entrevista com esses críticos para abordarmos seus conceitos e critérios adotados nas análises. O que podemos adiantar é que, como toda a obra, a telenovela não está descolada de seu contexto histórico, portanto sua crítica não pode se exercer sem a "experiência histórica" (NUNES, 2007), tal como elucida Bucci (2004) de que a crítica não deve enumerar somente a estética, mas deve ser vista como um fato social, discutindo a cultura e seus sujeitos implicados. 
Devido à particularidade do desenvolvimento da crítica de televisão, outra dificuldade se insurge: quem pode criticar? A sistematização da crítica reforça a necessidade de amplitude do debate em que ela está inserida. Quem são esses atores no caso desta pesquisa - jornalistas que escrevem o que delimitamos de crítica especializada? E quais fundamentos se inserem na apreciação de uma obra? A pungência da TV, em seus constantes mecanismos de transformação, tem nos mostrado que se debruçar sobre seus programas vem se revelando um desafio. De que TV estamos falando? De que públicos estamos discorrendo? São alguns dos questionamentos que temos que ter em perspectiva quando se fala em televisão e seus desdobramentos. Como também, de que forma a telenovela opera essa circulação de agenciamentos passada ao público, destacando que, como um formato tão visto, é tão pouco abordado. Desta forma, as análises críticas realizadas por jornalistas encontraram um terreno fértil no meio digital, o que facilita a abrangência de suas análises e seu imediatismo, propício a compartilhamentos e discussões, não somente nos comentários como em redes sociais.

O modelo de entrevista aplicado foi a semiestruturada, dando margem para possíveis perguntas que afloraram no decorrer da entrevista. Elas foram realizadas presencial e individualmente com cada crítico, feitas após a leitura das críticas, através da gravação via celular ${ }^{4}$. Com as respostas, foi possível destacar elementos que se sobressaíram nas análises e que podem ser explicitados por meio das perguntas. Esses pontos que se sobressaíram tanto nas leituras das críticas quanto nas leituras teóricas têm o objetivo de enriquecer a pesquisa quanto à função da crítica.

No caso da crítica de telenovela, alguns pontos são primordiais e devem constaram nas questões. O primeiro ponto recai na relação desses críticos com as telenovelas, especialmente sua relação afetiva, tendo em vista que a experiência de assistência dessas produções era feita em conjunto no âmbito familiar. O segundo ponto corresponde aos critérios adotados em seus textos e como se efetuou essa análise; assim, buscamos analisar os aspectos internos e externos de uma obra, tal como afirma Candido (1973, p. 4):

Hoje sabemos que a integridade da obra não permite adotar nenhuma dessas visões desassociadas; e que só podemos entender fundindo texto e contexto numa interpretação dialeticamente íntegra, em que tanto o velho ponto de vista que explicava pelos fatores externos, quanto o outro, norteado pela convicção de que a estrutura é virtualmente independente, se combinam como momentos necessários do processo interpretativo. Sabemos ainda, que o externo (no caso, o social)

\footnotetext{
${ }^{4}$ Transcrição das quatro entrevistas no Anexo 1
} 
importa, não como causa, nem como significado, mas como elemento que desempenha um certo papel na constituição da estrutura, tornandose, portanto interno.

Candido ressalta o papel da Sociologia no que concerne à análise de determinada obra; como essa influência é uma via de mão dupla: o meio social influencia e é influenciado por uma obra. Em suma, a crítica deve levar em consideração os aspectos do público, da obra e do autor. Entrever a maneira como a sociedade entende essa obra e estabelecer os tópicos de valoração que serão incorporados nesta crítica e a relação com o público. Consequentemente, as respostas atreladas ao entendimento das análises das críticas por telenovela nos deram variados pontos de tratamento para o objeto, compreendendo não somente a crítica, mas também a atividade de criticar.

\section{Estrutura da tese}

Esta pesquisa está dividida em duas partes, uma de caráter teórico e a segunda, de caráter empírico. Optamos por essa divisão como forma de organização do pensamento, saindo de um embasamento teórico do objeto de pesquisa para, em seguida, passarmos para o refinamento dos dados e sua análise. A primeira parte é formada pelo conjunto de três capítulos, que nos deram suporte conceitual para olharmos a telenovela e as críticas. E a parte secundária é composta por três capítulos, um de explicitação da metodologia e dois de análise dos dados.

O primeiro capítulo trata do panorama da televisão e da telenovela no Brasil, passando pelas características deste formato e como, no país, ele se consolidou num padrão específico de ficção nacional. Explicitamos a predileção pela telenovela através do recurso das emoções suscitadas pelo melodrama e o naturalismo. Em seguida, explanamos o folhetim e sua circulação de sentidos, considerando a crítica como parte dessa operação simbólica.

No segundo capítulo, debruçamo-nos em apresentar os pressupostos da crítica, inicialmente por meio de teóricos provenientes dos estudos literários tanto estrangeiros 
quanto brasileiros. Identificamos que o campo da crítica de literatura ${ }^{5}$ foi possível pelas transformações socioculturais do território europeu, como a ascensão da burguesia e a criação da imprensa, levando essa crítica aos jornais impressos. Posteriormente, realizamos uma breve introdução de três críticos - Helena Silveira, Artur da Távola e Décio Pignatari - relevantes para o début da crítica de televisão no Brasil.

O terceiro capítulo discorre acerca dos quatro Mapas da Mediações de Jesús Martín-Barbero (2015) operacionalizado nos aspectos que formam o objeto desta tese. Frisamos que os mapas das mediações podem aderir a qualquer objeto da comunicação conforme as perspectivas teórico-metodológicas do pesquisador. Desta maneira, o texto de Martín-Barbero é formado por diferentes camadas que dialogam entre disciplinas tais a Antropologia, a Filosofia, a Semiótica e a Comunicação; e essa interdisciplinaridade serviu de moldura para que, com os mapas, visualizássemos a telenovela, os críticos e as críticas.

O quarto capítulo contempla a descrição do método de análise e o cotejamento do objeto. Nele, detalhamos todo o processo de escolha das críticas, realização das entrevistas e a utilização do Maxqda, software de análise qualitativa. Incluímos também as fichas de análise, com todas as críticas selecionadas por crítico e telenovela. Nossa metodologia inclui um número extenso de dados empíricos, e, devido ao acesso aos dados pertencentes ao Obitel, pudemos realizar o cerceamento do objeto. Ainda abrangemos os meios para os quais chegamos nas categorias empíricas.

A análise das críticas e entrevistas está disposta no quinto capítulo, no qual realizamos a descrição de cada categoria, com o relato do uso do Maxqda, no recorte empírico. Como modo de análise, costuramos as categorias teóricas e as categorias advindas do campo. Em nosso entender, as mediações referentes aos mapas de MartínBarbero se prestam como categorias teóricas para pensarmos os códigos que mais se repetem na análise dos dados. Por meio desta combinação de análises, demonstramos os processos de criação, exame e reflexão acerca da telenovela, do ofício do crítico e do panorama da crítica.

\footnotetext{
${ }^{5}$ Percebemos que a crítica de literatura foi o embrião para a crítica de telenovela. Os três atores abarcados neste capítulo se pautaram primeiramente, em suas experiências no campo literário, e de lá, transportaram seus conhecimentos para a crítica de televisão adequando seus critérios ao seu objeto de análise.
} 
Os nossos dados empíricos são formados pelas críticas e pelas entrevistas, portanto, no sexto capítulo, apresentamos os retratos das informações de cada crítico. Os retratos de documento são um recurso visual possibilitado pelo software de análise qualitativa, no qual permite, em forma de quadro, uma visão geral dos documentos codificados. Cada código criado é representado por uma cor específica, desta forma, quando o retrato é gerado, ele mostra o conjunto de cores em maior evidência no documento. Assim, nesta parte da análise, trazemos dois retratos: um da crítica e outro da entrevista, colocados lado a lado, permitindo observar se o que é falado nas avaliações também foi abordado nas entrevistas, especialmente no que concerne ao processo de análise de uma telenovela, além das reflexões quanto ao trabalho e as ficções. Ainda neste capítulo, abordaremos os três conjuntos de códigos, que, na análise empírica, formaram um agrupamento do que, em nosso entender, são parâmetros de análise da crítica de telenovela.

Por fim, longe de saturar este objeto, aqui apresentamos uma mirada singela sobre a crítica de telenovela, campo ainda deficitário em fontes bibliográficas e em reconhecimento. Mas que, com contribuições pontuais, reacende discussões e debates. Assim, esperamos que esta tese forneça subsídios para futuras reflexões sobre o tema e que possamos compreendê-la como uma criação de seu tempo histórico, que abarca sujeitos e processos em constante transformação. 


\section{PARTE I}

Apontamentos teóricos 


\title{
CAPÍtUlo 1 - O Panorama Televisivo
}

\author{
"Novela é a mais tradicional forma de entretenimento popular da \\ televisão brasileira”. Maurício Stycer
}

Este capítulo explana o panorama da televisão e, consequentemente, a inserção da telenovela no cenário brasileiro. Partimos, portanto, da importância da televisão na tessitura social, que, por conta de sua instauração em pleno período ditatorial, solidificou a centralidade da TV em nosso contexto. Em seguida, abordamos o paradigma da telenovela brasileira, com suas características próprias quanto à serialidade e à abordagem de temáticas sociais. Posteriormente, adentramos numa análise filosófica, visualizando a telenovela como uma instauradora de afetos. Perpassamos a telenovela e seus agenciamentos, aclarando as transformações do cenário tanto tecnológico quanto social no qual a ficção está inserida. E, por fim, a telenovela e sua circulação de sentidos. Tal panorama tenta dar conta das modificações ocorridas no plano da produção das narrativas, bem como no plano da recepção, especialmente na utilização das redes sociais digitais, que complexificaram as relações de circulação de sentidos.

\subsection{A Televisão e a Telenovela}

O questionamento constante do porquê estudar a telenovela no Brasil e seus aspectos permeiam todas as fases e níveis desta pesquisa. Longe de chegar a uma conclusão definitiva, que indicaria a finalização deste processo, percebemos que alguns pontos iniciais precisam ser trabalhos acerca desse produto ficcional. Cabe lembrar que ,por meio do advento da televisão, no início da década de 1950, não demorou para as primeiras ficções serem produzidas e logo caírem no gosto popular. Advindas da tradição das radionovelas, as primeiras tramas alcançavam um público muito restrito, tendo em vista que inicialmente os aparelhos televisores só eram vistos no eixo Rio de Janeiro-São Paulo. Apesar desse início, com os anos, a televisão foi capaz de prover o que Lopes (2009) denomina como repertório comum, ofertas de informações que antes eram divulgadas apenas pelas instituições tradicionais e que, pela televisão, alargaram seu alcance. A problemática da televisão como um todo, permeada pelo trânsito de imagens constantes e seus significados, permitiu o aparecimento de um novo espaço público, 
esfera de discursos e da construção de ambiências sociais, na medida em que reverbera em variados espaços de discussões e impõem-se na demanda da construção de pensamentos sociais do que se configura como a sociedade brasileira.

Os discursos acerca do que seriam essas marcas de brasilidade evidenciadas pela televisão nos levou à ficção televisiva e sua inerente contribuição para a formação do ideal padronizado do entendimento de cultura nacional. O reconhecimento (FRASER, 2007; HONNETH, 2017), neste caso de si e do outro, a partir da tela envolve movimentos simbólicos abrangentes de quem até então era um telespectador passivo, no qual somente o movimento de zapear era possível. No atual panorama, com movimentos transitórios de constantes transformações, a televisão se organiza além da sua recepção e ultrapassa essa audiência estática de seu início. Nesse ir além, funda um emaranhado de enunciados que culminam na construção do repertório discursivo que alimenta o imaginário nacional, fomentado pelo ritual de assistência compartilhada.

Segundo Stycer (2018, p. 16), os planos para a inauguração da televisão no Brasil por Assis Chateaubriand Bandeira de Mello remontavam ao ano de 1944, por meio da visita à emissora estadunidense NBC. O plano consistia em implantar a tecnologia da televisão no país após o fim da Segunda Guerra Mundial. Depois de seis anos, o empresário realiza o début da televisão com a criação da TV Tupi, em 18 de setembro de 1950. Apesar de todo aparato para que a transmissão televisiva fosse possível, ainda eram necessários os aparelhos televisivos. Dessa forma, foram importados 200 aparelhos para serem instalados na capital paulistana. Reimão (2006) discorre que, neste período, era comum a difusão de espetáculos eruditos, como o teatro clássico e de vanguarda, além de shows populares esporádicos. Logo, o cenário televisivo era formado por:

A primeira geração da TV no Brasil (STYCER, 2018, p. 14)

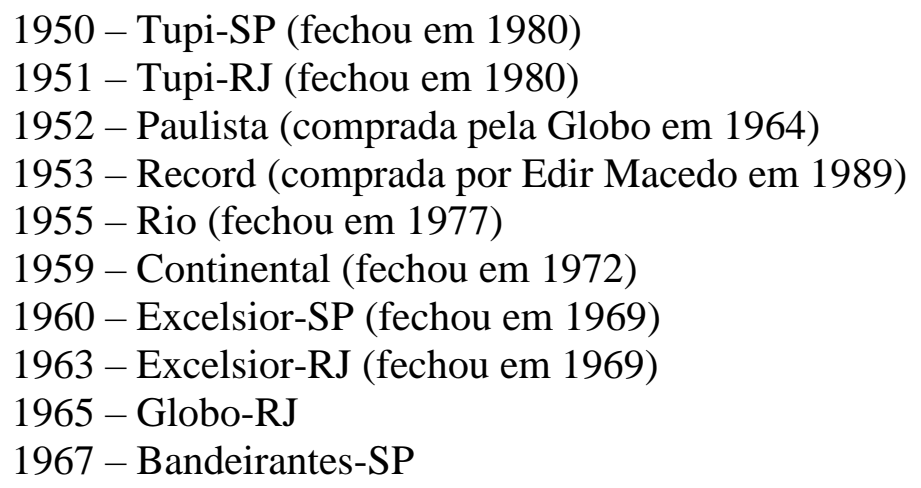


A TV Globo teve seu advento em abril de 1965 e funcionava, até então, como as demais emissoras existentes, como um canal local. Entretanto, levando em consideração a hipótese amplamente utilizada de estímulo por parte do governo militar, não demorou para a rede carioca se expandir e tornar-se nacional por meio de facilidades dadas pelo governo a Roberto Marinho. Stycer argumenta que, nas diferentes biografias acerca da emissora na qual ele tem como fonte, uma dessas facilidades era a implementação da Embratel e a criação do Ministério das Comunicações, em 1965, e, posteriormente, a da Telebrás em 1972 (STYCER, 2018, p. 21).

O governo militar entende como prioridade, do ponto de vista da 'segurança nacional, as obras de ampliação e modernização do sistema de telecomunicações e vai criar uma infraestrutura que, ao ser também utilizada pelos canais privados de televisão, tornará possível o alcance nacional da programação. (STYCER, 2018, p. 21 - 22).

Como instrumento simbólico, a televisão brasileira teve importante papel na construção da organização social, na edificação do espaço público midiático e na circulação de sentidos com a disposição do repertório nacional por meio de temas sociais. A dimensão desse suporte comunicacional no estabelecimento de marcadores socioculturais está calcada na interação social transmitidas por seus programas. Como ponto de partida, os questionamentos que pautam o texto televisivo levam em consideração a adaptabilidade da televisão nos lares brasileiros, tendo como a protagonista desses efeitos as ficções televisivas. Desse modo, as reconfigurações culturais e tecnológicas emergem questionamentos acerca dos contrastes culturais transmitidos e em quais dimensões contribuem para a construção desses significados.

Em sua análise crítica sobre a televisão, Raymond Williams (2016) visa, sob a tríade sociedade, tecnologia e cultura, situar o debate sobre a televisão e seus aspectos no que diz respeito ao seu fluxo de programação. O autor parte das versões de causa e efeito para o advento da televisão na sociedade, debruçando-se nas declarações sobre seus impactos, como a alteração da "nossa percepção básica da realidade e, por conseguinte, nossas relações uns com os outros e com o mundo" (p. 25), além das causas que levam em consideração as mudanças nas sociedades e como isso possibilitou o surgimento de uma tecnologia capaz de supri-la. A criação da televisão, como a de qualquer outra ferramenta tecnológica, em sua maioria, carece de intencionalidade, o que passa a nos interessar e se tornar de fato algo a ser estudado são seus efeitos e circunstâncias 
históricas. Em síntese, em sua fala, "uma tecnologia só adquire status efetivo quando utilizada para fins já contidos nesse processo social conhecido" (p. 27), Williams indica que o processo social o qual possibilitou a gestação da televisão ratifica mudanças sociais de outros níveis, no entanto,

De forma nenhuma, porém, essa é uma história de sistemas de comunicação que criaram uma nova sociedade ou novas condições sociais. A transformação decisiva e anterior de produção industrial e suas novas formas sociais, que tinham crescido a partir de uma longa história de acumulação de capital e de trabalho de melhorias tecnológicas, criaram novas necessidades, mas também novas possibilidades, e os sistemas de comunicação, incluindo a televisão, foram seu resultado intrínseco. (WILLIAMS, 2016, p. 32)

A partir disso, a reflexividade sobre a cultura e a televisão perpassa por seus mecanismos de ressignificação, o adquirir de novas funções e em como a sociedade em si constrói outras lógicas, convivendo bem com essas divergências. A criação de necessidade desencadeia transformações culturais, as invenções alteram e dão ênfase aos processos socioculturais vigentes, adequando-os às novas condições humanas. A sistemática mudança social ocorrida por meio da introdução dos aparelhos televisores nos lares brasileiros foi a chave inicial para o processo de modernização. A admissão dos aparelhos no eixo Rio de Janeiro e São Paulo figurou, para a indústria local, um auxílio na venda de bens de consumo. Isto posto, do ponto de vista econômico, a televisão possibilitou a expansão do mercado consumidor; já sob o viés da política, a ditadura recorreu à televisão como um recurso para imposição de sua integração nacional (HAMBURGUER, 2014).

A centralidade da televisão, levando em consideração sua institucionalização na época da ditadura por meio de políticas de integração e da criação de uma ideologia homogênea do País, nos leva a pensar se a integração nacional, ao nível alcançado na época do regime militar, seria possível sem a televisão. Marilena Chauí (2004) argumenta que tal "conhecimento/reconhecimento pela imagem do Brasil não se opera somente no sentido de apagar as diferenças sociais e regionais reais ou reduzi-las a aspectos folclóricos, mas opera no sentido de ocultar o país” (p. 12). Isso se dá, segundo a autora, pela dualidade fato-ficção, o fato é transformado em ficção e a ficção na realidade do cotidiano; desse modo, fatos são apresentados em sua interpretação já posta ao telespectador. Isso é operacionalizado pela formação da programação televisiva da TV 
Globo, que escalona em seu horário nobre telenovela seguido de telejornal. "As múltiplas linguagens que convivem na televisão - apresentações musicais, dramaturgia, esporte, jornalismo, dentre outras - materializam-se em uma série de enunciados singulares que se apresentam como eventos unitários, programas" (CARDOSO, 2008, p 18). Esses programas obedecem a uma lógica mercadológica, por meio de uma dança entre informação e entretenimento, que vem balizando o cotidiano do brasileiro desde a década de 1960.

O contexto que possibilitou a entrada da televisão no cerne da cultura brasileira está intrinsecamente ligado ao que Santaella (2008) denomina de salto na passagem da cultura oral para a cultura letrada. Enquanto em países europeus a linguagem impressa teve anos para se concretizar, pelos livros e jornais, no Brasil, esse processo foi quase inexistente - especialmente pelos altos índices de analfabetismo. Portanto, da cultura oral passamos para uma segunda oralidade fornecida pelo rádio e, posteriormente, pela televisão, a qual soube captar com maestria as características brasileiras. Deste modo, mesmo que, a princípio, a televisão só estivesse alocada nos domicílios mais abastados, os incentivos estatais possibilitaram sua entrada nas camadas mais pobres.

No caso brasileiro - ao contrário do que ocorrera em países da Europa ocidental, como a França -, no momento da consolidação da cultura de massa e da indústria cultura, ainda não se impusera plenamente a profissionalização dos meios intelectuais e artísticos, nem estavam bem estabelecidos polos autônomos de produção, nos quais a legitimidade artística estaria definida pelos próprios pares com base em critérios estéticos pouco afetados pela racionalidade da sociedade industrial. Ou seja, não havia uma sólida cultura erudita no país, com fronteiras bem estabelecidas entre as artes, a ser afetada pela cultura de massa. Esses processos ocorreram quase simultaneamente, sobretudo a partir dos anos de 1960. (RIDENTI, 2014, p. 31-32)

As mensagens veiculadas pela televisão foram determinantes para o que Lopes (2003) denomina de criação de um novo espaço público, no qual a visibilidade das discussões é elevada a novos patamares, pois são televisionadas. Consolidada por transformações da indústria e do capitalismo no país, a produção cultural teve seu maior rendimento na indústria televisual. Com a repetição dessas mensagens televisivas no ambiente doméstico, criou-se um entendimento da realidade da vida brasileira, com isso

A televisão oferece a difusão de informações acessíveis a todos sem distinção de pertencimento social, classe ou região. Ao fazê-lo, ela torna disponíveis repertórios anteriormente da alçada privilegiada de certas instituições socializadoras tradicionais como a escola, a família, a igreja, o partido político, a agência estatal. A televisão dissemina a 
propaganda e orienta o consumo que inspira a formação de identidades. Nesse sentido, a televisão, e a telenovela em particular, é emblemática do surgimento de um novo espaço público, no qual o controle da formação e dos repertórios disponíveis mudou de mãos, deixou de ser monopólio dos intelectuais, políticos e governantes, dos titulares dos postos de comando da sociedade. (LOPES, 2003, p. 18)

Ligada a processos sociais, a identidade é conservada e delimitada por estruturas sociais (BERGER e LUCKMANN, 2013 [1966], p. 221), realidade partilhada pelas representações e sentidos provenientes da televisão, especificamente das telenovelas. Tendo em vista que a televisão, em seu potencial midiático, fala do mundo, mas também fala de si mesma, ela impulsiona a vida cotidiana em seus referenciais e redireciona as perspectivas sociais. As mudanças estruturais envolvendo os meios midiáticos, a saber, televisão e internet, reposicionam os novos modelos de assistência de ficções, como a constituição de expansão dos públicos televisivos. Tal reorientação de hábitos, possibilitada por estratégias estéticas e mercadológicas, movimenta a dinâmica das mídias e o agenciamento de repertórios.

Freire Filho (2008) destaca cinco pontos de partida epistemológicos no qual a televisão pode ser abarcada. São aspectos que podem ser encontrados em análises que permitem o cerceamento do objeto tão abrangente quanto o cenário televisivo; e dentre esses elementos, destaca-se a televisão como fenômeno sociocultural, que, no dizer do autor, está "profundamente interconectado com a política, a esfera pública e a sociedade civil, com a cultura popular (e de massa), com o caráter mutável do lar e dos valores domésticos" (p. 130). Essa dimensão por si só é abrangente e incide nas investigações dos fatores internos e externos que demarcam a relação da TV com seu público. A sofisticação das ficções nacionais permitiu a mescla desses fatores em que temos articulados um contexto produtivo, a saber, a televisão, e as próprias narrativas que falam de um mundo e apresentam um contexto histórico-social.

\subsection{O Paradigma da telenovela brasileira}

Denominada Sua Vida me Pertence, de Walter Forster, a primeira telenovela brasileira teve sua estreia em 21 de dezembro de 1951 e contou com apenas 15 capítulos. Com uma clara influência da radionovela e do teatro, desde esse ano, a telenovela foi se firmando na programação das principais emissoras do país. Ao longo dos anos, as 
produções foram consolidando um padrão próprio, traço indelével da criatividade e subjetividade nacional. Segundo Mary del Priore (2019), a televisão expandiu o escopo de lazer do brasileiro a partir da metade do século XX, já que, com as telas, era possível passar mais tempo nos lares e, ainda "dava status, e não faltou quem convidasse as amigas para um chá com os artistas: elas na sala e eles na tela” (p. 256). O entretenimento dentro do lar possibilitou uma gama de modificações quanto à interação dentro do espaço doméstico, que, por conseguinte, passou a contar com um novo morador, a televisão, protagonista nas salas de estar que demandava, ao logo do dia, um público amplo e cativo.

A telenovela brasileira, caracterizada por sua construção narratológica complexa e extensa, configura-se entre os maiores produtos culturais do País. Produto cultural enraizado, como argumentamos, na subjetividade brasileira, haja vista que ela apresenta interstícios entre seu próprio lugar de produção e sua carga simbólica, criando bases de discussão e arejamento de ideias. O destaque dessas produções ficcionais se dá por seu caráter dialógico - no sentido de trazer uma agenda de assuntos ao qual a sociedade se debruça para conversas nos mais variados âmbitos sociais, proporcionando identificação cultural, por meio de seus bordões, atitudes, costumes, hábitos e o modos de fala. E disponibiliza um diário histórico, em que, pelas imagens e sons exibidos, constroem visões de mundo e a visão do outro. Essas características estão no cerne do que Lopes e Baccega (2001) expõem como o paradigma da telenovela brasileira ${ }^{6}$, que se distingue das demais produções realizadas por outros países.

Para a autora, a América Latina conta com dois paradigmas quanto à telenovela, o paradigma mexicano e o brasileiro. Ambos têm como base o melodrama, no entanto os contornos melodramáticos são distintos; a ficção brasileira apresenta características do naturalismo e da verossimilhança e, ao longo de sua produção e transmissão, atingiu altos níveis de sofisticação. Pela TV Globo, esse processo deu início ao que hoje denominamos de "padrão Globo de qualidade", especialmente a partir do comando de Glória Magadan no setor de teledramaturgia da emissora em $1965^{7}$. Em seu processo de consolidação, a telenovela soube trabalhar com os aspectos culturais vigentes na sociedade brasileira em pleno cenário ditatorial. A cada trama, um tema era apresentado ao telespectador, que,

\footnotetext{
${ }^{6}$ Lopes aborda esse paradigma especialmente nas reuniões do Centro de Estudos de Telenovela - CETVN, para designar as características únicas das ficções brasileiras. Entretanto, Baccega, ressalta essa característica no texto

${ }^{7}$ http://memoriaglobo.globo.com/perfis/talentos/gloria-magadan.htm
} 
ansioso, ia conhecendo os personagens e seu entorno. Em seu início, apresentavam as histórias por meio da experimentação, muitas advindas do teatro e do rádio, para então alcançar a estrutura vista hoje, com a abordagem de temáticas variadas:

Como é sabido, nossa telenovela passou depois por uma trajetória de gradual abrasileiramento temático e aperfeiçoamento de sua estrutura dramática, aprimorada pelos dramaturgos que a censura autoritária perseguiu no teatro e que terminaram por atuar na TV - veículo menos visado pela ditadura na época - e pela experiência de veteranos de outras artes ou meios. Esse aperfeiçoamento, pouco usual no restante das telenovelas latino-americanas, redundou na multiplicação de intrigas secundárias. (BALOGH, 2001, p. 170)

A mistura entre ficção e realidade é a tônica da telenovela brasileira, que soube, ao longo dos anos, estabelecer tal paradigma, um padrão de qualidade que a diferencia das demais produções pelo mundo. Esse traço a inclui como uma formadora de comportamentos e hábitos, além de incitadora de discussões. Ela está, por sua vez, no cerne da TV brasileira, sendo o melodrama - seu gênero matricial - o grande engajador de emoções. Segundo Baccega (2000), a linguagem da televisão é a narrativa, seu discurso oral "precisa fundamentar-se em fórmulas narrativas que possam ser memorizadas, ou seja, ela precisa trazer alusões a mitos, símbolos e estruturas do imaginário que sejam dadas como certas pelos receptores" (p. 46).

A telenovela nacional caracteriza-se como um paradigma único em si devendo aí ser inseridas as características estilísticas do realismo e do naturalismo que foi se moldando através do tempo e que é onde reside sua enorme capacidade comunicativa de criar narrativas que promovem sentidos junto à audiência que a cultiva (o que faz dela a maior audiência da televisão brasileira) e, por isso, a repercussão dos debates e discussões tanto na esfera pública (hoje, principalmente na internet) como na privada (conversações pessoais). A despeito da matriz cultural melodramática, ou por isso mesmo, essas narrativas, no contexto brasileiro, alcançam função mobilizadora de opiniões, isto é, um papel de convocação de debates na sociedade. Assim, no âmbito desta pesquisa, as ficções televisivas serão abordadas principalmente através dessa função de agenciadora de assuntos, estimulando a circulação de sentidos. Os agenciamentos propiciados pela telenovela abrem um campo profícuo de discussões acerca da própria sociedade brasileira. Trata-se de um caso único em que a força cultural de um produto televisivo pauta uma agenda pública e permanente (não há hiato temporal entre uma novela e outra) de debates mesmo para aqueles que não têm o hábito de sua assistência. 
Para os intuitos deste trabalho, tomamos como referência de telenovela as produções realizadas pela TV Globo, e como exposto na metodologia, as ficções pertencentes ao horário nobre. Anteriormente denominadas de "novela das oito", essas produções, com o passar dos anos, têm sido transmitidas por volta das 21 horas, exemplificando uma mudança crescente nos hábitos notívagos de assistência. Em 08 de novembro de 1965, nasce a "novela das oito", com a estreia de $O$ Ébrio (TV Tupi), com 75 capítulos. Essa faixa horária dedicada à ficção aparentemente foi criada para concorrer com o telejornal Repórter Esso transmitido pela TV Tupi quatro vezes ao dia às $8 \mathrm{~h}$, $12 \mathrm{~h} 55,18 \mathrm{~h} 30,20 \mathrm{~h} 25$ e $22 \mathrm{~h} 05$.

Em 2011, a partir de Passione, a Globo passou a denominar a faixa horária de "novela das nove". A mudança, por conseguinte, era mais condizente ao horário ao qual a telenovela é verdadeiramente transmitida, pois às $20 \mathrm{~h}$ se inicia o Jornal Nacional. Essa estratégia de programação formalizou o período de maior rentabilidade da televisão brasileira, em que se observa a construção de uma programação formada pelo enquadramento de entretenimento e informação. A intercalação dos programas tem se mostrado exitosa, no sentido de que eles ofertam ao seu público as informações importantes do dia, seguidos das ficções, que me muitos casos tratam de temas significativos.

A reflexividade sobre a sociedade brasileira abrangida pelas ficções se mostra, sobretudo, a partir dos mais variados assuntos que são postos todos os dias em cada capítulo. As diversas temáticas tendem a criar uma rede de assuntos que circulam nos mais variados meios, sejam nas redes sociais ou na mesa de bar; essa capacidade discursiva nos serve de insumo para a compreensão da telenovela e seu papel na difusão do que se considera cultura brasileira. Sabemos que as dimensões continentais do Brasil tornam difícil uma exposição completa de todos os aspectos de sua cultura, entretanto se sobressaem alguns aspectos culturais rotineiramente admitidos. As narrativas ficcionais televisivas se prestam para o entendimento dos processos culturais locais ou regionais vigentes e, como abordado, promovem o estreitamento das discussões compreendidas pelas tramas como as questões identitárias e sociais no País. 


\title{
1.3 Entre a Mimese e a Catarse: o melodrama
}

A representação do drama diário vivido pelas personagens das ficções acompanha a rotina do brasileiro ao longo da semana. Essa representação se insere por meio do viés melodramático advindo do folhetim, que se utiliza dos mecanismos da mimese e da catarse (ARISTÓTELES, 2018) para indução de sentimentos; a mimese como identificação e a catarse como a purificação das ações geradas pelos personagens. Isso só é alcançado pela exacerbação e intensificação de sentimentos suscitados por essas narrativas. Neste sentido, a mimese aristotélica prevê a imitação dos fatos com o intuito de torná-los reais e universais, "pois a tragédia é a mimesis não de homens, mas de ação e vida, e tanto a felicidade quanto a infelicidade estão na ação e a finalidade é a ação, não uma qualidade" (p. 49). Para o filósofo, o ser humano possui uma tendência inata para imitação, e, por meio desse ato, ele adquire os primeiros conhecimentos. As obras miméticas como as imagens têm o efeito de nos alegrar por seu caráter de conhecimento, "pois, por isso, alegram-se vendo as imagens porque acontece que os que contemplam aprendem e concluem o que é cada coisa, por exemplo, que este é aquele; porque, se por acaso alguém não as tiver visto antes, não produzirá prazer enquanto algo mimetizado, mas pelo acabamento ou pela cor ou por alguma outra causa semelhante" (p. 39). Em sua interpretação de Sobre a Arte Poética, Palhares (2013) comenta que a mimese está no cerne da capacidade criadora do ser humano, é a partir dela que provêm os mitos e com isso o humano é apto a variados tipos de comportamentos que são, por sua vez, insumos para histórias.

\begin{abstract}
A tragédia, através de uma maneira natural e verossímil/ plausível de compor os fatos, tornar-se-ia educativa pela imitação de personagens e ações importantes, além de ser um objeto capaz de suscitar prazeres específicos com efeitos voltados para a obtenção de sentimentos de compaixão e terror, surpresa e admiração, divertimento e indignação. (PALHARES, 2013, p. 17)
\end{abstract}

A catarse deriva das ações representadas pelos atores, que, por suas interpretações, suscitam no público sentimentos de empatia, admiração, raiva, terror e indignação. $O$ essencial seria o incitamento de emoções provocados pelas atuações e não necessariamente abarcadas pelo texto; essas emoções - durante e/ou após a representações - são purgadas, em um estado de libertação da alma. 
O recurso melodramático, utilizado como suscitador de sentimentos, tem como base as ações dos personagens, envolvidos em relações familiares, conflitos amorosos e intrigas, que são apresentados ao público em situações por vezes surpreendentes, pois a principal matéria-prima do melodrama é a própria emoção, que é manipulada para promover reações específicas (LIMA, p. 44, 2018). O que se percebe é que o melodrama, para estabelecer a mimese e atingir a catarse, trabalha com as dicotomias clássicas entre bem e mal, rico e pobre. São opostos que, bem empregados numa narrativa, dão início ao prosseguimento da ação, tendo em vista que "são os personagens, seus desejos, seus objetivos, suas fraquezas que puxam o drama para frente" (RODRIGUES, p. 53, 2014). Neste puxar é que temos o fio condutor de uma telenovela com diversos núcleos para um fôlego de aproximadamente oito meses de exibição diária.

A semelhança com a realidade é a tônica para os mecanismos do melodrama, que tem no sentimentalismo e naturalismo as fórmulas para a realização das telenovelas. Xavier (2003) ressalta o papel regulador do melodrama nas sociedades, pois, nesta função, seu papel é de ofertar "matrizes aparentemente sólidas de avaliação da experiência num mundo tremendamente instável” (p. 91). Conforme ele comenta:

Flexível, capaz de rígidas adaptações, o melodrama formaliza um imaginário que busca sempre dar corpo à moral, torná-la visível, quando ela parece ter perdido seus alicerces. Provê à sociedade uma pedagogia do certo e do errado que não exige uma explicação racional do mundo, confiando na intuição e nos sentimentos 'naturais do indivíduo na lida com dramas que envolvem, quase sempre, laços de família. (XAVIER, 2003, p. 91, grifos do autor)

Gledhill e Williams (2018) atentam para os variados conceitos e interpretações que concernem ao melodrama, sublinhando como ele é crucial para se entender as ficções dramáticas populares na modernidade. As teóricas entendem que o melodrama fez parte do processo de modernidade do contexto ocidental, essenciais na instauração das mídias e na criação dos dramas, pois o melodrama "é a proteína que pula de uma mídia a outra em diferentes culturas do mundo globalizado" (GLEDHILL; WILLIAMS, 2018, p. 15). Essa transformação social ocorrida na Europa, onde a hierarquia nobiliária perdeu espaço para processos de democratização, criou, de acordo com as autoras, uma estrutura de sentimento tal como concebida por Reymond Williams (1979) em sua análise sociocultural. A estrutura de sentimento, de acordo com o autor, corresponde ao sentimento social experienciado em determinada época. Tais acontecimentos históricos 
estão sujeitos a serem abarcados posteriormente, trazendo em si resquícios de sentimentos e experiências, porém também estão em constante transformações. As narrativas, como na literatura e na televisão, apresentam um contexto para a compreensão de uma época, dando um cenário para que se apresentem os fenômenos sociais ocorridos neste período. Estrutura de sentimento, contrapondo termos como ideologia, está atrelada à ideia de práticas mentais e sociais (CEVASCO, 2001). Na abordagem aderida por Gledhill e Williams, essa troca social que deu origem ao início da modernidade com uma série de rupturas e reorganizações que foram refletidas nas artes como o teatro, onde os dramas dessa burguesia em gestação foram amplamente desenvolvidos; tanto na companhia de teatro de Moliére como nas obras Le bourgeois gentilhomme e La maladie imaginaire.

O panorama histórico social, neste sentido, é importante para pensarmos como cada lugar nuançou os aspectos do melodrama. Na América Latina, Martín-Barbero (2015) já atenta para como o modelo comercial do melodrama, como as telenovelas, maneja os sentimentos de seus espectadores com o medo, o entusiasmo, a lástima e o riso. Apesar de estabelecer essas dicotomias, a telenovela brasileira, também em sua característica naturalista, explora as nuances da caracterização dos personagens, e sua ambiguidade em determinadas situações pode fazê-lo parecer contraditório e ser um recurso para intensificar os mecanismos de identificação, projeção e transparência (CANDIDO, 2000). Personagens complexos e ambivalentes possibilitam uma relação de proximidade entre o real e o fictício, e, no caso da telenovela, são personagens que escapam das ficções e adentram no campo do real, estabelecendo afinidade e até sendo marcado na memória da nação.

O tom emocional, ou seja, o apelo dramático da telenovela - marcante nas narrativas - estabelece essa ligação, alternando momentos de descontrole com momentos de êxtase. Isso fica claro nas viradas, como elucida Daniel Filho (2001), ao mencionar que a estrutura da telenovela obedece a quatro fases bem demarcadas, com blocos de seis em seis, correspondentes a uma semana. Assim temos:

1. Até o capítulo 30: os rumos que a história irá tomar;

2. Capítulo 50: a primeira grande virada na narrativa;

3. Capítulo 80: início da barriga;

4. Capítulo 110: segunda grande virada ou até mesmo a segunda parte da trama; 
5. Capítulo 130: até o final da telenovela.

Esse esquema proporcionado por Filho reforça seu argumento de que a "telenovela se industrializou" (2001, p. 180), sublinhando o estágio artístico de obra individual para obra coletiva. $\mathrm{Na}$ dança entre produção e recepção, os elementos que compõem as tramas vão se perfazendo para compor a obra num ecossistema complexo que compreende os autores, os atores, os diretores, além dos espectadores e da crítica. Nesse ecossistema são estabelecidas as tensões de sentido entre as gramáticas da recepção e as gramáticas da produção (VÉRON, 1980). Essas tensões fomentam o campo discursivo e imersivo da telenovela, e é por meio delas que as contradições e desdobramentos da trama tomam forma.

Os estudos para a compreensão da inserção social da telenovela se voltam para a característica catártica presente nas ficções, bem como sua reinterpretação e ressignificação por parte dos telespectadores. Como produto da indústria cultural, as ficções perpassam por assuntos que demonstram uma pedagogia da imagem e da alteridade; a primeira, no sentido das especificidades na maneira de contar, uma hibridização em seu modelo de produção, e a segunda, em seu recurso comunicativo, na capacidade de dispor e tratar de temas sociais diversos e complexos.

Pelas tensões de sentido, as representações que são abarcadas pela telenovela abrangem toda uma coleção das características sociais brasileiras. Por meio da mimese, ao mesmo tempo em que ratifica padrões de desigualdade e discriminação, também alimenta um repertório de sentidos que transpõem classes sociais, gênero, região, raça e gerações. Todavia, incontestavelmente, não mostra um consenso sobre as interpretações que possam advir dessa narrativa, isso fica claro ao observarmos as representações de grupos minoritários realizadas nas tramas. A eclosão de novos paradigmas com novas vozes e representações faz um contraponto aos estereótipos ainda comumente vistos. A insurreição de novos sujeitos, antes invisíveis, emerge para as telas, promove um avanço nos discursos mostrados. As mudanças ainda aparecem sensíveis em comparação a outras televisões pelo mundo, entretanto, multiplicam-se as temáticas das minorias, preservação do meio ambiente, entre outras.

Tal mudança está longe de se tornar um consenso, porém, vale ressaltar que os sentidos demarcados pela televisão levam a formar o que Anderson (2008) denominou de comunidades imaginadas, ou seja, "ela é imaginada porque mesmo os membros da mais 
minúscula das nações jamais conhecerão, encontrarão, ou sequer ouvirão falar da maioria de seus companheiros, embora todos tenham em mente a imagem viva de comunhão entre eles" (p. 32). A soberania dessa comunidade, mesmo sendo limitada, replica sentidos e identidades forjando esse sentimento de compartilhamento entre seus indivíduos. Para o autor, o ritual da leitura dos jornais contribui para a construção do sentimento de pertencimento característico da comunidade imaginada. Desse modo, um aspecto sensível à dimensão televisiva é sua evocação dos padrões de brasilidade, em outras palavras, o que se vê televisionado pertence ao emaranhado de traços da cotidianidade brasileira, como violência, relacionamentos, trabalho, saúde, bem-estar; aspectos que excedem a esfera pública e adentram em traços culturais específicos.

As ficções televisivas balanceiam as evidências dessa representação, amenizadas pelas funções melodramáticas e pedagógicas, imbricadas por meio da fala coloquial e da verossimilhança. No dizer de França (2009), a televisão opera como uma das instâncias do tecido social, é instrumento da manutenção da ordem dominante, de valores e tendências, assim,

é possível compreender as permanentes trocas entre a televisão e sociedade como pautadas por e resultado em permanentes equilíbrios e reequilíbrios. Alterações de valores, ocorrência de acontecimentos e transformações em diferentes aspectos da estrutura de uma sociedade, assim como, naturalmente, sua herança histórica, suas tradições, seus traços culturais específicos, incidem na televisão que se pode fazer, na programação, no perfil das diferentes emissoras (FRANÇA, 2009, p. $31)$.

Logo, a problematização dos temas sociais promove uma relação de retroalimentação entre sociedade e ficção, ao saber transportar os mais variados assuntos aos seus telespectadores, ao trabalhar com características de sua própria comunidade, demarcando traços de proximidade e do cotidiano. Porém, neste dialogismo entre realidade e ficção, os arranjos sociais vigentes evidenciam normas e padrões de comportamento muitas vezes padronizados, o que não conflui para a realidade. Logo, isso cria sentidos contraditórios, já que, ao mesmo tempo que abarca o contexto histórico social, as tramas nem sempre condizem com o real e nem sempre devem estar de acordo com o real, mas sim, seguir os ditames propostos pelo autor no interior da obra.

A televisão como um canal de articulação do pensamento, no sentido de utilizar o arcabouço das imagens em movimento para impor um pensamento e representar o mundo, 
está em conformidade com que Serelle (2011) afirma como "cultura da reparação", possibilitada, segundo o autor, pela falta de capital cultural, que alberga na programação televisiva e em seus produtos uma cartilha pedagógica de entendimento do mundo. Ele argumenta para a forma como as produções extrapolam o escopo ficcional na confecção de seus personagens e são adaptadas a exigências encontradas fora das narrativas, portanto, na sociedade em si.

\subsection{A Telenovela e seus Afetos}

A constante conversa entre aspectos internos (produção) e externos (recepção) que permeiam o fazer televisivo nos possibilita um olhar para a telenovela a partir de sua capacidade de criar conhecimento crítico por meio de seu critério de potencial cognitivo (BENJAMIN, 2018). Castro (2014), a partir de Benjamin, menciona que "é considerada uma arte uma obra que suscite reflexão e, deste modo, a própria criticabilidade já representa um juízo de valor positivo" (p. 21). A telenovela, ao longo de seu processo de concretização, criou e disseminou essa reflexão que gerou, em consequência, o procedimento crítico que a acompanha durante sua exibição.

Com isso, estabelecemos a telenovela por dois vieses: produto da indústria cultural, comercializado para diferentes países e exibido em diversas plataformas; e como uma obra audiovisual, no sentido de trazer um esforço de reflexão por meio do contexto sociocultural brasileiro. O caráter da indústria cultural leva em consideração as implicações quanto às lógicas empresariais e de mercado, na qual estão inseridos os produtos televisuais. Entremeada nessas duas lógicas, arte e produto, a telenovela ocupa lugar de destaque nas dinâmicas sociais do país, em que ressalta sentidos contraditórios e tensões, mas também são produções que, de certa forma, são produtos de seu tempo.

Isto posto, televisão se configura como uma ambiência multissensorial (SODRÉ, 2001), trabalhando diretamente no corpo do indivíduo e exercendo um papel de administrador do tempo de lazer e da subjetividade. Ainda pela mimese e a catarse, as ficções constituem uma ligação subjetiva que atua pelos mecanismos de identificação, transmissão e representação de significados. A ficcionalidade, portanto, desencadeia o relacionamento entre o indivíduo e a narrativa apresentada, criando laços empáticos, 
acarretando nos afetos. Pela noção de afeto (SPINOZA, 2009 [1677]), esse indivíduo, isto é, esse corpo afetado pela ambiência televisiva entra em contato com experiências que podem aumentar ou diminuir sua potência, tendo em vista que "por afeto compreendo as afecções do corpo, pelas quais sua potência de agir é aumentada ou diminuída, estimulada ou refreada, e ao mesmo tempo as ideias dessas afecções" (p.98). Tais afecções são justamente o corpo sendo afetado pelo seu contexto, são encontros que podem ocasionar um aumento ou diminuição da potência, dado que, para Spinoza, a pergunta central é o que pode um corpo. Logo, os afetos são biopolíticos (FOUCAULT, 2008), são constructos sociais possibilitados por dispositivos que instituem e permitem o advento de práticas que operam transformações em uma sociedade.

O que esse corpo pode fazer é o grande questionamento de Spinoza. Tal pergunta vai de contra ao pensamento filosófico anterior de que o corpo sempre foi subjugado às paixões, sendo as forças desse corpo suprimidas. Assim, baseado nas dicotomias, a razão em detrimento do corpo, a assimetria entre corpo e pensamento, o autor tende a desmontálas, promovendo a ideia de que não há esse distanciamento entre corpo e razão. Daí que adentramos na questão do afeto na comunicação, dado que o ser afetado é uma questão de existência, e, ao se colocar no mundo, ele está suscetível a ser afetado ou não, pois cada um vai ter um poder de afetar e ser afetado. Esse poder, no sentido de potência, é mais notado no afetar, porém no afetado também se constitui um poder, tendo em vista que ser afetado é uma condição que envolve o poder, não simplesmente uma passividade.

Spinoza (2009, [1677]) nota que "durante todo o tempo em que o homem é afetado pela imagem de uma coisa, ele a considerará como presente, mesmo que ela não exista" (p.111), pois a ampliação do grau de potência é justamente perceber, ter o poder de ser afetado e afetar. Isso ocorre porque o estado dos corpos (afetos) gera um sentimento referente àquela imagem, seja ela do passado ou do presente. E, para o filósofo holandês, o que pode um corpo em um ambiente é diferente do que pode o corpo em outro encontro; tudo depende desse encontro, e seu grau de potência é diferente de acordo com tais encontros que ocorrem no decorrer da vida.

Dessa forma, não há, segundo o filósofo, nenhuma ideia na mente à qual não corresponda um afeto no corpo, visto que está ligado inerentemente a uma tonalidade afetiva. Escolhas e decisões estão calcadas em redes multidimensionais que fomentam a relação afeto - ideia. Safatle (2018) argumenta que as "sociedades são, em seu nível 
fundamental, circuitos de afetos" (p. 15). Esses circuitos ou redes nos fazem perceber os comportamentos sociais entremeados aos sistemas de normas pelos quais uma sociedade é regida, "pois produções sociais nos campos da linguagem, do desejo e do trabalho são avaliadas em referência a normatividade que parecem intersubjetivamente partilhadas e, por isso, dotadas de força de coesão" (p. 15).

Nesse entendimento dos afetos, visto por Spinoza como "paixão do ânimo" (p. 152), vemos que a tonalidade afetiva a qual a telenovela carrega, acarretou num hábito cognitivo aprimorado pela competência do assistir junto. Essa prática cotidiana permite o lugar dos afetos, criando uma dependência normativa e, consequentemente, uma flexibilização desses afetos. As emoções suscitadas, que podem variar do choro, da indignação e da alegria, remetem à articulação dos mecanismos dos melodramas, que fazem a "ponte entre os olhos e o coração" (XAVIER, 2003, p. 92). Os afetos, por sua vez, compreendem o conjunto tanto das emoções quanto dos sentimentos. A expressão afetiva se mostra pelas transformações fisiológicas, enquanto os sentimentos correspondem ao um estado afetivo menos intenso que as emoções, porém mais durável.

Didi-Huberman (2013) explica que a emoção é um movimento portanto, tende à ação, "algo como um gesto ao mesmo tempo interior e exterior, pois, quando a emoção nos atravessa, nossa alma se move, treme, se agita, e nosso corpo faz uma série de coisas que nem sequer imaginamos" (p. 26). Esse afluxo proveniente das emoções são combinações de ações originadas no interior do indivíduo, porém são externalizadas e materializadas por expressões, choros e/ou gritos. O filósofo francês pondera que determinadas emoções, a partir da etnografia e da sociologia, podem ser vistas a partir de uma história cultural, decodificadas por meio de um contexto específico do que é esperado em algumas situações. São ações e gestos que fazem sentido e são reconhecíveis na sociedade onde está sendo feito, são o que ele afirma como "expressões coletivas das emoções que atravessam a história" (DIDI-HUBERMAN, 2013, p. 34). Tais gestos emotivos são configurados e esperados por determinada sociedade. Vale enumerar que esses comportamentos são reflexos do período histórico de cada contexto e formam o arcabouço de comportamentos referentes a cada situação.

As emoções, uma vez que são moções, movimentos, comoções, são também transformações daqueles e daquelas que se emocionam. Transforma-se é passar de um estado a outro: continuamos firmes em nossa ideia de que emoção não pode ser definida como um estado de pura e simples passividade. Inclusive, é por meio das emoções que 
podemos, eventualmente, transformar nosso mundo, desde que, é claro, elas mesmas transformem em pensamentos e ações. (DIDIHUBERMAN, 2013, p. 38)

Esse poder mobilizador das emoções está no cerne das ficções brasileiras, e elas são abrangidas pelas ações dos personagens e nas temáticas sociais contempladas em cena. As emoções são as incitadoras pelos dramas vividos por essas pessoas fictícias. As telenovelas do nosso corpus trazem sérios conflitos morais e éticos que corroboram para o andamento da trama, e, por conseguinte, enfatizam as emoções. Em Amor à Vida (Globo, 2013), o vilão da trama, Félix (Mateus Solano), joga sua sobrinha, uma criança recém-nascida, em uma caçamba de lixo. O Outro Lado do Paraíso (Globo, 2017), a protagonista Clara (Bianca Bin) é estuprada em sua noite de núpcias por seu próprio marido. Em Avenida Brasil (Globo, 2012), vemos Rita (Mel Maia), quando criança, sendo abandonada em um lixão pela madrasta. Em Salve Jorge (Globo, 2012), Morena (Nanda Costa) é vendida e escravizada por uma quadrilha de traficante de pessoas. E, em A Força do Querer (Globo, 2017), Ivana (Carol Duarte) revela a sua família que é transexual.

\subsection{A Telenovela como agência}

Em sua característica de obra aberta, superando por vezes a marca de 150 capítulos, a telenovela é reconfigurada, por exemplo, no que tange à sua serialidade, importante para notarmos a abrangência da circulação de sentidos. Termos como narrativa complexa (MITTELL, 2012), reconfigurações entre gêneros e formatos (LOPES E OROZCO-GÒMEZ, 2016), e televisão distribuída pela internet (LOTZ, 2017; LOBATO, 2019) têm trazido pontos de debate para a academia, bem como para os produtores e públicos. $\mathrm{O}$ avanço tecnológico alavancou a assistência das ficções para além do aparelho televisor domiciliar e a expandiu para inúmeras telas, que hoje permeiam nosso cotidiano pelos aplicativos reprodutores de conteúdo. Vale ressaltar que todas as mudanças e alterações a que as narrativas foram e são submetidas mudam a maneira como ela é apercebida pelo público, que implicam muitas vezes em fóruns de debates sobre as telenovelas na internet, com polêmicas que recaem em diversos aspectos do universo da telenovela. 
As novas experimentações observadas nas ficções no plano internacional têm trazido à televisão brasileira variadas formas de se narrar a ficção, que correspondem especialmente aos gêneros e aos formatos. De modo geral, pode-se dizer que os gêneros são um lugar exterior à obra, uma maneira de organização onde o sentido é produzido e consumido, uma vez que o gênero classifica uma obra. $\mathrm{O}$ formato está associado a questões que condizem com as lógicas de produção e fatores da indústria; logo, os formatos são comercializados e indicam a forma, o processo de produção pelo qual uma história é contada. Como argumenta Straubhaar (2018, p. 33) em seu entendimento acerca dos formatos, eles consistem num "pacote específico de produção, transferido de uma entidade de produção televisiva para outra, para ser adaptado em uma versão local”.

O que se observa ultimamente é uma hibridização entre gêneros e formatos (LOPES; OROZCO-GÓMEZ, 2016), vista nas novas modalizações de contar uma história. No âmbito das telenovelas brasileiras, destacamos que sua principal característica diz respeito a uma produção que reúne diferentes gêneros em uma mesma obra. A telenovela brasileira é, por essência, um formato compósito de gêneros (LOPES et al, 2016). Onde ela costuma alcançar marca elevada é nas telenovelas das $21 \mathrm{~h}$ da TV Globo, em que o gênero de base, o melodrama (já em si, um híbrido de drama e romance) pode aparecer imbricado ao policial, ao cômico, ao suspense, ao fantástico, articulados numa única narrativa.

Visando trabalhar as operações de circulação da telenovela, sabemos que, além das conversas usuais no próprio horário de assistência de um capítulo, as discussões em redes sociais têm se mostrado relevantes. Essas conversas são mais expressivas em redes sociais como o Facebook e o Twitter, sendo que, na primeira, notamos a presença de comunidades de fãs, onde as conversações se dão durante e após a exibição de um capítulo de uma telenovela. No Twitter, por sua vez, as conversas costumam ser feitas por indivíduos aleatórios, com postagens abertas e compartilhamento devido à utilização de hashtags. Nesta rede, o poder de convocação da telenovela à interação do público é mais evidente e instantâneo. Em ambas encontramos variados pontos de vista acerca dos personagens, da produção e de outras questões que podem emergir ao longo da exibição do capítulo, especialmente pela criação e do uso das hashtags. É o que acarreta o engajamento, a interpretação e o intercâmbio discursivos, evidenciando os processos de retroalimentação entre as ficções e a sociedade.

Neste cenário fragmentado, identificamos que as telas são as grandes protagonistas dessa dispersão da espacialidade dos conteúdos. A tela, neste caso, se torna 
a forma, e a telenovela, o conteúdo. Em consequência disso, temos o olhar como a principal mercadoria, sublinhando a centralidade do visual que permite uma multiplicidade cognitiva. A TV como objeto eletrônico disposto em determinado ambiente, os celulares ${ }^{8}$, que se tornaram umas das principais formas de assistência aderidas no Brasil, e os tablets e computadores, de mesa ou portáteis, formam um ecossistema de tecnicidades imbricados na vida cotidiana. Buitoni (2014, p. 223), portanto, discute essa hegemonia das telas, explicitando as grandes telas que perpassaram a humanidade:

No século XX, as telas se impuseram. Estamos na quarta tela. A primeira foi o cinema, grande formador do imaginário ocidental, atuando em espaços coletivos. A segunda tela, a televisão. Continuou a modelar o imaginário, mas invadindo espaços domésticos. Essas duas telas dificultaram a divisão de vizinhança e comunidade. A terceira tela, do computador, aglutinou competências linguísticas de livros e jornais e a cultura visual que já havia sido apresentada pelas artes e assumida pelo cinema e televisão. O computador foi adotado em ambientes de trabalho e também para uso pessoal. Finalmente, a quarta tela, para tela, a pequena tela dos celulares, passou a trabalhar com todas as outras tecnologias anteriores.

As ficções televisivas se veem espalhadas por essas plataformas - que, por sua vez, fomentam a interatividade do usuário - e expandem o processo de sua circulação de sentidos. Segundo Depexe (2015), “a circulação da telenovela se dá pelos sujeitos que a fazem circular, construindo as redes de conexões de sentidos dos usos e apropriações da telenovela e do Twitter" (p. 99). Esse processo de circulação de sentido nas redes "é um reflexo da interferência dos processos de midiatização latentes na sociedade onde tudo precisa passar pela mídia para obter legitimação diante do social” (PIENIZ, 2015, 224).

De acordo com Lopes (2011), o público pode mostrar sua participação nas redes por meio da interatividade em três níveis, a) uma interatividade passiva, sem que o usuário dê um feedback; b) uma interatividade ativa, na qual esse usuário oferece um feedback possibilitado pela plataforma que está utilizando; e c) uma interatividade participativa, em que se demonstra um usuário consumidor e produtor de conteúdo, aquele que ressignifica e constrói algo novo com aquilo que é oferecido. Aquino e Puhl (2011) demostraram que, no momento, as práticas de assistência das telenovelas estão imbricadas ao engajamento nas redes sociais, onde há uma constante negociação criativa entre os públicos e as telenovelas, como no caso dos fãs que se apropriam e ressignificam as narrativas. "As práticas referentes ao Twitter podem ser caracterizadas como novas

\footnotetext{
${ }^{8}$ Dados do Anuário Obitel 2018
} 
ritualidades na recepção de telenovela, envolvidas na busca por socialidade" (PIENIZ, 2015, p. 222), além de destacarem o caráter do assistir junto, comportamento-chave que marcou os rituais de assistência das telenovelas. Logo,

No Twitter, por exemplo, esse processo se mostra, dentre outras formas, simultâneo ao ato do receptor consumir conteúdos de algum meio de comunicação tradicional. Indivíduos assistem aos programas televisivos, ouvem rádio, estão no cinema, leem jornais impressos ou digitais e comentam sobre isso nesta rede social on-line. Podem ainda compartilhar links, buscar mais informações com seus pares ou, mesmo, tornarem-se parte do grupo que faz as notícias da mídia massiva circularem na web. (PIENIZ, 2015, p. 214)

As conversações sobre as telenovelas versam, em sua maioria, sobre as temáticas vistas em cena, durante ou após a transmissão. Como um recurso comunicativo, a telenovela faz um convite à reflexão, contudo ele não é harmônico devido ao texto televisivo sofrer com a influência das audiências. A conversa com o público pela apresentação de temas morais e éticos é a base da construção de significados na sociedade realizado pela telenovela. "É importante esclarecer que temas de importância social são aqueles que, em determinado momento histórico, refletem inquietações, geram questionamentos e propõem problemas a serem pensados, definidos, resolvidos pelo ambiente social em que circulam" (MOTTER; JAKUBASZKO, 2007, p. 59). Neste sentido, segundo a metodologia de análise das ficções do Anuário do Observatório IberoAmericano de Ficção Televisiva - Obitel, as temáticas são divididas em temáticas sociais e dominantes. Ambas atendem ao que Motter e Jakubaszko (2007, p. 60) assim delimitam:

temáticas referem-se a um conjunto de temas tratados na telenovela, ou seja, quando um tema ganha destaque dentro e fora da ficção, quando é bem articulado entre as dimensões social e melodramática da telenovela, desdobra-se, dando origem a uma multiplicidade de aspectos que são as várias faces e implicações do próprio tema, irradiadas de um ponto central que se conecta com diferentes ações e personagens dentro da narrativa e interfere decisivamente nos rumos da trama.

Para o Obitel, as temáticas dominantes correspondem a temas que exprimem a matriz melodramática, tais como as relações familiares, a ambição, a vingança, os preconceitos de classe e raça, a disputas de poder, a violência urbana entre outras. Essas temáticas fazem parte da organização das ações na trama e compreendem a sequência narrativa escolhida pelo autor. As temáticas sociais, diferentemente, trazem questões 
advindas de um contexto específico abordado em determinada trama, como estupro, conversão religiosa, adoção, alcoolismo, patologias psicológicas e bullying. Uma ficção televisiva seriada somente pode ser concebida na construção e na conexão com essas duas temáticas; bem imbricadas, elas dão vazão às tramas e ao desdobramento do recorte proposto pelo autor. De acordo com a Globo ${ }^{9}$, em 2018, foram exibidas 261 cenas de telenovelas em que foram abordados os direitos humanos, entre esse montante, $117 \mathrm{com}$ mensagens socioeducativas. A emissora destaca para essas ações de responsabilidade social nos folhetins, e o departamento responsável trabalha juntamente com os autores das produções no intuito de integrar as mensagens no contexto das tramas.

Lembramos que, embora essas temáticas sejam retratadas em outras ficções de outras emissoras ou até mesmo de outros horários da Globo, a trama das $21 \mathrm{~h}$ é vista como um espaço de tratamento de temas mais complexos ou polêmicos. São, portanto, agenciadores de debates na sociedade. Em pleno horário nobre, quando se acredita que a maioria das pessoas se encontra em suas casas, principalmente devido ao fim do horário comercial de trabalho, o prime time consiste na faixa horária mais bem paga da televisão nacional, que se inicia, no caso brasileiro, às $19 \mathrm{~h}$ e termina por volta das $23 \mathrm{~h}$, tendo seu ápice a partir das $20 \mathrm{~h}$ com a exibição do Jornal Nacional e, posteriormente, da novela das $21 \mathrm{~h}$.

Para muitos brasileiros, a volta para a casa após o trabalho e/ou estudo se configura como um momento voltado para as demandas domésticas, tais como o cuidado da casa e suas variadas exigências e os cuidados do corpo, como a alimentação, a higiene e o descanso. O que também está relacionado à atenção com a mente, inteiramente ligada às condições de seu entorno e das reivindicações corporais. Logo, o lar é um espaço complexo onde se dão questões de cunho pessoal, e onde, por meio da entrada da televisão nesta ambiência, os rituais do lar foram se adequando aos avanços ocorridos nesta plataforma. Desta maneira, a programação do horário nobre acompanha as ações que correspondem esse estar no lar, pois, usualmente, o aparelho televisivo está ligado. O papel sociocultural deste aparelho nas casas brasileiras (TUFTE, 1998; HAMBURGUER, 2011; PRIORE, 2019), em particular em subúrbios, periferias e vizinhanças, ressaltou os estudos acerca do assistir junto, prática usual na construção da competência cognitiva da assistência televisiva. Porém, ao longo dos anos, devido à facilitação de aquisição do

\footnotetext{
${ }^{9}$ Dados divulgados no evento Ponte - Retrospectiva Social da Globo, em 22 de novembro de 2018.
} 
aparelho e da sua importância dentro do contexto doméstico, ele adquiriu alta relevância como companhia diária na rotina do brasileiro.

Com a introdução de novas tecnologias - sejam elas TV a cabo, computador pessoal, telefone celular ou aparelhos de vídeo - na vida de muitas pessoas, a realidade sociocultural e econômica que constitui a domesticidade é constantemente desafiada. Tanto a tecnologia como tal, suas possibilidades para aumento de comunicação intercultural, como o aumento e diversificação de oferta de programas, são elementos que estão mudando as nossas vidas, e a maneira de organizar nossos lares, nossas famílias e outras comunidades interpretativas, e nossas moradias. De mesma forma, o aumento da comunicação global desafia o grau e caráter de domesticidade de nossa mídia. (TUFTE, 1998, p. 146)

A competência comunicativa fomenta a vertente dialógica da telenovela, que traz para o espaço televisivo assuntos que antes eram apenas de foro pessoal familiar. Todavia, hoje, há uma espécie de cobrança do papel da telenovela em tratar temas que possam ter influência na vida em sociedade. Uma responsabilidade que nos leva a refletir acerca do lugar da televisão no cotidiano do brasileiro. Assim,

O lugar da TV, ou melhor, a TV como lugar, nada mais é que um novo espaço público, ou uma esfera pública expandida. O exemplo brasileiro é um dos mais indicados do mundo para quem quer observar os detalhes de como se dá a expansão da nova esfera pública e, mais ainda, como se dá a sua constituição em novas bases. Às vezes tenho a sensação de que se tirássemos a TV de dentro do Brasil, o Brasil desapareceria. A televisão se tornou, a partir da década de 1960, o suporte do discurso, ou dos discursos que identificam o Brasil para o Brasil. Pode-se mesmo dizer que a TV ajuda a dar o formato da nossa democracia. (BUCCI, 2004, p. $31-32$ )

Discursos como esse, que circundam a telenovela, demonstram seu caráter transtextual que ultrapassa sua transmissão. O conceito de paratexto (GENNETE, 2009), que corresponde a mensagens em torno de um produto, uma organização textual advinda de outra, nos auxilia a pensar na transcendência do texto televisual, marcado por um trânsito de audiências (OROZCO GÓMEZ, 2011) extenso. Esse fluxo da audiência forma a impressão acerca da recepção, são os caminhos percorridos por esses consumidores que transpõem a transmissão das tramas. Pieniz (2015), ao discorrer sobre esse trânsito do receptor, enfatiza que esses “conteúdos resultantes deste processo são os produtos materiais das rotas midiáticas percorridas pelas audiências - os quais, por sua 
vez, ao serem lidos, ampliam a percepção sobre o tema em pauta" (p. 225). Tendo isso em consideração, a narrativa ficcional televisiva se apresenta como um texto principal, do qual se ramificam outros textos para formar o que vem a ser o campo discursivo da telenovela. A criação desses paratextos estimula esse trânsito, promovendo a circulação de sentidos através da inserção de temas contemporâneos e na construção de padrões de consumo, como as vestimentas e as gírias de um personagem.

Podemos caracterizar duas modalidades de paratexto: o peritexto e o epitexto. A partir da transposição do peritexto para o campo televisual, podemos dizer que ele é condizente com a própria obra, sendo formado, portanto, por elementos que formam e circundam a ficção no próprio espaço do texto. A saber, o título da trama, o autor e os próprios personagens. Já o epitexto também engloba o texto, no entanto é uma modalidade exterior, que inclui produtos importantes na sua divulgação. Neste caso, destacamos a crítica como um epitexto importante na circulação de mensagens acercas das ficções, em que, por meio deste tipo de paratexto, são abordados tópicos concernentes às ficções, direta ou indiretamente (GENNETE, 2009).

Essas modalidades, de certa maneira, também podem ser internas e externas. Internas, porque os paratextos do lado do produtor se afirmam num movimento extenso de criação de produtos e informações com relação às ficções, pois, afinal, a telenovela brasileira é um produto bastante rentável e muito comercializado. Quanto ao movimento externo dos consumidores, temos as conversas off-line e on-line, que reforçam a repercussão de uma trama. Os paratextos, evidentes quando se trata de telenovela, reforçam o entendimento de Lopes (2009) da telenovela como narrativa da nação e como recurso comunicativo. Desvela-se, assim, a centralidade da experiência social e estética da ficção serializada nas marcas renovadas do ritual de assistir à telenovela intrínseca ao brasileiro. Em suma, são processos que expandem a vida desse consumidor-produtor, visto que

Paralelo a estas trocas de ideias on-line, está o compartilhamento offline. No momento em que um receptor tuiteiro está em família e com ela comenta acerca dos tweets lidos, há uma reverberação do espaço do Twitter para o espaço onde a telenovela é assistida, por exemplo, e viceversa. Isso também é aqui entendido como trânsito, pois neste momento o receptor tuiteiro torna-se não só receptor de telenovela, mas também dos tweets dos demais telespectadores, ao mesmo tempo em que pode se tornar interagente. (PIENIZ, 2015, p, 226) 
O campo da sociabilidade desse usuário se expande e é enriquecido nas conversas tanto off-line quanto on-line. Nessa busca de diálogo, há também a procura de notoriedade sobre aquele assunto tratado. Isso, claro, é facilmente concebido pela competência de assistência de telenovela advinda do cotidiano. Falar de telenovela é um exercício inerente aos lares brasileiros. E ser reconhecido como fonte de informação acerca desse produto midiático desencadeia um conjunto de ações, uma dinâmica de relações próprias, que estimulam o compartilhamento em rede. Esse processo configura-se como "conjunto de "falas sobre falas" (dos usuários sobre a mídia, dos usuários sobre os usuários e da mídia sobre a mídia) que reforça a vocação do sistema de resposta social como espaço público de conversação" (DRUMOND, 2014, p. 203).

No que se refere à novela, os discursos reverberantes no microblog convergem para certa gramática produtiva, uma vez que, em geral, os Tweets mais populares são aqueles inspirados em valores determinados, como a sagacidade, a originalidade e o humor; logo, dependendo do êxito do internauta em manejar essas lógicas de produção, territórios interacionais vão sendo tecidos ao redor de seus avatares. Esses territórios, por sua vez, implicam em lugares de fala capazes de gerar distintos níveis de mobilização sobre a audiência on-line, relacionando-se, portanto, à capacidade do interagente de, performaticamente, ganhar visibilidade na rede. (DRUMOND, 2014, p. 204)

Fechine (2017) destaca a utilização do termo TV Social para explicar a interação entre telespectadores nas redes sociais enquanto assistem a um programa televisivo. E ssa comunicação acontece ao mesmo tempo da transmissão e permite a troca de ideias e conteúdos acerca do que está sendo visto. Esse comportamento reproduz o hábito de assistir televisão acompanhado, porém na forma digital, criando, como explicou Pieniz, em novas sociabilidades com outros usuários espectadores. Agora não há mais a necessidade de estar num mesmo cômodo, ou até sentado ao lado no sofá. Basta estar com o celular - aparelho mais usual para essas interações - e estabelecer contatos por meio do uso das hashtags. Portanto,

considera-se como TV Social qualquer troca que envolva conteúdos televisivos entre dois interagentes desde que seja mediada por tecnologias interativas, disponíveis no computador ou em dispositivos móveis, em plataformas que permitem relacionamentos e compartilhamentos. Quem acompanha o Twitter ou o Facebook, por exemplo, constata que todo dia seus milhões de usuários espontaneamente compartilham e comentam em seus perfis sobre conteúdos televisivos dos mais variados, dando lugar a novos comentários sobre o que postaram e promovendo uma espécie de 
conversa moldada pela lógica interacional das redes sociais. (FECHINE, 2017, p. 88)

A autora delimita que a TV Social voltada para a interação das redes sociais e usuários é mais utilizada pelo campo da comunicação, diferentemente da abarcada pela área da tecnologia, pautada pela criação de aplicativos para a televisão (FECHINE, 2017). Essa conversação em rede mostra-se sobretudo como uma circulação de sentidos sobre a telenovela em exibição propiciada, por vezes, pelos próprios produtores que fomentam essas interações. Almeida (2018) menciona que "a experiência combinada de assistirinteragir passa a exigir novos letramentos, uma vez que o indivíduo necessita desenvolver habilidades próprias à recepção televisiva em conjunto com aquelas concernentes aos ambientes digitais interativos" (2018, p. 92). Tal modelo de assistência revela novas ritualidades (MARTÍN-BARBERO, 2015) com as formas de experienciar a televisão e seus produtos, e comportamentos que preveem a inserção e aprimoramento de novos hábitos. Almeida ressalta a inclusão de linguagens e códigos na interação entre televisão e redes sociais digitais, recorrendo ao conceito de Scolari (2018) de literacia transmídia no desenvolvimento de competências cognitivas para o acompanhamento de conteúdos variados ao mesmo tempo. A simultaneidade de consumação de assuntos e tópicos em diferentes plataformas é a característica deste comportamento que prenuncia uma gestão da atenção mais desenvolvida, capacidade cognitiva para estar atento em múltiplos dispositivos.

Esse cenário exige o desenvolvimento de habilidades muito diferentes daquelas empregadas na visualização da televisão tradicional. Quando utilizam múltiplas telas ao ver $\mathrm{TV}$, os telespectadores somam à espectatorialidade audiovisual o manuseio de dispositivos portáteis interativos, o que requer a habilidade sensório-motora de empregar a força, a velocidade e os movimentos táteis adequados à operação de teclados e à navegação touch screen em pequenas telas. (ALMEIDA, 2018, p. 93)

Drumond, como mencionamos, usou a palavra interagente para se referir a esse consumidor de telenovela que utiliza o Twitter e até outras redes sociais digitais, além de dominar esse território interativo e ter a habilidade de manejar a plataforma com as inúmeras discussões que vão surgindo ao longo da exibição da telenovela. O que está atrelado às habilidades sensório-motora, de navegação hipermidiática, tecnológica, intelectuais, multitarefas, sociais e afetivas (ALMEIDA, 2018). São habilidades advindas 
do advento e aprimoramento da técnica, e que, de certa forma, têm transformado as relações sociais intrinsecamente. Nesse esforço de identificar as práticas dos interagentes em plena convergência, a autora refletiu acerca de motivações dos usuários para estabelecer o grau de envolvimento na construção de sua experiência multitela.

Estabelecer a comunicação enquanto a atenção está fragmentada parece ser uma habilidade intrínseca do interagente na contemporaneidade, tal qual a habilidade de acompanhamento das discussões na tela principal e nas demais telas realizando o movimento de caráter sensório-motor para a realização de movimentos corporais como o look up e look down (olhar para cima e olhar para baixo) (BLAKE, 2017). Na prática dos zapping, os movimentos requeridos, dependendo de onde era feita a assistência, correspondiam, em sua maioria, à utilização do controle remoto para a troca de canais e o ao aumento e à diminuição do volume; porém, novos comportamentos são requisitados na prática da TV Social, adicionando os movimentos no aparelho celular em telas touchscreen. Blake e Almeida ressaltam para a distração significativa acarretada por essa assistência segmentada, em que o acúmulo de atividades é constante, faz com se perca muito do que está sendo assistido na tela principal. "Assim, a postura do corpo em relação às diferentes telas é distinta. $\mathrm{O}$ que se percebe, portanto, é que a materialidade de cada plataforma pode limitar ou potencializar certas práticas durante a recepção televisiva" (ALMEIDA, 2018, p. 94).

A expertise em usar o celular, em especial os aplicativos, é o diferencial deste interagente, que pode digitar sem olhar em demasia para tela, pois já memorizou a disposições dos elementos para as postagens e de todos os aparatos concernentes a esse aparelho. Nas telenovelas brasileiras ainda não vemos a exibição de twits na tela da TV ao mesmo tempo da exibição dos programas, porém isso é comumente apercebido em realities shows, alguns telejornais, programas de entretenimento e entrevistas. Isso evidencia uma estratégia clara por parte da produção no incentivo de participação, criando proximidade com esse interagente, bem como em certa identificação com o que está sendo televisionado.

A economia da atenção, segundo Santaella (2010), está nessa concorrência pelo olhar humano, que se traduz em números de audiência e horas em frente a tela. Na TV Social, a resposta do receptor é quase instantânea e pode ser mensurada pelo buzz das redes sociais, quase instantâneo em comparação com números de rating e share. Há até programas em que os números de interação não condizem com o número de audiência, e 
quando há programas com números altos de audiência, poucos foram abordados nas redes sociais. Portanto, "a ideia de TV Social nos ajuda agora a descrever outra modalidade virtual de 'encontro', interação e sociabilidade ainda bem sintonizados com a grade de programação em fluxo" (FECHINE, 2017, p. 96).

De acordo com a Kantar Ibope Media, a simultaneidade do consumo televisivo com redes sociais digitais pode ser mensurada pelo número de impressões nessas redes. No caso do Twitter, por impressões entende-se como as ocorrências em que as postagens são visualizadas no feed ou na busca por uma postagem específica por meio de hashtags específicas. Em 2018, a Kantar Social TV Ratings mensurou que TV aberta alcançou mais de 31 bilhões de impressões em comparação com a TV Paga, com 3 bilhões, e a Netflix com 760 milhões $^{10}$. Nesta mesma pesquisa, entre o Top 10 da TV aberta, em termos de ficção, entrou em nono lugar o último capítulo da ficção das 21h, O Outro Lado do Paraíso (Globo, 2017-2018), no dia 11 de maio de 2018. Esses números, comparados à TV paga e ao streaming, demonstram a força da televisão aberta no alcance do seu público durante a transmissão de uma programação que obedece a horários fixos. Logo, a Kantar salienta os realities shows como o formato de maior número de impressões nas redes devido à sua interatividade e às estratégias voltadas para a participação do público, que, segundo a empresa, não foi diferente do que em 2017.

Conforme listamos acima, as habilidades para a utilização da TV como aparelho principal e as demais telas foi tema de variadas reflexões e vaticínios quanto ao futuro da TV e sua integração aos novos modelos de negócios como o streaming. Neste sentido, notamos que a televisão broadcasting soube incorporar as tendências de assistência possibilitadas pelas facilidades de acesso a conteúdo e a clara interação com o público para o compartilhamento e discussões dos assuntos tratados em cena. A mescla desses elementos foi possibilitada, também, pela questão geracional, pois a nova geração está apta a ser multitarefas, isto é, lidar com os elementos, funções e ferramentas que integram os dispositivos midiáticos para este acesso.

Nesse aspecto, a TV Social é uma experiência televisiva que requer um certo aprendizado e se mostra compatível com a geração de indivíduos já treinados a conectar fragmentos de informações dispersos em diversas mídias e constituídos de linguagens distintas, cabendo ao usuário realizar a interconexão das ideias e o descarte ou aproveitamento das informações conforme o seu interesse. Essa particularidade da TV Social acaba

${ }^{10} \mathrm{https}: / / w w w . k a n t a r i b o p e m e d i a . c o m / o-q u e-m a i s-m o v i m e n t o u-s o c i a l-t v-e m-2018-n o-b r a s i l-2 /$ Acesso em $15 \operatorname{dez} 2019$. 
privilegiando, portanto, a participação mais representativa de telespectadores que já possuem afinidade com esse tipo de interação e de processamento de informações. (ALMEIDA, 2018, p. 98)

A habilidade intelectual prevê o "desenvolvimento de um letramento específico" (ALMEIDA, 2018), haja vista que é necessário fazer associações entre temas e demais postagens, julgar o que está sendo transmitido, criar hashtags e threads ${ }^{11}$, ter insights para diferentes momentos que chamem sua atenção e dar prosseguimento à discussão estabelecida, que pode ser finalizada com o fim do programa ou até continuar após a exibição.

A sociabilidade é indubitavelmente marcante neste campo de variadas conversações, onde são estabelecidas conversas entre meros desconhecidos, que apenas por algum interesse comum estabelecem um diálogo e passam a formar grupos. Assim, percebemos a criação de vínculos sociais, tal como remarcado por Drumond (2014), na construção de territórios interacionais que fomentam debates e compartilhamentos.

Neste sentido, o âmbito social leva à questão afetiva nas interações com os usuários que utilizam de suas redes com a intenção de atacar e incitar o ódio, e / ou criticar de maneira enfática determinado personagem ou participante, enquadrando-se na categoria de haters, os que odeiam. São sentimentos trazidos à tona especialmente quando se trata de realities shows, tais como Big Brother e Master Chef, pois envolvem competições acirradas. Ao contrário dos que incitam ao ódio, há a categoria dos shippers nas redes sociais. O termo shippar é comumente conhecido como a prática realizada por fã em representar e torcer pelo romance de dois personagens, que podem ou não estar envolvidos na trama. É daí que advém a junção de nomes por meio da utilização de hashtags, a criação de vídeos e fanfics. Castilho e Penner (2017) explicam que o Twitter se mostra com a rede social de maior aderência para se falar sobre telenovela, e que, portanto, é "onde se concentra parte expressiva dos conteúdos e interações dos fãs de casais de personagens shippados" (p. 226).

No caso das telenovelas, vemos que os sentimentos retratados estão ligados aos acontecimentos com os personagens, abordando determinado drama e cenas importantes para a trama. Não obstante, os personagens nem sempre são os alvos das postagens, percebe-se o diálogo, em muitos casos, com o próprio autor, a emissora e com os críticos.

\footnotetext{
${ }^{11}$ As Threads do Twitter correspondem a uma sequência de postagens de mesmo assunto e do mesmo usuário. O objetivo da Thread é contar uma história, por isso elas são consecutivas e dão prosseguimento detalhando e contextualizando a temática abordada. Logo, são publicações em série, pois o termo em inglês significa fio.
} 
Esses últimos, jornalistas especialistas em televisão, veem no Twitter, por exemplo, uma maneira de conversar com o público dos folhetins e atentar para o que está sendo ressaltado nas conversas entre espectadores no momento da exibição.

Assistir e interagir parece se configurar como a nova prática de assistência de TV. Contudo, se analisarmos esse hábito desde o seu advento, veremos que assistir televisão sempre foi uma prática coletiva. Há quarenta anos, em um bairro de classe média, por exemplo, somente algumas casas dispunham do aparelho, dessa forma, esses lugares abriam as portas para que os vizinhos pudessem assistir aos programas. Em seguida, devido aos avanços econômicos, cada casa passou a adquirir seu aparelho, que era disposto majoritariamente na sala de estar, em frente ao sofá. Ao longo dos anos, essa configuração foi sendo alterada por mudanças sutis, mas que indicam as transformações que determinam a espacialidade e sociabilidade aos moldes propostos por Martín-Barbero (2015) em seus mapas das mediações. A sala, portanto, ainda é o lugar usual para se instalar o dispositivo; entretanto, outros cômodos foram sendo criados para abarcá-lo, como o surgimento das salas de TV, integradas por sofás que aumentam seu tamanho original e aparelhos de home theather, que melhoram a capacidade sonora do ambiente. E até mesmo anterior a essas salas específicas para a TV, temos os aparelhos dentro de cada cômodo que compõem esse domicílio. Desta forma, não é mais necessário assistir ao mesmo programa que outras pessoas e no mesmo lugar, pois outros cômodos dispõem de um aparelho. Esse processo remete à fragmentação do espaço de assistência da televisão, visto que, no atual panorama, outros dispositivos dão conta da exibição dos conteúdos.

\subsection{Telenovela e o pacto de recepção}

O conceito pacto de recepção cunhado por Lopes (2003; 2009) trabalha a telenovela como uma experiência comunicativa, social, cultural e estética. Com sua transmissão, ocorre um compartilhamento de repertório pelo seu público, acarretando a mobilização de diferentes instâncias de espectatorialidade. Nessa experiência estão circunscritos tanto os produtores quantos os receptores, estando essa dualidade no cerne das relações comunicativas. Atualmente, longe de um receptor "passivo", vemos um consumidor atuante e exigente em seu consumo televisual. Logo, partimos do princípio 
de que a circulação é efetuada na inter-relação da produção e da recepção, o que nos exige investigar esse espaço inter produção e recepção.

A partir de pacto de recepção de Lopes (2009), podemos identificar o conceito contrato de leitura, trabalhado por Eco (1987,1994), Verón (2004) e Charaudeau (2006), que compreende as ofertas discursivas e a construção de vínculos entre emissor e receptor, ao gerar sentidos. Para Verón, ler é trabalho, portanto ler é atividade do fazer, do produzir sentido. Em Eco, o leitor é pensado como produção de mensagem, em que o próprio autor idealiza seu leitor-modelo. Para Charaudeau, essa relação entre o produtor e o público é dependente de um contrato de comunicação, relacionado à assistência da telenovela. Em todos esses autores, verificamos a existência de um pacto, seja de leitura, de comunicação ou de recepção, que organiza o discurso entre os atores em relação, construindo valor simbólico a partir de discursos representacionais.

De maneira geral, o contrato traduz o acordo entre produtor e receptor na construção de vínculos que regem sua assistência por meio da enunciação de discursos. Tais vínculos são ocasionados por produtos midiáticos que criam conexão de fidelidade com seu receptor, ativando, assim, gramáticas de reconhecimento. Esse reconhecimento está na base do funcionamento dos contratos, sendo uma problemática ampla para a compreensão das relações entre a oferta e o consumo. De forma evidente, o objetivo de todo produtor de conteúdo é estabelecer um contrato com seus consumidores, é uma prática usual e evidencia o pensamento crítico de Martín-Barbero (2015), para quem a tecnologia não é o grande mediador entre as pessoas e o mundo, mas sim a mediação da "transformação da sociedade em mercado" (p. 20).

Após muito tempo simplificada, a relação entre a telenovela e seus públicos é vista hoje como bastante complexa. A telenovela é um discurso que gera discursos, o que provoca um permanente processo de negociação com seus espectadores que, por sua vez, é bastante heterogêneo e diversificado. Nessa negociação, há alguns requisitos, como o reconhecimento do que se fala e vê nas telas. O reconhecimento é, portanto, a base do contrato; todo o aparato da produção (diretor, autor e produtores) constrói uma ação discursiva que desemboca na construção da identidade daquele produto, que é o seu modo de construir sentidos para seu público. No caso da telenovela brasileira, marcada por uma tendência à narrativa naturalista, esta acaba sendo a base do repertório compartilhado (LOPES, 2009) e a base do contrato de recepção. 
Para Verón, todo contrato está imbricado em um discurso veiculado por um suporte midiático $^{12}$, em que, por meio de suas mensagens, percursos múltiplos são propostos a esse leitor. Por conseguinte, esse leitor é deixado a escolher os caminhos no qual deseja ou é levado a se perder naquilo que está ou foi exibido. Essas zonas são dotadas de discursos e formam um espaço composto por diferentes elementos como atores, cenários etc., aspectos que proporcionam sentidos desse produto midiático final. Nas palavras do autor, "ler é trabalho", um trabalho de movimento de leitura desse espaço, em que o leitor tem a liberdade de aceitar ou rejeitar aquilo que vê.

O deslocamento entre gostar e desgostar denomina um movimento constante da situação comunicativa. Enunciados são dirigidos ao telespectador de maneira a estabelecer uma relação. Na telenovela, tão imbricada no tecido social brasileiro, vemos que cabe ao produtor situar seu público em um campo de interesses, ao buscar maneiras de interação. A saber, os casos de merchandising social, com temáticas socais que criam um diálogo profícuo com o público. Diálogo que se inicia no âmbito domiciliar e que se propaga em espaços públicos como as redes sociais. Em síntese, o reconhecimento, isto é, o "eu me vejo na telenovela" (LOPES, 2009) está na realização desse contrato de recepção.

No dizer de Charaudeau, a "troca linguageira" (2004) entre a produção e a recepção é premente nos contratos. Esse ato de linguagem pode ser regulado por diferentes indivíduos e é onde o discurso é constituído. Em seu entender, os contratos atuam em suas estratégias de enunciação de forma interna e externa. A tríade principal do funcionamento da linguagem, a sua forma interna, está em primeiro lugar na locução, quem está falando; em segundo, na relação, como é estabelecido o contato com o leitor (suporte midiático), e em terceiro, a tematização, que tipo de mensagem ele está passando a-seu público. Neste sentido, as falas que compõem a sociedade estão dispostas,

Por um jogo de regulação das práticas sociais, instauradas pelos indivíduos que tentam viver em comunidade e pelos discursos de representação, produzidos por justificar essas mesmas práticas a fim de valorizá-las. Assim se constroem as convenções e as normas dos comportamentos linguageiros, sem as quais não seria possível a comunicação humana (CHARAUDEAU, 2004, p.67).

\footnotetext{
${ }^{12}$ Os trabalhos de Verón tiveram base empírica em revistas e jornais. Hoje, podemos tratar esses suportes como sendo as múltiplas telas que nos circundam.
} 
A forma externa dos contratos (p. 68) compreende quatro condições: a identidade, a finalidade, o propósito e o dispositivo. São os aspectos semióticos mais visíveis da mensagem, sendo a identidade a condição que leva ao reconhecimento de um produto ficcional; a finalidade, o objetivo e as expectativas da recepção; o propósito corresponde ao tema de um discurso; e, por fim, o dispositivo, isto é, o suporte através do qual a mensagem será transmitida.

Os pensamentos de Charaudeau e Verón se complementam acerca da participação ativa do sujeito, como ator principal da relação comunicativa e em como os discursos constroem o sentido de acordo com os padrões culturais de cada indivíduo.

Umberto Eco $(1987 ; 1979)$ trabalha a noção de leitor ideal ou modelo, em que cabe ao autor conceber seu público leitor previamente à escrita de sua obra, por exemplo, em termos de variáveis socioeconômicas, demográficas ou de escolaridade. Entretanto, esse ato de escolha prévia pode acabar por fechar o texto, já que ele está saturado de marcas específicas que irão levá-lo a uma compreensão particular. De qualquer forma, o leitor é pensado e concebido a partir do lugar da produção do texto. Ao contrário desse modelo, temos o texto aberto, que é pensado de maneira mais livre, sem as deliberações que dizem respeito ao texto fechado. Esse texto permite ao leitor a liberdade para interpretar e, segundo Eco, é proposto a um público heterogêneo.

Uma das características destacadas desse "leitor modelo" é sua capacidade de procurar alguns elementos que estão presentes nesse mesmo texto, mas que não foram ditos. São conteúdos coletados e compartilhados pelos leitores sobre determinada obra, criando um compilado de significados intrínsecos ao texto, mas não explicitados. Eco ressalta que:

O texto está, pois, entremeado de espaços em branco, e interstícios a serem preenchidos, e quem o emitiu previu que esses espaços e interstícios seriam preenchidos e os deixou brancos por duas razões. Antes de tudo, porque um texto é um mecanismo preguiçoso (ou econômico), que vive da valorização de sentido que o destinatário ali introduzi; e somente em caso de extremo formalismo, de extrema preocupação didática ou de extrema repressividade o texto se complica com redundâncias e especificações ulteriores - até o limite - em que se violam as regras normais de conversação. Em segundo lugar, porque, à medida que passa a função didática para a estética, o texto quer deixar ao leitor a iniciativa interpretativa, embora costume ser interpretado com uma margem suficiente de univocidade. Todo texto quer que alguém o ajude a funcionar. (ECO, 2011 [1979], p. 37) 
A incompletude do texto é referida pelo autor, pois, enquanto não relacionado com os códigos necessários, este texto permanece incompleto. Neste sentido, o texto da telenovela é esmiuçado pelo crítico que fala a um espectador específico, acostumado a interpretar os códigos e signos desta ficção. Neste caso, não é uma competência gramatical, mas sim uma competência das regras do folhetim e dos hábitos e costumes culturais que são reconhecidas pelo destinatário. Apesar da função da crítica - como iremos esmiuçar nos capítulos seguintes - ser desvelar pontos obscuros nas tramas, o leitor da crítica é um espectador de telenovela, que vai em busca das avaliações, entre os variados motivos, para entender certos aspectos que não ficaram claros e enxergar pontos de vistas acerca da ficção.

A telenovela é um texto aberto, na medida em que permite usos e interpretações (ECO, 2011). "Autor-modelo" e "leitor-modelo" são duas categorias para pensarmos nos críticos e nas telenovelas. Por autor-modelo aludimos tanto ao texto da telenovela, produto audiovisual de longa serialidade, quanto ao crítico, em sua atividade de escrever análises sobre os folhetins. O leitor-modelo é capaz de executar a interpretação necessária para o texto, isto é, o crítico é um leitor apto em compreender o trajeto comunicacional do produto televisivo, atualizando e dotando este texto primário de outras interpretações, e, por conseguinte, alargando sua semiose social.

A noção de contrato a partir de Umberto Eco está na introdução dos termos neotelevisão e paleotelevisão (ECO, 1984, p.182-183), especialmente no enunciado da autorreferencialidade, como ele aponta:

A característica principal da Neotevê é que ela fala (conforme a Paleotevê fazia ou fingia fazer) sempre menos do mundo exterior. Ela fala de si mesma e do contato que estabelece com o próprio público. Não interessa o que diga ou sobre o que ela fale (também porque o público, com o controle remoto, decide quando deixá-la falar e quando mudar de canal). Ela, para sobreviver a esse poder de comutação, procura entreter o espectador dizendo-lhe 'eu estou aqui, eu sou eu e eu sou você'.

Como assinalamos, o reconhecimento é uma das características-chave dos contratos, nele se baseiam a noção de identidade e os modos de interação com o público. Desse modo, é comum vermos no âmbito televisivo modelos de interação que permitem situar o telespectador em campos de interesse revelados na sua grade de programação. No caso brasileiro, a linearidade das faixas horárias e as poucas alterações permitiram um encadeamento de hábitos propagados por meio da televisão. A ideia central, por parte da produção na realização de uma grade, é atingir um segmento do público de cada vez, com 
algumas apostas em formatos e gêneros inovadores, tendo em conta a harmonização e coerência entre os programas. São estratégias que auxiliam o campo de produção a definir os públicos-alvo de seus produtos e, portanto, seus contratos de leitura.

François Jost (2004), por outro lado, estabelece um contraponto com a ideia de contrato de leitura. Diferentemente dos autores discutidos acima, Jost introduz o modelo de promessa, que é trabalhado em três perspectivas: semiótica, análise do discurso e campo sociológico. Afirma que a televisão faz referência a três universos simbólicos, que ele denomina de "mundos". Assim, têm-se o mundo real, onde a experiência televisiva como as transmissões ao vivo se fazem presentes; o mundo ficcional, onde predominam as ficções, como a telenovela e as séries; e o mundo lúdico, onde se assiste a jogos. Esses mundos não são estritos, podendo se mesclar e hibridizar.

No modelo de promessa, o gênero é estrutura central que envolve todo seu mecanismo. Cada gênero televisivo seria uma promessa a seu público, tendo em vista que, por meio deles, pode-se inferir do que se trata determinado programa, em outras palavras, são importantes no estabelecimento de uma conexão com o receptor. $O$ gênero é operacionalizado em duas instâncias, a da promessa ontológica, em que há a promessa de autenticidade, e a promessa pragmática, que permite a etiquetagem de programas para fins de organização e criação de arquivos (2004, p. 18).

Uma das grandes características da televisão é seu poder de socialização, o que nos leva à circulação de sentidos possibilitada pela sua enunciação. Em vista disso, a promessa ocorre em dois momentos: (1) durante a assistência, momento em que o receptor passa a aceitar o que está televisionado; (2) quando ele interpreta e avalia aquilo recebido, exigindo, assim, uma participação mais efetiva do público.

O modelo de promessa, em uma perspectiva semiótica, mostra que os programas são um objeto semiótico complexo; em uma perspectiva de análise do discurso, anuncia que o gênero condiciona a circulação dos programas no universo da programação; e a perspectiva sociológica determina que os gêneros se transformam de acordo com demandas sociais e históricas. As críticas de Jost ao contrato de leitura têm por base seu entendimento de que o produtor deixa seu interlocutor livre para interpretar e reconhecer, sendo que esse reconhecimento nem sempre leva ao engajamento, e, ainda, pode ser que o receptor reconheça a promessa, mas seja incrédulo em alguns aspectos.

$\mathrm{O}$ crer da promessa e o reconhecer do contrato implicam diferentes cenários enunciativos que perpassam as mediações, evidenciando o campo de lutas em que estão as empresas de comunicação, entremeados pela tecnicidade e permeados por dispositivos 
de sensibilidade, modos de percepção das narrativas (entre o fazer e o sentir) e as variedades de dispositivos. A telenovela, além das transformações vigentes entre os gêneros e formatos, trabalha o reconhecimento da fala pela mimetização do cotidiano brasileiro, ligada ao padrão de teledramaturgia, aliada ao melodrama e ao naturalismo e fortemente atravessada por temáticas sensíveis ao público.

Verón $(1980,1987)$, através da noção de semiose social, constitui-se em autorchave para entendermos os processos discursivos que vão além da transmissão da telenovela. Nesse sentido, percebemos que as ficções, ao serem transmitidas, constroem atos de ressignificação que alcançam ambientes de discursividade, adentrando nos cenários da subjetividade e do cotidiano. Sua importância recai na explicação desses discursos sociais, em que se destaca a noção de discurso trabalhada através de teorias da discursividade e do sentido.

Para Verón (1980; 2004), a noção de sentido está ligada às mensagens, em outras palavras, uma propriedade unida à elementos que podem ser visualizados. Desse modo, a produção de sentidos "remete a certas operações realizadas por emissores e receptores, que podem ser reconstruídas a partir das próprias mensagens, e expressas num modelo" (p. 12). Denomina essas operações condições de produção e condições de reconhecimento do sentido posto. Nesse sentido, a televisão é vista como um dispositivo produtor de sentidos. Verón é formado em Sociologia na Argentina, mas foi somente em seu período na França que adensou suas obras. Nesse período, estudou na École de Hautes Études, com Roland Barthes e Levi-Strauss. Fica claro a influência do que ele aludiu como duas correntes históricas da linguística: a saussuriana, com seu modelo binário do signo, e a pierciana, com a tríade da significação.

$\mathrm{Na}$ primeira fase de suas pesquisas, Verón buscava entender a análise da mensagem em si mesma. No entanto, isso não o ajudava a obter uma noção mais ampla de todo o processo comunicacional e do discurso apenas se debruçando neste aspecto. $\mathrm{Na}$ segunda fase, o teórico já se voltava para a produção e em como esse processo produtivo deixa marcas nestes produtos midiáticos, o que lhe permitiu uma visualização desses traços e, assim, clarificar todo o processo. Em outras palavras, ele passa a trabalhar nas duas instâncias, a produção e a recepção, pois ambas atuam no processo de produção de sentidos. Neste entremeio da produção e da recepção é que a circulação se faz mais visível, já que a comunicação, a seu ver, se faz presente por meio do desequilíbrio entre 
os eixos da produção e da recepção. Nessa passagem entre a produção e a recepção é que ocorre a transferência de signos, passando de emissor para o público, e em signos tornados sentidos (VERÓN,1980).

Segundo o autor, dois pontos de vistas são de extrema importância no processo de produção do sentido. São eles: a gramática de produção e a gramática de reconhecimento. Para o teórico, sentido se configura a partir da relação entre as instâncias de produção e de reconhecimento, sendo a gramática de produção um processo coletivo que está atrelado ao discurso e suas condições de produção, enquanto as gramáticas de reconhecimento podem ser enquadradas como um emaranhado de significados apreendidos em um discurso difundido. As duas gramáticas formam o que ele definiu como processo de circulação (VERÓN, 1987).

Ao vermos as gramáticas como processos geradores do texto, percebemos que o discurso não pode ser apreendido fora do discurso do próprio usuário, tendo em vista que ele é construído por esse usuário. Portanto, para dar prosseguimento à análise, Verón explica que sua metodologia é formada pelo enunciado (unidade do discurso) e pela enunciação (a forma desse conteúdo os modos de dizer); além dos múltiplos mercados discursivos acerca da telenovela, em que o conceito de contrato de leitura emerge.

Fizemos até aqui um elenco de algumas teorias que contribuíram com explicações sobre diferentes aspectos e implicações do conceito de contrato de recepção. Elas nos serão úteis para compreendermos a circulação de sentidos e a crítica de telenovela. Entendendo que os discursos de cada crítica são regidos por um contrato com seus leitores. Cada jornalista tem critérios e características que o diferenciam como emissor de um discurso que tem um certo lugar de fala. O leitor dessa crítica também é partícipe desse processo, sobretudo quando ele reconhece esse discurso, ativando, assim, as gramáticas de reconhecimento.

Explicitamos a maneira como esse receptor constrói o sentido a partir de suas vivências, isto é, do seu contexto, e evidencia-se uma troca incessante de sentidos no contrato entre produtor e receptor. Logo, a crítica aciona as gramáticas de reconhecimento enquanto integram as gramáticas de produção. Em outras palavras, a críticas se configuram como um discurso do discurso, já que indicam à produção de sentido pela telenovela, ao passo que criam mais um discurso acerca daquela ficção em 
um mecanismo de retroalimentação que vai além das gramáticas. Desse modo, a crítica explicita o processo de circulação das ficções analisadas.

Fausto Neto (2009; 2018), teórico da circulação de sentidos, apresenta-a por meio das operações de dispositivos que complexificam os processos comunicacionais, criando procedimentos analíticos que habilitam certa inteligibilidade ao funcionamento da mídia. Segundo o autor, a circulação está situada na "arquitetura comunicacional" influenciada pela ação dos dispositivos circulatórios, prevendo a compreensão do que denominou de “equipamentos analíticos" para a análise e descrição dos sentidos construídos pelas interfaces midiáticas.

\begin{abstract}
A associação do conceito de circulação associado à noção de dispositivo tem a ver com as profundas alterações tecnológicas, na forma de meios e de discursos, que engendram a "arquitetura comunicacional", hoje. Os mídia não são apenas compêndios de um processo interacional, mas oferecem seus postulados e lógicas para a própria organização social. Instituem, por suas novas feições, zonas complexas de intensos feedbacks entre os atores removendo posições, redefinindo protocolos de comunicação, estabelecendo novas concepções e natureza de vínculos, alterando espacialidades e temporalidades sobre as quais se funda o ato comunicativo. A circulação, ao deixar de ser uma problemática de intervalos entre elementos de um determinado processo de comunicação, passa a se constituir em um dispositivo central, uma vez que as possibilidades e a qualidade das interações sócio-discursivas se organizam cada vez mais em decorrência da natureza do seu trabalho de transformação da arquitetura em processos comunicacionais. (FAUSTO NETO, 2009, p. $63-64)$
\end{abstract}

O conceito de circulação trabalhado por Fausto Neto (2009) está ligado intrinsecamente a questões que dizem respeito ao avanço da técnica. Essa transformação, hoje amplamente observada nos meios, é uma problemática que já nos envolve e faz parte do nosso entendimento do contexto das ficções. O que se vê é um entendimento de circulação que ultrapassa a dicotomia da produção e da recepção. São processos de interação nos quais o telespectador se percebe inserido ou não. Há de se entender que a passividade, que antes se alegavam existir, já não é mais uma norma. O processo de circulação de sentidos requer desse usuário uma ação, mas, ao mesmo tempo, sem esperar um engajamento. As lógicas de enunciação ao qual o autor assinala foram transfiguradas, deixou de ser somente a tevê, o rádio e o jornal, para passar a envolver um espaço virtual que complementa todas as outras mídias. 
A complementariedade das mídias prevê um receptor entremeado neste cenário tecnológico intricado, "de um lado, concentrados em processos de complexas convergências tecnológicas; por outro lado, observa-se que os receptores perambulam por várias mídias, migrando em seus contratos com os mesmos, e quebrando zonas clássicas de fidelização com vários deles" (FAUSTO NETO, 2009, p. 64).

Em suma, a circulação arquiteta novas dinâmicas além da produção e da recepção; e por seu funcionamento entende-se como a criação e o deslocamento dos usuários para novas zonas de contato entre as mídias. São zonas que requerem do público novas maneiras de interação e adoção de novos comportamentos. Essas dinâmicas, como aponta Fausto Neto, ainda se configuram como uma problemática complexa que nos desafia a cada olhar para o cenário da comunicação.

Neste capítulo, traçamos um panorama do que consideramos mais relevante no cenário televisivo contemporâneo e que nos dá subsídios para pensarmos acerca da circulação de sentido da telenovela neste âmbito. Reforçamos que a crítica de telenovela, nesta pesquisa, é entendida como um circuito relevante de circulação de sentidos transmitidos pela TV, que também está inserida no cerne da prática do jornalismo cultural, tópico a ser abordado no próximo capítulo.

As abordagens teóricas abarcadas aqui são articulações quanto à história da televisão no país, sua implementação nas casas e a consolidação do paradigma da telenovela brasileira. Desta forma, apresentamos e contextualizamos o objeto telenovela, partindo do princípio de que as ficções compreendem e dialogam com seu próprio contexto, portanto são produtos de seu tempo. Bucci e Khel (2004), em referência ao livro de Roland Barthes "Mitologias", trazem suas interpretações sobre o fenômeno da televisão:

Ora, eis aí uma descrição nada ruim do que se faz a televisão: rouba falas (verbais, visuais, gestuais), todas falas 'naturais', e as devolve aos falantes. Como se ela mesma, televisão, fosse uma falante - o que aliás ela é, mas isso não vem ao caso. Uns ainda creem que a TV 'influencia' a plateia, como se ela desse ordens de conduta para a plateia, como se fosse urdida, arquitetada, premeditada, num espaço exterior ao da 
própria linguagem compartilhada entre os falantes. Não é bem isso. Se a TV 'influencia', ela influencia exatamente na medida em que precipita o mito, que já está lá, na fala roubada, pressuposto. Em outras palavras, a TV só influencia porque é o elo que industrializa a confecção do mito e o recoloca na comunidade falante. A TV não manda ninguém fazer o que faz; antes autoriza, como espelho premonitório, que seja feito o que já é feito. Autoriza e legitima práticas de linguagem que se tornam confortáveis e indiscutíveis para a sociedade, pelo feito da enorme circulação e da constante repetição que ela promove. A TV sintetiza o mito (BUCCI e KHEL, 2005, p. 19).

A necessidade de entender esse elo entre a televisão e cultura, em sua prática de circulação de sentidos, já foi a pergunta central de diferentes estudos do campo da comunicação e das ciências sociais. Como principal produto da indústria cultural brasileira, a telenovela foi um objeto de estudo no entendimento do elo entre ficção e nação, e não é à toa o conceito de Lopes (2009) de telenovela como "narrativa da nação" ser tão aludido, pois explicita as diferentes interpretações sobre o país. Portanto, o que tentamos oferecer foram "evidências de que a teleficção capta e expressa, ou seja, de alguma forma modifica, interpretações do Brasil” (HAMBURGUER, 2011, p. 62). 


\section{CAPÍTULO 2 - Entre critérios e repertórios: o fazer da crítica}

"Então, a crítica vai refletindo. Você elogia muito um primeiro capítulo que foi incrível, na semana seguinte a novela está ruim. A crítica reflete isso”. Patrícia Kogut

O capítulo a seguir apresenta um apanhado teórico e histórico acerca da crítica. Longe de obter uma saturação desse objeto, a finalidade está em apresentar aportes teóricos acerca da crítica, especialmente do ponto de vista dos estudos literários, ponto de partida da prática e onde encontramos a ancoragem necessária para uma primeira mirada da crítica de televisão e, posteriormente, nas análises referentes à telenovela. Os autores deste primeiro tópico são, em sua maioria, cânones dos estudos de crítica, majoritariamente estrangeiros tais como Roland Barthes, Terry Eagleton e Walter Benjamin. No contexto brasileiro, adentramos na temática por meio de Antonio Candido e Afrânio Coutinho, que se debruçaram nos estudos da literatura, crítica e sociedade. A gênese da crítica de telenovela nos jornais impressos foi abordada pela análise de três atores importantes para o advento dessa atividade, a saber: Helena Silveira, Artur da Távola e Décio Pignatari. E, por fim, debatemos acerca do que se entende por crítica contemporânea de telenovela.

\subsection{Crítica: Pressupostos}

A crítica é em si a atividade adotada para designar critérios de apreciação e de análise acerca de determinado produto. Consta como uma avaliação com o propósito de favorecer certo valor simbólico e até mesmo legitimar uma obra. Tendo isso em vista, a crítica é uma modalidade utilizada primeiramente pela literatura, pelo teatro, pelas artes plásticas e no cinema e nas demais artes; todavia, no caso estrito da televisão, ela se mostra incipiente, dando passos lentos para o que seria uma tradição da crítica de televisão. Em vista dessa dificuldade primordial, adentramos então nas especificidades das análises relativas à telenovela, produto midiático popular, que, no território brasileiro, alcança novos moldes e paradigmas. 
Assim, nesta pesquisa, a crítica será explanada não somente em sua forma ou em seus parâmetros de apreciação das obras televisivas ficcionais, mas como uma mediação da telenovela no país, no sentido em que "a telenovela é tão vista quanto falada" (LOPES, 2009, p. 9) e sua crítica compõe a semiose social desse cenário televisivo (VÉRON, 1980). Junto a esta primeira consideração, temos em conta a afirmação de Silva e Soares (2013, p.01) como "a frágil reflexão acadêmica sobre teorias e procedimentos de crítica de mídias no Brasil”, que, ao longo dos anos, apesar de esporádicas, vão aumentando de volume. A esse diagnóstico podemos acrescentar que os estudos sobre a crítica de televisão crescem, especialmente com essa crítica sendo realizada no âmbito digital.

Falar de televisão e telenovela é algo bastante natural no contexto brasileiro, onde os circuitos de discussões ao qual a telenovela é submetida são variados. E a crítica entendida como especializada (realizadas nos jornais) se encontra prescrita em outras produções culturais. $\mathrm{O}$ imediatismo da televisão aberta faz com que ela seja facilmente apreendida, contudo, tomar sua análise como algo simples e corriqueiro é discutido por Eduardo Cintra Torres (1998), na afirmação de que a crítica de televisão não deve complicar o que já se considera simples, mas sim "tornar simples o que é efetivamente um elaborado produto com uma construção própria, com códigos de leitura próprios, com uma narrativa própria, e com fortes condicionantes de realização nas audiências e nos agentes econômicos e políticos que envolvem e agem na e a partir da televisão" (p. 08). Segundo o autor, quem analisa a televisão está, inicialmente, lendo-a. Consequentemente, as lentes para esse exercício devem ser ajustadas de acordo com as características de um programa televisivo. "Criticar é apreciar, analisar e compreender" (p. 09), por isso, a crítica deveria fugir do lugar-comum, espaço que não permite ao telespectador subsidiar ideias e conhecimentos sobre a obra analisada.

Em nosso enfoque, o papel da crítica é construir pontos de referência e fornecer elementos para a recepção de uma obra, sobretudo com a sua característica de incorporação do contexto em que está sendo colocada. A crítica de TV deve estar atenta ao cenário no qual aquela obra está inserida, para quem aquele texto está servindo de referência, e, acima de tudo, quem é aquele leitor/espectador ao qual aquele crítico está estabelecendo uma discussão por meio da sua leitura analítica daquela ficção. Até porque a crítica deve estar inteirada com o entorno, dialogar com este lugar.

Com isso, é notável que a pauta de valores é central. Em outras palavras, a crítica trabalha por meio de três eixos: a arte, a política e a sociedade. O posicionamento crítico 
pela confecção da crítica denota que aquela obra analisada gera um interesse coletivo, que, portanto, há um público interessado na leitura desse material. Isso subscreve o potencial crítico das telenovelas, em sua tônica de recurso comunicativo (LOPES, 2009), uma suscitadora de discursos, o lugar de fala, o espaço simbólico de onde aquele crítico está operacionalizando seus discursos e seus repertórios de análise. São os parâmetros de criticabilidade que obedecem às lógicas propostas ao longo dos anos de exibição das telenovelas e, além de tudo, respeitam as peculiaridades do formato realizado no país.

E há ainda outro componente, o reconhecimento, ao tratar de temáticas representativas tanto na ficção quanto na crítica, seja por meio de uma reivindicação, ou pela descrição na própria análise. É neste sentido que a ideia do reconhecimento como paradigma moral (SERELLE, 2019) se insere, com as ficções a discutir questões de reconhecimento e ativar representações, pois "as personagens de ficção, ainda que pertencentes a mundos autônomos em relação ao nosso, abrem possibilidades para que os públicos experimentem identidades por meio delas" (p. 12). Tendo a crítica essa característica de confluir, incidir e dialogar com as demandas sociais, é importante notar o valor de reconhecimento como um elemento interno das obras, e assim refletir até que ponto tais fatores externos implicam nos fatores internos na narrativa, num dialogismo entre estética e sociedade.

A clara influência da crítica literária na crítica de telenovela é notável em seu advento, em que, até então, havia parcos parâmetros de comparação para uma ficção contínua operacionalizada por um aparelho instalado no âmbito doméstico. Aos poucos, portanto, esse crítico foi aprimorando seus critérios de análise e entendendo, apesar do preconceito vigente, que as ficções televisivas atendiam às suas próprias regras de narrativa, influenciadas fortemente pelo teatro, o melodrama e o folhetim. Também foram compreendendo a inscrição do espectador, que, com o aprimoramento da tecnologia, atualmente adentra nos rumos das narrativas, com seus comentários em redes sociais. Em síntese, esse crítico do advento da televisão foi aprendendo e solidificando seu arcabouço analítico ao mesmo tempo que seu telespectador e leitor.

Em vista disso, a tarefa central do crítico é se expressar por meio das mídias, avaliando e opinando acerca de características que, em seu olhar, emergem em sua leitura. Segundo o Dicionário de Comunicação, a crítica é a 
Discursão fundamentada e sistemática a respeito de determinada manifestação artística, publicada geralmente em veículo de massa e emitida por um jornalista, professor, escritor ou por outros especialista, em geral vinculados profissionalmente ao veículo como colaboradores regulares. Apreciação estética e ideológica, desenvolvida a partir de um ponto de vista individual em que entra a experiência prática e/ou teórica do crítico, a respeito de um trabalho literário, teatral, cinematográfico, de artes plásticas, etc. O exercício da crítica implica na compreensão de tudo o que entra no processo de criação de uma obra artística, suas técnicas, suas significações, suas propostas e sua importância dentro de um contexto cultural. (RABAÇA; BARBOSA, p. 140,1978)

A apresentação de um novo olhar sobre o que está sendo visto é uma das características mais básicas da crítica, dado que o crítico tenta intercambiar uma relação com seu leitor abstrato e com a ficção que está em exibição. Barthes (2007) afirma que a crítica é uma linguagem sobre a linguagem, portanto uma metalinguagem. O objeto de uma obra, seja ela literária ou televisiva, é constituído pelo mundo; o da crítica se configura como o objeto secundário que advém deste mundo, logo a crítica é um discurso que existe amparado em um primeiro discurso, como ele enumera:

Isso é para dizer que, mesmo se o crítico, por função, fala da linguagem dos outros a ponto de querer aparentemente (e por vezes abusivamente) concluí-la, assim como o escritor, o crítico nunca tem a última palavra. Ainda mais, é esse mutismo final, que forma sua condição comum, que desvenda a identidade verdadeira do crítico: o crítico é um escritor. Essa é uma pretensão de ser, não de valor; o crítico não pede que lhe concedam uma "visão" ou um "estilo", mas somente que the reconheçam o direito a uma certa fala, que é a fala indireta. (BARTHES, 2007, p. 14)

A atividade crítica está calcada em diversos atos intelectuais ligados ao panorama histórico e subjetivo. Haja vista que, para Barthes (2007), o objeto da crítica é o mundo, a relação da linguagem crítica com a linguagem do autor. A função da crítica é desvelar validades e não uma verdade inerente da obra. Tal validação corresponde a um sistema de signos entremeados na sociedade, mas que não condizem necessariamente com o real, porém tem que atender aos ditames e regras propostos por aquela narrativa, atender ao sistema de signos que o autor construiu, em outras palavras, a verossimilhança.

No cerne dos processos históricos em que a crítica tem seu desenvolvimento, Eagleton (1991) faz uma análise do advento da crítica literária no início do século XIX, 
na Europa. Sua abordagem aponta para o nascimento de uma nova formação cultural na Inglaterra que culminou para a criação e sedimentação de uma crítica literária pautada pelas lutas contra o Estado Absolutista. Naquele momento histórico, as opiniões eram tratadas nos famosos cafés, lugar propício a discussões de cunho intelectual e social, realizadas por políticos, advogados, escritores, cientistas, entre outros. Essas reuniões, ao longo do tempo, formaram o que o autor denomina como opinião pública, que logo passou a ser socialmente reconhecida. No cenário político inglês da época, onde questões da esfera pública e das lutas entre o povo e a nobreza nobiliária se faziam prementes, identifica a crítica como um discurso aberto que demanda do público uma discussão, e “todo julgamento é concebido com vistas a um determinado público, e a comunicação com o leitor é parte integrante do sistema" (p. 04).

Neste período histórico, Eagleton destaca que as primeiras críticas escritas em periódicos ingleses ainda não apresentavam os moldes em que, em seguida, passaram a ser vistas nos jornais diários, pois “a esta altura, a crítica não é ainda 'literária', mas sim 'cultural'” (1991, p. 12). Em seu percurso histórico, a crítica do século XVIII era relativa à política cultural, no século seguinte dizia respeito à moralidade pública, e, no século $\mathrm{XX}$, tratava da literatura.

A atividade crítica em si, com suas ameaçadoras insinuações de conflito e dissenção, oferece-se para desintegrar o consensualíssimo da esfera pública; e o próprio crítico, situado no ponto principal dos grandes circuitos de troca dessa mesma esfera, difundindo, catalisando e reciclando seu discurso, representa um elemento potencialmente rebelde dentro dela. (EAGLETON, 1991, p. 14)

Como relata Eagleton, o advento da crítica no século XIX era um reflexo das transformações socioeconômicas ocorridas na Europa, particularmente com a arte se espraiando e sendo consumida por outras camadas sociais. Anteriormente, o teatro e a literatura eram artes apenas abrangidas pela nobreza, que dispunham de saraus com leituras e apresentações de peças teatrais. Com a ascensão da burguesia, esse público se amplia e passa a desfrutar de diferentes formas de arte, até como uma maneira de se inserir nos padrões sociais vigentes. Neste cenário, os críticos emergem com a proposta de uma discussão ampla dos valores da arte e seus julgamentos. "É característica do momento a ampliação do alcance da arte, antes restrito à burguesia, a um público maior, o que culminaria no que Habermas (2003) à frente vai chamar de mudança estrutural da esfera pública burguesa” (GRECO, 2017, p. 207). 
Com o intuito de formular uma visão generalizada dos princípios e técnicas da crítica literária, Northrop Frye (1957) apresenta os fundamentos teóricos e técnicas da análise literária, defendendo-a como uma estrutura de pensamento e conhecimento. $\mathrm{Na}$ introdução de A Anatomia da crítica (1957), o autor estabelece as diferenças entre a crítica genuína e o gosto pessoal, sendo a primeira baseada no que chamou de corpo literário, estudos sistemáticos de trabalhos literários. É nesta introdução que ele trata, por meio de uma linguagem informal, do conceito de crítico no âmbito da literatura:

A literatura sempre foi reconhecida como um produto vendável, produzindo-a os escritores inventivos e consumindo-a, os leitores cultivados, com críticos à testa. Deste ponto de vista, o crítico é, segundo a metáfora de nossa página inicial, o revendedor. Tem alguns privilégios de atacadista, como exemplares gratuitos para resenha, mas sua função tal como se distingue do livreiro, é essencialmente como uma espécie de pesquisa do consumidor. (FRYE, 1957, p. 27)

Todorov (2013 [1984]), em sua interpretação de Frye, adverte para a falta de lugar do julgamento de valor nos estudos literários, tendo em vista que, para Frye, "o julgamento de valor preexiste ao conhecimento e sobrevive a ele; mas não se confunde com ele e há, entre os dois, uma solução de continuidade" (p. 147). Esta relação mostra que o conhecimento está voltado para o objeto de análise, enquanto o julgamento voltase para o sujeito, o próprio crítico. Isto é, a interpretação do crítico é designada à obra, porém quando elabora uma avaliação, ele geralmente fala de si mesmo como consumidor e espectador e até mesmo como representante de seu tempo. Isso mobiliza a lógica do crítico como partícipe relevante na composição da semiose social da telenovela, sendo ao mesmo tempo consumidor e espectador, mas que discorre a partir da sua subjetividade. Dessa forma, ele elucida que,

Quando lemos uma obra, lemos sempre muito mais do que uma obra: entramos em comunicação com a memória literária, com nossa própria memória, com a do autor, com a da própria obra; as obras que já lemos, e mesmo outras, estão presentes em nossa leitura e todo o texto é um palimpsesto. (TODOROV, 2013 [1984], p. 145)

O entendimento dos efeitos sociais da arte, pela associação entre obra e contexto, é ressaltado em $O$ Caminho Crítico (1973), em que Frye destaca que a crítica deve ressaltar a aproximação entre a estrutura da literatura e os fenômenos culturais. Essa perspectiva crítica combinada oferta um equilíbrio no tratamento da obra, e sem isso, a 
análise perde sua tônica, pois ela deve estar em constante conversa com seu entorno social.

Benjamin (2018), em seu programa de crítica literária (1929 - 1930), acredita que "o aspecto decisivo da atividade crítica é o de saber se ela se fundamenta numa análise objetiva, num plano estratégico que contenha em si mesmo uma lógica e uma honestidades próprias" (p. 107). Ele enumera que uma boa crítica deve conter duas partes, a saber, "o comentário crítico e a citação" (p. 9), que não necessariamente devem estar sempre juntos, mas que uma análise contundente deve oferecer ao leitor um desses aspectos. A partir do contexto literário alemão, o autor esboça uma reflexão quanto aos aspectos da produção com a pungência do mercado literário da época e aborda as diferenças entre o que dele denominou de público e os círculos de leituras. Esses dois polos evidenciavam a distinção de classe vigente no período, no qual o público via os livros como forma de entretenimento, e os círculos como "fontes de sabedoria, estatutos de suas pequenas e abençoadas associações" (p. 108).

A diversidade de pontos de vistas e critérios de avaliação aos quais uma crítica pode ser abarcada reforça os inúmeros métodos com os quais uma obra pode ser abordada. O contexto literário apresenta diferentes formas de aproximações de análise, e, no caso da telenovela, como um produto audiovisual de abrangência ampla, deve-se sempre lembrar de sua característica única como formato aberto e de serialização longa. Esse olhar para o formato baliza também o olhar para a análise. Benjamin, tendo seu pano de fundo a literatura, visualiza os métodos para a crítica que nos ajudam a:
a) falar apenas do autor - falar apenas da obra;
b) vera obra na sua relação com as outras obras do autor - a obra em si;
c) situar ou comparar a obra do ponto de vista histórico-literário, antecipatório, referencial;
d) ver a obra enquanto representante de uma tese - Uma tese enquanto representante de uma obra (BENJAMIN, 2018, p 110).

A atualidade desse método reflete sobre a função da crítica como mediadora e decodificadora de uma obra e em como esse crítico deve estar atento às transformações temporais e estéticas advindas da narrativa, de maneira a saber passar isso ao seu público.

Castro (2014), analisando o trabalho de Benjamin, reforça que "o crítico só penetra na imanência da obra de arte e, consequentemente, desenvolve seu potencial cognitivo 
dela, se reconhecer em seu cerne os pontos que despertam a reflexão e a forma mais adequada de conduzir esse processo" (p. 23). Em suma, o papel da crítica é construir pontos e fornecer os elementos necessários para a interpretação da narrativa.

Afrânio Coutinho (1969), no livro Crítica e Críticos (1969), analisa o trabalho crítico de Tristão de Ataíde ${ }^{13}$ a fim de examinar e apresentar um conceito da crítica por meio da obra deste autor. No texto, chama a atenção ao processo de análise de Ataíde, sobre o qual Coutinho relata: Sua atitude era de ordem valorativa. Selecionava os livros, reunia-os em grupos, relacionava-os segundo gêneros ou temas, comentava-os, analisavaos e julgava-os. E toda essa operação à luz de princípios estéticos, da tradição dos gêneros, do seu gosto apurado em cultura e experiência de leitor inteligente e esclarecido" (COUTINHO, 1969, p. 226). Esta análise, em particular, é exposta para se entender duas tradições de se realizar a crítica no contexto ao qual o autor esmiuçou, a tradição francesa da crítica em periódicos e o moderno reviewing dos jornais estadunidenses. De acordo com o teórico, este último tem um caráter de resenhador e bibliógrafo de livros. Os dois modelos, grosso modo, explicam as maneiras de fazer crítica em periódicos na implementação do exercício da crítica nesses espaços.

Coutinho afirma que, para Tristão de Ataíde, crítica é "apreciação, isto é, julgamento" (p. 234). Por essa afirmação, o autor analisa que o crítico exerce sua avaliação a partir de uma dualidade, que, nas palavras de Ataíde, se configura como "um objeto, a obra a julgar; um juízo de valor que parte do sujeito do julgamento" (p.234). É neste duplo que se concretiza a tônica de sua definição de crítica, ao qual ele argumenta: A crítica é, no final, atividade valorativa, judicante a que está, portanto, afeto um juízo de valor, este é claro, de natureza estética e não ética. Esse é o ápice a que pretende chegar a atividade crítica, até mesmo por seu sentido etimológico. Criticar é julgar, no caso, esteticamente" (COUTINHO, 1969, p. 234).

A crítica não é uma forma de devaneio espiritual - a propósito das obras literárias, não é ensaio ou crônica, predominantemente subjetivas. É uma espécie de realismo, ligado à própria natureza das coisas, à verdade, ao objeto, portanto, isto é, ao objeto literário, cujo valor deve apreciar e julgar. Por isso, na crítica o elemento objetivo prima sobre o subjetivo, o realismo crítico sobre qualquer idealismo. A crítica é lógica e não mágica nem lúdica. (COUTINHO, 1969, p. 235)

\footnotetext{
${ }^{13}$ Pseudônimo do crítico literário e escritor Alceu Amoroso Lima (1893 - 1983).
} 
Isto posto, a crítica deve se pautar pela análise daquilo que está sendo mostrado, portanto experienciado, e não do que deveria ser, de acordo com a visão de quem está avaliando. É perceptível, em certas análises, o estudo do que certa obra não mostrou, mas que deveria mostrar. Esse idealismo, como sublinhou Coutinho, é um elemento que prejudica a realização da crítica, pois o avaliador se pauta em algo que não existe e que, ao seu ver, deveria existir. Ressaltar que algo deixou a desejar é factível numa análise, pois são pontos que saltam aos olhos e envolvem discussões no que diz respeito a parâmetros estéticos e estilísticos do próprio texto. A telenovela, por se tratar de uma obra longa, apresenta um conjunto de críticas que podem ser alterados no decorrer da exibição. Ao crítico, a possibilidade de mudança de ponto de vista, é salutar dependendo da evolução da trama, do personagem e da própria encenação do ator em sua construção do personagem. Como um produto audiovisual, vários pontos podem ser ressaltados na análise e podem ser retomados no decurso da transmissão.

Para Durão (2016), a crítica sofre grande influência de tendências sociais, pois está em conversação com os processos históricos de determinada época. O autor trabalha os vetores que compõem a crítica e seu envolvimento na esfera pública. O que nos chama a atenção é a oposição entre "crítica normativa e crítica imanente" (p.16); a crítica normativa é realizada comparando a obra com alguma norma existente ou com algum parâmetro estético. No entanto, a crítica imanente trabalha sua análise a partir dos princípios estabelecidos pelo próprio crítico, isto é, tende a recair para "a lógica do mercado da indústria cultural” (p.18), em suma, é uma análise que atende às lógicas mercadológicas, exaltando a obra analisada em seu caráter de produto.

Uma vez que a crítica é inevitavelmente valorativa e já que que ela tem a ambição de ser rigorosa e universal - por mais que se ampare na visão de um sujeito singular -, tanto mais será fiel a si mesma quanto mais se entregar ao texto que analisa, sem pensar em seu autor ou no mundo que o cerca. Isso significa que, ao criticar determinado artefato, ao apontar insuficiências, limitações ou equívocos, ela imediatamente projeta uma dimensão paralela, na qual tais defeitos não existiriam. A crítica mobiliza, assim, um dever-ser que não pode englobar desde uma minúcia textual até uma concepção totalmente diferente de mundo. Isso não deixa de ser uma homenagem ao objeto criticado. (DURÃO, 2016, p. 19, grifos do autor)

Isso demonstra que uma avaliação aponta constantemente parâmetros do que se espera de uma obra. Entremeada em sua análise - ou comentário crítico - como partilha 
Benjamin, o crítico formula hipóteses do que poderia ter sido e do que extrapola da narrativa que foi apresentada, haja vista que ela "reconfigura a obra de tal maneira que seu significado passa a ser aquilo que foi enunciado e torna-se difícil imaginar qual era o seu sentido anterior à crítica” (p. 20). Esse processo leva a crer que o espectador/leitor passa a ver a ficção pela lente da interpretação ao qual ele foi sujeitado, que pode ser de concordância ou discordância. A apreciação do crítico ressignifica a percepção desse receptor, estimulado pela perspectiva do comentário lido. O que pode levar a tensões, com o desacordo de ideias, ou, até mesmo, de concordância com algo que naquele momento, não foi percebido. A retroalimentação desse diálogo entre o leitor e o crítico é estimulada pelo acompanhamento de comentários em suas próprias páginas e pelo uso das redes sociais, especialmente do Twitter, utilizado no decorrer da transmissão da telenovela.

Antonio Candido (1973) advoga para a importância dos fatores sociais nas análises de uma obra. Comenta que os elementos sociais estão entre os muitos elementos que pautam uma crítica, porém sem se tornar em modelo clássico de se fazer uma análise. É sabido que questões sociais incidem em uma obra, cabe ao crítico discernimento para tratar do assunto de maneira que abarque tanto os aspectos estilísticos quanto aspectos culturais. "Uma crítica que se queira integral deixará de ser unilateralmente sociológica, psicológica ou linguística, para utilizar livremente os elementos capazes de conduzirem a uma interpretação coerente" (CANDIDO, 1973, p. 07). A relação dialética entre fatores internos e externos da obra advém especialmente de experiências, reflexões, condições sociopolíticas e pesquisas que formam o escritor e balizam suas ideias no momento de confecção da narrativa. O tempo de maturação e concretização da ficçãoleva em consideração os elementos que permeiam esse autor estabelecido em seu contexto. Com isso, as obras não se configuram como um fato histórico em si, porém podem indicar uma relação dialógica.

A esse respeito, Maingueneau (2001 [1993]) elucida que "vincular uma obra ao que a tornou possível, pensar seu surgimento num tempo e num local determinado é uma tarefa tão antiga quanto o estudo da literatura" (p. IX). De fato, o autor enumera duas ações dominantes quanto às maneiras em que se pode encadear uma obra em seu contexto, são elas a história literária e a orientação estilística. Pensar em uma obra como representativa de seu tempo ou a própria expressão de uma realidade não oferta um "valor explicativo" para como ela pode ser o reflexo desse período histórico. A orientação 
estilística analisa a obra por meio do funcionamento de aspectos interiores para depois associá-las com elementos de seu entorno. Longe de rechaçar os aspectos internos e externos, a hipótese do autor é de que "somos levados a tomar consciência de que o contexto não é colocado fora da obra, numa série de invólucros sucessivos, mas que o texto é a própria gestão de seu contexto” (p. 23). Assim, ele reforça que

De fato, a obra é indissociável das instituições que a tornam possível: não existe tragédia clássica ou epopeia medieval fora de uma certa condição dos escritores na sociedade, fora de certos lugares, de certos modos de elaboração ou de circulação de textos. Pode-se, portanto, estender à literatura o que Michel de Certeau diz da história: 'a positividade de um lugar sobre o qual o discurso se articula, sem contudo se reduzir a ele' deve substituir as 'pretensões subjetivas' ou as generalidades edificantes'. (MAINGUENEAU, 2001[1993], p. 19)

Trazendo para o âmbito das ficções, é possível, através do autor, pensar numa existência social da telenovela, tendo em conta o lugar fronteiriço entre realidade e ficção, no qual as narrativas transitam, sendo impossível uma história encerrar-se em si mesma sem obter aspectos e confundir-se com a sociedade.

Machado de Assis, no texto $O$ ideal do crítico $^{14}$, apresenta críticas a respeito do ofício do crítico e ainda fornece orientações quanto à atividade. Segundo o autor, "a profissão de crítico deve ser uma luta constante contra todas essas dependências pessoais, que desautoram os seus juízos, sem deixar de perverter a opinião" (2011, p.10). Entre as recomendações para o devido fazer da crítica, ele descreve:

Não compreendo o crítico sem consciência. A ciência e a consciência, eis duas condições principais para exercer a crítica. A crítica útil e verdadeira será aquela que, em vez de modelar as suas sentenças por um interesse, quer seja o interesse do ódio, quer o da adulação ou da simpatia, procure reproduzir unicamente os juízos da sua consciência. Ela deve ser sincera, sob pena de ser nula. Não lhe é dado defender nem os seus interesses pessoais, nem os alheios, mas somente a sua convicção, e a sua convicção deve formar-se tão pura e tão alta, que não sofra a ação das circunstâncias externas. Pouco lhe deve importar as simpatias ou antipatias dos outros; um sorriso complacente, se pode ser recebido e retribuído com outro, não deve determinar, como a espada de Breno, o peso da balança; acima de tudo, dos sorrisos e das desatenções, está o dever de dizer a verdade, e em caso de dúvida, antes calá-la, que negá-la. (ASSIS, 2011, p. 09)

\footnotetext{
${ }^{14}$ Publicado originalmente no Diário do Rio de Janeiro, em 8 de outubro de 1865.
} 
A partir desses primeiros aportes acerca da crítica literária, refletimos sobre o advento da crítica de televisão no âmbito brasileiro como a delimitadora de laços sociais e culturais, levando em consideração as características da telenovela brasileira e de sua grade de programação.

\subsection{A crítica nos jornais impressos}

A impressa brasileira foi inaugurada em 13 de maio de 1808, no Rio de Janeiro, com a criação da Imprensa Régia fundada por Dom João, príncipe regente. Com o monopólio das publicações, em que eram vetados quaisquer artigos ou livros que ferissem os princípios impostos pelo Império, a impressa brasileira só deslanchou após a compra das prensas por pessoas abastadas que foram responsáveis por romper com o monopólio real. Em 1822, com a Independência, quase 400 anos após a criação da prensa por Guttenberg, a imprensa nacional toma novos rumos com a livre circulação de livros e de opiniões.

No Brasil, a crítica, como será exposto adiante, aconteceu com certo atraso, embora não parecesse ignorar a movimentação internacional do gosto. Se as primeiras críticas, aparecidas na década de 1820, lembram as querelas pré-iluministas, os folhetinistas dos anos de 1840 escrevem em espantosa sincronia com o feuilleton parisiense. O gênero que só pode vicejar na capital da cultura também vinga no Brasil, e assume, naturalmente, características próprias. Os folhetinistas se proliferam no Rio de Janeiro com vícios semelhantes aos de seus colegas franceses, embora não ostentem as mesmas qualidades de especialização. (GIRON, 2004, p. 43-44, grifos do autor)

Essa crítica, a priori, compreendia aos produtos culturais em circulação na época, portanto, o teatro, a música e os parcos livros publicados. A consumação desses elementos abrangia uma elite constituída entre a corte no Rio de Janeiro, na época capital do país, e as províncias mais proeminentes. $\mathrm{O}$ costume de ler jornais tardou a se constituir, levando em conta a demora da instauração da prensa e das constantes censuras, além da pouca alfabetização da população. Entretanto, neste processo de formação da imprensa, os responsáveis por escrever nas páginas dos jornais eram políticos, funcionários públicos e religiosos, que foram se constituindo, ao longo dos anos, em jornalistas.

Neste cenário fundante, temos o princípio da crítica pela criação dos suplementos e cadernos de cultura. Os suplementos nos principais jornais impressos do país procuravam atender aos ditames da indústria cultural, a partir da cobertura desses 
produtos. De início, há a presença do rádio, para, em seguida, passarmos para o cinema e chegarmos à televisão. O papel desses suplementos está atrelado aos discernimentos de produção jornalística e aos mecanismos de legitimação e deslegitimação de um produto. Com esse espaço, pela gênese do jornalismo cultural, legitimou-se a palavra especialista com a missão de informar e formar esse leitor, atribuindo a isso a característica mercadológica. Esse interesse mercadológico é tratado por Coelho (2000, p. 91) quando menciona que

Os cadernos culturais adotaram, todos, o formato de uma primeira página com um assunto só. De modo que, qualquer assunto que aparecer, que for escolhido, exige um tom quase que de consagração, algo de garrafal. Novamente, como nem sempre a lógica da "notícia" impera - e, sim, uma escolha, uma valoração estética, o "fato" -, o "destaque" da capa opera uma inversão. A notícia do dia não é um disco tal ou livro x, é a notícia que é o livro x foi capa da "Ilustrada", o disco tal foi capa do "Caderno 2".

Costa (2012) aborda o papel do jornalismo cultural como guia de consumo, no qual as manifestações culturais são representativas do sistema econômico e dos padrões culturais que possibilitam tais expressões. Portanto, esse jornalismo está inserido numa cadeia ampla de ofertas culturais e tem o objetivo de atender seus leitores.

Os gêneros jornalísticos opinativo e interpretativo (MARQUES DE MELO; ASSIS, 2016) podem ser utilizados para se pensar a crítica no cerne do campo do jornalismo. O primeiro surgiu no século XVIII como um fórum de ideias; já o segundo se traduz por seu papel educativo de cunho esclarecedor, passando a se estabelecer a partir do século XX. Em vista dessa classificação, a crítica, por conseguinte, está inserida no gênero de opinião, pois trabalha no sentido de orientar as audiências para determinada obra. Essa orientação está prescrita em seu objetivo de oferecer respostas às demandas sociais e oferecer um panorama das atividades culturais. Tanto o gênero opinativo quanto o interpretativo são formatos aos quais, por vezes, podemos atribuir algumas características em comum. Entretanto, os espaços destinados para se fazer uma análise e oferecer uma interpretação estão cada vez mais escassos. Perde-se o lugar nas páginas impressas, no entanto, ganha-se nos portais de notícias on-line.

Esses dois fatos, que se conectam de forma simultânea e intermitente perante o público, a crise da crítica (interna) se desdobra na crise de mediação do crítico (externa) - parecem indicar uma depressão nas práticas do Jornalismo Cultural que respondem pela busca de uma 
identidade mais consistente do gênero, alguma âncora epistêmica e sociológica que não o deixe ao sabor das idiossincrasias do mercado ou da técnica, nem mesmo ao sabor das pulsões do público na era de uma sociabilidade que põe o foco de suas virtudes não exatamente sobre $o$ refinamento intelectual dos consumidores, mas no seu embrutecimento de gosto e estilo. Quer dizer, não é tanto a qualidade do que é publicado sobre as práticas culturais de qualquer espécie que importa, mas essa voracidade de consumo que tem o poder de mediocrizar tudo o que ela toca e que desperta em todos os agentes envolvidos pelo Jornalismo Cultural um forte ceticismo sobre o que ele é capaz de produzir. (FARO, 2012, p. 12 - 13)

Há a percepção de que a crítica de TV está muito próxima dos interesses da indústria, atuando para o benefício da mercantilização de algum produto da indústria cultural. A crítica de um livro, peça teatral ou de um filme pode incentivar o consumo do produto, ao contrário da crítica de um produto da televisão aberta, que tem um acesso facilitado pela transmissão constante. Assim, percebemos uma diferença crucial, tendo em vista que a procura pela crítica de televisão, a priori, funciona como uma forma de entender e verificar pontos de vistas sobre um programa que já está sendo consumido.

\subsection{A crítica de telenovela}

O advento da crítica de telenovela no Brasil se deu nos jornais impressos na década de 1960, nos cadernos de cultura dos jornais Folha de S. Paulo, O Globo e Estado de São Paulo. Assim, deduzimos que a crítica de televisão despontou logo após as primeiras telenovelas. A partir desse fato e levando em conta o contexto histórico do Brasil, Magno (2017) ressalta o papel das críticas no desenvolvimento de discussões históricas entre as décadas de 1960 e 1970 ,

Se a partir dos anos 1963/64 a telenovela se tornou um lugar possível para mostrar e discutir questões e problemas suscitados no contexto de uma época em geral e do Brasil em particular, nos anos 1970, a telenovela ganhou contornos inesperados e ricos em textos, imagens, sujeitos e temários, além do alto padrão tecnológico. Particularmente, a intensa produção dos anos 1970 e a profundidade das temáticas sociais e políticas que enredavam as telenovelas fez o Estado, que naqueles anos se apresentava como sujeito único e condutor máximo do processo histórico, voltar os olhos para essa produção e a censura se tornou uma das personagens constantes em muitos momentos das telenovelas brasileiras. (MAGNO, 2017, p. 02) 
$\mathrm{O}$ advento das telenovelas no Brasil encontrou grande impulso com o regime militar, na constituição do mercado cultural do país (LOPES, 2014). Nesse processo socioeconômico e industrial, o Estado era o grande organizador da cultura. E, apesar desse “impulso" dado pelos militares, a televisão não ficou de fora da censura, o que levava os autores de telenovelas a grandes discussões acerca do que seria cortado em seus roteiros.

O panorama da crítica especializada entre os anos de 1960 a 1980 encontra seus maiores expoentes nos críticos Artur da Távola, em sua coluna no jornal O Globo, entre os anos de 1972 a 1987 e em Helena Silveira, em sua coluna no jornal Folha de S. Paulo, entre os anos de 1973 a 1984.

\section{Helena Silveira}

Em 1973, é inaugurada a coluna Helena Silveira vê $\boldsymbol{T V}$, no jornal Folha de S. Paulo. A escritora e jornalista se dedicava à análise dos produtos televisivos e estabelecia sua crítica como uma das mais contundentes da época. Sua importância, como relata Costa (2000), está em oferecer ao público subsídios para os processos que envolvem a televisão, não somente um relato apreciador de uma narrativa, mas também evidenciando a técnica e o contexto das transmissões. Portanto, "ela mostrava como era a linguagem televisiva e com que olhos vê-la" (p. 193). Sua relevância no meio está em difundir discussões concernentes à programação televisiva e seus produtos de forma crítica, enfatizando o potencial artístico da televisão e denunciando o preconceito dos intelectuais.

No trecho abaixo, a crítica relata sua inserção na atividade:

Quando Cláudio Abramo me sugeriu, na redação das Folhas, que eu me tornasse crítica de televisão, creio que, ao contrário do que ele esperava, aceitei com prazer. Vivi um tempo com nojo da palavra escrita. Uma coisa estranha. Achava que as palavras estavam gastas como as pedras puídas e limosas das velhas ruas. E a imagem, sobretudo aquela imagem que nos chegava a domicílio, era um golpe rude na ficção romanesca. Incumbi-me de uma página de jornal inteira, semanalmente, com o título de 'Helena Silveira vê TV'. (SILVEIRA, 1983, p. 237)

Como remarcamos, a crítica de telenovela nasceu justamente com a própria telenovela. O parâmetro para a análise das primeiras críticas era o arcabouço advindo especialmente da literatura, sendo o cinema ainda um gênero novato. Dessa forma, 
Silveira, sendo ela própria escritora, abarca a telenovela por meio de seu repertório literário para, em seguida, ao longo de suas análises, introduzir elementos da cinematografia, pois estava a tratar de um formato audiovisual, e as imagens eram um fator determinante na composição da obra.

É importante entender também que o fato das crônicas de Helena Silveira terem sido escritas quase concomitantemente ao desenvolvimento do próprio gênero de teleficção, permite acompanhar o processo pelo qual a telenovela foi conquistando espaço e público e foi se tornando um gênero próprio de manifestação cultural. Assim, a crítica de Helena Silveira revela a própria organização do pensamento acerca da telenovela, o olhar com que foi recebida pelo público culto e os critérios que serviram de base para um primeiro esforço de análise estética da telenovela. Portanto, a crítica da escritora nos dá elementos não só relativos à telenovela como também possui valor intrínseco como desenvolvimento de uma metalinguagem televisiva. (COSTA, 1997, p. 02)

Figura 01

Helena Silveira vê TV- 30 de maio de 1979, Folha de São Paulo

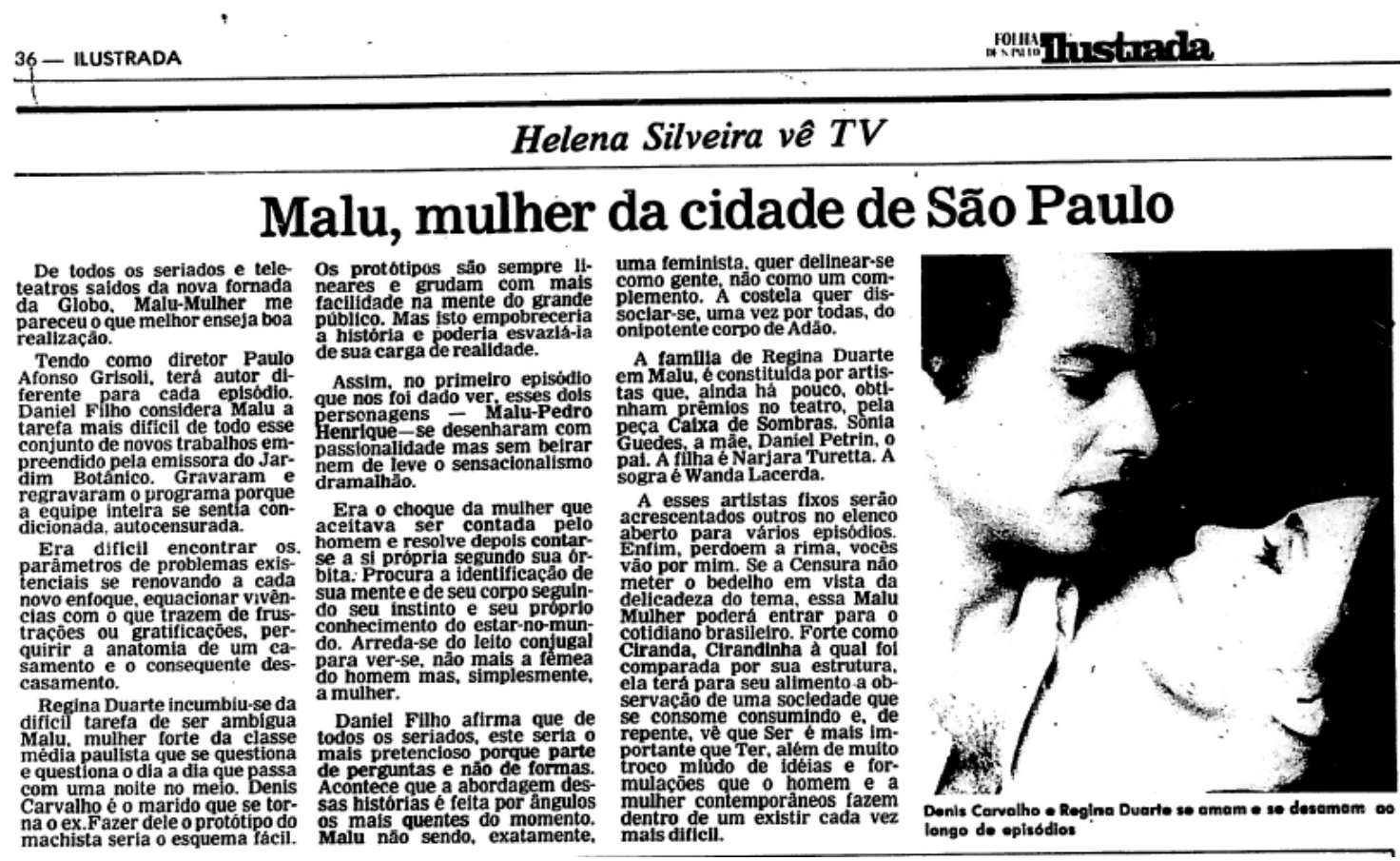

Fonte:noticias.bol.uol.com.br/entretenimento/2008/11/24/ilustrada-50-anos-quotmalu-mulherquot-equotpretensiosoquot.jhtm Acesso 20 dez. 2019

Na crítica acima, datada de 30 de maio de 1979, Helena aborda a série Malu Mulher, exibida pela Globo de 24 de maio de 1979 a 22 de dezembro de 1980. A análise 
recai sobre a primeira semana, e a autora a considera como uma das mais bem realizadas até o momento. Nela, alude a questões do elenco e escolha de direção, dando destaque para o enredo inovador acerca da personagem principal Malu, mulher forte e de classe média que logo no primeiro episódio se separa do marido. Algo até então pouco trabalhado na televisão brasileira.

Nos anos de 1970, a telenovela atinge uma espécie de evolução, com o melhoramento das imagens e dos textos no desenvolvimento das tramas (MAGNO, 2017; HAMBURGUER, 2014). Neste período, as histórias passam a mostrar temas mais políticos, constatando as transformações na estrutura social do país, como destacou Silveira com a crítica de Malu Mulher. Esses novos contornos das ficções incidiam nas críticas, tendo em vista que um dos fatores levantados pelos críticos era a inserção dos aspectos sociais na trama, o que hoje se observa.

Ainda, explica Magno (2017, p.18):

Naqueles anos 1960/70 esses críticos debatiam e defendiam a necessidade de entendermos o significado da telenovela como um autêntico produto nacional e que ela deveria ser usada "como um veículo de cultura e informação", que deveria ser "bem-feita, bem urdida, sem perder suas qualidades de comunicação". Consideravam que o papel do crítico de televisão não era o de combater a telenovela, mas, como escreveu Helena Silveira, "contribuir para que essa forma de ficção no vídeo melhore sempre mais, no sentido de sua fatura. Que cada vez mais profissionais cuidem dela, quer na produção, quer na direção, no roteiro, no cenário, nas trilhas musicais acolhida, basta olharmos tudo que foi e vem sendo feito desde lá.

\section{Figura 02}

Helena Silveira vê TV, Folha de São Paulo, em 22 de setembro de 1978 


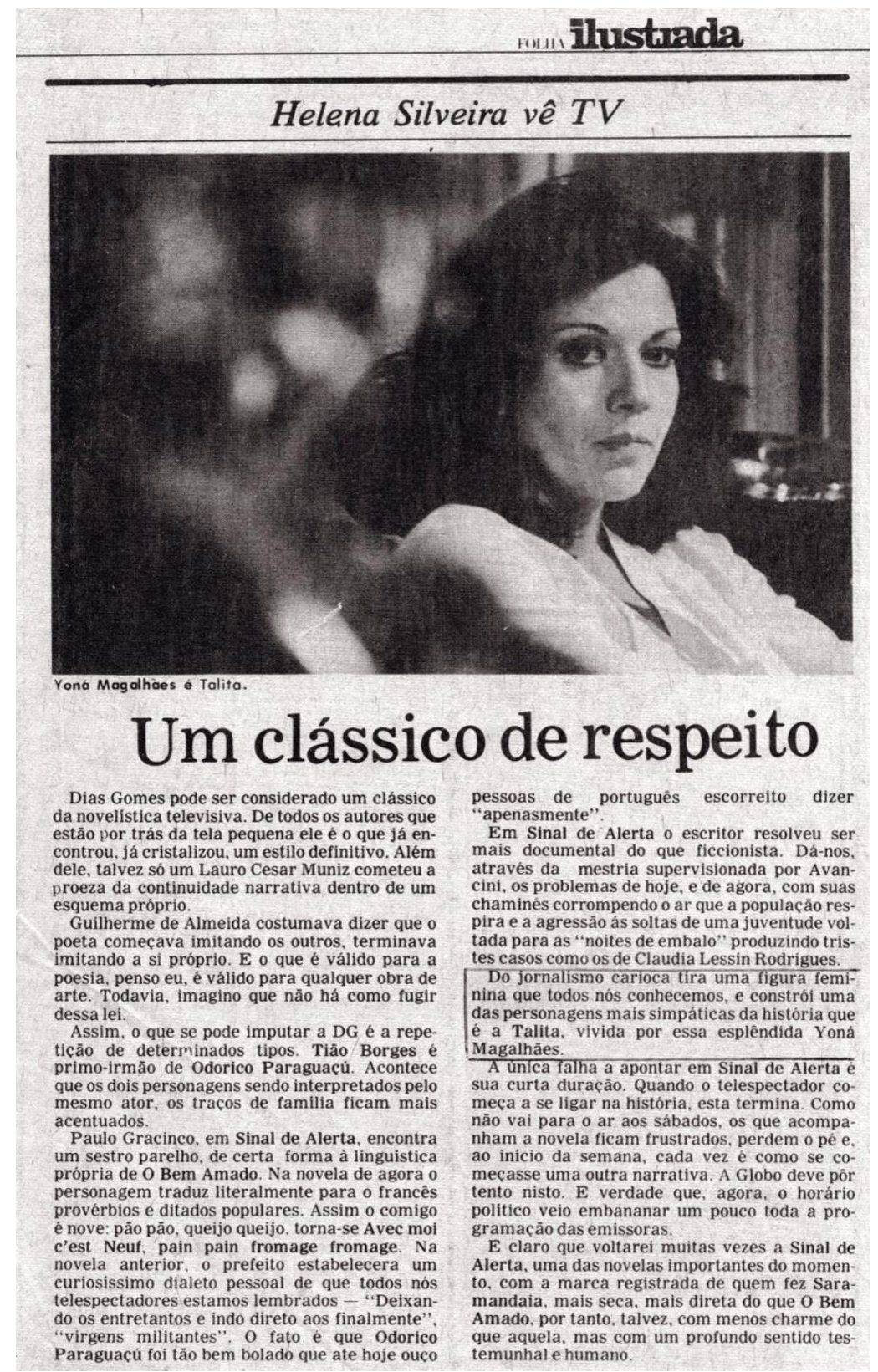

Fonte: http://yonadivadatv.blogspot.com/2012/01/yona-magalhaes-criticas-e-materias-em.html Acesso 20 dez. 2019

Na avaliação acima, Helena tratou do autor Dias Gomes e sua recente ficção Sinal de Alerta (Globo, 1979), na qual ressalta a atuação de Yoná Magalhães e os aspectos da trama que são evidenciados ao longo de sua transmissão. Ao lermos, a crítica faz relação com outras obras do autor como $O$ Bem-Amado, estabelecendo conexões entre personagens e atuações. O que se sobressai na análise é tom de diálogo estabelecido entre Helena e seus leitores, além da maneira como enumera os problemas e até elogia elementos que fazem da trama, como intitulada, "um clássico de respeito". 
Uma característica da crítica de Silveira é a maneira como ela traduz a telenovela ao destacar aspectos que, até então, passam despercebidos, incluindo os ruídos causados na programação diária devido ao horário político eleitoral, ou um elogio para a direção da obra. Na figura acima, já relatava os aspectos da telenovela que demonstram a construção dos traços atribuídos a essas ficções. Em seu parecer, ela enumera: a) inserção de bordões ou frases icônicas de personagens no contexto brasileiro; b) as características de roteiro; c) a verossimilhança e o naturalismo, ao destacar que Sinal de Alerta é "mais documental, que ficcionista"; e d) a atuação, sublinhando o papel de Yoná Magalhães.

A atualidade da crítica de Silveira está no olhar para esses atributos, que ainda são vistos na crítica atual. A mirada crítica para o produto televisivo perpassa um conjunto de elementos que podem ser esmiuçados no decorrer da trama, que compreende períodos de seis a oito meses. Tal conjunto de elementos é traduzido pelo repertório do crítico, que, por meio da reflexividade, da subjetividade apura sua análise. É importante dizer que a assistência da telenovela é uma competência corrente, em outras palavras, construída no cotidiano com narrativas que são - de maneira geral - reflexos de seu tempo.

\section{Artur da Távola}

Artur da Távola ${ }^{15}$, crítico do jornal $O$ Globo entre os anos de 1972 a 1987 e da revista Amiga, adota uma posição interessante, pois passa a problematizar sua atuação de crítico, como por exemplo, no artigo "Existe mesmo a crítica de TV?"16, de 1976. Na comemoração de seus quatro anos de coluna no jornal carioca, o jornalista aborda o exercício da crítica de televisão pontuando as especificidades do fazer televisão no País. Sua argumentação recai no papel da crítica como contestadora dentro do aparato da indústria cultural, devendo trabalhar em três níveis: sociologia da comunicação, psicologia e conhecimento da técnica de televisão.

Quanto aos níveis elencados, Távola reconhece a importância do contexto na obra de ficção, entendendo-a como uma representação de seu tempo, sem deixar de lado os aspectos estilísticos próprios das telenovelas. No nível da psicologia, vemos que as

\footnotetext{
15 Artur da Távola, pseudônimo do jornalista e advogado Paulo Alberto Moretzsohn Monteiro de Barros, inicia sua jornada de crítico após seu período de exílio na Bolívia e no Chile. Amante de música clássica, além de se dedicar à sua coluna no jornal $O$ Globo, o intelectual ainda seguiu carreira no poder Legislativo e no Executivo, exercendo o cargo de Secretário das Culturas do Estado do Rio de Janeiro. ${ }^{15}$

16 Távola, Artur. Existe mesmo a crítica de televisão? O Globo, 29 out. 1976.

Disponível em:http://www.tvpesquisa.com.pucrio.br/mostraregistro.asp?CodRegistro=4132

8\&amp;PageNo=1. Acesso 25. Jun. 2017.
} 
análises críticas tentam entender a representação, ou seja, de que mundo determinada ficção está falando, sem esquecer que a própria ficção gera seu próprio mundo. O crítico esclarece que, no caso da telenovela, por seu caráter de obra aberta, há de se levar em consideração que a crítica é feita enquanto a trama vai se desenvolvendo, "uma das peculiaridades interessantes do crítico de televisão (se é que o gênero existe) é a de poder influir no processo criativo. Ele influi no processo, exatamente porque vê junto com o público" (idem). E, mais:

Cabe, portanto, ao crítico da televisão, muito mais do que enfeixar a verdade definitiva em cada artigo; muito mais do que afirmar os seus critérios estéticos subjetivos, ou as suas necessidades de 'status' intelectual em cima de um meio (a tevê) ainda sem tradição cultural; cabe, portanto, ao crítico de televisão, saber-se um agente do próprio processo de 'fazer'; televisão, com todas as limitações e com todo o poder que isso implica. Se o crítico influi no processo, ele é parte dele. Mesmo que não queira. Mesmo que negue o sistema. É uma contradição e uma limitação que tem de aceitar. Criticando teatro, cinema, livro e artes plásticas ele influi no público e na cultura de seu país (quando é bom crítico). Criticando televisão ele influi no próprio processo de elaboração da televisão. Ele é tão responsável quanto qualquer diretor de emissora. O crítico de televisão, querendo ou não, é uma espécie de advogado do consumidor. (Ibidem)

No transcurso de interpretação de todo processo da telenovela, o crítico de ficção deve apontar, analisar e comentar questões em suas análises. Para isso deve conhecer a fundo o funcionamento televisivo, com suas particularidades técnicas e estáticas. Destacamos que um dos maiores entraves de se fazer uma análise sobre determinado programa televisivo está justamente no tempo de reflexão. Não há um afastamento temporal que permita, neste caso, uma reflexão do todo da obra. As ficções são transmitidas de segunda a sábado, com um volume final de mais de 150 capítulos, o que torna difícil abordá-las diariamente e sistematizar o andamento da narrativa levando em conta suas principais características. Dessa forma, o desafio para o crítico está em acompanhar essas particularidades da telenovela, sem claro, perder de vista seus elementos narrativos e suas tematizações.

\section{Figura 03}

Revista Amiga, nº 527, 26 de junho de 1980 


\section{ARTUR DA TÁVOLA}

⿷匚⿳丨コ丨

repente chega junho e a gente percebe $O$ ano já vai em meio. $O$ ano é engrano começo até que um dia damo-nos conta de que a metade já passou. Não tem sido um an tão brilhante para a nossa TV como foi 1979 , por exemplo, cheio de vida éñ tentativas de program séries brasileiras.

1980 está sendo normal como televisāo. A Tupi agoniza e seus dirigentes depois de anos de incompetência continuam negando o real e cul pando sempre os outros pelo próprio fracasso. Gente desempregada, salários atrasados, um A Bandeirantes depois de ter investido sem esultado de audiência (devido a como ínvestiu não devido a investir) retraiu-se um pouco, mas, tratando de dar força nova às telenovelas e de manter os programas ao vivo que ainda tem. Mas teoricamente está parada.

A TVE do Rio de Janeiro só agora joga no ar uma programaçãa nova em apenas quatro programas. A TV Cultura formulou muito bem uma politica para 1980 . Ideias ót mas que ouví numá entrevista de Carlo

A Globo manteve o esquema do ano passado, diminuindo o número de séries brasileiras. Ela sempre dá um jeito de numa semana por mês meter uma série filmada. Há menos séries. E a perda de "Aplauso" não foi recuperada. Lançou o "TV Mulher, é certo, bom programa. Nao compensou, porem, a perda de espaço para a progra pçara para a garotada à tarde. $\mathrm{E} O$ próprio "Sitio do Pica-Pau-Amarelo" está se afastando demais de Lobato em 1980

A TVS do Silvio Santos (e Record em.Săo Paulo) se em matéria de programação continua no mesmo, tem, por outro lado, grande e importantíssima novidade: a conclusáo dos estudios e do complexo de produçáo de radio e TV. Agora poderá partir com alguma base para a sonhada correta.

No meio desse panorama menos brilhante que o do ano passado em termos de televisão e de novelas que ainda nảo deram um grande pique de qualidade, uma presença avultou no panorama artístico do ano, fol a dona do primeiro semestre: Nata ano, tor a dona do primero surpresa (nao para mim que de muito a aponto Com ela, nasce uma presença fortíssima (e inesperada até mesmo para os estrategistas e "gênios" dos canais), de alta beleza, talento e um cristal de gente boa que dela salta para comove

\section{Num ano de poucas novidades importantes na TV a vitória de Natália do Vale representa 0 resultado de muitos anos de trabalho honrado e talento, mostrando como vale a pena perseverar naquilo em que se acredita}

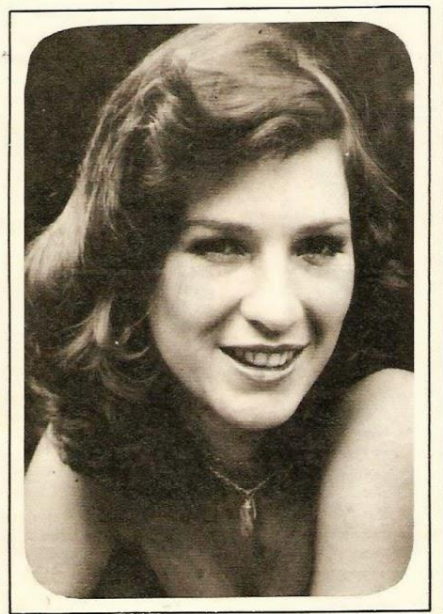

e fecundar o público. Natália é a principal revela ção do ano televisivo, a julgar pelo primeiro emestre.

Podia só ser bonita. Podia só ser boa atriz Podia só ser naturalmente modesta e bem formada. Cada uma dessas qualidades, isoladaodas. Com atrizes da idade e na condição de Natáli acontece o seguinte: elas passam anos acuOula á surpreendem a todos. É que nos anos e anos dos pequenos papéis, das pontas nos humorístcos, dos ensaios teatrais, o talento ia encubando se acumulando, sem personagens para o receber e dimensionar. Quando os raros bons personagens aparecem a atriz ja estava pronta em ensica e sensibilidade de há muito. Aí é um leve saber auanto cozinhou tudo aquilo no co Co lento a quanto cozinhou ça.

consegue um em traduz certas docuras indriláveis da Regina Duarte, nem certas encucaçóes clássicas de Dina Sfat. Consegue um tipo intermediário em que a feminilidade é natural tanto pode tender para a ternura mais profunda hhada (na linha de Dina). Conta juventude forca e uma beleza bíblica de como ver pela constataçáo do bera biblea de comoque mora dentro. Na minha opiniāo é, desde Isabel Ribeiro, a força maior aparecida no video brasileiro: uma vocaçâa acentuada para a dramaturgia, um rosto mistico e multiplo, um pedaço vivo de sentimento à espera da forma

A Márcia de "Água Viva" corresponde a uma consagração. Uma justa consagração. E fácil perà personagem, que a partir de uma certa altura autor começou a escrever para ela solar. E el solava tāo bem (ela e Cláudio Cavalcanti) que o autor nem secansou de repetir e repetir cenas de brigas dela com o Edyr. E quem pensar que é um milagre, uma apariçao súbita, desconhece que para chegar a esse ponto uma atriz precisa de em existencial e forc de prosseguir sem, coraaos encantos fáceis e ilusórios dos escândalos ou das declaracoes bombásticas ou sem ceder a certas formas de decadência travestidas de vanguarda. A vitória de Natália coroa anıos de trabatho muito sério, honradez pessoal, caráter talento. Foi a melhor coisa da televisấo em 1980 té agora. A melhor e mais linda.

Fonte: http://revistaamiga-novelas.blogspot.com/2015/04/artur-da-tavola-comenta-nataliado-vale.html Acesso 20 dez. 2019

Na crítica acima, Távola apresenta o panorama do ano de 1980, destacando o trabalho da atriz Natália do Vale, como é mostrado pela foto no centro da publicação. Não apenas em termos de ficções - com as telenovelas e as séries - o crítico proporciona o cenário televisivo que marcou o ano em questão, relatando entraves na programação, apostas das emissoras e problemas estruturais dos canais. $\mathrm{O}$ trecho em que aborda a atrizchama a atenção devido a sua leitura do desempenho de Natália, relatando seus percalços e escolhas para se chegar a um personagem relevante. A leitura de Távola dos personagens femininos e das atrizes que despontam na televisão mostra sua expertise e 
sensibilidade em abarcar papéis que irão impactar o público e a crítica. Não basta ser bonita, como ele afirma, mas sim levar a cabo uma carreira de fôlego com papéis que irão, de certo modo, aprimorar sua formação.

Conforme lemos a crítica, Távola enumera toda trajetória percorrida pela profissional, pois ler uma produção seriada exige o esforço e adequação do olhar até o ponto em que a trama está sendo exibida. Paulatinamente, a cada dia, as ficções vão se completando e chegando a sua totalidade. Deste modo, a telenovela, ao contrário de produtos prontos, exige a compreensão de quem a analisa e de sempre levar em conta a características de que ela é um fazer e ver em conjunto. Isso se mostra em sua crítica e em seu repertório, onde, aos poucos, a cada publicação, vai-se aludindo a determinado aspecto que mereça destaque.

\section{Figura 04}

O Globo, Segundo Caderno, 18 de outubro de 1984 


\section{ARTUR

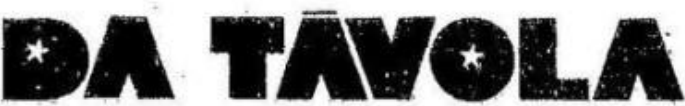

\section{Vejo muito televisão e vou anotando... anotando...}

Falo muito de sonoplastia. 0 material sonoro não é simples sublinhar da ação. E parte dela; às vezes, ela pro. pria. N'outras o acentuar contrapon. tos que expressam estados de espirito oụ instâncias supraverbaís. Trilha so. nora, sonoplastia, direção musical é a parte mais fraca e menos brasileira de nossas telenoveias e telepecas.

Chamo por isso a atenção do teles. peotador para a qualidade do traba. lho realizado em Rabo de Saia. Walter Avancini é o diretor que mais impor. tância dá à sonoplastia. Entrega-a, em geral, a Julio Medaglia competen. te maestro que năo fica a colocar dis. $\cos$ da parada de sucesso em fundo com letras e ritmos que nada, absolu. tamente nada, têm a ver com o entre. cho. Coloca música ou sons, incidên. cias sonoras, acordes. Rabo de Saia é a prova. A música não apenas comenta, situa, acentua, critica, debocha ou reforça a ação, como deriva de uma escolha profundamente afinada com a região nas quaís as cenas se pas. sam. Aparece, ainda, a música, como expressāo da alma brasileira em sua altá dimensão. Ė muito boa, Precisa ser observada para se ver como é di. ferente da esmagadora maioria, principalmente das telenovelas.

\section{O PIRLIMPIMPIM H}

Por elogiar o desempenho musical ácima citado, não é possível ficar sem ưma palavra de crítica à direção mu. sical do especial infantil Pirlimpim. pim II que a Rede Globo apresentou sexta passada. Perdăo, mas Gretchen com suspiros e rebolados é indicado para crianças, por favor essa näo. $\mathrm{Mas}$ seria um pecado venial. Grave mesmo é entupir a criança de sub. rock. Apenas um frevo havia; o único ritmo brasileiro no meio de uma dire. cẫo musical repetitiva dos esquemas de sucesso fácil

A propósito dos especiais infantis, cuja produçåo safra 84 val chegando ao final com saldo positivo, cabe uma reflexão: a Globo já dominou a linguagem especifica $e$ os especiais transformam-se, ademais, em produ. to de exportaçẳo muito qualificado (exceto na parte musical - repito sem qualquer originalidade, criativi. dade e conexão com a cultura brasi. leira). Está, portanto, dominada tecnologia e know-how do espetáculo videosonoro. Estảo provados os me. canismos de comunicaç̃̃o com as crianças, Aos poucos, atores infantis interessantes, verśateis, văo se to. rìmbando. Está, portanto, dominado o formato e a Rede Globo avançou no setor em 84.

Parece-me porém que para 85 Globo deveria experimentar caminho paralelo ao atual. Este é um espetácu. 10 de televisão no qual a música co manda. E um show infantil. Proponho a experiência de valorizar, ano que vem, a historia. E uma troca de predominância: em vez de show musical, uma história para crianças, narrada com a mesma variedade surrealista, com bastante música, com show e es petáculo mas predominando a narrativa $\mathrm{A}$ farta literatura infant disponivel permitírá narrativàs notá veis para a equipe de Augusto Cesa Vanueci. E nossa televisão vai ganha um novo e surpreendente produto.

\section{LUCINHA LINS}

Os astros andam favoráveis a Luci. nha Lins (que devería especializar-se como atriz). Sua participação em Rabo de Saia é deliciosa e provocante, fazendo aquela mulher tåo ardente quanto reprimida, carola por inteiro do lado de fora mas olhos chispantes de desejo, algo diabólico a se infiltrar nas pretensôes beatilicas. Lucinha es tá muito bem em $\mathrm{R}$ abo de Saia e an dou aparecendo ainda, semana passa. da, horário vespertino num filme dos Trapalhões em peripécias num circo cujo dono, seu pai, ê interpretado por Paulo Fortes. Nasceu para o video.

\section{PAULOFORTES}

Uma confissão: acho o Paulo Fortes um barato! Não é portanto, ape. nas um barítono mas um "barátono"! Admiro-lhe 0 nenhum preconceito. Como vejo muito televisão, nesses úl. timos meses ele apareceu: 1) numa propaganda de supermercado muito bem-feita em vídeo-teipe (havia um errado preconceito de que anúncio em vt não pode ser bom. Felizmente está caindo); 2) neste filme acima citado, 0 dos Trapalhőes; 3) num outro que vive a passar na TV Record, alta noite e "repetiu-se" semana passada o do Dr. Cornélio, por ele interpretado; 4) numa entrevista a Clodovil há um mês.

Admiro-lhe a facundia, a versatilidade, o nenhum preconceito, a alegria constante. A bela vo Como importante baritono poderia viyer de não me toques, lá nas alturas. Prefere, po. rém, o caminho da comunicação po. pular, do contato diversificado com 0 público. $\mathbf{E}$ quem (ou)viu sua entrevis. ta a Clodovil por certo encontrou um homem de cultura, altamente infor. mado, simpatiquérrimo. Sou-lhe fả.

\section{OSVALDO DINIZ MAGALHĀES}

Prazer rever o velho mestre e pio. neiro da ginástica pelo rádio, oiten. tão, saudável e sempre alegre em re. portagem segunda passada na Rede Manchete. Hoje que a ginástica explo. de em todas as ruas, televisóes, praias em verdadeiro culto ao corpo organizado, vê-se que a semente do pioneiro da ginástiea pelo rádio frutí. ficou. Lembra Fernando Pessoa: "tu. do vale a pena se a alma nåo é peque. na.'

Fonte: http://www.paulofortes.com.br/site/index.php/quem-foi/criticas Acesso 20 dez. 2019

Távola, nesta avaliação, traz um apanhado das tendências presente na televisão. A programação infantil, a sonoplastia - algo a ser aprimorado nos anos seguintes , e a atuação do ator Paulo Fortes, foram alvo de sua análise, em que se sobressai um olhar técnico e sociológico. $\mathrm{Na}$ avaliação, os pontos destacados evidenciam que, em seu repertório, a conexão com a cultura brasileira é importante na televisão. A crítica sociológica traz os instrumentos necessários para estabelecer uma conversa com o público. A televisão brasileira e, consequentemente sua telenovela, concretizou o modelo 
de ficção e programação num palimpsesto que perdura há muitos anos, especialmente o da TV Globo. As transformações ao longo dos anos vão acompanhando mudanças estruturais e contextuais absorvidas da sociedade, numa relação dialógica. Neste período, percebia-se um esforço das emissoras em abordar aspectos da cultura nacional, fidelizando o público e criando o que entendemos por televisão brasileira. Portanto, elementos como a sonoplastia, que foram se aperfeiçoando pelo advento da técnica e das formas de utilização dessas ferramentas e a utilização de tendências de programação.

Sua prática de anotar o que vê sendo transmitido dá pistas sobre a maneira como sua crítica é efetuada. Neste período, a televisão era consumida no imediatismo da transmissão, cabendo ao crítico uma dinâmica de assistência intensa e voraz. O imediatismo dessa crítica só não era mais instantâneo quanto ao que estamos acostumados com a crítica contemporânea, pois dependia da publicação em jornais impressos, mediante a deadlines - prazo de finalização das matérias. Logo, tomar notas era um trabalho constante para exercer tal parecer e estar atento às tendências, escolhas e, como explicado acima, aos problemas sonoros.

\section{Décio Pignatari}

O teórico, tradutor e crítico Décio Pignatari, outro importante ator no advento da crítica de televisão no país, escreveu, entre os anos de 1970 e 1980, nos veículos Jornal da Tarde / Estado de São Paulo, textos críticos sobre televisão. As análises abordavam a estrutura e o processo televisual, desde as ficções até as políticas implícitas neste âmbito. Em Signagem da Televisão (1984), o autor apresenta nove divisões temáticas que dissertam acerca da televisão. Utilizando a palavra signagem ao invés de linguagem, ele explica que "na era da semiótica, ou teoria geral dos signos, essa invasão do verbal para cima do não verbal, dos códigos verbais em relação aos códigos icônicos ou dos códigos audiovisuais pode induzir a distorções" (p. 8); desta maneira ele faz uma junção entre as palavras signo e linguagem, apontando para sua análise semiótica da TV.

No texto Como analisar a linguagem da televisão (1984, p.13), Pignatari argumenta que:

A televisão é um veículo de veículos, é um grande rio com grandes afluentes. Só que é um rio reversível: recebe devolve influências. Quanto à imagem, desaguam na TV: o desenho, a pintura, a fotografia, o cinema. A palavra escrita é um rio subterrâneo, mas poderoso: a literatura está por baixo de toda narrativa, a imprensa sob todos os 
noticiosos e todos os documentários e reportagens. A palavra falada é um lençol d'água, está por toda parte: presenças do teatro e do rádio, que também influem nos espetáculos musicais e humorísticos. Mas a linguagem marcante, de base, é a do cinema: composição e montagem de imagens. A diferença está que a TV é um cinema caudaloso e ininterrupto que, ritmado pelos comerciais, se distribui por milhões de receptores, numa linguagem que combina todas as linguagens, numa produção seriada e industrializada da informação e do entretenimento. (PIGNATARI, 1984, p. 14)

O autor ressalta a questão da linguagem, das formas e dos significados, tendo em vista que "encontrou na Teoria Geral dos Signos, de Charles S. Peirce, um modelo teórico produtivo para se pensar a literatura e acultura nacional e internacional, partindo da possibilidade de se conceber toda sorte de objetos culturais como "signos"” (VIEIRA; HOISEL, 2016, p. 82). Por meio de um olhar semiótico, sua produção se voltou para a análise da cultura brasileira vista a partir da inserção da televisão neste cenário. Sua análise Realismo: novelas tão chatas quanto a vida? (p. 60), Pignatari comenta como as ficções criam, transformam e desfazem hábitos. A avaliação discorre acerca de uma característica que viria a ser intrínseca da telenovela brasileira: o realismo. Porém, desenvolveu uma crítica tanto das narrativas e dos envolvidos na produção quanto aos que têm preconceito com o aparelho, mencionando que "a classe média se orgulha de exibir seus aparelhos, a alta burguesia e a possível aristocracia os escondem: a escolaridade é inversamente proporcional à televisualidade...” (PIGNATARI, 1982, p. 60)

$\mathrm{Na}$ crítica Telenovela, criação brasileira, Pignatari explica o contexto da implementação das ficções no país e a sua raiz nos folhetins:

Tratando apenas de telenovela moderna, ou seja, a que se desenvolve com a revolução industrial, sem recuarmos a tempos remotos e suas formas narrativas (contos, sagas e romances medievais; representações cênicas da Idade Média; romances de cavalaria, etc.), podemos dizer que a raiz e a matriz da telenovela se desenvolvem sob a forma de escrita, no periodismo diário, com o nome de folhetim - a primeira manifestação de ficção destinada às massas urbanas. Parece incrível, mas o folhetim (o de um Nélson Rodrigues, por exemplo) perdurou no Brasil até a quarta década deste século, quando o filme seriado norteamericano - essa espécie de folhetim cinematográfico - já estava em fase de extinção e quando a radionovela, importada de Cuba, já arrastava em seu torvelinho verbosonoplástico milhões de corações e orelhas de ouvintes "radioativamente" contaminados. (PIGNATARI, 1984, p. 80). 
Nesta análise, o autor aponta ao público a divisão temática e de público ao qual as telenovelas da Globo são submetidas, padrão que perdura até os dias de hoje:

A novela das 6 destina-se a adolescentes; pressupõe, em sua nostalgia, uma certa visão de cultura e, em geral, é adaptação de um romance, com que presta tributo à nossa literatura romântica, incluindo a narrativa marcadamente linear. As novelas dos demais horários seguem o padrão inovador da telenovela brasileira, criado, é bom lembrar, por Lima Duarte e Braúlio Pedroso (com influência indireta de Fernando Faro, em Beto Rockfeller nos áureos tempos novelísticos da Tupi. Que padrão é esse? É o das estórias paralelas, ocorrendo em grupos sociais diversos, que se vão cruzando à medida que se dá a ascensão social (exemplos: O Astro, Dancin' Days). A estrutura básica desse tipo de narrativa mas sem o ingrediente do igualitarismo burguês - vem da literatura e pode ser observado (para não irmos mais longe) em obras como Contraponto (Aldous Huxley), Hotel Xangai (Vicki Baum), Caminhos Cruzados e $O$ Resto é Silêncio (Érico Veríssimo). A novela das 7 destina-se aos jovens (18 a 25 anos), a das 8 aos coroas e das 10 aos intelectuais ou pretendentes a tais, embora hoje se observe uma tendência à mistura de faixas etárias. (PIGNATARI, 1984, p. 61)

A produção teórica e crítica de Pignatari revela o olhar singular e a sensibilidade do autor em perceber as características e peculiaridades de se escrever sobre televisão. Em O Caso de Lauro César Muniz (p. 75), o crítico baseou-se para tratar do problema do público de telenovela e o papel do autor em delimitar este público. Sabemos que as telenovelas têm um público heterogêneo, de diferentes classes sociais, porém um texto de determinado autor pode, de antemão, delimitar qual público será mais eficaz, como ele afirmou: "Para assegurar-se um público de classe média para cima, a telenovela precisa de um Gilberto Braga para cima; para garantir uma audiência de classe média para baixo, necessita de uma Janete Clair para baixo (PIGNATARI, 1984, p. 76).

Em relação ao público, a telenovela apresenta uma característica sui generis, se comparada ao cinema e o teatro. Não importa que forças, interesses ou pressões atuem na realização de um filme, nem as previsões que sobre ele se façam: a película primeiro tem que estar pronta para depois ser submetida à prova do público, da bilheteria e da crítica. A mesma coisa com uma encenação teatral. Não assim com a telenovela. Há um momento crítico em que ela tem que "pegar". Se isto não acontece, todo mundo entra em pânico. Cada qual o que mais quer é ver-se livre daquele pesadelo, que lhe desgasta a imagem, o futuro e o bolso. Então, todos os maus fluidos que emanam da frustação e do ódio convergem para o autor. E o autor, tala como o técnico de futebol de time perdedor, tem de segurar a barra, não pode sair por aí culpando dirigentes e colegas. Como a novela não pode ser tirada do ar, assim 
sem mais aquela, dá para imaginar a agonia da turma. (PIGNATARI, 1984, p. 76)

A proposta da breve introdução destes três críticos de televisão foi para entendemos sua pertinência para o estabelecimento de um campo da crítica de telenovela no Brasil. Os exemplos abarcados aqui serviram de aportes para o panorama da crítica contemporânea e o tratamento dos dados que serão aludidos nos capítulos seguintes. Os processos de análise e até mesmo a evolução da telenovela para um formato que vemos hoje foram elementos que ressaltamos e que permanecem intrínsecos na crítica de hoje.

\subsection{O que entendemos por crítica de telenovela}

Acredita-se que a crítica de TV surgiu a partir das publicações na revista semanal inglesa The Listener, criada pela BBC, em 1929. A revista, publicada toda quarta-feira, cobria as principais transmissões literárias e musicais e tinha como finalidade exercer a curadoria dos produtos culturais existentes na época. O periódico, ao contrário de outra revista da $\mathrm{BBC}$ - o Radio Times, tinha um papel literário mais denso, com textos críticos e construtivos a respeito de produtos artísticos. Não é à toa que grandes nomes da literatura inglesa foram colaboradores da publicação, como Virginia Wolf, George Orwell, TS Elliot, Sylvia Plath, entre outros. De maneira geral, as publicações davam conta dos aspectos políticos e artísticos que permeavam o cenário inglês do século $\mathrm{XX}$, e a priori eram feitas acerca de programas radiofônicos e da literatura, para, posteriormente, cobrir a televisão, até seu fim, em 1991.

A crítica de televisão tem um papel central de interpretação de formas culturais. Por conseguinte, ela se difere da crítica de cinema, de teatro e da literatura, pois a telenovela é um produto em construção, obra aberta de longa serialidade. A prática de sua crítica demanda tempo para o acompanhamento da obra e, ao mesmo tempo, é rápida, pois, após determinado capítulo, o crítico deve discorrer sobre o que foi transmitido. A maturação do pensamento para o tratamento de uma ficção deve ocorrer ao longo da narrativa, que dura em média oito meses. Nesse período, a crítica e o crítico conversam com seu púbico, bem como com os próprios produtores desse conteúdo. Assim, temos uma tríade simplificada deste mecanismo de interação: 


\section{Figura 05}

Desenho da pesquisa

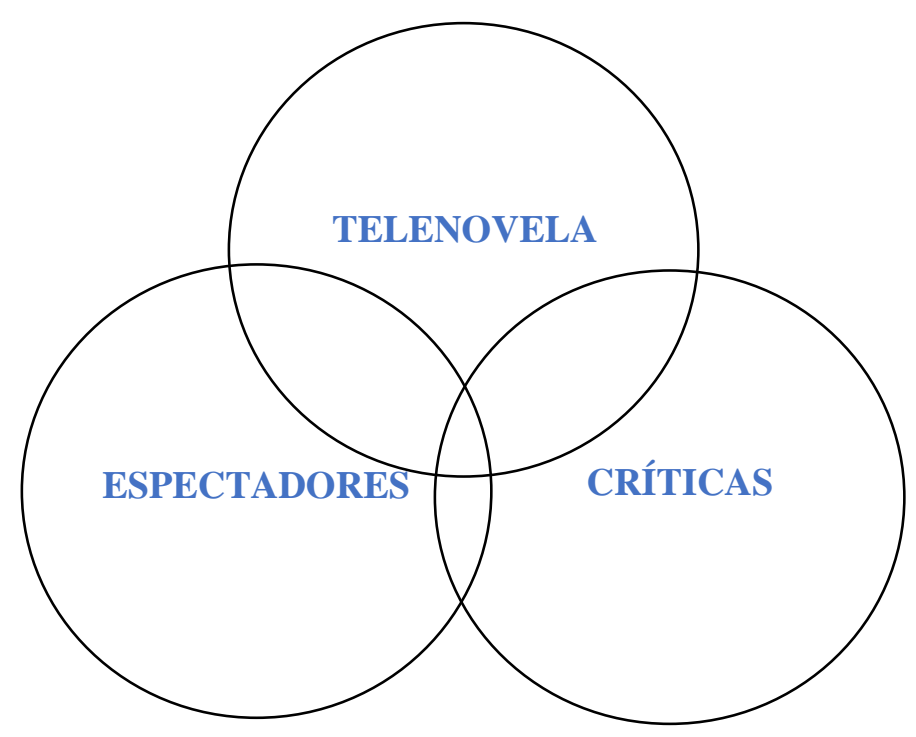

Fonte: Elaborado pela autora

Esse dialogismo ou a semiose social da telenovela atende especificamente às formas que essa crítica tomou e como ela foi se consolidando com os anos, pois esses profissionais, como referido, acompanharam as transformações do formato e, por meio de seus repertórios, estabeleceram um modelo próprio de análise. Esse processo de instauração de uma competência televisiva foi abarcado pela população brasileira e independentemente dos inúmeros ruídos e das divergências televisionadas, cremos que a televisão abriga um papel importante na seleção de discursos circulantes, que correspondem à "soma empírica de enunciados com visada definicional sobre o que são os seres, as ações, os acontecimentos, suas características, seus comportamentos e os julgamentos a eles ligados" (CHARAUDEAU, 2006, p. 118). No dizer de Gomes (2012, p. 16), “esses discursos se espalham em vários campos do saber e vão se atualizando dependendo do período histórico e do lugar, o que, consequentemente, designa modos de ser. Portanto, "um discurso circulante é o que atualiza uma formação discursiva, tornando-a materialidade".

Tal repertório comum provido pela telenovela possibilita a expertise para se estabelecer uma análise, no entanto a compreensão desse formato perpassa camadas de avaliação e de memória que, juntas, trabalham para a construção do olhar crítico apurado quanto aos aspectos internos e externos que compõem a telenovela brasileira. É, portanto, 
necessário saber ler esse formato. Haja vista que a televisão se configura como "um meio oral, e como outros discursos orais, precisa fundamentar-se em fórmulas narrativas que possam ser memorizadas, ou seja, ela precisa trazer alusões a mitos, símbolos, estruturas do imaginário que sejam dadas como certas pelos receptores" (BACCEGA, 2000, p. 46). Neste entendimento, a pergunta que nos move é apreender o que é próprio dessa crítica de telenovela e como se opera a crítica contemporânea, onde a internet ampliou o espaço dessas análises.

Segundo Tondato (2000), a crítica de telenovela deve atuar na comunicação entre produtor e receptor e servir ao "espectador comum, sem tecnicismos e/ou intelectualismo" (p.38). A crítica de televisão no geral tem uma questão temporal determinante, ela é feita a posteriori, após a exibição da narrativa. Pode ser realizada depois da transmissão do primeiro capítulo, ou até mesmo passada uma semana de difusão. Tondato ressalta que, diferentemente da crítica de outros produtos artísticos, a crítica não induz ao consumo da telenovela, mas sim, legitima um consumo já existente. Isto posto, o leitor das análises acerca desta temática está em busca da legitimação dos seus argumentos, de buscar opiniões sobre o que ele está acompanhando. Sobre isso, Maurício Stycer, na crítica denominada Sua excelência, o espectador (2016, p. 23), argumenta:

A televisão é a forma de entretimento mais barata e popular que existe. A maioria das pessoas a assiste desde criança e, naturalmente acumula um enorme repertório a respeito. $\mathrm{O}$ conhecimento incorporado facilita não apenas a compreensão do que se vê na tela como diálogo com quem escreve a respeito.

Com esse intuito, notamos que a crítica participa do mundo dos valores de uma sociedade, sendo a telenovela um produto de grande alcance em números de audiência e de conversações tanto virtuais quanto analógicas. Neste mundo de valores, a crítica articula a proposição daquela obra, reconhecendo as tendências e especialmente a mensagem transmitida. Para Corner (2007; 2013), existem dois questionamentos fundamentais quanto à crítica contemporânea: o primeiro elucida o posicionamento cultural e a função da crítica como categoria de atividade; e o segundo examina as transformações do caráter da crítica em vista do surgimento de novos espaços, com a polifonia de vozes e, por conseguinte, a existência de amadores e especialistas em plena convivência. Os questionamentos perpassam o entendimento do lugar em que essa crítica 
de televisão tem se colocado nos últimos anos, com a redução dos espaços nas redações de jornais impressos e a clara migração da crítica televisual para os sites e blogs. Portanto, uma diversificação de espaço de discussão que sai das páginas impressas ou até permanecem por lá, contudo, encontram maior alcance no âmbito digital. No entanto, neste espaço da cibercultura, esse crítico encontra uma gama de outras vozes que se autointitulam especialistas, trazendo um embate neste meio.

Outro ponto levantado é que, no decorrer de sua leitura da crítica, esse espectador, conforme Corner (2013), encontra satisfação de ver seu ponto de vista ser esmiuçado, seja para concordar ou discordar. Destarte, há certa atratividade em se chegar a conclusões acerca daquela experiência cultural. As ficções se mostram como uma dimensão central da textualidade da televisão, porém, sem a discussão do conteúdo, o crítico pode recair em uma crítica puramente estética, sem a preocupação para elementos que conversem com os processos sociais e os modos culturais implícitos na narrativa.

Nesse pensamento, Greco (2017) ressalta o casamento entre o conhecimento da história da arte e o julgamento. Essa união é crucial para a validação das ideias e argumentos propostos na análise, visto que não basta apenas ter horas em frente à televisão para opinar com seriedade acerca de determinado programa. "Sem conhecimento do objeto julgado não é possível reconstruir sua história, e sem a compreensão do objeto não é possível julgá-lo” (p. 208).

Amanda Lotz (2008) pergunta-se se pode existir uma crítica de televisão, e, em sua reflexão, ela destaca a diferenciação da análise de televisão das demais formas de artes, e chama a atenção para os novos espaços de crítica e o aumento do número de canais e de programas. Sua análise recai no contexto estadunidense, entretanto podemos trazer para o nosso contexto e inferir que a crítica de televisão soube acompanhar as transformações da televisão e a do jornalismo. A multiplicidade de canais e programas dinamizou a mirada crítica, na qual o crítico tem de estar atento a inúmeras características que englobam os processos televisuais. Percebe-se um esforço desses profissionais em entender os processos econômicos e institucionais que englobam a televisão.

Jan Teurlings (2017) utiliza o termo the Demotic Turn (a Virada demótica, tradução nossa) de Graemer Turner (2010) para abordar as transformações tecnológicas quanto à produção e distribuição de conteúdo, aos modelos de negócios, aos respectivos papéis de produtores e consumidores, à cultura de celebridades e ao tipo de identidade cultural 
oferecida pela mídia. Segundo ele, a participação ativa de espectadores que, com a democratização dos espaços de interação, passaram a compartilhar suas opiniões nas diferentes redes sociais digitais foi uma das consequências dessa virada para a crítica de televisão. Dessa interação e discussão em rede, o espectador atingiu um alto grau de discursividade acerca desse produto midiático, ocasionando o que Teurlings denominou de "protoprofissionalização" da crítica de televisão, onde os espectadores atingiram um alto nível de profissionalização dentro do assunto pelo qual eles se interessam. Ou seja, esse espectador possui um conhecimento considerado abrangente acerca do formato ou de determinada ficção, de maneira que ele frequentemente aborda sobre a trama bem como dos meandros da indústria e do setor.

Le Grignou (2008), em sua análise do contexto francês, ressalta que o jornalista de televisão se encontra numa misère de position, pois é vista como uma especialidade desvalorizada, ao contrário do que anteriormente se pensava da posição da crítica como pertencente ao mundo das artes. A análise da teórica francesa é claramente fruto de seu tempo e fora do contexto no qual se observa o boom das séries, especialmente do cenário estadunidense. No entanto, fazendo um paralelo com o contexto brasileiro, ainda há a percepção errônea quanto à atividade de crítica de TV. Maurício Stycer relata que a crítica de telenovela é o patinho feio da crítica; Cristina Padiglione destaca que todos têm uma opinião formada sobre televisão e futebol, pois são assuntos que nos acompanham durante nossa vida e que, por ser tão corriqueira, a atividade de criticar seria trivial, basta assistir à TV.

A competência cognitiva para se falar sobre televisão é algo comum na sociedade brasileira. Há sempre algo a se comentar sobre os folhetins em exibição até mesmo exercendo comparações com outras produções e personagens que foram mais marcantes. Logo, a polifonia de vozes que permeiam a telenovela é constante, construindo o que denominamos de universo de circulação de sentidos da telenovela, pois é normal que os espectadores, de certa maneira, acumulem um capital simbólico acerca das narrativas e tendem a abordá-las juntamente nos comentários das críticas e/ou nas redes sociais.

Paul Rixon (2011), em sua obra TV Critics and Popular Culture: A History of British Television Criticism ${ }^{17}$, apresenta o mapa do cenário histórico da crítica televisiva britânica, ressaltando as mudanças estruturais e discursivas que ocorreram ao longo dos

\footnotetext{
${ }^{17}$ Tradução nossa: Críticos de TV e cultura popular: uma história da crítica televisiva britânica.
} 
anos. Nesta análise, Rixon delimita três categorias nas quais a crítica pode ser vista: os neo-critics, a soft TV criticism e a Internet/public critic blogging. Os neo-critics foi o termo cunhado pelo autor para designar os profissionais que escrevem suas críticas dotados de um estilo humorístico e que escrevem com certo desprezo, com discernimento crítico acerca dos programas televisivos; nesta categoria estão inseridos críticos que mostram uma linguagem mais debochada e aberta, longe da rigidez da crítica literária.

A soft TV criticism é o que mais se assemelha a uma notícia do que necessariamente a uma crítica. Essa modalidade não se pauta em programas específicos da grade, mas sim aborda a televisão de maneira geral, o que, consequentemente, é insuficiente em termos de análise. A própria utilização do termo soft - neste sentido, uma crítica branda - já designa para as notícias que tratem de diferentes aspectos que envolvem o campo da televisão, como notícias dos famosos, dos bastidores e da produção no geral. No contexto brasileiro, a soft $T V$ criticism pode ser relacionada com o colunismo social, que, aliás, nesta pesquisa, não é enquadrado como crítica. Não podemos afirmar que os colunistas não fazem críticas, ou que os críticos que analisamos não façam reportagens que abranjam outros pontos da TV, no entanto visualizamos a crítica formada por critérios e reflexões e que fogem do adjetivo soft, que denota a uma leveza de análise.

Internet/public critic blogging refere-se aos usuários que, por meio de seus blogs, fazem críticas dos conteúdos televisivos seguindo seus gostos e seu comprometimento com essas páginas. Esta categoria retrata os produtores de conteúdo amadores, que não estão atrelados a nenhum veículo de comunicação e que, pela facilidade de criação de blogs e canais em plataformas como o Youtube e Instagram, apresentam seus pontos de vistas em formato de resenhas críticas. Esses produtores são, em sua maioria, fãs dos conteúdos analisados e, através do conhecimento adquirido no decorrer da assistência, acumularam certo capital simbólico sobre tal ficção.

As três categorias de Rixon servem para enumerar a dilatação da atividade crítica no cenário atual em tempos de internet e facilitação da informação. Entretanto, em vista da particularidade da telenovela brasileira, a sua crítica também apresenta suas especificidades que a delimitam para os folhetins. O crítico português Eduardo Cintra Torres (2011) apresenta os fundamentos do crítico de acordo com sua experiência nos jornais e como acadêmico: 
O crítico - não exerce a crítica para exclusivo benefício próprio; a crítica tem por objectivo, como qualquer outra actividade, a prática do bem.

- A crítica situa-se não entre, mas em relação com a obra criticada e o autor desta.

- Ao escrever num mass media, o crítico deve tomar em conta que escreve para um leitor comum e para um leitor especializado, devendo satisfazer a ambos.

- O leitor visado do crítico - deve ser um leitor ideal colectivo, que se desdobra: o leitor colectivo do órgão que o publica e um leitor colectivo que, não lendo, existe no horizonte ético da sua praxis, a — sociedade do seu tempo - com as suas preocupações estéticas e sociais.

- A crítica é - um texto de um especialista com - maior ou menor preparação técnica/académica no ramo a que se dedica e com empatia pela disciplina que critica.

- A crítica deve ter fundamentação científica ou teórica para - libertarse do seu próprio autor, pois - a afectação a preceitos teóricos a liberta de taras pessoais e de gosto pessoal do crítico; mas ela - exprime um ponto-de-vista que é também pessoal.

- A crítica é - alheia à maledicência e deve reger-se por - uma absoluta independência, pois sem ela - não há verdadeira crítica, sendo, por isso, - feita de acordo com convicções profundas do crítico e independente dos gostos e opiniões dos próprios leitores concretos, razão porque - o crítico não conhece os seus leitores.

- A crítica exerce-se num ambiente dialógico e - evita os juízos definitivos, -esclarece, elucida e analisa, tem - sempre um objectivo positivo, mesmo quando aponta aspectos negativos, visa $o$ esclarecimento e a melhoria da disciplina na qual se insere, sendo por natureza útil aos criadores e aos leitores. (TORRES, 2011, p. 8)

No sentido colocado acima, Torres salienta as noções qu, a seu ver, são importantes para o exercício da crítica. Destas colocações, acrescentamos a noção de que o crítico deve apreciar o objeto da sua crítica e ter em conta os atributos desta ficção. Pensando nisso, Stycer (2016, p. 24) admite que, para fazer uma crítica, é necessário "conhecimento histórico, capacidade de argumentação, sensibilidade e, não menos importante, coragem para confrontar o senso comum".

As críticas também podem ser vistas como fonte primária para pesquisadores de televisão, tendo uma função de arquivo. "Criticar significa inserir a obra em um contexto histórico-sociocultural" (TONDATO, 2000, p. 33), logo ela expressa um reflexo de um período histórico em específico. Esse relato é realizado pouco depois da exibição, desta forma se torna um informe não somente do folhetim, mas de fatores externos que incidem na trama. A televisão, como um aparato disseminadora de discursos e interpretações, tem na voz do crítico formas para se entender os signos culturais e estilístico da época. A crítica apoia-se em diferentes critérios de análise que nos dão pistas para entendermos o 
contexto das produções, e compreendermos os processos de transformação do mercado audiovisual, das mudanças advindas do advento da tecnologia e das mudanças quanto as formas de assistência. O texto da crítica de TV deve ser feito para consumo imediato, como o próprio objeto de crítica, caso contrário perderá sua função, visto que trata de assuntos acontecidos, de consumo transitório, cujo arquivamento só servirá para relatos históricos (TONDATO, 2000, p. 38).

É importante a leitura de críticas das diversas manifestações artísticas. Como vimos, em parte porque a crítica impressa geralmente resiste ao tempo, documentando e recuperando espetáculos que, sem ela, só teriam registro na memória do público, sempre fragmentada e essencialmente afetiva. Assim, a crítica registra, divulga e recupera. É elemento fundamental para a compreensão não só da obra como dos critérios através dos quais a obra foi recebida e apreciada pelo público. (COSTA, 1997, p. 02)

Neste capítulo, priorizamos a abordagem de aspectos teóricos que consideramos necessários para adentramos na análise das críticas de telenovela. Falamos do espaço desta modalidade interpretativa nos jornais impressos, nos cadernos de cultura e nos principais críticos que foram a gênese da crítica de telenovela no País. Podem se perguntar, ao longo da leitura deste capítulo, a razão para que os pressupostos teóricos majoritariamente com autores do campo da crítica literária - figurassem como nossa base teórica principal. É que não podemos negar que a crítica teve seu advento concreto com as análises sobre a literatura, em mudanças estruturais na sociedade ocidental, na criação da imprensa e, por conseguinte, no acesso à informação. O teatro, berço do melodrama, já era uma atividade artística pungente, bem como a música. Todavia, os romances, as novelas e os folhetins foram esmiuçados e formaram um conjunto de críticas que possibilitaram o campo da crítica literária. Desta fonte é que muitos críticos brasileiros beberam e construíram seus próprios parâmetros e critérios, pois, mesmo o cinema sendo um produto audiovisual e sua crítica tendo sido apresentada em revistas e jornais, os filmes são produtos prontos, sem possibilidade de alteração após seu lançamento; de outra parte, o folhetim audiovisual traz semelhanças com o folhetim francês impresso semanalmente, que favoreceu a criação dos costumes e hábitos europeus e a leitura desse gênero pelas camadas mais populares. $\mathrm{O}$ que destacamos aqui é justamente a prolongação 
desta narrativa, 150 a 200 capítulos, são aproximadamente oito meses de conteúdo diário (menos os domingos), que está sendo feito neste período temporal. Assim, a telenovela e a crítica são conteúdos abertos.

Por fim, remarcamos que, no contexto brasileiro, o campo da crítica de telenovela conta com um número reduzido de profissionais que atuam em veículos de comunicação. A transição do espaço da crítica, a valorização das atividades num ambiente marcado por uma polifonia de vozes, exibem processos de transição do ofício e da própria televisão. No capítulo a seguir, que marca o fim desta construção teórica, explanaremos os mapas das mediações concebidos por Jésus Martín-Barbero, que se constituiu como nossa estrutura teórica-metodológica nas análises. 


\section{CAPÍTULO 3 - Os Mapas e as Críticas: um olhar teórico- metodológico}

A novela um pouco assalta quem está no sofá. É uma hora que você fala assim: 'ah eu não tenho nada para fazer, vou ver novela', ou então 'eu não quero pensar em nada', ou eu já vi gente assim: 'a novela é tão ruim que eu adoro ver, porque eu quero não pensar em nada. Cristina Padiglione.

Ao inserirmos o objeto crítica de telenovela, mobilizamos os mapas da mediação propostos por Jésus Martín-Barbero para entender a função dessas críticas como mediadoras no campo da circulação de sentido. Neste capítulo, visualizamos os quatro mapas como diacrônicos, isto é, reflexos das transformações ocorridas no espaço latinoamericano, que, por sua vez, transmitem os processos comunicacionais que permeiam as análises críticas e as telenovelas. O objetivo é identificar os críticos e as críticas nos mapas, relatando o processo de delimitação do objeto empírico e no posicionamento em que ele se encontra neste encadeamento de circulação de sentidos.

\subsection{A telenovela, as críticas e os mapas das mediações}

Já deixamos claro que a telenovela é uma ferramenta ininterrupta de circulação de sentidos na sociedade, até mesmo organizadora das noções de brasilidade, portanto, eficaz na demonstração de códigos culturais unificadores. Também tem, em sua atuação, a capacidade de abordagem de assuntos do âmbito pessoal, e, assim, extrapola e embaralha os polos do público e do privado. Com essas características fundantes, a ficção opera dentro das casas, no âmbito domiciliar e expande sua eficiência dialógica nos demais domínios do espectador. Entretanto, nos últimos anos, os conteúdos ficcionais se tornaram viajantes, abrangentes em diferentes plataformas e reproduzidos em variados dispositivos. Neste cenário, a telenovela caminhou e acompanhou esse contexto, no qual adentrava não somente as casas dos espectadores, mas o acompanhava no caminho para 
o trabalho/escola, e até mesmo podia ser transmitida nos intervalos entre um e outro. Isto é, os conteúdos passaram a ser nômades.

Em vista disso, os mapas igualmente souberam seguir essa mudança de cenário, vislumbrando as modificações que a tecnologia possibilitou na rotina dos sujeitos. Com a complexidade do pensamento de Martín-Barbero, Lopes (2018) denomina a obra do teórico colombiano de Teoria barberiana da Comunicação, pois é "caracterizada por uma epistemologia, metodologia e conceitos próprios" (LOPES, 2018, p. 39). Segundo a autora, a epistemologia barberiana ressalta a relevância das periferias e, assim, designa o olhar para o popular e o subalterno. Isso evidencia a crítica do autor para as análises do espaço latino-americano feitas por meio de modelos hegemônicos europeus, que pouco condiziam ou conversavam com esse espaço marcado por processos coloniais exploratórios que originaram culturas mestiças. Logo, "mudar o lugar das perguntas para tornar investigáveis os processos de constituição do massivo para além da chantagem culturalista que os converte inevitavelmente em processos de degradação cultural" (MARTÍN-BARBERO, 2015 [1987], p. 29).

Nesse momento, bebi das fontes, porque foi quando recebi, para pensar a comunicação, uma série de insumos de tipo filosófico, antropológico, inclusive a partir de uma certa concepção da crítica literária que coloca que coloca a comunicação como fenômeno muito forte em termos antropológicos e filosóficos, e muito antes que Habermas se dedicasse a fazer sua obra da comunicação (MARTÍN-BARBERO, 2018, p. 106)

A teoria de Martín-Barbero ultrapassa os processos de recepção e da produção, mesmo sendo abarcada constantemente para formulações e estudos do campo da recepção. Neste trabalho, a crítica é vista como uma mediação, porém é simultaneamente produto feito por um espectador, que, amparado em seu ofício, realiza uma avaliação para os demais leitores. Esse posicionamento estratégico do crítico lhe permite estabelecer tal diálogo com o público dessa narrativa. Seu entre lugar é marcado por influências da produção (aparatos que compreendem a telenovela) e a própria recepção(espectador). $\mathrm{O}$ crítico acompanha a telenovela juntamente com o público da ficção e o próprio leitor de seus textos. Operando como uma metalinguagem (BARTHES, 2007) e como um paratexto (GENNETE, 2009), as análises sobre a telenovela estão em uma conversa com o público, pela sensibilidade do olhar para com as narrativas analisadas, ou pelas conversas com seus leitores nos comentários ou nas redes sociais. 
O espaço das críticas teve impulso com a internet, permitindo o contato com as variadas análises feitas na década de 2010, possibilitando o caráter da crítica como arquivo. Neste amplo compilado, coube-nos estabelecer uma cartografia das críticas na busca por aspectos que dialoguem com a importância de se trabalhar com essas análises e apreender seu lugar no campo da comunicação. Nos apropriamos da cartografia para situar e adentrar nas dinâmicas dessa crítica contemporânea de comunicação. E nesse cartografar as críticas, temos - no cerne do fazer metodológico - o anseio de observação do objeto juntamente com seus variados aspectos.

A cartografia prevê a construção de mapas e modelos, e em Martín-Barbero ela se configura como um método, estratégia metodológica na qual o pesquisador vai a campo munido de pistas metodológicas, métodos que guiam o cartógrafo em seu ofício de pesquisa. Em uma investigação científica, a cartografia visa à compreensão de fenômenos sociais por meio de uma mirada transdisciplinar "que é conhecida por realizar deslocamentos de conceitos e autores de seus lugares tradicionais e rupturas com aportes reducionistas ou maniqueístas" (LOPES, 2018, p. 46).

O modelo de cartografia pensado por Martín-Barbero tem diversas coincidências com o modelo rizomático de Deleuze Guattari, como relembra Lopes (2018). As similaridades estão, certamente, no entendimento de que a cartografia prevê variadas conexões entre diferentes pontos. É um olhar amplo para os processos analisados, porém tentando encontrar as particularidades e pontos afins.

Deleuze e Guattari (2011 [1980]) discorrem que o pensamento rizomático é um sistema aberto, portanto, são linhas que se movem e abrem em múltiplas direções, redes não hierárquicas que em "qualquer ponto de um rizoma pode ser conectado a qualquer outro e deve sê-lo" (p. 22). Entre as características desse pensamento estão o princípio da cartografia, em que o rizoma se encontra sempre no meio, produzindo novos agenciamentos. Assim,

O mapa não reproduz um inconsciente fechado sobre ele mesmo, ele o constrói. Ele contribui para a conexão dos campos, para o desbloqueio dos corpos sem órgãos, para sua abertura máxima sobre um plano de consistência. Ele faz parte do rizoma. O mapa é aberto, é conectável em todas as suas dimensões, desmontável, reversível, suscetível de receber modificações constantemente. Ele pode ser rasgado, revertido, adaptarse a montagens de qualquer natureza, ser preparado por um indivíduo, um grupo, uma formação social. (DELEUZE; GUATTARI, 2011, p. 30) 
Por conseguinte, os mapas das mediações estão em constante processo de produção e transição, e o cartógrafo está em pleno processo de experimentação, criando formas de leitura da realidade social. E nisso recai a potência dos mapas como mecanismo metodológico de um olhar sobre o objeto, sendo o mapa "uma questão de performance" (DELEUZE; GUATTARI, 2011, p. 30). Neste sentido, cartografar designa todos os elementos que intercruzam o trabalho. Kastrup e Passos (2013) reiteram que, numa investigação, a cartografia incita a reunião de vetores heterogêneos inseridos na pesquisa que envolvem desde "o pesquisador e seu campo de interlocuções acadêmicas e instrumentos técnicos, agências de fomento, compromissos políticos, alianças institucionais, bem como o objeto e suas diversas articulações” (p. 267). Deste modo, para Souza e Francisco (2016, p. 813), a cartografia "se opõe à política cognitiva cartesiana-positivista propondo outras linhas e outros modos de tecer compreensões acerca dos homens e do mundo, mapeando paisagens, mergulhando na geografia dos afetos, dos movimentos e das intensidades".

Rizoma é um modelo descritivo de uma formação que se opõe a construções lineares e hierárquicas. É o esquema de uma proliferação, ou de uma conectividade nômade, que não tem centro e se irradia em todas as direções; cada elemento pode-se cruzar-se com outro influenciando ou modificando-o. Caracteriza-se pela multiplicidade, pela heterogeneidade e por delinear-se como resistência às tradicionais árvores do conhecimento. (GOMES, 2014, p. 381)

As similaridades entre os mapas das mediações e o princípio rizomático são alertadas por Lopes (2018) no texto Teoria Barberiana da Comunicação. Os pontos em comum são, especialmente, as variadas relações que podem ocorrer entre as outras mediações que compõem um dos mapas, isto é, múltiplas relações e mobilizações dependendo do objeto de pesquisa. O pensamento de Martín-Barbero é justamente um exercício da interdisciplinaridade, por meio de um olhar que nos faz compreender os processos culturais diversificados em vigor, numa mescla de diferentes áreas como a Comunicação, a Filosofia, a Antropologia e a Semiótica. E tem o objetivo de analisar esse novo contexto, buscando novas genealogias para o que estamos vivendo, além de alcançar uma ruptura epistemológica. 
Tendo isso em vista, a seguir abordaremos os quatros mapas teóricometodológicos com o intuito de realizar os entrecruzamentos e enquadramentos nos quais os eixos perpassam, dando conta das mediações que o objeto opera, além de refletir a historicidade da crítica em meio a essa temporalidade contemporânea dos conteúdos televisuais.

A obra barberiana, até o momento, conta com três mapas das mediações apresentados em diferentes reedições de "Os Meios e as Mediações"; o quarto mapa foi divulgado por meio de entrevista do autor concedida ao pesquisador Omar Rincón, em 2017. Tal atualização dos mapas já demonstra seu caráter mutável, sempre atento às transformações socioculturais. Desde 1987 até 2017, quatro mapas foram introduzidos, e cada um vai acrescentando novos eixos e mediações ao anterior. $\mathrm{O}$ único elemento inalterado nesses anos são os espaços constitutivos das mediações, lugar central nos mapas, a saber: comunicação, cultura e política. Longe de designar um conceito de mediações, Martín-Barbero, ao longo de sua obra, vai dando indicações do que para ele são as mediações. São, portanto, algumas colocações que vão dando uma ideia do que se trata. Em nossa interpretação, o ato de mediar, por si, já designa intervir, ligar os pontos ou conectar as redes. Como um analista da cultura, o autor se pauta no entendimento de todo o processo de comunicação, não somente trata do ponto de vista da recepção, onde ele é altamente referenciado. Neste sentido, ele elucida que "o campo daquilo que denominamos de mediações é construído pelos dispositivos através dos quais a hegemonia transforma por dentro o sentido do trabalho e da vida da comunidade" (p. 265). Tais dispositivos apontam as possibilidades interpretativas do processo comunicacional no relacionamento complexo entre a produção e o consumo.

Lopes (2018, p. 51) sublinha o conjunto de princípios aos quais o conceito de mediações é atribuído, nele ela postula que "todo processo de comunicação é articulado a partir das mediações". Neste sentido, a cultura e os modos de ver estão imbricados neste processo, como relata Ronsini (2011, p. 95):

Uma função da análise cultural pela via das mediações é o entendimento dos processos hegemônicos não estritamente derivados do poder político e econômico dos setores dominantes ou do sincronismo do relato com o tempo vivido, mas da textura dos distintos modos diacrônicos de experimentar o tempo e o espaço. 
Os mapas da mediação abarcam os processos socioculturais vigente neste espaço latino-americano; um espaço igualmente mestiço, no sentido de descontinuidades culturais e hibridizações entre o folclore - popular, entre o que é considerado alta e baixa cultura (MARTÍN-BARBERO, 2018). Dessa forma, pontuamos a intenção dos mapas para esta pesquisa nas próprias palavras do autor:

O que busco com esse mapa é reconhecer que os meios de comunicação constituem espaços-chave de condensação e intersecção de múltiplas redes de poder e de produção cultural, mas também alertar para o pensamento único que legitima a ideia de que a tecnologia é hoje o 'grande mediador' entre as pessoas e o mundo, quando o que a tecnologia medeia hoje, de modo mais intenso e acelerado, é a transformação da sociedade em mercado, e deste em principal agenciador da mundialização (em seus muitos e contrapostos sentidos". (MARTÍN-BARBERO, 2015, p. 20)

O autor delimita, na primeira versão de Dos Meios às Mediações (1987), os três lugares de mediação, o que está no meio entre a produção e a recepção no consumo de produtos midiáticos. São, respectivamente, a cotidianidade familiar, a temporalidade social e a competência cultural. Esses lugares de mediação podem ser entendidos como os primórdios do que posteriormente ele denominará de Mapa das mediações.

Por cotidianidade familiar o teórico compreende como o lugar onde ocorrem as experiências de assistência da televisão, espaço da recepção; um contato direto dos espectadores com as figuras que somente podem ser vistas na telinha e os desdobramentos que advêm dessa assistência. Nos primórdios da TV no País, Priore (2019, p. 256) comenta que "alguns dos que desconheciam o aparelho, misto de rádio e cinema, acreditavam que os artistas ganhariam vida e sairiam da tela, outros se maravilhavam diante do corpo e do rosto daqueles de que até então só conheciam a voz”. Dentro das casas se estabelecem relações heterogêneas, entre elas as sociais e institucionais, que permeiam e balizam o dia a dia de um domicílio.

Quando mencionamos os circuitos de circulação de sentido da telenovela, entendemos que a cotidianidade familiar corresponde ao ambiente familiar, lugar de trocas, hábitos, interações constantes entre membros da família, amigos, bairro. Constituiu-se como um lugar de ancoragem do aparelho televisivo e de onde se consolidou essa interação e movimentou o falar sobre televisão, a curiosidade sobre os artistas, do que ia se passar naquela semana e os desdobramentos da trama. 
A temporalidade social corresponde aos variados tempos que compõem o nosso cotidiano. No caso específico da televisão, temos a confluência de duas temporalidades, o tempo do relógio, representado pelo fuso horário nacional e no qual nos pautamos para o exercício do trabalho, escola e afins; e o tempo do capital, representado pela grade de programação da emissora, que é definido pelas lógicas de produção do canal em questão. Os dois são dependentes das contingências da rotina, e de certa forma, disputam entre si pela atenção desse espectador. Levando em conta as duas temporalidades relatadas, é válido explicar que a disputa entre o tempo do relógio e o tempo da internet, este último, diferentemente do palimpsesto da programação, é marcado pela espacialidade do campo virtual, onde há espaços em que são alocados os portais de notícias, sites, blogs e páginas de redes sociais digitais. Em suma, a cibercultura é atrelada à ubiquidade, à onipresença destas redes e conteúdos acessíveis por meio de plataformas e dispositivos. Por consequência, não há um tempo da internet, mas sim um lugar, uma espacialidade.

A competência cultural está associada à aptidão desse receptor em entender os códigos visuais e textuais de determinadas narrativas, por conseguinte, uma habilidade de reconhecimento. Aludimos para a competência cognitiva do brasileiro em ler conteúdos ficcionais e entender as lógicas intrínsecas do fazer televisivo. A repetição possibilitou a construção desse know-how, entendimento das peculiaridades das tramas. A literacia midiática (SCOLARI, 2018) dos espectadores é fundamentada na repetição do palimpsesto, especialmente da TV Globo, que fundamentou uma grade de programação e na construção de um prime time calcado na intercalação entre entretenimento e informação. Ao pensar nestes lugares de mediação, devemos considerar as diferenças de contextos, com condições culturais e sociais distintas (JÚNIOR, 2018).

Em nossos eixos de análise (telenovela - crítico - críticas), os mapas serão articulados de forma a captar as configurações culturais inseridas nas transformações históricas em nosso território. A produção industrial e cultural da telenovela esteve ligada a um processo massivo capitalista juntamente ao um premente recurso ditatorial unificador do território nacional. Promovidos pelo surgimento da técnica do vídeo, tal procedimento leva em conta que, na década de 1950, apenas as elites usufruíam do recurso televisivo; na década seguinte, em 1960, sua intercorrência nos lares brasileiros passa a ser mais significativa. Neste período é que os domicílios ou a família formam a "unidade básica de audiência" (MARTÍN-BARBERO, 2015, p. 295), é a intercorrência 
do assistir junto, da proximidade tanto dos personagens assistidos quanto da cercania familiar.

Sarlo (2016 [1997]), em vista das transformações culturais e políticas abarcadas nos territórios latino-americanos, apresenta, nas Sete hipóteses sobre a videopolítica, conjecturas quanto às mudanças estruturais com o advento das tecnologias que abrangem $\mathrm{o}$ audiovisual pois,

A videosfera é um espaço hegemônico em expansão. A dimensão simbólica do mundo real foi reorganizada com uma radicalidade e uma extensão somente comparáveis às mudanças causadas pela propagação dos impressos que, como se sabe, foram um fator decisivo na esfera pública moderna. Estamos vivendo o capítulo mais espetacular de um processo de propagação e democratização, muito embora suas características não possam ser consideradas invariavelmente democráticas. (SARLO, 2016, p. 129)

Este primeiro mapa das mediações parece dar conta das transformações na cultura que possibilitaram as configurações de hábitos fundamentais com a instauração da televisão e da assistência de telenovela. As complexidades até o momento abarcadas davam conta desse cenário comunicacional no qual o objeto se encontrava. A telenovela com grandes pontos de audiência e as críticas e os críticos dentro das redações dos jornais impressos, ainda caminhavam para uma consolidação de linguagem, mas já enxergando nas ficções um caminho para estabelecer uma discussão com esse leitor assíduo das telas e das folhas de jornais.

\section{Figura 06}

Primeiro Mapa Metodológico das mediações (1987) 


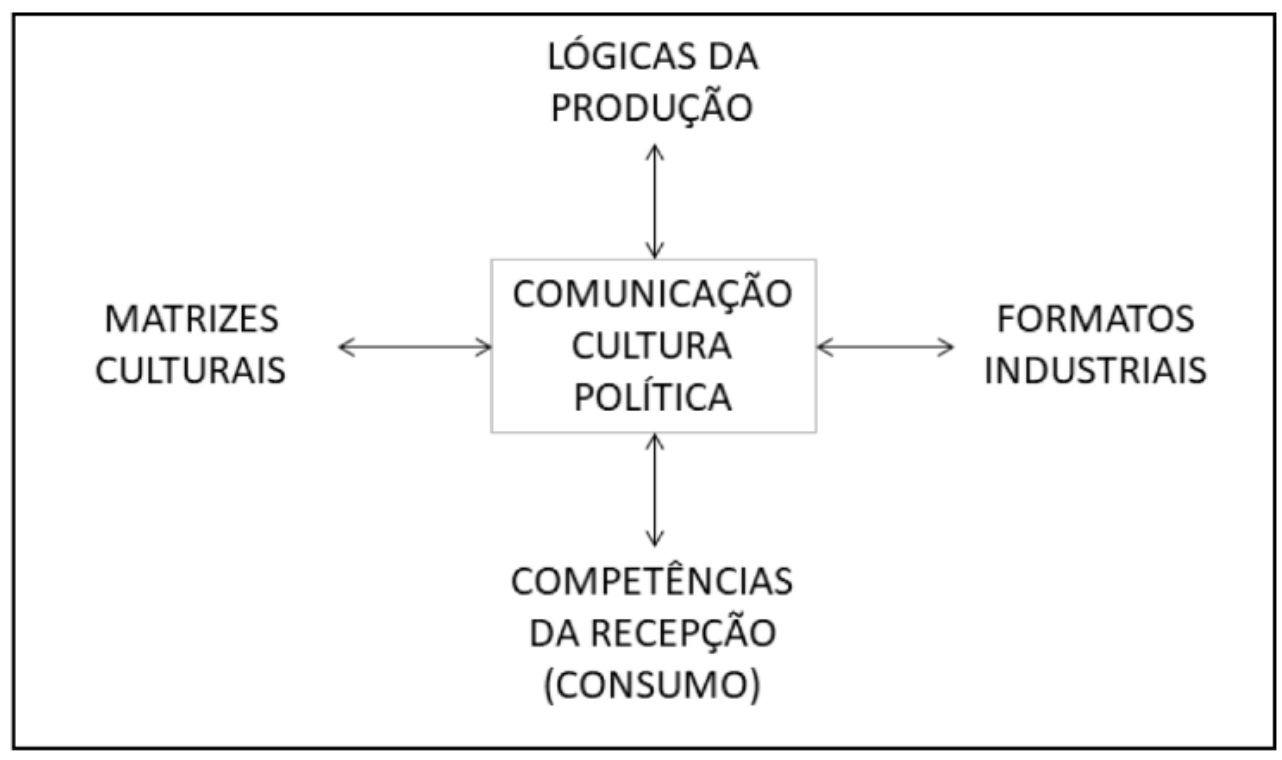

Fonte: Lopes (2018)

Neste primeiro mapa, observamos o eixo diacrônico - com as matrizes culturais $(\mathrm{MC})$ e os formatos industriais $(\mathrm{FI})$ - e o eixo sincrônico - com as lógicas de produção (LG) e as competências da recepção (CP). Num primeiro olhar, a telenovela pode ser abrangida por todo o mapa, pois as lógicas de produção compreendem o campo do produtor com os donos das emissoras e os anunciantes; os formatos industriais com o próprio formato da telenovela abrigada numa programação televisiva que intercala informação, a partir dos noticiários, e as ficções, pelas narrativas. Esse palimpsesto proposto especialmente pela TV Globo, ao longo dos anos, tem um papel fundamental na pauta diária do brasileiro, um relógio simbólico de direcionamento temporal, concretizado por um modelo estrito de informação seguido de ficção. As matrizes culturais se referem ao gênero melodrama, com sua intensidade de emoções, padrões morais e valores de classes em ascensão. Como ressalta Xavier (2003), a mescla de sentimentalismo e prazer visual possibilitam ao melodrama sua hegemonia no campo das artes visuais. $\mathrm{O}$ autor discorre que "ao entrelaçar drama e experiência visual, ele legitima a exibição, em cena, daquilo que pode criar a ponte entre os olhos e o coração, incluindo as ações extremas, ao contrário do que acontecia na tragédia clássica" (p. X). As competências da recepção abarcam o consumo, logo as audiências e sua ligação com as mídias. Ronsini (2011) explica que os estudos da vida cotidiana, as negociações e a circulação podem ser percebidas na análise dos textos midiáticos consumidos por esse espectador. 


\section{Figura 07}

Segundo Mapa metodológico das mediações (1998)

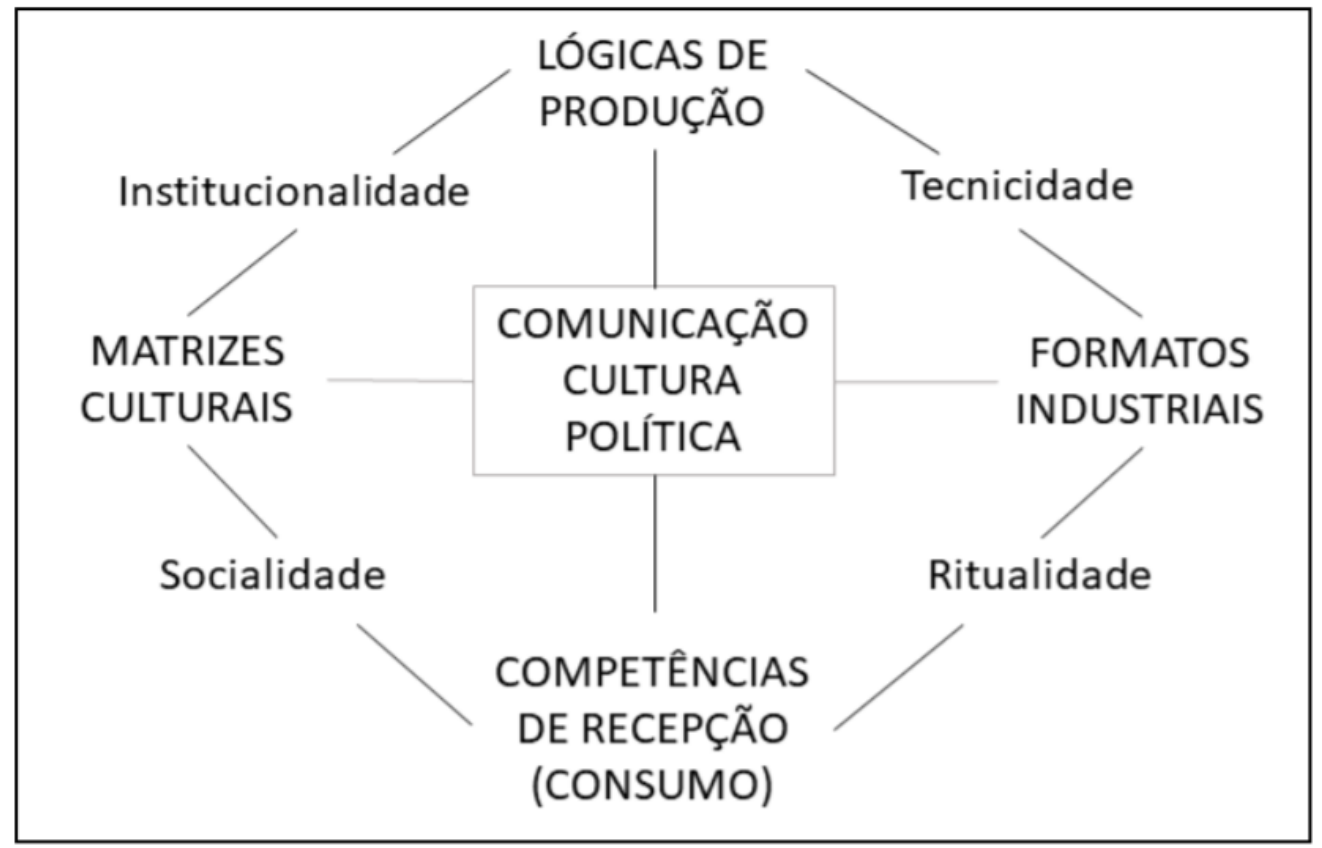

Fonte: Lopes (2018)

No intervalo de aproximadamente dez anos, o teórico apresenta seu segundo mapa dotado de novas mediações, porém com os mesmos eixos do primeiro mapa. As quatro mediações inseridas correspondem a Institucionalidade, Tecnicidade, Socialidade e Ritualidade. Em um primeiro olhar, vemos que o estudo da cultura é central por meio da inserção das novas mediações, logo percebemos que as mediações são advindas dos meios, tentando compreender a comunicação neste processo, pois, "é possível operacionalizar a análise de qualquer fenômeno social que relaciona comunicação, cultura e política, impondo-se como uma dimensão da articulação entre produtores, mídia, mensagens, receptores e cultura" (LOPES, 2018, p. 54). Entendendo o contexto de concepção deste mapa, observamos que é reflexo das mudanças vigentes em meio ao fim do século XX e entrevendo os novos processos culturais do novo século. As mediações se articulam de maneira a dar conta desse panorama de transformações estruturais pelo advento da técnica e das alterações referentes quanto ao uso dessas ferramentas.

Nas interseções dos dois eixos, o mapa desenha quatro espaços para descentrar nosso olhar de pesquisadores, e onde se localizam outras mediações. A relação entre as matrizes culturais e a lógica da produção é mediada por diferentes regimes de institucionalidade (interesses e poderes existentes, públicos e privados), enquanto a relação entre as 
matrizes culturais e as competências da recepção é mediada por várias formas de socialidade (laço social, relações cotidianas das pessoas enquanto agentes). Entre a lógica da produção e os formatos industriais media a tecnicidade (o novo contexto dos meios; operadores técnicos, perceptivos e estéticos) e entre os formatos industriais e as competências da recepção media a ritualidade (modos autorizados de olhar, ouvir, ler, ligados à memória social do gosto, da classe, do hábito). (LOPES, 2018, p. 55)

Neste mapa instrumentalizaremos a circulação de sentidos da telenovela pelas submediações, que, como mencionado por Lopes, correspondem a quatro espaços descentralizantes. As novas mediações estão nos entremeios dos espaços principais e exprimem as relações existentes nas dinâmicas da produção e da recepção. Logo, essas mediações constituem o universo de circulação da telenovela. $\mathrm{O}$ ambiente familiar bem como o ambiente de trabalho mostram-se pela mediação da socialidade, no qual estão os domicílios, onde a televisão se impõe como um dos principais meios de obtenção de informação e de entretenimento, e o ambiente de trabalho, ambiente social de discussões diversas, formam as relações desses usuários. Os produtos midiáticos (jornais, sites, empresas de comunicação, TV) operam a partir da mediação da institucionalidade, pois retratam os interesses mercadológicos de distribuição de seus conteúdos. As discussões em redes sociais digitais traduzem a mediação da tecnicidade e da ritualidade, pois demonstram como as conversações em redes interagem com a telenovela e muitas vezes são focos de discussões nesses meios.

Reconhecidos tais circuitos neste segundo mapa, expressamos a complexidade da circulação de sentidos. “A circulação é concebida como 'região' na qual os sentidos não apenas transitam, mas também são tecidos" (FAUSTO NETO, 2018, p. 30); isto posto, a circulação atua nas dinâmicas dos processos interacionais entre a produção e recepção. E o lugar de produção é um espaço de potencialização desses sentidos, haja vista que é atravessado por lógicas diversas que se entrecruzam.

Verón (1993) se apoia em duas hipóteses para o processo de produção de sentido:

a) Toda produção de sentido é necessariamente social. E não se pode descrever e nem explicar satisfatoriamente um processo significante, sem explicar suas condições sociais produtivas.

b) Todo fenômeno social é, em uma de suas dimensões constitutivas, um processo de produção de sentido, tanto faz o nível de análise (mais ou menos micro ou macrossociológico). (VÉRON, 1993, p. 125) 
Como explicitado no mapa, os circuitos são atribuídos por mais de uma mediação, pois os processos de circulação e produção de sentidos perpassam por camadas ou tecidos que vão se constituindo no decorrer da vida desse espectador ao abarcar as variadas narrativas que o cercam. O caráter social do sentido evidencia os espaços enunciativos percorridos pela telenovela no seu modo de inserção na cultura brasileira, sendo os discursos seu principal insumo. De acordo com Bakhtin (2016, p.117), “o discurso é tão social quanto a língua, as formas de enunciado também são sociais e, como a língua, são igualmente determinadas pela comunicação". Dessa forma, levamos em consideração a telenovela como um discurso dialógico que forma e espraia seus sentidos, assim,

O discurso é uma manifestação concreta da língua e se produz necessariamente num contexto particular, em que entram em conta não somente os elementos linguísticos, mas também as circunstâncias de suas produções: interlocutores, tempo e lugar, relações existentes entre esses elementos extralinguísticos. Não se trata de frases, e sim de frases enunciadas ou, mais resumidamente, de enunciados. (TODOROV, 2013 [1978], p. 11)

Por mais que tratemos os sentidos e discursos pela lógica dicotômica da produção e recepção, também levamos em conta que esses processos, do ponto de vista das mediações, são possíveis pela materialidade da comunicação e suas interações no tecido social. Dessas interações é que são construídos esses circuitos de sentidos na recepção. No entanto, não ocorrem de maneira unilateral ou de mesma intensidade, já que são fluxos de discursos que engendram um novo ecossistema comunicacional. No contexto de concepção deste mapa, as submediações emergiram para constatar as implementações das novas interfaces e dispositivos ${ }^{18}$ que suscitaram neste período. Entretanto, este mapa clarifica as mediações impostas na maneira como os sentidos trabalham com a socialidade amparadas nas noções advindas das relações cotidianas, designando seu discernimento dos atores sociais e dos vínculos de poder.

A ritualidade e a sociabilidade são atreladas neste mapa à competência de recepção ligadas ao consumo. Isso indica que são mediações que influem na construção dos usos sociais dos meios de comunicação, consequentemente, ao campo da recepção. Essa utilização dos meios é delimitada por hábitos familiares, condições socioculturais e

\footnotetext{
18 "Chamarei literalmente de dispositivo qualquer coisa que tenha de algum modo a capacidade de capturar, orientar, determinar, interceptar, modelar, controlar e assegurar gestos, as condutas, as opiniões e os discursos de serem viventes" (AGAMBEN, 2014 [2006], p. 39)
} 
outras formas de utilização que são construídas e mantidas por diversos fatores do contexto deste usuário.

\section{Figura 08}

Terceiro mapa metodológico das mediações (2010)

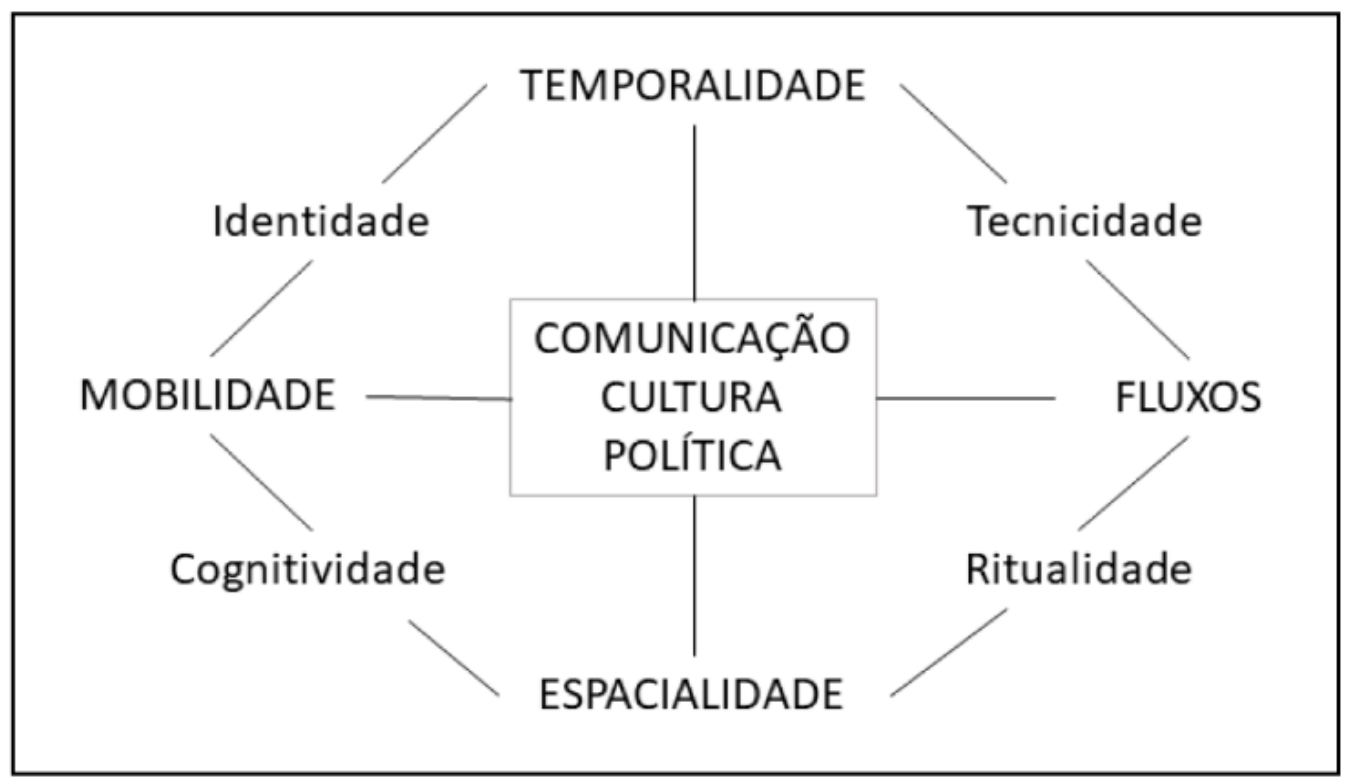

Fonte: Lopes (2018)

Denominado de Mutações Comunicativas e Culturais contemporâneas 1, este mapa, do início dos anos 2010, apresenta as mudanças aparente nos eixos, com a adição da Temporalidade, Mobilidade, Fluxos e Espacialidade, além das novas mediações: Cognitividade e Identidade. Este mapa tende a dar conta das mutações culturais contemporâneas, sendo a temporalidade trabalhada entre o moderno e o contemporâneo; e os espaços articulados entre habitado, produzido, imaginado e praticado. Os fluxos e a mobilidade correspondem aos fluxos de informações e imagens em um espaço hiperconectado.

Nesta pesquisa, as críticas tratadas são veiculadas nas mídias digitais em formato blog ou site. Dessa forma, com este mapa operacionalizamos esse espaço digital, entendendo-o como um ambiente de circulação de sentidos, um "espaço produzido", segundo Martín-Barbero (2018 [2009]). A dificuldade de separar o virtual do real, só realça as características desses espaços ubíquos, com as inovações das tecnologias e alargamentos de fronteiras virtuais, que permitem criações e compartilhamentos, além de estabelecerem laços socioculturais. Para Santaella (2010), essas transformações nos 
territórios informacionais são abarcadas como "espaços intersticiais", que se configuram por serem "misturas inextrincáveis entre espaços físicos e o ciberespaço, possibilitadas por mídias móveis" (p. 99).

No dizer de Santaella (2010, p. 18):

Estes são espaços hiperconcetados, espaços de hiperlugares, múltiplos espaços em um mesmo espaço, que desafiam os sentidos de localização, permanência e duração. São espaços povoados por mentes multiconectadas e, por consequência, coletivas, compondo inteligência fluidas. Estas costumam ser definidas pela capacidade de encontrar significado na confusão e de resolver novos problemas, pela habilidade de interferir e compreender as relações entre vários conceitos independentemente de conhecimentos já adquiridos.

O pensamento de Martín-Barbero quanto à mobilidade encontra confluência no de Santaella, haja vista que mobilidade alude a um senso de deslocamento. Lembrando que, para o teórico, as temporalidades são divididas entre o moderno e o contemporâneo; entre o olhar para o futuro e o olhar para a memória. A compreensão do espaço-temporal com as redes digitais é processada em fluxo constante, seja de pessoas, imagens e sons, até mesmo fluxos de sentidos. Santaella sublinha que a mobilidade virtual acarretou transformações da dimensão espaço-tempo com o surgimento de novas temporalidades, em que a relação com o tempo é modificada, pois as velocidades que o abrangem foram aumentadas.

A agilidade das comunicações urdidas por interfaces e dispositivos são alvo de reflexões e pesquisas, que, no momento, debruçam-se nos estudos acerca das consequências dessa aceleração. Sabemos que a mediação da temporalidade para os propósitos desta pesquisa está atrelada tanto à rapidez de discussão em redes sociais sobre a telenovela quanto às postagens das críticas e sua inserção nesse campo de discussão. A exibição da telenovela transcende o aparelho físico em transmissão, para intercambiar olhares com as redes sociais digitais. Do lado do espectador, nesse ínterim, abre-se um leque de comentários e conversas on-line que disputam sua atenção. Para o crítico, o dever de assistir atendendo aos horários impostos pela grade foi, durante muito tempo, a forma de acompanhamento das tramas. Entretanto, com o surgimento das plataformas de streaming, abrangem-se as maneiras de ver e acompanhar as ficções, exemplificando as novas temporalidades que vão sendo implementadas. 
As reconfigurações nas formas de consumir conteúdos avançam pela mediação da cognitividade - processo de aquisição de percepção, conhecimento e raciocínio - , para a ritualidade, ligadas a novas espacialidades que propiciam tais comportamentos, além da socialidade e ritualidade - que em si são indissociáveis. Para Ronsini (2011, p. 86),

\begin{abstract}
A respeito da cognitividade, penso que dificilmente o conjunto de fatores como valores, crenças e emoções, que influem no processo de aquisição de conhecimentos ou informações, pode ser visto separadamente da noção de identidade, assim como a noção de subjetividade, entendida como o processo de constituição do eu. A categoria identidade, possivelmente, pode subsumir tais noções. A identidade, por sua vez, sendo constituída nas relações sociais, não é tida como outra mediação, mas como resultado complexo das interações dos sujeitos na vida cotidiana.
\end{abstract}

A ritualidade condiz com ambiências favoráveis à interação e à repetição (MARTÍN-BARBERO, 2018), tendo os meios a capacidade de ditar e conferir normas e prescrições quanto aos usos. Isso recai na experiência audiovisual com a trajetória de leitura subordinadas à questão do gosto, que, por sua vez, é vinculado a condições sociais. Isto posto, "a ritualidade regula a interação entre os espaços e tempos da vida cotidiana e os espaços e tempos concebidos pelos meios, através das práticas de recepção constituídas pelo olhar, pela escuta e pela leitura" (JACKS, 2008, p. 23).

A submediação da tecnicidade - entre temporalidade e fluxos - exibe lugar estratégico para exprimir a instrumentalidade da técnica, haja vista que "a tecnicidade refere-se às características do próprio meio de comunicação enquanto organizador perceptivo" (RONSINI, 2011, p. 84).

Figura 09

Quarto mapa metodológico das mediações (2017) 


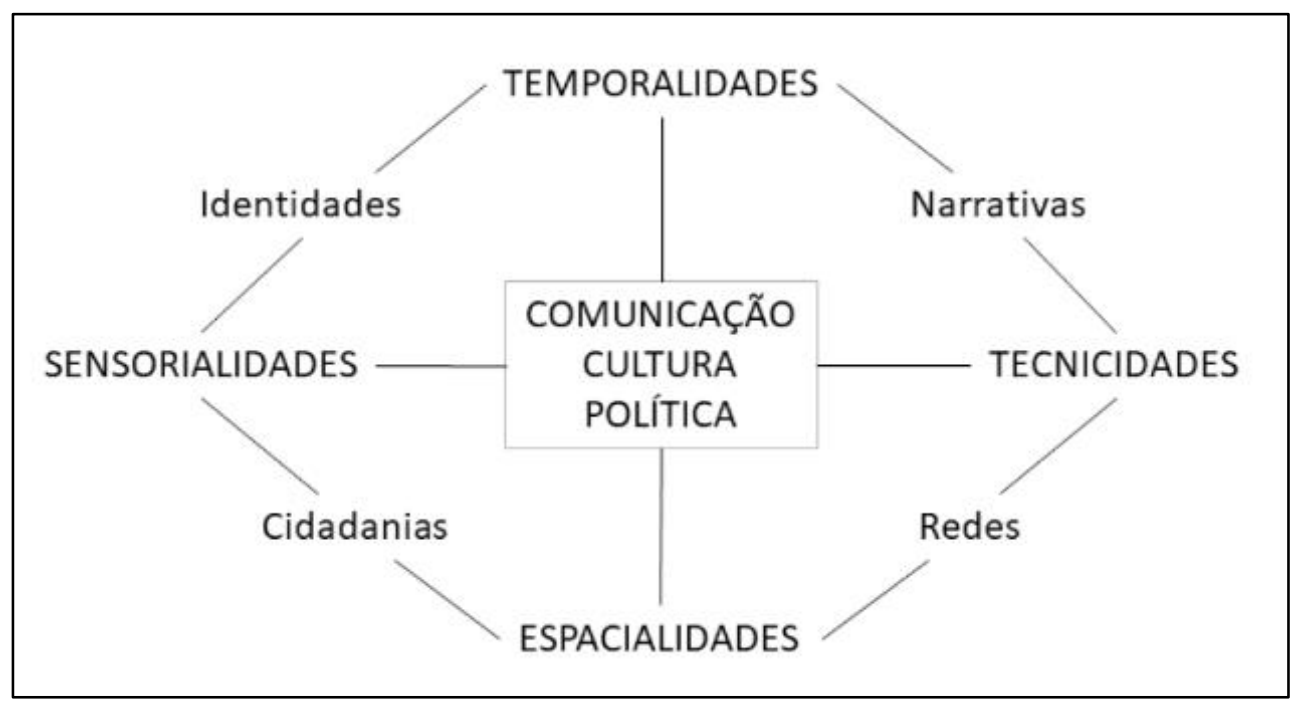

Fonte: Lopes (2018)

Neste quarto, e até então último mapa, Martín-Barbero dá prosseguimento ao estudo das Mutações comunicativas e culturais contemporâneas e tenta dar conta desse panorama comunicacional hiperconectado. Divulgado por meio da entrevista concedida a Omar Rincón, em 2017 (LOPES, 2018), este mapa apresenta dois novos eixos: a tecnicidade e a sensorialidade, enquanto as novas mediações se configuram pelas narrativas, redes e cidadanias. Percebemos que a tecnicidade, no mapa anterior, era uma submediação e, neste último, foi alçada a eixo principal. A mobilidade, por conseguinte, foi substituída por sensorialidades. Isso evidencia a relevância dessas mediações em meio aos processos socioculturais vigentes.

Com este mapa, trabalharemos as críticas acerca das telenovelas publicadas periodicamente em sites e blogs. Essas postagens, no âmbito digital, apresentam uma diferenciação das publicadas em jornais impressos, que atendem a uma dinâmica específica quanto ao deadline e ao espaço voltado a elas. Essa migração da crítica de televisão dos periódicos impressos para o âmbito digital indica a redução do espaço dessa crítica nas redações, assim como a diminuição dos suplementos voltados para essa cobertura, especialmente no caso da crítica de televisão. Logo, esse papel da crítica sofreu modificações, pois "ela deixa de ser um gatekeeper para ser um gatewatcher" "19 já que passaram a surgir outras vozes, e a fala do crítico deixou de ser tão fechada. Nessa disputa

\footnotetext{
${ }^{19}$ Fala de José Geraldo Couto, jornalista e crítico de cinema, no $2^{\circ}$ Simpósio de Crítica, na Escola de Comunicações e Artes, da Universidade de São Paulo, em 29 de setembro de 2018.
} 
de falas, as opiniões são pulverizadas e rivalizam tal território em que se estabeleceram novas características como o diálogo interativo, a democratização das múltiplas vozes e a interação veloz. E, justamente nessa nova dinâmica, a crítica translada para a internet num território comum de diálogo. Especialmente na crise dos jornais impressos, onde a notícia está se efetivando na cibercultura e nas redes sociais digitais.

A mediação sensorialidade - inaugurada neste mapa - tem a ver com a noção de sensorium de Benjamin (2012), em que condiz com as reconfigurações das formas de ser e estar no mundo, com as relações intersubjetivas e a percepção humana. Isto posto, o sensorium é determinado por cada período histórico, uma vez que é a junção das práticas cotidianas com os aparatos sensoriais. Desta maneira,

Definimos o sensorium como a configuração e organização de nosso aparelho sensorial e nervoso, que é determinado não apenas naturalmente, mas também historicamente. Esse elemento histórico refere-se ao tipo de conhecimento que está presente nele - no nosso caso, o conhecimento científico - pelo desenvolvimento da técnica sobre o qual falaremos como tecnologia e, juntamente com esse desenvolvimento, a transformação dos modos de produção. Entre esses três elementos, existem conexões que nos permitem relacionar o tipo de conhecimento com o grau desenvolvimento de forças tecnológicas e produtivas, e estas, por sua vez, com as expressões políticas, econômicas ou artísticas presentes na sociedade. O ponto de convergência de todos esses elementos e manifestações com o sensório, que metodologicamente, tomamos como ponto de partida ou perspectiva a estética, a partir da qual podemos evidenciar processos sociais que vão além das manifestações artísticas de uma sociedade. (FRANCO, 2009, p. 104) $)^{20}$

Martín-Barbero (2015) elucida que Benjamin foi crucial na instauração de uma nova mediação que "permite pensar historicamente a relação da transformação nas condições de produção com as mudanças no espaço da cultura, isto é, as transformações

\footnotetext{
${ }^{20}$ No original: Al sensorium lo definimos entonces como la configuración y organización de nuestro aparato sensorial y nervioso, que está determinado no sólo naturalmente sino también históricamente. Este elemento histórico se refiere al tipo de conocimiento que en él se hace presente en nuestro caso, el conocimiento científico-, por el desarrollo de la técnica -de la cual hablaremos en adelante como tecnología y, junto a este desarrollo, por la transformación de los modos de producción. Hay, entre estos tres elementos, conexiones que nos permiten relacionar el tipo de conocimiento con el grado de desarrollo de las fuerzas tecnológicas y productivas, y éstos, a su vez, con las expresiones políticas, económicas o artísticas que se hacen presentes en la sociedad. El punto de convergencia de todos estos elementos y manifestaciones con el sensorium, que metodológicamente hemos tomado como punto de partida o de perspectiva, es el de la estética, desde la cual podemos hacer evidentes procesos sociales que van más allá de las manifestaciones artísticas de una sociedad. De esta manera fue que Benjamin, a través del estudio de la literatura de Francia del siglo XIX, pudo hacer comprensibles las relaciones entre estas manifestaciones estéticas con las expresiones sociales que encontraban lugar en esa sociedad.
} 
do sensorium dos modos de percepção, da experiência social” (p. 80). Esta mediação, como notamos, é encadeada com a tecnicidade, que neste mapa está em lugar de destaque. A utilização de novos aparatos técnicos, como computadores, notebooks, tablets e celulares, desloca nossa temporalidade, resultando num desvio perceptivo quanto às práticas das linguagens midiáticas e seus discursos. Porém, longe de um determinismo tecnológico, nosso esforço está em compreender a circulação de sentidos nessas práticas sociais, como a assistência da telenovela e a confecção da crítica. A leitura das críticas na internet possibilita um campo singular de interação entre os espectadores e os próprios profissionais, o que gera um campo social singular com mecanismos próprio de comunicação.

John, Ribeiro e Silva (2019) estudam a mediação da sensorialidade pelo viés da psicologia, em que, por sensorialidades, podem ser entendidas as expressões das experiências humanas, uma função cognitiva e mental. O desafio, segundo os autores, é explicar a sensorialidade contemporânea, ou até mesmo o sensorium latino-americano, porém a dificuldade está em determinar uma conceituação fechada do termo, mesmo aludindo ao trabalho de Benjamin. Portanto, os autores aludem a concepções abrangentes quanto às noções de sensorialidade, porém sempre atreladas ao entendimento de que sensório se perfaz pela experiência do indivíduo na cultura e a sua interpretação das sensações. Como está aludido:

A sensorialidade é uma característica da humanidade, compartilhando, através da mediação de outros sujeitos mais experientes, os significados simbólicos e culturais de uma sociedade. Na condição humana, atribuímos, através da linguagem (também simbólica), significados aos sentidos que compõem o sistema sensorial na interação com o mundo externo, permitindo nomear, consciente e / ou inconscientemente, as experiências vividas carregadas de afeto, sentimento e a emoção como um campo de expressões de nossas necessidades, forjadas ou não. Assim, podemos nos referir aos mundos interno e externo, ao ser interior e ao eu, ao consciente e ao inconsciente, à consciência perceptiva e à noção de desejo de pensar em sensorialidade. (JOHN; RIBEIRO; SILVA, 2019, p. 123) ${ }^{21}$

\footnotetext{
${ }^{21}$ No original: La sensorialidad es un rasgo característico de la humanidad al compartir, a través de la mediación de otros sujetos más experimentados, los significados simbólicos y culturales de una sociedad. En la condición humana, atribuimos, por medio del lenguaje (también simbólico), significados a los sentidos que componen el sistema sensorial en la interacción con el mundo externo, permitiéndonos nombrar, consciente y/o inconscientemente, las experiencias vividas cargadas de afecto, sentimiento y emoción como campo de expresiones de nuestras necesidades, ya sean forjadas o no. Así, podemos referirnos a los mundos interno y externo, al ser interior y self, al consciente e inconsciente, a la conciencia perceptiva ya la noción de deseo para pensar la sensorialidad.
} 
Devido à abrangência de utilização desses mapas, e por este em especial, não ter sido comentado por Martín-Barbero, adentramos num campo em que cabe a nós lançarmos um olhar na perspectiva da mediação da narrativa para este mapa. Deste modo, a mirada aqui abrangida acerca das narrativas abarca as inúmeras histórias que circundam e discorrem acerca do sujeito e seu contexto. Desde os mitos, a literatura, o teatro, o cinema e a televisão, estamos rodeados de narrativas que, por vezes, alimentam o imaginário e são representativas de sua época. Desde as tragédias gregas até as lendas advindas de povos locais e fundantes de uma sociedade, as histórias integram nossa existência e dão vazão ao que se passa no cerne das experiências do indivíduo.

As narrativas de determinado contexto abrigam, além de entreterem, códigos e signos característicos deste território, logo a leitura dessas narrativas se cumpre na decodificação simbólica, sendo a televisão o aparelho eficaz nesta instauração. Apontamos que as marcas de brasilidade foram amplamente difundidas e até mesmo solidificadas ao longo da transmissão das telenovelas, aliadas à formação da competência de assistência.

Visto a explicação e descrição dos quatro mapas, cada um deles é mais complexo que o anterior e funciona como um complemento do outro. Assim, o texto de Jésus Martín-Barbero possui inúmeras camadas e dialoga com diferentes disciplinas do campo das ciências sociais e da comunicação.

\subsection{Onde estão os críticos nos Mapas?}

A pergunta que denomina este tópico demonstra um exercício de reflexão contínuo na tentativa de visualizar o lugar dos críticos de telenovela nos mapas das mediações. Como sabemos, os quatro mapas se complementam e se atualizam na medida em que as características do contexto vão se apresentando. O panorama da crítica de telenovela no País tem acompanhado o cenário contemporâneo pelo qual a televisão e seus conteúdos vêm passando. A transição da crítica para o âmbito digital também seguiu as mudanças que concernem ao campo do jornalismo, pela migração do impresso para o digital. Deste modo, o ofício da crítica no âmbito da cibercultura é resultante destes variados processos. 
A abrangência dos mapas de Martín-Barbero nos possibilita uma gama de olhares para um objeto. O lugar dos críticos, em nosso ver, pode ser abarcado por todos os mapas, tendo em vista que eles são um espelho do cenário sociocultural no qual foram concebidos. A crítica acompanha intrinsecamente os processos da telenovela e as demandas de seu público, numa relação simbiótica. Os críticos de telenovela são profissionais que dependem do desempenho das ficções para efetuar seu trabalho. Uma telenovela que não cria repercussão, seja por seus aspectos bons ou pelos ruins, inviabiliza o trabalho desse profissional, pois não há interesse em conhecer ou saber algum aspecto da trama. O dialogismo entre público e a crítica é percebido pelas mediações da sociabilidade e tecnicidade. Maurício Stycer e Nilson Xavier, dois críticos analisados nesta tese, mencionam experiências na utilização do Twitter, especialmente no horário de exibição das telenovelas, período em que se observam as discussões acerca da trama. Os críticos afirmam que a rede social digital é uma fonte de pautas e de insights, ideias que, posteriormente, podem virar análises.

As mudanças históricas - que poderíamos chamar de mediações exteriores à comunicação - e a introdução de novas tecnologias interiores ao campo - fazem mover as teorias, e, nesse caso, MartínBarbero está atento tanto aos meios que operam pontualmente quanto aos que estão operando transversalmente, como é o caso da internet. (JACKS, 2008, p. 20)

A figura abaixo mostra a fusão dos três mapas das mediações propostos por Martín-Barbero (Silva e Baseio, 2019, p. 171). A imagem mostra a evolução e principalmente a complementação de cada mapa. As autoras destacam que, no quarto mapa, notamos que as mediações estão dispostas no plural, algo inédito; pois como veremos na figura abaixo, nos mapas anteriores, as mediações foram estabelecidas no singular. Isso é um indicativo, segundo Silva e Baseio (2019), de que tais mediações expressam contextos múltiplos e complexos, afinal são mutações culturais da comunicação, como é intitulado o mapa.

Portanto, pela imagem seguinte, refletiremos sobre o lugar dos críticos em três lugares distintos, entendendo essas ambiências como espaços simbólicos operacionalizados a partir das mediações. 


\section{Figura 10}

Fusão dos Mapas metodológicos das mediações

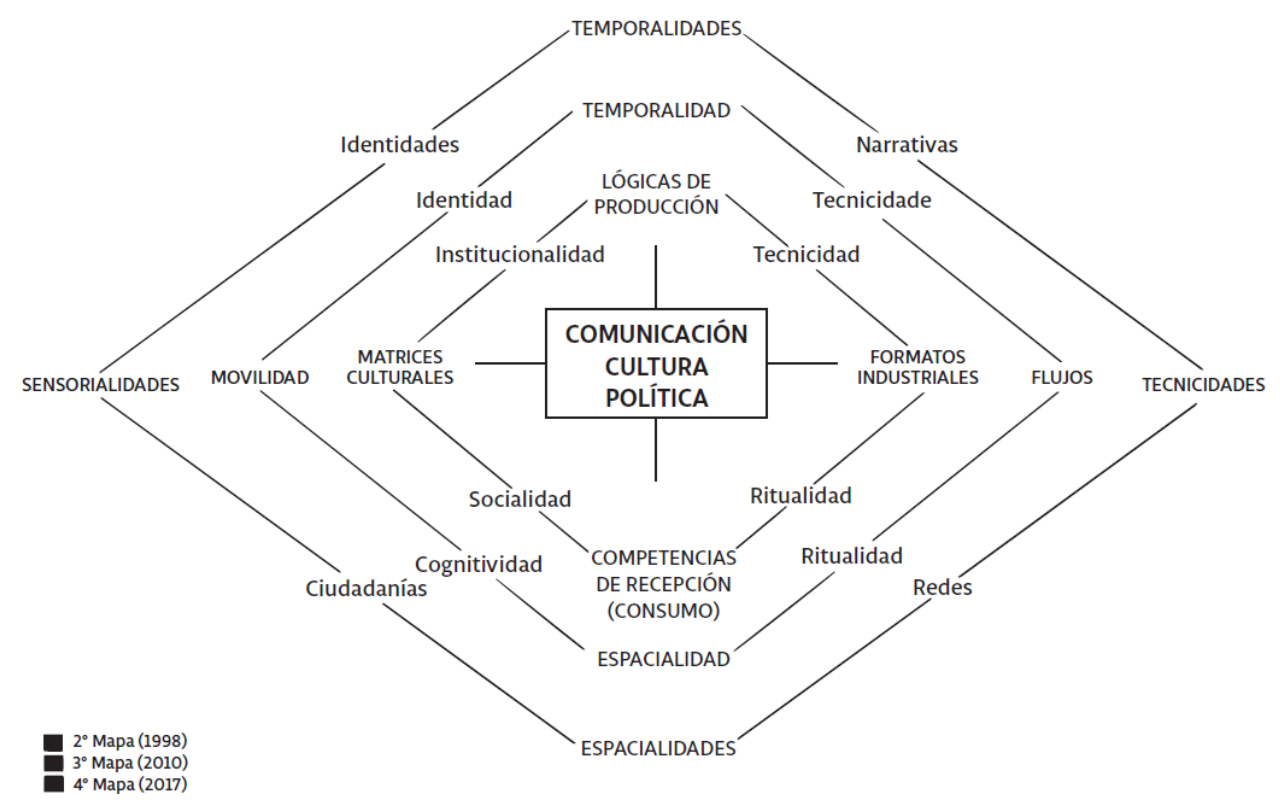

Fonte: Silva e Baseio, 2019, p. 171.

- Crítico como um produtor de conteúdo: Neste posicionamento, os críticos estão alocados no lado direito dos mapas e condizem com as mediações: formatos industriais, ritualidades, tecnicidades, redes e fluxos. Traçando uma linha imaginária no meio do mapa, a parte direita pode ser entendida como o campo da mídia, lugar dos processos da produção, das gramáticas da produção (VERÓN, 1980). Os críticos analisados são profissionais atrelados a uma determinada instituição jornalística, que os legitima para o exercício da crítica e que, ao longo de suas carreiras, foram dotados de certo capital simbólico que os levam ao reconhecimento de suas análises neste campo de atuação.

As mediações citadas compreendem as transformações no campo da crítica com novos tempos (temporalidades) e novos espaços (espacialidades). De críticos que passaram a atuar em portais de notícias na internet e, pelas facilidades desse espaço, tem a possibilidade de exercerem o ofício em um tempo flexível. A ritualidade são os usos sociais dos meios de comunicação e suas diferentes leituras (RONSINI, 2011). Complementada pela tecnicidade, materialidades dos dispositivos, dotam essa crítica de uma rapidez que antes era inviável no jornal impresso, e cabe ao crítico certa 
autonomia de sua escrita. As duas mediações têm uma relação estreita, já que perfazem a relação entre a comunicação e a cultura. No caso dos críticos, a tecnicidade, as redes e os fluxos operacionalizam a atividade desse crítico contemporâneo junto ao seu espaço de trabalho, com suas próprias regras de utilização do seu próprio site/blog. $\mathrm{O}$ fluxo de trabalho se tornou distinto, pois há o controle das ferramentas para a postagem das avaliações, o que claramente nos leva a outras ritualidades quanto ao processo de criação.

Esse processo que hoje identificamos como convergência midiática é, segundo Pieniz (2014), a materialidade da tecnicidade, pois tal convergência é originada no tecido social e envolve novos aparatos, linguagens e estabelecem novas sociabilidades. A técnica, portanto, ressignificou a paisagem comunicacional e criou demandas de interação do que se consome. Porém sem desprezar alguns hábitos que ainda permanecem, tais como o consumo de narrativas e a interação sobre elas.

O lugar desse crítico, pensando a partir do campo da produção, o percebemos pela lente das transformações ocorridas no campo do jornalismo e a diminuição da materialidade dos jornais, que passam a contar com um conteúdo disposto nas ambiências virtuais.

- Crítico como um espectador: Para pensarmos neste lugar dos críticos, olhemos para o lado esquerdo do mapa acima com as mediações: sociabilidades, sensorialidades, matrizes culturais e identidades. A parte esquerda deste mapa, em nossa interpretação, é entendida como o campo da recepção. O crítico, antes de analisar, precisa consumir o que irá avaliar. Sendo que, para se fazer uma reflexão original sobre uma obra, é necessário instrumentalizar métodos e critérios para a compreensão do que está sendo recebido, assim, entendemos o crítico como um espectador de telenovela, apreciador do folhetim e entendedor do formato em exibição. A relação dos críticos com as telenovelas é vista, a priori, por uma relação que teve início na infância, calcada nas relações familiares e na sociabilidade nos demais espaços em que se falava sobre as ficções. A matriz cultural do melodrama, com características do realismo, deu origem ao formato de narrativa apresentado na televisão brasileira. A sensorialidade, mediação aparente neste último mapa, aborda nossa maneira de lidar com os estímulos externos. O sensório é um conjunto de habilidades que vão se construindo em processos sociais em certos períodos históricos. O espectador contemporâneo é dotado de mecanismos sensoriais que o habilitam para uma atenção fragmentada e a ser 
multitarefas. A particularidade deste crítico está no acompanhamento de múltiplos programas, em certos momentos, com a atenção voltada para as redes sociais no celular, já que as múltiplas telas oferecem uma experiência multimodal, com acesso aos variados conteúdos.

- Crítico como mediador: Estabelecemos que o crítico atua como mediador entre o público e a obra analisada. Neste campo, olhemos para o centro do mapa nas mediações lógicas de produção, as competências recepção, institucionalidade e a sociabilidade. Pelas lógicas de produção entendemos as dinâmicas empresariais que concernem à telenovela, como um produto comercializado e exportado, e a construção da competência comunicativa, "capacidade de interpelar/construir públicos, audiências, consumidores" (MARTÍN-BARBERO, 2015, p. 18). Torres (2011), em seus fundamentos da crítica, menciona que a crítica não está entre a obra criticada, mas está em relação, haja vista que ela depende desta relação de proximidade. Essa ligação é vista pela interação dos críticos nas redes sociais digitais e pela leitura e moderação de comentários. Na interação nas redes sociais, Maurício Stycer relata:

Seguindo e sendo seguido por pessoas com gostos mais ou menos semelhantes, o Twitter oferece a oportunidade de transformar a experiência de ver um determinado programa num bate-papo animado. É como se estivessem todos na sala, trocando ideias, discutindo e, frequentemente, brigando por conta de opiniões mais fortes, digamos, a respeito da falta de sutileza de Walcyr Carrasco ou da atuação do juiz no Maracanã. (STYCER, 2016, p. 40)

Outro relacionamento comumente visto são os diálogos entre os críticos, que se realizam por meio da citação de determinada crítica em seus textos. A referenciação ocorre através do link da postagem, seja no meio da crítica ou ao fim. Há dois exemplos em que notamos essa interação: quando o crítico aborda determinada temática que já foi objeto de análise posterior à sua, reforçando seu ponto de vista ou trazendo o leitor para se pensar no que está sendo abordado, desta vez por outro viés ; e quando algo foi remarcado em outra narrativa, mas que se repete.

A leitura de seus colegas, em muitos casos, apresenta um olhar para um aspecto que não foi visto por esse crítico. E também ressalta para o reconhecimento dos pares dos que integram este campo da crítica de telenovela. O que de certa forma contribui para identificarmos quem está exercendo a crítica com certo grau de comprometimento. 
Este capítulo encerra a construção teórica desta pesquisa. A finalidade deste levantamento é demonstrar como este objeto é transdisciplinar, e orientar o nosso olhar para o entendimento da crítica e sua circulação de sentidos. As discussões aqui apresentadas tomarão forma com a apresentação da análise empírica, tratada nos capítulos seguintes.

A seguir, iremos discriminar o processo prático deste estudo, como o cotejamento do objeto, a operacionalização dos dados, tanto das críticas das telenovelas quanto das entrevistas semiestruturadas e o elenco de categorias. 


\section{PARTE II}

Análise 


\section{CAPÍTULO 4 - Universo da Pesquisa: detalhamento da metodologia de análise}

"Novela é uma obra longa e pode chegar um momento em que todos ficam cansados, até o público.” Nilson Xavier

A intenção deste capítulo é explicitar os percalços metodológicos abarcados na pesquisa. Apesar de, na introdução, termos explicado os caminhos percorridos, aqui nos deteremos na definição do objeto e no processo de observação para chegarmos ao objeto empírico, além dos tipos de análise feitas com os dados coletados. Ressaltamos que a escolha deste objeto é um exercício que envolve o habitus de pesquisador e a construção de uma estratégia de pesquisa que vai se iniciar na observação do campo da crítica de telenovela para se chegar ao elenco de críticas e de críticos que foram analisados. Deste modo, os tópicos do capítulo correspondem ao delineamento do objeto, ao elenco de telenovelas, às entrevistas, aos críticos (com dados provenientes das entrevistas e de pesquisa prévia), e às análises temáticas e enunciativas.

\subsection{Os críticos e as críticas}

Nosso intuito é demonstrar os rumos trilhados nesta tese quanto ao cotejamento do objeto, como chegamos ao elenco final de críticos e a quantidade de críticas utilizados na análise empírica. Para isso, dotados das pistas, adentramos no universo da crítica publicada regularmente na mídia digital. Nesse meio, o emaranhado de avaliações quanto às ficções era enorme. Essas publicações ocasionalmente vinham após as telenovelas, outras aguardavam uma ou duas semanas. De 2012 a 2018, foram exibidas 12 ficções no horário das 21h da TV Globo:

\section{Tabela 01}




\begin{tabular}{|c|l|l|}
\hline $\mathbf{1}^{\mathbf{a}}$ & Avenida Brasil (2012) & 41,1 \\
\hline $\mathbf{2}^{\mathbf{a}}$ & Salve Jorge (2012-2013) & 40,0 \\
\hline $\mathbf{3}^{\mathbf{a}}$ & Amor à Vida (2013-2014) & 41,3 \\
\hline $\mathbf{4}^{\mathbf{a}}$ & Em Família (2014) & 31,41 \\
\hline $\mathbf{5}^{\mathbf{a}}$ & Império (2014-2015) & 32,42 \\
\hline $\mathbf{6}^{\mathbf{a}}$ & Babilônia (2015) & 26,15 \\
\hline $\mathbf{7}^{\mathbf{a}}$ & A Regra do Jogo (2015-2016) & 34,5 \\
\hline $\mathbf{8}^{\mathbf{a}}$ & Velho Chico (2016) & 29,5 \\
\hline $\mathbf{9}^{\mathbf{a}}$ & A Lei do Amor (2016-2017) & 30,3 \\
\hline $\mathbf{1 0}^{\mathbf{a}}$ & A Força do Querer (2017) & 35,4 \\
\hline $\mathbf{1 1}^{\mathbf{a}}$ & O Outro Lado do Paraíso (2017-2018) & 39,9 \\
\hline $\mathbf{1 2}^{\mathbf{a}}$ & Segundo Sol (2018) & 33,0 \\
\hline
\end{tabular}

Fonte: Elaborado pela autora - Anuários Obitel 2013 - 2019

A partir deste primeiro cenário, de forma a operacionalizar devidamente, escolhemos as cinco telenovelas com maior número de ratings, que designam as tramas com maior número de audiência. Dessa forma, as ficções escolhidas foram:

\section{Tabela 02}

\begin{tabular}{|r|c|}
\hline $\mathbf{1}^{\mathbf{a}}$ & Avenida Brasil (2012) \\
\hline $\mathbf{2}^{\mathbf{a}}$ & Salve Jorge (2012-2013) \\
\hline $\mathbf{3}^{\mathbf{a}}$ & Amor à Vida (2013-2014) \\
\hline $\mathbf{4}^{\mathbf{a}}$ & A Força do Querer (2017) \\
\hline $\mathbf{5}^{\mathbf{a}}$ & O Outro Lado do Paraíso (2017- \\
& 2018) \\
\hline
\end{tabular}

Fonte: Elaborado pela autora

Com esse primeiro mapeamento, pudemos identificar as tramas que são representativas do período escolhido, sendo que, dessas telenovelas, foram listadas quatro 
críticas de cada crítico, obedecendo às quatro fases principais em que uma telenovela é disposta.

Quanto à escolha dos críticos, identificamos os seguintes profissionais:

\section{Tabela 03}

\begin{tabular}{|l|l|}
\hline Maurício Stycer & UOL \\
\hline Cristina Padiglione & Estadão/Folha \\
\hline Nilson Xavier & UOL \\
\hline Patrícia Kogut & O Globo \\
\hline Flavio Ricco & UOL \\
\hline Daniel Castro & UOL \\
\hline José Armando Vannucci & Vannucci Comunicações \\
\hline
\end{tabular}

Fonte: Elaborado pela autora

No entanto, devido à assiduidade da escrita, à quantidade de análises acerca da telenovela, além da periodicidade das postagens - neste processo de escolhas e rupturas metodológicas - optamos por permanecer apenas com a análise dos seguintes críticos:

Tabela 04 - Críticos selecionados para análise

\begin{tabular}{|l|l|}
\hline Maurício Stycer & UOL (blog) \\
\hline Cristina Padiglione & Folha (site) \\
\hline Nilson Xavier & UOL (blog) \\
\hline Patrícia Kogut & O Globo (site) \\
\hline
\end{tabular}

Fonte: Elaborado pela autora

Com esse elenco, passamos para a escolha das críticas, das quais foram eleitas apenas 4 de cada ficção. Os critérios para a seleção, apesar de atenderem ao modelo apresentado por Filho (2001), teve um caráter subjetivo, pois foram tabuladas todas as críticas dos quatro críticos provenientes das 12 telenovelas da primeira tabela, representados pela tabela e gráfico abaixo: 
Tabela 05 - Número de críticas realizadas por crítico

\begin{tabular}{|l|c|}
\hline Crítico & $\begin{array}{c}\text { Número de críticas } \\
\text { realizadas }\end{array}$ \\
\hline Maurício Stycer & 200 \\
\hline Patrícia Kogut & 166 \\
\hline Nilson Xavier & 150 \\
\hline Cristina Padiglione & 76 \\
\hline TOTAL & 592 \\
\hline
\end{tabular}

Fonte: Elaborado pela autora

Gráfico 03 - Produtividade dos Críticos de 2012 - 2018

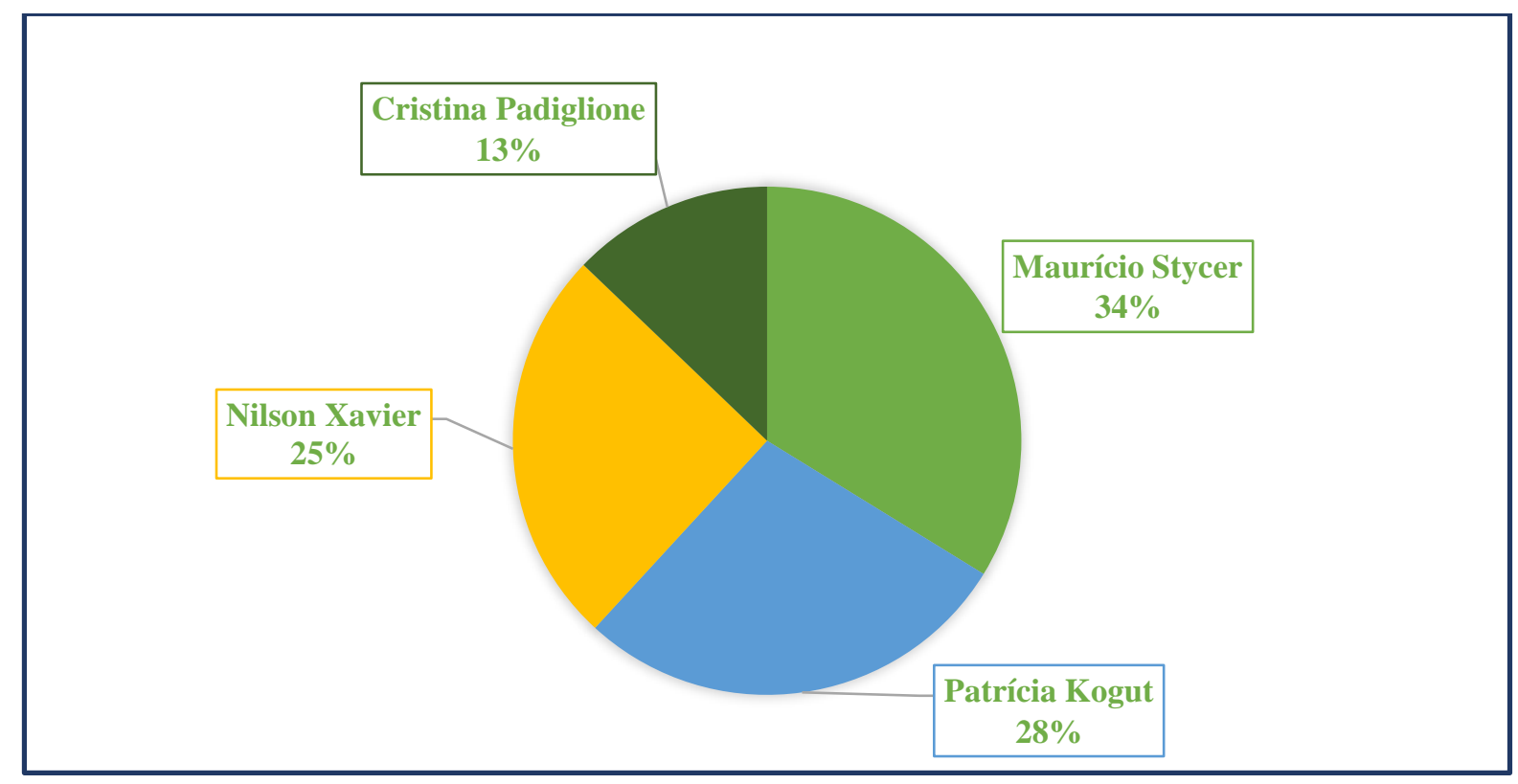

Fonte: Elaborado pela autora

Em seguida, foi realizada uma leitura preliminar, pois algumas avaliações tinham elementos de notícias e/ou não foram indexadas como críticas. Desse montante e pela escolha das 5 telenovelas, como discriminado na Tabela 02 , apuramos $\mathbf{7 6}$ críticas ao todo 
para a análise $\mathbf{2}^{22}$. No caso de Cristina Padiglione, esclarecemos que, devido à sua saída como jornalista do site do jornal Estado de São Paulo para o site alocado no portal do jornal Folha de São Paulo, houve um período curto de pausa na escrita das críticas.

Essa cartografia do objeto é necessária para que detalhemos os dados brutos da pesquisa, que, consequentemente, nos levaram à construção do próprio objeto empírico. Na coleta de dados, identificamos as críticas como dados primários, que foram alcançados pela observação do cenário da crítica de telenovela publicada nas mídias digitais. Os dados secundários são compostos - como visto na primeira parte da tese - pelas consultas bibliográficas, no que concerne à crítica de literatura, onde as análises de ficção têm mais influência. Notamos que este estudo é formado pelos eixos das telenovelas, dos críticos e das críticas.

\subsection{As Entrevistas}

As entrevistas para esta tese foram realizadas presencial e individualmente com cada crítico. De antemão foram elaboradas 16 perguntas, que abordavam a relação do profissional com as telenovelas e as especificidades de seu ofício. No entanto, com as leituras das críticas, alguns questionamentos emergiram e foram incorporados ao longo do roteiro pré-estruturado, entremeados nas respostas dos entrevistados. Tais entrevistas tiveram, em média, dependendo do crítico, entre 40 min a 1 hora 20 minutos de duração. Os críticos foram deixados livres para responder às perguntas da maneira que achavam melhor, obtendo, assim, uma fala relativamente espontânea, evidenciando suas subjetividades na discrição das experiências dos seus ofícios, a prática da escrita, bem como o relato de episódios passados (BARDIN, 1977, p. 94).

De acordo com Poupart (2008, p. 228), a colaboração do entrevistado para a realização desta etapa da pesquisa é primordial para a "produção de um sentido que seja o mais verdadeiro e o mais aprofundado possível”. Um dos argumentos para a utilização das entrevistas para o autor é de ordem ética e política, haja vista que este recurso permite ao pesquisador aprofundar o conhecimento dos obstáculos e contrariedades que emergem na rotina desses profissionais.

\footnotetext{
${ }^{22}$ Em Anexo., em QR code.
} 
A transcrição desse material, disponível nos anexos, foi realizada de maneira fonética, porém algumas interjeições foram retiradas para melhor compreensão. As nossas interrupções durante a entrevistas também não constam na transcrição. Entretanto, as respostas foram colocadas em sua totalidade, descartando também algumas interrupções que foram advindas do ambiente no qual as entrevistas foram realizadas.

Apesar da criação de um plano prévio para a abordagem do assunto, as entrevistas em si são polifônicas; este atributo faz com que sua análise se mostre complexa, haja vista que se configura como um "discurso marcado pela multidimensionalidade das significações exprimidas, pela sobre determinação de algumas palavras ou fins de frase" (BARDIN, 1977, p. 94). Sublinhamos, portanto, a dificuldade metodológica de mesclar os conteúdos das entrevistas com as críticas em si, já que a singularidade de cada crítico elencado nesta pesquisa deve ser representativa do todo. Assim, a seleção e leitura das críticas, como apontamos, foi realizada antes da execução da entrevista, logo foi possível estabelecer a delimitação de temáticas advindas das repetições encontradas em todas as 76 críticas.

A multidimensionalidade das entrevistas permite que olhemos para esses dados por diferentes frentes de análise, assim optamos por realizar uma análise temática, com os principais temas e subtemas, que, por sua vez, chamamos de categorias empíricas proveniente dos dados colhidos. Essas categorias empíricas foram adequadas a categorias teóricas advindas das mediações de Martín-Barbero, que foram confrontadas e mescladas com as categorias temáticas que emergiram do campo.

\section{$\underline{\text { Entrevista semiestruturada }}$}

Nome:

Idade:

Formação escolar completa:

Alguns hábitos e gostos:

- de leitura: alguns livros de que mais gosta

- de cinema: filmes de que mais gosta 
1. Como você se iniciou na escrita da crítica de ficção televisiva e há quanto tempo exerce a função profissionalmente?

2. Qual sua relação com a televisão, especificamente com a telenovela?

3. Que critérios você leva em consideração para escrever suas críticas?

4. Você acompanha as discussões e comentários acerca de telenovelas? Como?

Em que meios?

5. Na sua opinião, qual é o papel da crítica de telenovela?

6. Quais seriam os requisitos para ser um bom crítico de telenovela?

7. Como é para você a distinção social entre a crítica de teatro e de cinema e a crítica de telenovela? Existe essa distinção? Por quê?

8. Quais são os aspectos de sua crítica que, na sua opinião, mais tendem a provocar debate pelo público?

9. Como obra aberta, a telenovela permite que você a acompanhe enquanto está sendo feita. Como essa característica molda a sua crítica?

10. É de praxe que a primeira crítica acerca de uma telenovela seja logo após o capítulo de estreia. Quais os parâmetros que você usa para analisar uma obra que está começando?

11. Em sua opinião, o que difere a crítica de telenovela da crítica de programas televisivos como realities, ou de auditório?

12. A telenovela das $21 \mathrm{~h}$ da Globo é uma das produções mais comentadas na sociedade brasileira. Por isso, a seu ver, a crítica das ficções desse horário exige mais responsabilidade?

13. Como crítico, o que diferencia a crítica de telenovela da crítica de séries norteamericanas?

14. Poderia citar os seus top ten das ficções brasileiras de todos os tempos?

15. Poderia fazer uma análise resumida de como vê a crítica de telenovela no Brasil (pelo menos a que conhece)? 
16. Para que serve a crítica de telenovela?

Por fim, esse percurso nos possibilitou vermos se há confluência entre o que foi dito nas entrevistas com o que foi escrito e publicado nas críticas, entrevendo o processo de escrita desses profissionais e seus repertórios e tipos de avaliações.

\subsection{Dossiê sobre os Críticos}

Neste tópico, faremos uma breve introdução dos críticos estudados na pesquisa a fim de apresentá-los antes de adentrar na análise. Essa apresentação foi realizada a partir da observação das páginas on-line e das entrevistas com perguntas semiestruturadas.

\section{Nilson Xavier}

Data de Nascimento: 10 de dezembro de 1968

Cidade Natal: Joinville, SC

Formação: Administração

Trajetória: Portal UOL - desde 2012, site Teledramaturgia, e canal do Youtube.

Livros: Voltados para estudos de televisão e telenovela.

Filmes: Tenta ir sempre ao cinema, pelo menos uma vez por semana, e costuma frequentar o cinema Itaú Augusta.

\section{Figura 11}

Página do site 


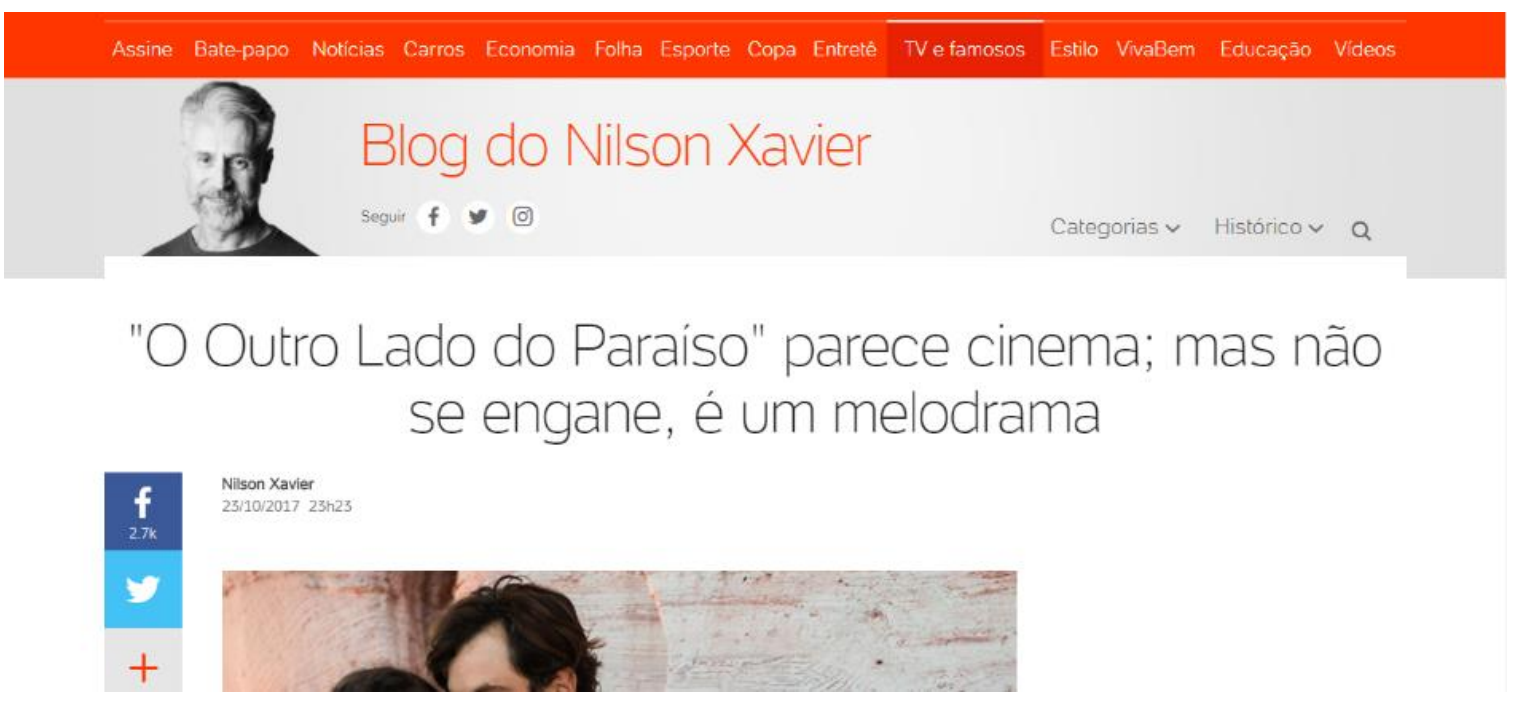

Fonte: https://tvefamosos.uol.com.br > blog > nilsonxavier Acesso: 16 jan 2020

Nilson Xavier é jornalista, já identificado em pesquisa anterior como "fã-curador" (LOPES et al, 2015) de telenovela, pois apresenta desde a infância grande interesse pelas ficções e, em sua trajetória, sempre compilava informações acerca da telenovela, o que o levou a publicar o livro Almanaque da telenovela (2007). Anteriormente ao almanaque e até o lançamento de seu blog, Nilson lançou o site "Teledramaturgia", onde constam informações referentes a telenovela, minisséries, séries, trilhas sonoras e outros formatos exibidos na televisão aberta. Foi por meio desse site que ele passou a escrever para o blog, alocado no site do UOL, a partir de 2012. Nele, encontram-se notícias acerca das ficções passadas e atuais. São publicações voltadas somente para as tramas, sem se ater a outros programas que a TV oferta. Por meio das abas "categorias" e "histórico", o crítico separa suas postagens por telenovelas e minisséries, em que se encontra tanto as notícias quanto as críticas.

Segundo Lopes et al (2015), a paixão de Nilson pelas telenovelas se desenvolveu na infância pelo ato de assistência compartilhada e perdurou na fase adulta, com a compilação de discos de vinil com as trilhas sonoras, além da curadoria de matérias acerca das telenovelas. Tal repertório adquirido deu origem ao site e ao livro. Utilizador assíduo do Twitter, recurso utilizado para a dicas de pautas e a interação com seus leitores, Nilson ainda adquire informações por meio da leitura de livros sobre telenovela, desde textos acadêmicos a leituras de profissionais da TV. 
Em 2019, o crítico deixa o portal da UOL e passa a ter uma coluna no portal de notícias do Huffington Post Brasil (Huffpost).

\section{Maurício Stycer}

Data de Nascimento: 09 de maio de 1961

Cidade Natal: Rio de Janeiro, RJ

Formação: Economia (UFRJ), Comunicação Social (PUC-Rio), Mestrado em Sociologia pela Universidade de São Paulo, voltado para Jornalismo Esportivo.

Trajetória: Jornal do Brasil; Estado de São Paulo; Folha de São Paulo (colunista); redator chefe da Carta Capital; Portal UOL (repórter e crítico).

Leituras: Costuma ler sobre não ficção, acerca da Mídia e TV, biografias sobre personalidade ligadas à Comunicação.

Filmes: Tenta ir ao cinema uma vez por semana e busca ver todo filme brasileiro em cartaz.

\section{Figura 12}

\section{Página do site}

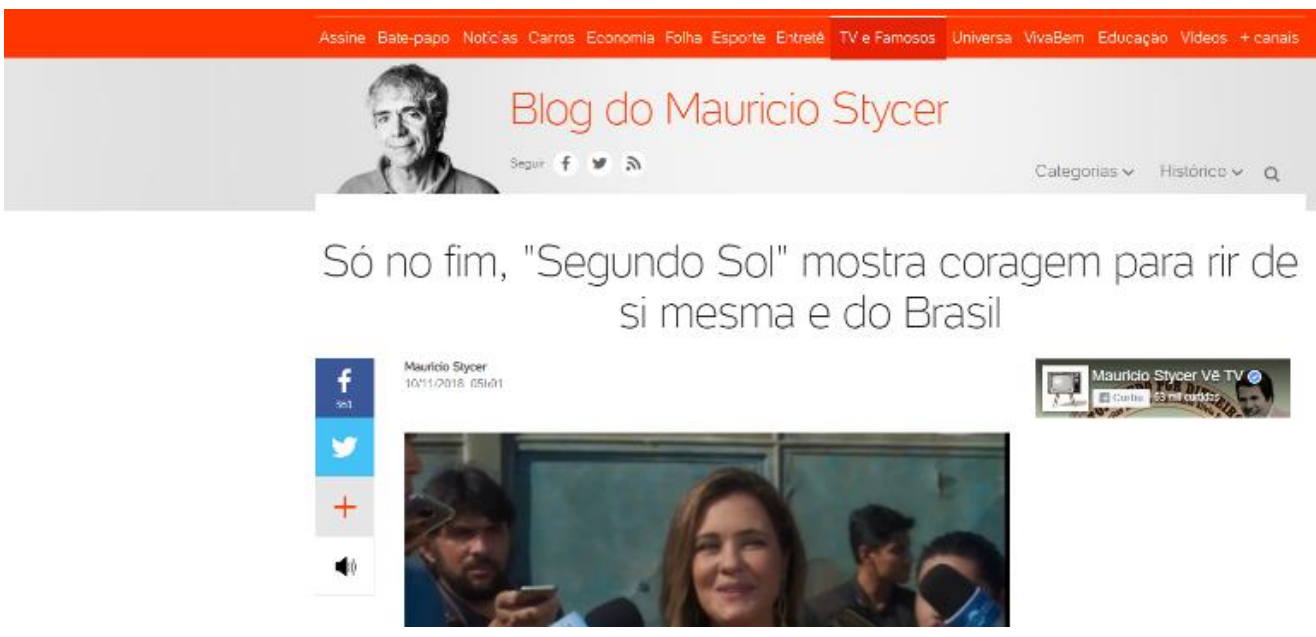

Fonte: https://tvefamosos.uol.com.br > colunas > mauricio-stycer Acesso: 16 jan 2020

Desde 2010 no portal UOL, o jornalista Mauricio Stycer publica suas críticas sobre a TV, bem como em sua coluna no jornal Folha de S. Paulo, aos domingos. A 
abordagem do crítico atende aos ditames do formato ao qual ele atende, ou seja, publicações contínuas acerca dos mais variados assuntos que compõem o universo da televisão. Em seu blog, as categorias vão desde "a cena da semana", passando por "celebridades" e chegando na categoria "Detetive vê TV", onde o autor comenta os erros cometidos nos programas, seja telenovela ou reality shows. Por se tratar de um blog, as postagens seguem o fluxo dado pelo jornalista. No canto superior do lado direito, nota-se a presença das abas "categorias" e "histórico", no qual podemos efetuar as buscas pelas críticas. Sem estabelecer uma categoria própria destinada à crítica, as análises ficam dispostas em meio a um misto de notícias, com as informações da trama, índices de audiência e as críticas. Publicou os livros História do Lance! - Projeto e prática do jornalismo esportivo (2009), Adeus controle remoto, uma crônica do fim da TV como a conhecemos (2016) e Topa tudo por dinheiro: As muitas faces do empresário Silvio Santos (2018).

Por meio do Twitter, Stycer estabelece relação com seus leitores, além de coletar dicas de pautas acerca da telenovela que está no ar. Essas discussões fomentam a interação e funcionam de termômetro para o que estão achando dos temas e personagens abordados.

\section{Cristina Padiglione}

Data de Nascimento: 03 de abril de 1970

Cidade Natal: São Paulo, SP

Formação: Comunicação Social - Jornalismo

Trajetória: Coluna no jornal Folha da Tarde, O Estado de São Paulo, Folha de São Paulo. Leituras: Os livros do Jô Soares, "50 anos do Jornal Nacional”, livro do Lucas Paraíso sobre roteiro. Livros sobre televisão, comunicação, leituras técnicas. O grande sertão veredas, está lendo há 10 anos. Livros dos Milton Hatoum. Biografia do Nirlando Beirão. Biografia do Roberto Marinho.

Filmes: Bacurau, gostou bastante. Queria assistir o novo do Almodóvar e do Tarantino.Em razão dos filhos, tem visto todos os filmes de super-heróis e da franquia Jogos Vorazes.

Séries: O Pico da Neblina (HBO), Chernobyl (HBO), Vikings (History Channel) 


\section{Figura 13}

Página do site

\section{TIEIEAP}

Gistina Padiglione, ou Padl, Epaga

paraver $n$ I deste 1990 , da Folha da Farde ac Estadke, passando por Iormal da Tardece follhades:Paulo

Minha novela Minha série Meu show 0 que tem de bom Jornalismo\&Doc Tá bombando Bastidores Fale conosco f (0) ( Q

\section{'Outro Lado do Paraíso' fecha $1^{a}$ semana com bom saldo de audiência, apesar de perder público dia após dia}

Fonte: https://telepadi.folha.uol.com.br/ Acesso: 16 jan 2020

Em seu site, Cristina Padiglione relata: “Cristina Padiglione, ou Padi, é paga para ver TV desde 1990, da Folha da Tarde ao Estadão, passando por Jornal da Tarde e Folha de S.Paulo”. Após finalizar sua coluna on-line no site do jornal Estado de São Paulo, a jornalista cria o Telepadi, sua própria página destinada a discorrer sobre as nuances da telinha alocada pelo site Folha de São Paulo. Os textos versam das notícias às críticas, no entanto, ao esmiuçarmos a página, não encontramos uma seção específica voltada para as críticas, o que se nota são apenas diferenciações por tópicos: "Novela", "Série”, "Show", "Fica a Dica", "Vida real", "Celebridade", "Bastidores", "Memória".

Geralmente suas análises estão dispostas na sessão "Novela", onde estão contempladas as notícias e críticas sobre o que está em transmissão. O que se observa é que, ao contrário das mídias de outros críticos, a jornalista optou por denominar seu site relacionando as palavras televisão e o seu sobrenome, Padiglione, resultando em “Telepadi".

Em meio a suas críticas, a jornalista busca chamar atenção do leitor ao mesmo tempo que cobra das ficções que aborda uma razão de ser, uma lógica e até organicidade, distanciando-se daquele pensamento de que novela é mais emoção do que razão. 


\section{Patrícia Kogut}

Data de Nascimento: 1964

Cidade Natal: Rio de Janeiro

Formação: Comunicação Social - Jornalismo, PUC - Rio

Trajetória: Se iniciou como professora de francês e de inglês.

Leituras: Tem influência na literatura francesa, não especificou nenhum livro.

Filmes: Devido à rotina no jornal e à constante assistência de telenovelas e séries, a jornalista relatou que não costuma acompanhar o cinema. Somente alguns filmes esporádicos.

\section{Figura 14}

Página do site

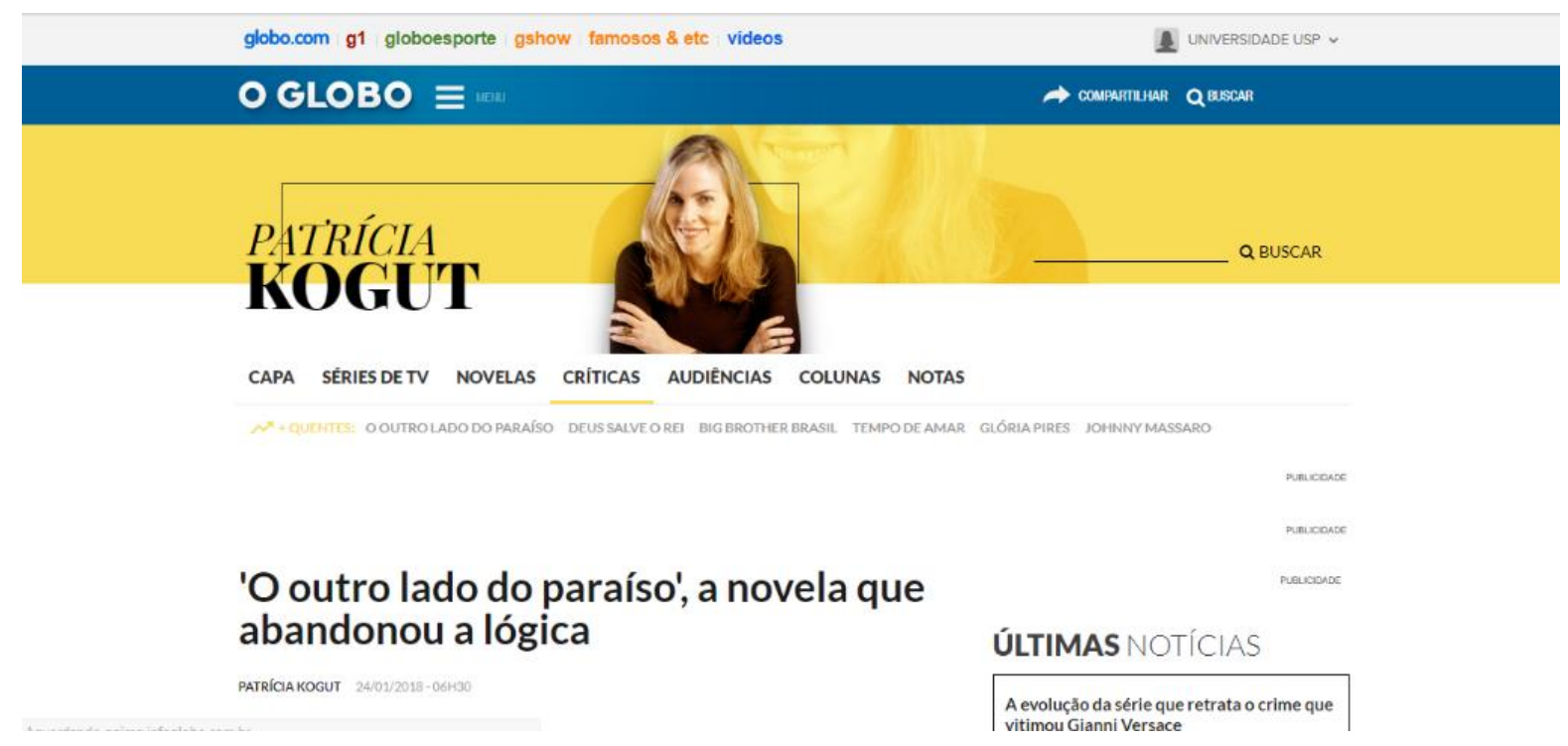

Fonte: https://kogut.oglobo.globo.com > noticias-da-tv Acesso: 16 jan 2020

A jornalista Patrícia Kogut tem seu site alocado na página on-line do jornal $O$ Globo. Além das análises de ficções brasileiras, Kogut também realiza sua crítica de ficções estrangeiras, muitas vezes que estão em exibição em canais de TV paga e plataforma de streaming. Em formato de site, sua página é dotada com as categorias “Capa", "Séries de TV", "Novelas", "Críticas", “Audiências", "Colunas" e "Notas". Essa categorização facilitou na busca pelos temas de interesse e na compilação das críticas. $\mathrm{O}$ que destacamos de antemão - pela leitura das críticas - é a utilização de Kogut pelo título 
telenovela moderna. O uso do termo é uma indicação de que a ficção é uma trama ágil com conflitos interessantes, por isso inferimos que o termo é empregado de maneira positiva.

A jornalista também é autora do livro 101 atrações de TV que sintonizam o Brasil (2016), em que aborda os programas que, ao seu ver, marcaram o Brasil.

\subsection{As críticas selecionadas}

A tabela a seguir compreende as críticas selecionadas para análise de acordo com a metodologia supracitada. Elas foram divididas por telenovela e selecionadas em fichas, que contêm o título, a data e o crítico responsável. As críticas foram posicionadas em ordem cronológica, da sua data de publicação até a da data de estreia das ficções.

\section{Tabela 06 - AVENIDA BRASIL}

\begin{tabular}{|c|c|}
\hline \multicolumn{2}{|c|}{ PATRÍCIA KOGUT } \\
\hline $\begin{array}{l}\text { Por: Patrícia Kogut } \\
\text { Data: 02/04/2012 }\end{array}$ & $\begin{array}{l}\text { Título: CRÍTICA: Falta graça e } \\
\text { originalidade aos núcleos cômicos das } \\
\text { novelas }\end{array}$ \\
\hline $\begin{array}{l}\text { Por: Patrícia Kogut } \\
\text { Data: } 19 / 05 / 2012\end{array}$ & $\begin{array}{l}\text { Título: 'Av. Brasil' aborda choque entre } \\
\text { classes sociais com ironia }\end{array}$ \\
\hline $\begin{array}{l}\text { Por: Patrícia Kogut } \\
\text { Data: } 17 / 09 / 2012\end{array}$ & $\begin{array}{l}\text { Título: CRÍTICA: A árdua tarefa de } \\
\text { escrever histórias longas }\end{array}$ \\
\hline $\begin{array}{l}\text { Por: Patrícia Kogut } \\
\text { Data: } 10 / 10 / 2012\end{array}$ & $\begin{array}{l}\text { Título: CRÍTICA: 'Avenida Brasil' deixa } \\
\text { série americana comendo poeira }\end{array}$ \\
\hline \multicolumn{2}{|c|}{ CRISTINA PADIGLIONE } \\
\hline $\begin{array}{l}\text { Por: Cristina Padiglione } \\
\text { Data: } 28 / 03 / 2012\end{array}$ & $\begin{array}{l}\text { Título: 'Avenida Brasil': um thriller em } \\
\text { busca do público }\end{array}$ \\
\hline $\begin{array}{l}\text { Por: Cristina Padiglione } \\
\text { Data: } 17 / 10 / 2012\end{array}$ & $\begin{array}{l}\text { Título: Quem matou Max se vai. } \\
\text { "Avenida Brasil" fica }\end{array}$ \\
\hline $\begin{array}{l}\text { Por: Cristina Padiglione } \\
\text { Data: } 20 / 10 / 2012\end{array}$ & $\begin{array}{l}\text { Título: Clichês de final de novela } \\
\text { contrariam caráter inovador }\end{array}$ \\
\hline $\begin{array}{l}\text { Por: Cristina Padiglione } \\
\text { Data: } 23 / 10 / 2012\end{array}$ & $\begin{array}{l}\text { Título: Ainda Carminha, para sempre } \\
\text { Carminha: amém, Adriana }\end{array}$ \\
\hline \multicolumn{2}{|c|}{ MAURÍCIO STYCER } \\
\hline $\begin{array}{l}\text { Por: Maurício Stycer } \\
\text { Data: 04/04/2012 }\end{array}$ & $\begin{array}{l}\text { Título: Depois do prólogo vertiginoso, } \\
\text { "Avenida Brasil encara desafio de, } \\
\text { finalmente, começar }\end{array}$ \\
\hline
\end{tabular}




\begin{tabular}{|c|c|}
\hline $\begin{array}{l}\text { Por: Maurício Stycer } \\
\text { Data: } 20 / 07 / 2012\end{array}$ & $\begin{array}{l}\text { Título: "Avenida Brasil" chega ao } 100^{\circ} \\
\text { capítulo mostrando classe C para turista } \\
\text { ver }\end{array}$ \\
\hline $\begin{array}{l}\text { Por: Maurício Stycer } \\
\text { Data: } 12 / 08 / 2012\end{array}$ & $\begin{array}{l}\text { Título: A cena da semana: "Avenida } \\
\text { Brasil" no julgamento do mensalão }\end{array}$ \\
\hline $\begin{array}{l}\text { Por: Maurício Stycer } \\
\text { Data: } 18 / 09 / 2012\end{array}$ & $\begin{array}{l}\text { Título: Trama com as fotos de Nina } \\
\text { expõe dificuldade do autor em esticar } \\
\text { "Avenida Brasil" }\end{array}$ \\
\hline \multicolumn{2}{|c|}{ NILSON XAVIER } \\
\hline $\begin{array}{l}\text { Por: Nilson Xavier } \\
\text { Data: 03/06/2012 }\end{array}$ & $\begin{array}{l}\text { Título: Tramas e personagens de } \\
\text { "Avenida brasil”" lembram Nelson } \\
\text { Rodrigues }\end{array}$ \\
\hline $\begin{array}{l}\text { Por: Nilson Xavier } \\
\text { Data: 20/07/2012 }\end{array}$ & $\begin{array}{l}\text { Título: Avenida Brasil: capítulo de } \\
\text { virada frustra telespectadores }\end{array}$ \\
\hline $\begin{array}{l}\text { Por: Nilson Xavier } \\
\text { Data: } 19 / 09 / 2012\end{array}$ & $\begin{array}{l}\text { Título: Situações incoerentes têm } \\
\text { cansado o público de Avenida Brasil }\end{array}$ \\
\hline $\begin{array}{l}\text { Por: Nilson Xavier } \\
\text { Data: 03/06/2012 }\end{array}$ & $\begin{array}{l}\text { Título: Avenida Brasil: uma tragédia } \\
\text { grega no subúrbio carioca }\end{array}$ \\
\hline
\end{tabular}

\section{Tabela 07 - SALVE JORGE}

\begin{tabular}{|c|c|}
\hline \multicolumn{2}{|c|}{ PATRÍCIA KOGUT } \\
\hline $\begin{array}{l}\text { Por: Patrícia Kogut } \\
\text { Data: } 23 / 10 / 2012\end{array}$ & $\begin{array}{l}\text { Título: CRÍTICA: 'Salve Jorge, novelão } \\
\text { clássico, faz boa estreiam }\end{array}$ \\
\hline $\begin{array}{l}\text { Por: Patrícia Kogut } \\
\text { Data: } 30 / 11 / 2012\end{array}$ & $\begin{array}{l}\text { Título: Tráfico de pessoas, bom tema de } \\
\text { 'Salve Jorge' }\end{array}$ \\
\hline $\begin{array}{l}\text { Por: Patrícia Kogut } \\
\text { Data: 07/01/2013 }\end{array}$ & $\begin{array}{l}\text { Título: 'Salve Jorge e a dificil missão de } \\
\text { manter a verossimilhança }\end{array}$ \\
\hline $\begin{array}{l}\text { Por: Patrícia Kogut } \\
\text { Data: } 25 / 03 / 013\end{array}$ & $\begin{array}{l}\text { Título: Fantasia e Realidade as duas } \\
\text { praias de Salve Jorge }\end{array}$ \\
\hline \multicolumn{2}{|c|}{ CRISTINA PADIGLIONE } \\
\hline $\begin{array}{l}\text { Por: Cristina Padiglione } \\
\text { Data: } 17 / 05 / 2013\end{array}$ & $\begin{array}{l}\text { Título: Salve Jorge sai de cena com o } \\
\text { pior ibope das } 9\end{array}$ \\
\hline \multicolumn{2}{|c|}{ MAURÍCIO STYCER } \\
\hline $\begin{array}{l}\text { Por: Maurício Stycer } \\
\text { Data: } 31 / 10 / 2012\end{array}$ & $\begin{array}{l}\text { Título: Fé no "novelão" clássico leva } \\
\text { Glória Peres a se repetir em "Salve } \\
\text { Jorge" }\end{array}$ \\
\hline $\begin{array}{l}\text { Por: Maurício Stycer } \\
\text { Data: } 22 / 11 / 2012\end{array}$ & $\begin{array}{l}\text { Título: Comparação entre Tufão e Theo } \\
\text { ajuda a explicar resistência a "Salve } \\
\text { Jorge" }\end{array}$ \\
\hline
\end{tabular}




\begin{tabular}{|c|c|}
\hline $\begin{array}{l}\text { Por: Maurício Stycer } \\
\text { Data: } 07 / 05 / 2013\end{array}$ & $\begin{array}{l}\text { Título: Surras viram rotina em "Salve } \\
\text { Jorge" }\end{array}$ \\
\hline $\begin{array}{l}\text { Por: Maurício Stycer } \\
\text { Data: } 18 / 05 / 2013\end{array}$ & $\begin{array}{l}\text { Título: O que levou Glória Perez a } \\
\text { perder o rumo de "Salve Jorge" }\end{array}$ \\
\hline \multicolumn{2}{|c|}{ NILSON XAVIER } \\
\hline $\begin{array}{l}\text { Por: Nilson Xavier } \\
\text { Data: } 23 / 10 / 2012\end{array}$ & $\begin{array}{l}\text { Título: Salve Jorge tem boa estreia e } \\
\text { pode melhorar }\end{array}$ \\
\hline $\begin{array}{l}\text { Por: Nilson Xavier } \\
\text { Data: } 18 / 01 / 2013\end{array}$ & $\begin{array}{l}\text { Título: Trama Central de "Salve Jorge" } \\
\text { tem se mostrado pouco funcional }\end{array}$ \\
\hline $\begin{array}{l}\text { Por: Nilson Xavier } \\
\text { Data: } 19 / 03 / 2013\end{array}$ & $\begin{array}{l}\text { Título: "Salve Jorge" derrapa na } \\
\text { coerência e subestima a inteligência do } \\
\text { telespectador }\end{array}$ \\
\hline $\begin{array}{l}\text { Por: Nilson Xavier } \\
\text { Data: } 17 / 05 / 2013\end{array}$ & $\begin{array}{l}\text { Título: Incoerências e furos de roteiro } \\
\text { ajudaram na repercussão "Salve Jorge" }\end{array}$ \\
\hline
\end{tabular}

\section{Tabelo 08 - AMOR À VIDA}

\begin{tabular}{|c|c|}
\hline \multicolumn{2}{|c|}{ PATRÍCIA KOGUT } \\
\hline $\begin{array}{l}\text { Por: Patrícia Kogut } \\
\text { Data: } 24 / 05 / 2013\end{array}$ & $\begin{array}{l}\text { Título: As novelas se parecem, mas } \\
\text { marca autoral ajuda a fazer a diferença }\end{array}$ \\
\hline $\begin{array}{l}\text { Por: Patrícia Kogut } \\
\text { Data: } 18 / 06 / 2013\end{array}$ & $\begin{array}{l}\text { Título: Organizações sindicais querem } \\
\text { patrulhar as novelas. Faz sentido? }\end{array}$ \\
\hline $\begin{array}{l}\text { Por: Patrícia Kogut } \\
\text { Data: } 25 / 07 / 2013\end{array}$ & $\begin{array}{l}\text { Título: Amor à Vida é o título mais } \\
\text { cerebral da história das novelas }\end{array}$ \\
\hline $\begin{array}{l}\text { Por: Patrícia Kogut } \\
\text { Data: } 21 / 11 / 2013\end{array}$ & $\begin{array}{l}\text { Título: A surra de Amor à Vida e o efeito } \\
\text { da revanche na audiência }\end{array}$ \\
\hline \multicolumn{2}{|c|}{ CRISTINA PADIGLIONE } \\
\hline $\begin{array}{l}\text { Por: Cristina Padiglione } \\
\text { Data: } 22 / 05 / 2013\end{array}$ & $\begin{array}{l}\text { Título: Amor à Vida transgride, só que } \\
\text { não }\end{array}$ \\
\hline $\begin{array}{l}\text { Por: Cristina Padiglione } \\
\text { Data: } 19 / 11 / 2013\end{array}$ & $\begin{array}{l}\text { Título: Show de Matheus Solano vale } \\
\text { recorde a 'Amor à Vida' }\end{array}$ \\
\hline $\begin{array}{l}\text { Por: Cristina Padiglione } \\
\text { Data: 03/02/2014 }\end{array}$ & $\begin{array}{l}\text { Título: Autor conduziu para beijo gay: } \\
\text { palmas para ele }\end{array}$ \\
\hline \multicolumn{2}{|c|}{ MAURÍCIO STYCER } \\
\hline $\begin{array}{l}\text { Por: Maurício Stycer } \\
\text { Data: } 25 / 05 / 2013\end{array}$ & $\begin{array}{l}\text { Título: Com ousadias e bizarrices, } \\
\text { 'Amor à Vida' começa com gosto de X- } \\
\text { Tudo }\end{array}$ \\
\hline $\begin{array}{l}\text { Por: Maurício Stycer } \\
\text { Data: } 01 / 08 / 2013\end{array}$ & $\begin{array}{l}\text { Título: Sem história, "Amor à Vida" } \\
\text { busca causar impacto em cenas isoladas }\end{array}$ \\
\hline $\begin{array}{l}\text { Por: Maurício Stycer } \\
\text { Data: } 18 / 09 / 2013\end{array}$ & $\begin{array}{l}\text { Título: Carrasco aplica terapia de } \\
\text { choque no espectador de "Amor à Vida" }\end{array}$ \\
\hline
\end{tabular}




\begin{tabular}{|c|c|}
\hline $\begin{array}{l}\text { Por: Maurício Stycer } \\
\text { Data: } 18 / 11 / 2013\end{array}$ & $\begin{array}{l}\text { Título: Desmascarado, Felix esqueceu } \\
\text { que tinha argumento para desmontar a } \\
\text { denúncia }\end{array}$ \\
\hline \multicolumn{2}{|c|}{ NILSON XAVIER } \\
\hline $\begin{array}{l}\text { Por: Nilson Xavier } \\
\text { Data: } 20 / 05 / 2013\end{array}$ & $\begin{array}{l}\text { Título: Estreia de Amor à Vida é } \\
\text { marcada por capítulo ágil e envolvente }\end{array}$ \\
\hline $\begin{array}{l}\text { Por: Nilson Xavier } \\
\text { Data: 09/08/2013 }\end{array}$ & $\begin{array}{l}\text { Título: Amor à Vida é uma excelente } \\
\text { novela mexicana brasileira }\end{array}$ \\
\hline $\begin{array}{l}\text { Por: Nilson Xavier } \\
\text { Data: } 22 / 10 / 2013\end{array}$ & $\begin{array}{l}\text { Título: Prolongamento de Amor à Vida } \\
\text { faz autor praticamente criar nova novela }\end{array}$ \\
\hline $\begin{array}{l}\text { Por: Nilson Xavier } \\
\text { Data: 31/04/2014 }\end{array}$ & $\begin{array}{l}\text { Título: Amor à Vida entra para história } \\
\text { com o beijo gay }\end{array}$ \\
\hline
\end{tabular}

\section{Tabela 09 - A FORCA DO QUERER}

\begin{tabular}{|c|c|}
\hline \multicolumn{2}{|c|}{ PATRÍCIA KOGUT } \\
\hline $\begin{array}{l}\text { Por: Patrícia Kogut } \\
\text { Data: 06/04/2017 }\end{array}$ & $\begin{array}{l}\text { Título: Dois pontos altos de A Força do } \\
\text { Querer }\end{array}$ \\
\hline $\begin{array}{l}\text { Por: Patrícia Kogut } \\
\text { Data: } 14 / 05 / 2017\end{array}$ & $\begin{array}{l}\text { Título: Identidade de gênero em A Força } \\
\text { do Querer, novela das } 21 \mathrm{~h}\end{array}$ \\
\hline $\begin{array}{l}\text { Por: Patrícia Kogut } \\
\text { Data: } 26 / 08 / 2017\end{array}$ & $\begin{array}{l}\text { Título: A Força: o drama de Ivana vai } \\
\text { além dos tabus clássicos da televisão }\end{array}$ \\
\hline $\begin{array}{l}\text { Por: Patrícia Kogut } \\
\text { Data: } 15 / 10 / 2017\end{array}$ & $\begin{array}{l}\text { Título: A Força do Querer é uma novela } \\
\text { moderna }\end{array}$ \\
\hline \multicolumn{2}{|c|}{ CRISTINA PADIGLIONE } \\
\hline $\begin{array}{l}\text { Por: Cristina Padiglione } \\
\text { Data: 03/04/2017 }\end{array}$ & $\begin{array}{l}\text { Título: Glória Perez vira a página da } \\
\text { novela das } 9 \text { hoje, sem sair do Brasil }\end{array}$ \\
\hline $\begin{array}{l}\text { Por: Cristina Padiglione } \\
\text { Data: } 23 / 08 / 2017\end{array}$ & $\begin{array}{l}\text { Título: Carol Duarte sofre primeira } \\
\text { mutação para transformar Ivana em Ivan }\end{array}$ \\
\hline $\begin{array}{l}\text { Por: Cristina Padiglione } \\
\text { Data: } 18 / 10 / 2017\end{array}$ & $\begin{array}{l}\text { Título: Com morte trágica de Irene, } A \\
\text { Força do Querer bate novo recorde de } \\
\text { audiência }\end{array}$ \\
\hline $\begin{array}{l}\text { Por: Cristina Padiglione } \\
\text { Data: } 20 / 10 / 2017\end{array}$ & $\begin{array}{l}\text { Título: Merchan de lingerie com } \\
\text { tranvesti e modelo GG em A Força do } \\
\text { Querer acusa que o mundo mudou }\end{array}$ \\
\hline \multicolumn{2}{|c|}{ MAURÍCIO STYCER } \\
\hline $\begin{array}{l}\text { Por: Maurício Stycer } \\
\text { Data: 05/05/2017 }\end{array}$ & $\begin{array}{l}\text { Título: Novela sobre mulheres fortes, } A \\
\text { Força do Querer tem melhor início desde } \\
2013\end{array}$ \\
\hline
\end{tabular}




\begin{tabular}{|c|c|}
\hline $\begin{array}{l}\text { Por: Maurício Stycer } \\
\text { Data: } 29 / 08 / 2017\end{array}$ & $\begin{array}{l}\text { Título: Drama de Ivana comoveu porque } \\
\text { o público percebeu que ele era } \\
\text { importante }\end{array}$ \\
\hline $\begin{array}{l}\text { Por: Maurício Stycer } \\
\text { Data: } 05 / 09 / 2017\end{array}$ & $\begin{array}{l}\text { Título: Você tem dúvidas sobre quem são } \\
\text { os protagonistas de A Força do Querer }\end{array}$ \\
\hline $\begin{array}{l}\text { Por: Maurício Stycer } \\
\text { Data: } 18 / 11 / 2013\end{array}$ & $\begin{array}{l}\text { Título: Oito problemas, lacunas e } \\
\text { absurdos no capítulo final de A Força do } \\
\text { Querer }\end{array}$ \\
\hline \multicolumn{2}{|c|}{ NILSON XAVIER } \\
\hline $\begin{array}{l}\text { Por: Nilson Xavier } \\
\text { Data: 03/04/2017 }\end{array}$ & $\begin{array}{l}\text { Título: Com boa estreia, A Força do } \\
\text { Querer teve primeira fase que durou } \\
\text { meio capítulo }\end{array}$ \\
\hline $\begin{array}{l}\text { Por: Nilson Xavier } \\
\text { Data: } 23 / 06 / 2017\end{array}$ & $\begin{array}{l}\text { Título: Entenda por que A Força do } \\
\text { Querer é a melhor novela de Glória } \\
\text { Perez desde O Clone }\end{array}$ \\
\hline $\begin{array}{l}\text { Por: Nilson Xavier } \\
\text { Data: } 10 / 10 / 2017\end{array}$ & $\begin{array}{l}\text { Título: A Força do Querer reforça o } \\
\text { valor do merchandising social em } \\
\text { novelas }\end{array}$ \\
\hline $\begin{array}{l}\text { Por: Nilson Xavier } \\
\text { Data: } 20 / 10 / 2017\end{array}$ & $\begin{array}{l}\text { Título: A Força do Querer mobilizou } \\
\text { audiência, mas não foi unanimidade }\end{array}$ \\
\hline
\end{tabular}

\section{Tabela 10 - O OUTRO LADO DO PARAÍSO}

\begin{tabular}{|c|c|}
\hline \multicolumn{2}{|c|}{ PATRÍCIA KOGUT } \\
\hline $\begin{array}{l}\text { Por: Patrícia Kogut } \\
\text { Data: 09/11/2017 }\end{array}$ & $\begin{array}{l}\text { Título: A linha fina entre a diversão e a } \\
\text { vulgaridade na novela das } 21 \mathrm{~h}\end{array}$ \\
\hline $\begin{array}{l}\text { Por: Patrícia Kogut } \\
\text { Data: } 14 / 01 / 2018\end{array}$ & $\begin{array}{l}\text { Título: O Outro lado do paraíso peca } \\
\text { pelo simplismo das tramas }\end{array}$ \\
\hline $\begin{array}{l}\text { Por: Patrícia Kogut } \\
\text { Data: } 24 / 01 / 2018\end{array}$ & $\begin{array}{l}\text { Título: } O \text { outro lado do paraíso, a } \\
\text { novela que abandonou a lógica }\end{array}$ \\
\hline $\begin{array}{l}\text { Por: Patrícia Kogut } \\
\text { Data: } 10 / 05 / 2018\end{array}$ & $\begin{array}{l}\text { Título: O beijo de Samuel e Cido em "O } \\
\text { outro lado do paraíso" }\end{array}$ \\
\hline \multicolumn{2}{|c|}{ CRISTINA PADIGLIONE } \\
\hline $\begin{array}{l}\text { Por: Cristina Padiglione } \\
\text { Data: } 23 / 10 / 2017\end{array}$ & $\begin{array}{l}\text { Título: } O \text { outro lado do paraíso é melhor } \\
\text { como propaganda turística do que como } \\
\text { novela }\end{array}$ \\
\hline $\begin{array}{l}\text { Por: Cristina Padiglione } \\
\text { Data: } 27 / 11 / 2017\end{array}$ & $\begin{array}{l}\text { Título: Globo joga cenas fora e redita } 12 \\
\text { capítulos para acelerar reforma de } O \\
\text { outro lado do paraíso }\end{array}$ \\
\hline
\end{tabular}




\begin{tabular}{|c|c|}
\hline $\begin{array}{l}\text { Por: Cristina Padiglione } \\
\text { Data: 06/02/2018 }\end{array}$ & $\begin{array}{l}\text { Título: Novela da Globo trata pedofilia } \\
\text { com ação paga: merchan divide coachs e } \\
\text { revolta psicólogos }\end{array}$ \\
\hline $\begin{array}{l}\text { Por: Cristina Padiglione } \\
\text { Data: } 16 / 03 / 2018\end{array}$ & $\begin{array}{l}\text { Título: Até quando a felicidade das } \\
\text { mocinhas dependerá de um casamento }\end{array}$ \\
\hline \multicolumn{2}{|c|}{ MAURÍCIO STYCER } \\
\hline $\begin{array}{l}\text { Por: Maurício Stycer } \\
\text { Data: } 27 / 11 / 2017\end{array}$ & $\begin{array}{l}\text { Título: Guinada na novela é a chance de } \\
\text { Walcyr corrigir os muitos erros da } 1^{a} \\
\text { fase }\end{array}$ \\
\hline $\begin{array}{l}\text { Por: Maurício Stycer } \\
\text { Data: } 26 / 01 / 2018\end{array}$ & $\begin{array}{l}\text { Título: Público não teve como não notar } \\
\text { um furo no início de O outro lado do } \\
\text { Paraíso }\end{array}$ \\
\hline $\begin{array}{l}\text { Por: Maurício Stycer } \\
\text { Data: } 08 / 02 / 2018\end{array}$ & $\begin{array}{l}\text { Título: “É só novela”? Duas cenas de O } \\
\text { outro Lado do Paraíso" mostram que } \\
\text { não }\end{array}$ \\
\hline $\begin{array}{l}\text { Por: Maurício Stycer } \\
\text { Data: } 11 / 05 / 2018\end{array}$ & $\begin{array}{l}\text { Título: Por que a crítica detonou e o } \\
\text { público comprou 'O outro Lado do } \\
\text { Paraíso }\end{array}$ \\
\hline \multicolumn{2}{|c|}{ NILSON XAVIER } \\
\hline $\begin{array}{l}\text { Por: Nilson Xavier } \\
\text { Data: } 23 / 10 / 2017\end{array}$ & $\begin{array}{l}\text { Título: "O outro lado do Paraíso" } \\
\text { parece cinema; mas não se engane, é um } \\
\text { melodrama }\end{array}$ \\
\hline $\begin{array}{l}\text { Por: Nilson Xavier } \\
\text { Data: } 23 / 03 / 2018\end{array}$ & $\begin{array}{l}\text { Título: Texto antiquado de "O outro } \\
\text { lado do Paraíso" banaliza e debocha da } \\
\text { prostituição }\end{array}$ \\
\hline $\begin{array}{l}\text { Por: Nilson Xavier } \\
\text { Data: } 22 / 04 / 2018\end{array}$ & $\begin{array}{l}\text { Título: Haja fôlego! Maior qualidade } \\
\text { "O outro lado" é a trama ágil e } \\
\text { dinâmica }\end{array}$ \\
\hline $\begin{array}{l}\text { Por: Nilson Xavier } \\
\text { Data: } 11 / 05 / 2018\end{array}$ & $\begin{array}{l}\text { Título: Com trama ultrapassada, "O } \\
\text { outro lado" teve público certo: } o \\
\text { conservador }\end{array}$ \\
\hline
\end{tabular}

\subsection{As telenovelas do corpus}

- AVENIDA BRASIL (2012)

Produção: Globo

Direção: Ricardo Waddington, Amora Mautner, José Luiz Villamarim

Roteiristas: João Emanuel Carneiro 
Elenco: Débora Falabella, Adriana Esteves, Murilo Benício, Cauã Reymond, Marcelo Novaes

Período de Exibição: 26 de março de 2012 a 19 de outubro de 2012 Número de capítulos: 179

Sinopse: Avenida Brasil conta a história de uma jovem que, desde os 11 anos, planeja um acerto de contas com a madrasta. Rita (Mel Maia), órfã de mãe, era criada, com muito amor, pelo Pai Genésio (Tony Ramos). Tudo muda quando ele se casa com Carmen Lúcia, a Carminha (Adriana Esteves), uma mulher ambiciosa e dissimulada. Com Genésio, ela se passava por esposa doce e dedicada; com Rita, era uma madrasta má. (Fonte: Memória Globo)

Temáticas abordadas: A trama de Avenida Brasil tinha como tema central a vingança. Ambientada em duas fases, a narrativa apresentou a saga de Rita/Nina, que, abandonada no lixão, retorna anos mais tarde para o acerto de contas com a madrasta, responsável por todos os seus infortúnios. De acordo com o Anuário Obitel 2013 (LOPES; MUNGIOLI, p. 147), as temáticas tratadas pelo folhetim foram o casamento por interesse atrelado à infidelidade de alguns personagens da trama central; segredos do passado, troca de identidade, incentivo à leitura, o universo do futebol, o primeiro amor dos personagens principais, e especialmente a ascensão e identidade da classe C. Lopes e Mungioli (2013) mencionam que "a ascensão foi representada na telenovela, embora ainda com traços de estereotipia, a partir das enunciações de personagens do subúrbio: o fictício Divino" (p.157). Logo, no Divino, foi onde se passou toda trama de vingança da protagonista, além de evidenciar os hábitos e comportamentos dessa classe social.

- SALVE JORGE (2012-2013)

\section{Produção: Globo}

Direção: Marcos Schechtman, Fred Mayrink

Roteirista: Glória Perez

Elenco: Nanda Costa, Rodrigo Lombardi, Giovanna Antonelli, Claúdia Raia, Totia Meirelles

Período de Exibição: 22 de outubro de 2012 a 17 de maio de 2013

Número de capítulos: 179 
Sinopse: O tráfico internacional de pessoas é o principal mote da novela, que traz como heroína a jovem Morena (Nanda Costa), moradora do Complexo do Alemão, no Rio de Janeiro, um dos principais núcleos da trama. Ela recebe uma proposta para trabalhar na Turquia e, ao chegar ao país, percebe que foi traficada, passando a lutar para livrar-se da máfia do tráfico e ver presa a chefe da gangue no Brasil, Lívia Marine (Claudia Raia). Ao longo de toda a trama, Morena vive um romance de idas e voltas com Theo (Rodrigo Lombardi), capitão da cavalaria do Exército, devoto de São Jorge, que deseja assumir a relação e criar como seu o filho da jovem, Júnior (Luis Felipe Lima). (Fonte: Memória Globo)

Temáticas abordadas: Salve Jorge era uma telenovela ambientada em dois cenários: o Rio de Janeiro e a Turquia, sendo a interculturalidade uma das questões dominantes na trama. Segundo o Anuário Obitel 2014, os temas mais sublinhados na ficção foram o crime organizado, interligado ao tráfico internacional de pessoas, além da exploração sexual. Um dos panos de fundos da narrativa era o Morro do Alemão, onde cenas envolvendo a polícia e o exército eram constantes. A busca da origem familiar e o preconceito de classe também foi uma temática significativa para a narrativa, abordada a partir do núcleo das pessoas que viviam nas comunidades. A complexidade dos assuntos retratados nesta telenovela é uma marca particular das narrativas da autora Glória Perez, que, através de suas histórias, insere temas sensíveis na sociedade, gerando discussões e ressaltando para assuntos que muitas vezes passam despercebidos.

- AMOR À VIDA (2013 - 2014)

Produção: Globo

Direção: Mauro Mendonça Filho

Roteiristas: Walcyr Carrasco

Elenco: Antonio Fagundes, Mateus Solano, Suzana Vieira, Paolla Oliveira, Malvino Salvador

Período de Exibição: 20 de maio de 2013 a 31 de janeiro de 2014

Número de capítulos: 221 
Sinopse: Amor à Vida é uma trama contemporânea e urbana, ambientada em São Paulo, cujo tema central gira em torno dos segredos que movem as relações familiares. Em primeiro plano está a rica e bem-sucedida família Khoury, um modelo de família feliz, formada pelo médico César (Antonio Fagundes), sua mulher Pilar (Susana Vieira) e os filhos Félix (Mateus Solano) e Paloma (Paolla Oliveira). Sob as aparências, porém, escondem-se segredos alimentados por mágoas, ciúmes, ambições e falta de afeto. (Fonte: Memória Globo)

Temáticas abordadas: Amor à Vida foi a primeira telenovela da TV Globo a transmitir um beijo gay em horário nobre. Com mais de duzentos capítulos, a trama teve muito espaço para o tratamento de temáticas sociais, entre as relações familiares, a ambição e a vingança. Como um dos cenários da trama era um hospital, as temáticas sociais que envolviam tratamentos contra doenças eram frequentes, portanto, conforme o Anuário Obitel 2015, a doença autoimune lúpus, o HIV, o alcoolismo e o câncer foram doenças retratadas em cena, além das questões como o assédio moral e o romance na terceira idade. A narrativa da produção foi dividida em duas fases, recurso comumente utilizado nas telenovelas. O relacionamento homoafetivo foi um tema de destaque, por apresentar um casal formado por dois homens que queriam um filho por meio de barriga de aluguel e por mostrar um personagem gay, que vive um casamento infeliz de fachada com uma mulher. No decorrer da trama, o romance homoafetivo foi se construindo, culminando no beijo há tempos aguardado na televisão.

\section{- A FORÇA DO QUERER (2017)}

Produção: Globo

Direção: Rogério Gomes, Pedro Vasconcelos

Roteiristas: Glória Perez

Elenco: Juliana Paes, Isis Valverde, Paolla Oliveira, Marco Pigossi, Emilio Dantas, Carol Duarte, Maria Fernanda Cândido, Dan Stulbach

Período de Exibição: 3 de abril de 2017 a 20 de outubro de 2017

Número de capítulos: 172

Sinopse: Caio (Rodrigo Lombardi) e Bibi (Juliana Paes) se conhecem na faculdade de Direito e estão noivos, mas têm visões diferentes do amor. Ele está prestes a assumir um alto cargo em uma indústria de alimentos, quando a moça termina a relação 
por ter medo de ser trocada pelo trabalho do noivo. A decepção de Bibi dura até ela encontrar o garçom e estudante Rubinho (Emílio Dantas) e ser flagrada por Caio com a nova paixão. Decepcionado, o executivo decide ir para os Estados Unidos. (Fonte: Memória Globo)

Temáticas abordadas: Força do Querer foi uma telenovela ambientada no Rio de Janeiro e na fictícia Parazinho, cidade localizada no estado do Pará, na região Norte do País. Ao contrário de suas produções anteriores, Glória Perez voltou seu olhar para dentro do Brasil, levando em conta os aspectos linguísticos e culturais da região, como a extração da castanha-do-pará, a expressão oral "Égua" e as lendas e mitos amazônicos. A transexualidade foi o tema enfatizado pela trama, pois "o drama de Ivan/Ivana ressaltou as complexas questões de identidade e política de gênero" (LOPES e GRECO, 2018, p.126). Ainda nesta temática, foram sublinhadas a busca pelo nome social, a autoaceitação, as relações amorosas e sexuais e a gravidez de transgênero. $\mathrm{O}$ tráfico de drogas e o cotidiano das favelas foi evidenciado pela personagem Bibi Perigosa, mulher do chefão do tráfico. De acordo com o Anuário Obitel 2018, as outras temáticas abarcadas foram o vício em jogo, o transformismo e os padrões de beleza.

\section{- O OUTRO LADO DO PARAÍSO (2017 - 2018)}

Produção: Globo

Direção: Mauro Mendonça Filho, André Felipe Binder

Roteiristas: Walcyr Carrasco

Elenco: Bianca Bin, Sérgio Guizé, Marieta Severo, Rafael Cardoso, Thiago Fragoso, Glória Pires, Fernanda Montenegro, Lima Duarte

Período de Exibição: 23 de outubro de 2017 a 11 de maio de 2018

Número de capítulos: 172

Sinopse: Clara (Bianca Bin) vive com o avô Josafá (Lima Duarte) no Jalapão. Ao conhecer Gael (Sergio Guinzé), sente uma atração imediata pelo rapaz e é correspondida. Mas a vilã Sophia (Marieta Severo) torna-se um empecilho. Ela só aceita o casamento do filho ao descobrir que as terras do avô de Clara têm esmeraldas. Para abrir e controlar o garimpo, Sophia interna a nora em um manicômio. Dez anos depois, Clara foge do hospício e ressurge milionária. O desejo é se vingar de sua principal inimiga: a sogra. Com o apoio do advogado Patrick (Thiago Fragoso), ela também pretende recuperar a 
guarda do filho que teve com Gael, que passou a ser criado pela irmã dele, Lívia (Grazi Massafera). (Fonte: Memória Globo)

Temáticas abordadas: $O$ Outro Lado do Paraíso foi uma trama ambientada majoritariamente em Palmas, capital do estado do Tocantins. Ao contrário de outras produções do mesmo horário, que se passam no eixo Rio de Janeiro - São Paulo, a telenovela inovou ao trazer como pano de fundo outros contextos do território nacional. A narrativa, segundo o próprio autor, foi baseada no clássico da literatura francesa $O$ Conde de Monte Cristo de Alexandre Dumas, haja vista que a protagonista Clara retorna a Palmas com seu plano de vingança. Pedofilia, violência contra a mulher, racismo e homofobia foram algumas das principais temáticas sociais discutidas na telenovela. A prostituição e o nanismo foram retratados pelo núcleo do bordel e pela personagem anã, maltratada e humilhada pela mãe. A relação entre mães e filhas, a ambição, os jogos de poder foram elementos que marcaram a trama.

\subsection{Análise qualitativa: utilização do Maxqda na categorização}

A partir das leituras das críticas, estabelecemos uma divisão temática com as recorrências de temas que emergiram. Por conseguinte, denominamos essas temáticas de categorias empíricas correspondentes aos aspectos gerais que englobam os dados compostos pelas 76 críticas e pelas quatro entrevistas. A codificação dos dados é um processo que resulta na construção e delimitação de categorias, que são compostas por um grupo de segmentos reunidos em uma mesma classe ou rubrica e são intituladas de acordo com as características que se destacam. Em outras palavras, segundo Bardin (1977), o processo de codificação é a classificação e o reagrupamento de elementos que atendem a critérios estabelecidos na metodologia de determinado estudo.

A divisão temática ocorreu a partir do que Flick (2012) denomina de três estágios de codificação, a saber: a codificação aberta, a axial e a seletiva. Na codificação aberta, o intuito é organizar a massa de dados e expressá-los na forma de conceitos por meio de uma lista de códigos e, consequentemente, de categorias. A codificação axial corresponde ao aprimoramento das categorias estabelecidas na codificação aberta, relacionando e diferenciando as categorias e subcategorias. E a categorização seletiva visa estabelecer a categoria essencial dentre as quais outras categorias podem emergir a partir da 
interpretação do pesquisador. $\mathrm{O}$ processo de codificação desta pesquisa teve como objetivo o refinamento dos dados colhidos: as críticas e as entrevistas. Com o cotejamento destes dados, estabelecemos as categorias que servirão de insumo para a análise de conteúdo e para estabelecermos que forma crítica de telenovela no Brasil se efetua.

A codificação dos dados passou por esses três estágios. O primeiro estágio ocorreu na seleção das críticas e no preenchimento das fichas acima. Nesta seleção e leitura pudemos construir uma lista de temas que se sobressaíam. Em seguida, alimentamos o programa com todos os dados e a lista de códigos encontrados. Porém, ao longo da codificação, iam surgindo novos códigos que eram inseridos. O processo de codificação consistiu na seleção de segmentos - frases e/ou parágrafos - identificados e relacionados a um código ou até mesmo diferentes códigos. A seleção é quantificada, ou seja, após a codificação, cada código apresenta um número total de segmentos codificados.

Os códigos, como veremos no capítulo a seguir, foram designados com uma cor específica, que os diferencia dos demais códigos. ${ }^{23}$ Como deixamos claro, a codificação incidiu nas críticas e entrevistas, um segmento pode ser designado para vários códigos ao mesmo tempo, pois, em nosso entendimento, uma frase ou parágrafo podem ser considerados em múltiplos códigos.

A utilização de softwares de análise qualitativa foi uma forma eficiente de tratamento de dados, na qual foi possível trabalhar com uma quantidade extensiva de dados empíricos com maior facilidade no que concerne ao tratamento e visualização do percurso, melhorando a transparência do estudo. A organização feita pelo software possibilita uma gama de recursos para a visualização desses dados pelas ferramentas visuais, tais como mapas de códigos, retrato de documentos e nuvem de palavras.

Logo, pela utilização do software de análise qualitativa Maxqda, codificamos os seguintes dados:

- Texto e Roteiro

- Atuação e desempenho da atriz/ator

- Repercussão nas redes sociais digitais e audiências

- Direção

- Verossimilhança

- Realismo

- Temáticas sociais

\footnotetext{
${ }^{23}$ A tabela de códigos e suas respectivas cores será especificada no capítulo seguinte.
} 
- Reflexões sobre a telenovela

- Construção de personagem

- Estética

- Trabalho

- Utilização de redes sociais

- Reflexões sobre a crítica

- Relação com a telenovela e TV

- Critérios de análise

- Processo de análise

Por meio do recurso do software, podemos extrair os seguintes materiais:

i) relatório sintético com a quantidade de segmentos codificados e o número de linhas específico;

ii) o número de categorias e a ordenação de categorias feitas pelo número de segmentos;

iii) e recursos visuais como mapas de códigos, nuvem de palavras e retrato do documento.

\subsection{Categorias teóricas}

A análise teórica advém das mediações propostas por Jésus Martín-Barbero e abarcadas no capítulo 3. Esclarecemos que, desde o primeiro mapa das mediações em 1989, o autor, ao longo desses anos, buscou atualizar as mediações de acordo com as demandas socioculturais. Até o fim desta pesquisa, contamos com quatro mapas que vão se complementando ao longo de suas publicações. As mediações, nesta pesquisa, se configuram como categorias teóricas, pois dão conta das muitas camadas que permeiam os processos comunicacionais e dos eixos abordados: telenovela, crítica e críticos.

A combinação de análise entre teórico e empírico pretendeu dar conta da complexidade deste objeto de pesquisa, que visa explicar o funcionamento da crítica contemporânea. Logo, na tabela abaixo, estão dispostas duas colunas: na da esquerda, estão organizadas as categorias empíricas e, na da direita, as categorias teóricas. Tendo em vista que a circulação de sentidos da telenovela opera em lugares, circuitos, combinamos as duas análises como uma forma de operacionalizar a análise. 
Tabela 11 - Categorias Empíricas e Teóricas

\begin{tabular}{|c|c|}
\hline CATEGORIAS EMPÍRICAS & $\begin{array}{l}\text { CATEGORIAS } \\
\text { MEDIAÇÕES }\end{array}$ \\
\hline Texto e Roteiro & $\begin{array}{l}\text { Narrativas; formatos industriais; matrizes } \\
\text { culturais }\end{array}$ \\
\hline Atuação e desempenho do ator/atriz & Narrativas; lógicas de produção \\
\hline $\begin{array}{l}\text { Repercussão nas redes sociais digitais e } \\
\text { Audiência }\end{array}$ & $\begin{array}{l}\text { Narrativas; Redes, tecnicidade, identidades, } \\
\text { ritualidade; sociabilidade }\end{array}$ \\
\hline Direção & $\begin{array}{l}\text { Narrativas; formatos industriais; matrizes } \\
\text { culturais }\end{array}$ \\
\hline Verossimilhança & Narrativas, temporalidades \\
\hline Temáticas Sociais & $\begin{array}{l}\text { Narrativas; temporalidades; identidades; } \\
\text { cidadanias }\end{array}$ \\
\hline Reflexões sobre a telenovela & Ritualidade; lógicas de produção, formatos \\
\hline Construção de personagem & $\begin{array}{l}\text { Narrativas; formatos industriais; matrizes } \\
\text { culturais }\end{array}$ \\
\hline Estética & $\begin{array}{l}\text { Narrativas; formatos industriais; matrizes } \\
\text { culturais }\end{array}$ \\
\hline Trabalho & $\begin{array}{l}\text { Ritualidades, espacialidade, tecnicidade, } \\
\text { socialidade }\end{array}$ \\
\hline Utilização de Redes sociais & $\begin{array}{l}\text { Narrativas; Redes, tecnicidade, identidades, } \\
\text { ritualidade; sociabilidade }\end{array}$ \\
\hline Reflexões sobre a crítica & $\begin{array}{l}\text { Narrativas; formatos industriais; matrizes } \\
\text { culturais; temporalidades }\end{array}$ \\
\hline Relação com a Telenovela e TV & $\begin{array}{l}\text { Ritualidade; Identidade; tecnicidade, } \\
\text { temporalidades }\end{array}$ \\
\hline Critérios de Análise & $\begin{array}{l}\text { Lógicas de produção, formatos industriais; } \\
\text { matrizes culturais }\end{array}$ \\
\hline Processo de Análise & $\begin{array}{l}\text { Lógicas de produção, formatos industriais; } \\
\text { matrizes culturais, ritualidades }\end{array}$ \\
\hline
\end{tabular}

As mediações identificadas, juntamente com as categorias empíricas, foram a moldura para pensarmos no ofício do crítico e na circulação das críticas. Notamos que as mediações 
tendem a explicar os processos culturais que desencadeiam mudanças estruturais em diferentes campos sociais. As mutações, como o Martin-Barbero denomina, abarcam mudanças em diferentes âmbitos do espaço latino-americano, entretanto, quando costuramos as categorias empíricas e teóricas, pretendemos dar conta de elementos tais como a habilidade de reconhecimento em relação às narrativas e seus códigos e signos; a temporalidade social, as espacialidades da crítica, sua transposição de lugar no campo do jornalismo; e entender a complexidade do campo comunicacional em condições culturais e sociais distintas. Deste modo, abaixo aludimos à fusão dos mapas de Martín-Barbero (2015), que incluem todas as mediações propostas até o momento e que, nesta pesquisa, são vistas como categorias teóricas. 


\section{CAPÍTUlO 5 - Categorização e Análise}

"As críticas só podem vir no bojo do que eu vejo, não dá para fazer antes"

Cristina Padiglione

O foco deste capítulo é a explicitação das categorias empíricas decorrentes do processo de categorização. Nele, pautaremos os segmentos destacados referentes aos temas que se sobressaíram. Ao todo, identificamos 16 categorias, sendo que, desse total, o código Realismo se constitui como um subcódigo da categoria Verossimilhança. Logo faremos a apresentação do que consideramos cada código e quais os segmentos que evidenciam esse tema em específico. A categorias teóricas foram relacionadas juntamente com os códigos advindos do campo, pois os mapas de Martín-Barbero (2015) nos fornecem uma moldura para olharmos as categorias empíricas. Através da análise combinada das críticas e das entrevistas, evidenciamos os processos de criação, análise e reflexão acerca da telenovela, do ofício do crítico e do panorama da crítica.

\section{Visão Geral dos Códigos}

As 16 categorias (também denominadas de códigos) trabalhadas nesta pesquisa, tal como explicado no capítulo anterior, foram estabelecidas a partir do campo, portanto advindas das leituras das críticas e das entrevistas. Abaixo, explicitamos os códigos com as cores referentes a cada um deles e a porcentagem de segmentos codificados. Em seguida, temos o mapa dos códigos onde, de modo geral, vemos a quantidade de segmentos codificados, além da relação intrínseca entre eles. Cabe lembrar que as categorias apresentadas neste capítulo são todas complementares, isto é, por mais que as diferenciemos na abordagem, os segmentos podem versar sobre diferentes códigos ao mesmo tempo. Portanto, os códigos se totalizam. 
Gráfico 04 - Segmentos Codificados

\section{Segmentos codificados de todos os documentos}

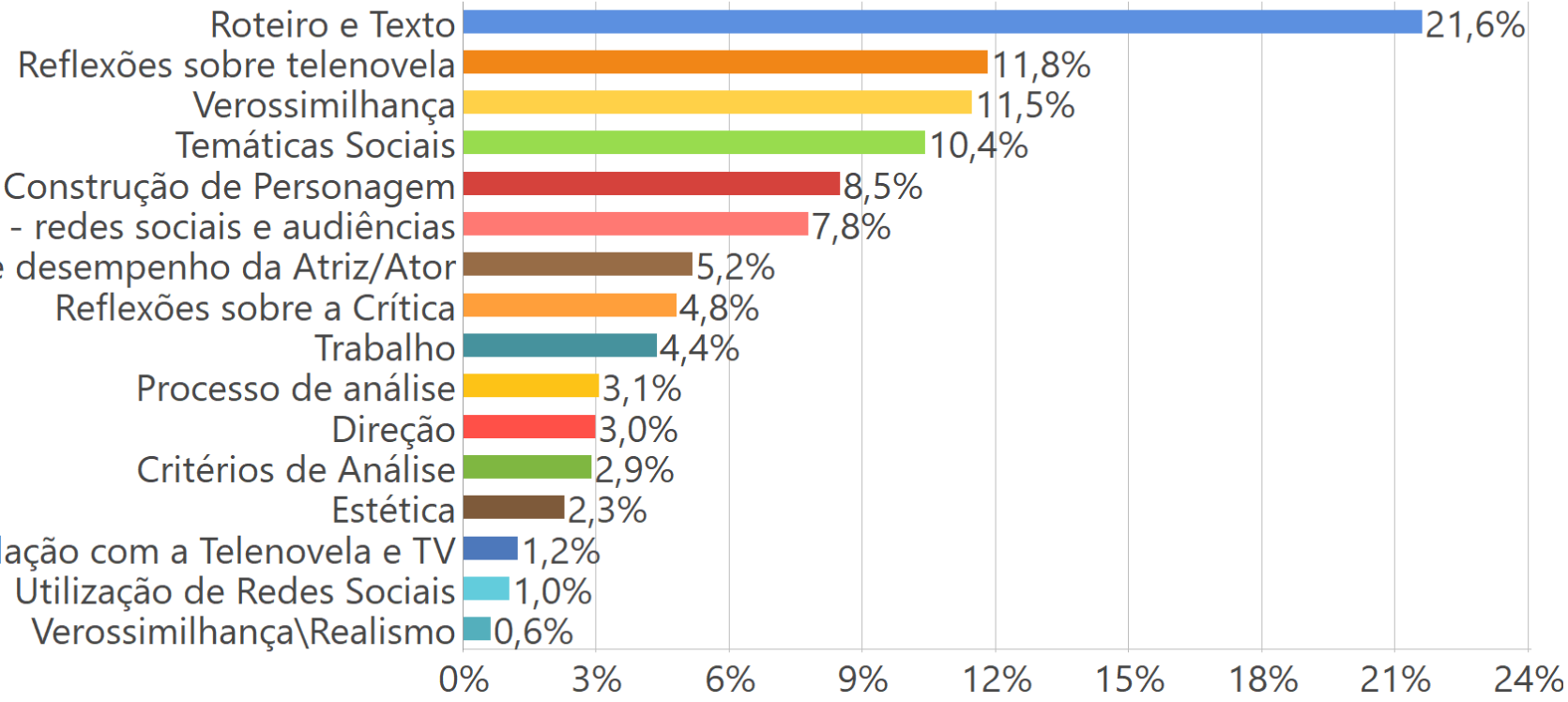

Repercussão - redes sociais e audiências

Atuação e desempenho da Atriz/Ator

Reflexões sobre a Crítica

Trabalho

Antética

$$
3,0 \%
$$

$2,9 \%$

Relação com a Telenovela e TV $1,2 \%$

Utilização de Redes Sociais $\quad 1,0 \%$

$0 \% \quad 3 \%$ 


\section{Figura 15}

Mapa dos códigos

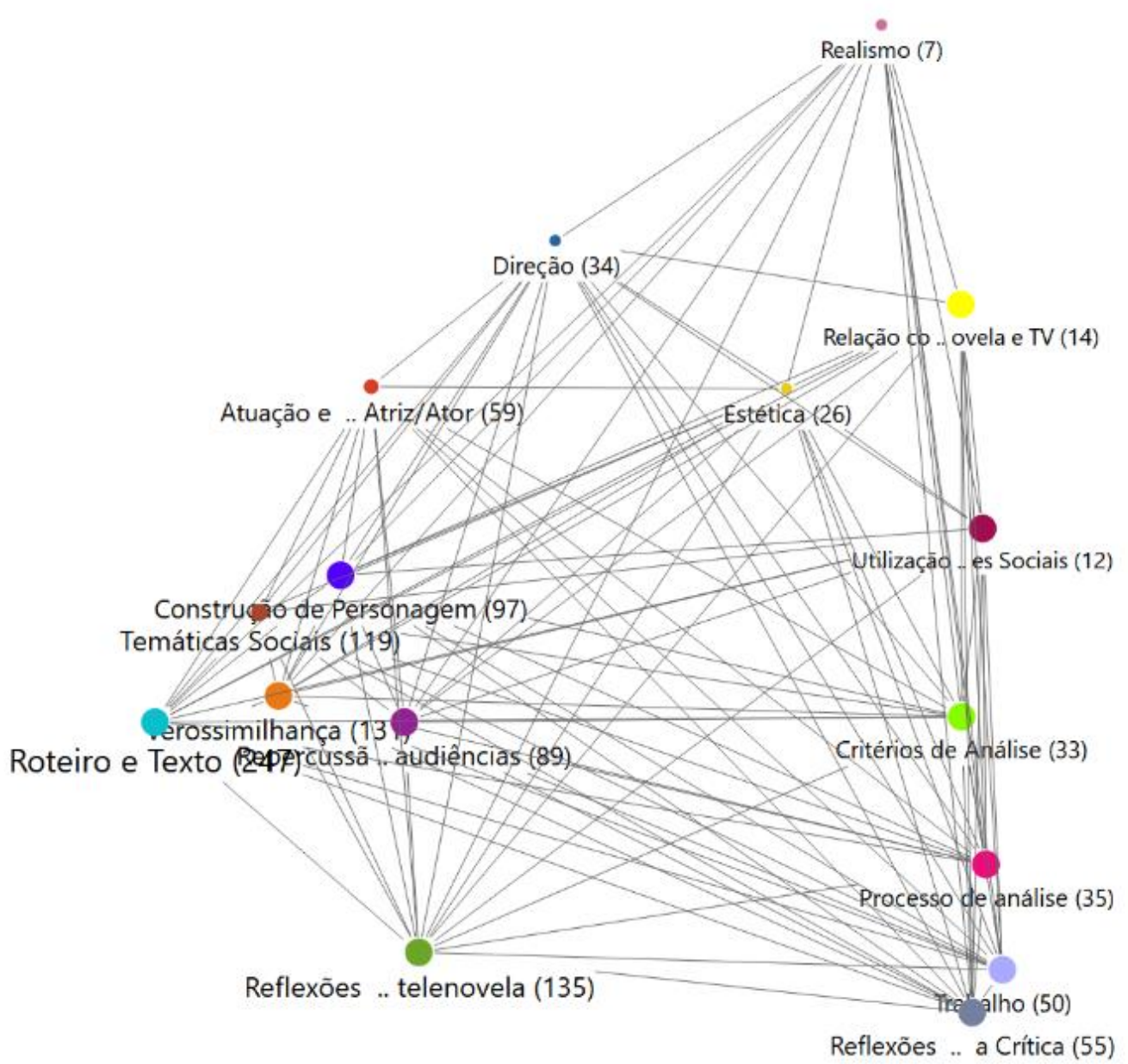

Fonte: Elaborado pela autora - Maxqda

O mapa de código é um recurso visual possibilitado pelo Maxqda no qual, de acordo com o software, exibe as relações entre os códigos num mapa específico. Portanto, quanto maior foi a frequência com que dois códigos foram atribuídos juntos, mais próximos eles apareceram no mapa. Assim, inferimos que Construção de Personagem, Reflexões sobre a telenovela, Roteiro e Texto, Verossimilhança, e Temáticas Sociais, são as categorias que tiveram maior peso e segmentos codificados, portanto, tiveram maior ligação e relação com outras categorias elencadas. A formação desses pontos de 
confluência evidencia a relação intrínseca no que concerne ao entendimento acerca da telenovela e da televisão. Abaixo, temos uma nuvem de palavras que demonstra a categoria de maior a menor relevância em termos de segmentos codificados.

\section{Figura 16}

Nuvem de palavra dos códigos

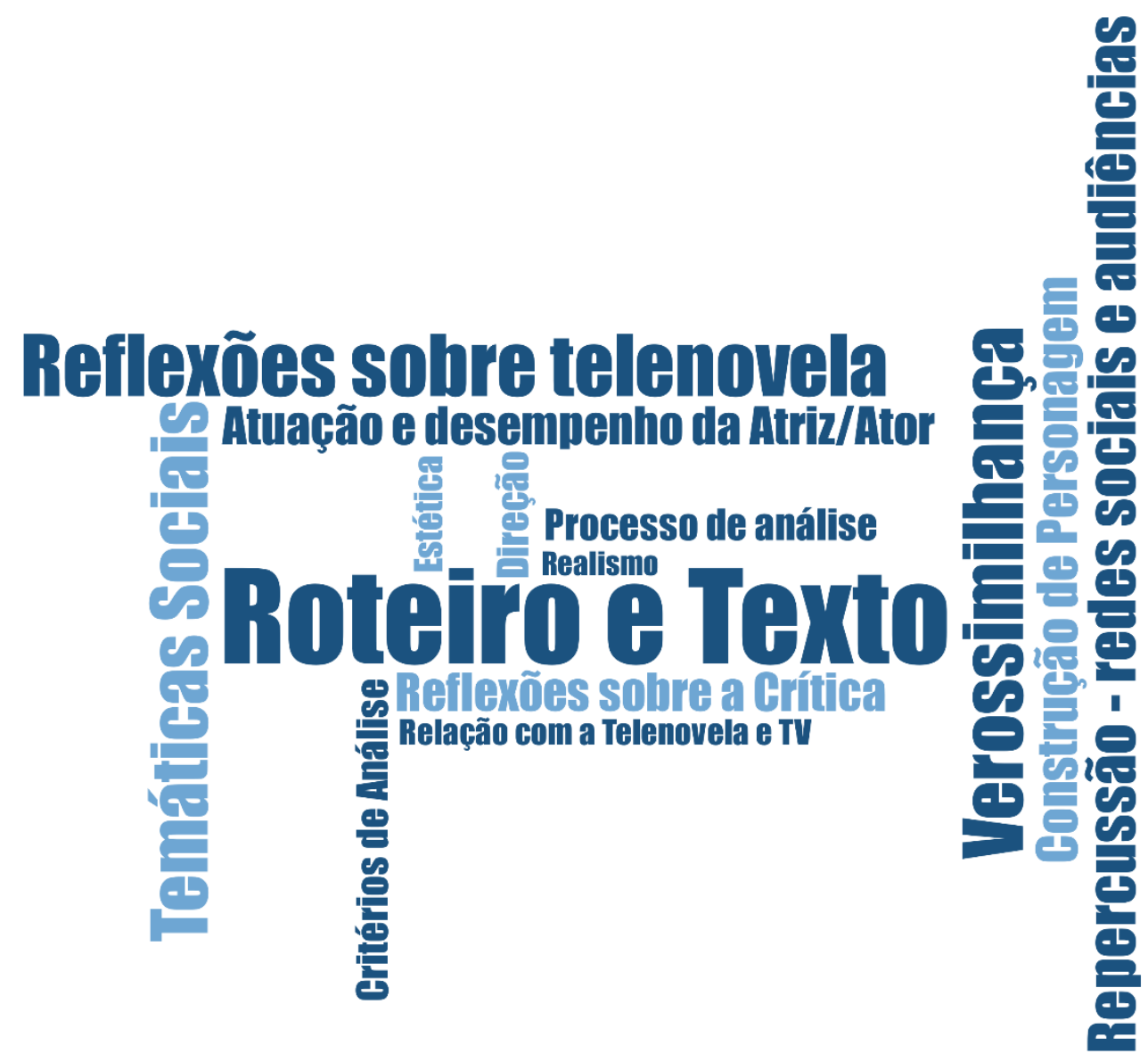

Fonte: Elaborado pela autora - Maxqda 


\section{1 ROTEIRO E TEXTO}

Esta categoria contou com 247 segmentos codificados, isto é $21,6 \%$ de todos os documentos analisados, se configurando como o código com maior número de segmentos. A partir disso, concluímos que este tema é sempre um ponto de partida para se falar em telenovela, pois é no roteiro que estão inclusas a elaboração da ideia, da sinopse e da estrutura da ficção. Como um produto audiovisual, a telenovela tem como um dos focos de análise seu texto e roteiro, são esses elementos que figuram na análise principal das narrativas. No âmbito da ficção televisiva brasileira, quem concebe o texto, sua ideia principal é o autor da telenovela. Segundo Lemos (2017, p. 68):

O roteiro é a primeira etapa de criação de um produto que passará por acréscimos, recriações, cortes e criações até a obra audiovisual completa. Os autores-roteristas brasileiros, especificamente os de telenovela, são reconhecidos pelo estilo que imprimem as suas obras, tanto textual quanto temático e fazem parte, em sua maioria, do quadro de profissionais da TV Globo, maior produtora e exibidora do gênero no presente. A autonomia criativa dos autores sempre esteve, portanto, sujeita, a interferências e a controles, do sistema empresarial de produção e distribuição.

Desta maneira, esse autor pode ou não optar pela utilização de colaboradores que vão auxiliá-lo na escrita dos capítulos, levando em conta a extensa duração das telenovelas, e as variadas alterações que são efetuadas na história dependendo de números de audiência e repercussão junto ao público. A marca autoral é um dos grandes fatores realçados pelos críticos, pois dependendo ao autor, o crítico compreende a inserção de certos elementos e, até mesmo como podem ser abarcados no folhetim. Sobre este aspecto Padiglione comenta acerca do preconceito de determinados trabalhos de alguns autores:

A Maria Adelaide também não é uma pessoa que só tenha feito coisas ruins. Você vai fazer uma conversa com Gilberto Braga, que é sempre divertido, você sempre está esperando muita coisa. Então tem os preconceitos. Tem o preconceito da crítica. O preconceito do Walcyr, então você já vai achando que vai ser aquele tatibitate, mas eu sempre me lembro que ele fez Verdades Secretas que foi muito boa, e eu sempre acho que ele consegue - naquela história do beijo gay do Félix - criar, ele é bom de criar um ambiente, em que as coisas menos aceitáveis sejam aceitáveis. Isso é muito interessante, muito hábil da parte dele. Mas eu lamento que para isso ele tropece em diálogos tão ruins, em situações ruins. 
Glória Perez, por exemplo, é uma autora que ao longo de sua carreira, apresentou em suas narrativas várias características que circunscrevem a ficção como sua, tais a ambientação das tramas em lugares longevos, explorando culturas pouco conhecidas do público, porém sempre fazendo a conexão com o Brasil. O texto da autora preza pelo viés didático na explanação de temáticas que envolvem patologias tais a cleptomania (América, Globo, 2005) e a esquizofrenia (Caminhos das Índias, Globo, 2009). Logo, Perez é uma autora que se destaca ainda como discipula de Janete Clair, escritora de telenovelas que predominava o realismo fantástico. O texto além de expor o estilo desse autor, ainda deve se adequar ao horário ao qual aquela determinada ficção será exibida, pois a televisão obedece a classificação indicativa de faixa etária da sua grade de programação. Assim, em se tratando de TV Globo, especialmente nas telenovelas do horário nobre, vemos que ela é dividida em um público específico, delimitando a forma como cada temática será abordada.

De acordo como Rodrigues (2014, p. 16) a estrutura da narrativa é um conjunto de história e enredo, logo "a medida de autoria é dada pela maneira como os elementos da narrativa articulam o enredo". Assim, a inovação deve estar no formato e não nos temas abordados. A vingança, por exemplo, é uma temática dominante nas telenovelas, as injustiças são a tônica da ação, ou podemos dizer o "chamado à aventura" (CAMPBELL, 1949), quando o protagonista se depara com um conflito que o impulsiona à ação. Tal comenta Nilson Xavier acerca de Avenida Brasil:

Como se para atender a todos os públicos, Avenida Brasil reuniu vários estilos de dramaturgia em só produto. Transgrediu a fórmula do folhetim clássico ao apresentar uma história de vingança em detrimento a uma história de amor. Apresentou uma heroína torta, de personalidade dúbia: Nina foi capaz de roubar e enganar para atingir seus objetivos. A estética da novela a aproximou do cinema. A linguagem narrativa fez lembrar os seriados americanos. Os ganchos bombásticos cativaram e mantiveram o telespectador preso à tramaainda não existe melhor maneira de fidelizar a audiência.

Xavier ressalta que o dinamismo faz parte das lógicas dos formatos industriais, e das demandas e consequência de um público acostumado a um fluxo de narrativa acelerado. O dinamismo foi a maior qualidade do roteiro do autor, que mostrou fôlego com mil e uma reviravoltas e o poder de fisgar o público e mantê-lo grudado em sua história por seis meses, causando catarses e, assim, fidelizando a audiência. Neste 
sentido, pensemos neste código por meio da mediação Narrativas, na qual segundo Pereira e Baseio (2019, p. 182), "sugere analisar os processos comunicativos na ótica das práticas, lidando com fragmentos, ritos e repetições reproduzidos no tempo e espaço cotidianos". A telenovela compreende a um texto diário, que desde seus advento está inserida no tecido social brasileiro, e levando em conta a interpretação das autoras acerca da concepção de Narrativas por Martín-Barbero (2018), vemos que a matriz cultural do melodrama impulsiona a sociabilidade e está nos cerne das relações cotidianas gerando os rituais de assistência e acompanhamento das narrativas.

Apesar da telenovela permitir certo nível de repetição e reiteração de situações, Xavier enfatiza para os elementos que, ao seu ver, empobrecem a trama, como no trecho: [...] a novela descambou para um festival de maniqueísmo, reiteração de falas e tramas (à exaustão), diálogos tatibitate e humor de gosto duvidoso, carregados pela mão pesada do autor, sem filtro, nuances, meios-termos ou sutilezas. A estética da repetição se constitui como um recurso marcante nas telenovelas brasileira, com a retomada de cenas do capítulo anterior, cenas em que os personagens narram o que se passou entre outros. É frequente a utilização de elementos repetitivos e isso se explica pela telenovela ser um programa diário, em que nem sempre o telespectador poderá assisti-las todo dia.

A novela, devido à sua extensão e às frequentes interrupções mencionadas, precisa de mecanismos de reiteração da narrativa para reassegurar o entendimento do espectador já cativo, mas que eventualmente tenha perdido algum capítulo e para fisgar o espectador não-cativo, seduzindo-o para o acompanhamento de uma trama maior com a qual não está familiarizado. A telenovela é a mestra das fofocas, dos comentários, das recordações. Todas essas estratégias visam ao retorno do vasto caudal das ações prévias para o espectador. (BALOGH, 2002, p.166)

Sobre o autor da trama, o crítico avalia que Carrasco tem a manha, conhece todos os segredos do folhetim, gênero que originou a telenovela. Todos os clichês do melodrama (ou quase todos) estão lá. Embalados por uma trilha sonora pontual, a interpretação over dos atores e o texto mais over ainda do autor. Neste trecho o crítico demonstra seu conhecimento acerca da matriz cultural da teledramaturgia brasileira, o melodrama. Mencionamos que essa herança advém dos folhetins publicados nos jornais impressos, que na América latina ganhou outras nuances num processo de hibridização, gerando o paradigma da telenovela brasileira. Trazer ao público esta informação remarcada na crítica sugere o que os crít função da crítica: trazer referências ao público. 
No fragmento seguinte, Xavier elenca os elementos que para ele, até o momento de exibição da trama, apresentam problemas no texto, o que ao seu ver comprometem a imersão do telespectador na estória contada:

Vilões caricatos (que parecem saídos de um filme de 007 ou de um desenho animado da Disney), situações bizarras, furos de roteiro, entrechos que subestimam a inteligência do telespectador, Morena versão cabelo liso, Morena versão cabelo encaracolado. Fica muito difícil embarcar no balão de "Salve Jorge" e "voar com a novela", como suplica a autora, quando ela cria uma fantasia descabida no desenvolvimento de um tema realista que merecia um tratamento mais cuidadoso.

Cristina Padiglione, inclusive narra as cenas de O Outro Lado do Paraíso em que os diálogos mostram aspectos que, na sua opinião, são estereotipados e até rasos:

A produção é nova, mas os diálogos mergulham num mar de clichês, no melhor estilo deja vu. "Gael chegou como um vento forte que arrebata e tirou os meus pés do chão (...) me fez voar" (Clara/Bianca Bin); "eu quero destruir o casamento de fulano" (Juca de Oliveira), "Ouço vozes" (Mercedes/Fernanda Montenegro, a vidente), "procurei por você a vida toda" (Gael/Sérgio Guizé), "já vi que tá mesmo gostando dela" (Raquel/Érika Januza a Renato/Rafael Cardoso).

Patrícia Kogut, por sua vez, sublinha a infantilidade do texto de Carrasco, ao mencionar que apesar do talento e do brilho de Marieta em todas as suas cenas, a voltagem do conflito fica com frequência inevitavelmente prejudicada pelo tatibitate do texto. Em Amor à Vida, Kogut destaca que a vulgaridade - em vez da ironia desvaloriza a trama.

A qualidade do diálogo, como observamos é um ponto recorrente. Porém, vale ressaltar que a telenovela possui um ritmo de confecção industrial, mas que não a exime de apresentar um roteiro de qualidade e que faça sentido nos meses de transmissão. Maurício Stycer aponta:

Outro problema é a falta de cuidado com o texto. Nada de diálogos inteligentes ou provocativos. Tudo é dito de forma meio grosseira, sem sutileza. Esta dificuldade já havia aparecido nas duas novelas "adultas" recentes de Carrasco, "Amor à Vida" e "Verdades Secretas", mas ressurgiu de forma ainda mais gritante em "O Outro Lado do Paraíso". 
Stycer ainda aponta que, apesar da pobreza do texto, a dinâmica da trama permitiu que o espectador se ligasse na narrativa, o que em muitos casos se mostra um recurso de êxito. $O$ didatismo e o coloquialismo ajudaram o espectador a se aproximar da trama. A reciclagem de temas não foi notada ou não incomodou - ao contrário, mostrou a eficácia de recontar as mesmas boas e velhas histórias.

Em Avenida Brasil, ficção aclamada tanto pela crítica quanto pelo público, em certos pontos, especialmente na barriga, apresentou cenas problemáticas quanto a continuidade e a ignorância do autor quanto as novas formas de armazenamentos de arquivos de mídia, o que ocasionou em estranhamento por parte do público, que não entendeu se foi um problema de falta de pesquisa, ou se foi um recurso para estender trama.

Mais do que dar um ar anacrônico e inverossímil à novela, as cópias em papel das fotos de Nina expõem claramente as dificuldades do autor em desenvolver a própria história. Precisando enrolar, ele optou por um caminho ruim, que acabou irritando o espectador e colocou a qualidade do seu texto em questão.

Artificial, infantil, vulgar, pobre foram alguns dos adjetivos adotados nas análises quanto ao Texto. A comparação com as telenovelas mexicanas não escapou da abordagem, tal como sublinha Cristina Padiglione: $O$ diálogo entre Emílio de Mello e Glória Pires denuncia um homem frio, com carreira em primeiro, segundo e terceiro lugar, mas a sequência remete a uma novela mexicana, dada a artificialidade presente no texto.

Walcyr não é de render pouca audiência. Apesar dos diálogos lugarcomum, é bom desenvolvedor, cria amarras para atrair o público e consegue sua torcida para os assuntos mais controversos (vide o beijo gay de Félix, em "Amor à vida", aplaudido até por conservadores, $e$ prostituição, drogas e suicidio em "Verdades Secretas"). Até por isso, convém aguardar que os próximos capítulos agucem a fome de história desse público órfão de Glória Perez.

Percebemos que nem sempre a qualidade do texto é um mérito para uma boa audiência. Furos no roteiro podem acontecer ao longo dos meses, e mesmo a falta de qualidade, o dinamismo da trama ameniza os efeitos de diálogos pobres. Algo percebido pelos críticos em suas análises. Tal ressalta Stycer sobre Glória Perez: 
Chama a atenção, também, o fato de Gloria Perez ser uma das poucas autoras da Globo a escrever suas novelas sem ajuda de colaboradores. Numa trama com mais de 90 personagens e capitulos de 50 minutos, seria inevitável que ocorressem os acidentes vistos em "Salve Jorge".

Tramas mais amena em termos de ação, ou até mesmo com diálogos extensos parecem ter perdido a tônica nas novelas contemporâneas. Os ganchos, as surpresas e reviravoltas substituíram os diálogos enormes nas mesas do café da manhã, marcadas por conversas triviais do cotidiano daquele núcleo. Anteriormente víamos nas tramas, um se levanta e se senta, cenas em que os personagens iam à feira, passeavam pelo bairro, sem necessariamente ter sentido na narrativa, apenas pelo simples prazer de mostrar o cotidiano daqueles personagens. Embora, na estrutura das telenovelas prevemos a existência das barrigas, as teleficções apresentam agilidade que acaba, por vezes, deixando o texto deficitário. Claro que alguns autores, segundo os informantes, conseguiram realizar a combinação certa de texto e dinamismo como A Força do Querer e Avenida Brasil. Sobre este aspecto Padiglione comenta que: É evidente o esforço de Avenida Brasil para se comunicar com a massa, mas a eficiência do autor João Emanuel Carneiro não faz disso um demérito, ao contrário: põe o público diante de um thriller eletrizante, com texto de qualidade.

Visando condizer a realidade social, os mapas das mediações dão pistas para se entender os processos comunicacionais atuais. Visto isso, no último mapa de 2017, a mediação Narrativas emergiu como eixo secundário ligados às mediações Temporalidades e Tecnicidades (LOPES, 2018). O aparecimento desta mediação ratifica a relevância das narrativas em nosso contexto, especialmente às tecnologias que possibilitam a assistência em diferentes dispositivos eletrônicos. Entendemos que o consumo de narrativas é inerente ao ser humano, o que se percebe são as formas de contar as histórias é que foram se adaptando ao longo dos anos, com a criação dos diferentes formatos tais o cinema, o teatro, a literatura e a telenovela.

A telenovela como um formato industrial é outra mediação que vale abordar em relação ao código. Formatos industriais era um eixo fundante ligado as mediações da tecnicidade e da ritualidade até o segundo mapa. A telenovela em sua característica fundante é um formato industrial, pois folhetins da televisão brasileira estão, desde a década de 1960, em constante exibição. A produção não para. E após o fim de uma narrativa, outra já está em seu lugar, seguida por seu público e crítica. Neste sentido, logo 
após finalizarmos uma narrativa já somos apresentados a outros personagens e tramas. A telenovela brasileira também é exportada para diferentes países, sendo que, por meio do streaming, ela também pode ser assistida em diferentes localidades geográficas.

\subsection{REFLEXÕES SOBRE A TELENOVELA}

Este código contabilizou com 135 segmentos e advém de trechos - argumentações e comentários - que os críticos realizaram acerca de alguma característica intrínseca da telenovela. Consideramos para este código as falas, tanto das críticas quanto das entrevistas, que abordem questões inerentes ao formato e/ou específica da narrativa que está sendo analisada, mas que, por meio desta análise, trate de forma geral acerca do formato telenovela.

O que ficou evidente nesses fragmentos é que tais reflexões também podem ser entendidas como uma propriedade, um atributo consolidado das telenovelas, além de ressaltar os mecanismos que permitem a esse leitor de ler a $T V$. A crítica de telenovela almeja que o leitor entenda as características, principalmente ao fazer leitura cruzadas, associações com produções anteriores, e até com a literatura, pois se trata de um texto decodificador. Deste modo, partimos do conceito de Pallottini (1998) do que se configura telenovela a partir do paradigma brasileiro:

A telenovela seria, assim, uma história contada por meio de imagens televisivas, com diálogo e ação, criando conflitos provisórios e conflitos definitivos; os conflitos provisórios vão sendo solucionados e até substituídos no decurso da ação, enquanto os definitivos - os principais - só são resolvidos no final. A telenovela se baseia em diversos grupos de personagens e de lugares de ação, grupos que se relacionam interna e externamente - ou seja -, dentro do grupo e com os demais grupos; supõe a criação de protagonistas, cujos problemas assumem primazia na condição da história. E, na atualidade, tem uma duração média de 160 capítulos, sendo que cada capítulo tem, aproximadamente, 45 minutos de ficção. (PALLOTTINI, 1998, p. 35)

Patrícia Kogut, alerta para o caráter comercial das teleficções, complementando seu argumento, relembra ao espectador que as ficções reiteram situações e experiências que ocorreram em capítulos anteriores, pois a telenovela é um produto que pode ter sua 
assistência iniciada em qualquer momento da trama, tendo em vista que ela sempre relembra seu telespectador do que está acontecendo na trama principal.

Todo mundo sabe que os folhetins são produções industriais, extensas e trabalhosíssimas. Sabemos também que este tipo de narrativa é, por natureza, reiterativa. Praticamente a cada capítulo, o enredo é "lembrado" ao público. Essa prática visa a capturar o sujeito que acaba de entrar na sala, aquele que não assistiu aos capítulos precedentes, e até mesmo o incauto que viu tudo, mas não entendeu nada até aquele ponto e precisa de mais uma explicaçãozinha. OK. Apesar de tudo isso, uma novela pode ser excelente e original.

O incauto, como a jornalista indica, indica que, em muitos casos, é comum deixar o aparelho televisivo ligado e realizar alguma atividade neste período tempo. Neste período, o espectador capta momentos da programação televisiva, o que pode ou não o levar a uma assistência mais imersiva. A fragmentação da atenção não prejudica a telenovela, já que ela leva em conta que o olhar de seu consumidor pode nem sempre estar concentrado nesta atividade, o chamado loop up e look down, no sentido de olhar para cima (tela principal) e olhar para baixo (geralmente para o celular). O hábito de ligar a televisão ao chegar em casa e tê-la como companhia é algo percebido em pesquisas de recepção voltadas para a análise do aparelho no âmbito familiar. Como a maioria das tramas do horário nobre se passam no período noturno, entende-se que esta faixa horária compreende o retorno ao lar do trabalho, dos estudos, e tem como forma de entretenimento o acompanhamento das narrativas.

De acordo com Pallotinni (1998, p. 64) “a repetição da informação, a redundância, acrescentada à extensão natural da telenovela e a seu caráter fragmentado, pode dar a sensação de ritmo lento, o que não é exato”. O reiterar também está subtendido que, apesar de ser um recurso inescapável para que escreve telenovela, não pode também ser um elemento limitador de uma boa narrativa, há de se encontrar um meio termo para não empobrecer o texto.

Entendemos as reflexões como argumentos utilizados pelos críticos para explicar o porquê de tal recurso ser utilizado ou não em determinada ficção. A crítica, neste caso, um argumento, e o delimita a partir do tema que buscou apresentar, porém aquela percepção pode perdurar até o capítulo, semana ou mês seguinte. Cabe levar em consideração o que Rallo (2005 [1999], p. XVII, grifos da autora): 
Houve quem quisesse ler o texto crítico como um texto argumentativo que apresenta um método de leitura de outro texto, tentando torna-la convincente, fazendo que uma interpretação seja aceita como demonstração. Ora, não há razão alguma para esperar-se que o texto crítico seja uma demonstração, que alcance o status de um texto científico.

A crítica de telenovela, como sua obra de análise, está sujeita a modificações que desencadeiam futuras reavaliações. $O$ folhetim apresenta um texto heterogêneo que somente pode ser compreendido no decorrer de sua transmissão. Neste caso, percebemos que as alterações são intrínsecas as tramas, sendo este aspecto levado em consideração nas análises. Através da fala dos críticos ponderamos sobre a dificuldade de interpretar e analisar uma obra inacabada. Para isso, deve-se ter em mente que inevitavelmente uma trama irá apresentar certos problemas, como as inescapáveis barrigas, quando a trama não avança. Porém, após essas pausas, somos sempre apresentados a novos conflitos e personagens que nos irá demandar um certo nível de atenção.

Patrícia Kogut faz uma diferenciação entre o romance e a telenovela:

A novela tem um número determinado de capítulos, é criada com a premência do tempo; o romance é escrito ao ritmo dos autores e tem o número de páginas que ele quiser. Alguém poderia dizer que romance é arte e novela, embora tenha muitos componentes dela, é indústria cultural, ditada por suas necessidades. Ambos, porém, são oceanos a se atravessar.

Outra reflexão contundente ao atual período de convergência das mídias se configura pela inserção da televisão e da telenovela num cenário de múltiplas telas. Conforme abarcado nos capítulos anteriores, os conteúdos migram e podem ser consumidos em diferentes plataformas, dependendo do grau de acesso deste espectador. No caso da Globo, é visível sua adequação neste domínio, com a criação e expansão de sua plataforma de streaming, o Globoplay. Além do streaming, as redes sociais já são uma realidade no contexto das telenovelas, pois neste espaço os usuários se manifestam e dialogam com o que é transmitido. As próprias emissoras utilizam deste recurso no fomento a interatividade e repercussão das narrativas. E, com isso, Nilson Xavier esclarece:

A televisão sempre acompanhou a evolução social e tecnológica. $O$ futuro da telenovela depende disso. Algumas produções já 
compreenderam esse contexto. Não se pode mais ignorar que falhas passem despercebidas. Antigamente, se uma falha fosse notada, o máximo que se podia fazer era escrever uma carta para a redação de uma revista. Hoje em dia, milhares de telespectadores assistem à novela e comentam juntos, no momento em que ela vai ao ar. Nada passa despercebido e qualquer falha vira alvo de reclamação ou troll. Independente se paga-se para isso ou não. $O$ bonde do recalque, parece, vai continuar de olho.

Por Bonde do recalque, Xavier destaca o grupo de espectadores que utilizaram o Twitter para ressaltar os problemas estéticos e falhas de roteiro na telenovela Salve Jorge. O próprio nome Bonde do Recalque foi determinado pela autora que se sentia ofendida pela atuação dos usuários na abordagem da ficção nas redes. Esse exemplo, mostra o dialogismo entre a crítica, a telenovela e as redes sociais, pois Glória Perez constantemente respondia aos espectadores via sua página na rede social. Essa interação direta da autora com seu público também foi explorada pela crítica, que vê esse comportamento mais frequente, e soube abordá-lo nas análises. O crítico ainda enumera que telenovela é entretimento, argumento que Glória Perez utiliza nas redes sociais, porém explica:

Glória está certa, o folhetim é um estilo que permite vôos altos. Mas, pelo menos 48 anos separam o folhetim de Glória Perez dos folhetins de outra Glória, a Magadan, novelista que usava e abusava de tramas rocambolescas e fantasiosas em países exóticos, na década de 1960. A telenovela no Brasil é o que é hoje porque se sofisticou a tal ponto (como narrativa e programa televisivo de entretenimento) que seu público conhece e reconhece estilos e propostas.

A observação quanto à contextualização é enumerada pelos informantes, que determinam e apresentam a seu público a função da crítica. A função do crítico é sobretudo apresentar a contextualização sobre a narrativa abordada. Contextualizar é, acima de tudo, ofertar o panorama, o ponto de partida ao qual a trama é exibida ao seu público. É por isso que a crítica é a mediadora entre os campos da recepção e a produção. Como sublinha Tondato:

Falhar nesta contextualização pode criar armadilhas para o crítico, que vai transformar seu trabalho em apenas uma descrição de algo que ele vê com os mesmos olhos de todos, viesado por preconceitos, estereótipos e regras, negando-se a oportunidade de revelação da constituição e conformação da televisão como espaço público que é. $\mathrm{O}$ crítico de TV deve entender este meio como algo além de um meio. (TONDATO, 2000, p. 34, grifos da autora) 
Neste sentido Stycer ressalta não é 'só uma novela', pois se trata de entender o alcance e inserção da telenovela no País, entender este meio não apenas do lado da produção e seus mecanismos de realização de um produto, mas sim tratá-lo através da experiência do telespectador e da maneira como ele percebe esta trama.

Sempre que escrevo sobre novelas no blog ou comento no Twitter, há leitores que criticam minha preocupação com o assunto. "É só uma novela", costumam argumentar, querendo dizer: "é ficção", "não tem importância", "é uma bobagem". Este desinteresse ou preguiça em enxergar o impacto que as novelas podem ter na vida das pessoas ainda me surpreende.

Esta categoria empírica pode ser entendida pelo entrelaçamento das mediações (MARTÍN-BARBERO, 2018): Ritualidade, Tecnicidade e Temporalidade. Em concordância com o que foi apresentado no terceiro capítulo, as mediações pretendem alicerçar teoricamente as categorias que emergiram pelos dados. Sabemos ainda, que as mediações estão interligadas e foram apreendidas pelas transformações socioculturais do panorama latino americano.

A ritualidade, tecnicidade e a temporalidade são relacionadas pelo entendimento de que a telenovela e, por conseguinte, a televisão, possibilitam novas percepções temporais, que influenciam diretamente nos rituais diários do espectador. De acordo com Rocha e Roche (2019, p. 68) a temporalidade concebida por Jésus Martín-Barbero corresponde pela experiência do tempo, como a noção de tempo é concretizada, isto é, "seu uso social é o que define o ritmo da vida humana e o que define as temporalidades". São diversos os tempos aos quais somos sujeitos e isto, claramente, altera a maneira como a os programas televisivos são entendidos. A grade de programação do horário nobre da Globo sofreu pouquíssimas transformações ao longo dos anos. A fórmula entretimento e informação foi a responsável pela concepção do tempo noturno da sociedade brasileira, se configurando como a faixa horária mais rentável da emissora.

Temporalidade social, neste contexto, corresponde às formas distintas de organização dos horários da televisão e que forma a base das matrizes culturais. A mediação estrutura os momentos da vida cotidiana, subjetivos e produtos, marcados pela rotina, fragmentados e organizados circularidades do dia. Estes tempos estabelecem repetição; estruturada nestes tempos, a TV promove o comprometimento do 
cotidiano do mercado e passa a tornar sua fonte de rentabilidade de programação. (ROCHA; ROCHE, 2019, p. 73) ${ }^{24}$

A literacia do crítico para tecer essas reflexões mostra o compromisso no entendimento dos meandres das telenovelas. O exercício do olhar, o acompanhamento das variadas notícias e discussões, além das leituras acadêmicas e ficcionais são rituais constantes de aprimoramento de leitura das narrativas. Esse habitus faz parte da própria temporalidade do crítico, que tem em seu cotidiano a supervisão de variadas fontes que influem na sua visão da telenovela. Maurício Stycer relata sua vivência de crítica de televisão:

Primeiro por que a TV aberta entra na casa de $98 \%$ das pessoas de graça. Você não paga, você não fala hoje eu vou sair de casa para ver uma novela. Novela entra na sua casa, você só tem o trabalho de ligar e desligar a televisão, mudar de canal ou não. Então é um tipo de entretenimento, mas democrático que existe. As pessoas assistem desde criança, todo mundo tem repertório de televisão. Grande maioria das pessoas tem repertório, grande maioria tem opiniões sobre televisão. Isso faz com que o trabalho do crítico seja desvalorizado, diferentemente do cinema, do teatro que exige um aprofundamento diferente, que exige uma dedicação diferente.

Machado de Assis em sua análise sobre a literatura brasileira determinou o seguinte termo: instinto de nacionalidade. Nas palavras do escritor a expressão corresponde a um certo reconhecimento sobre as obras oriundas deste território, em seu dizer "poesia, romance, todas as formas literárias do pensamento buscam vestir-se com as cores do país" (2011 [1873], p. 13). No âmbito da telenovela ressaltamos para o paradigma da telenovela brasileira, momento ao qual se inicia a partir de Beto Rockfeller (Globo, 1968), quando as teleficções adotam padrões de brasilidade, que permite o reconhecimento de seu público. Durante a entrevista, Maurício Stycer comenta que: tem uma tradição no Brasil, da novela se tornar um assunto fora da novela, e isso é uma das coisas mais interessantes que tem na maneira brasileira de fazer o folhetim televisivo. A

\footnotetext{
${ }^{24}$ No original: Temporalidad social, en este contexto, correspondería a las distintas formas de organización de los tiempos de la televisión y que toman por base la matriz cultural que estructura los tiempos de la vida cotidiana, subjetivos y productivos, marcados por la rutina, la fragmentación y la circularidad del día. Estos tiempos instauran la repetición; estructurada en estos tiempos, la TV promueve el compromiso de lo cotidiano en el mercado y pasa a hacer de su programación fuente de rentabilidade.
} 
telenovela brasileira em si apresenta este instinto de nacionalidade, está em sua confecção a utilização dos traços nacionais. Tal confirma Renato Janine Ribeiro (2004, p. 26):

Sem ilusões! A TV cala a política, e omitirá o quanto possa os movimentos populares, o descontentamento, a desigualdade social. Deles, nem palavra, ou só em programas de pouca audiência. Mas em matéria de costumes a TV fez há muito tempo uma opção pela melhora. No humor, o elo mais fraco da sociedade é ridicularizado. No noticiário, é ignorado. Na novela, porém, ele é valorizado. Em que pesem seus problemas, a novela é o gênero de nossa Tv que melhor exprime um ideal de justiça e um sonho de felicidade.

Sobre este aspecto Padiglione pondera:

Então, tem o Beto Rockfeller que eu acho que é extremamente importante, O Bem-Amado, que também traz uma capacidade de crítica que o jornalismo não tinha na época, não tinha condição, o que você tinha na censura você não tinha no Bem Amado, então isso além de ser genial, a novela está posicionada localizada numa época que ela mais incrível ainda. E é uma coisa de microcosmo de Brasil, talvez o primeiro que tenha feito, o coronelismo.

A telenovela tem uma característica determinante que condiciona todos os fatores de sua produção: ele é uma obra aberta, no sentido de ser feita enquanto está sendo produzida. Esta característica define sua maneira de ser realizada, pois está sujeito a diferentes mudanças no decorrer da transmissão. As transformações mais usuais são referentes ao roteiro, e consequentemente aos núcleos da narrativa e suas tramas. Daniel Filho (2003, p. 67) aponta que:

Uma obra aberta como a novela, é um fantasma para os autores, mas ao mesmo tempo é o que há de mais fascinante, pois torna o gênero um produto completamente diferente. Novela é o único exemplo que eu conheço em que o ator é coautor, o público é coautor, todo mundo é coautor porque o trabalho de cada um vai somando e vai modificando a obra. Muitas vezes, sem a gente conversar com os atores, eles vão expondo mudanças que, quando vemos, alteram o caminho da história.

Para Maurício Stycer o fato de ser aberta não justifica certas alterações drásticas sem demonstrar algumas pistas para seus espectadores:

Eu sei que é uma obra aberta, tem que ter essa consciência, mas isso não pode justificar. Isso justifica para o autor, mas não pode justificar para o crítico o fato de ser uma obra aberta. 'Ah normal, a novela é uma obra aberta isso mesmo, aceita', eu não posso falar isso. $O$ autor pode até estar pensando isso, o público vai aceitar, ele sabe que novela 
é uma obra aberta. Mas mesmo sendo uma obra aberta acho que tem limites e parâmetros.

Este código, como tentamos exemplificar pelos fragmentos das entrevistas e das críticas, ponderam acerca da teleficção de maneira geral. Ora podem ser entendidas como reflexões, ora passam como argumentos exemplificando a temática proposta nestas determinadas postagens. O que notamos é que esses segmentos indicam uma crítica de telenovela, que não somente recapitula o capítulo da semana anterior, mas sim assinala questões próprias do folhetim brasileiro, fazendo com que seu leitor, ao lê-la, passe a identificar os mecanismos intrínsecos e que nem sempre ficam claros. As reflexões são inerentes nos quatro tipos de críticas analisadas. Os profissionais exibem um compromisso pelo esforço de clarificar uma narrativa, que ainda muitos acreditam, que não há segredos.

\subsection{VEROSSIMILHANÇA - REALISMO}

A Verossimilhança foi o terceiro código com maior número de segmentos verificados, contabilizando 11,5\%, além de seu subcódigo, Realismo, com 0,6. Segundo Aristóteles (2018, p. 75) ser coerente e verossímil se mostra como um dos pontos principais de uma narrativa. A escolha do autor para a composição de sua ficção deve ditar os parâmetros de gênero aos quais aquela narrativa vai seguir. $\mathrm{O}$ formato telenovela, ao longo de sua história, comumente apresenta tramas naturalistas, ou seja, são estórias que prima pela retratação da realidade, evidenciando as experiências humanas em contextos específicos. O naturalismo também pode ser entendido como um braço do realismo, chegando na América latina especialmente pela teleficção.

Ser verossímil e coerente (ARISTÓTELES, 2018) no que se propõem já se constitui como um dos traços da telenovela das $21 \mathrm{~h}$, que admite o gênero naturalista e em alguns casos o realismo fantástico, como A Indomada (1997) e O Sétimo Guardião (2018). Balogh (2002) afirma que as ficções dessa faixa horária introduziram temáticas que ela denominou de "malditas" e "polêmicas", advindas principalmente do extinto horário das $22 \mathrm{~h}$ da Globo. A autora sublinha os conflitos dramáticos exacerbados e até mesmo, questões sobre sexo e violência tratados de maneira mais aberta.

Para a crítica, a verossimilhança é um elemento significativo, pois numa narrativa de longa serialidade a perda de sentido ou problemas de continuação, contribuem para 
que a trama fique confusa falhando na interação com o receptor e até mesmo quebrando os termos do pacto de recepção (LOPES, 2009).

No modelo de promessa de Jost (2004) cada gênero televisivo admite um tipo de promessa, tendo em vista que conhecendo este gênero é possível que identifiquemos o que queremos. Logo, a promessa se estabelece no entendimento de reciprocidade, no direito de exigir do campo contrário, pois "todo gênero, com efeito, repousa na promessa de uma relação com o mundo cujo modo ou grau de existência condiciona a adesão ou a participação do receptor" (p. 33).

Frente à televisão, a primeira questão que se põe ao telespectador é saber se as imagens que ele vê remetem a objetos existentes ou a quimeras, entidades fictícias. Certos programas ou certos filmes referem-se ao nosso mundo e trazem informações que aumentam nosso conhecimento sobre ele. A informação está então submetida ao exercício da prova. (JOST, 2004, p. 33)

A prova, neste sentido, é justamente a do espectador, que pode, a partir das ferramentas que dispõem, requerer da produção coerência do que está sendo transmitido. A crítica, por sua vez, adentra neste campo como a requerente ideal, apontando para as cenas e trechos problemáticos, como Kogut aborda:

Na última semana em "Salve Jorge", Théo (Rodrigo Lombardi) foi atropelado por um ônibus ao salvar o filho de Morena (Nanda Costa). Depois de abalroado pelo veículo, ele caiu desmaiado no asfalto $e$ acabou, sem esboçar reação, socorrido por uma ambulância. Apenas duas cenas adiante, apareceu saltitante em casa, atrás do menino. A única vítima do acontecido parecia ser a sua camisa, rasgada aqui e ali.

O requerimento da crítica para o cuidado com a concatenação das cenas é algo perceptível, como notamos na codificação dos segmentos. Neste sentido, Maurício Stycer comenta:

Ora, "é só uma novela", dizem muitos espectadores. Mas o que essa cena pode sugerir a milhares de pessoas? Que a fé é capaz de curar danos que a ciência considera irreversíveis. Que pessoas com deficiência devem alimentar esperanças em milagres, em "um ser de luz". Entendo perfeitamente, por isso, que muita gente tenha considerado a cena um desrespeito, uma exploração indevida do drama alheio. 
O Modelo de promessa, ao contrário dos modelos de contrato, designa ao espectador o direito de exigir, haja vista que "um outro traço, decorrente de noção de promessa, é que ela não se atualiza a não ser na confiança mútua” (JOST, 2004, p. 28). Desta maneira, Cristina Padiglione aponta para a falta de lógica da proposta criada pelo autor:

Carrasco teria outros meios para chegar ao fim desejado: matar mãe e filho, deixando o galã Malvino Salvador livre para encontrar a mocinha Paolla dentro de alguns capítulos. Que venham dizer que isso é novela e seria preciosismo exigir da ficção uma verossimilhança que muitas vezes nem a vida real tem. De acordo. O caso não é a busca pela realidade, e sim pela lógica mínima.

A coerência como já havíamos mencionado no código de roteiro e texto, se repete na verossimilhança, pois se refere as lógicas internas das narrativas. Partindo da ideia de que a telenovela deve apresentar sua história de maneira simples, é necessário que ela não confunda seu espectador, e que deve primar pela clareza, mostrando a seus público o papel que cada personagem tem na trama, a credibilidade do cenário, e se caso haja cenas de ação, busque sempre se perguntar o que faz sentido. A demanda e a própria cobrança da crítica podem parecer redundante, mas é de extrema importância, tendo em vista que essa discussão sobre o verossímil possui muita ressonância nas redes sociais.

Cristina Padiglione esclarece que uma narrativa ficcional deve ser fidedigna ao que se propõem:

Eu não acho que novela tem que ser realista, nem novela nem série, nem nada que é ficção, mas tem que ter credibilidade. Você pode assistir, sei lá The Walking Dead, que o mundo acabou e eles estão lutando contra zombies; e você pode acreditar naquilo tudo, se aquilo for bem feito. Não precisa falar a verdade, a gente não está vendo documentário. Não precisa ter o sotaque, eles têm que tentar aproximar, mas se for mal feito, você não acredita.

Nilson Xavier reflete sobre o realismo nas telenovelas, e como o horário das $21 \mathrm{~h}$ se presta em apresentar uma trama realista, é necessário que se mantenha constante aos pressupostos criados e levados a cabo no folhetim.

Cada novela segue uma linha, uma proposta, que pode ser realista, naturalista, caricata, fantasiosa, etc. Cabe ao público embarcar na história ou não. Não se exige $100 \%$ de realismo de uma novela, caso contrário não seria folhetim, seria documentário, ou outro tipo de programa. Mas um mínimo de verossimilhança se faz necessário em uma obra que tem a pretensão de seguir uma linha realista de 
dramaturgia. E é aí que Avenida Brasil tem falhado, ou, ao menos, extrapolado.

Do ponto de vista da produção, Daniel Filho apresentou a estrutura da telenovela brasileira que admite em sua confecção, as famosas viradas, que são as surpresas, plot twist, elementos novos que foram criadas para dar fôlego a essa obra de longa serialidade. A telenovela admite cerca de duas grandes viradas, a primeira dela ocorre usualmente a partir do terceiro mês, e a segunda, somente para o fim da trama, pois vai desencadear os momentos finais da trama. São nessas viradas que a verossimilhança é posta a prova, haja vista que elas admitem adulterações no núcleo principal, o que, geralmente acarreta mutações de roteiro.

Na maioria das vezes, os autores de novela são brilhantes executando essas mudanças. Isso é uma qualidade essencial. Quando alguém se dispõe a escrever novela não pode pensar que está fazendo uma obra autoral. Se for teimoso e insistir: "A minha história é essa, se não quiserem ver, deliguem", terá que trabalhar em outro veículo, porque novela é feita para atender ao público. Quando a história começa a ficar incomunicável, tem que ser mudada. Temos que atuar para ver o que está errado. (FILHO, 2003, p. 181)

Este excerto de Filho demonstra a telenovela em seu papel como formato industrial, que por ter em vista o lucro representado pelos números de audiência, sofre interferências tanto do campo da recepção quanto da produção, mesmo com exigências distintas. Os muitos capítulos que compõem a telenovela, abrangem uma temporalidade distinta, que necessita de um fôlego (barriga), e ao mesmo tempo, precisa dos ganchos, que ainda servem para marcar as mudanças temporais.

O problema maior se observa quando a narrativa exibe uma rejeição por parte do público, o que acontece geralmente quando há temáticas consideradas polêmicas, como a introdução de casais inter-raciais, que entre as décadas de 1960 a 1980, sofreram desaprovação do público. O primeiro ator negro a se destacar numa telenovela foi Zózimo Bulbul, em Vida em Conflito (TV Excelsior, 1969). Na ficção o ator viveu um romance com a personagem de Leila Diniz, que como uma vingança contra a mãe, decide namorar um jovem negro. O romance gerou diversas reações contrárias nas audiências, uma vez que até então, não havia casais interracial explícitos na TV. No entanto, como ocorreu até pouco tempo com o beijo gay, ao casal não foi permitido beijar ${ }^{25}$. E, apesar dos protestos dos atores, a produção não se atreveu a demonstrar a intimidade do casal. Com a

\footnotetext{
${ }^{25}$ Cf. https://www1.folha.uol.com.br/fsp/ilustrad/fq1205200626.htm
} 
controvérsia, os rumos da narrativa foram alterados e, em seguida, o relacionamento terminou. Pecado Capital (Globo, 1975), em sua primeira versão, apresentou o primeiro negro com formação acadêmica da televisão, interpretado por Milton Gonçalves. Médico psiquiatra formado pela renomada universidade de Harvard, Percival passa a namorar uma personagem branca. Nesta produção, houve o intento da autora Janete Clair de tratar a discriminação racial por meio do relacionamento entre uma branca e um negro, entretanto, sem surpresas, o público não ficou satisfeito com esse desdobramento e o romance não engatou. Em Torre de Babel (Globo, 1998), a rejeição do público foi por conta de um casal lésbico, interpretadas por Christiane Torloni e Silvia Pfeiffer. Apresentadas como um par a mais na trama, sem o objetivo de problematizar a relação e pela rejeição do público mais conservador, o casal acabou morto na explosão do shopping; estratégia de Silvio de Abreu para contornar a desaprovação.

Nesses exemplos vemos que, a produção exige do autor uma mudança que contingencie as demandas de ambos os lados. Que como salienta Filho (2003, p. 182), "para introduzir uma nova história visando resolver outra que não vem tendo boa receptividade, podemos antecipar mudanças. Para isso, precisamos reescrever os capítulos".

Nilson Xavier explica que o maior problema não se configura pela mudança, mas pela forma que ela é inserida na trama, que regularmente é realizada de maneira aquém ao esperado devido ao tempo necessário para a reescritura.

Acho que é importante se você for escrever um livro ou qualquer linguagem, livro ou cinema. Como é que um autor faz isso? Eu me sinto traído como telespectador. Ele trai o telespectador, ele vendeu uma coisa e é outra. Novela das sete atual também, a Globo vendeu uma coisa e é outra completamente diferente, já mudou de novo. Começou com uma história de Samantha, no segundo capitulo já não era mais Samantha, já era outra história. Ela vendeu como Samantha, na campanha de divulgação da novela, era Samantha, uma história muito parecida com a série. O segundo capitulo era outra história que não tinha a nada a ver com o que a Globo vendeu. Ai de repente virou Vale Tudo e a crítica caiu matando em cima. Já mudaram, não é Vale Tudo. Agora é uma novela cíclica. Eles inventam coisas, primeiro é um doce de leite que está barato, depois os garotos que fazem strip-tease, depois já é outra situação. Parece que a novela não tem um norte. Parece que eles escrevem ao sabor do que vai acontecer. Parece que é uma novela que não é pensada. Isso é muito estranho. Eu não estou nem criticando, pode ser uma proposta também. Uma coisa meio seriada, pode ser, por que não? Só que tem que ver como você coloca isso para o público. 
Daniel Filho aponta algumas fórmulas utilizadas na telenovelas que são insumos para as grandes viradas, e dentre entre elenco está a descoberta de que um personagem não morreu, como se sucedeu em O Outro Lado do Paraíso, quando Kogut argumentou: Renan (Marcello Novaes) vai voltar da morte, como se os espectadores fossem desmemoriados. Nada faz sentido. Conhecida por vez ou outra apresentar parte inverossímeis, a trama de Walcy Carrasco, apresentou segundo ele, um roteiro inspirado em O Conde de Monte Cristo, de Alexandre Dumas. Portanto, em seu primeiro plot twits, vimos Clara transmutada, de mocinha frágil e ingênua, para mulher rica e empoderada.

Apesar de toda discussão de todo amadurecimento da personagem e das reviravoltas em sua vida, Padiglione questiona o relacionamento entre ela e seu interesse amoroso: Em que momento os dois teriam enganado o telespectador e desenvolvido um romance que ninguém viu? Não houve beijos, abraços, arroubos, declarações de amor, nada. De onde essa relação insípida e inodora tirou inspiração para um casamento? O questionamento da jornalista se pauta pela discrepância do romance, tendo em vista que pouco dele foi visto em cena para justificar um casamento.

\subsection{TEMÁTICAS SOCIAIS}

Como sublinhamos, a telenovela brasileira é marcada pela abordagem de temas sociais que, ao longo da trama, são desenvolvidos pelos diferentes núcleos. O tratamento de questões sociais é uma característica consolidada e, dessa forma, espera-se que algum tema seja introduzido nos elementos narrativos, derivando em diferentes discussões no âmbito da recepção e na pauta da crítica, que em diferentes momentos pode ressaltar a maneira como alguma temática foi integrada. Portanto, com 119 segmentos codificados, notamos que este código é relevante para se qualificar um folhetim, além de estar atrelada aos códigos: Roteiro e Texto e desempenho da Atriz/Ator.

É comumente percebido que no espaço de tempo da ficção alguns temas se mostrem prementes, e na descrição das cinco telenovelas, apontamos as principais temáticas sociais que impulsionaram a estória dos folhetins. A partir do compêndio codificado, diferenciamos dois conjuntos: críticas que apontaram temáticas e seu desenvolvimento, e críticas que apontaram temáticas mal empregadas. As primeiras críticas claramente apontam as questões sociais mais imediatas, são, portanto, as que irão ser abrangidas em toda a telenovela. Essas, por sua vez, são mais discutidas nas críticas, 
além de embasadas. O outro conjunto são temáticas que também são foco desde o início, mas que, devido à sua inserção na trama, teve um avanço considerado inferior do que se esperava, ou até mesmo irresponsável.

As críticas que apresentaram temáticas de forma didática e responsável foram, segundo os críticos A Força do Querer, com a abordagem sobre a transexualidade, o vício em jogo, como enumera Patrícia Kogut: A arquiteta é viciada em jogo, algo que tem tudo para tocar o público. Vale lembrar que, em "América", a autora tratou de cleptomania com muita sensibilidade. Sobre a personagem Ivana, que no decorrer da trama se transforma em Ivan, a jornalista faz os seguintes apontamentos: Esta semana em "A força do querer", Ivana (Carol Duarte) contou aos pais que está tomando hormônio. A revelação não foi espontânea. Ela aconteceu depois de muita pressão. Kogut inclusive chega a qualificar que, o tema é muito bom e está na ordem do dia. A interpretação de Carol pode colaborar para que essa trama corra com toda a sutileza que ela merece.

A primeira, de Ivana na terapia. Foi uma sequência longa, cheia de silêncios. O risco de entediar o público acostumado à ação acelerada era grande. Mas isso não aconteceu. A personagem foi falando dos pais, de alguns acontecimentos marcantes da infância e de suas angústias. Carol, excelente, teve ali uma oportunidade de provar seu talento. E provou. Fez lembrar a dinâmica da série "Sessão de terapia" (do GNT), em que um ator dava seu recado com poucos recursos além do texto. A tarefa não é para qualquer um e Carol se deu muito bem.

Nilson Xavier, por sua vez, aponta para os casos, onde questões sociais foram tratadas na telenovela de forma irresponsável:

Não vejo romantização à prostituição na novela. Mas o tema é tratado
como se fosse uma coisa do outro mundo (uma visão antiquada) e
banalizado e debochado por meio do texto ultrapassado de Walcyr
Carrasco. E isso vale ainda para as outras abordagens:
homossexualidade, racismo, nanismo, violência contra a mulher.
Reforço: não é mimimi de politicamente correto. Na vida real, já há
ideias retrógradas e estigmas demais envolvendo prostituição. Mas
trivializar e fazer troça não é mostrar a realidade. Tampouco é uma
forma eficiente de combater preconceitos. Pelo contrário, é nociva, já
que o efeito é oposto. Como diria aquele personagem militante de
Marcelo Adnet no "Tá no Ar": "Quanto desserviço, dóna RédGlobo!".
Só que, neste caso, com razão.

Dessa mesma telenovela, o crítico acrescenta em outra publicação que as polêmicas que envolvem a utilização de alguma temática social: 
A única abordagem levada com alguma coerência foi a pedofilia, cuja sequência do julgamento do pedófilo foi aplaudida (menos o final, quando tudo vira um salseiro). Mesmo assim, arranhada com uma polêmica. Por que um problema grave como o enfrentado pela personagem Laura foi tratado por uma advogada novata que fez um curso de coach e aprendeu a fazer hipnose? Por que Laura não procurou um profissional experiente da área específica, um psicólogo ou um terapeuta? Porque tratava-se de um "merchan", uma ação paga pelo Instituto Brasileiro de Coaching. Assim o autor forçou uma situação para justificar a ação de merchandising. Pegou mal, muito mal.

Sobre esta mesma temática, Cristina Padigline expõe que: Os conselhos regionais de Psicologia e o Federal emitiram notas manifestando contrariedade ao que chamam de 'desserviço da Globo à população'. Os próprios coachs não estão de acordo com o uso do seu ofício nas condições em que a novela de \#WalcyrCarrasco propõe. A crítica ainda sublinha que:

Não é incomum que profissionais de vários segmentos se sintam mal representados por obras de ficção, ainda mais quando a vitrine é gigantesca, como é o caso da Globo. A questão, aqui, não custa endossar, é que toda a controvérsia parte de uma ação paga, dentro de um campo que afeta a saúde mental. É uma área muito delicada para ser tratada como script publicitário pouco transparente.

Para tratarmos destes dois conjuntos, nos debruçaremos no entendimento das temáticas sociais. Hamburguer (2014, p. 310) aponta que as telenovelas "ao mesmo tempo captam e expressam novas tendências econômicas, sociais e culturais", além disso "como uma "janela para o mundo" em diferentes momentos trata de temas controversos, em que reflete seu contexto ou exclui pontos importantes da sociedade brasileira. Logo, a construção de "retratos sociais" (ALMEIDA, 2014, p. 270) sempre esteve no cerne da teledramaturgia, especialmente da TV Globo. As temáticas sociais apresentadas nas telenovelas são uma fonte de tratamento das críticas analisadas. Por meio desses temas a trama insere questionamentos e discussões ao seu público, muitas vezes de maneira didática. No meio acadêmico temáticas sociais também podem ser abarcadas pelo termo merchandising social (SCHIAVO, 2006), pois somente a palavra merchandising é designada para as diferentes ações promocionais de serviços e/ou produtos.

Shiavo (2006) explica a emissora inseriu ações de merchandising social há mais de 30 anos, sendo as questões sociais introduzidas de forma a não somente apresentar o 
problema, mas também dar soluções exequíveis por meio dos personagens e ações. $\mathrm{O}$ autor ressalta que mostrar as soluções para o conflito social apresentado é uma evolução da prática do merchandising, inclusive com a exibição de cartelas educativas após a transmissão, e de depoimentos de pessoas reais que passaram por aquela situação.

Essa evolução temática se justifica por duas razões principais. Em primeiro lugar, responde a uma característica intrínseca ao merchandising social: a contemporaneidade. Para ser efetivo em seus propósitos de alavancar e sustentar mudanças comportamentais junto aos telespectadores, o merchandising social deverá estar em conexão direta com as expectativas gerais da sociedade. Além disso, sua efetividade também depende da aceitação da telenovela pela audiência. Sendo a telenovela um produto de edutainment dirigido a grandes audiências, as expectativas do público telespectador também devem ser levadas em consideração. Isso implica elaborar cenas e/ou situações socioeducativas mais próximas ao cotidiano dos telespectadores, fundadas nas questões sociais que mais o preocupam, no momento. (SCHIAVO, 2002, p. 03)

O setor de Responsabilidade Social da Globo afirma o papel da emissora em contribuir para as variadas discussões de temas sociais em sua programação, o que inclui a telenovela. A inserção desses temas é discutida juntamente com os autores, para possibilitarem a melhor colocação desses elementos na narrativa. Desse relacionamento também advém as diferentes campanhas sociais criadas pela emissora que escapam do escopo da narrativa e são levadas para outras plataformas.

Nas críticas realizadas, ressaltar como determinada temática foi utilizada se traduz na qualidade da narrativa, portanto em seu valor no destaque de temas controversos e maneira como o autor dispôs na trama. Saber trabalhar os temas sociais é uma característica central das telenovelas brasileiras, pois,

[...] a ficção televisiva seriada estabelece os parâmetros da história de amor impossível, aliada à eterna luta entre o bem e o mal. Logo nos primeiros capítulos. Depois, ela se desenvolverá a partir do contexto social em que está inserida, respeitando- se tempo e espaço históricos da sociedade. É desse modo que os grandes temas do cotidiano permeiam toda a telenovela. Eles são alçados à condição de elementos do universo ficcional. Sem eles não haveria como manter-se no ar uma telenovela, por exemplo, por seis ou oito meses, como é o caso brasileiro. A inclusão do cotidiano, seus temas políticos, econômicos, sociais, seus comportamentos mecânicos se dá numa lógica ficcional que tem por referência a lógica cultural daquela sociedade. Assim, as transformações que ocorrem no nível ficcional, a solução de tensões, o encaminhamento de soluções de problemas passam a sugerir soluções 
possíveis no nível do real, pois estão todos imersos na mesma história cultural: dramaturgos e espectadores. (BACCEGA, 2003, p. 10)

Acerca das ficções de Glória Perez, Maurício Stycer comenta sobre Salve Jorge que A personagem de Aisha, por exemplo, parece existir exclusivamente para discutir o tráfico internacional de bebês. É louvável a preocupação de Gloria Perez com o assunto, mas isso não a exime da obrigação de inserir o tema na ficção com sabor, o que não está conseguindo até agora. Em outro trecho ainda sobre a mesma autora, o crítico relembra:

Além disso, acrescentou aos seus folhetins a preocupação em discutir temas reais, de grande apelo midiático, como doação de órgãos ("De Corpo e Alma") ou crianças desaparecidas ("Explode Coração"). As chamadas ações de responsabilidade social que introduziu em suas tramas deram às novelas um caráter jornalístico, que se contrapõe ao da fantasia.

Com relação a mesma telenovela, Nilson Xavier frisa a atuação da atriz, para em seguida, chamar atenção para as questões sociais enfatizadas neste núcleo:

Thammy "Gretchen" Miranda chamou a atenção positivamente. Sem levantar bandeira, a lésbica Jô esteve lá quietinha em sua mesa boa parte do tempo, cumprindo sua função profissional. Ponto para a autora, que não teve a pretensão de discutir a homossexualidade de Jô. Glória preferiu outro viés, mais condizente com a trama central da novela: gays e travestis foram incluídos no grupo dos traficados. Pena que os gays apresentados eram bem caricatos e estereotipados. Diferente das travestis, que ganharam uma caracterização mais realista.

Serelle e Sena (2019) investigam as polêmicas sobre a questão da representação de dois filmes brasileiros na crítica especializada realizada em jornais, revistas e blogs. Por meio da teoria do reconhecimento de Honneth, os autores, em sua análise, tratam das demandas de grupos sociais por representações de personagens trans e negros de maneira complexa e espessa, fugindo dos estereótipos conhecidos.

Levando isso em consideração, a telenovela, por meio da abordagem de questões sociais, se viu em constantes debates acerca do reconhecimento e representação. $\mathrm{Na}$ interpretação de Serelle e Sena (2019, p. 153) sobre a noção de reconhecimento de Honneth, a identidade do indivíduo não é construída isoladamente, mas sim "apenas quando é posto em relação com outro e reconhecido em suas capacidades e propriedades, 
ele passa a conhecer os aspectos constituintes de sua particularidade, os quais o levam à compreensão de sua individualidade e ao autorreconhecimento." Os autores comentam que o valor do reconhecimento é um elemento interno da obra, e a função da crítica é abordá-lo, pois as análises incorporam o contexto onde estão sendo colocadas. As demandas por reconhecimento nas telenovelas implicam em constantes discussões políticas, que são originadas pelas exigências do público, e que podem acarretar polarizações. "A crítica feita pelos movimentos identitários, contudo, privilegia o reconhecimento, que se torna critério para análise das ficções" (SERELLE; SENA, 2019, p. 165). O tratamento de temáticas sociais só foi possível pela fragmentação entre os campos do público e do privado, e este processo foi configurado logo após a implementação da TV:

\begin{abstract}
A onipresença do olho mágico da televisão no centro da vida doméstica dos brasileiros, com poder (imaginário) de tudo mostrar e tudo ver que os espectadores lhe atribuem, vem provocando curiosas alterações nas relações entre o público e o privado. Durante pelo menos dois séculos, o bom gosto burguês nos ensinou que algumas coisas não se dizem, não se mostram e não se fazem em público. Essas mesmas coisas, até então, reservadas ao espaço da privacidade, hoje ocupam o centro da cena televisiva. Não que o gosto burguês deva ser tomado como referência indiscutível da ética que regula a vida em qualquer sociedade. Mas a inversão de padrões que pareciam tão conveniente estabelecidas nos países do Ocidente dá o que pensar. No mínimo podemos concluir que a burguesia do terceiro milênio já não é a mesma que ditou o bom comportamento dos dois séculos passados. No máximo, supõe-se que os fundamentos do contrato que ordenava a vida social entre os séculos XIX e XX estão profundamente abalados, e já vivemos, sem nos dar conta, em uma sociedade pós-burguesa, num sentido semelhante ao do que chamamos uma sociedade pós-moderna. (KHEL, 2004, p. 141)
\end{abstract}

Candido (1973) contesta até que ponto é preciso refletir sobre os fatores externos implicados nos fatores internos da obra. Não obstante, temos consciência que a crítica de telenovela sabe articular a estética com a sociedade, pois apresentar o contexto da ficção é uma de suas funções. Fraser (2007) apresenta, o que ela denominou de modelo de status, na qual explica que "o que exige reconhecimento não é a identidade específica de um grupo, mas a condição de membros do grupo como parceiros integrais na interação social" (2007, p. 107). A falta de reconhecimento, neste caso, está associada a uma subordinação social e não a algum tipo de deformação ou até depreciação da identidade de um determinado grupo (FRASER, 2007, p. 107). Identidade e reconhecimento, neste caso, 
são opostos, dado que o que está em questão não é a identidade rejeitada, mas a subordinação destes indivíduos.

No trecho abaixo, Padiglione discute a relação homossexual através de duas personagens lésbicas da telenovela Segundo Sol (Globo, 2019):

Como tinha em Segundo Sol, tinhas as meninas, a Nanda Costa e, esqueci o nome da menina, é uma atriz nova, mas aquilo incomodava muito, era uma relação aparentemente bem resolvida e não trocavam um beijo. A questão de gênero tem chamado muito atenção, como se a gente já tivesse muito calejado de falar quem é bom e quem é mal, quem é ético e quem não é ético, então isso não chama mais atenção. O que chama a atenção é a exposição, a materialização ou não de uma relação gay. Teve um tempo que chamava muito atenção cenas de nus, se vai transar ou não vai, acho que a gente superou um pouco isso. Acho que faz parte daquele periodo pós censura, em que as pessoas estavam experimentando um pouco de tudo.

Por este fragmento da entrevista de Padiglione, entendemos que o "não reconhecimento aparecem quando as instituições estruturam a interação de acordo com as normas culturais que impedem a paridade de participação" (FRASER, 2007, p. 108). O modelo de status trabalhado pela teórica é elaborado a partir do entendimento que:

Entender o reconhecimento como uma questão de status significa examinar os padrões institucionalizados de valoração cultural em função de seus efeitos sobre a posição relativa de seus atores sociais. Se e quando tais padrões constituem os atores como parceiros, capazes de participar como iguais, com os outros membros, na vida social, aí nós podemos falar de reconhecimento recíproco e igualdade de status. (FRASER, 2007, p. 108, grifos da autora)

\subsection{CONSTRUÇÃO DE PERSONAGEM}

O código em questão contou com 97 segmentos codificados, representando os fragmentos nos quais os críticos apontam para características de determinados personagens e seu desenvolvimento no folhetim analisado. A alusão aos personagens também está diretamente ligada aos códigos: texto e autor, e ainda à escolha do ator e da atriz que irá personificá-lo. De acordo com Aumont e Marie (2003, p. 226) personagem designa o "papel interpretado pelo ator"; através da perspectiva do cinema, os autores explicam que a partir da evolução do teatro ocidental o personagem passou a ser atrelado a imagem do ator, "transformando-o em uma entidade psicológica e moral, encarregada de produzir no espectador um efeito de identificação". Este personagem, por sua vez, se 
torna uma entidade psicológica independente, com traços físicos, com vestimentas e maquiagem que condizem com seu papel naquela trama, e por seus traços psicológicos e morais, que irão nortear seu comportamento na estória.

Para Rodrigues (2014, p. 42) os "personagens têm relação direta com o gênero no qual a narrativa está inserida", portanto sua criação está ligada ao que ela denomina de história-base, onde são delimitados o tempo, o espaço e os cenários. Os personagens, como ela ratifica, se perfazem em seus próprios mundos, criados pelos autores. E na acepção de Ryan (2014) esse mundo pode ser entendido por storyworld, em que

Os personagens, com suas ações, são os principais responsáveis por
gestar outros rumos e possibilidades à história - seja a partir de sua
criação pelo autor ou de sua apreensão pelo leitor -, dando-nos a ilusão
de que são, de fato, indivíduos autônomos. As propriedades que os
constituem, afinal, foram tomadas de empréstimo do mundo "real" de
referência. (LOPES et al, 2019, p. 23)

Em Eco (2011 [1979]) entendemos que estas propriedades são ações, ou também compreendidas como curso de eventos, pois dentro de uma narrativa ficcional ele é possível e está subordinado aos processos de atribuições de propriedades. Este mundo, como demonstra Ryan, é o mundo do personagem e não do autor da trama, tendo em vista que, é nele (mundo) e a partir das incontáveis ações, que a ficção irá se suceder.

Pela perspectiva da telenovela, Pallottini (1998, p. 141) elucida que o personagem é um "ser de ficção, humano ou antropomorfo, criado por um autor e filtrado por ele" (PALlOTTINI, 1998, p. 141). O folhetim audiovisual leva - em seu processo de produção, gravação e edição - quase um ano para ser concretizado. Muito antes disso, o ator é apresentado ao ser fictício que irá interpretar, cabendo a ele a maneira como irá cercar este ser. Rodrigues acredita que construir um personagem é necessário dotá-lo dos atributos tais como: "nome, idade, aparência física, maior fraqueza" (RODRIGUES, 2014, p. 44). A autora faz uma diferenciação na relação entre papel e personagem, pois como ela sublinha, é comumente visto como a mesma coisa. "Papel é um atributo da trama, porque é mutável, enquanto características de personagens são fixas ou, pelo menos, começam como fixas" (p. 57). Em outras palavras, personagem é o protagonista, o vilão, o anti-herói entre outros.

Candido (2011) reforça que os personagens são seres esquematizados para o contexto de determinada obra fictícia. Dentro deste mundo, ele está suscetível ao tecido 
de valores formulados. A construção dos personagens e, assim, sua análise pelo crítico se mostra a partir das nuances captadas pelo avaliador sobre este ser. Candido prevê que os personagens podem ser planos, quando são formados por uma única ideia; ou esféricos, construído por variadas dimensões, estabelecendo uma relação de afinidade entre o ator e o ser ficcional.

Essas duas características servirão para nos guiar nos extratos codificados mostrados a seguir, pois em muitos casos o argumento utilizado pelos críticos para se tratar da construção do personagem esteve ligado a falta de perspectiva do personagem na trama, onde ele se "perdeu" na história, e a pouca profundidade desse ser no tratamento de alguma temática. Ressaltamos que as narrativas contemporâneas pedem a criação de personagens complexos, em que se observa até mesmo, certo desvio de conduta ética e moral. Nestas condições, observamos sempre a busca pela redenção, o acerto de contas que levará este ser a uma mudança de vida e de caráter. As transformações, neste sentido, estão inerentes nas telenovelas, como em Amor à Vida, com o personagem Félix, em que Stycer ressalta: $O$ Félix teve uma enorme reviravolta, era um personagem dramático virou um personagem de humor. Sobre essa transformação o informante explica:

[...] tudo bem é uma obra aberta, não estou proibindo de mudar, agora eu como crítico que estou assistindo aquilo todo dia, não posso deixar de manifestar a minha surpresa com uma reviravolta drástica sem que eu tenha sido preparado para aquilo, sem que eu entenda por que o personagem... sem que o autor tenha dado pistas para você entender por que que o personagem mudou.

Ainda sobre Félix, Stycer assinala que, o personagem foi responsável por um momento de ousadia na teledramaturgia brasileira. No quarto capítulo da novela, numa cena memorável, Felix reconheceu para Edith, sua mulher, que é gay, mas que precisa continuar vivendo uma situação mentirosa com ela. Interpretado por Matheus Solano, Félix foi um personagem que se redimiu. De vilão, que joga sua sobrinha na caçamba de lixo, passa por um processo de reparação, e termina na primeira cena de beijo gay. As motivações para a vilania de Félix até então era explicada pela sua ambição e inveja da sua irmã mais nova. Entretanto, ao longo da narrativa, distinguimos que o verdadeiro anseio de Félix era a aceitação por parte do pai e de sua própria orientação sexual. Neste processo de mudança, passamos a divisar que o personagem foi se destacando na trama, como indica Nilson Xavier: 
A regeneração de Félix trouxe consigo outro fato interessante em "Amor à Vida". Lá pela metade da novela, os conflitos do casal romântico central - Paloma e Bruno (Paolla Oliveira e Malvino Salvador), se não estavam resolvidos ou esvaziados, dependiam unicamente de Félix. Foi quando vimos a "bicha má" tomar o posto de protagonista de Paloma e Bruno, que, a essa altura, já era um casal insosso e sem torcida do público.

Patrícia Kogut, em sua avaliação de Amor à Vida questiona o título da ficção por meio da análise do personagem Félix, frisando o protagonismo dele na ficção:

Mas o que mais deixa embatucado o público da novela é o seu título. "Amor à vida"? Por que cargas d'água, criatura?, como indagaria Félix. A história não pode ter sido batizada numa alusão a ele. $O$ personagem é um infeliz em todos os aspectos. Vive trancado no armário, odeia o filho, se sente desprezado pelo pai (que de fato não o tem em alta conta). Com medo de a sobrinha ficar com a fortuna da família (outro ponto mal explicado, já que a herança dos pais seria dele e da irmã), roubou a criança de Paloma logo depois do parto e a atirou numa caçamba de lixo. Não ama a vida, ama?

No entender de Stycer, a transformação de Félix faltou sentido, pois as ações do personagem, até então, forma de uma crueldade ímpar:

Você vai falar: 'ah legal, deu muito certo, essa virada fez bem'. É, mas faz sentido? Um negócio tão dramático esse início, jogar um bebê numa caçamba, coisa mais dramática que isso, não consigo imaginar, uma das coisas mais dramáticas que eu vi na televisão, um dos gestos mais brutos numa novela que teve nos últimos anos.

Como um habitante da realidade ficcional, o personagem, de acordo com Brait (1985, p. 11) “representam pessoas, segundo modalidades próprias da ficção”. Levando isso em conta, a telenovela como um formato industrial de longa extensão, admite personagens cambiáveis, no sentido de que podem sofrer alterações no decorrer da transmissão. As alterações já são popularmente conhecidas, entretanto alguns casos de transformações drásticas se destacaram e foram sujeitas à crítica. Nilson Xavier indica a mudança de Ninho, personagem de Amor à Vida:

Alguns personagens, quando não totalmente desnecessários e sem trama (como o quadrilátero Patrícia-Michel-Silvia-Guto) tiveram tantas modificações de personalidade ao longo da trama quanto pedia o roteiro. Ninho (Juliano Cazarré) é um deles, que foi se transformando de acordo com as situações novas que o autor criava. Sim, as pessoas mudam ao longo da vida. Mas onde 
fica a estrutura psicológica do personagem, sua identidade e a coerência narrativa da trama? Ninho se tornou um personagem mal costurado, uma espécie de Frankenstein da Teledramaturgia brasileira. Na melhor das hipóteses, não passou de um coringa nas mãos do autor, um tipo que ele podia usar a qualquer momento em alguma nova situação criada.

As fases do personagem de Amor à Vida foram, em diferentes momentos, foco de análise de Xavier, que aponta para mudanças drásticas de personalidade de um personagem, sem nem ao menos haver alguma justificativa por parte do roteiro que balize a mudança:

Como já comentei aqui no blog anteriormente, Ninho (Juliano Cazarré) teve sua personalidade alterada pela terceira vez por conta da necessidade de roteiro. $O$ personagem começou como um tipo hippie-adicto-sedutor, que enlouqueceu de paixão a patricinha Paloma (Paolla Oliveira). Para raptar a filha Paulinha (Klara Castanho), Ninho se transformou num bobalhão, uma releitura de seu Adauto de "Avenida Brasil". Na fase atual, para justificar novos entrechos, Ninho voltou de Nova York como um artista de certa repercussão. Agora Ninho é yuppie. Será que até o final de janeiro ele muda de novo?

As personagens esféricas (CANDIDO, 2011), em sua construção, são tridimensionais, pois suas características dão a impressão de que são reais. Para uma telenovela, um personagem deve ter um fôlego para suportar os vários meses de exibição. Entretanto, como comentamos, a reação do público é fator determinante para a manutenção deste ser fictício a partir da primeira perspectiva do autor. Os fatores externos, como gostamos de remarcar, interferem sobre maneira na narrativa do folhetim, tendo em vista que um enredo simplificado demanda um personagem complexo, com camadas.

No que diz respeito à produção, constatamos, ao longo da discussão, que boa parte das mudanças envolveu a criação de universos narrativos mais complexos, que exigem dos telespectadores um envolvimento emocional e cognitivo mais apurado tanto em função do uso de diferentes temporalidades como em função de uma maior complexidade na construção de personagens e, portanto, de suas motivações e relações com outros personagens. (MUNGIOLI; PELEGRINI, 2012, p. 35) 
Esta funcionalidade do personagem, é outro aspecto suscitado nas críticas, pois o que conta não é necessariamente, a quantidade, mas a qualidade na construção deste ser, tal como finaliza Maurício Stycer:

"Salve Jorge" tem muitos personagens, "Avenida Brasil" era enxuta, alguns espectadores reclamam. Confesso que acho divertido este entra e sai de gente na novela. O problema não é o número, mas o fato de haver personagens mal construídos, repetitivos ou sem função. (Stycer)

\subsection{REPERCUSSÃO - REDES SOCIAIS E AUDIÊNCIAS}

Esta categoria corresponde a repercussão das telenovelas nas redes sociais e na audiência tradicional. O código foi visualizado especialmente quando em determinada análise, o crítico menciona os índices de audiência, ou relata a reverberação da ficção nas redes. Patrícia Kogut anuncia: Foi o ponto alto do capítulo, que alcançou 44 pontos (SP) e movimentou as redes sociais. Este trecho exemplifica o que compreendemos por dois tipos de repercussão: a audiência, número que compreende a quantidade de domicílios que assistem a determinado programa televisivo; e as redes sociais, por meio do Twitter pela indexação de hashtags. O modelo de audiência tradicional, ainda é a métrica mais utilizada para quantificar em pontos, os níveis de assistência. O controle é realizado em tempo real, e é possível saber as variações de visualização dos programas no horário de sua exibição. O Instituto Brasileiro de Opinião Pública e Estatística, o Ibope, faz esta medição por meio do Peoplemeter - aparelho que regista a audiência em cada domicílio - sendo este valor relevante para contratos publicitários e o entendimento das preferências dos públicos.

A repercussão em redes sociais pode ser entendida pela TV Social - prática que corresponde em assistir Tv enquanto interage em alguma rede social. O comportamento, como mencionamos nos capítulos anteriores, se tornou um dado para a medição do que se chama de buzz. A Kantar Ibope Media, empresa que realiza as duas formas de medição, dimensiona o número de impressões, que é quantidade de vezes que uma postagem sobre um programa foi visualizada. Como demonstra a imagem abaixo:

\section{Figura 17}

Social TV para TV aberta em 2018 


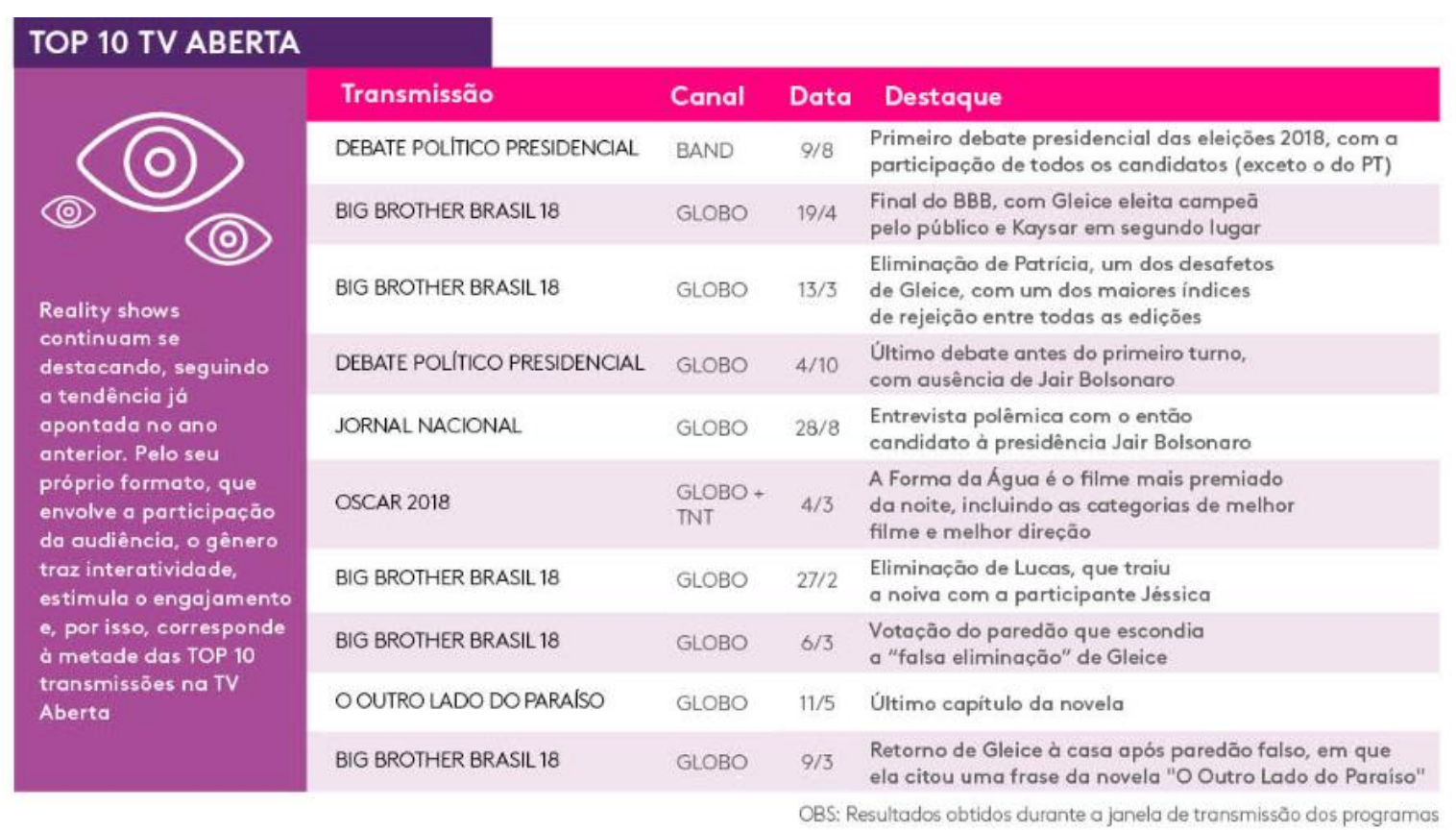

Fonte: Kantar Ibope Media - https://www.kantaribopemedia.com/o-que-mais-movimentou-socialtv-em-2018-no-brasil-2/ Acesso: 25 jan. 2020

Para a crítica, a repercussão funciona como um elemento de argumentação, pois ainda se debate a perda da audiência das telenovelas, como aponta Nilson Xavier:

O cara é mestre em prender o público com suas tramas rocambolescas e cheias de reviravoltas - em minha opinião, sua maior qualidade como novelista e o seu segredo de sucesso. Com ótimos ganchos, alguns capitulos-chave e sequências de impacto, o novelista conseguiu manter o interesse de seu público cativo por oito meses seguidos. E sem barriga (aquele momento da trama em que nada acontece), mesmo tendo que espichar a novela. Carrasco alcançou, inclusive, o feito de levantar o Ibope do horário das nove da Globo.

Entrevendo as mediações de Martín-Barbero neste código, verificamos que as mediações narrativas, redes, tecnicidade, identidades, ritualidade e sociabilidade podem ser encaixadas nas práticas que versam esta categoria. No dizer de Ronsini (2012, p. 71) "as ritualidades cotidianas organizadas com base no uso dos meios técnicos comunicacionais contribuem igualmente para definir as identidades do receptor, definições (móveis e transitórias) de si mesmo e de pertencimento coletivo". O uso das redes sociais aliado a prática de assistência tradicional é um dado levado em conta na percepção da crítica, o que assinala para a conjunção da sociabilidade, das tecnicidades e 
das redes. A identidade, neste sentido, se apresenta pela particularidade da conversação em rede, que explana a telenovela, onde é imperativo saber e relacionar os códigos simbólicos que se traduzem nesta narrativa.

Mencionar as audiências se tornou um ponto chave das críticas, e ressalta como os profissionais devem estar sempre atentos a esse elemento de medição da repercussão e interação com o público. Patrícia Kogut sinaliza para a repercussão de um recurso utilizado na trama:

Mesmo as redes sociais - tradicional "cantinho da detração" explodiram com elogios a ele. Tapas e socos, não há dúvidas, atraemo público. O recurso, claro, deve estar sempre em sintonia com a dramaturgia. Do contrário, pode perder a força e cair no vazio. Não foi o que aconteceu aqui.

Maurício Stycer, em seu argumento, assinala para o modelo de negócios ainda em vigor na televisão aberta:

\footnotetext{
"O Outro Lado do Paraíso" atraiu um novo público e o prendeu, sem decepcionar. Com estas suas qualidades e facilidades, entregou tudo que prometeu, capítulo a capítulo. Mostrou a força do folhetim na TV. É um grande mérito na TV aberta, cujo modelo de negócios é baseado em audiência e publicidade.
}

Cristina Padiglione, no que lhe concerne, apresentou como as redes sociais como um termômetro para se entender as dinâmicas de reclamação do público, e como isso pode influenciar a emissora e os anunciantes, que se valem dos números de audiência para contratos publicitários e de merchandising nas ficções.

Pelo barulho gerado nas redes sociais, a intolerância parece vencer. Mas como anunciante não dá tiro no pé e a Globo está longe de se assemelhar a uma ONG, a presença de duas grandes ações de merchandising de uma famosa marca de lingeries no penúltimo capitulo de "A Força do Querer" endossa que a tolerância é maioria no placar do público.

Em meio as discussões sobre a perda de audiência da TV aberta para as variadas telas disponibilizadas, hoje já se sabe que a Globo soube contornar este aspecto por meio de sua plataforma de streaming, o Globoplay. O conteúdo passou a ser a troca de moeda de plataforma de vídeo on demand, em que hoje agregam um número elevado de diferentes conteúdos, incluso a telenovela. Cristina Padiglione, afere que, com a atenção fragmentada, a atenção desse telespectador já constitui um ganho diante das múltiplas 
condições de assistência de produções disponíveis no momento. Com isso, ela discorre: Convenhamos, é muita coisa para esses tempos em que a gente pode ter mais de 100 canais em casa, internet e as Netflix da vida, sem falar nos Candy Crushs e games na tela do celular, né não?

A repercussão nas redes sociais é voltada, como aponta a críticas para exaltar e reclamar de aspectos que, no olhar do espectador, não ficou claro ou não agradou. Isso, como vemos, se tornou uma base de argumentação da crítica, que munida da opinião de seu público, utiliza desse argumento para construir sua própria narrativa do aspecto analisado.

Cristina Padilgione realizou o seguinte comentário acerca de Salve Jorge: Mas, se pouco importa o que será da vilã Lívia (Cláudia Raia) ou do casal de mocinhos, Théo

(Rodrigo Lombardi) - que ganhou o pejorativo apelido de 'Pasthéo' - e Nanda, Salve Jorge fez a diversão dos tuiteiros na segunda tela, com erros de continuidade e falta de lógica.

Já Maurício Stycer, em sua atuação constante no Twitter, explica sobre Avenida Brasil: As famosas "provas" de Nina contra Carminha seguem rendendo história em "Avenida Brasil". Diariamente recebo e-mails ou mensagens no Twitter de espectadores indignados com o tratamento dado por João Emanuel Carneiro ao caso.

Nilson Xavier problematiza o sentido das redes sociais para a telenovela, e assinala: Os números do Ibope ainda interessam ao mercado. Mas a repercussão na Internet tem uma função maior: é formadora de opinião, tão influenciável quanto os velhos "group discussions" entre donas de casa organizados pelas emissoras.

\subsection{ATUAÇÃO - DESEMPENHO DA ATRIZ E ATOR}

Identificamos esse código por meio da reincidência de segmentos que abordavam a atuação e o desempenho de determinada atriz/ator. Contando com 5,2\% dos documentos analisados no software, entendemos que a atuação se constitui por um código complementado pela construção da personagem, tendo em vista que - em muitos casos a escalação de algum ator é determinada pelo perfil do papel.

No conjunto de fragmentos sobre esta categoria, notamos que as apreciações feitas pelos críticos podem ser divididas em três vieses: as críticas que comentam a boa atuação, 
as que enfatizam a atuação que não foi boa, e a última, o desempenho do ator que apresentou certa evolução no papel em questão. Sempre lembrando que a telenovela por seu formato extenso, permite certas mudanças no que concerne ao roteiro e a seus personagens, e a união entre o ator e o ser fictício, pode levar certo tempo de adequação seja para melhor ou para pior. Há casos em que os críticos mencionaram os atores que foram mal empregados na narrativa, pois devido ao conjunto de seus trabalhos se configuram como grandes nomes da teledramaturgia.

Glória Pires pareceu pouco à vontade em sua personagem. A cena da atriz e de Juca de Oliveira na morte do personagem dele foi um dos momentos mais constrangedores da novela, em que os atores não conseguiram escapar do texto raso e da direção pouco cuidadosa. Atuações que deixaram a desejar em uma encenação digna dos piores dramalhões latinos. (Nilson Xavier sobre O Outro lado do Paraíso)

Nilson, ainda comenta para o que acredita ser o desperdício de certos atores, que devido aos problemas com o roteiro e a construção do personagem, são prejudicados na trama:

A personagem de Fabiana Karla sofreu toda espécie de humilhação gratuita, desnecessária e sem graça para, quando finalmente se casar com um príncipe encantado (seu sonho), voltar à estaca zero. Isso sem falar no malfadado "bigodinho" (a depilação íntima) da personagem, uma piada que descambou para o mau gosto. Assim como Tatá Werneck, Fabiana Karla foi outro talento desperdiçado com uma personagem que só cansou. (Nilson Xavier, acerca de Amor à Vida)

Patrícia Kogut sobre A Força do Querer, ressalta a interpretação de Carol Duarte, em sua atuação como Ivana/Ivan: Desde sua primeira aparição, Carol Duarte mostrou talento, presença, intensidade. O papel é repleto de armadilhas, mas ela desvia de todas, pisando sempre no terreno da sutileza, usando técnica, mas sem nunca deixar de lado a emoção. Que boa atriz.

Daniel Filho (2003, p. 269), em experiência discorre que existem atores que possuem "a envergadura para fazer qualquer tipo de papel: Fernanda Montenegro, Marília Pêra, Paulo Gracindo, Raul Cortez”, porém também admite que existem atores que, curiosamente, se dão melhor fazendo papeis de pessoas mais velhas, tal como Mario Lago e Ítalo Rossi (FILHO, 2003, p. 270). Para o produtor a existência de tipos de atores delimitam sua escolha para os papeis, 
Existe, em suma, uma coisa chamada "qualidade de estrela" - star quality - que a pessoa simplesmente tem ou não tem. Isso independe de o camarada ser bom ou mau ator. Independe também da beleza. Existem homens e mulheres assustadoramente belos que, no entanto, não possuem star quality. Outros são belos e ainda possuem a qualidade de estrela. (FILHO, 2003, p. 267)

Em vista disso, a escolha do profissional para atuação está atrelada a diferentes fatores considerados pela produção, e que recebem a validação da crítica, como nos segmentos a seguir:

A aposta em Nanda Costa se mostrou um acerto, ela tem presença e talento. Giovanna Antonelli, delegada que vive um gato e rato com o ex-marido com quem tem uma filha complicadinha, brilhou. Como ela, Alexandre Nero, Antônio Calloni e Zezé Polessa. Há repetições de atores (Dira Paes e Nero, marido e mulher em "Fina estampa", são patrão e empregada agora, só para dar um exemplo), mas, com um elenco tão extenso, elas parecem impossíveis de driblar. (Patrícia Kogut sobre Salve Jorge)

A Carminha de Adriana Esteves em Avenida Brasil, foi uma personagem de grande destaque e se configurou como o papel mais lembrado na pesquisa intitulada $A$ Construção de mundos na telenovela brasileira: um estudo de caso a partir das cinco personagens mais lembradas (LOPES et al, 2019). Para o estudo foi realizada uma pesquisa empírica, demandando aos informantes qual foi, na sua opinião, o personagem de telenovela que mais marcou a sua vida. Dentre as respostas, a que teve mais citações foi justamente Carminha, especialmente para a faixa etária entre 18 e 34 anos. Segundo a análise:

A Carminha vista pelo público foi lembrada essencialmente pela construção de personagem e pela atuação da atriz. Sua comicidade irônica, misturada a uma dose significativa de ambição e maldade, deram um tom à personagem que foi memorável aos telespectadores: "Ela era cômica, solar, apesar de todas as maldades". A interpretação da atriz é outro ponto fundamental nessa construção. A personagem está cada vez mais identificada com o ator que a encarna, transformada, portanto, "em uma entidade psicológica e moral, encarregada de produzir ao espectador um efeito de identificação" (AUMONT; MARIE, 2007, p. 226). Outros elementos têm relação com questões femininas/feministas que permitem o aparecimento de mulheres fortes e poderosas, que lutam por algo, são revolucionárias, livre e cheias de ambição, bem como pelo fato de serem vilãs. A vilania aparece como uma característica quase suficiente na definição do motivo pelo qual a personagem é lembrada: "Carminha, uma vilã inesquecível". (LOPES et al, 2019, p. 33 - 34, grifos da autora) 
Cristina Padiglione, na crítica final de Avenida Brasil apresenta suas considerações acerca da atuação de Adriana Esteves, para ela o casamento entre a personagem e a atriz foi uma conjunção que deu certo desde o início da narrativa:

Uma feliz conjunção entre texto, atuação e direção nos brindaram com essa estupenda personagem. E eu já não sabia se chorava por ver o destino da ex-senhora Tufão ou por pensar na longa trajetória de uma super atriz que soube se reinventar e se tornar a gigante que nos brindou por oito meses.

Da coadjuvância de Top Model ao protagonismo de Carmen Lúcia, muitas mocinhas e algumas vilãs passaram por debaixo da pele dela. Foi Sandrinha, a culpada pela explosão do shopping, em Torre de Babel, foi Nazaré na primeira fase de Senhora do Destino, mas foi também heroína em A Indomada e cômica em Toma Lá Dá Cá.

\subsection{REFLEXÕES SOBRE A CRÍTICA}

Este código contempla todos os segmentos referentes a reflexões sobre a crítica de telenovela no contexto brasileiro. Contabilizando 4,8\% dos segmentos codificados, entendemos por reflexões os questionamentos a acerca do ofício da crítica e sua função. Os fragmentos nos dão indícios sobre o fazer da crítica, no entanto não os consideramos como critérios de análise, pois são em sua maioria, a percepção do profissional sobre sua atuação neste meio. Na codificação desta categoria empírica, percebemos que ela surge com uma indagação importante, para que serve a crítica? A questão foi posta aos críticos nas entrevistas, mas pode ser vista também, nas críticas, interpostas nas argumentações.

Padiglione aponta que para ser crítica de ficção, primeiro gostar de novela. Eu acho chato o cara que vai escrever sobre isso para ficar procurando os defeitos. Ao mesmo tempo o crítico não pode ser aquele cara - não que não possa ser aquele cara bonzinho, mas ele está ali justamente para cobrar, trazer a luz. Já Nilson Xavier indica que a crítica seja uma referência para quem consome e para quem faz. Acho que é para isso que serve. E para levantar discussão também. Para Patrícia Kogut, o fazer da crítica é fundamental ser justo, ouvir, se esforçar. Não fazer uma coisa que você não conhece, falar do que você conhece. Tentar entender como aquilo foi feito, fazer com responsabilidade. E ser uma pessoa que lê, que se informa, essas coisas também muito importantes. E Maurício Stycer ressalta que o crítico deve pensar no seu leitor-espectador, acho que dá para gente como crítico, justamente, ajudar o espectador entender por que 
que ele está gostando ou não está gostando de determinada novela. O que que ele está vendo às vezes tem significados não está evidente, não tão óbvios.

Para Durão (2016, p. 14), “o discernimento crítico depende de um emprego adequado, ou seja, desinteressado e descompromissado, da capacidade de análise e reflexão". Ponderar sobre o exercício da crítica é uma atividade autorreflexiva constante, onde o crítico deve estar sempre disposto a rever parâmetros, e analisar de que maneira tem olhado determinada obra. O juízo pessoal, como comenta Durão, deve ser deixado de lado, porém, ele admite que "é difícil estar completamente aberto para aquilo que a obra quer dizer, porque o confronto com ela nunca se dá a partir do nada” (p. 17). Mesmo antes da telenovela ir ao ar, o crítico já dispõe de algum conteúdo que o deixa de antemão, a par do que se trata a ficção. Os releases por parte da emissora já foram enviados, e os convites para entrevistas já foram disponibilizados, portanto, o crítico já estabeleceu os primeiros pressupostos sobre a obra. Este discernimento é testado somente na transmissão dos primeiros capítulos, que logo vão confirmando ou construindo novas hipóteses. Aliado a isso, a percepção do público contribui para a análise, por meio das conversações em rede.

Nos segmentos codificados para este código, percebemos um empenho em examinar o próprio ofício, bem como entender seu lugar nos campos do jornalismo cultural e como parte do universo de sentidos da telenovela. Stycer explica que o sistema que envolve a crítica de televisão no País não se leva a sério, pois a visão do senso comum é que basta assistir muita televisão para se tornar crítico. Sobre eles aspecto, Nilson Xavier aponta para uma polifonia de vozes acarretada pela tecnicidade, onde várias pessoas se consideram ou se autointitulam críticos, apenas pela criação de blogs:

Agora eu concordo com você quando você diz que houve esse boom, mas não por conta das séries em geral, mas porque a internet permite isso. E aí que está também a questão da profissionalização em separar o que é joio do trigo, por que qualquer pessoa pode simplesmente abrir um blog e começar a falar do que ela acha que ela entende. Ou tem uns que são muito bons, que são desconhecidos que realmente são bons e que crescem com o passar do tempo. Que só não são profissionais não estão num grande veículo e que fazem o trabalho sozinho, tem também. E tem os que vivem de achismos, tem os haters, tem vários tipos. Então tem que saber separa o que é crítica de verdade, o que é crítica jornalística, o que é crítica profissional do que é crítica amadora nesse caso.

Cristina Padiglione relata que, apesar do entendimento sobre a crítica de televisão ter melhorado ao longo dos anos, ainda se percebe certa descrença quanto a credibilidade 
da profissão, pois ainda se acredita que fazer crítica de TV é um segmento do colunismo social:

Ah eu acho tão triste a crítica de televisão em geral no Brasil, sabe, acho muito triste. Porque desde que comecei a fazer isso 30 anos atrás, eu tenho que explicar sempre que eu faço crítica de televisão e não fofoca. Quando você fala assim, eu escrevo sobre televisão, as pessoas falam assim: 'tipo a Sônia Abrão? Tipo a revista Contigo?'. Revista Contigo tinha muita coisa de novela, mas depois virou meio Revista Caras.

Neste sentido, Patrícia Kogut expressa que o reconhecimento na sua área de atuação é visto, muitas vezes, pelos comentários dos leitores, quando entendem o argumento e dialogam com a crítica.

A crítica é perfeita quando você escreve um negócio e você recebe um milhão de e-mails, falando assim 'vocês leem meus pensamentos, era isso que eu queria dizer'. A crítica não é um capricho, não é uma cisma, não é um poderzinho, não é para ser nada disso, ela pode ser. Cismar com uma pessoa, implicar com uma pessoa, ela não é para ser nada disso. Coisa de profissional, fria, e dialogar com a televisão.

Nilson Xavier reflete acerca de como a repercussão da telenovela funciona de insumo para a crítica, pois uma ficção que não repercuti de alguma forma, os leitores pouco aludem às críticas. Nesta relação simbiótica, vemos que, períodos de narrativas fracas, no sentido de não levantarem discussões, ou não terem uma audiência satisfatória, também influencia na leitura das críticas. E isso, em muitos casos, não está relacionado a qualidade da trama, mas ao que o espectador identificou que mereça um debate.

Vou te dizer uma coisa que é um parâmetro nosso, a gente gosta de novela que gera repercussão, não importa se é boa ou se é ruim. Novelas que as pessoas queiram ou tenham vontade de ler sobre. Por exemplo $O$ outro lado do paraíso, era um paraíso para gente porque gerava muita pauta, pessoas queriam ler, gerava buzz, gerava buchicho, mesma coisa com A Força do Querer e mesma coisa Avenida Brasil. Então quando a novela faz sucesso nesse sentido é maravilhoso para gente. Pior coisa que acontece é quando a telenovela não repercute. A novela é legal quando ela repercute porque todo mundo quer ler. Uma novela que não repercute ninguém quer ler.

Isto posto, a fala abaixo de Maurício Stycer, determina que a contextualização é um elemento primordial da crítica. E a contextualização aí, é vista pelo lado da produção, 
com os elementos próprios das instituições que confeccionam a telenovela, e o contexto externo, que podemos dizer que é o da recepção, e que envolvem o consumo, a sociabilidade e a ritualidade.

Um eu jáfalei, acho que é a questão do contexto, isso eu acho essencial. Acho que você precisa ser didático, claro. Tem um lado do trabalho do crítico que é difícil explicar, eu chamo que é um pouco a sensibilidade, que é sua relação subjetiva que você tem ali, com o assunto, com a interpretação, que comove a uns e não comove a outros, atinge alguns e não atinge outros. E saber comunicar isso para o leitor também, deixar claro que às vezes determinado assunto, determinada interpretação, determinado ator, está transmitindo algo diferente, mesmo que ele não esteja vendo isso. Mas é uma carga de subjetividade. Aí é um terreno pantanoso.

\subsection{TRABALHO}

O que código denominado de Trabalho compreende a trajetória profissional dos críticos e a maneira com eles foram introduzidos neste ofício. Os segmentos codificados correspondem a 4,4\% dos dois documentos, e são compostos por fragmentos que relatam o caminho profissional, e a alguns aspectos que expõem a maneira como é feito o trabalho.

Cristina Padiglione iniciou no jornalismo impresso na década de 1990 na cobertura de televisão e não parou mais. A jornalista indica que as críticas são uma análise feita após, mesmo que alguns pontos da narrativa já tenham sido mostrados pela emissora.

Primeiro tem as matérias que você faz e tem as críticas. As críticas só podem vir no bojo do que eu vejo, não dá para fazer antes. Às vezes você faz uma entrevista uma matéria e sabe que aquilo vai funcionar. A última matéria minha no Estadão foi o primeiro dia de gravação da novela da Maria Adelaide na Globo, aquela A Lei do Amor. Quando eu vi as gravações era com o Gianechini e a Claúdia Abreu no Ibirapuera, eu falei 'nossa, esse casal não tem liga nenhuma'. Na gravação eu falei. Ai criou-se um preconceito já meu que aquilo não ia dar certo, mas ai eu vi o trailer e falei 'nossa, isso ai não tem nenhum...'; se o trailer - que é uma coisa feita para gerar interesse não conseguia te trazer... Ah gente o trailer é ruim, tomara que a novela seja melhor, e não era. Então algumas coisas você vai muito no preconceito.

Padiglione ainda comenta sua breve experiência na TV Gazeta, onde era convidada como crítica:

Nesse tempo depois em 2017, eu estava na Folha, não eu estava no blog que foi pra Folha, em abril de 2017 eu entrei no programa do Ronnie 
Von para fazer televisão, para falar de TV, e era conteúdo não era fofoca. E dai esse programa acabou há dois meses. Infelizmente. Adorava. Era uma possibilidade de falar da TV na TV, sabe, por que era a Gazeta. Então, todo mundo falava assim: 'ah mas ele vai para outra emissora e você vai junto", primeiro eu não sei se eu vou junto e segundo que não é a mesma coisa, entendeu. Ele está em casa agora, estava estudando propostas sei lá do quê. Mas se for assim Rede TV ou Bandeirantes não dá para ficar falando de novela da Globo, entendeu. Aí você tem que entrar no campo da fofoca e eu não sou muito boa nisso mesmo. Então foi um tempo feliz ali de Gazeta, muito feliz. É isso.

A crítica de Nilson Xavier é focada na teledramaturgia, ou seja, telenovelas, séries e minisséries. A ficção é seu insumo para as análises e advém de sua longa experiência com fã de telenovela. Foi essa perícia adquirida pela coleta de informações e dados sobre as ficções que levou Xavier a escrita das críticas, pois o que antes era um passatempo, virou uma profissão. Eu tinha um blog particular, que era meu, fazia ali resenhas de novelas, análises críticas, e ele perguntou para mim: você não quer fazer isso que você faz no Uol e ganhar por isso? Ai eu falei: é tudo que eu quero! Daí estou no UOL desde então, foi aí que eu comecei.

Entre as demandas de sua profissão está em moderar os comentários que recebe nas postagens. Neste processo, encontra diferentes opiniões e até ofensas. Porém Xavier explica que isso não chateia, e opta por relevar comentários mal intencionados.

Acompanho e inclusive faço a mediação. Apago alguns comentários. Todos os blogueiros do UOL, pelo menos no Uol é assim, quando eles escrevem alguma coisa passa primeiro por uma triagem os comentários. Por exemplo, são bloqueados de cara tudo que tem palavrão, a própria ferramenta do UOL já faz isso. Não permite aparecer palavrão. Assim, eu vou lá leio os comentários e tiro os que eu acho que são ofensivos a minha pessoa, ao meu trabalho, ou que não tem nada a ver. Até deixo alguns, para pessoa passar uma vergonha.

Um dos entraves para quem escreve crítica se mostra a partir do fragmento abaixo, onde o crítico aponta para a reação de algumas pessoas a sua crítica:

Mas assim, existem os dois lados, sou elogiado quando elogio, mas é tipo elogio de mãe. A mãe sempre vai elogiar o filho. Então eu não me iludo muito com isso. É muito fácil você receber um elogio da pessoa 'ah eu gosto de você, você elogiou meu trabalho'. Eu quero ver você fazer o contrário, você reconhecer uma crítica. Ou para discutir. Porque você pode não concordar comigo, mas se você discutir comigo, nós vamos discutir. Ai existe discussão, ai que é legal, interessante; é levantas a discussão. Não, não concordo com você e ponto final isso não é discussão, isso é fascismo. Intolerância à recepção de crítica. 
Então tem todas essas questões que a gente avalia. Eu não me iludo muito com quem elogia meu trabalho, por que é complicado, é muito fácil você concordar com a pessoa, 'ah realmente', mas isso não gera discussão. Vai gerar discussão quando você discorda.

Patrícia Kogut relembra que a escrever sobre televisão era visto como uma área desvalorizada e pouco bem quistas entre os jornalistas deste período. Escrever sobre telenovela, então, quase ninguém aceitava. Ela comenta que, hoje com o boom das séries, houve uma procura mais intensa. E aí, hoje, todo mundo quer, todo mundo quer escrever sobre séries; eu não digo nem novela não. É sobre séries. Você vê repórteres de política querendo fazer crítica de série, é uma coisa que não existia isso no jornal. Então tinha mesmo uma hierarquização disso.

As tarefas de crítico e espectadora comum é confrontada por Kogut. Em sua sala na redação do jornal O Globo, o aparelho televisivo fica ligado a todo tempo, no volume mínimo, com isso ela comenta que constantemente fica até mais tarde na redação para não perder os capítulo de Por Amor, em reprise no Vale a Pena ver de Novo.Para quem acredita que o crítico deve assistir telenovela todo dia Kogut explica:

As novelas da Licia Manzo que eu adoro, aquela Sete Vidas, eu assisti porque eu sou uma telespectadoras, se eu me interesso tem duas maneiras de você assistir: assistir profissionalmente, quer dizer eu não preciso assistir todo dia, não preciso ser uma enciclopédia de novela, eu preciso ver o que eu sei que vai ser uma virada naquela novela, eu não preciso ver novela das nove todo dia. Eu me interesso sobre aquela novela eu escrevo mais sobre aquela novela. Sendo das nove ou não. Agora sempre com a mesma responsabilidade.

A dinâmica de trabalho do crítico ainda inclui saber o que se comenta e quais os profissionais que trabalham com a crítica. Conhecer o campo, segundo Maurício Stycer, é essencial para exercer a atividade. A crítica está prescrita nas regras que configuram a arte (BOURDIEU, 1996), pois funciona como um paratexto (GENETTE, 2009), um texto que está subjugado a outro. Assim, Stycer pontua:

Leio, todas. Sempre que eu acho necessário, que eu acho que contribui, seja para dizer que eu concordo, seja para dizer que eu discordo. Quando eu discordo nem sempre eu cito, por que às vezes pode soar indelicado. Mas eu acho isso fundamental, quando eu falo de contexto, eu estou falando disso também. Me assusta às vezes ver profissionais que estão - em qualquer área, o que inclui também televisão; profissionais dedicados a uma determinada área, que não tem uma noção completa sobre o que os colegas que estão fazendo a mesmas 
coisas estão produzindo. Isso é uma obrigação, sem a qual não é possivel esse trabalho. Eu leio tudo o que é escrito por pessoas que reconheço que contribuem para esse oficio. Acho essencial.

\subsection{PROCESSO DE ANÁLISE}

Num total de 3,8\% dos segmentos codificados, Processo de análise reflete maneira com as críticas foram analisam as ficções e quais parâmetros são escolhidos. Sabemos que este processo é subjetivo e envolve uma série de requisitos que podem ser formados no decorrer da análise, mas que nem sempre são claros, ou podem ser facilmente explanados. Contudo, percebemos que alguns critérios estruturais foram sendo construídos ao longo da carreira desses críticos, e que, por conseguinte, já estão inseridos em seus repertórios de análise.

Quando interpelamos os críticos acerca de seu processo de análise, entendemos que eles estão unidos aos critérios que perpassam a análise de telenovela:

Segundo Nilson Xavier:

Essa pergunta é meio capciosa e subjetiva também. Porque, por exemplo, eu acho que para você escrever com propriedade sobre qualquer assunto, seja televisão, cinema, teatro, música ou literatura; você tem que primeiro ter um ótimo conhecimento sobre o assunto, você tem que ter vivência sobre aquele assunto, ou seja, experiência. E não só sobre o assunto, você tem que ter referências em atividades paralelas, mas relacionadas.

Patrícia Kogut descreve que seu processo de análise está atrelado a sua rotina de trabalho, na redação do jornal. Nesta espacialidade, é que escreve seus textos, e assiste pontualmente os programas televisivos. Outra característica da jornalista reside no fato que ela também faz críticas de séries de canais pagos, no entanto, ela explica que a maior procura em seu site ainda é por telenovela, especialmente após a transmissão de cenas polêmicas e grandes viradas.

É uma boa pergunta. Tem gente que fala assim: 'ah deve ser tão bom ser você, porque seu trabalho é uma moleza, você fica sentada na frente da televisão, você passa o dia vendo televisão'; e isso não é verdade. A televisão fica ligada aqui sem som, você vê está ligada, eu liguei, eu não estou vendo isso. Eu ligo, mas o meu trabalho não é ficar vendo televisão loucamente. O meu trabalho é ver televisão pontualmente. É escolher o que é importante e comentar o que é importante na televisão. Então, não é ficar zapeando e vendo qualquer coisa irrelevante. Não é. $\hat{E}$, às vezes, você enxergar com seu olhar, você procurar uma coisa que 
não está no mainstreaming, não é campeã de audiência, mas é legal e você apontar aquilo para o seu leitor. Então tem uma coisa de você observar a televisão, mas tem uma coisa de você refletir o que é relevante na televisão. Então, se uma novela está dando um monte de audiência, você pode ignorar aquilo, falar 'ah ...' como um capricho. Eu acho que você tem que ser profissional, refletir a importância que aquilo está tendo para o seu leitor. Então, eu não vejo só o que gosto. Eu vejo o que as pessoas estão vendo e comento o que as pessoas estão vendo. Ai quais são os critérios, o quê que mede isso? Têm as redes sociais que você pode olhar, medir uma temperatura, a audiência, tem o quê que as pessoas estão falando. Tem o meu gosto, tem coisas que eu não gosto. Mas eu não desprezo, não deixo de comentar porque eu não gosto.

Cristina Padiglione é enfática quando aponta para o texto como um de seus procedimentos de análise principais:

A gente cresceu fazendo muita novela e as minisséries e os seriados eram todos com linguagem de novelas, chegou um momento em que eu mais era conhecedora de novela que de séries internacionais, comecei a ouvir as pessoas reclamarem disso, quem assistia muita série lá fora. Olha as séries feitas no Brasil, são todas uma versão de novela, elas não têm um texto de série. E comecei a me dedicar, tentar entender o que é um texto de série. E quando você começa a ver as coisas de fora você vê uma diferença, e onde está essa diferença, no diálogo. Basicamente no diálogo, que a gente chama atenção, que a gente descambou aqui.

Maurício Stycer descreve como foi seu processo de análise a partir de uma telenovela das $18 \mathrm{~h}$ :

Órfãos da Terra eu demorei 20 capítulos. Os primeiros três capitulos da novela eu falei: 'isso aqui e maravilhoso, não é possivel que a novela vá continuar assim, como é que vai ser. Mas no início eu achei tão bom que eu fiquei com pé atrás, não é possível que uma novela fique tão boa. Eu demorei mais até. Dai eu vi, foi virando uma novela normal, perdeu aquele apuro técnico do início, normal, efeitos especiais e tal. Mas continua muito boa. É tão claro que a Globo tem um cuidado especial com a embalagem do primeiro capitulo, isso é tão evidente, que eu acho que primeiro capitulo é quase uma publicidade estendida de 50 minutos. Um grande comercial, 'olha venha ver essa novela que ela é incrivel'.

\subsection{DIREÇÃO}

A direção foi código que contabilizou 3\% dos segmentos analisados pelo Maxqda. Neste processo de análise, percebemos que os críticos aludem a direção da telenovela para expressar contentamento com o que está sendo realizado até aquele momento. 
Entendemos que a telenovela é uma obra que pouco alude ao papel do diretor, apenas em casos pontuais. Maurício Stycer, na crítica Novela de diretor frisa que "diferentemente do cinema, onde os diretores reinam, no mundo da teledramaturgia quem sempre deu as cartas forma os autores" (STYCER, 2016, p. 155). O jornalista acrescenta que para o público brasileiro a telenovela é conhecida pela autoria, até porque é comumente apresenta como a novela de fulano ou sicrano nas chamadas. Nesta mesma crítica, o jornalista analisa o trabalho do diretor Luiz Fernando Carvalho, responsável pela direção de Velho Chico (Globo, 2016) e Meu Pedacinho de Chão (Globo, 2014), ambas de Benedito Rui Barbosa. Em sua crítica, Stycer (2016, p. 155) salienta:

O diretor teve outros méritos. Extraiu desempenhos incríveis de atores que estavam com suas imagens atreladas a determinados tipos e pareciam incapazes de mudar. Revelou potencial de atores menos conhecidos. Ousou na forma de narra e apresentar a história. Brincou com vários gêneros da TV e do cinema.

Stycer acredita que o trabalho de Luiz Fernando delimita novas fronteiras, pois foge da repetição e dos padrões usuais da telenovela. Para o crítico, telenovelas que mostram um empenho em fugir do tradicional e ir em busca de características novas são válidas e demandam coragem para não repetiram as fórmulas usuais.

Mas só o que gostaria de sublinhar em relação a essa coisa de melhores é que eu nesse últimos dez anos, por exemplo, que eu estou olhando profissionalmente para a TV, acho que não é novo é anterior a isso, é o trabalho do Luís Fernando Carvalho como diretor, sempre foi uma coisa que me chamou muito a atenção. Meu Pedacinho de Chão, Velho Chico, Dois Irmãos, uma vontade de explorar novas fronteiras na teledramaturgia. E eu procurei, acompanhando os trabalhos dele, realçar isso também. Porque a Tv por ser muito industrial tende a repetição mesmo. Acho importante sublinhar quando existe um esforço de fugir da repetição.

Em nossa codificação, Direção, aparecia geralmente nas críticas de estreia e/ou nas de balanço. Nesses primeiros apontamentos, ao diretor eram atribuídos a estética cinematográfica, a iluminação e até trilhas sonoras. As análises de balanço geral, ressaltavam a maneira como contribuiu para a interpretação dos atores. A imagem e o texto são a conjunção básica das telenovelas, desta maneira, constantemente são fatores de análise, como coloca Patrícia Kogut sobre O Outro Lado do Paraíso: nem o brilho de Gloria ou o esforço da direção (artística, Mauro Mendonça Filho, geral, André Felipe Binder) salvam essa trama do naufrágio vergonhoso. É um mar de absurdos. Sobre a 
ficção de Glória Perez, Salve Jorge, a crítica aponta: $O$ diretor de núcleo, Marcos Schechtman, acertou em cheio nas cenas de rua em Istambul. Mesmo com a alta qualidade das cidades cenográficas da Globo, as externas proporcionam um frescor difícil de ser superado. O mesmo valeu para o Alemão.

Segundo Daniel Filho (2003) o diretor é aquele que encontra a maneira de contar aquela história, pois não cabe aos roteiristas dar indícios de como encenar a narrativa. $\mathrm{O}$ papel da direção, no caso da telenovela, é interpretar o texto do autor, que pode vir ou não com descrição dos cenários. O ritmo ou a maneira como aquilo será interpretado cabe à coordenação deste diretor e sua equipe técnica. $\mathrm{O}$ estilo do texto pode ser alterado quando a direção achar condizente, visto que o diretor tem a função de "determinar como a cena deve ser feita" (FILHO, 2003, p. 189).

Acerca da primeira fase de O Outro Lado do Paraíso, Nilson Xavier, declara: A direção (equipe de Mauro Mendonça Filho) apresentou um ótimo trabalho na primeira fase da novela, valorizando a produção através da iluminação, arte e trilha sonora, com tomadas sofisticadas, destacando os cenários naturais do Tocantins. Enumerando o aspecto estético como argumento para se falar da Direção. E em outros como um recurso de melhoramento do texto: Mesmo assim, em momentos pontuais, a direção teve resoluções bem administradas para o texto: a fuga de Clara do manicômio, seu retorno triunfal, o julgamento do pedófilo e o casamento de Mercedes e Josafá foram alguns dos melhores momentos da novela. Em outro momento, também sobre a mesma novela, Xavier declara que: Por outro lado, direção e elenco acabaramalgumas vezes contaminados pelo simplismo.

Nilson ainda aponta que $O$ diretor é sempre um upgrade para o currículo de qualquer novelista. No caso de A Força do Querer, o crítico a mudança de direção na telenovela, acentuando como a alteração foi benéfica para a narrativa:

Sai Marcos Schechtmann, que dirigiu as quatro novelas anteriores da autora, entra Rogério Gomes em "A Força do Querer". Schechtmann deveria trabalhar com praticamente a mesma equipe, o que deixava as novelas muito parecidas. Rogério traz uma proposta estética diferente, dá um novo tom, um novo estilo, outros ares à obra de Glória. Não querendo desmerecer o trabalho de Schechtmann, mas a mudança de diretor foi um importante upgrade para a autora. Sabemos que a maioria dos novelistas têm o seu diretor preferido, mas promover mudança de ares é muito importante, para todos. 
Cristina Padiglione exemplifica o desempenho da direção por meio da cena emblemática de Amor à Vida, em que o personagem Félix revela a sua irmã Paloma que jogou sua filha no lixão. Ao ser desmascarado diante de toda a família, Félix nos mostrou um ator irrepreensível e despertou em Paolla Oliveira a melhor performance de sua vida até aqui, sob uma precisa direção de Mauro Mendonça Filho. O diretor em questão, já trabalhou em diferentes tramas de Walcyr Carrasco, um autor altamente criticado por seu texto.

Outro destaque dado pela jornalista, foi à diretora Amora Mautner por seu trabalho com João Emanuel Carneiro em Avenida Brasil, na qual ela exalta: Salve dona Amora Mautner, diretora responsável por alcançar um resultado artesanal em um trabalho que demanda ritmo industrial.

Nos primeiros apontamentos sobre $O$ outro Lado do Paraíso, a jornalista pontuou:

Dito isso, é preciso avaliar que a estreia de "O Outro Lado do Paraíso", novela de Walcyr Carrasco, com direção artística de Mauro Mendonça Filho, encantou muito pelas imagens, pelo jogo de câmeras (um rodopio incessante sobre as profecias de Mercedes/Fernanda Montenegro beirou a provocação de uma labirintite no espectador, porém impressionou), trilha sonora, luz, atuação do elenco, mas não pelo texto, não pela história, ainda mal apresentada.

O trabalho de direção admite uma temporalidade e espacialidade própria, que de acordo com os subsídios oferecidos pelo roteiro, criam as imagens que vemos transmitidas. Filho (2003) lembra que os primeiros dias de gravação é sempre um momento de certo nervosismo, pois ainda não se sabe se o que foi combinado irá funcionar. Também menciona que uma equipe demora aproximadamente dez dias para afinar o ritmo, pois ele associa a produção de uma telenovela a uma orquestra, onde todos devem estar alinhados no mesmo propósito para o projeto seguir.

\section{12 CRITÉRIOS DE ANÁLISE}

Os critérios de análise correspondem aos trechos que representam os princípios que pautam o juízo de valor dotado pelo crítico. Esta categoria contabilizou 2,9\% dos segmentos codificados. Cada crítico utiliza critérios particulares que são empregados nas avaliações. Assim, os trechos destacados, revelam de alguma maneira, os fundamentos 
abarcados pelos profissionais na confecção de seus textos, bem como os elementos usuais que eles buscam enumerar.

Benjamin (2018) no texto A Tarefa do crítico, de 1931 discorre que "o grande crítico será aquele que, através de sua crítica, dá aos outros a possiblidade de formar uma opinião sobre a obra, em vez de ser ele a dá-la" (119 - 120). Assim, o crítico, na visão do teórico, deve situar esse leitor e estar sempre preocupado em contextualizar.

Para Stycer um critério relevante é a tentativa de inovar, como ele menciona:

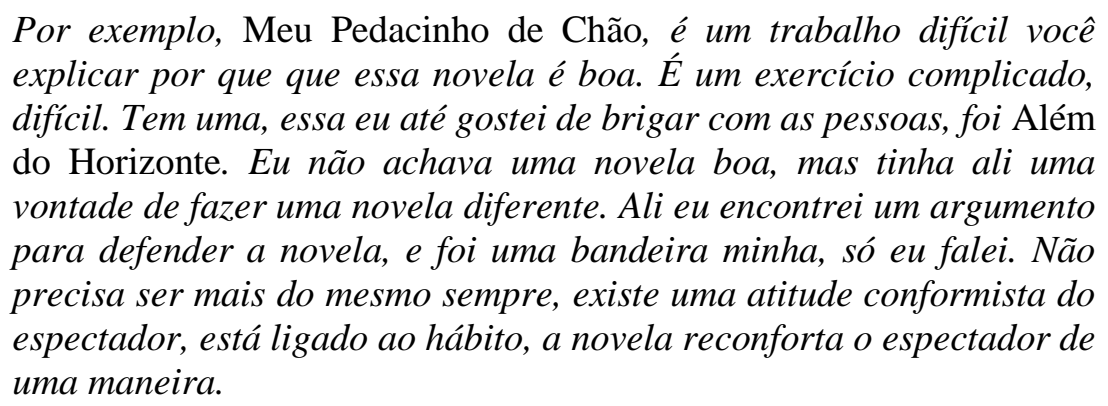

Neste fragmento, o crítico aponta uma particularidade que ele busca em cada narrativa que analisa, que é a inovação do próprio formato da telenovela, especialmente em faixas horárias que prezam por um tipo específico de gênero. Nos dois exemplos apontados no trecho acima - o das $18 \mathrm{~h}$ e das $19 \mathrm{~h}$ da Globo - temos um modelo consolidado de folhetim, o primeiro voltado para o romance, e o segundo para a comédia. Todavia, a experimentação ocorre em momentos pontuais e, podem nem sempre agradar ao público, como o caso de Meu Pedacinho de Chão, com o realismo fantástico e Além do Horizonte, uma trama de aventura e mistério.

Nilson Xavier não determina um critério específico, pois para cada telenovela há um olhar singular. Entretanto, o crítico ressalta para as características que uma crítica deve considerar: "Então, é a vivência, a experiência, e um background intelectual mesmo, a questão das referências que eu falei. Ter referências não só sobre aquilo que você quer escrever". O conhecimento acerca das particularidades de cada emissora e as forças políticas e ideológicas que permeiam as produções também são levadas em conta, como ele afirma:

Por exemplo, eu publiquei hoje sobre a volta de Por Amor, o anterior foi sobre Jezabel, estreia da TV Record, uma produção muito boa, a gente vê que houve uma avanço da TV Record na produção de novelas biblicas, mas ela carrega um ranço de doutrinação religiosa, que nós 
sabemos que existe, por que a Cristiane Cardoso que é a filha do Edir Macêdo ela que faz a supervisão. A Vivian de Oliveira brigou com a Record por causa dela, pediu demissão. A gente sabe que existe isso. E a gente vendo e sabendo disso, a gente consegue então traçar esse tipo de paralelo, a gente consegue analisar de uma forma melhor do que um simples telespectador da Record, às vezes que é da Igreja ou não é da Igreja e que aceita tudo de forma passivamente e que gosta.

Cristina Padiglione, enumera seus critérios:

Primeiro gostar de novela. Eu acho chato o cara que vai escrever sobre isso para ficar procurando os defeitos. Ao mesmo tempo o crítico não pode ser aquele cara - não que não possa ser aquele cara bonzinho, mas ele está ali justamente para cobrar, trazer a luz. Ou esses efeitos que o texto produz são as falhas, o quê que tem de errado ali, o quê que tem de nocivo ali, tem coisas que são nocivas, essa é a palavra. Podem trazer uma má influência para o espectador.

Já Patrícia Kogut chama atenção para a obrigatoriedade do núcleo cômico nas telenovelas das 21h. A fórmula, segundo a jornalista, é usada de maneira demasiada e muitas vezes é um núcleo que pouco interfere na história principal. Abaixo, Kogut relata sobre as tramas de Walcyr Carrasco, autor de Amor à Vida:

Tem o negócio do núcleo cômico obrigatório, você leu minhas críticas, você viu, aquilo é pesquisa. Aquilo falam assim 'ah o público quer...'. É uma fórmula, eu não gosto da fórmula. Eu acho que tem dois lados isso o que ele faz, ele é um cara que fala diretamente para o público ninguém pode negar isso, tem muita audiência. Quer dizer, as pessoas estão vendo o que ele faz. Mesmo esse que reclamam, estão gostando porque estão assistindo, estão prestigiando. Mas ele fala muito diretamente, fala para todo mundo, é muita reiteração, é muito diálogo pobre, isso eu falo nas minhas críticas. Eu acho que empobrece o resultado.

Identificamos neste código que o primeiro capítulo é um ponto remarcado pelos informantes e determinante para a crítica. Eles relatam que nos veículos de comunicação nos quais trabalham exigem que se faça uma análise do primeiro capítulo, no entanto eles ressaltam que essa avaliação ocorre com muita cautela, tendo vista que o primeiro capítulo, na maioria dos casos, é uma vitrine, portanto uma parte bem tratada esteticamente. De acordo com ele, há um tratamento diferenciado na estreia de uma telenovela. Nilson Xavier aponta 
Então eu sempre escrevo, mas escrevo muito cheio de dedos, porque eu não tenho informação nenhuma, geralmente a emissora faz uma estreia que é para encantar as pessoas. Agora o que vai ser de fato a novela, precisa de duas semanas pelo menos para você gabaritar. Para você dizer: a novela é isso ou a novela é aquilo. Senão, não. As minhas críticas de estreias geralmente são muito superficiais, mas também as minhas críticas de final são um balanço completo da novela. Então eu mudo muitas vezes, a novela como sendo uma obra aberta, a crítica também está aberta rever sempre... Não é como uma crítica de um livro pronto, uma peça pronta, de um disco pronto. É diferente, os produtos estão prontos, a telenovela não. Ela vai se moldando com o tempo. Eu gosto de mudar de crítica, muda minha opinião. Eu gosto quando começa ruim e me surpreende. Agora triste quando começa boa e decai, como no caso do Tempo não Para, começou tão boa, eu gostava tanto e virou um nada praticamente. É uma pena.

Os critérios de análise são pontos subjetivos adotados por cada crítico, entretanto estão atrelados intimamente às lógicas de produção, aos formatos industriais e as matrizes culturais. Isto posto, faz parte da indústria que produz a telenovela e à empresa jornalística onde atuam. Este jornal ou portal de notícias precisa noticiar o lançamento desta produção, por isso não pode prescindir de uma crítica de estreia, com as percepções do primeiro capítulo. Neste ponto, as lógicas de produção preveem uma rotina produtiva que dá conta das demandas do público. E, sendo a telenovela uma matriz cultural de formato industrial, é pertinente que a cobertura jornalística se faça presente.

Cristina Padiglione comenta sobre seus critérios para escrever uma análise do primeiro capítulo:

Primeiro capítulo não é hora de malabarismos, eu tenho que apresentar x personagens, quem odeia quem, quem está a fim de quem, quem é pai é mãe, uma arvorezinha genealógica. Mas de uma maneira orgânica, não aquela coisa jogral. É isso que a gente leva em conta. Qual é o fôlego de sedução daquele primeiro capítulo para quem vai ver depois. É uma história que conseguiu me puxar para o segundo capítulo, para uma novela isso é essencial. É isso que está em jogo ali, ela vai me chamar para o segundo capítulo ou não? Eu tive vontade de ver o segundo capítulo? É meio isso.

Neste código foram apontados os trechos que condiziam com os critérios de análise. Sob o ponto de vista da literatura, Rallo (2005) explica que para se compreender a crítica de determinado autor, "parece importante depreender os princípios nos quais ele se apoia e a base de dados de sua análise, para depois explicitar sua lógica e sua argumentação, a fim de julgar a validade da conclusão à qual chega esse comentário" (p. 
XIX). Por conseguinte, tem em conta que o texto televisivo é heterogêneo e de admite certa complexidade e longevidade, admitindo um número reduzido de abordagens, que são colocadas em prática pelo olhar do crítico.

O que também notamos pelos segmentos, é que a crítica não admite um modelo de análise estanque. O que podemos inferir da análise dos quatro críticos é que eles abordam o texto da telenovela sempre em relação ao seu contexto, numa conversa constante com os aspectos externos à obra, pois a ficção por ela mesma é incompleta. Isso se dá especificamente por a telenovela ser um texto dialógico e simbiótico da sociedade em que está sendo feita.

\subsection{ESTÉTICA}

A estética da telenovela é muito pautada pelo olhar do diretor e a equipe de arte, por este fato, nas críticas este código é muitas vezes mencionado juntamente a direção. No dizer de Aumont e Marie (2003, p. 108), estética foi "inventada (por volta de 1750) para designar uma 'ciência dos sentimentos', a palavra é empregada hoje, igualmente no plural para se referir às diversas concepções do belo e da arte".

Por estética também estamos nos referindo ao padrão globo de produção, que se configura por um emaranhado de regras, algumas explícitas, outras não, que orientam as produções dentro da emissora. No decorrer dos anos esse padrão foi se consolidando e continua fundamentando a noção estética de telenovela entendida hoje. Os recursos técnicos disponibilizados pela Globo para suas ficções somente remarcam a qualidade embutida no formato industrial. Na observação dos segmentos, vimos a comparação das telenovelas com o cinema, parâmetro visual e estético abarcado nas análises. Os primeiros capítulos, como foi enumerado, são as partes que mais apresentam apuro estético, uma vez que sua finalidade é convidar o espectador à estória.

Vale ressaltar que nos últimos cinco anos foi percebido a tendência de ficções ambientadas fora do eixo Rio de Janeiro - São Paulo, cidades que já são conhecidas do grande público, pois são usualmente o cenário das narrativas. Outros centros urbanos do País foram o pano de fundo dos folhetins, sendo que dentre as telenovelas selecionadas nesta pesquisa, duas atendem a esta características, a saber: O Outro Lado do Paraíso, que teve Palmas, no Estado do Tocantins como contexto central; e A Força do Querer, 
que se dividiu entre duas localidades, a fictícia Parazinho, no Estado do Pará, e no Rio de Janeiro.

As externas, gravações feitas fora do estúdio, registram os elementos estéticos mencionados nas análises. Em Amor à Vida, fomos apresentados logo nos primeiros capítulos, há gravações no Peru: A bela fotografia valorizou as paisagens de Macchu Picchu e do centro de São Paulo, muito bem representado na novela, indica Nilson Xavier. Sobre outra novela do mesmo autor, o crítico discorre:

E de fato é cinematográfica: fotografia deslumbrante, com belas imagens do Jalapão, no Tocantins. Um tom amarelo-terra, com clara referência ao western americano, inclusive na direção e na trilha sonora. Mas não se engane. Trata-se de um melodrama em forma de novela. E dos mais rasgados.

Em Salve Jorge, parte de seu cenário era dividida entre o Rio de Janeiro e a Turquia, o que para Glória Perez se constitui como um recurso habitual em suas tramas. Logo, Xavier afere que depois de dois capítulos já é merecedor de elogios o fato da novela não ter dado ênfase maior à cultura turca, e sim à trama central no Brasil - com belas tomadas do Morro do Alemão, no Rio (inclusive as imagens jornalísticas inseridas na trama). E acrescenta que a estética turca não parou nas imagens, mas em como a novela vai pintando a Turquia gradativamente, com as dancinhas coreografadas, bordões, cenários, figurinos, cultura e hábitos exóticos.

Maurício Stycer, por sua vez, verificou que ao longo dos meses Salve Jorge, foi apresentada uma série de problemas técnicos e estruturais da narrativa, e por isso padeceu de sérios problemas de produção e acabamento, inimagináveis em novelas deste horário. As novelas das 21 horas são as produções mais caras da emissora, por conta deste investimento, espera-se que ela apresente certo cuidado tanto no texto quanto nas partes estéticas, como frisou o crítico. Além disso, as ficções desse horário são normalmente exportadas, vendidas por números de capítulos.

Avenida Brasil foi uma telenovela prestigiada pela crítica e público. Mesmo assim, alguns pontos podem ser questionados ao longo da exibição. Do lado estético, Stycer aponta para os cenários dicotômicos representados na ficção. Separados entre os núcleos da zona sul e do periférico bairro do Divino, Stycer explica que o autor de Avenida Brasil teve problemas em apresentar esteticamente, os dois contextos. 
O núcleo da zona sul, aliás, merece um tratamento especial em "Avenida Brasil". Enquanto o registro no Divino busca uma aparência realista, quando a câmera atravessa a cidade, a novela ganha tons de "Zorra Total". O mundo de Cadinho \& Cia é tão caricato que não há como ofender as classes A e B que assistem à novela.

Para Patrícia Kogut, o estético foi mostrado em Avenida Brasil pela especificidade da imagem semelhante ao cinema. Tanto o enquadramento mantendo o balanço do mar, quanto a interpretação da Adriana (Esteves) são únicas, de um tônus cinematográfico nunca visto na TV. Cristina Padiglione discorre que Avenida tem todos os predicados de uma boa telenovela, mas peca na escolha da trilha sonora, que em seu entender, prejudica o valor estético:

Novelão. É o que Avenida Brasil promete ser. Biscoito fino servido à massa, com exceção da abertura, a pior de todos os tempos já feitas pela Globo. Na tentativa de promover hit chiclete, gênero que gruda no ouvido, a emissora tropeça feio, do som às imagens, em edição mediocre. Pena.

Os segmentos que compunham este código somaram apenas 2,3\%, dos documentos analisados, demonstrando a atenção moderada dada a elementos estéticos, com considerações apenas pontuais. A solução para entender este aspecto abarcado nas críticas é fazer uma leitura das ficções juntamente com o código da direção. Em razão de que a equipe de direção é a responsável pelos princípios estéticos da narrativa.

\section{14 RELAÇÃO COM A TELENOVELA}

Para os informantes seu relacionamento com a telenovela teve início como a da maioria dos brasileiros: na infância. A assistência compartilhada, como mencionamos, é um traço significativo e constitutivo desta literacia audiovisual. Este código contou com $1,2 \%$ dos segmentos codificados.

Padiglione relata sobre a preferência em sua casa: Em casa tinha um hábito muito forte de Globo, não se assistia SBT, minha mãe detestava Silvio Santos, ela dizia 'não suporto a voz desse homem', agora com troféu imprensa todo ano ela vai ficar babando, achar o máximo.

Xavier destaca que a relação afetiva pautou sua experiência com a telenovela: 
Afetiva, porque vêm desde criança. Desde criança eu sempre gostei muito de televisão, eu cresci na frente da televisão. E desde criança eu anotava de forma sistemática tudo o que eu assistia, desenhos, novelas, séries da minha infância. Então esse foi um hábito que eu nunca larguei, mesmo depois da vida adulta, depois de ter entrado na carreira de informática eu nunca abandonei isso. No ano de 2000 lancei meu site Teledramaturgia e foi como tudo começou.

Patrícia Kogut relembra: Acho que a minha relação com a telenovela é a de todos os brasileiros. Sei lá, eu me lembro de telenovela na minha infância. A telenovela é assim, é um pouco que nem aquelas músicas na vida de todo mundo, sei lá...

Maurício Stycer recorda dos momentos passados em frente à tela na infância:

Tenho essa relação afetiva de infância com a TV, realmente é uma coisa muito presente na minha vida nos anos 1960 e 1970. Via tudo, quando criança programas infantis, Capitão Asa que era Xuxa da época, eu era fã. As séries infanto juvenis, todas que passavam na minha época. Eu sou da época de Nacional kids, Bat masterson, Família Waltons, todas essas séries americanas que as TVs compravam e muitas outras. A Tv mais ou menos a partir - eu sou de 1961 - minha memória lembra de coisas de 1967 e 1968.

Final dos anos de 1960 comecei a ver novela também. Minha mãe não deixava inicialmente eu ver novela das oito, era tarde, eu lembro de brigar com ele porque queria ver novela. Depois passei a ver e continuei como telespectador normal, não como telespectador obsessivo, nunca fui um telespectador obsessivo de tv, tenho uma lembrança boa era uma coisa que eu gostava, mas não era uma coisa prioritária na minha escala de atividades.

O relacionamento com a televisão remarcado pelos críticos teve seu advento, na infância, marcado pela sociabilidade familiar. Nesta espacialidade, são construídos os primeiros entendimentos sobre o que se fala de TV e como isso se espraia nas demais relações com o indivíduo. Segundo Jésus-Martín Barbero, a mediação das ritualidades "nos remete ao nexo simbólico que sustenta toda a comunicação: à sua ancoragem na memória, aos seus ritmos e formas, seus cenários de interação e repetição" (2018, p. 18); Tais rituais constituídos no cotidiano são impulsionados pelas relações com os formatos industriais, isto é, a telenovela ou demais programas televisivos, e implicam em maneiras distintas do "olhar, do escutar e do ler" (MARTÍN-BARBERO, 2018, p. 18). Essas sensorialidades remetem a memórias afetivas de um tempo passado, são lembranças que 
voltam a mente, e são amparadas pela temporalidade da grade de programação, e consequentemente a uma ficção que era destaque neste tempo lembrado. O que queremos dizer é que pelas ritualidades do cotidiano, as telenovelas se constituem na memória afetiva, em particular, pelo olhar e pelas discussões que decorrem dela.

\subsection{UTILIZAÇÃO DE REDES SOCIAIS}

Este código obteve o menor número de segmentos selecionados, contabilizando $1 \%$ dos segmentos codificados. A presença digital dos críticos em redes sociais digitais se mostra pela interação com seu público e com o público das telenovelas. Por mais que suas páginas estejam prescritas em seus sites e blogs, é comum a presença e intercâmbio frequente destes profissionais. Maurício Stycer e Nilson Xavier ressaltam sua predileção pelo Twitter, enquanto Patrícia Kogut, pelo Instagram e Cristina Padiglione, pelo Facebook. Levando em consideração as particularidades de cada rede, vemos que a conversa nas redes com os leitores acontece em diferentes níveis, dependendo da maneira como é efetuada.

O Twitter, em sua forma de publicação com número de caracteres reduzidos, tem se mostrado um instrumento de estudo no campo da recepção de telenovela como aponta nos trabalhos de Depexe (2015), Pieniz (2015), Greco (2016), Drumond (2014), Fechine (2017). Durante a exibição das telenovelas é comum ao usuário engajado a utilização das hashtags nomeadas pelo nome da ficção ou por algum personagem, como foi o caso da reprise de Vale Tudo (Globo, 2018), no canal por assinatura Viva, que teve como principal indexação a hashtag \#mordomoeugenio (LOPES et al, 2019).

Souto (2019) aborda a repercussão da crítica de telenovela no Twitter, ela identificou que alguns dos atores analisados tem por hábito a utilização do Twitter ao mesmo tempo da exibição da telenovela, comentando acerca do que está em transmissão. Para esse tipo de postagem a autora denominou de "tweet opinativo", tendo em vista que ele está interagindo e avaliando o capítulo em exibição. Ao contrário de postagens onde o intuito é a divulgação das críticas, o "tweet opinativo" proporciona a proximidade com seus leitores e outros espectadores, que se veem com uma oportunidade de dialogar com o crítico, até mesmo o alertando para possíveis pautas, como enumera Nilson Xavier:

Meu caderninho é o Twitter. Às vezes eu faço uma enquete, 'o que você está achando disso', as pessoas me dão ideias. Às vezes eu jogo um 
verde, para ver se aquilo gera buchicho. O Stycer faz isso também. Quem usa bastante o Twitter faz isso. Eu comecei no meu trabalho nisso, porque eu já tuitava antes de escrever crítica, então eu já estava nesse universo antes de começar a escrever.

Super funciona a dinâmica de Twitter, para mim funciona. Acho que Patrícia Kogut vai dizer que não, mas o Maurício vai dizer que sim também, certeza. Maurício também vai dizer que sim, mesmo porque a gente pega muita pauta do que nasce no Twitter, tanto eu quanto ele.

\section{Com este mesmo intuito Maurício Stycer explica:}

Então eu acho importante saber sempre o quê que as novelas estão falando e como as pessoas estão reagindo a ela. E com a internet isso se tornou mais fácil. As redes sociais repercutem mais as novelas, então se um assunto é tratado em determinado capítulo se ele chama atenção para bem ou para o mal rapidamente reverbera, se transforma numa discussão e vira uma pauta.

Ao contrário dos outros de Stycer e Xavier, Kogut elucida sua preferência pelo Instagram, rede social voltada para a publicação de fotos e vídeos:

Vou ser super franca com você, eu acho o Twitter meio chato, mas é gosto. Assim, de todas as redes, eu tento; eu tenho muitos seguidores no Twitter, as coisas que eu escrevo no meu site, elas entram no Twitter automaticamente. Eu uso o Twitter para medir temperatura e tal. Mas eu adoro o Instagram, eu adoro. A gente tem o perfil do Facebook da coluna, e tudo isso eu olho muito. O Instagram da coluna eu faço, ele é muito ativo, todo manual, ao contrário do Twitter que é misto. As coisas que entram no meu blog, que hoje em dia a gente chama de site porque ele foi redesenhado, elas entram no Twitter. E eu entro ali para comentar também, mas o Instagram é todo feito à mão. Uma rede que eu uso muito. Eu vejo os comentários de leitores, a gente vê, a gente presta atenção. Às vezes a gente precisa de uma nota 0 , falo assim 'vê o quê que os leitores estão dizendo?', ai eu olho o que que os leitores estão dizendo; tem uma dica ali. Aí eu vou e procuro no Youtube para assistir. Então eu uso sim, eu sou superatenta. 'Vamos fazer, vamos entrevistar essa atriz, as pessoas estão interessadas nela'...Faço muito, direto.

O fato de a jornalista ressaltar que as postagens no Instagram são "todas feita à mão" ressalta para o caráter autoral das publicações, que consequentemente como relatado pelos demais críticos, levam sempre a uma pauta. $\mathrm{O}$ uso das redes e a criação de pautas foi a consideração mais importante deste código, e que nos chama à atenção para 
uma característica cada vez mais central no trabalho desses profissionais. Se pensarmos na atividade do crítico nas distintas formas de artes e até em tempos pré-internet, vemos que cabia a ele a confecção de seu argumento e avaliação, a opinião do público era sempre à posteriori à leitura efetiva da crítica. A TV Social (FECHINE, 2017), que se configura pelas conversações em rede quando telenovela e/ou programa televisivo está em transmissão, e conforme mencionamos nos capítulos anteriores, a esse comportamento é mais frequente e pode ser quantificado pela número de impressões que um programa alcançou nas redes no momento da exibição.

Sob o ponto de vista da Globo, Cristina Padiglione explica a dinâmica de divulgação das novelas, e como as redes sociais se tornaram uma fonte de informações relevantes:

Então, eles não querem estar mal na televisão lida, que aquilo pode chamar alguma coisa. Além disso, essa coisa de rede social também, tornou qualquer palavrinha que é dita sobre um programa uma coisa que pode viralizar, que se retuita dez mil vezes, entendeu. Então, tem um alcance hoje muito maior que antes, eu acho. Tanto que eles estão fazendo uma divisão, tem uma turma que vai pras coletivas que é chamado pelas assessoria de imprensa e tem uma turma que é chamada por mídia social, mas o Nilson [Xavier] estava na turma das mídias sociais e ele ficava num hotel melhor que o nosso. Porque eles têm uma preocupação de como aquilo vai ecoar, entendeu.

Em seu blog, Maurício Stycer possui um quadro chamado de "Detetive Vê TV", que visa mostrar os erros de continuação nas telenovelas. Para este quadro, o crítico se pauta na contribuição do leitor para realizá-lo, que ao longo de seus anos no ofício foi recebendo dicas e sugestões dos leitores. O processo colaborativo foi intensificado nas redes sociais, espaço de constante debate e acerca da TV.

O Detetive Vê TV surgiu de sugestões de leitores, eu criei o termo, mas ofato de eu ser muito ativo no Twitter, discuti e dialogar com as pessoas que se comunicam comigo, isso criou uma relação. Então as pessoas se sentiram a vontade pra começar a me sugerir coisas, 'ah por que você não escrever sobre não sei o quê?', 'Por que você não faz não sei o quê?', até que começaram: 'você viu não sei o quê?', apontando erros. De fato, o blog é uma experiência de processo colaborativo real, desde o início foi e ainda é. E eu sempre cito quem colaborou as pessoas amam. Pergunto antes por que as vezes a pessoa é anônimo não quer falar. Quando posso citar e eu cito as pessoas ficam radiantes. 
Por meio de sua pesquisa empírica, Almeida (2018), identifica sete habilidades cognitivas na TV Social, entre elas as competências: Tecnológica, Afetiva, Multitarefa e Intelectual. No dizer da autora, o panorama social e televisual "sinaliza a necessidade do desenvolvimento de novas competências e habilidades pelos telespectadores para dar conta de um modelo de espectatorialidade televisiva complexo, dinâmico e multissensorial”. Na utilização das redes sociais aliada à assistência da telenovela podemos entender que os críticos que realizam as duas tarefas são versados nos códigos televisuais e nas competências que o permitem ver TV e usar as redes concomitantemente. Desta forma, pelo quadro abaixo temos uma ideia geral das habilidades:

\section{Figura 18}

Habilidades cognitivas na TV Social

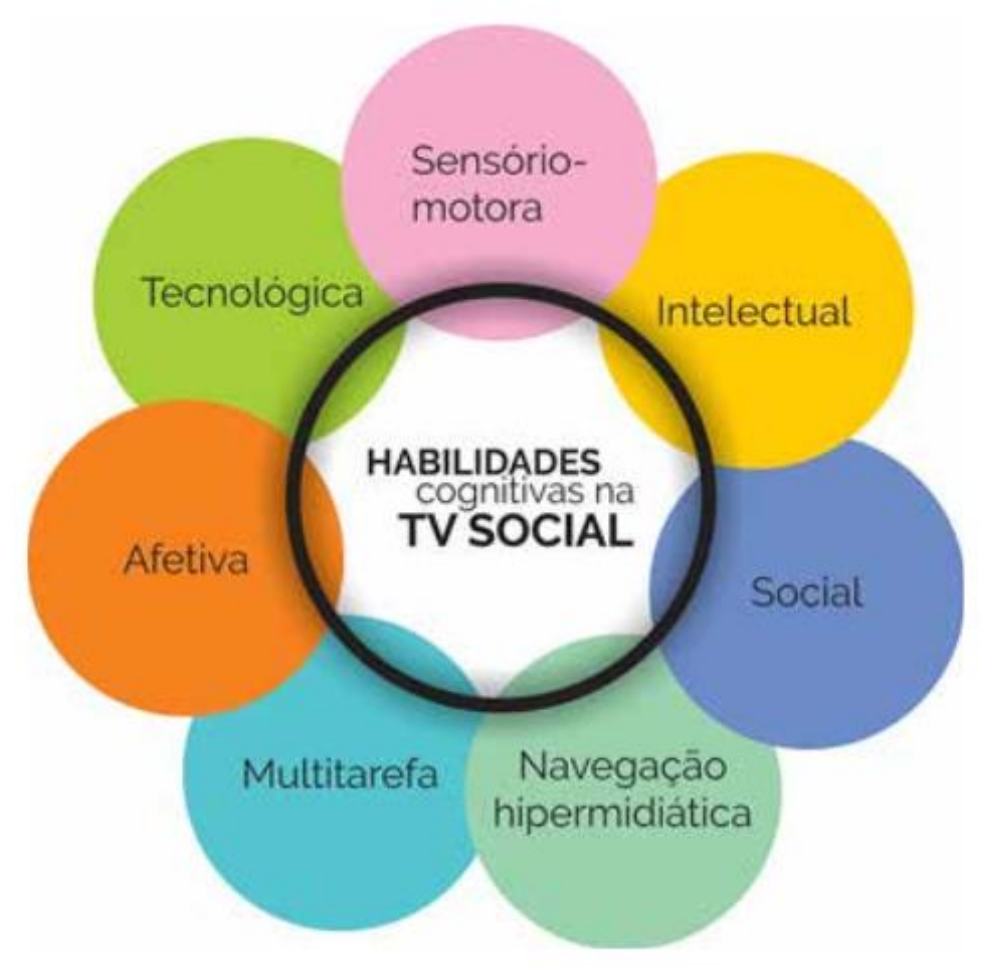

Fonte: Almeida (2018, p. 103)

Em suma, as múltiplas habilidades suscitadas pela TV Social estão resumidas na figura acima. Notamos que para Stycer e Xavier, a habilidade multitarefa é crucial como ferramenta de trabalho. Condizendo com que Almeida sublinha: 
Na TV Social ela se traduz pela capacidade de se realizar diversas atividades em outro(s) dispositivo(s) e/ou plataforma(s) durante a visualização televisiva, dividindo a atenção entre elas de forma muito rápida. A leitura e a publicação de comentários enquanto o programa é exibido requer a maestria de processar informações em alta velocidade, fazer conexões igualmente ligeiras entre diferentes narrativas, conteúdos anteriormente transmitidos e situações novas no programa, navegar em outro dispositivo e saltar de uma interface a outra numa experiência multissensorial que trabalha diversos domínios de linguagem. (ALMEIDA, 2018, p. 97)

Entretanto, temos que levar em conta que cada usuário acumula as habilidades de acordo com suas próprias demandas, que podem ser procedentes da experiência pessoal, ou motivadas pelo trabalho, tal como identifica a autora. Em relação aos críticos analisados, muito do interesse nas redes sociais são provenientes de uma prática pessoal, que em seguida, se mesclou com a profissional, até pelas configurações do mercado e da prática da crítica.

\section{****}

Por fim, as páginas anteriores apresentaram os resultados da codificação pelo software Maxqda, indicando os códigos e seus respectivos números de segmentos codificados. Aqui, optamos por mostrar código a código, relatando os fragmentos dos documentos por categoria, atribuindo uma ideia geral do que cada um representava para cada crítico. Reafirmamos que todos os códigos, de alguma maneira, se complementam, e isto é notado pela reincidência de segmentos. A seguir, optamos pela análise inversa. Cada tópico analisará um crítico através dos documentos das críticas e entrevista. 


\section{CAPÍTULO 6 - Entre entrevistas e críticas}

A crítica ela é boa inclusive para o público também como uma referência. Não só para quem produz, para quem faz, como também para quem também consome aquilo. Nilson Xavier

Neste capítulo, por meio da categorização realizada, mostraremos os Retratos das categorias provenientes de cada crítico. Reforçamos que as categorias foram abarcadas tanto do documento que contém as críticas quanto no das entrevistas. O retrato de documento consiste numa ferramenta visual possibilitada pelo Maxqda, que constrói uma imagem com a incidência das categorias no referido documento. Como cada categoria foi dotada de uma cor específica, este quadro evidencia a gama de cores dos códigos utilizados. Desta maneira, os retratos dos documentos das entrevistas e das críticas foram dispostos lado a lado. Esse recurso visual viabilizará uma ideia geral dos temas mais abordados nos dados empíricos. Optamos por fazer uma análise de cada crítico, e, com isso, os tópicos abordados dão conta da relação entre o que foi relatado nas entrevistas e o que foi escrito nas análises.

Abaixo temos a lista de código e suas respectivas cores: 
Tabela 12 - Códigos e suas cores

\begin{tabular}{|c|c|c|}
\hline Cor & Código & Segmentos codificados \\
\hline$\bullet$ & Realismo & 7 \\
\hline - & Trabalho & 50 \\
\hline$\bullet$ & Utilização de Redes Sociais & 12 \\
\hline$\bullet$ & Reflexões sobre a Crítica & 55 \\
\hline - & Relação com a Telenovela e TV & 14 \\
\hline - & Critérios de Análise & 33 \\
\hline$\bullet$ & Processo de análise & 35 \\
\hline$\bullet$ & Construção de Personagem & 97 \\
\hline$\bullet$ & Estética & 26 \\
\hline$\bullet$ & Reflexões sobre telenovela & 135 \\
\hline$\bullet$ & Temáticas Sociais & 119 \\
\hline$\bullet$ & Verossimilhança & 131 \\
\hline$\bullet$ & Direção & 34 \\
\hline$\bullet$ & Repercussão - redes sociais e audiências & 89 \\
\hline$\bullet$ & Atuação e desempenho da Atriz/Ator & 59 \\
\hline$\bullet$ & Roteiro e Texto & 247 \\
\hline
\end{tabular}

Fonte: Elaborado pela autora - Maxqda 


\subsection{Cristina Padiglione}

Retratos dos documentos:

\section{ENTREVISTA}

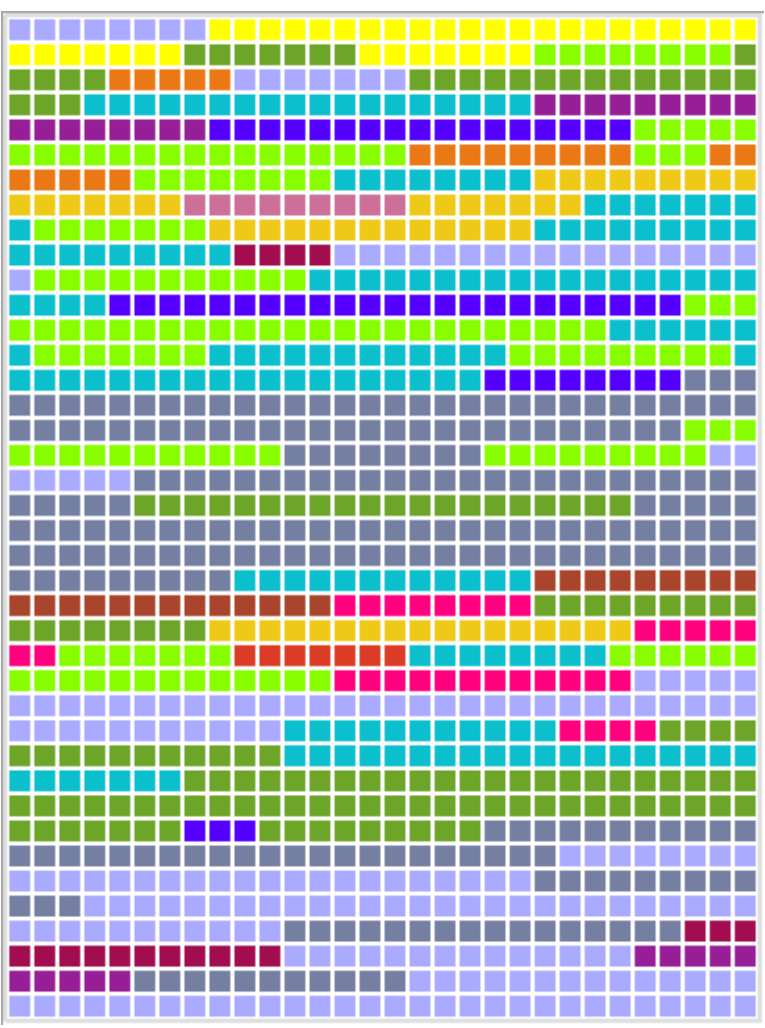

\section{CRÍTICAS}

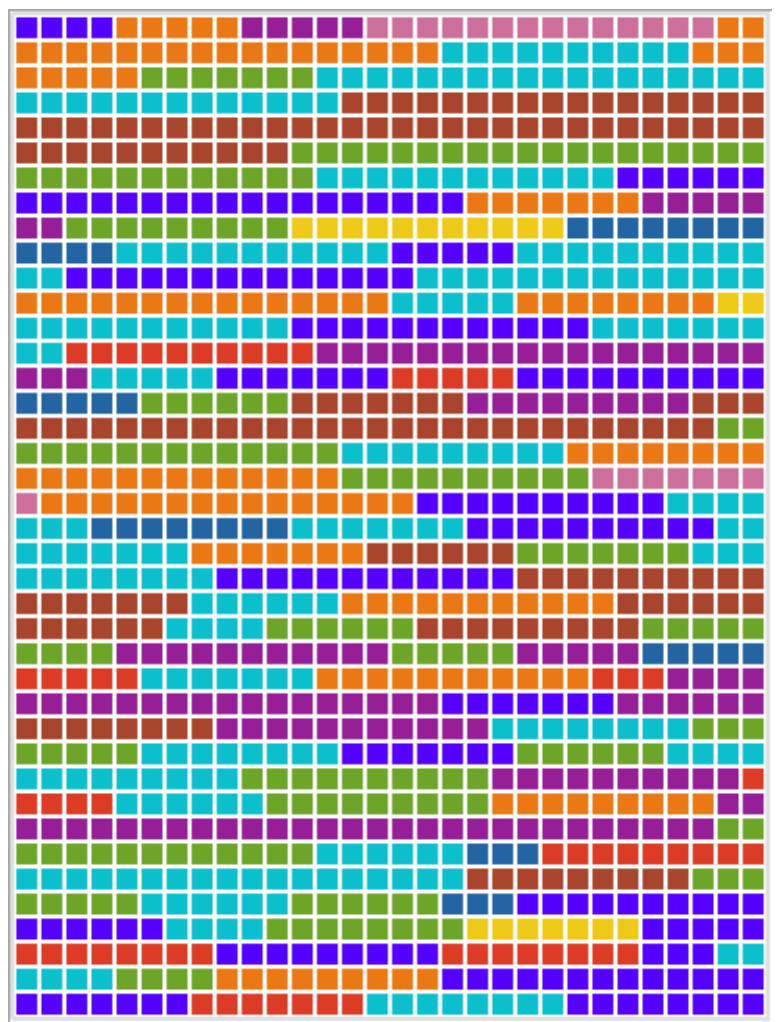

Fonte: Elaborado pela autora - Maxqda

A jornalista Cristina Padiglione iniciou sua carreira na cobertura de TV no jornal Folha da Tarde, na década de 1990. Desde então, passou pelos principais veículos de comunicação com foco no jornalismo cultural. A transição do impresso para as mídias digitais nos portais de notícias, se deu a partir da página on-line do jornal O Estado de São Paulo. Lá, a jornalista, com sua coluna, pôde abordar os assuntos centrais no que concerne à televisão, entretanto, como ela afirma, dentre os programas televisivos, $o$ interesse maior é sempre novela. Sua permanência no jornal perdurou até agosto de 2016, pois em outubro do mesmo ano, nasceu o TelePadi, que, em suas palavras, é um blog com cara de site. 
No retrato da entrevista, notamos a incidência do código trabalho, na cor lilás claro. Sua atuação no jornalismo e na crítica de telenovela foi, de fato, um dos objetivos da entrevista semi-estruturada. No caso de Padiglione, no período temporal que escolhemos para análise (2012-2018), houve uma mudança quanto ao local de trabalho, tal como relatamos em seu dossiê. Logo, foi fundamental que a jornalista se dedicasse a explanar essa transferência de veículo e até mesmo de formato, haja vista que ela saiu de uma coluna num site de jornal para uma página somente sua, com demanda de conteúdo mais exclusiva. A jornalista ainda narra um fato relevante ocorrido logo após a criação do blog:

Eu saí do Estadão em agosto de 2016 e em outubro eu fundei o blog. Já lancei o blog em outubro de 2016. Você quer ver uma coisa, quando o Domingos Montagner morreu em setembro já, em 2016, é 15 de setembro eu não lembro... Na data do Domingos Montagner eu dei meu primeiro furo no blog, já é anterior a outubro. E as pessoas ficaram malucas porque já falaram: 'nossa, olha ela saiu do estadão e ela já está dando furo porque ela é boa pra cacete e tal'. Acho que o Luís Fernando nem sabia que eu tinha saído e acabou falando comigo, ou sabia mas tinha uma confiança porque a gente tinha... Mas ali teve uma sorte por que eu procurei o cara por e-mail, por que eu tenho o celular dele e ele me respondeu meia hora depois. Era a solução da novela, ele morreu na sexta e no sábado de manhã eu troquei o e-mail com o Luís, e ele falou assim: 'eu vou fazer uma câmera que as pessoas olham pra ele, as pessoas vão se dirigir a câmera e tal'. E eu fiz esse texto, super bombou. Aí Globo inconformada que ele falou comigo antes, por que ele era um desobediente, fez um texto e distribuiu uma hora depois.

A primeira linha do retrato de entrevista corresponde à predominância da categoria Relação com a Telenovela, e com ela vemos a influência das narrativas na construção da memória coletiva, além de instauração de hábitos de assistência, constituintes de rituais de consumo da programação televisiva. Padiglione menciona que o hábito de assistir televisão era constante em sua casa, inclusive sua mãe e tia a estimulavam a ver a telenovela, pois, devido ao trabalho, muitas vezes elas perdiam alguns capítulos. Assim, cabia a ela relatar o que tinha acontecido neste determinado capítulo para as duas.

Na verdade, no meu tempo de criança, a minha mãe por exemplo fazia bolo para fora com a minha tia, era minha babá eletrônica a novela. Não tinha essa coisa de hoje dizer que criança não pode ver novela. Elas diziam assim: 'vai lá assistir à novela e depois conta pra gente o que aconteceu'. Então, eu tenho uma memória, sei lá, de 'Estúpido Cupido’ que eu devia ter sete anos de já estar assistindo novela. 
Esse acesso à televisão - como da maioria dos brasileiros - continua contribuindo para o desenvolvimento da competência simbólica e ao acompanhamento dos diferentes canais que foram surgindo ao longo do advento da TV. Ligação afetiva é pungente e está atrelada a uma atividade que envolve membros da família no âmbito do lar. A ritualidade e a socialibidade, primordiais na constituição do consumo da telenovela, iniciam-se no espaço domiciliar, e se espraiam para outros campos da vida deste indivíduo.

Ainda no retrato da entrevista, notamos uma grande ocorrência da categoria Reflexão sobre a Crítica (cor cinza), em que foram selecionados segmentos que correspondem ao papel da crítica e a trechos que, durante a análise, emergiram para pensarmos no lugar dessas análises no universo de circulação da telenovela. Nesta categoria, foram predominantes as ponderações acerca do campo de crítica de TV no Brasil, uma reflexão de seu próprio trabalho. A reflexão está atrelada tanto à atividade da crítica bem como da relação específica entre brasileira e ficção. No segmento selecionado abaixo, a jornalista menciona acerca dessa competência adquirida do assistir televisão e ficções e como isso é feito desde cedo pelo brasileiro, o que o torna entendedor dos mecanismos que compreendem o campo da telenovela.

Eu acho que é enxergar algumas coisas que o espectador não viu. Para isso não virar uma conversa de botequim. Porque a gente tem a novela, o futebol e a música, são coisas que todo mundo entende um pouco. A gente tem quantos, sei lá, 100 milhões de técnicos de futebol, 100 milhões de autores de novela, todo mundo entende um pouco. Você vai numa reunião de pauta em jornal, ninguém se mete na pauta de economia, ninguém se mete quando o crítico de música erudita começa a falar sobre concerto do Verdi que vai chegar no municipal e que vai ser interpretado por ... Mas quando você entra em novela sempre tem alguém pra dar um palpite, você em futebol todo mundo tem palpite, quando entra em música popular também é a mesma coisa. Tem algumas coisas que chamam essa conversa de botequim. São coisas que estão presentes na sua vida desde que você se entende por gente. Então todo mundo entende um pouco.

Por "conversa de botequim", a jornalista ressalta para a aptidão do brasileiro em entender os códigos e contextos do folhetim nacional. Marcados por uma ritualidade latente, a literacia televisual é uma característica inerente de gerações que cresceram em frente da televisão, num palimpsesto contínuo, em que a televisão não acabava após o fim da transmissão, mas se desdobrava em conversações nas diferentes esferas da vida cotidiana. A circulação desse sentido dotou esse espectador de uma gama extensa de 
repertório. Entretanto, ressaltamos que somente esse acervo simbólico não o faz capaz de analisar uma obra, deve-se ter em conta outros fatores condizentes com o fazer da crítica.

A Reflexão sobre a Telenovela se destacou nos retratos a partir da cor verde escuro. A categoria dá pistas sobre as características e argumentos que surgiram na análise do folhetim. Os pontos mais relevantes foram a configuração dos capítulos, ao formato em si, e o entendimento de que telenovela é uma obra de ficção e está inserida numa indústria particular, que tem em vista o lucro de seus produtos. No fragmento abaixo, Padiglione explana:

No sentido de que ele escolhe a série que ele vai ver, a novela um pouco assalta quem está no sofá. É uma hora que você fala assim: 'ah eu não tenho nada para fazer, vou ver novela', ou então 'eu não quero pensar em nada', ou eu já vi gente assim: 'a novela é tão ruim que eu adoro ver, porque eu quero não pensar em nada; não quero novela engajada pra pensar em coisa nenhum eu quero só sentar e quero tudo mastigado'. Tem isso! Tem esse público que não quer pensar em nada. Então, ele é um pouco assaltado neste sentido. A novela entra muito por inércia, a série é um negócio que o cara vai muito buscar. Ele pode mudar de canal, ele pode desligar, ele pode procurar um filme, ele pode dormir, ele escolheu ver a série. Então, ela é mais escolhida do que escolhe. Eu acho que neste sentido tem um público mais exigente, que está a fim de consumir alguma informação, alguma qualidade, não é tão passivo de conformista como é o público da novela. A gente está falando da média geral, não é que todo mundo veja novela com esse olhar.

Visto quase que igualmente tanto no documento da crítica quanto no das entrevistas, este código, como afirma Padiglione, tem como intuito chamar a atenção do leitor para algo que passou despercebido. Ela explica que as novelas estão presentes na vida diária do brasileiro, mas que, devido a essa facilidade, há certos elementos que passam despercebidos e que a crítica deve trazer essas coisas que não estão sendo vistas. Ao levantar isto nas suas análises, possibilita uma crítica que dialoga com as questões pertencentes às gramáticas de produção, com as diferentes condições que envolvem produzir uma telenovela, e as gramáticas de reconhecimento abarcadas nas suas avaliações, que entram em contato com as gramáticas de reconhecimento de seus leitoresespectadores.

O Critério de análise é formado pelos segmentos que concernem aos parâmetros de análise adotados pelo profissional. Visto somente no documento das entrevistas, o código aponta para as normas e fundamentos empregados nas avaliações. Esses parâmetros não foram em tese detalhados, pois, de acordo com cada telenovela, a leitura é feita de uma forma. Entretanto Padiglione costuma ressaltar a organicidade, ponto que, 
para ela, é essencial que uma novela tenha. Em seu dizer, a organicidade está em conjunção com a verossimilhança, seria apresentar uma trama que faça sentido dentro da narrativa proposta.

A organicidade, pode-se dizer que eu levo em conta essa. Inclusive se os diálogos, se você ouve aquele diálogo e pensa 'nossa isso poderia estar acontecendo do meu lado', eu adoro isso, é uma coisa que me encanta profundamente. Que faz você embarcar numa história. Então eu levo muito na emoção, desde que tenha lógica. Não dá para ser um negócio completamente fora de propósito.

Mesmo alertando para o caráter da telenovela como ficção, a jornalista censura histórias que fogem do escopo pretendido: Eu levo em consideração se ela é panfletária ou não, porque não basta que ela tenha uma boa mensagem social, se ela for panfletária ela é um recado quase perdido.

É que a novela precisa ser didática, ela é um negócio que o cara geralmente está vendo com mais gente. Isso eu levo em conta também, Sempre levo em conta o contexto, ai eu não posso também exigir da novela do SBT e da Record que ela tenha um nível de produção de quem gasta lá 200 mil dólares por capítulo, mas ela não pode ser tão tosca.

No retrato das críticas, vemos a ocorrência das categorias Construção do Personagem e Roteiro e Texto, esta última também presente no retrato das entrevistas, mas em menor quantidade. Os dois códigos trazem semelhanças, pois cabe ao ator dar vida ao roteiro proposto, entretanto, o que remarcamos como construção de personagem diz respeito às variadas reviravoltas que envolvem um personagem durante a telenovela. No entanto, ressaltamos que, numa produção de longa serialização, é possível, dentro da história, a transformação dos personagens, devido às viradas na narrativa, às passagens de tempo, e outras mudanças previstas no roteiro. Assim, um personagem bem construído admite várias camadas que vão aparecendo no decorrer do folhetim, mas que, ao mesmo tempo, façam sentido na ficção. A crítica de Padiglione reivindica esse bom senso das ficções que são objeto de seu escrutínio. A informante remarca para determinados pontos da trama, chamando a atenção do leitor para algo que possa ter ficado subentendido. Tais os exemplos abaixo:

Temos ali um vilão que se redimiu, um grande ator a sustentar o personagem e sua virada (Félix/Mateus Solano), e um bom rapaz, disposto desde o início da história a constituir família, como se diz, com filhos e relação conjugal estável, mas ciente de que não poderá gerar 
uma criança apenas com o parceiro, homem como ele (Niko, Carneirinho/Thiago Fragoso).

A protagonista da trama de O Outro Lado do Paraíso, Clara, foi uma das abordagens de Padiglione acerca da construção de seu papel. O desenvolvimento da personagem é pautado nas análises da crítica desde o início da ficção, especialmente no tange ao vocabulário utilizado pela mocinha. Outro personagem da trama de Walcyr Carrasco escrutinado pela informante foi Renato, médico dedicado e interesse amoroso da protagonista, que, sem preparação do público, mostra-se um dos vilões da trama. Único personagem que parecia dúbio em "O Outro Lado do Paraíso”, Renato, interpretado por Rafael Cardoso, acaba de se revelar malvado, muito malvado. Nuance para quê??

A mocinha, Clara, levou duas cantadas no primeiro capítulo e se repetiu na reação - "fico envergonhada" /"fico sem jeito". Para quem diz não ser muito estudada, criada no meio do mato, nada mal chegar à primeira aula indicando livro de Ruth Rocha ("Marcelo, Marmelo, Martelo") e usando palavras como "compartilhar". (Ok, já vão dizer que sou preconceituosa: porque alguém do meio do mato não poderia pronunciar esse termo, mas a verdade é que não faz parte dos hábitos do mato nem combina com o restrito vocabulário exibido pela personagem na estreia).

Em lugares pontuais no retrato das entrevistas, a Verossimilhança (laranja) aparece bem distribuída no retrato das críticas, é neste código que, em nosso entender, a autora cobra certa veracidade da narrativa que está sendo apresentada. Este foi um ponto abarcado nas diferentes análises em telenovelas distintas. A categoria, fortemente atrelada aos códigos Roteiro e Texto e Construção do Personagem, mostra-se como questão central de análise da teledramaturgia, como na análise da cena emblemática do primeiro beijo gay da emissora: O beijo gay, primeiro na história da produção que reúne a maior plateia do País, veio emoldurado nesse contexto de família de comercial de margarina, no sentido mais conservador do termo: filhos, união estável, amor, casa, afeto, lealdade e juras eternas. Neste segmento, sobre Amor à Vida, Padiglione alerta que, por mais avanços no campo da diversidade, e por ter narrado a história de um personagem homossexual, alguns aspectos da trama apresentavam um pensamento com resquícios do conservadorismo brasileiro, o que, aparentemente, pavimentou a aceitação da cena nos públicos mais conservadores.

A atuação, código em vermelho, apresenta as críticas feitas à interpretação de determinado ator na trama. De acordo com Pallottini (1998, p. 140), "um bom ator salva 
um mal personagem e, ao contrário, um mau ator enterra um bom personagem; a má escalação de um elenco pode pôr a perder um bom trabalho". Pela durabilidade das telenovelas, a quantidade de vezes que entramos em contanto com aquele ator entremeado nesta história intensifica a sensação de proximidade com o personagem. Isso pode ser notado na escalação de Adriana Esteves para a vilã de Avenida Brasil:

Carminha, como revelou o diretor de núcleo Ricardo Waddington, pedia uma atriz com carisma de heroína. Alguém que arranca a cabeça da boneca da enteada no primeiro capítulo tinha de cativar o público por algum outro fator, e Adriana ganhou a plateia de cara, mesmo com (ou talvez por isso mesmo) aquela atrocidade.

Uma feliz conjunção entre texto, atuação e direção nos brindaram com essa estupenda personagem. E eu já não sabia se chorava por ver o destino da ex-senhora Tufão ou por pensar na longa trajetória de uma super atriz que soube se reinventar e se tornar a gigante que nos brindou por oito meses.

A repercussão, em lilás escuro, representa os segmentos que trataram tanto da audiência tradicional quanto da ressonância das narrativas em redes sociais digitais. $\mathrm{O}$ código é percebido nos dois documentos, entretanto é mais frequente nas críticas, onde a jornalista costuma relatar os pontos de audiência da semana analisada ou de uma cena importante. Os pontos de audiência, métrica usual da Kantar Ibope, consiste na verificação de índices de programas televisivos. A telenovela, estando no horário nobre da televisão, ou seja, na faixa horária de maior rentabilidade em termos de assistência, ainda tem o horário das 21 horas com um dos mais visualizados. Portanto, é comum a métrica ainda ser relatada em matérias jornalísticas e nas críticas. Entretanto, outra maneira de trabalhar com a repercussão de uma ficção são as redes sociais, especialmente o Twitter.

Da conversa na padaria e no escritório, o "debate" sobre mocinhos e vilões se estendeu a fóruns públicos, graças à expansão da web, multiplicando opiniões, pontos de vista, soluções e piadas em torno do script. Quem jamais pensou em convidar outros autores, atores, políticos e jornalistas para ver novela em casa, hoje divide o sofá até com o Nilo (José de Abreu), compulsivo tuiteiro, e sabe do que se ocupa o agora vereador Andrea Matarazzo quando zapeia das eleições para a mansão do Tufão.

É nesta rede que as conversações durante o período de transmissão são mais pungentes. A indexação por meio das hashtags permite analisar os números de impressões 
que a telenovela - em seu período de transmissão - alcançou. Além do Twitter, as páginas do Facebook voltada para comunidades são um meio de circulação de sentidos das ficções.

\begin{abstract}
Avenida Brasil se despede nesta sexta não com recordes extraordinários de audiência, ou não com essa audiência linear mensurada pelo Ibope pelo televisor. Nesse aspecto, novela das 9 já teve muito mais público registrado pelo Ibope, mas isso foi em um tempo em que as redes sociais não estavam aqui para testemunhar até onde vai a ocupação da plateia com as questões levantadas pelo enredo.
\end{abstract}

Os códigos discutidos nos dois retratos são um resumo do que se sobressaiu na codificação. Lembrando que esses elementos em destaque se complementam, e todos, em certo aspecto, abordam a telenovela e a crítica. Como exposto, as entrevistas complementaram o entendimento da crítica e ofereceram novos códigos referentes ao processo de confecção das análises e da rotina de trabalho de Padiglione. Se olharmos com atenção, perceberemos que, no retrato das entrevistas, as cores são mais coesas e formam fileiras mais extensas de uma única cor, enquanto, no retrato das críticas, as linhas de somente uma cor são mais curtas e se repetem no decorrer da imagem, o que indica que, nas críticas, os componentes levados mais em consideração são o que denominamos de técnicas, que envolvem a valoração do texto e da estética. Além disso, no documento das entrevistas, discorremos acerca da atividade da crítica, a jornada de trabalho, e seu processo criativo. 


\subsection{Maurício Stycer}

Retratos dos Documentos:

ENTREVISTA

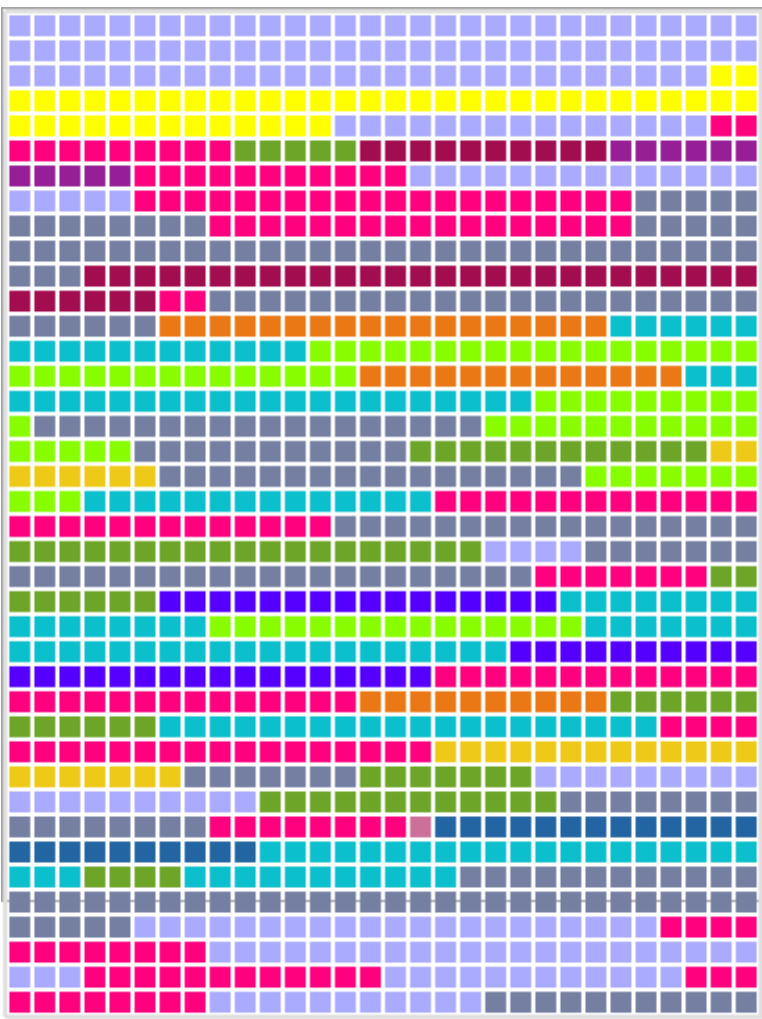

\section{CRÍTICAS}

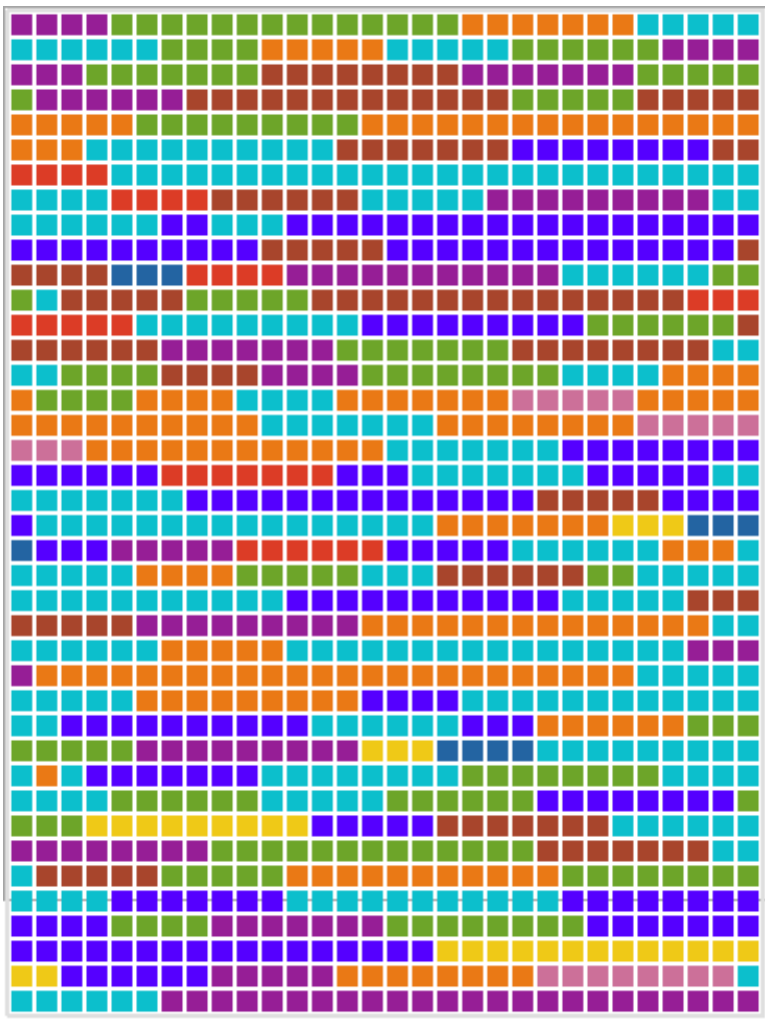

Fonte: Elaborado pela autora - Maxqda

A primeira formação acadêmica de Maurício Stycer foi em Economia e somente em seguida cursou Comunicação Social com habilitação em Jornalismo. Seu interesse pela área advém do desejo de ser jornalista cultural, o que logo mais foi possível com sua entrada no jornal O Globo, no Caderno B, em 1989. Sua entrada nos portais de notícias nas mídias digitais foi no IG, em 2008, onde criou um blog que servia de complemento de suas matérias no portal de notícias. Neste espaço, como ele comenta, era feito um making of das matérias que considerava relevante, e isso perdurou por um ano e meio.

Eu sempre vi televisão, e me arrisquei ali muito jovem não são bons textos, mas tem ali uma vontade de escrever sobre isso. Acho isso interessante, então isso é um preâmbulo. Minha atual de dedicação, ela começa em 2008, quando eu fui trabalhar no segundo semestre no portal $I G$, foi meu primeiro trabalho numa empresa de internet. Eu fui 
contratado para ser repórter especial do portal, ainda tinha pouca intimidade com internet, e eu pergunte: vem cá, esse negócio de blog..., 'você quer um blog? A gente vai te dar um blog também'. E me deram um blog em paralelo com meu trabalho de repórter. E eu comecei a experimentar nunca tinha feito blog. Era moda blog, blogueiro. Era visto como uma coisa muito pessoal. E eu comecei a usar o blog como complemento do trabalho de repórter. Então, por exemplo, eu fazia uma reportagem especial, fiz uma série sobre adoção, no dia que a reportagem ia ser publicada eu ia no blog e fazia uns bastidores da noticia, um post contando os detalhes dos bastidores da reportagem que eu tinha feito. E assim eu comecei a fazer o blog, e ai eu via um filme e fazia um post, eu via uma exposição fazia um post, eu via um programa de Tv que achava interessante eu fazia um post. E aí eu comecei a escrever e começou a ter repercussão. Nesse processo que eu fiquei escrevendo esse blog no Ig, um ano e meio que foi o período que eu trabalhei lá.

Sua entrada na cobertura de televisão não se deu pela telenovela, mas pelo reality show Big Brother Brasil, na época, em sua nona edição, no ano de 2009. Sua coluna sobre o BBB foi a primeira a enxergar de maneira séria o reality, algo a que poucos profissionais da área se dedicavam. A partir disto, Stycer criou um olhar próprio para o programa ao focar sua análise na edição, na atuação do diretor e na do apresentador, o jornalista Pedro Bial. Por meio desta perspectiva, o crítico afirma que é possível argumentar acerca do programa, pois, apesar de um formato engessado, a edição era responsável por apresentar o que seria transmitido na semana, e isso em si já proporcionava um tipo de avaliação.

Sua entrada no UOL, pertencente ao conglomerado do Grupo Folha, iniciou-se em 2010, tendo como foco a TV aberta, mesmo abordando outros assuntos em reportagens. Seu blog, como ainda é exibido na página, versa acerca dos mais variados programas da televisão. Entretanto, como ele indica, novela é um assunto fora da novela, assim procurava estar inteirado de todas as estreias de ficção.

O UOL é quase uma televisão em termos de público que entra, um público muito grande, de todas as faixas econômicas é muito grande, é um tráfego de internet enorme. Então eu percebo que quem procura ali o meu blog são pessoas que assistem TV aberta. Então eu me preocupo em saber tudo o que está acontecendo em TV aberta em todas as estreias, em todas as áreas. Então esse é o primeiro ponto.

O que se sobressai na entrevista de Stycer é a recorrência das categorias Processo de Análise, Reflexão sobre a Crítica e Trabalho. Percebemos que essas categorias abordam o ofício do crítico, especialmente da sua trajetória no jornalismo, sua relação 
com a televisão e como se configura seu processo de avaliação dos programas televisivos. Relatamos que as entrevistas foram realizadas com o intuito de complementar o entendimento acerca das críticas, aprofundando o conhecimento sobre sua atividade na área. Neste sentido, no retrato da entrevista, a ponderação acerca da crítica é marcante e está intrinsecamente ligada à ocupação do jornalista.

A cor lilás claro indica o código trabalho no retrato da entrevista, porém inexistente no retrato das críticas. A discrepância em si não indica muita coisa, haja vista que as entrevistas foram mais focadas em entender a trajetória profissional dos críticos. Voltando para o que podemos interpretar deste código, a atuação de Stycer em seu blog, até o ano de 2018, ia além das postagens, pois até esta data ele era o moderador dos comentários realizados ao fïm das publicações. A atividade de moderar, segundo ele, ajudou na modulação de seu texto, ou seja, aprendeu a mudar o tom de sua crítica, que, até então, ele acreditava ser muito duro e enfático em suas opiniões. Todavia, acredita que deve sempre dizer ao telespectador que o programa é ruim, mesmo que ele o aprecie.

O UOL sempre me ofereceu moderar os comentários do meu blog e eu sempre recusei, porque desde o início eu percebi que ali na caixa de comentários, aquilo ali era, primeiro, uma usina de pautas para mim, e segundo me ajudava a sentir a temperatura dos assuntos. Seja quando enfurecia demais os leitores, seja quando eles se empolgavam demais. Isso me ajudou a modelar o meu texto muitas vezes. Lendo os comentários, as respostas, por obrigação que eu me impus de moderar, eu perdia muito tempo com isso sempre. Eu parei em 2019, porque o UOL instalou um sistema que eles chamam lá de inteligência artificial, para moderar, eu resolvi abrir mão; então esse é o primeiro ano que eu não estou fazendo.

A utilização das redes sociais digitais preenche quase uma fileira no retrato. Em cor vermelho escuro, o código demonstra a utilização do Twitter pelo crítico, espaço em que são construídos um diálogo e a possibilidade de assistir ao programa com inúmeras pessoas. Para ele se tornou uma ferramenta importante de trabalho e formalizou uma experiência de processo colaborativo. Sobre esta característica, o crítico narra: "Fui levado ao Twitter, inicialmente, pela vontade de promover os textos que promovia no blog. Era (e ainda é) uma oportunidade de mostrar meu trabalho a uma audiência que não o conhecia. Rapidamente, porém, entendi essa função secundária da rede social" (STYCER, 2016, p. 39) 
E desde o início eu percebi esse diálogo, essa experiência que é incrível de você assistir televisão como se você estivesse numa sala com várias pessoas ao mesmo tempo. Todo mundo vendo a mesma coisa. Isso realmente é uma experiência incrível. Então o Twitter é uma ferramenta muito importante para o meu trabalho. Aprendo, recebo dicas, ouço reprimendas, corrijo coisas em função de comentários, já muitas vezes ocorreu, apontando erros, imprecisões.

$\mathrm{Na}$ cor cinza, a reflexão sobre a crítica é recorrente em variados pontos do documento. Isso indica a observação e a ponderação acerca de sua própria atividade. Stycer acredita que a crítica afeta muito pouco o processo de criação da telenovela. A crítica, por sua vez, está mais voltada para o espectador, ajudando-o a entender seus gostos e até mesmo mostrar uma intenção oculta por parte da produção. A contextualização foi o argumento-chave empregado para exercer a atividade de crítico, e conforme sublinhamos, a crítica tem como características explicar o contexto em que determinada obra está sendo lançada. Isto posto, ele analisa os truques das ficções, especialmente as tramas naturalistas, sujeitas à crítica contextual. Para ofertar este olhar, deve haver, tal como ele enumera, didatismo, sensibilidade e clareza, em outras palavras, saber comunicar sobre um tema mesmo que o telespectador ignore e não esteja vendo.

Um eu já falei, acho que é a questão do contexto, isso eu acho essencial. Acho que você precisa ser didático, claro. Tem um lado do trabalho do crítico que é difícil explicar, eu chamo que é um pouco a sensibilidade, que é sua relação subjetiva que você tem ali, com o assunto, com a interpretação, que comove a uns e não comove a outros, atinge alguns e não atinge outros. E saber comunicar isso para o leitor também, deixar claro que às vezes determinado assunto, determinada interpretação, determinado ator, está transmitindo algo diferente, mesmo que ele não esteja vendo isso. Mas é uma carga de subjetividade. Aí é um terreno pantanoso.

Ponderar acerca da crítica levou Stycer a aludir que o telespectador, em certos casos, possui uma atitude conformista. Isso se explica porque a telenovela reconforta, e, em algumas ocasiões, não há o interesse de adentrar nas temáticas sociais abarcadas em cena, mas somente utilizar as ficções como uma fonte de entretenimento. Desta maneira, ele busca não ter medo de arriscar e expor uma opinião, que pode não ser bem interpretada, seja pelo público ou pelo autor.

É um requisito, respondendo a sua pergunta, é mostrar muitas vezes o que não está na aparência. Tentar mostrar para o espectador eventualmente o que ele não esteja vendo. Não ter medo de ir contra a 
corrente, acho isso fundamental. Não ter medo de arriscar as suas opiniões, por exemplo O Sétimo Guardião eu fui a única pessoa que elogiou no início, já de cara todo mundo saiu matando. Eu vi uma coisa ali que me interessou pessoalmente, tentei mostrar para as pessoas. Tentei fazer uma reflexão por que que ele [o autor] está voltando a isso, é um subgênero que está meio morto na teledramaturgia.

A crítica é o patinho feio. Essa afirmação está no bojo do que Stycer refere como preconceito com a televisão, sempre vista como "algo menor, menos importante" (2016, p. 17). As razões para isso, em sua opinião, é que a Tv aberta entra na casa dos espectadores de graça e se configura como um entretenimento democrático, isso permitiu que as pessoas construíssem um repertório extenso acerca das ficções. Levando isto em conta, há a percepção de que, para escrever sobre televisão, é necessário assistir muito, e com isso seria simples efetuar uma análise. Ao longo de seus anos de trabalho na área, Stycer cita uma situação:

Gosto de repetir uma história exemplar. Certa vez recebi um e-mail do autor de um programa que critiquei. Ele tinha razões para estar chateado, já que havia classificado sua criação de 'constrangedora'. A sua resposta, porém, me surpreendeu. Disse ele: "Constrangedor é um homem de 50 anos ganhar a vida comentando programas de TV". Em outras palavras, para esse criador, cujo ofício principal é escrever para a televisão, a crítica não passa de um trabalho menor, desimportante, que deve ser exercido por pessoas mais jovens inexperientes. Pela primeira vez foi possível ver claramente que o preconceito contra televisão não é apenas de quem assiste, mas também de quem a produz (STYCER, 2016, p. 17).

Apesar desses entraves, o crítico explica que seu trabalho é reconhecido pelo grau de exigência, algo percebido por produtores e autores, o que demonstra uma compreensão do trabalho realizado. O rigor na confecção de suas avaliações e a honestidade são dois pontos que ele costuma notar quando aludem sobre seu trabalho. Pois ele parte do princípio de que o papel do crítico não é sempre falar mal, como é comumente difundido, e sim desvendar um texto.

O código reflexões sobre a telenovela, na cor verde mais escuro, disposto em múltiplos pontos dos dois retratos, enuncia a inquietação de estar a todo instante refletindo acerca do folhetim e seus desdobramentos nos meses de exibição. Observamos que este código é mais evidente no retrato das críticas, onde as publicações periódicas apontam e descrevem aspectos abarcados nas cenas. Um dos pontos enumerados nos dois documentos foi o fato da telenovela ser uma obra aberta, o que autoriza o autor a efetuar, 
de acordo com suas necessidades, alterações significativas. Pallottini (1998, p. 60) ressalta que a obra aberta, no sentido dado à telenovela, compreende como um texto passível de variadas organizações, sem um final dado, mas que pode ser concluída em determinada fase.

Isso demanda, por um lado, um leitor mais ativo, dono de uma certa erudição relativa ao enunciado. $\mathrm{O}$ consumidor deve estar preparado para enfrentar a obra, que, por sua vez, deve ter característica de inovação, formais ou de conteúdo. Obra aberta corresponde a uma visão nova do mundo, não- estatuído, não convencional, imprevisível. As convenções da telenovela, ou seja, seu moralismo forçoso, seu caráter, digamos logo, comercial (a telenovela do mundo capitalista deve vender, mas será que isso só ocorre no mundo capitalista?) tira dela o teor de obra aberta. Ficam, no entanto, indiscutíveis, as possibilidades de correção de rumos sempre feitas a partir dos acontecimentos do dia e da resposta da audiência (PALLOTTINI, 1998, p. 60).

Em ambos os documentos, a verossimilhança é visível. Identificada na cor laranja, a categoria assinala para a cobrança do crítico neste aspecto chave das narrativas, pois a verossimilhança está atrelada à ideia da mimese aristotélica, na imitação do real. Entretanto, esse real nem sempre diz respeito à noção de realidade entendida no contexto social real, mas na veracidade construída naquela narrativa. As noções de construção de mundos (RYAN, 2012) e mundos possíveis (ECO, 2002) nos revelam que a narrativa tem que fazer sentido na proposição de mundo no qual foi criado, ou seja, ser verdadeiro aos elementos nos quais se propôs a construir, como no caso da crítica à Avenida Brasil:

Nina, moça moderna, bem informada, jamais faria a opção primária
que fez. Não custa lembrar que, no início da novela, a personagem se
aproximou da família de Tufão ficando amiga de Ivana em salas de
bate-papo na internet. É evidente que o autor sabe disso. Por que,
então, foi por este caminho? Só vejo uma resposta: a necessidade de
esticar a trama de "Avenida Brasil".

Em seu modelo de promessa, Jost (2004) explica que o receptor tem o direito de exigir, sendo que a promessa é uma via de dois lados, o da produção e da recepção. Por conseguinte, o espectador exige que a ficção respeite uma regra fundamental: "a da coerência do universo criado com os postulados e as propriedades que o fundam" (p.37). Com isso, Stycer ressalta para a realização de entretenimento com certo grau de inteligência, que foge de um modelo de telenovela engessado e que busque fugir da repetição. 
Tenho certa preocupação com isso, porque as novelas quase todas se pretendem realistas, então acho que elas ficam um pouco sujeitas a essa crítica, a questão da verossimilhança, da possibilidade de realmente disso estar acontecendo. Você falou que um dos casos que você está estudando é Salve Jorge uma novela que abusou disso; e é interessante você ver que sempre a defesa que a Glória Perez fez foi 'não, mas eu tenho uma história assim de uma pessoa que fez isso'.

Atrelada ao código texto e roteiro (azul turquesa), o código construção do personagem (azul mais escuro) foi relatado nos dois documentos. As duas categorias são, de longe, o caminho mais usual para se tratar um folhetim. Texto e roteiro fala de conteúdo, enquanto construção de personagem comtempla majoritariamente a performance. Stycer, na crítica a seguir, apresenta as personagens de A Força do Querer, e, a partir de sua intepretação, ele vai qualificando as ações de cada ser fictício:

Ritinha (Isis Valverde) é a sereia que seduz dois homens, o chucro Zeca (Marco Pigossi) e o riquinho Ruy (Fiuk), e faz gato e sapato de ambos. Bibi (Juliana Paes) trocou um homem rico, Caio (Rodrigo Lombardi), por um pobretão, Rubinho (Emilio Dantas), por paixão. Jeiza (Paola Oliveira) é PM, luta MMA e não tem medo de cara feia. E mais. Silvana (Lilia Cabral), jogadora compulsiva, ignora a pressão do marido rico e poderoso, Eurico (Humberto Martins). Joyce (Maria Fernanda Cândido) é a "perua" que dedicou a vida à futilidade com uma convicção de guerreira. Irene (Débora Falabella) parece ser uma maluca esclarecida, dedicada a viver uma "Atração Fatal" com o marido das outras.

Texto e Roteiro e Verossimilhança foram códigos que apareceram nos dois documentos. Como relatamos, os dois se configuram como elementos técnicos, tendo em vista que, numa narrativa, a coerência é um atributo necessário para o estabelecimento do pacto de recepção (LOPES, 2009). Na crítica “Tiro, porrada e Bomba” (STYCER, 2016, p. 121), temos um exemplo do que se refere às duas categorias:

Amor à Vida, de Walcyr Carrasco, foi outra novela que apostou nesta política de choque, com um texto de baixa qualidade, sem substância. O resultado, em termos de Ibope, foi um pouco melhor do que Salve Jorge, de Glória Perez, uma novela com história bem mais rica, mas problemas sérios de lógica.

Quando interpelamos o crítico sobre o que ele considera um texto de qualidade, ele relembra da aptidão dos textos de autores já consagrados, como Manuel Carlos. Uma das características das telenovelas é o primor pela ação, que, em certos casos, acontece em detrimento do texto. O que se percebe na telenovela das nove é a ênfase em ficções 
aceleradas e dinâmicas, todavia há autores que conseguem realizar este casamento entre ação e texto de qualidade. Porém, em muitos casos, quem se submete à desvalorização é o texto. Em sua primeira crítica sobre Avenida Brasil, Stycer indica: Nos primeiros seis capítulos e meio, João Emanuel Carneiro promoveu um festival de acontecimentos e exageros poucas vezes visto de forma tão vertiginosa numa novela. Neste entendimento, Stycer argumenta que:

As novelas da Lícia Manzo têm uma característica nova que elas trazem. Quer dizer, nova não, tem muito de novela do Manoel Carlos que é a coisa do diálogo caprichado, da conversa, novela no gogo. Ela, acho que tem uma habilidade incrível, a maneira dela fazer você ficar assistindo 30 a 40 minutos só de pessoas conversando, "sem ação". Acho incrível, é uma coisa muito interessante.

Em contrapartida, no texto "Grande acerto com problemas estruturais" (STYCER, 2016, p. 137), o crítico analisa a Avenida Brasil, considerada com unanimidade uma telenovela exitosa.

Carneiro teve o mérito de armar uma trama atraente, em torno de duas mulheres de origem humildade - uma má, Carminha, sem limites para se dar bem na vida, e outra, Nina, sua enteada, disposta a se vingar do mal que a primeira lhe causou. Melodrama clássico em formato de folhetim.

Acreditamos que os retratos dos documentos nos possibilitam uma maneira de realizar uma análise interpretativa, não necessariamente comparativa, pois são documentos completamente distintos, mas um olhar para a criação e o criador. Os críticos aludem à telenovela como insumo para seus próprios textos, e até mesmo na função de representante dos espectadores, ao cobrar do campo da produção a coerência e a qualidade. Nas entrevistas, Stycer afirma que acha desleal fazer uma crítica de primeiro capítulo. E, para ser justo, somente escreve uma ou duas semanas após a estreia, pois depois deste período, já possui conteúdo suficiente para realizar uma análise. Podemos distinguir que, no retrato das entrevistas, vimos linhas mais longas e coesas, sugerindo códigos mais reflexivos, ao passo que as críticas apresentam códigos referentes à estética e ao texto, além das inserções das ponderações sobre a crítica e o papel da telenovela na sociedade brasileira. Divisamos que Stycer não relata sobre seu processo de análise nas críticas e apresentou pouca reflexão sobre o ofício, pelo menos nos documentos que analisamos. Porém, no texto "Como ser crítico de televisão", publicado no livro Adeus controle remoto: uma crônica do fim da tv como conhecemos (2016, p. 21), o jornalista, 
num tom autorreflexivo, apresenta observações acerca da profissão citando o texto de Maureen Ryan, crítica do Huffington Post, sobre como ser crítico:

1. Você perde boa parte do seu tempo vendo porcaria na TV.

2. O diálogo com os leitores, pela internet, é ótimo, mas também pode ser cansativo por conta de comentaristas mal intencionados.

3. É preciso aceitar que, mesmo com recursos de gravação e conteúdo on-line, você nunca será capaz de assistir a tudo que quer.

4. É triste constatar que muitos programas que você admira fracassam e são cancelados por falta de audiência.

5. As pessoas que trabalham na TV nem sempre reagem bem ao que você escreve. (STYCER, 2016, p. 22)

Pelo texto de Ryan, Stycer procurou contemplar seu público com as dinâmicas e entraves que é escrever sobre televisão. Inclusive, o crítico sempre aponta que a crítica de televisão no Brasil é constantemente vista como a menor entre as demais. 


\subsection{Patrícia Kogut}

Retrato dos documentos:

ENTREVISTA

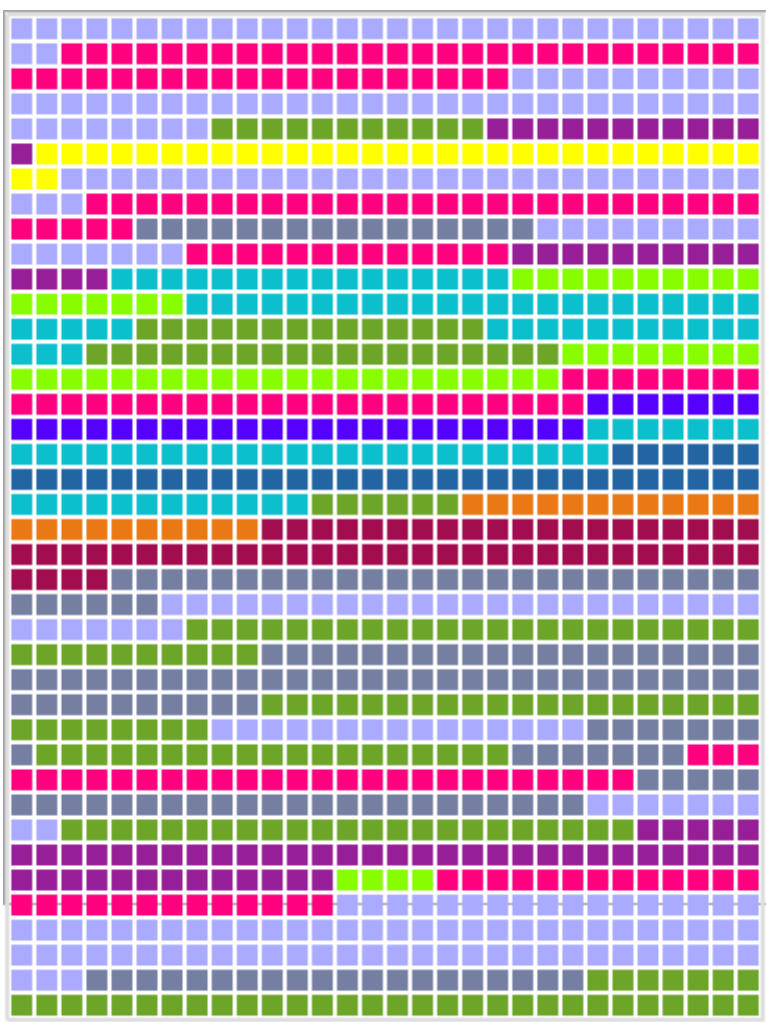

\section{CRÍTICAS}

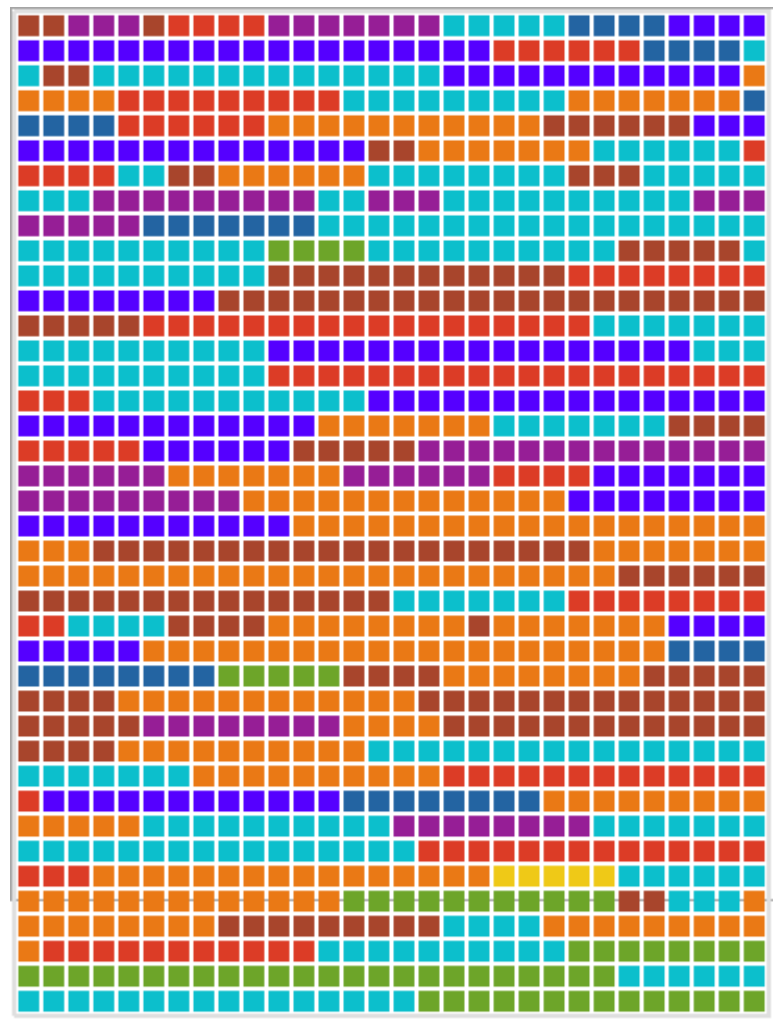

Fonte: Elaborado pela autora - Maxqda

O jornalismo não foi a primeira opção profissinal para Patrícia Kogut, que anteriormente ao curso de Comunicação Social, habilitação em Jornalismo, cursou um ano de Letras em Francês. Neste período, passou a estagiar na Editora Bloch, nas extintas revistas Manchete, Fatos \& Fotos, Desfile e na Pais e Filhos, que perdurou até 1995. Em seguida, se iniciou no Jornal O Globo, no suplemento de TV, e foi neste estágio que estreou sua atividade como crítica de televisão. A coluna de televisão, como ela relata, foi herdada e, até aquele momento, o que se tinha de crítica neste espaço era apenas o nota 10 e nota 0. Em 1996, Kogut relembra que começou a fazer críticas pontuais, especialmente de estreias, mas foi somente a partir dos anos 2000 que ela passou a se dedicar ao ofício com mais frequência, abarcando não somente a crítica de telenovela, mas também a crítica de séries estrangeiras em canais de TV Paga. 
Eu comecei o negócio da crítica de séries, que ninguém fazia e com isso eu trouxe eu acho (tudo eu estou falando o que que eu acho que é) um leitor, que é um leitor jovem, que é um leitor que estava sem lugar, porque ninguém estava fazendo isso, porque era um assunto que estava chegando no Brasil e tal.

O código Trabalho (lilás claro) se refere, neste caso, à trajetória profissinal de cada profissional entrevistado neste estudo. O código é visto majoritariamente no retrato das entrevistas, pois foi onde focamos em perguntas que tratassem acerca desta trajetória. Logo, ele se destaca no retrato do documento da entrevista, especialmente no início e no fim. Com ele entendemos o percursso profissional da jornalista na cobertura de televisão e como foi que chegou a realizar a crítica. Também contemplamos neste código a rotina de trabalho que envolve também a reflexão sobre a crítica bem como os critérios de análises. Abaixo, Kogut comenta sobre sua rotina na redação do O Globo:

A televisão fica ligada aqui sem som, você vê está ligada, eu liguei, eu não estou vendo isso. Eu ligo, mas o meu trabalho não é ficar vendo televisão loucamente. O meu trabalho é ver televisão pontualmente. $E$ escolher o que é importante e comentar o que é importante na televisão. Então, não é ficar zapeando e vendo qualquer coisa irrelevante. Não é. É, às vezes, você enxergar com seu olhar, você procurar uma coisa que não está no mainstreaming, não é campeã de audiência, mas é legal e você apontar aquilo para o seu leitor. Então tem uma coisa de você observar a televisão, mas tem uma coisa de você refletir o que é relevante na televisão.

O azul turquesa que representa o código Roteiro e Texto mostra-se no retrato da entrevista, porém tem mais predominância no retrato das críticas. Este código se dispõe a tratar da importância de um roteiro bem construído e sua execução no decorrer da transmissão. Neste quesito está implicado o que a jornalista denomina de Novela Moderna, que, para ela, significa uma trama que não admite muita enrolação, são diálogos e cenas mais curtas, e isso, ela explica, é reflexo da disputa pela atenção do telespectador, que, por sua vez, ficou mais fragmentada. Nas novelas modernas, os elencos são compactos e é preciso cativar o espectador com um enredo que não estaciona.

A reincidência desse código no documento das críticas mostra como ele é um requisito importante na análise, alçando a acuidade também da autoria. Sabemos que a questão estética das ficções, pautadas pelo padrão Globo de qualidade, dota as narrativas 
com excelência quanto à cenografia, edição e direção. Porém, é no texto que a cobrança pelo cuidado é maior, e é justamente neste ponto que Kogut afirma: Mas o texto é o principal de uma novela. Eu acho que você ser popular e não fazer isso. A Glória Perez na Força do Querer, ela falou para o público, ela sabe ser popular, você não ficava ouvindo palavrão, não ficava ouvindo essa coisa chula. A crítica ainda destaca os autores que, ao seu ver, apresentam um texto cuidadoso:

Então, falando em quem tem texto bom, as novelas do Miguel Fallabella que talvez não foram grandes sucesso de audiência, mas um cara preocupado com diálogo, com o português. É legal isso, eu acho um prazer. O João Emanuel, é espirituoso, ele aposta no ouvido do telespectador.

Em verde escuro, o código Reflexões sobre a telenovela é visto com maior frequência no retrato das entrevistas do que no documento das críticas. Distribuído do início ao fim, podemos relacionar este código com o Relação com a Telenovela, em amarelo forte, presente somente no retrato das entrevistas. A telenovela possui uma relação íntima com seus espectadores, pois é no ambiente familiar que se iniciam os primeiros contatos. Kogut afirma que somente acompanha as ficções brasileiras, pois entende seu valor de formação na cultura nacional e na relação afetiva. Em vista disso, ela aponta: A crítica de novela ela tem muito mais repercussão do que a crítica de série. A novela é o canhão de audiência, é o produto mais importante da televisão, tenho total consciência disso e procuro ser lida por esse leitor que quer isso.

Como os demais entrevistados, não lembra ao certo como passou a assistir, mas que a teleficção sempre esteve presente no cotidiano, desde a infância.

Todos os discos do Caetano que me acompanhava. Todo verão ele lançava um disco, e aquilo para mim acompanhou, trilha sonora da sua vida, a novela tem isso. A novela ela está na tua memória, ela está na tua formação, ela tem esse valor de formação. A gente viu a evolução da novela, a gente se apaixonou por alguns personagens, aquilo está na vida de todos nós, e eu cresci no Brasil, né. Acho que é igual de todo mundo.

As reflexões sobre a telenovela tiveram como questão central a ficção como obra aberta, o que condiciona a crítica a ter esta abertura de avaliação, sempre relacionada ao que está sendo visto naquele momento. 
A novela tem um número determinado de capítulos, é criada com a premência do tempo; o romance é escrito ao ritmo dos autores e tem o número de páginas que ele quiser. Alguém poderia dizer que romance é arte e novela, embora tenha muitos componentes dela, é indústria cultural, ditada por suas necessidades. Ambos, porém, são oceanos a se atravessar.

A jornalista menciona que a internet a libertou da grade horária, em particular, com a utilização da plataforma de streaming Globoplay, facilitando o acesso aos capítulos a qualquer momento.

O Globoplay me salva muitas vezes. Por exemplo, essa cena da Maria da Paz atirando, eu não vi no horário, eu não estava em casa. Eu vi no Globoplay. A internet me libertou dos horários, porque por exemplo, quando o primeiro capítulo eu tenho que assistir, eu tenho que fazer aquela crítica; às vezes sei lá, você tem outras coisas na sua vida, você tem filho, você tem não sei o que, aconteceu um negócio. E aí eu não fico tão presa ao horário, eu tenho o horário que eu tenho que escrever, naquele horário eu tenho que escrever. Mas eu posso assistir daqui mais tarde.

O código que representa a utilização das redes sociais é o vermelho escuro, aparecendo principalmente no documento das críticas. Cabe relatar que Patrícia Kogut, ao contrário de Nilson Xavier e Maurício Stycer, pouco utiliza o Twitter. Para ela, a rede social que mais gosta é o Instagram, que utiliza majoritariamente para divulgação das postagens do blog. O espaço deste aplicativo permite uma interação abrangente com o público, que, por meio de comentários, tem acesso ao que os leitores estão pensando e assim pode sentir o termômetro da repercussão, além de ter ideias para pautas.

Vou ser super franca com você, eu acho o Twitter meio chato, mas é gosto. Assim, de todas as redes, eu tento; eu tenho muitos seguidores no Twitter, as coisas que eu escrevo no meu site, elas entram no Twitter automaticamente. Eu uso o Twitter para medir temperatura e tal. Mas eu adoro o Instagram, eu adoro. A gente tem o perfil do Facebook da coluna, e tudo isso eu olho muito. O Instagram da coluna eu faço, ele é muito ativo, todo manual, ao contrário do Twitter que é misto. As coisas que entram no meu blog, que hoje em dia a gente chama de site porque ele foi redesenhado, elas entram no Twitter. E eu entro ali para comentar também, mas o Instagram é todo feito a mão. Uma rede que eu uso muito. Eu vejo os comentários de leitores, a gente vê, a gente presta atenção. Às vezes a gente precisa de uma nota 0 , falo assim 'vê o quê que os leitores estão dizendo?', ai eu olho o que que os leitores estão dizendo; tem uma dica ali. Aí eu vou e procuro no Youtube para assistir. Então eu uso sim, eu sou superatenta. 
A Construção do personagem em azul escuro é marcante no retrato das críticas. Outra cor, bastante visível neste mesmo documento, é o laranja, representante da Verossimilhança. Ambos abordam aspectos estruturais das narrativas que são frequentes nas críticas.

\begin{abstract}
A mais evidente é a tirania de Joyce, figura frívola e obcecada por vestidos e saltos altos. Sem falar na sua dificuldade para enxergar o outro. As novelas tradicionalmente costumam sublinhar bem as características de seus personagens. Para dar o seu recado com clareza, Gloria pegou esse caminho e opôs Joyce e Ivana, como nas clássicas dinâmicas de heroína e vilã. O tema é muito bom e está na ordem do dia. A interpretação de Carol pode colaborar para que essa trama corra com toda a sutileza que ela merece.
\end{abstract}

A questão da verossimilhança nas telenovelas é constante devido ao naturalismo e ao realismo. Por mais que algumas ficções admitam certa fantasia, o horário das $21 \mathrm{~h}$ sempre se pautou por narrativas que abarcam a realidade ou a aparência do que acreditamos ser verdadeiro. O mundo ficcional criado para esta narrativa é sempre pautado de regras que abrangem componentes externos e internos. Para Ryan (2014), o mundo narrativo é composto por existentes, referente aos personagens e aos objetos que compõem a trama; o cenário; as leis físicas, que se configuram pelos princípios que determinam quais os eventos que podem ocorrer nesta história; as regras e valores sociais, que regem os personagens e suas obrigações; os eventos, que são as ações que contribuem para as transformações na ficção; e os eventos mentais, elemento subjetivo que define as reações dos personagens.

Isto posto, Kogut, em suas argumentações, requer uma lógica, como em Outro Lado do Paraíso, sobre a mãe que não reconhece a filha: Entre algumas barbaridades, ela não reconheceu a filha que abandonou na infância. E vice-versa. Ué, ninguém teve a curiosidade de olhar uma fotografia antiga ou de pesquisar a internet? O wi-fi é ruim em Palmas?

Outro exemplo desta cobrança pela coerência está em Salve Jorge, que tinha como um dos núcleos principais as favelas cariocas:

A violência encenada, entretanto, é um risco. Foi graças aos exageros dramáticos que Morena, em meio a um tiroteio, deitou-se no chão protegendo o filho e... gritando. Quem grita quando se esconde? A derrapada não chegou a atrapalhar: a ideia de misturar imagens reais da chegada da UPP ao Complexo foi excelente e bemexecutada. A guerra era do Rio, mas ganhou o coração de todos os brasileiros, público para o qual a novela se dirige. 
Temáticas sociais (cor marrom) foi um tópico somente aludido no retrato das críticas. Sabemos que a telenovela atua como um recurso comunicativo (LOPES, 2009), em que campanhas sociais são inseridas na narrativa. Balogh (2002, p. 164) aponta que a ficção das $21 \mathrm{~h}$ é mais comprometida com a realidade, em seu viés naturalista, portanto admite o merchandising social:

Essas pequenas mensagens inovadoras abarcam um espectro bastante grande de temas e problemas sóciopolíticos que levam os atores ao papel de porta-vozes, de bardos, instando o público a tomar prevenções contra o câncer de mama, exigir nota fiscal de compra para evitar sonegação, a doar órgãos para salvar doentes e até mesmo a votar com responsabilidade, entre outros (BALOGH, 2002, p. 164).

Ao referir-se sobre a personagem transsexual Ivana/Ivan, de A Força do Querer, Kogut reflete: A tarefa da autora não é fácil: ela não trata apenas de um assunto que era proibido na teledramaturgia. É mais profundo que isso. Ivana expressa um drama ainda pouco conhecido da maioria dos espectadores. O cuidado de Glória Perez na inserção dos elementos que favoreceram abordagem do tema é mencionado:

A primeira, de Ivana na terapia. Foi uma sequência longa, cheia de silêncios. O risco de entediar o público acostumado à ação acelerada era grande. Mas isso não aconteceu. A personagem foi falando dos pais, de alguns acontecimentos marcantes da infância e de suas angústias. Carol, excelente, teve ali uma oportunidade de provar seu talento. E provou. Fez lembrar a dinâmica da série "Sessão de terapia" (do GNT), em que um ator dava seu recado com poucos recursos além do texto. A tarefa não é para qualquer um e Carol se deu muito bem.

Nas críticas de Patrícia Kogut, os códigos Roteiro e Texto, Temáticas Sociais, Verossimilhança e Construção do Personagem foram mais expressivos, comprovando os principais critérios técnicos adotados pela jornalista. Seu processo de escrita, como ela descreve, é feito na própria redação do jornal, em sua sala, onde a TV está o tempo todo ligada no volume mais baixo. Além disso, ela comenta que escreve todos os dias, numa rotina estrita de acompanhamento das ficções, tendo em vista que seu blog também contempla a crítica de séries de TV paga. 
A Nota da Kogut é um quadro diário no qual a jornalista designa 10 e 0 para determinada cena ou aspecto mostrado na televisão, seja de um programa ou reality. Kogut explica que as notas já são uma forma de crítica sintetizada, pois são frases curtas, que existem desde os primórdios da coluna no jornal impresso e que segue no blog. Outra interação importante nas notas é a sua publicação na página do Instagram da coluna, que conta com mais de 300 mil seguidores até o momento. A página em si funciona como um chamariz para as postagens do blog e dos pequenos vídeos (stories), apresentam notícias da televisão, sinopses das telenovelas e as notas. A jornalista, dentre os críticos estudados, é a que mais utiliza a rede social que tem como foco a postagem de imagens. Nestas publicações, o espaço para as curtidas, o compartilhamento e os comentários funcionam como uma estratégia de divulgação, como ferramenta de interação com os leitorestelespectadores e fonte de pautas, pois as redes funcionam como um termômetro da audiência convencional.

Em síntese, os retratos dos documentos demonstraram as características de Patrícia Kogut na confecção das críticas, no seu processo de análise e quais critérios ela adotou. E, apesar de escrever para o jornal pertencente ao mesmo grupo empresarial da TV Globo, a crítica consegue apresentar seu ponto de vista por meio dos argumentos técnicos que contribuem para o embasamento de suas avaliações. Desta maneira, Kogut acredita que a cultura brasileira não é muito afeita à crítica, porém confia que o papel deste ofício é justamente dialogar e refletir a importância daquilo que o público está assistindo. 


\subsection{Nilson Xavier}

Retratos dos documentos:

ENTREVISTA

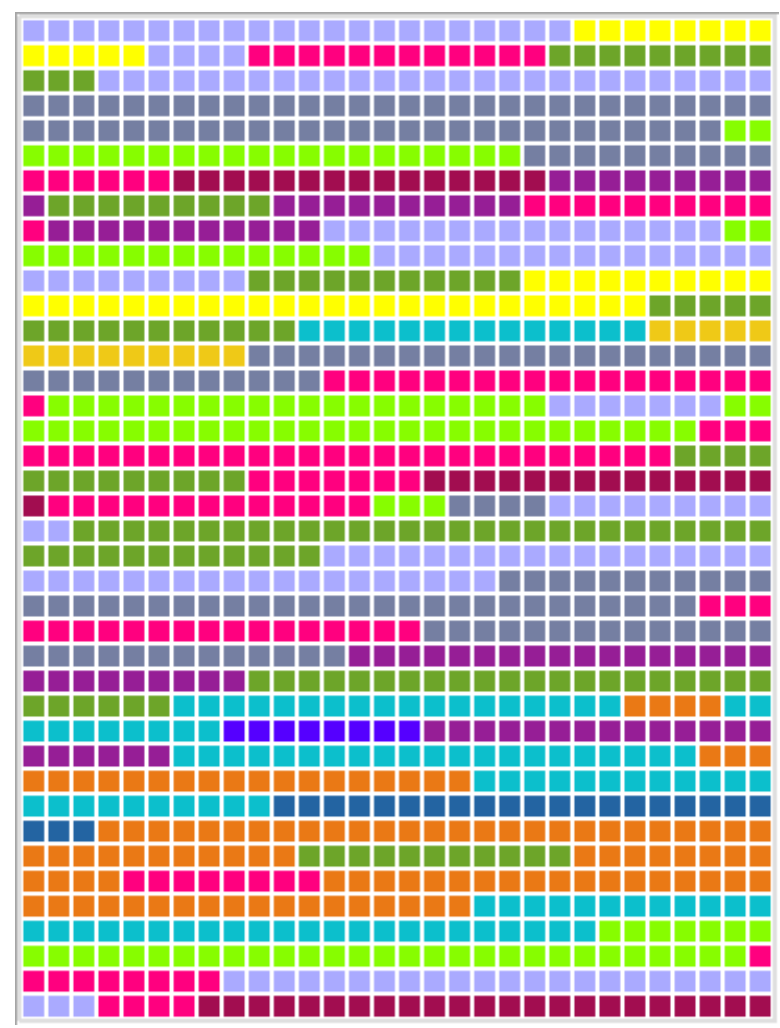

\section{CRÍTICAS}

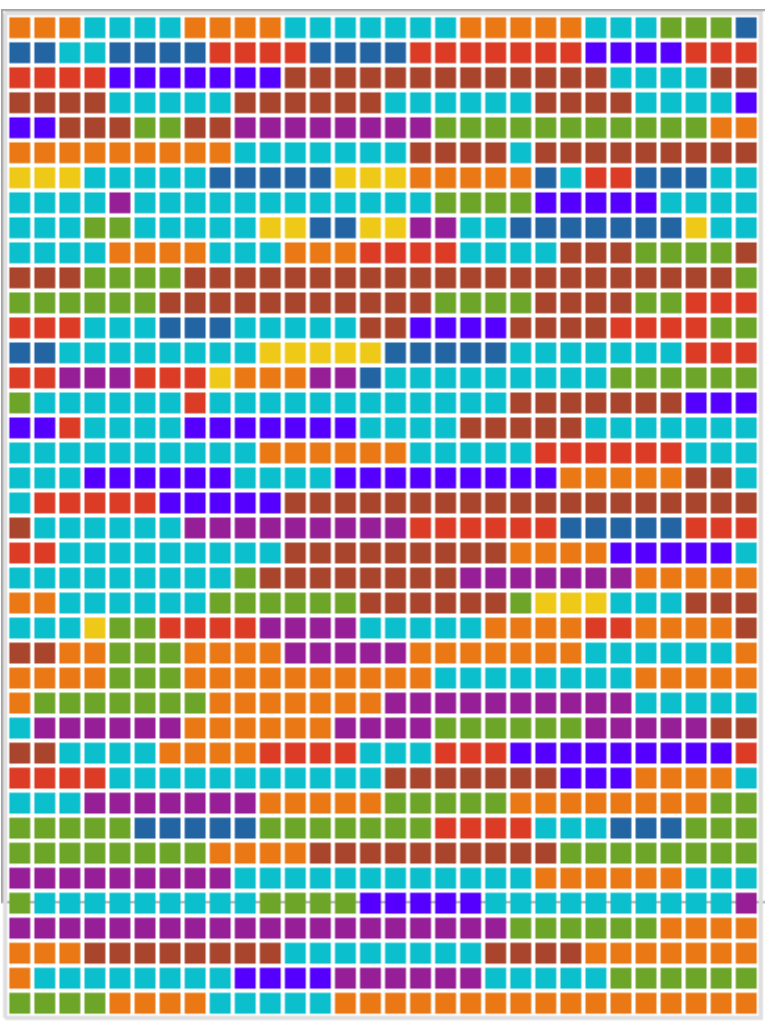

Fonte: Elaborado pela autora - Maxqda

Diferentemente dos demais críticos, o blog de Nilson Xavier é voltado especificamente para as teleficções. Sua trajetória neste ofício também é distinta, pois sua formação acadêmica é em Administração e somente após anos trabalhando na área de informática que resolveu se dedicar exclusivamente à escrita sobre as narrativas. Sua relação com a telenovela, identificada no retrato das entrevistas pela linha de cor amarelo, iniciou-se na infância, e, desde então, passou a anotar todas as ficções que o interessavam. A afetividade com a telenovela é apercebida pela sua atividade de colecionador, especialmente das trilhas sonoras das telenovelas.

Afetiva, porque vêm desde criança. Desde criança eu sempre gostei muito de televisão, eu cresci na frente da televisão. E desde criança eu anotava de forma sistemática tudo o que eu assistia, desenhos, novelas, séries da minha infância. Então esse foi um hábito que eu nunca 
larguei, mesmo depois da vida adulta, depois de ter entrado na carreira de informática eu nunca abandonei isso. No ano de 2000 lancei meu site Teledramaturgia e foi como tudo começou.

Segundo Lopes et al (2015, p. 32), Xavier é um exemplo de fã-curador, pois acumulou mais de 20 anos de material sobre as telenovelas, o que possibilitou a criação do site Teledramaturgia ${ }^{26}$ em 2003, com informações sobre as ficções, e a publicação do livro Almanaque da Telenovela Brasileira (2007). Com sua atuação no site, Xavier passou a ser reconhecido como uma fonte acerca do tema, o que o levou a conceder entrevistas e o impulsionou a continuar nesta atuação.

Coletando informações desde criança e tendo como base o livro de Ismael Fernandes, Nilson ampliou seu conhecimento sobre as telenovelas e tem certeza de que teve a ideia certa na hora exata: lançou o site Teledramaturgia quando a internet começou a engatinhar. $\mathrm{Na}$ sequência, criou o site Teledramaturgia, que começou modesto, cresceu e notabilizou seu autor na área, ou seja, construiu um self totalmente relacionado a um tema do qual era fã: "hoje eu vejo que eu tive um estalo, uma boa ideia no momento certo, no momento propício, porque, se não fosse eu fazer, outra pessoa teria logo depois feito. Porque minha ideia não é original, só que eu tive ela primeiro". (LOPES et al, 2015, p. $34-35$ )

O percurso profissional de Nilson é representado pela categoria Trabalho, na cor lilás claro, no retrato da entrevista. Foipor meio da visibilidade conquistada que, em 2012, passou a colaborar no canal Viva, e, neste mesmo ano, estreou com o blog no portal UOL, como explica:

Desde 2012 no UOL, e eu comecei por causa da minha trajetória, eu tinha o site, ele ganhou projeção. Lancei o almanaque de Telenovela Brasileira em 2007, e ganhou mais projeção. Então eu fiquei conhecido tanto entre estudantes, quanto em curiosos, quanto de profissionais de televisão e dos jornalistas. Então o James Cimino que é um jornalista que hoje está fora do Brasil, mas na época em 2012 ele era jornalista do UOL, ele me convidou para escrever para o UOL, foi aí que eu comecei a escrever no UOLl. Eu tinha um blog particular, que era meu, fazia ali resenhas de novelas, análises críticas, e ele perguntou para mim: você não quer fazer isso que você faz no OLl e ganhar por isso? Aí eu falei: é tudo que eu quero! Daí estou no UOL desde então, foi aí que eu comecei.

${ }^{26}$ Ver teledramturgia.com.br 
Até este momento, o site era visto pelo crítico como um hobbie, uma maneira de continuar com seu trabalho de curadoria que teve início na infância. Porém, a consolidação de seu papel como crítico só veio por meio do blog, em que adquiriu mais reconhecimento no campo e entre seus pares. Como adquiriu ao longo dos anos um arcabouço simbólico e material acerca das ficções, Xavier relata que a confecção da crítica é ao mesmo tempo um trabalho subjetivo como também compreende alguns pressupostos, tais como conhecimento sobre o formato telenovela, as referências e até mesmo o campo do audiovisual como um todo. Para isso, em seu cotidiano, o crítico não dispensa as idas ao cinema, o que incrementa seu conhecimento e sua vivência.

Você tem que escrever bem, você tem que dominar a língua, lógico; $e$ você tem que ter todas essas referências que eu falei para você. Referências de cinema, de livros e a Vivência. Ter visto muito novela na vida. E como eu cresci na frente da TV, eu tenho essa referência, acho que para escrever sobre o que eu me proponho a escrever, eu me sinto apto. Pelo menos as pessoas consideram isso também.

Os critérios de análise, código disposto num verde claro, é visto somente no documento da entrevista. Nesta parte, o crítico explica que suas avaliações são pontuais do momento:

\begin{abstract}
A minha crítica é sempre pontual do que eu vi daquele momento. Já mudei minha crítica várias vezes. Aquele menino Bruno Montaleone que fez a novela $O$ Tempo não para. Assim que a novela estreou eu critiquei o desempenho dele achei muito ruim, só que com o passar do tempo eu vi que ele teve um avanço, e eu revi minha crítica ao final. Então, a telenovela ela pode começar boa ou ficar ruim depois, isso acontece. O Tempo não Para é um exemplo disso. Babilônia, o primeiro capitulo era maravilhoso, mas depois, se você olhar a minha primeira crítica de Babilônia eu enalteço a novela, melhor roteiro, uma coisa assim que escrevi... É muito ruim escrever no início, é péssimo.
\end{abstract}

Como a crítica acompanha o ritmo imposto pela telenovela, o olhar do crítico analisa o que foi realizado até aquele instante, deste modo é normal e até frequente, a mudança de opinião acerca da obra. O que o crítico não acha benéfico são as análises de primeiro capítulo, pois, geralmente, a estreia de uma telenovela é um capítulo com maior apuro estético e que tem o intuito de convidar o telespectador para vê-la. Desta maneira, há certo cuidado no texto e na imagem nos primeiros capítulos. Sabendo deste aspecto, Xavier procura alertar para esta característica, afirmando que procura escrever com prudência, porque eu não tenho informação nenhuma, geralmente a emissora faz uma 
estreia que é para encantar as pessoas. Agora o que vai ser de fato a novela, precisa de duas semanas pelo menos para você gabaritar. Para você dizer a novela é isso ou a novela é aquilo.

O código Roteiro e Texto está disposto nos dois documentos, com maior frequência nas críticas. Para o crítico, o texto da telenovela, por mais que admita alterações ao longo da exibição, deve partir de certa coerência no tratamento das questões que a narrativa propôs. $\mathrm{Na}$ entrevista, o crítico aponta para a virtude do texto:

Não, acho que quem apresentou alguma coisa nesse sentido foi a Glória Perez com A Força do Querer, que realmente era uma novela que trazia temas muito interessantes para nossa sociedade e de uma forma muito bem colocada. Sem subestimar o público e sem querer causar sensacionalismo, como às vezes o Carrasco faz. Um texto cuidadoso, um texto bom, um texto bonito.

O humor carrasquiano - outra marca indelével do autor - esteve onipresente. Combinado com o seu texto, soou infantil muitas vezes, quando não sem graça. Várias sequências e personagens resvalaram na comédia digna de programas de humor populares e de gosto duvidoso. Outro cuidado que o autor precisa ter. Alguns acham graça, mas não é unanimidade

A redundância textual da telenovela poderia ser um fator para que, em certos casos, haja uma deterioração do texto. A repetição é uma característica particular do folhetim, inclusive Pallottini (1998) ressalta que os autores têm a função de repetir de diferentes maneiras, através dos personagens ou acrescentando novas informações. A recapitulação é algo esperado de seu público, que, por vezes, pode esquecer de informações mencionadas há meses.

O texto da telenovela é estruturalmente muito mais frouxo do que o texto artístico, por ser extremamente fragmentado e muito extenso. É mais passível de remodelação, de absorção e até de invasão de elementos externos como os dados do cotidiano, o merchandising e a incorporação de outras linguagens, sejam literárias, visuais ou audiovisuais. Desse modo, a serialidade da telenovela tende a ser menos rica em termos de significação do que texto artístico, basicamente ambíguo e plurissignificativo. Em contrapartida, o que a novela parece deixar de lado em termos de significação, ganha, aparentemente, em termos de comunicação (BALOGH, 2002, p. 163). 
Outro código recorrente nos dois documentos é a Verossimilhança (laranja). Pela mimese, imitação da realidade, a verossimilhança, no caso da telenovela, é explicada pela sua característica naturalista, especialmente a telenovela das $21 \mathrm{~h}$ se pauta em temas prementes da sociedade brasileira.

Novela nenhuma tem a obrigação de fazer merchandising social. Não precisa ter campanha de conscientização nem resvalar no politicamente correto. Entretanto, quando a obra se propõe a isso (caso de "O Outro Lado do Paraíso"), espera-se um mínimo de qualidade e o comprometimento com a pauta da sociedade. Melhor que a trama tivesse ficado no horário das seis.

Temáticas sociais foi notificado somente no documento das críticas. Xavier é um crítico atento aos temas sociais abordados nas tramas e costuma relatá-los nas críticas, como no caso de $O$ outro lado do Paraíso, que aponta: Ao tratar racismo, homossexualidade, nanismo, alcoolismo, violência doméstica, assédio, corrupção e prostituição, o autor perdeu a oportunidade da abordagem profunda, conduzindo tudo para a caricatura ou a discussão rasa, com desfechos mal alinhavados e vazios. A demanda pela responsabilidade no tratamento de assuntos polêmicos e sérios é intrínseca à sua crítica. Nilson requer do autor a qualidade do texto e que se construa uma reflexão nas questões sociais levantadas, e ainda requer do público a atenção para escapar das armadilhas de uma ficção sem racionalidade.

Da mesma forma, a racista, que durante a novela inteira proferiu impropérios contra negros, ao final, como num passe de mágica, tomou consciência de seu preconceito. Não houve a intenção de levar homossexualidade e racismo à pauta da sociedade, apenas apresentar como alívio cômico para fisgar audiência. Um desserviço se pensarmos que personagens preconceituosos (assim como os vilões) funcionam como uma válvula inconsciente de escape, para que o público extravase o preconceito através de esquetes de humor.

O código Construção do personagem é pontuado do início ao fim do documento das críticas. Partindo do princípio de que as personagens são responsáveis pela concretização da afinidade entre o indivíduo e a narrativa, o peso dado pelo crítico para a categoria é evidente. Como um código técnico que faz referência ao texto da telenovela e por conseguinte à autoria, o crítico ainda ressalta para a escalação dos atores, o que está ligado à categoria Atuação (vermelho), tal como o fragmento abaixo: 
Bianca Bin, ótima na primeira fase da história, caiu na armadilha da cara de paisagem para justificar uma personagem fria e vingativa; $e$ Julia Dalavia ficou limitada a uma personagem ruim e sem camadas, diferente de seus trabalhos anteriores, pelos quais foi bastante elogiada.

[...] brilharam Eliane Giardini, que imprimiu personalidade e carisma à sua personagem racista; Fernanda Montenegro, que tentou levar com dignidade uma personagem nada crivel; Marieta Severo, que sabiamente fugiu do tom cômico na criação da vilã maniqueísta; $e$ Laura Cardoso, que mesmo com uma personagem pequena, deu a impressão de se divertir em cena. Há de se registrar ainda as ótimas atuações da experiente Ana Lúcia Torre e da novata Bella Piero, e o desperdício de Fábio Lago, Zezé Motta e Tainá Müller, atores talentosos relegados a papéis menores e sem importância.

O código repercussão - audiência e redes sociais designa para as críticas que mencionam tanto a audiência tradicional quanto aquela audiência percebida pelas conversões em redes pelo número de impressões nas redes sociais. A discussão sobre como mede a audiência e fatores que contribuem para tal número não escapa da crítica do profissional.

Sabemos que Ibope mede audiência, não qualidade, e que audiência e qualidade nem sempre andam juntas. Para explicar o ibope da novela, vários fatores podem ser considerados, como a fraca concorrência, a crise econômica e o hábito de manter a TV ligada na Globo.

A percepção da audiência das redes é notada, principalmente, pela utilização das redes, código também em destaque nos documentos. Nilson relata a forma como emprega as redes: Como eu estou em contanto no Twitter sempre, acho que eu consigo fazer esse apanhado no geral ou mesmo até um afunilamento de informações, de forma a organizar até as minhas ideias na hora em que eu for escrever.

É também pela rede social que o crítico se sente ancorado para entender a percepção do público, como uma espécie de feedback instantâneo do que está sendo transmitido: Agora a novela não tem como, não te dá essa possibilidade. Então eu nem vejo Órfãos da Terra antes, eu prefiro ver no calor em que ela está sendo exibida e acompanhar com o Twitter, porque dai eu tenho respaldo de quem tá vendo junto comigo.

Souto (2019), em sua análise dos críticos de televisão no Twitter, distingue que Nilson Xavier é o único entre os críticos contemporâneos que, tendo iniciado sua carreira 
escrevendo para um portal de notícias on-line e ainda empregar nas críticas o uso da redes sociais, deu-lhe conhecimento dos códigos e estilo comum de escrita nesse ambiente. A ferramenta, a priori, é qualificada para a divulgação das postagens no blog. No entanto, como também observamos nos demais críticos, as redes são usadas como usina de pautas e para entender o que o público está comentando sobre a telenovela, seja no horário da exibição ou posteriormente.

Mas são as mensagens superficiais e de caráter apenas opinativo que tendem a despertar maior interesse entre os seguidores, restando pouca ou nenhuma interação dos usuários com os tuítes que divulgam a produção crítica propriamente dita. Nota-se também que, independente de as mensagens publicadas pelos críticos serem opinativas ou relacionadas à sua produção, os comentários gerados a partir deles apresentam teor predominantemente frívolo e com baixo potencial de contribuição ao desenvolvimento e à evolução das produções audiovisuais brasileiras (SOUTO, 2019, p. 05).

Por meio do excerto abaixo, temos uma ideia da dinâmica de construção da crítica pela rede social:

Meu caderninho é o Twitter. Às vezes eu faço uma enquete, 'o que você está achando disso', as pessoas me dão ideias. Às vezes eu jogo um verde, para ver se aquilo gera buchicho. O Stycer faz isso também. Quem usa bastante o Twitter faz isso. Eu comecei no meu trabalho nisso, porque eu já tuitava antes de escrever crítica, então eu já estava nesse universo antes de começar a escrever

A competência simbólica e cognitiva de Xavier no Twitter fica explícita em suas críticas onde sempre destaca as hashtags de maior relevância e a forma como interage com diferentes pessoas pelo aplicativo da rede.

Avenida Brasil foi a primeira novela coqueluche da Internet. Que o
digam os memes referenciando a trama, a cascata diária de "oioiois"
no Twitter e as inúmeras charges engraçadinhas no Facebook. Hoje já
não se espera mais o dia seguinte para comentar a novela com o
vizinho. É tudo em "real time", como se o telespectador fosse à janela
gritar para os vizinhos o que achou de determinada cena. Avenida
Brasil conseguiu reunir todas as noites milhóes de brasileiros, ávidos
em compartilhar opiniões, em um mesmo sofá, virtual.

Vale comentar a utilização de Glória Perez no Twitter, na época de Salve Jorge, telenovela com graves problemas de roteiro. O comportamento da autora na plataforma foi um dos assuntos tratados na análise da ficção, pois ela constantemente utilizava sua conta na rede social para rebater as críticas que recebia quanto à coerência de algumas 
cenas e problemas de continuação, o que levou a uma série de discussões virtuais com os telespectadores. Xavier, por sua vez, relata a conduta de Perez:

A acusação de que existia uma campanha deliberada contra "Salve Jorge" - em que até sugeriu que havia gente recebendo dinheiro para falar mal da trama - mostra que a aproximação com o público tem dois lados: pode aproximar ou afastar. Bloquear perfis que criticam e retuitar apenas os que elogiam talvez tenha sido uma forma nada amistosa de lidar com a situação. Pelo contrário. A meu ver, gerou antipatia e só alimentou ainda mais o bonde do recalque.

A exigência que telenovela das $21 \mathrm{~h}$ merece um texto mais realista e cuidadoso é uma das demandas da crítica de Nilson Xavier. As discussões sobre os embates entre a fantasia e o realismo, as enrolações do roteiro, as chamadas barrigas, além das observações acerca do papel da telenovela na sociedade brasileira, são alguns dos temas abordados nas críticas. Com seu trabalho de curador e fã do folhetim nacional, Xavier é conhecedor dos pormenores que compreendem as tramas, o que deixa perceptível, em seu texto, que contêm detalhes e ligações com outras telenovelas além da que está em análise.

\subsection{O Conjunto dos códigos analisados}

Os códigos apresentados nesta pesquisa correspondem a uma pesquisa de caráter empírico na qual, por meio uma metodologia multidisciplinar, procuramos compreender a crítica de telenovela contemporânea realizada nas mídias digitais. Entre os destaques da pesquisa, focamos em apresentar parâmetros de análise para o estudo da crítica de telenovela, espaço que ainda necessita aprofundamento tanto da área da acadêmica como do jornalismo. Isto posto, separamos os códigos em três grandes conjuntos, no qual, em nosso entender, correspondem a três grandes categorias de análise na qual as críticas de telenovela podem ser abarcadas. O intuito não é dá peso para cada grupo, mas, sim, apresentar pontos de aproximação que as análises podem ser tratadas. Salientamos que esses dados, e logo a categorização, foram construídos a partir de nossa base de dados coletados de quatro críticos de televisão e cinco telenovelas do horário nobre brasileiro, que foram representativas, isto é, com maior audiência no período entre 2012 a 2018. Nossa finalidade não é divulgar um manual definitivo acerca da análise de críticas, todavia, expor as pistas metodológicas advindas de uma cartografia da crítica e de críticos. 
Neste sentido, reunimos em três grupos os códigos:

- Códigos Técnicos: Concernentes aos códigos que demarcam um juízo de valor e estão ligados a análises de produtos audiovisuais, tais como o Roteiro e Texto, Verossimilhança - Realismo, Temáticas Sociais, Construção de personagem, Repercussão, Atuação e desempenho da atriz/ator, Direção e Estética.

- Códigos Reflexivos: Está atrelado às práticas culturais, ao habitus (BOURDIEU, 2011) como capital cultural acumulado. Este grupo é composto por Reflexões sobre a telenovela, Reflexões sobre a crítica, Processo de Análise, Critérios de Análise e Relação com a Telenovela.

- Códigos de Práticas profissionais: São correspondentes ao fluxo de trabalho e, consequentemente, atuação no campo. Identificamos os códigos Trabalho e Utilização de Redes Sociais.

Os códigos técnicos são intrínsecos ao entendimento do potencial cognitivo da telenovela, isto é, a criticabilidade de uma obra (CASTRO, 2014, p. 21). A própria existência de uma crítica voltada para a teleficção já se torna uma constatação dos atributos reflexivos e artísticos deste produto. Sem levarmos em consideração a ficção como um produto da indústria cultural, pensamos na telenovela como uma produção que admite um lado mercadológico, pois visa à comercialização, e do ponto de vista do entretenimento, que, pelo naturalismo, discute temas importantes da sociedade. Benjamin chega a afirmar que "o aspecto decisivo da atividade crítica é o de saber se ela se fundamenta numa análise objetiva, num plano estratégico que contenha em si mesmo uma lógica e uma honestidade próprias" (2018, p. 107); por esses códigos temos uma noção das estratégias e dos eixos principais de análise que levam para a argumentação central das críticas.

Outro ponto que descreve este conjunto são os aspectos internos e externos de uma obra, a partir de Antonio Candido. Na explicação de Castro sobre o trabalho de Candido, ela explica que "em sentido mais abrangente, crítica seria, para Candido, o esforço de interpretação da obra, que inclui os aspectos estéticos - os fatores literários, o "gosto" - e o histórico cultural - os fatores não literários" (CASTRO, 2014, p. 38). Para Candido, os fatores externos devem esclarecer o advento de uma obra e não ao contrário, como comenta Castro (2014). Esse movimento de dentro para fora está atrelado ao que 
os críticos destacaram como contextualizar a ficção, em outras palavras, conceder uma interpretação dos aspectos ficcionais que estão sendo exibidos. Aspectos estéticos, que denominamos de técnicos, são pressupostos fundamentados no juízo de valor, na veracidade e no entretenimento, afinal a telenovela é uma narrativa que visa ao lazer. Logo, a crítica de telenovela, apesar da marcante subjetividade, é refém de sua estrutura em capítulos, o que ocasiona uma crítica fragmentada, expectante das ações daquela semana ou mês.

Candido rechaça a existência de um método para o exercício da crítica, em seu entender, métodos estão relacionados a doutrinas e modelos estanques, o que, para a sensibilidade da crítica, seria um fator limitante. Castro (2014, p. 40) aponta que "um método seria, nesse sentido, uma modalidade de crítica; já a crítica, por sua vez, não tem que ser a aplicação de um método". O crítico deve, portanto, seguir uma metodologia de análise, que pode diferir a cada crítica. É fazer o que mais cedo Benjamin apontou como plano estratégico.

A capacidade da telenovela de criar conhecimento crítico é o traço que observamos na análise das críticas pela atualização de elementos que compõem as análises de produtos audiovisuais e literários. O Roteiro e Texto, Construção de personagens, Verossimilhança e temáticas sociais são categorias que incorporam características vistas em distintos gêneros narrativos, enquanto a estética, a direção e o desempenho da atriz/ator são códigos que compõem o universo do audiovisual e do teatro.

Nas críticas analisadas, percebemos como um artifício de argumentação a citação de algumas partes da narrativa retirando a imagem e dando ênfase ao texto. A intenção de elucidar essas cenas é, em sua maioria, uma maneira de contribuir para realçar a percepção do leitor, que aliado à descrição e uma foto eventual, focaliza nos aspectos tratados na análise. Benjamin (2018, p. 114) distingue que "não pode haver crítica sem pelo menos uma citação da obra que é recenseada"; assim, as críticas usualmente demonstravam seus pontos de vistas por meio da inserção de trechos da narrativa fundamentando sua premissa.

Por Códigos reflexivos, constatamos as categorias Reflexões sobre a telenovela, Reflexões sobre a crítica, Processo de Análise, Critérios de Análise e Relação com a Telenovela, que, em nosso entender, enumeram práticas socioculturais que incidem nas análises críticas. Vinculadas à ideia de habitus (BOURDIEU, 2011), este conjunto de códigos é um registro de novas configurações, ritualidades, sociabilidades de tecnicidades (MARTÍN-BARBERO, 2018). Ao contrário do primeiro grupo de códigos, que se voltava 
para os eixos técnicos da crítica, este grupo se pauta pelo aspecto subjetivo e reflexivo das análises. Castro (2014, p. 09) afirma que a crítica é "recorte cifrado de sua própria experiência, de sua visão de mundo, suas escolhas, seu percurso formativo", assim sublinhamos o caráter abstrato da confecção da crítica.

Das críticas analisadas, é evidente o afunilamento dos temas abordados, tendo em visto que cada crítica se volta para um único tema ou versa sobre questões afins. Tal como relatado pelos profissionais, a busca de pauta decorre, em muitos casos, da interação com o público, seja em comentários ou em redes sociais, é recorrente dissertar sobre um determinado tema que se destacou na semana ou em um único capítulo. Até mesmo a partir de uma única temática, estender a análise para várias narrativas.

O habitus, para Bourdieu (2011), se configura como práticas sociais pelas quais os sujeitos se apercebem do mundo social, está submetido a práticas socioculturais e condições de existência, sendo que, para Setton (2002), Bourdieu entende habitus como uma teoria, e seu conceito tem como proposta discernir a mediação entre indivíduo e sociedade. Abaixo ela explica que:

Habitus surge então como um conceito capaz de conciliar a oposição aparente entre realidade exterior e as realidades individuais. Capaz de expressar o diálogo, a troca constante e recíproca entre o mundo objetivo e o mundo subjetivo das individualidades.11 Habitus é então concebido como um sistema de esquemas individuais, socialmente constituído de disposições estruturadas (no social) e estruturantes (nas mentes), adquirido nas e pelas experiências práticas (em condições sociais específicas de existência), constantemente orientado para funções e ações do agir cotidiano (SETTON, 2002, p. 63).

No caso dos códigos apresentados neste estudo, a reflexão foi a chave para juntálos neste grupo, pois, em todos os segmentos codificados, visualizamos uma tentativa de ponderar acerca de sua profissão, sua vivência no jornalismo e como crítico. A transformações no espaço da crítica compreendem a novas ritualidades e sociabilidades, acarretadas por transformações nas tecnicidades, com o advento do streaming e no próprio processo de escrita e análise das narrativas.

Este conjunto de códigos tem como foco o estudo a partir do crítico, com seus parâmetros de análise e as diferentes interpretações propostas a cada crítica. Levamos em consideração sua relação com a telenovela, que, como vimos, forma-se na infância, na assistência constante dos programas televisivos e sua inserção na escrita. A reflexividade 
presente nas críticas está inserida no próprio intento de relatar ao público o que está subentendido nas tramas e ainda no campo da produção. Nesses fragmentos de autoavaliação ficam implícitas as condições de fala dos profissionais, sua aderência no campo, seu arcabouço simbólico sobre televisão, sua visão de mundo e seu sentido de gosto.

Sartre (2015, p. 27) aborda o problema da subjetividade a partir da filosofia marxista e afirma que "quando se fala de subjetividade, fala-se de certo tipo, como veremos, de ação interna, de um sistema, de um sistema de interioridades, e não de uma ação imediata com o sujeito". A subjetividade, assim como o habitus, podem ser entendidas a partir das ações internas e a relação com o social. Nestas percepções compreendemos a questão do juízo de gosto, que, na noção de Bourdieu, constrói-se tanto pelas condições materiais quanto por condições do campo simbólico, edificadas pelas instituições que fomentam as competências culturais.

A crítica de telenovela dificilmente desestimula a assistência da ficção. Ela, ao contrário, serve de apoio, fórum de discussão e como arquivo para estudos posteriores. $\mathrm{O}$ leitor que vai em busca da crítica, regularmente a procura para validar sua percepção e/ou esclarecer pontos que não ficaram claros. Os leitores de críticas de telenovela, são, na nossa percepção, os que acompanham constantemente as telenovelas e aderem à crítica como forma de complementação da percepção acerca desta narrativa. A telenovela é um produto de fácil acesso, seja via aparelho televisor, tablet, computador ou celular com antena/acesso à internet. Outra facilidade é a sua constância, pois ininterruptamente uma telenovela é seguida de outra.

O código de práticas profissionais representa o fluxo de trabalho e a atuação no campo da crítica. Os códigos trabalho e utilização das redes sociais são os que refletem este conjunto, haja vista que apontam para as particularidades da atividade crítica, incluindo novas espacialidades e temporalidades (MARTÍN-BARBERO, 2018). Cada crítico estudado possui uma jornada de trabalho distinta e a divide com outras atividades que são complementares. Patrícia Kogut relatou que escreve suas análises em sua sala na redação do Jornal O Globo. Este espaço é composto por uma televisão, que está o tempo todo ligada no volume mínimo. Ali, como ela ressalta, é onde são feitas todas as atividades que compõem a alimentação do blog, a construção de pautas e a escrita da crítica, constituindo-se por uma rotina diária de exercício da profissão. Dentro do mesmo jornal, Kogut perpassou pelo Revista da TV para, em seguida, chegar ao blog, neste sentido acompanhou as transformações das redações, com a diminuição de profissionais, sendo que, no momento, ela se constitui como a única crítica de televisão. 
Além de mudanças espaciais físicas, notamos a abrangência da espacialidade virtual engendrada pelas tecnicidades. Foi nas mídias sociais digitais que a ressonância das críticas de televisão alcançou novos patamares, o que ocasionou diferentes temporalidades dentro do escopo do jornalismo cultural. As análises de telenovelas são trabalhadas a posteriori, logo estão sujeitas ao tempo das telenovelas em sua forma de exibição na televisão aberta. Por conseguinte, com o advento do streaming, novas estratégias mercadológicas de lançamento das ficções são combinadas ao modelo clássico da programação estática, tais como as estreias das tramas primeiramente na plataforma de streaming da emissora anteriormente à sua exibição na TV aberta, como foi o caso da telenovelas das 18h, Órfãos da Terra (Globo, 2018). Como se tratava de uma estratégia ainda em estudo, não sabemos se chegaremos a ver esse tipo de estreia, no caso do capítulo do dia seguinte, primeiramente no Globoplay, em uma telenovela das $21 \mathrm{~h}$, porém já vislumbramos mudanças de comportamento quanto à possibilidade de assistência do capítulo após a exibição em seu próprio tempo e em outras plataformas.

A temporalidade do crítico se refere a dois aspectos: ao seu tempo de assistência dos programas e ao seu tempo de escrita e publicação. Sabemos que a primeira interessa ao período disposto para assistir a um determinado número de programas, seja ficção, variedades ou até notícias. Esta etapa delibera certos aspectos que vão transparecer na análise e para a captura de elementos significativos à avaliação. Stycer e Xavier relataram que, para a telenovela, por exemplo, este tempo é passado juntamente às redes sociais, prática que garante a interação e compartilhamento de ideias para futuras críticas. A experiência de processo criativa pelo Twitter é colaborativa, como fica claro nas palavras dos críticos, e propicia novos olhares e sobre a ficção assistida. No espaço virtual, a telenovela alcança novas sociabilidades, dado que o espaço social de assistência foi aumentado pelas variadas plataformas. O tempo de escrita, da mesma forma, tornou-se diverso. A escrita pode ser feita de qualquer ambiente e ter acesso ao sistema que correspondente ao site ou blog. As páginas on-line são de responsabilidade do crítico, cabe a ele ou até a colaboradores técnicos o encargo de acrescentar conteúdo ou realizar modificações.

Maurício Stycer, além da tarefa de jornalista e crítico, divide seu tempo como professor universitário para cursos de Jornalismo. Trabalhou, até o momento, em cinco faculdades, além de seu mestrado em Sociologia, pela Universidade de São Paulo. O conhecimento sobre o campo da televisão no País é notado em sua última publicação acerca do apresentador Silvio Santos. O primeiro capítulo de Topa tudo por dinheiro: as 
muitas faces do empresário Silvio Santos (2018), Stycer aborda a introdução da televisão no País em pleno regime militar. Ele comenta que esse intróito é importante para embasar a temática que propõe no livro, inclusive esse foi o argumento utilizado com seu editor, que propôs a redução do capítulo. Entre acadêmico, jornalista e crítico, Stycer procura manter o grau de exigência pelo qual é conhecido e que constantemente desagrada alguns autores. Com isso, ele reforça que sua crítica tem independência total, sendo que suas análises são oriundas de um repertório cultivado pelo conhecimento histórico, pela prática de argumentação, além da sensibilidade.

No período temporal averiguado nesta pesquisa, Cristina Padiglione passou da coluna na página on-line do jornal O Estado de São Paulo para uma página própria, intitulada TelePadi. A mudança de espacialidade e sociabilidade é observada nesta transição para um espaço virtual próprio, onde se percebe um aumento na cobertura de diferentes aspectos da televisão, além das críticas. A assistência da telenovela, como ela ressalta, é feita em casa, bem como sua escrita. Ademais, o momento da publicação de seus textos vai de acordo com seu próprio cronograma.

Nilson Xavier tem no Twitter uma ferramenta de trabalho, onde a sociabilidade da rede social viabiliza sua imagem como crítico e como fonte sobre as telenovelas pelo site, o Teledramaturgia. Lopes et al (2015, p. 37) comenta que "com essa vasta experiência e muito conhecimento, ele se tornou referência para pesquisadores, jornalistas, estudantes e profissionais da área". Por meio do site e da publicação de seu livro foi que passou a escrever críticas. Este ofício é complementado pela leitura e estudos de livros que abordem as teleficções, como as biografias de personalidades da TV, seja de apresentadores como produtores, livros acadêmicos que versem sobre a telenovela e o acompanhamento diário.

Para efetuar o ofício da crítica, os profissionais levam em conta o conhecimento sobre como se dá o funcionamento da televisão no contexto brasileiro. Isso é um aspecto estrutural e fundante para o exercício da crítica, tendo em vista a singularidade do paradigma da telenovela brasileira. Logo, é importante compreender as particularidades de cada emissora, de cada diretor e de cada autor. 
As linhas acima tiveram como proposta a interpretação dos retratos de documentos das críticas e entrevistas. A finalidade era obter uma visão geral do que foi codificado nos dados e, a partir disto, criar conjuntos de códigos que delimitem e abranjam a crítica contemporânea brasileira. Em síntese, mesclamos a análise com a apresentação de pressupostos que, em nosso entender, englobam o sistema que permeia essa crítica. 


\section{CONSIDERAÇÕES FINAIS}

A crítica tem que ter uma margem, você tem que olhar aquele capítulo. Isso é um pouco de experiência, você não pode decretar, porque se você decreta, às vezes, a novela degringola e você tem que ter coerência na sua crítica. Patrícia Kogut

O percurso realizado por esta pesquisa é fruto de um planejamento extenso, que foi se materializando ao longo destes quatro anos de doutoramento. Longe de esgotar o tema, achamos que as reflexões e avanços possibilitados contribuíram para o campo dos estudos da crítica de telenovela, bem como a de televisão. Olhar para a telenovela - uma produção intrinsecamente brasileira - sempre nos oferece um leque abrangente para atentarmos para a sociedade. E tendo isso em mente, as páginas anteriores apresentaram um panorama da crítica deste produto midiático, que, há mais de 60 anos, transmitiu inúmeras histórias que por vezes falavam de seu povo e estavam presentes na maioria das casas no País.

Entre os variados desafios, o principal era entender como funcionava a crítica de telenovela, num espaço específico: as mídias digitais. Tendo seu advento nos jornais impressos, a crítica de televisão era lida majoritariamente no papel. E com poucos profissionais que se dedicavam ao estudo da telinha, como ficou comumente conhecida, as críticas eram uma mistura de colunismo social e análise. Poucos foram os responsáveis por trazerem uma crítica séria do formato, discutindo os elementos particulares desse formato compósito de gêneros (LOPES et al, 2016).

De caráter empírico metodológico, nossas principais dificuldades consistiram em como cercar esse objeto, e, ainda, como apresentar uma análise em que tanto as críticas, os críticos e as telenovelas pudessem ser contemplados. Como explicitamos na metodologia, o trajeto de cotejamento do objeto foi extenso. Tentamos reduzi-lo para que fosse o mais operacional possível no tempo que nos cabia. A utilização de um software de pesquisa qualitativa foi a resposta para minorarmos todos os dados empíricos coletados, o que, de certa maneira, levou-nos a um novo caminho para futuras pesquisas. O uso de programas como o Maxqda, até então, para nós, era um desafio. Amplamente 
empregado nas pesquisas como uma forma de codificação e visualização de dados, o auxílio deste recurso só foi possível através da aquisição do software pelo Centro de Estudos de Telenovela-CETVN e dos cursos possibilitados aos seus pesquisadores.

Os seis capítulos que compreendem esta tese buscaram, de forma resumida, entender a crítica de telenovela contemporânea e suas dinâmicas, especialmente na circulação de sentidos das telenovelas. Para isso, a pergunta principal que nos moveu foi como se configura essa crítica de ficção televisiva contemporânea, realizada em sites e blogs, e de que forma ela explicita as operações de circulação de sentidos? Na tentativa de responder a esta questão, valemo-nos de uma metodologia transdisciplinar, que de antemão já entendia que essa crítica é digital e abrange um número variado de leitores devido à sua capacidade de compartilhamento. Sabemos que essa crítica prevê a colocação de comentários ao fim da postagem, levando ao crítico a possibilidade de saber a opinião de seus leitores, e que os críticos utilizam redes sociais diversas. E ainda entendemos que esta avaliação pode ser publicada momentos após a transmissão de determinado capítulo.

Como objetivo geral, tínhamos a finalidade de entender a crítica de telenovela contemporânea, um texto opinativo discrepante das demais classes artísticas, especialmente por se tratar de uma produção em construção. A efemeridade da crítica de telenovela se explica na medida em que esse texto somente pode ser lido até aquele último capítulo exibido, pois foi até esse momento que o olhar do crítico analisou. Tendo isso em vista, procuramos selecionar quatro críticas de cada telenovela, compreendendo justamente que uma postagem é uma leitura de uma parte pertencente ao todo. Logo, a única crítica a qual podemos estabelecer como completa é a última, que se configura como um balanço dos aproximadamente 150 capítulos, quantidade média de uma telenovela das 21 horas.

Para os objetivos empíricos, a pesquisa se dispôs a entender os critérios e os processos de análise. São fatores particulares e subjetivos de cada crítico, porém, por meio da leitura das críticas e das entrevistas, pudemos fundamentar os procedimentos por meio da categorização dos dados. A criação das categorias se deu pela reincidência, ou seja, aquilo que mais emergiu no conjunto de dados. As entrevistas, por outro lado, serviram de complementação das informações colhidas nas críticas, que no capítulo seis foram confrontadas. Os critérios de análise levavam em conta o que se sobressaía numa 
determinada semana ou no capítulo anterior, a postagem podia ser relacionada a um personagem, a uma temática social, ao texto do autor, entre outros. As categorias empíricas são um reflexo deste processo e dos parâmetros de análise. E ainda podem ser entendidas como elementos de um protocolo de compreensão das críticas de telenovela.

Trabalhamos com duas hipóteses, uma teórica e outra empírica. A hipótese de caráter epistemológico previu que a crítica de telenovela atuava como expositora e disseminadora das questões de seus públicos, delimitando os temas que considera mais interessantes e relevantes, por meio dos termômetros das redes sociais e dos dados da audiência. Confirmamos esta hipótese por meio das categorias Utilização das redes sociais e repercussão - audiência e redes sociais, que nos mostraram - com a codificação - que os críticos compartilham suas publicações e interagem com o público no momento de exibição da telenovela. Até mesmo reparamos que as redes sociais influem na crítica à medida que a entendemos como um elemento na construção da crítica pela interação constante de alguns críticos, como Maurício Stycer e Nilson Xavier. Como demarcado, os dois utilizam suas páginas como uma forma de interação com o público da telenovela que usa a rede social (Twitter) para comentar e discutir a ficção ao mesmo tempo que vê a ficção. Portanto, neste instante, os jornalistas relatam que conseguem extrair desses momentos de discussões com outros espectadores pautas, insights, se o público está apreciando a trama e elementos que, para eles, podem ter passado despercebidos. A hipótese de caráter prático prevê que as críticas são uma leitura de seu tempo, apontando para a abrangência da televisão, a relevância dos temas abordados e o caráter da telenovela como um produto da indústria cultural brasileira. Esta hipótese foi entendida pela construção das categorias que contemplavam as diferentes nuances do que se entende pela crítica de telenovela no Brasil. Pela categorização, procuramos entender cada aspecto que permeia a análise das ficções com os principais profissionais que trabalham neste meio. Logo, na prática, a crítica, em sua função de mediadora, tem como função central desvelar um texto primário, que, neste caso, é o folhetim. Entretanto, o espectador de teleficção já é dotado de uma competência cognitiva propiciada pela circulação de sentidos acerca das ficções, que lhe permite entender os principais aspectos daquele texto. Assim, a crítica estabelece um diálogo com seu leitor/espectador sobre a narrativa, argumentando para elementos referenciados em cena e o contexto no qual aquela trama foi inserida.

Com isso, nesta tese, apontamos as seguintes considerações: 
- a crítica de uma obra ficcional televisiva é formada pelo conjunto de várias críticas publicadas no decorrer da transmissão;

- o crítico é passível de alterar sua opinião no decorrer da exibição, pois, como uma narrativa aberta a modificações, o folhetim está sujeito a alterações advindas do campo da produção, que foram, talvez, influenciadas pelo campo da recepção, como forma de reinvindicação;

- a circulação de sentidos da telenovela se perfaz na crítica de telenovela justamente pelas interações com seu público em diferentes âmbitos, além dos críticos serem tanto mediadores como espectadores;

- as ficções televisivas são produtos específicos de seu tempo, isto posto, a crítica efetua uma leitura pontual numa temporalidade específica. Com isso a crítica oferece um vislumbre do produto midiático e o contexto na sociedade brasileira;

- entendimento do lugar da crítica de telenovela no campo do jornalismo, que, no dizer dos críticos relatados nesta pesquisa, ainda é considerada uma atividade marginal, levando em consideração outras formas artísticas.

A divisão em duas partes desta pesquisa se prestou para visualizarmos o panorama da crítica por meio do entendimento do cenário televisivo nacional, do advento da crítica de telenovela e da influência da crítica literária neste meio. Os autores citados, cânones dos estudos literários e da linguística, serviram para que olhássemos para o objeto munidos de pressupostos teóricos que favoreceram nossa análise. O último capítulo da terceira parte, voltado para a obra do teórico Jésus Martín-Barbero, auxiliou-nos pela abordagem da teoria das mediações, primordial na costura entre a teoria e os dados empíricos.

A segunda parte desta tese teve como finalidade explanar os materiais advindos do campo, ou seja, as críticas e as entrevistas. Num primeiro momento, abordamos, no percurso metodológico, que se configurou como uma parcela extensa deste estudo. Chegar a este objeto e ao modo como ele seria operacionalizado exigiu um processo de ruptura epistemológica, na qual a apreensão da realidade não é feita de forma imediata, mas, sim, por atividades intelectuais complexas que possibilitem ao investigador a ruptura na prática, não aquela realizada no instante da construção da problemática. É por esta razão que fomos tão minuciosos em clarificar os passos da pesquisa. 


\section{A utilização do Maxqda: percalços e contribuições}

A utilização do software de análise qualitativa Maxqda auxiliou a mineração dos dados, levando em conta a quantidade coletada, indicada na análise. Relatamos a pertinência de tipo de programa para as pesquisas no campo da comunicação, na qual foi possível a criação de ferramentas visuais que permitiram a interpretação dos dados de maneira visualmente lúdica. A forma que optamos para divulgar os dados foi pertinente para organização dos capítulos 5 e 6, onde expomos a descrição das categorias e a comparação entre os temas abordados nas críticas e nas entrevistas. O intuito não foi elaborar um protocolo definitivo, porém apresentamos eixos de análise da crítica de televisão, entrevendo possíveis percursos de avaliação. Também não tínhamos como objetivo dizer se a crítica é boa ou ruim, portanto, uma crítica da crítica. Mas, sim, quem são e como estão fazendo os profissionais que se dedicam a esse ofício. Esclarecer, a partir da nossa interpretação, quais critério e pressupostos são adotados, pois, em se tratando de telenovela, os padrões podem ser alterados a cada semana.

Até a delimitação da metodologia, não sabíamos qual software de análise qualitativa iríamos utilizar, no entanto, pela quantidade extensa de dados, buscávamos formas de trabalhá-los com o intuito de dimensioná-los em categorias. No campo da comunicação, o programa de análise de dados mais conhecido é o Nvivo. Em nossa percepção e pela conversa com outros pesquisadores, o programa parecia a ferramenta mais usual para pesquisa qualitativa na área, até pelos estudos emergentes em Grounded Theory ou Teoria Fundamentada. Todavia, em meio às reuniões do CETVN, deliberando sobre a possível compra dessa ferramenta para o centro, efetuamos uma busca sobre quais programas serviriam melhor aos nossos propósitos. Nesta averiguação, chegamos à conclusão de que o Maxqda configurava-se na melhor escolha, pois sua interface é de fácil acesso e intuitiva.

Apesar de já possuir um desenho metodológico, o uso do software complementou sobremaneira a etapa de análise a partir das ferramentas visuais. O que pensávamos, até aquele estágio da pesquisa, era a realização da categorização a partir das reincidências, todavia, não havíamos aprofundado a maneira como iríamos apresentá-las. Somente na utilização diária foi que chegamos aos retratos dos documentos, aplicados no capítulo 06. Essas imagens motivaram a análise entre os documentos - críticas e entrevistas facilitando termos a visualização geral do que se tratava cada documento. 
Refletindo acerca da utilização do Maxqda, entendemos que independentemente do software utilizado, o que se deve levar em consideração é que tipo de pesquisa se deseja fazer, em outras palavras, deve-se efetuar uma pergunta, como um problema de pesquisa, para que, assim, os dados possam ser estudados. As múltiplas ferramentas que podem ser abarcadas dependem em grande parte, se não totalmente, do objeto e dos métodos propostos. Deles é possível enxergar variadas interpretações, cabendo ao pesquisador, em seus níveis e fases, abarcar o que melhor irá auxiliá-lo.

\section{Para Discussão}

O desafio epistemológico apresentado nesta pesquisa foi apenas uma contribuição pequena diante dos estudos sobre telenovela e sua crítica. Nossa abordagem utilizou um corpus extenso, necessário para os fins do estudo, porém longe de se esgotar. A crítica, por si, já é um campo de longo estudo, sendo que cada campo artístico molda sua crítica de acordo com as especificidades da obra. Portanto, a crítica de telenovela é consideravelmente nova em comparação com as demais, tendo seu advento somente na década de 1960, com a implementação da TV no País.

Outro ponto que vale remarcar é se a telenovela é digna de uma crítica, pois sua inserção na indústria cultural audiovisual a qualifica como um produto, e que, portanto, atende a demandas comerciais. Esta discussão não é novidade e permeia os estudos de telenovela desde que passou a ser analisado na academia. Greco (2016, p. 293) relata o "desencorajamento" e até a "descrença" de alguns colegas ao afirmarem que "não existe novela cult", objeto de estudo de sua tese de doutorado. Retomemos o "mal olhado" relatado por Martín-Barbero e Rey sobre os pesquisadores do campo das ciências sociais em tratar da televisão, um instrumento simbólico tão consolidado no cotidiano da América Latina. Maurício Stycer (2016, p. 17), no texto Um ofício sem prestígio, menciona que "por mais surpreendente que possa parecer, ainda existe certo desdém em relação à televisão em ambientes jornalísticos. Na comparação com outras formas de entendimento ou cultura, ela é sempre vista como algo menor, menos importante". Como explicado no tópico acerca do paradigma da telenovela brasileira, é perceptível a qualidade das produções e evidente engajamento da população, que logo é inserida num contexto de circulação de sentidos, visto segundo Véron (1991) como um processo complexo e não linear. 
Por meio desta reflexão, notamos que a crítica de telenovela é uma atividade simbiótica entre os profissionais que a efetuam e o público leitor-espectador. A crítica também é um texto incompleto, as análises são realizadas somente do material visto até aquele instante da transmissão. Lida separadamente, ela não fornece subsídios para o todo da narrativa, pois é feita de retalhos. Aliás, somente a última crítica, ou seja, o balanço da telenovela pode ser considerado uma avaliação da obra inteira. Portanto, para se entender a análise de uma ficção de longa serialidade, é necessário que se tenha em mãos o conjunto de críticas feitas para aquela trama, que, como enumeramos, é composta de pelo menos quatro análises.

Para compreensão do título desta tese, A crítica de telenovela como operação de circulação de sentidos, é necessário que retomemos a noção-chave que permeou esta pesquisa. Verón (1991) menciona que a circulação de sentidos na sociedade é um processo não linear, tendo como modo de análise o campo da produção e do reconhecimento. A gramática de produção e as múltiplas gramáticas de reconhecimento (p. 123) já evidenciam como esse processo da circulação discursiva é complexo e de caráter assimétrico. Para entendermos a gramática de produção, temos que ter em vista "a descrição das condições de produção implica sempre conceituar os arranjos institucionais dentro dos quais a produção dos discursos sociais estudados ocorre" (VERÓN, 1991, p. 123). Levando isto em conta, os críticos selecionados para este estudo estão atrelados a empresas de comunicação que lhes permitem dispor de um espaço próprio (blog ou site) alocado em seus portais de informações, que lhe dão autonomia para exercer um juízo de valor acerca de uma obra. Neste contexto, temos o Grupo Folha, com Maurício Stycer, Nilson Xavier e Cristina Padiglione; e o Grupo Globo, com Patrícia Kogut, que se configuram como os dois maiores grupos de comunicação do País. Em suma, o lugar de falar, nestes termos, o espaço da produção de onde estes críticos avaliam, lhes permite um grau elevado de visibilidade, o que também está atrelado à sua trajetória e reconhecimento na área.

Como percebemos na categoria Trabalho, o percurso profissional dos críticos se desenvolveu na relação com o jornalismo cultural, na cobertura de televisão, para, em seguida, serem levados para a crítica, trajeto que, para eles, desenvolveu-se de maneira natural. Nilson Xavier, por outro lado, adentrou na crítica através de seu trabalho de curadoria sobre as telenovelas; sua expertise no assunto o tornou qualificado para exercer a atividade, sendo que este fazer é complementado pelas leituras sobre comunicação e televisão. 
As gramáticas de reconhecimento, como Verón enumera, "são explicadas por condições de reconhecimento, e estas, em uma sociedade complexa, são múltiplas" (p. 123). Os críticos ressignificam os sentidos apresentados pelas telenovelas, estabelecendo um processo de reconhecimento próprio, que, posteriormente, vai desencadear em uma crítica. Por conseguinte, o teórico ressalta a multiplicidade de reconhecimentos em seu modelo, cada um dependendo de fatores socioeconômicos, educacionais e culturais. Os códigos abarcados nos capítulos anteriores, portanto, são as marcas do reconhecimento que cada crítico distinguiu na telenovela analisada, o que igualmente está atrelado a suas condições de recepção.

O autor explica que uma estratégia discursiva dada não terá o mesmo sentido para dois sujeitos com um cabedal cultural diferente. Fator esse, totalmente exterior a toda análise de produção, pois as regras de uma gramática de reconhecimento exprimem uma espécie de "encontro" entre propriedades discursivas que são invariantes, remetendo a determinadas condições de produção, e uma modalidade de leitura que remete a determinadas condições de reconhecimento (SANCHOTENE, 2019, p. 118).

Tanto as gramáticas de produção e como as de reconhecimento formam a semiose social da telenovela. Os variados reconhecimentos se reconfiguram a cada geração e período histórico. Pelas telenovelas, vemos transformações referentes a condutas morais que vão se alterando à medida que, na telinha, são dispostos padrões que vão se complementando aos que já foram postos. Neste sentido, Bucci (2004, p.241) aponta que “o Brasil se comunica pela televisão. O Brasil se conhece e se reconhece pela televisão, e praticamente só pela televisão, que reina absoluta sobre o público nacional, com um peso muitas vezes superior aos outros veículos". A teledramaturgia, por conseguinte, é o local onde são dramatizados os conflitos de foro pessoal, mas que, na televisão, alcançam os recônditos do Brasil profundo.

Pois a novela é o gênero dramática em que o Brasil melhor se saiu. Nela não ouvimos discursos: presenciamos situações. A dramaturgia funciona mais que a palavra seca. Daí seu alcance social. Por isso é errado dizer que a TV não educa. Ela varreu preconceitos de costumes. Alguém lembra que, ainda, nos anos 60, muitas famílias não recebiam "desquitadas"? Uma mulher sem o marido só escaparia da plena exclusão social se mostrasse, por um sofrimento infinito, que não tinha culpa. Se lutasse pela felicidade, seria uma pária (RIBEIRO, 2004, p. 23). 
Dissertamos, até o momento, sobre os códigos técnicos, reflexivos e profissionais que se refletem na crítica. Entretanto, deixamos de lado a relação entre esses críticos como profissionais que validam o trabalho uns dos outros, tal como nos parâmetros de um reconhecimento entre os pares (BOURDIEU, 1996) do campo da crítica. O que ficou evidente, no período de observação e colheita dos dados, foi a referenciação entre eles. Por a crítica ser feita em páginas on-line, é permitido a inserção de links, que direcionam o leitor a outros textos, seja uma publicação antiga do próprio crítico, ou que encaminhe para uma postagem do outro profissional. Entre os críticos analisados, é possível ver esta ocorrência, pois cada olhar é singular e pode relatar algo que passou despercebido para os demais. Além disso, há casos em que dois ou mais críticos abordam sobre a mesma temática em suas últimas críticas. Outro exemplo é quando uma crítica se inicia a partir de um argumento apontado numa crítica precedente de outro crítico.

Os argumentos contrários também são citados, como bem comenta Nilson Xavier, ao relatar que já chegou a referenciar textos que tinham uma opinião contrária ao seu, contribuindo para o fomento da discussão acerca da obra. Maurício Stycer dimensiona que a leitura de seus colegas de trabalho faz que, às vezes, tenha algum insight, perceba algo que pode ter passado despercebido em sua própria análise. O crítico ainda comenta que, enquanto houver profissionais que escrevam sobre televisão, a profissão irá perdurar. Entretanto acredita que ainda há muitos casos de uma crítica de TV mais voltada para o comentário do que para a análise em si. Desta maneira, é necessário que se explique o mérito de pautar a televisão com clareza e discernimento para seu público.

O percurso metodológico proposto chega ao seu fim. Delimitar o encerramento de uma tese é ter em consideração as proporções deste objeto, que, pelas contingências do tempo e dos materiais, teve que ser recortado para caber nesta pesquisa. A crítica é um campo vasto que depende de uma obra primeira, esta, por sua vez, admite características próprias que irão balizar o olhar subjetivo do crítico. Ao longo de sua concretização como um campo de estudo, a crítica acumulou um enorme arcabouço teórico e fundamentações em cada campo artístico, desde o teatro - seu advento - , passando pelas artes plásticas e chegando nas séries e na telenovela. $\mathrm{O}$ que quero dizer é que há muito a ser lido e estudado. Assim como a vida, uma tese é feita de escolhas. Cada passo foi pensando para facilitar e operacionalizar a demonstração dos dados angariados, e, neste trajeto, muito se deixa de lado, o que, posteriormente, pode vir a ser uma pesquisa de pós-doutorado, ou até mesmo ser ressignificado em novos artigos sobre a temática. 
As conclusões chegadas aqui mostram que a crítica de telenovela necessita consolidar seu campo, e isso se inicia justamente em entender o lugar que a telenovela alcança na vida dos brasileiros, posto que a "telenovela tanto mais presente quanto mais consegue propor uma síntese do imaginário popular” (BUCCI, 2004, p. 41). Pelos atores, aqui analisados, confirmamos hipóteses e até criamos categorias que irão nos auxiliar e complementar futuras análises. Mas também ter em conta que tanto a TV como sua crítica discutem relações sociais e simbólicas e também relações ideológicas construídas nos campos da produção e da recepção.

Ao finalizar este trabalho, recorro a uma fala recorrente dos críticos: novela não é só novela. Elas abrem espaço para discussões, alterações de paradigmas e se configuram por ser uma das formas mais democráticas de acesso ao entretenimento. 


\section{REFERÊNCIAS}

\section{a) Referências acadêmicas}

ARISTOTÉLES. Sobre a arte poética. Belo Horizonte: Autêntica, 2018.

ASSIS, M. de. O jornal e o livro. São Paulo: Companhia das Letras, 2011.

AGAMBEN, G. O Amigo \& O que é dispositivo?. Chapecó, SC: Argos, 2014.

AUMONT, J.; MARIE, M. Dicionário Teórico e Crítico. Campinas, SP: Papirus, 2003.

AQUINO, M. C.; PUHL, P. Vale Tudo no Twitter: a visibilidade da ficção televisiva em tempos de convergência midiática. Alceu. V. 23, p. 34-48, 2011.

ALMEIDA, H. B. Pedagogia Feminista no formato da teledramaturgia. In: MICELI, S.; PONTES, H. Cultura e Sociedade: Brasil e Argentina (orgs.). São Paulo: Editora da Universidade de São Paulo, 2014.

ALMEIDA, M. Habilidade do Telespectador na TV Social. Revista GEMInIS, São Carlos, UFSCar, v. 9, n. 3, pp.89-106, set. / dez. 2018.

BLAKE, J. Television and The Second Screen: Interactive TV in the age of social participation. London e New York: Routledge, 2017.

BAKHTIN, M. Os gêneros do discurso. São Paulo: Editora 34, 2016.

BACCEGA, M. A. Crítica de Televisão: aproximações. In: MARTINS, M. H. (Org.). Outras leituras: literatura, televisão, jornalismo de arte e cultura, linguagens interagentes. São Paulo: Instituto Cultural Itaú, 2000, p. 37-54.

BACCEGA, M. A. Narrativa ficcional de televisão: encontro com temas sociais. Comunicação \& Educação, São Paulo, (26): 7 a 16, jan./abr. 2003

BARTHES, R. Crítica e Verdade. 3 ed. São Paulo: Perspectiva, 2007.

BALOGH, A. M. O Discurso Ficcional na TV: Sedução e Sonho em doses homeopáticas. São Paulo: Editora da Universidade de São Paulo, 2002.

BARDIN, L. Análise de Conteúdo. São Paulo: Edições 70, 2011.

BENJAMIN, W. Linguagem, tradução, literatura (filosofia, teoria e crítica). Belo Horizonte: Autêntica Editora, 2018. 
BERGER, P.; LUCKMANN, T. A construção social da realidade: tratado de sociologia do conhecimento. São Paulo: Vozes, 2013.

BOURDIEU, P. Gostos de classe e estilos de vida. In: ORTIZ, R. (Org.). Pierre Bourdieu: sociologia. São Paulo: Ática, 1993. p. 82-121.

BOURDIEU, Pierre. As regras da arte: gênese e estrutura do campo literário. São Paulo: Companhia das Letras, 1996.

BOURDIEU, P. A Distinção: Crítica Social do Julgamento. São Paulo: Zouk, 2011.

BUITONI, D. S. Comunicação e fluxos Contemporâneos: a indispensável imagem. In: FRANÇA, V. V.; ALDÉ, A.; RAMOS, M. C. (orgs.). Teorias da Comunicação no Brasil. Salvador: Edufba, 2014.

BUCCI, E. A crítica de televisão. In: BUCCI, E. \& KEHL, M. R. Videologias: ensaios sobre televisão. São Paulo: Boitempo, 2004.

BRAGA, J. L. A sociedade enfrenta sua mídia: dispositivos sociais da crítica midiática. São Paulo: Paulus, 2006.

BRAIT, B. A Personagem. São Paulo: Ática, 1985.

CANDIDO, A. Literatura e Sociedade: estudos de teoria e história literária. 3 ed. São Paulo: Editora Nacional, 1973.

CANDIDO, A. A Personagem no Romance. In: CANDIDO, A. et al. . A Personagem na Ficção. São Paulo: Ed Perspectiva, 2011.

CAMPBELl, J. O Herói de Mil Faces. São Paulo: Editora Pensamento, 1989

CARDOSO, J. B. A Semiótica do cenário televisivo. São Paulo: Annablume; Fapesp, USCS - Universidade de São Caetano do Sul, 2008.

CASTRO, É. G. A aprendizagem da crítica: literatura e história em Walter Benjamin e Antonio Candido. São Paulo: Fapesp, Intermeios, 2014.

CASTILHO, F.; PENNER, T. "Shippers" no Twitter: práticas de fãs de ficção televisiva. Lumina, v. 11, n. 2, p. 216-233, mai./ago. 2017.

CEVASCO, M. E. Para ler Raymond Williams. São Paulo: Paz e Terra, 2001.

COUTINHO, A. Crítica e Críticos. Rio de Janeiro: Organizações Simões Editora, 1969. 
CHARAUDEAU, P. Discurso das Mídias. São Paulo: Contexto, 2006.

CHARAUDEAU, P. Linguagem e Discurso: Modos de Organização. São Paulo: Contexto, 2008.

COSTA, C. A milésima segunda noite: da narrativa mítica à telenovela: análise estética e sociológica. São Paulo: Annablume, 2000.

COSTA, C. Como Helena Silveira vê TV. (1997). Disponível em www.portcom.intercom.org.br > pdfs Acesso 29 out. 2019.

COSTA, J. M. Sabático: um novo tempo para a leitura? (A retomada do Suplemento Literário no Estado de S. Paulo). 2012. Dissertação (Mestrado em Mestrado em Divulgação Científica e Cultural) - Lingüística, Letras e Artes, Universidade Estadual de Campinas, Campinas, 2012.

CORNER, J. Television Studies and the idea of criticism. (2007). Disponível em http://screen.oxfordjournals.org/ Acesso 29 out. 2019.

CORNER, J. 'Criticism': Notes on the Circulation of Cultural Judgement. Jomec Journal Journalism, Media and Cultural Studies. (2013) Disponível em: cf.ac.uk/jomec/jomecjournal/4-november2013/Corner_Criticism.pdf Acesso 29 out. 2019.

COELHO, M. Jornalismo e Crítica. In: MARTINS, M. H. (org). Rumos da Crítica. São Paulo: Senac/Itaú Cultural, 2000, pp. 83-94.

DELEUZE, G. Crítica e Clínica. São Paulo: Editora 34, 2011.

DELEUZE, G; GUATTARI, F. Mil Platôs: capitalismo e esquizofrenia 2, vol. 1. São Paulo: Editora 34, 2011.

DEPEXE, S. D. Distinção em 140 caracteres: classe social, telenovela e twitter. 2015. 235 f. Tese (Doutorado em Comunicação midiática). Universidade Federal de Santa Maria, Santa Maria, 2015.

DIDI-HUBERMAN, G. Que Emoção! Que Emoção? São Paulo: Editora 34, 2016.

DURÃO, F. A. O que é crítica literária? São Paulo: Nankin Editorial, Parábola Editorial,

2016. 
DRUMOND, R. Vem ver \#Telenovela, @Você Também: Recepção Televisiva e Interações em Rede a partir do Twitter. Revista Novos Olhares, V.3, n. 2, pp. 200-211, 2014.

ECO, U. Seis passeios pelos bosques da ficção. São Paulo: Companhia das Letras, 1994.

ECO, U. Lector in fabula. São Paulo: Perspectiva, 1987.

ECO, U. TV, a transparência perdida. In: . Viagem na irrealidade cotidiana. Rio de Janeiro: Nova fronteira, 1984.

EAGLETON, T. A função da crítica. São Paulo: Editora Martins Fontes, 1991.

JACKS, N. Repensando os estudos de recepção: dois mapas para orientar o debate. Ilha Revista de Antropologia, v. 10, n. 02, 2008.

JOHN, V.M.; RIBEIRO, R.R.; SILVA, G.H. da. Sensorialidad: la mediación que siempre estuvo presente. In: RINCÓN, O. (ed.); JACKS, N.; SCHIMITZ, D.; WOTTRICH, L. (orgs.) Un nuevo mapa para investigar la mutación cultural. Diálogo con la propuesta de Jesús Martín-Barbero. Quito: CIESPAL, 2019.

KEHL, M. R. Visibilidade e Espetáculo. In: BUCCI, E. \& KEHL, M. R. Videologias: ensaios sobre televisão. São Paulo: Boitempo, 2004.

FAUSTO NETO, A. Olhares sobre a recepção através das bordas da circulação. XVIII Encontro da Compós. Belo Horizonte: Compós, 2009. p. 1-13. Disponível em: < http://revistaalceu.com.puc-rio.br/media/Alceu20_Neto.pdf>.

FAUSTO NETO, A. Circulação: trajetos conceituais. Rizoma, Santa Cruz do Sul, v. 6, n. 2, p. 8, dezembro, 2018.

FOUCAULT, M. O Nascimento da Biopolítica. São Paulo: Martins Fontes, 2008

FARO, J. S. Jornalismo e Crítica da cultura: a urgência da nova identidade. Revista Fronteiras, 14 (3), pp. 192-198, set - dez 2012.

FIORIN, J. L. Linguagem e Ideologia. São Paulo: Editora Ática, 1998.

FILHO, D. O Circo Eletrônico: fazendo TV no Brasil. Rio de Janeiro: Jorge Zahar Ed., S2003.

FREIRE FILHO, J. Por uma nova agenda de investigação da história da TV no Brasil. In: RIBEIRO, A. P. G.; HERSCHMANN, M. (orgs.). Comunicação e História: interfaces e novas abordagens. Rio de Janeiro: Mauad X; Globo Universidade, 2008. 
FRYE, N. Anatomia da Crítica. São Paulo: Editora Cultrix, 1957.

FRYE, N. O Caminho Crítico. São Paulo: Perspectiva, 1973.

FRASER, N. Reconhecimento sem ética?. Lua Nova, São Paulo, 70, pp. 101-138, 2007.

FRANCO, H. Sensorium e internet: Una aproximación al fenómeno tecnológico desde la obra de Walter Benjamin. 2009. Dissertação (Mestrado em Comunicación) -Facultad de Comunicación y Lenguaje, Pontifícia Universidad Javeriana, Colômbia, 2009.

FLICK, U. Introdução à Metodologia de Pesquisa: Um Guia Para Iniciantes

(Métodos de Pesquisa). São Paulo: Editora Penso, 2012.

GARCÍA CANCLINI, N. Cultura Híbridas: estratégias para entrar e sair da modernidade. São Paulo: Editora da Universidade de São Paulo, 2015

GENETTE, G. Paratextos Editoriais. São Paulo: Ateliê Editorial, 2009.

GIRON, L. A. Minoridade Crítica: A ópera e o teatro nos Folhetins da Corte: 18261861. São Paulo: Editora da Universidade de São Paulo; Rio de Janeiro: Ediouro, 2004.

GOMES, M. Ao abrigo dos discursos circulantes. Rumores, edição 12, ano 6, n. 2, pp. 4-17, julho-dezembro 2012.

GRECO, C. A TV cult no Brasil: Memória e culto às ficções televisivas em tempos de mídias digitais. 2016. 306f. Tese (Doutorado em Ciências da Comunicação) - Escola de Comunicação e Artes, Universidade de São Paulo, São Paulo, 2016.

GRECO, C. Crítica especializada e crítica popular: autoridade e gosto no debate sobre qualidade na TV. In: FERIN, I. F; CASTILHO, F; GUEDES, A. P. (orgs.). Ficção Seriada Televisiva no Espaço Lusófono. Covilhã (PT): Editora LabCom.IFP, 2017.

HAMBURGUER, E. A Ficção Televisiva e as Relações de Gênero. In: MICELI, Sérgio; PONTES, Heloísa. Cultura e Sociedade: Brasil e Argentina (orgs.). São Paulo: Editora da Universidade de São Paulo, 2014.

HAMBURGUER, E. Diluindo fronteiras: a televisão e as novelas no cotidiano. In: SCHWARCZ, L. M.; NOVAIS, F. A. (orgs.). Histórias da vida privada no Brasil 4: contrastes da intimidade contemporânea. São Paulo: Companhia das Letras, 1998.

HAMBURGUER, E. Telenovelas e Interpretações do Brasil. Lua Nova, São Paulo, v. 82, pp. 61-86, 2011. 
HONNETH, A. Luta por reconhecimento: a gramática moral dos conflitos sociais. São Paulo: Editora 34, 2009.

JENKINS, H.; FORD, S.; GREEN, J. Spreadable media: creating value and meaning in a networked culture. New York: New York University Press, 2013.

JOST, F. Seis lições sobre a televisão. Porto Alegre: Sulina, 2004.

JÚNIOR, L. G. De Mediações em mediações: a questão da tecnicidade em MartínBarbero. Matrizes, v. 11, n 3, set/dez., 2017.

KASTRUP, V.; PASSOS, E. Cartografar é traçar um plano comum. Fractal, Rev. Psicol. [online], vol.25, n.2, pp.263-280, 2013.

LEMOS, L. M. P. O autor roteirista e a ficção televisiva brasileira na era transmídia. 2017. 228f. Tese (Doutorado em Ciências da Comunicação) - Escola de Comunicação e Artes, Universidade de São Paulo, São Paulo, 2017.

LE GRIGNOU, B. La télévision et ses critiques : Un journalisme en « simili ». Questions de communication, 14, pp. 243-262, 2008. Disponível em: http://journals.openedition.org/questionsdecommunication/1737 Acesso 07 jan. 2020.

LIMA, C. A. R. Telenovela transmídia na rede globo: o papel das controvérsias. 2018. 266f. Tese (Doutorado em Comunicação) - Centro de Artes e Comunicação, Universidade Federal de Pernambuco, Recife, 2018

LOPES, M. I. V. Pesquisa em comunicação. 10. ed. São Paulo: Edições Loyola, 2014. LOPES, M. I. V. Telenovela como recurso comunicativo. Matrizes v. 3, n. 1, p. 21-47, 2009.

LOPES, M. I. V. Uma metodologia das mediações. In: Lopes, M. I. V. et al. Vivendo com a Telenovela. Mediações, recepção e teleficcionalidade. São Paulo: Summus, 2002, p. 39 a 82.

LOPES, M. I. V. A recepção transmidiática da ficção televisiva: novas questões de pesquisa. In: FREIRE FILHO, J.; BORGES, G. (orgs). Estudos de Televisão: diálogos Brasil-Portugal. Porto Alegre: Sulina, 2011.

LOPES, M. I. V; GRECO, C.; ORTEGA, D.; CASTILHO, F.; LEMOS, L. M. P.; NÉIA, L. M.; CARNEVALLI, M. A.; LIMA, M.; PEREIRA, T. Brasil: a "TV transformada" na ficção televisiva brasileira. In: LOPES, M. I. V; OROZCO-GÓMEZ, G. (orgs.). (Re)invenção de gêneros e formatos da ficção televisiva: anuário Obitel 2016. Porto Alegre: Sulina, 2016, p. 135-175. 
LOPES, M. I. V; GRECO, C.; ORTEGA, D.; CASTILHO, F.; LEMOS, L. M. P.; NÉIA, L. M.; LIMA, M.; PEREIRA, T. SANTOS, A. Brasil: dinâmicas da ficção televisiva na transição multicanal. In: LOPES, M. I. V; OROZCO-GÓMEZ, G. (Org.). Ficção televisiva Ibero-Americana em plataformas de video on demand: Anuário Obitel 2018. Porto Alegre: Sulina, 2018, v. 1, p. 103-134.

LOPES, M. I. V; MUNGIOLI, M. C. P.; FREIRE, C., GRECO, C.; LEMOS, L. M. P.; KARHAWI, I.; SUZUKI, H. BRAZIL: A Telenovela como fenômeno midiático. In: LOPES, M. I. V; OROZCO-GÓMEZ, G. (Org.). Memória social e ficção televisiva em países ibero-americanos: anuário Obitel 2013. Porto Alegre: Sulina, 2013, v. 1, p. 129168.

LOPES, M. I. V; MUNGIOLI, M. C. P.; FREIRE, C., GRECO, C.; LEMOS, L. M. P.; BERNADAZZI, R.; DANTAS, S.; PENNER, T. BRASIL: trânsito de formas e conteúdos na ficção televisiva. In: LOPES, M. I. V; OROZCO-GÓMEZ, G. (Org.). Estratégias de produção transmídia na ficção televisiva: anuário Obitel 2014. Porto Alegre: Sulina, 2014, v. 1, p. 119-160.

LOPES, M. I. V; MUNGIOLI, M. C. P.; FREIRE, C., GRECO, C.; CASTILHO, F.; LEMOS, L. M. P.; BERNADAZZI, R.; DANTAS, S.; LUSVARGHI, L.; MAURO, R.; SUZUKI, H.; PENNER, T. BRASIL: tempo de séries brasileiras? In: LOPES, M. I. V; OROZCO-GÓMEZ, G. (Org.). Relações de gênero na ficção televisiva: anuário Obitel 2015. Porto Alegre: Sulina, 2015, v. 1, p. 117-160.

LOPES, M. I. V; MUNGIOLI; M. C. P.; FREIRE, C.; LEMOS, L.; LUSVARGHI, L.; DANTAS, S.; BERNADAZZI; R.; PENNER, T. A autoconstrução do fã: performance e estratégias de fãs de telenovela na internet. In; LOPES, M. I. V. (org). Por uma teoria de fãs da ficção televisiva brasileira. Porto Alegre: Sulina, 2015.

LOPES, M. I. V. at al. A Construção de Mundos na telenovela brasileira: um estudo de caso a partir das cinco personagens mais lembradas. In: LOPES, M. I. V. (org). A Construção de mundos na ficção televisiva brasileira. Porto Alegre: Sulina, 2019.

LOPES, M. I. V. A teoria barberiana da comunicação. Matrizes v. 13, n. 1, p. 39-63, 2018.

LOTZ, A. 'On "Television Criticism": The Pursuit of the Critical Examination of a Popular Art'. Popular Communication, 2008, 6:1, pp. 20 - 36.

LOBATO, R. Netflix Nations: The Geography of Digital Distributions. New York: NYU Press, 2019.

MARTÍN-BARBERO, J. Dos meios às mediações: comunicação, cultura e hegemonia. 7ed. Rio de Janeiro: UFRJ, 2015. 
MARTÍN-BARBERO, J. Dos Meios às mediações: 3 introduções. Matrizes v. 13, n. 1, p. 39-63, 2018.

MARTÍN-BARBERO, J; REY, G. Os exercícios do ver: hegemonia audiovisual e ficção televisiva. São Paulo: Editora Senac, 2004.

MARQUES DE MELO, J.; ASSIS, F. Gêneros e formatos jornalísticos: um modelo classificatório. Revista Intercom, São Paulo, v.39, n.1, p.39-56, jan./abr. 2016.

MAGNO, M. I. C. Quando o Brasil ficcional faz pensar o Brasil real. Como a crítica entra nessa história?. Revista Observatório, vol. 3, n. 3, maio, 2017.

MAINGUENEAU, D. O contexto da obra literária. 2 ed. São Paulo: Martins Fontes, 2001.

MITTELL, J. Complexidade narrativa na televisão Americana contemporânea. Matrizes. Ano $5-\mathrm{n}^{\mathrm{o}} 2$ jan./jun. 2012.

MOTTER, M. L.; JAKUBASZKO, D. Telenovela e realidade social: algumas possibilidades dialógicas. Comunicação e Educação, ano XII, n. 1, pp 55-64, jan/abr 2007.

MUNGIOLI, M. C. P. PELEGRINI, C. Narrativas Complexas na Ficção Televisiva. In: Revista Contracampo, v. 26, n. 1, ed. abril, pp. 21-37. Niterói: Contracampo, 2013.

NUNES, B. Crítica literária no Brasil, ontem e hoje. In: MARTINS, M. H. Rumos da Crítica. 2 ed. São Paulo: Senac/Itaú Cultural, 2007, pp. 51-79.

ORTIZ, R.; BORELLI, S. H. S.; RAMOS, J. M. O. Telenovela: história e produção. $1^{\text {a }}$ ed. São Paulo: Brasiliense, 1989.

PALHARES, C. A Mimese na poética de Aristóteles. Cadernos Cespuc, Belo Horizonte, n. 22, 2013.

PALLOTTINI, R. Dramaturgia de Televisão. São Paulo:Moderna, 1998.

PIGNATARI, D. Signagem da televisão. São Paulo: Brasiliense, 1984.

PIENIZ, M. Mediação estrutural da tecnicidade: o trânsito das audiências a partir do Twitter. Matrizes, v.9, n.1, p. 213-228, 2015.

PIENIZ, M. Tecnicidade como mediação empírica: a reconfiguração da recepção de telenovela a partir do Twitter. 2013. 198f. Tese (Doutorado em Comunicação e Informação). Universidade Federal do Rio Grande do Sul, Porto Alegre, 2013. 
PRIOLLI, G. Crítica de Televisão. In: MACEDO, C.; FALCÃO, A.; ALMEIDA, C. J. M. (orgs.). TV ao vivo: depoimentos. São Paulo: Brasiliense, 1988, p. 147-155.

PRIORI, M. del. Histórias de gente brasileira, volume 4 - Testemunhos (1951 - 2000): República. São Paulo: LeYa, 2019.

POUPART, J. A entrevista de tipo qualitativo: considerações epistemológicas, teóricas e metodológicas. In: POUPART, J et al. Pesquisa qualitativa: Enfoques epistemológicos e metodológicos. Petrópolis, RJ: Vozes, 2008.

RABAÇA, C. A.; BARBOSA, G. G. Dicionário Essencial de Comunicação. São Paulo: Elsevier, 2002.

RALLO, É. R. Métodos de crítica literária. São Paulo: Martins Fontes, 2005.

RIBEIRO, R. J. O Afeto autoritário: Televisão, Ética e Democracia. Cotia, SP: Ateliê Editorial, 2004

RIDENTI, M. Caleidoscópio da Cultura Brasileira (1964-2000). In: MICELI, S.; PONTES, H. Cultura e Sociedade: Brasil e Argentina (orgs.). São Paulo: Editora da Universidade de São Paulo, 2014.

RIXON, P. TV critics and popular culture. A history of British television criticism. London/New York, I.B.Tauris, 2011.

RODRIGUES, S. Como escrever séries: roteiro a partir dos maiores sucessos da TV. São Paulo: Aleph, 2014.

RONSINI, V. A Perspectiva das mediações de Jesús Martín-Barbero (ou como sujar as mãos na cozinha da pesquisa empírica de recepção). In: GOMES, I. M. M.; JANOTI JUNIOR, J. (orgs). Comunicação e estudos culturais. Salvador: EDUFBA, 2011.

ROCHA, S.; ROCHE, F. L. Temporalidades: para pensar la contemporaneidad de lo nocontemporáneo. In: RINCÓN, O. (ed.); JACKS, N.; SCHIMITZ, D.; WOTTRICH, L. (orgs.). Un nuevo mapa para investigar la mutación cultural. Diálogo con la propuesta de Jesús Martín-Barbero. Quito: CIESPAL, 2019.

RYAN, M. L. Stoty/Worlds/media: turning the instruments of a mediaconscious narratology. In: RYAN, M. L; THON, J. Storyworlds across media. Lincoln/London: Un. Nebraska Press, 2014.

SANTAELLA, L. A Ecologia pluralista da comunicação: conectividade, mobilidade, ubiquidade. São Paulo: Paulus, 2010. 
SAFATLE, V. O circuito dos afetos: corpos políticos, desamparo e fim do indivíduo. Belo Horizonte: Autêntica Editora, 2018.

SARTRE, J-P. O que é a subjetividade? Rio de Janeiro: Nova Fronteira, 2015.

SARLO. B. Paisagens Imaginárias: Intelectuais, Arte e Meios de Comunicação. São Paulo: Editora da Universidade de São Paulo, 2016.

SANCHOTENE, C. Gramáticas de reconhecimento: a construção do leitor coprodutornas fanpagesdaFolha de S.Pauloe do Estadão. Revista Latino-americana de Jornalismo, v. 6, n. 1, pp 117-140, 2019.

STRAUBHAAR, J. D. Telenovelas no Brasil: de roteiros viajantes a um gênero e rotoformato nacional e transnacional. In: MOREIRA, S. V.; OTA, D. C. (ORGS.). Comunicação, mídia e cultura: estudos Brasil - Estados Unidos. São Paulo, SP: Intercom, Campo Grande, MS: Ed. UFMS, 2018.

SCOLARI, C. A. Literacia transmedia na nova ecologia mediática, 2018. Disponível em: http://transmedialiteracy.upf.edu/sites/default/files/files/TL_whit_port.pdf Acesso $03 \mathrm{fev}$. 2020 .

SERELLE, M. A ética da mediação: aspectos da crítica da mídia em Roger Silverstone. Matrizes, v. 10, n. 2, pp 75-90, 2016.

SERELLE, M. Reconhecimento como categoria de crítica cultural. Estudos em Jornalismo e Mídia, Vol. 16 nº 1, pp. 11 - 20. Jan/ jun 2019.

SERELLE, M; SENA, E. Crítica e reconhecimento: lutas identitárias na cultura midiática. Matrizes, V.13, n. 1, jan/abr, 2019.

SETTON, M. da G. J. A teoria do habitus em Pierre Bourdieu: uma leitura contemporânea. Revista Brasileira de Educação, n. 20, maio/jun/jul/ago, 2002.

SODRÉ, M. A televisão é uma forma de vida. Famecos, v. 8, n. 16, 2001.

SOARES, R. de L. Margens da comunicação: discurso e mídias. São Paulo: Annablume editora, 2009.

SOARES, Rosana; SERELLE, Márcio. A crítica de TV no Brasil: valores e repertórios. Revista Intexto, Porto Alegre, n. 28, pp. 171-189, 2013.

SOUTO, C. Crítica em 280 caracteres: uma análise da crítica de televisão e de sua repercussão no twitter. Panorama, v. 9, n. 1, pp. 02-06 jan/jun. 2019. 
SOUZA; S.; FRANCISCO, A. O Método da Cartografia em Pesquisa Qualitativa: Estabelecendo Princípios... Desenhando Caminhos.... Atas - Investigação Qualitativa em Saúde, V. 2, 2016.

SILVEIRA, H. Paisagem e memória. Rio de Janeiro/São Paulo: Paz e Terra/Secretaria Municipal de Cultura, 1983.

SILVA, G.; SOARES, R. Para pensar a crítica de mídias. Revista Famecos, v.20, n. 3, pp. 820-839, 2013.

SILVA, G.; SOARES, R. Lugares da crítica na cultura midiática. Comunicação mídia consumo, São Paulo, v. 13, n. 37, pp. 9-28, maio/ago. 2016.

SILVA, L.A.P.; BASEIO, M.A.F. Narrativa(s) como estratégia(s) de comunicabilidade. In: RINCÓN, O. (ed.); JACKS, N.; SCHIMITZ, D.; WOTTRICH, L. (orgs.). Un nuevo mapa para investigar la mutación cultural. Diálogo con la propuesta de Jesús Martín-Barbero. Quito: CIESPAL, 2019.

SPINOZA, B. Ética. Belo Horizonte: Autêntica, 2013.

SCHIAVO, M. R. Dez Anos de Merchandising Social. IN: XXIX Congresso Brasileiro de Ciências da Comunicação, UnB, 2006

TORRES, E. C. Ler a televisão: o exercício da crítica contra lugares comuns. Lisboa: Oeiras Celta Editora, 1998.

TORRES, E. C. Crítica jornalística na era do receptor empoderado. Contemporânea Revista de Comunicação e Cultura, v. 09, n. 01, 2011.

TODOROV, T. Crítica da crítica: um romance de aprendizagem. São Paulo: Unesp, 2015.

TONDATO, M. Apontamentos sobre a crítica de TV. Comunicação \& Educação. São Paulo, (19), pp. 32-38, set./dez. 2000.

TEURLINGS, J. Social Media and the New Commons of TV Criticism. Television \& New Media, V. 19, Issue 3, pp. 208-224, march, 2018.

TUFTE, T. Televisão, modernidade e vida quotidiana: Discussão sobre o trabalho de Roger Silverstone face a diferentes contextos culturais. Comunicação e Sociedade, $n$. 29, 1998.

VERÓN, E. Fragmentos de um tecido. São Leopoldo: UNISINOS, 2004. 
VERÓN, E. La semiosis social: fragmentos de uma teoria de la discursividad. Argentina: Gedisa, 1987.

VÉRON, E. A produção de sentido. São Paulo: Cultrix: Editora da Universidade de São Paulo, 1980.

VERÓN, E. Pour en finir avec la "communication". In: Réseaux, v. 9, n46-47, La communication : une interrogation philosophique. pp. 119-126; 1991.

VIEIRA, H. J.; HOISEL, E. A signagem de Décio Pignatari. Estudos Semióticos, Vol. 12, n. 2, São Paulo, pp. 82-88, 2016. Disponível em: http://www.revistas.usp.br/esse Acesso em 01 jan. 2020.

XAVIER, I. O olhar e a Cena - Melodrama, Hollywood, Cinema Novo, Nelson Rodrigues. São Paulo: Cosac \& Naify, 2003.

WILlIAMS, R. Televisão: tecnologia e forma cultural. São Paulo: Boitempo; Belo Horizonte: PUCMinas, 2016.

\section{b) Referências dos críticos}

KOGUT, P. 101 atrações de TV que sintonizam o Brasil. Rio de Janeiro: Estação Brasil, 2017.

STYCER, M. Adeus, controle remoto: uma crônica do fim da TV como a conhecemos. São Paulo: Arquipélago, 2016.

STYCER, M. Topa tudo por Dinheiro: as muitas faces do empresário Silvio Santos. São Paulo: Todavia, 2018.

XAVIER, N. Almanaque da Telenovela Brasileira. São Paulo: Panda Books, 2007. 


\section{ANEXOS}

\section{$\underline{\text { Críticas }}$}

As críticas analisadas nesta pesquisa estão disponíveis na íntegra no QR Code abaixo:

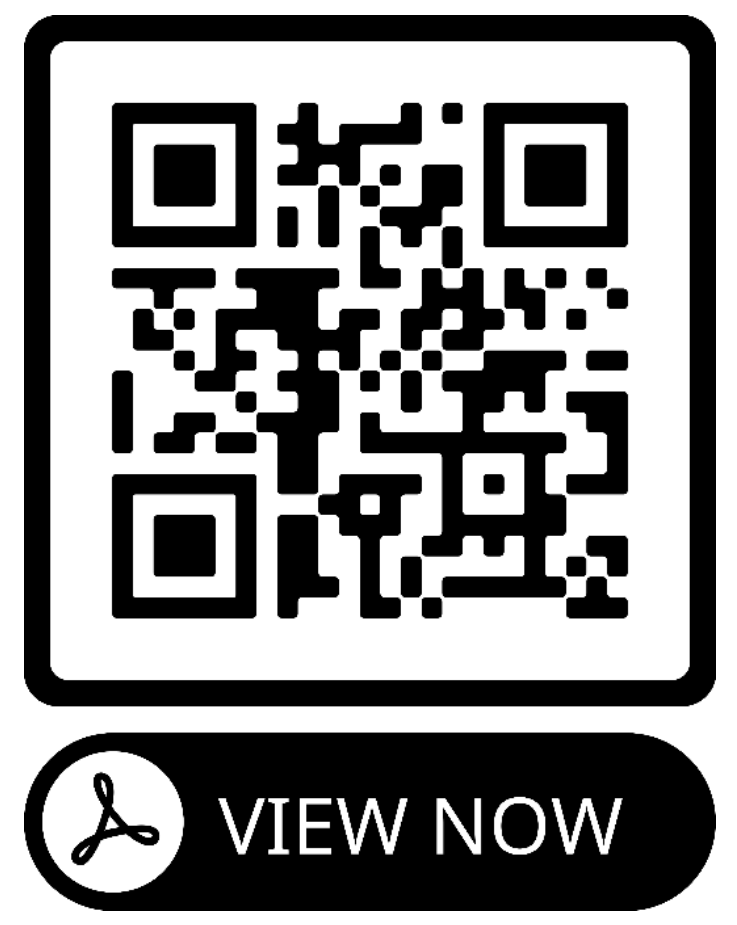

\section{$\underline{\text { Entrevistas }}$}

As entrevistas contidas neste anexo compreendem ao percurso metodológico explicado no capítulo 04 e que foram delimitadas durante os anos desta pesquisa doutoral. São entrevistas qualitativas e semiestruturadas, pois como veremos, foram adicionadas outras perguntas procedentes das leituras das críticas. A utilização das entrevistas para este trabalho nos ofereceu a oportunidade de interrogar os informantes do nosso objeto científico, neste caso, a crítica de telenovela. Desta maneira, "as entrevistas constituem uma porta de acesso às realidades sociais" (POUPART, 2008, p. 215), atuando como um recurso para compreendermos diferentes contextos. 
As quatro entrevistas estão disponibilizadas na íntegra, porém são de ordem fonéticas, sendo retiradas algumas interjeições para melhor compreensão. Com um guia de perguntas semiestruturadas, onde apresentamos um tema parcialmente delimitado, deixamos os informantes livres para responde-las da maneira que desejassem, o que fez que cada entrevistas fosse realizada num fluxo específico. Segundo Poupart (2008, p. 216), o recurso para a utilização da entrevista qualitativa são abarcados em dois argumentos, o primeiro é entender com profundidade as perspectivas - do que ele denomina de atores sociais - na compreensão das condutas sociais; o segundo argumento, o que se aproxima mais do objetivo do uso de entrevista nesta tese, é que "ela abriria a possibilidade de compreender e conhecer internamente os dilemas e questões enfrentados pelos atores sociais”. Esses argumentos estão alinhados ao trajeto metodológico percorrido, sendo as entrevistas um instrumento a complementar a análise das críticas selecionadas.

Assim, os entrevistados foram: Nilson Xavier, Maurício Stycer, Cristina Padiglione e Patrícia Kogut. A ideia central era entender as lógicas dessa crítica contemporânea de telenovela com suas dinâmicas e dificuldades; levar ao leitor a trajetória, as condutas e percepções dos atores aqui apresentados. Nas linhas a seguir seguem as histórias de profissionais, que desde cedo em suas carreiras, tiveram como ponto de partida o olhar voltado para a telinha, como antigamente se mencionava sobre a TV em comparação com a tela de cinema. Novas telinhas surgiram e nesse ínterim a crítica também foi se modificando. Nos capítulos acima, portanto, foram utilizados trechos desses diálogos, que, por conta das contingências metodológicas não puderam ser dispostos na íntegra; porém, acreditamos que as partes mais interessantes da vivência desses profissionais estão dispostas a seguir. Logo, as entrevistas serão mostradas na ordem em que foram realizadas, bem como o local em que foram feitas.

\section{Nilson Xavier}

Entrevista realizada dia 29 /04/ 2019, no Café Fellini, localizado no Espaço Itaú cinema Augusta.

1. Como você se iniciou na escrita da crítica de ficção televisiva e há quanto tempo exerce a função profissionalmente? 
Desde 2012 no Uol, e eu comecei por causa da minha trajetória, eu tinha o site, ele ganhou projeção. Lancei o almanaque de Telenovela Brasileira em 2007, e ganhou mais projeção. Então eu fiquei conhecido tanto entre estudantes, quanto em curiosos, quanto de profissionais de televisão e dos jornalistas. Então o James Cimino que é um jornalista que hoje está fora do Brasil, mas na época em 2012 ele era jornalista do UOL, ele me convidou para escrever para o Uol, foi aí que eu comecei a escrever no uol. Eu tinha um blog particular, que era meu, fazia ali resenhas de novelas, análises críticas, e ele perguntou para mim: você não quer fazer isso que você faz no Uol e ganhar por isso? Aí eu falei: é tudo que eu quero! Daí estou no UOL desde então, foi aí que eu comecei.

3. Qual sua relação com a televisão, especificamente com a telenovela?

Afetiva, por que vêm desde criança. Desde criança eu sempre gostei muito de televisão, eu cresci na frente da televisão. E desde criança eu anotava de forma sistemática tudo o que eu assistia, desenhos, novelas, séries da minha infância. Então esse foi um hábito que eu nunca larguei, mesmo depois da vida adulta, depois de ter entrado na carreira de informática eu nunca abandonei isso. No ano de 2000 lancei meu site Teledramaturgia e foi como tudo começou. Levei o site até 2012 apenas como um hobbie e acabei me profissionalizando por meio das minhas críticas no UOL.

4. Que critérios você leva em consideração para escrever suas críticas?

Essa pergunta é meio capciosa e subjetiva também. Porque, por exemplo, eu acho que para você escrever com propriedade sobre qualquer assunto, seja televisão, cinema, teatro, música ou literatura; você tem que primeiro ter um ótimo conhecimento sobre o assunto, você tem que ter vivência sobre aquele assunto, ou seja, experiência. E não só sobre o assunto, você tem que ter referências em atividades paralelas, mas relacionadas. Então, por exemplo, a telenovela é audiovisual, é importante eu estar ligado no audiovisual como um todo, por que a telenovela se espelha muito no cinema, se espelha muito na série americana, por exemplo. Ou mesmo na literatura, então você tem que ter uma bagagem intelectual diria até para poder escrever com propriedade sobre o assunto. Não adianta só você ter crescido vendo telenovela. Isso não basta. Você tem que escrever bem, você tem que dominar a língua, lógico; e você tem que ter todas essas referências que eu falei para você. Referências de cinema, de livros e a Vicência. Ter visto muito novela na vida. E como eu cresci na frente da TV, eu tenho essa referência, acho que para escrever sobre o que eu me proponho a escrever, eu me sinto apto. Pelo menos as pessoas consideram isso também.

Então eu não tenho pretensão de falar sobre as outras telenovelas, porque eu não vejo, nunca vi, nunca me interessei em ver. Não sou como o Mauro Alencar, por exemplo, que foi fazer doutorado no México.

5. Você acompanha as discussões e comentários acerca de telenovelas? Como? Em que meios?

Acompanho e inclusive faço a mediação. Apago alguns comentários. Todos os blogueiros do UOL, pelo menos no Uol é assim, quando eles escrevem alguma coisa passa primeiro 
por uma triagem os comentários. Por exemplo, são bloqueados de cara tudo que tem palavrão, a própria ferramenta do UOL já faz isso. Não permite aparecer palavrão. Assim, eu vou lá leio os comentários e tiro os que eu acho que são ofensivos a minha pessoa, aо meu trabalho, ou que não tem nada a ver. Até deixo alguns, para pessoa passar uma vergonha.

6. Na sua opinião, qual é o papel da crítica de telenovela?

A crítica de televisão existe pelo menos desde a década de 1970, a revista Amiga já tinha seus críticos de televisão, o Artur da Távola, Ferreira Neto, Olivia Friedman, um povo daquela época Simira Arruda, Helena Silveira. Então se você vai no site TV pesquisa da PUC lá tem várias resenhas que eles escreveram, dos jornais como O Globo. Agora eu concordo com você quando você diz que houve esse boom, mas não por conta das séries em geral, mas porque a internet permite isso. E aí que está também a questão da profissionalização em separar o que é joio do trigo, por que qualquer pessoa pode simplesmente abrir um blog e começar a falar do que ela acha que ela entende. Ou tem uns que são muito bons, que são desconhecidos que realmente são bons e que crescem com o passar do tempo. Que só não são profissionais não estão num grande veículo e que fazem o trabalho sozinho, tem também. E tem os que vivem de achismos, tem os haters, tem vários tipos. Então tem que saber separa o que é crítica de verdade, o que é crítica jornalística, o que é crítica profissional do que é crítica amadora nesse caso.

Acho importante, assim como toda a crítica. A crítica é importante, não desrespeitando a opinião pública, porque aí é uma outra coisa. Existe distanciamento entre a crítica e a crítica jornalística. A Clarice no livro dela chama de crítica jornalística. Livro muito bom. A crítica jornalística é diferente da crítica popular, mesmo por que o viés é outro. Então por exemplo $O$ outro Lado do paraíso, a crítica jornalística foi unânime, a novela era ruim, mas ela era um fenômeno de audiência. Um coisa absurda a audiência que ela teve. Então é uma discrepância muito grande, não é o mesmo peso e a mesma medida.

Eu estaria sendo um tanto quanto pretensioso se eu dissesse que para nortear o trabalho dos outros, do autor, ou do diretor, ou do ator, ou da emissora. Eu acho que soa um tanto quanto pretensioso dizer que é nortear. Não é nortear, por que eu acho que toda a pessoa que trabalha dentro dos limites dela parte do princípio que ela acredita no trabalho dela. $\mathrm{Ou}$, às vezes está fazendo por necessidade também. Aceita fazer qualquer coisa porque precisa também, tem isso também. Eu acho que o papel [da crítica] é importante, não para nortear, mas pelo menos para suscitar uma discussão, é uma boa palavra. Levantar então um questionamento. Por exemplo, eu publiquei hoje sobre a volta de Por Amor, o anterior foi sobre Jezabel, estreia da TV Record, uma produção muito boa, a gente vê que houve uma avanço da TV Record na produção de novelas bíblicas, mas ela carrega um ranço de doutrinação religiosa, que nós sabemos que existe, por que a Cristiane Cardoso que é a filha do Edir Macêdo ela que faz a supervisão. A Vivian de Oliveira brigou com a Record por causa dela, pediu demissão. A gente sabe que existe isso. E a gente vendo e sabendo disso, a gente consegue então traçar esse tipo de paralelo, a gente consegue analisar de uma forma melhor do que um simples telespectador da Record, às vezes que é da Igreja ou não é da Igreja e que aceita tudo de forma passivamente e que gosta. Assim é um outro olhar. A crítica ela é boa inclusive para o público também como uma referência. Não só para quem produz, para quem faz, como também para quem também consome aquilo. Acho que não é nortear, nortear acho pretensioso, mas como 
referência eu acho que é importante sim, tanto para quem produz quanto para quem consome.

Como eu estou em contanto no Twitter sempre, acho que eu consigo fazer esse apanhado no geral ou mesmo até um afunilamento de informações, de forma a organizar até as minhas ideias na hora em que eu for escrever. Eu também sinto que o Twitter é um bom termômetro, claro que não oficial, porque afinal de contas, os grupos de discussões não é o Twitter, são as senhoras donas de casa, que não tem nada a ver com o povo do Twitter. Então não é a mesma balança. Mas eu acho importante até para eu me nortear no que eu vou escrever sobre. É engraçado por exemplo, isso eu já escrevi que a novela $O$ sétimo Guardião é uma novela que não repercuti, as pessoas não comentam, os bastidores repercutem mais do que a própria história; é uma história que não interessa, é uma história que vai acabar e daqui há dois anos ninguém vai lembrar, ela vai ter passado batido. Já O outro lado do Paraíso vai ser sempre lembrada pelo absurdo do texto, pelos personagens, ela vai ser lembrada de uma forma boa ou não, ela vai ser lembrada. A Força do Querer lembrada pela qualidade, Avenida Brasil... Então assim, as novelas elas têm isso também, o público ajuda muito, eles também me ajudam como crítico, a organizar meu pensamento, organizar o que eu vou escrever.

7. Quais seriam os requisitos para ser um bom crítico de telenovela?

O primeiro é a experiência, a vivência sobre o assunto que é alvo da crítica. A experiencia é muito importante, então por exemplo, o crítico que tem 20 anos, quais os parâmetros que ele vai ter para tecer uma crítica, ele não tem a vivência que nós mais velhos temos. Por isso que os críticos sempre são vistos como aqueles velhos chatos, sabe desleixados, tem um filme argentino que não lembro o nome, que daí mostra um bando de crítico de cinema que são todos iguais, uma gente mal-amada, mal-humorada, por isso que crítico tem esse estereótipo. Então, é a vivência, a experiência, e um background intelectual mesmo, a questão das referências que eu falei. Ter referências não só sobre aquilo que você quer escrever. Por exemplo um cara que vai comentar sobre futebol, eu não tenho que saber só sobre a jogada, ele tem que saber sobre tudo, sobre o métier do futebol inteiro, sobre o esporte inteiro. Eu não vou comentar só sobre o que eu estou vendo, eu sei que por trás existe toda uma cadeia de produção, profissionais envolvidos. Sei como funciona, sei como é o roteiro de uma novela.

Eu não tenho fontes, eu não trabalho com isso. Não faço esse tipo de trabalho, porque eu acho que aí entra o colunismo social. Quem tem fontes é o Ricardo Feltrin, é Flávio Ricco, acho que nem o Maurício Stycer tem fontes. Eu não tenho. Eu recebo como todos os jornalistas, que é por meio da Comunicação da TV Globo, pelas áreas de comunicação das emissoras, pela sala de imprensa da Globo que envia tudo antes para a gente poder divulgar os produtos. Então a gente é chamado para divulgação na imprensa esse tipo de coisa, mas nenhuma informação privilegiada, nunca tive informação privilegiada de ninguém. Tenho claro, por exemplo, sou amigo do Euclides Nogueira, ele vai me falar alguma coisa, ele me fala em in off, me pede segredo, em nome dessa amizade eu acato e está tudo certo. Ou quando tem alguma coisa que ele possa me dar para publicar, eu publico. É o máximo.

8. Como é para você a distinção social entre a crítica de teatro e de cinema e a crítica de telenovela? Existe essa distinção? Por quê? 
Não é valorizada, porque a telenovela não é valorizada. É um produto de massa, ainda mais agora. De massa sempre foi e sempre foi desvalorizada desde sempre. Eu acho que está pior agora, porque além de ser desvalorizada pelos “intelectuais", ela é desvalorizada inclusive pela new generation que prefere as séries e faz esse tipo de comparação. Que usam esse tipo de parâmetro. Por exemplo, as pessoas da minha geração de quando eu era jovem elas cresceram vendo televisão como única fonte de entretenimento, por que Tv era isso e Tv aberta. Porque Tv aberta era nossa única fonte de entretenimento mesmo. Não existia nem TV a cabo. Tv a cabo só foi aparecer nos anos 1990, com a nova geração que cresceu com Tv a cabo que já recebeu leque muito maior de opções do que nós. Nós não tínhamos outra opção. Hoje em dia então é uma diferença absurda, as crianças não sabem nem o que é Tv aberta, eles assistem tudo a hora que eles querem no computado, no tablet, eles não ligam a TV. Então já um outro universo. Novela então para eles, não sabem nem o que é, os bem jovenzinhos. Porque os pais também já são uma geração mais jovem, mais jovens até do que eu. Então já não tem essa relação afetiva como eu tenho. Por isso que eu digo que é mais forte hoje do que antigamente, de não ter a valorização dos intelectuais e também não tem da nova geração, justamente porque a nova geração não criou esse laço afetivo que nós tivemos. Aí eles vão ter com os críticos das séries americanas, dos gamers que tem bastante. E com esses eles vão criar laços, mas com a gente não. É muito engraçado isso, a Globo faz séries tão boas quanto as da Netflix, quanto as séries estrangeiras. Assédio é maravilhosa, Sob Pressão é maravilhosa. São séries incríveis, tudo é incrível da produção ao roteiro, a direção, tudo muito melhor do que muita série estrangeira que a Netflix coloca no streaming. E que as pessoas às vezes babam. É engraçado isso, a pessoa não se vangloria de ver Assédio, que é uma série até importante, mas se vangloria de ver sei lá, $3 \%$.

9. Quais são os aspectos de sua crítica que, na sua opinião, mais tendem a provocar debate pelo público?

É quando a crítica faz desperta no público o que ele não consegue enxergar, não por que é limitado, mas por que está encantado com aquele produto ou ele odeia tanto aquele produto, são os dois extremos, que ele fica cego não consegue enxergar o que nós às vezes conseguimos enxergar. Tanto em termos da narrativa, tanto em termos de produção, eu acho que o legal é isso quando o crítico faz o público perceber isso. Ou às vezes o profissional também tá fazendo algo que ele não tá sabendo, uma coisa que ele não enxerga e que os outros enxergam, quem está fora enxerga. Às vezes você faz uma coisa que para você é ótimo, mas para o outro pode não ser ótimo. Aí a pessoa vem e fala umas verdades na sua cara. É como aquele amigo que diz umas verdades. Eu tinha uma terapeuta que ela falava do véu de Maia, um véu que deixa cego você não consegue ver a realidade, por que você está iludido. Então tem muito isso. Quem produz às vezes fica cego não consegue ver os problemas é aí que entra a crítica. Ou o público gosta demais ou odeia demais e não consegue ponderar, está cego de uma forma ou de outra, para o bem ou para o mal.

10. Como obra aberta, a telenovela permite que você a acompanhe enquanto está sendo feita. Como essa característica molda a sua crítica?

A minha crítica é sempre pontual do que eu vi daquele momento. Já mudei minha crítica várias vezes. Aquele menino Bruno Montaleone que fez a novela O Tempo não para. 
Assim que a novela estreou eu critiquei o desempenho dele achei muito ruim, só que com o passar do tempo eu vi que ele teve um avanço, e eu revi minha crítica ao final. Então, a telenovela ela pode começar boa ou ficar ruim depois, isso acontece. O Tempo não Para é um exemplo disso. Babilonia, o primeiro capítulo era maravilhoso, mas depois, se você olhar a minha primeira crítica de Babilonia eu enalteço a novela, melhor roteiro, uma coisa assim que escrevi... É muito ruim escrever no início, é péssimo. O Maurício, por exemplo, não gosta de escrever no primeiro capítulo, ele não escreve. É que eu escrevo, porque o homem pede. Porque como assunto está quente então é bom para a audiência do UOL. Então eu sempre escrevo, mas escrevo muito cheio de dedos, porque eu não tenho informação nenhuma, geralmente a emissora faz uma estreia que é para encantar as pessoas. Agora o que vai ser de fato a novela, precisa de duas semanas pelo menos para você gabaritar. Para você dizer a novela é isso ou a novela é aquilo. Senão não. As minhas críticas de estreias geralmente são muito superficiais, mas também as minhas críticas de final são um balanço completo da novela. Então eu mudo muitas vezes, a novela como sendo uma obra aberta, a crítica também está aberta rever sempre... Não é como uma crítica de um livro pronto, uma peça pronta, de um disco pronto. É diferente, os produtos estão prontos, a telenovela não. Ela vai se moldando com o tempo. Eu gosto de mudar de crítica, muda minha opinião. Eu gosto quando começa ruim e me surpreende. Agora triste quando começa boa e decai, como no caso do Tempo não Para, começou tão boa, eu gostava tanto e virou um nada praticamente. É uma pena.

Para novela o Globoplay não mudou nada. Agora por exemplo, Órfãos da Terra estão acrescentando um capítulo antes do que vai ao ar, mas é o máximo que eles conseguem fazer, as séries não, as séries eles já colocaram inteiras antes da estreia, o que é maravilhoso, por que você tem uma crítica final pronta no dia da estreia. Isso é bom, mas você não pode dar spoiler, e se equipara a crítica de um filme de uma peça. Você viu o produto todo daí você pode fazer uma crítica. Agora a novela não tem como, não te dá essa possibilidade. Então eu nem vejo Órfãos da terra antes eu prefiro ver no calor em que ela está sendo exibida e acompanhar com o Twitter, porque daí eu tenho respaldo de quem tá vendo junto comigo.

Super funciona a dinâmica de Twitter, para mim funciona. Acho que Patrícia Kogut vai dizer que não, mas o Maurício vai dizer que sim também, certeza. Maurício também vai dizer que sim, mesmo porque a gente pega muita pauta do que nasce no Twitter, tanto eu quanto ele.

11. É de praxe que a primeira crítica acerca de uma telenovela seja logo após ao capítulo de estreia. Quais os parâmetros que você usa para analisar uma obra que está começando?

Meu caso sim porque é um pedido do portal, mas é o que eu digo para você é sempre muito fria. Fria no sentido de que é muito prematura, sempre escrevo de forma prematura. Vejo no calor do momento o que senti, mas não é nada refletivo. Por isso que é sempre muito rasas as minhas críticas de estreia. Num primeiro capítulo de estreia não, em hipótese nenhuma. Como é um pedido eu, que as pessoas leiam, mas eu vou escrever depois.

12. Em sua opinião, o que difere a crítica de telenovela da crítica de programas televisivos como realities, ou de auditório? 
Acho que entrando dentro dos critérios que eu coloquei-experiência, referência - você pode dentro disso tratar de qualquer assunto. O que difere a crítica da novela do reality? Eu não vou me sentir apto a fazer uma crítica profunda de um reality show tanto quanto eu faço de uma telenovela. Já escrevi, mas é muito mais uma opinião minha do que uma crítica. Os outros programas que não são dramaturgia, é muito mais uma opinião mesmo. Por isso que já escrevi sobre cinema também, arranho sobre cinema. Eu prefiro escrever sobre cinema do que de reality, porque eu entendo mais. Então eu me sinto mais a vontade em escrever sobre dramaturgia porque é a área que eu me propus a me especializar. Mas reality por exemplo eu dou opinião. Dou opinião sobre programa de auditório, já escrevi sobre o programa da Tatá Werneck, por exemplo. De vez em quando eu escrevo sobre outros programas.

13. A telenovela das $21 \mathrm{~h}$ da Globo, é uma das produções mais comentadas na sociedade brasileira. Por isso, a seu ver, a crítica das ficções desse horário, exige mais responsabilidade?

Ela é mais comentada porque ela é maior audiência. Ela é há quase 50 anos o produto de maior audiência da Tv brasileira, não importa se ela vai bem ou não de audiência, não importa se ele é ruim ou não. Mesmo O Sétimo Guardião que não tem repercussão é o programa de maior audiência. É claro tem capítulos que não, mas na média geral é sempre a telenovela das nove, antiga telenovela das oito o programa de maior audiência da televisão brasileira. É o que gera mais buzz, o que gera mais texto para nós, independente da repercussão. Para mim não exige mais responsabilidade. Para emissora a responsabilidade é maior porque os anunciantes pagam mais exigem mais retorno, o horário exige mais, então paro o autor a responsabilidade é muito maior ainda. Tem autor que não quer saber de horário das nove. Alcides Nogueira não quer saber, Maria Adelaide Amaral escreveu uma e foi péssima, com certeza nunca mais vai escrever, não é porque a Globo não quer, ela mesma que não quer. Para mim não interessa se ela dá audiência ou não para falar a verdade, eu vou escrever.

14. Como crítico, o que diferencia a crítica de telenovela da crítica de séries norteamericanas?

Você tem que saber distinguir, você tem que saber que são formatos diferentes. A telenovela é uma coisa, série é outra. Série norte americana é outra, série latina é outra, novela turca é outra, é tudo formato diferente. Então, respeitando essas diferenças e essas limitações, você consome aquilo diferente e faz uma leitura diferenciada daquele produto e aí a tua crítica é montada e o resultado dela é tudo diferente também.

15. Poderia citar os seus top ten das ficções brasileiras de todos os tempos?

Vale Tudo; Roque Santeiro; Tieta; O Bem Amado; Avenida Brasil; Mulheres de Areia; Pecado Capital; Gabriela; O Rebu; A Força do Querer; O Rei do Gado

16. Poderia fazer uma análise resumida de como vê a crítica de telenovela no Brasil (pelo menos a que conhece)?

Nós somos muito unidos [críticos], no sentido que nós somos companheiros, parças. Eu não sei te dizer. Aí é que tá, eu não tenho uma parâmetro de como era antes, e como eu 
sou o mais novo de todos nesse universo e como eu só tenho esse modelo, essa minha resposta vai ser muito limitada. Quem vai poder te dar essa resposta melhor vai ser uma pessoa mais experiente, acho que nem o Maurício Stycer, por que ele coçou a escrever sobre Tv nem faz muito tempo assim, 10 anos. Quer dizer ele já era de jornalismo esportivo, se não me engano. Então talvez Cristina Padiglione te responda melhor e até Patrícia Kogut. Eu gosto e respeito meus colegas, respeito muito as opiniões deles. Eu fico muito envaidecido de estar entre eles, e você estar me entrevistando juntamente com eles, eu fico muito envaidecido disso. De ter esse reconhecimento, isso muito me envaidece. E gosto muito do que eles escrevem, nem sempre bate. Por exemplo, Verão 90, eu escrevi sobre a novela não criticando a estreia, e fui atrás do que meus amigos me escreveram. O Flávio Ricco elogiou, o Chico Barney - tudo bem é zoeira - mas ele elogiou, então eu coloquei abaixo do texto os links pros textos deles, da Cristina Padiglione, do Maurício Stycer, do Flávio Ricco e do Chico Barney e do Tony Góes também. E coloquei textos de pessoas que pensavam como eu e que pensavam diferente de mim. Inclusive eu mandei uma mensagem para o Flávio Ricco perguntando: posso colocar seu texto? Porque você elegia e eu massacro, não quero que você veja como provocação não tem nada a ver; ele respondeu; não, lógico que pode, as pessoas tem opiniões divergentes mesmo. Nós temos opiniões divergentes algumas vezes. Movimentar também a discussão. Então assim, qual o cenário? eu não sei te dizer realmente por que eu só conheço esse, por que eu sou muito novo, só desde 2012 com essas pessoas. Não conheço esse que vieram antes de mim, a não ser claro Artur da Távola já falecido, Helena Silveira já falecida, Ferreira Neto já falecido, então eu não conheço eles. Um coisa que me veio a cabeça agora, o Walcyr Carrasco era crítico de televisão, ele escrevia para a Contigo e uma vez eu mostrei pro Maurício até, eu achei uma crítica, um recorte da revista Contigo ele criticando a novela da Glória Perez, dizendo que era fantasiosa demais. Dizendo que era fantasiosa demais, falei para o Maurício, olha só quem está falando? A crítica detonada, não sei se era de Corpo e Alma ou era de Explode Coração.

17. Para que serve a crítica de telenovela?

Eu respondi acima, não acho que seja para nortear, acho que seja para uma referência para quem consome e para quem faz. Acho que é para isso que serve. E para levantar discussão também.

18. Quantas pessoas leem as suas críticas?

Não tenho isso, porque quem detém isso é o UOL. Até tenho uma ferramenta que a gente vê as estatísticas do site, mas eu não tenho como te dizer isso, por que ela não vem de uma forma orgânica para gente, vem num totalzão. Então não tem como eu te dizer quantas pessoas leem as minhas críticas. Vou te dizer uma coisa que é um parâmetro nosso, a gente gosta de novela que gera repercussão, não importa se é boa ou se é ruim. Novelas que as pessoas queiram ou tenham vontade de ler sobre. Por exemplo O outro lado do paraíso, era um paraíso para gente porque gerava muita pauta, pessoas queriam ler, gerava buzz, gerava buchicho, mesma coisa com A Força do Querer e mesma coisa Avenida Brasil. Então quando a novela faz sucesso nesse sentido é maravilhoso para gente. Pior coisa que acontece é quando a telenovela não repercute. A novela é legal quando ela repercute porque todo mundo quer ler. Uma novela que não repercute ninguém quer ler. A lei do Amor era horrível, ninguém queria ler. É que preciso escrever, era horrível, precisava catar pauta. Sétimo Guardião tenho escrito muito pouco. Uma 
coisa que a Padiglione me falou e que é verdade, a segunda metade do ano passado foi horrível para televisão de um modo geral, por causa da política. As pessoas só queriam saber de política. Aí veio o horário de verão, as audiências da TV caíram muito, demais. As audiências da novela foram péssimas. Desde dezembro do ano passado e todo verão deste ano, as audiências das novelas foram muito ruins. Não tinha novelas boas para ver e as pessoas não queria comentar, as pessoas ficaram muito da metade do ano para cá focadas em política e continuam ainda. O cenário político é o que tem gerado pauta paras pessoas, que tem interessado as pessoas, muito mais que entretenimento. Então, eu espero que o Walcyr Carrasco venha para mudar um pouco isso, para o bem. Apesar de escrever ruim, assim eu falo de uma forma eu odeio o Walcyr, mas não é verdade. Eu acho que o Walcyr Carrasco escreve novelas muito boas, no horário das seis, Eta Mundo Bom era maravilhosa, Verdades Secretas era maravilhosa, tenho muitos elogios de escrita para essas duas novelas, que foram novelas da época que eu comecei a escrever. Então são novelas ótimas, são novelas incriveis, muito boas, o Cravo e a Rosa, Chocolate com Pimenta, Alma Gêmeas e até Caras e Bocas, todas novelas boas. Só não acho que ele é autor de novela das oito. Acho que a das oito pede um texto que não subestime tanto a minha inteligência.

19. Você comenta que a novela das nove ela merece um texto mais realista que o das outras. Você acha que de uns anos para cá está tendo esse cuidado com o texto?

Não, acho que quem apresentou alguma coisa nesse sentido foi a Glória Perez com A Força do Querer, que realmente era uma novela que trazia temas muito interessantes para nossa sociedade e de uma forma muito bem colocada. Sem subestimar o público e sem quere causar sensacionalismo, como às vezes o Carrasco faz. Um texto cuidadoso, um texto bom, um texto bonito. Ela teve uns problemas, teve. Teve personagens que foram desperdiçados, atores desperdiçados. Mas no geral era uma novela muito interessante. Então é uma pena que quando apareça, não tenha essa repercussão. Infelizmente eu só consigo citar essa. Porque por exemplo Velho Chico é uma novela barroca demais. Eu gostava, mas era muito barroca, novela muito difícil de engolir. Público não consegue acompanhar, para eles aquele pessoal vivia suado demais na tela. Era uma reclamação. Era todo mundo muito suado. É uma coisa que o público não quer ver. Isso é muito bonito, mas para o horário das onze, para o cinema. Mas no horário das nove? Acho que não é uma boa para o público não. E o texto do Benedito cansou um pouco também. É um texto meio cansativo, tinha poucos núcleos, poucos personagens, e não trazia nenhuma novidade na história. Era um Romeu e Julieta. Não trouxe novidade nenhuma. Tudo muito bonito, mas é um bonito que cansa. Não ganhou repercussão. Não é como novela da Glória Perez. Agora, por exemplo, Império, era uma bobagem. Nem é uma novela ruim totalmente, mas não trouxe nada de novo. A Lei do Amor era péssima, era tudo ruim nessa novela. Babilônia começou bem, mas ficou péssima também. Era muito difícil. Amor à Vida, meu Deus do céu que novela horrível! Só era legal por causa do Félix, que era muito carismático. Mas meu Deus se não fosse carismático, se não fosse o Mateus Solano, coitado. Também era uma novela muito ruim, as abordagens muito ruins. Aquela coisa do Walcyr Carrasco tratar autismo e obesidade de forma tão irresponsável nessa novela. Uns comentários de mal gosto, uma coisa horrorosa. E depois ele fez de novo em $\mathrm{O}$ Outro Lado do Paraíso também, um casal gay de muito mal gosto. Aquela anã, coitada daquela atriz.

Respeitar a proposta da novela, porque as vezes a novela pode ter uma proposta de fantasia enlouquecida, mas respeitar aquilo. E mesmo a fantasia tem as suas regras. 
Deus salve o Rei por exemplo, aconteceu um fato no início da novela que não é possível, que o rei abdicar do trono. Aquilo é um absurdo e não cabe em nenhuma história medieval, só para poder gerar determinando fato para fazer a história andar, ele fez o rei abdicar do trono. Aquilo é um absurdo, eu critiquei muito isso. Porque para mim perdeu completamente a credibilidade. Então são códigos, a Clarice fala muito bem sobre isso, ela entrevistou a Cristina Padiglione, ela fala muito bem sobre isso também, são códigos que devem ser respeitados. E isso não é só para novela, para tudo, para Game of Thrones, para qualquer série. Pro cinema, paro teatro. Tem que respeitar a proposta e ela tem que estar clara para o público. Senão o público não embarca, o público dica completamente perdido, confuso, não entende, daí vira uma salada. Aí muda conforma e a necessidade do roteiro, ou seja, o autor faz outra novela; ou trai a proposta da novela. O personagem do Juliano Cazarré em Amor à Vida era um personagem coringa, quem escreveu isso muito bem foi o Maurício Stycer. Personagem coringa na mão do autor, ele servia para tudo na novela, para poder justificar o roteiro dele. Isso não é coisa de uma narrativa bem-feita, não é coisa de uma escrita bem-feita, de uma história que foi pensada, parece uma coisa que é feita as coxas. Então isso eu critico também. Acho que é importante se você for escrever um livro ou qualquer linguagem, livro ou cinema. Como é que um autor faz isso? Eu me sinto traído como telespectador. Ele trai o telespectador, ele vendeu uma coisa e é outra. Novela das sete atual também, a Globo vendeu uma coisa e é outra completamente diferente, já mudou de novo. Começou com uma história de Samantha, no segundo capítulo já não era mais Samantha, já era história. Ela vendeu como Samantha, na campanha de divulgação da novela era Samantha, uma história muito parecida com a série. O segundo capítulo era outra história que não tinha a nada a ver com o que a Globo vendeu. Aí de repente virou Vale Tudo e a crítica caiu matando em cima. Já mudaram, não é Vale Tudo. Agora é uma novela cíclica. Eles inventam coisas, primeiro é um doce de leite que está barato, depois os garotos que fazem strip-tease, depois já é outra situação. Parece que a novela não tem um norte. Parece que eles escrevem ao sabor do que vai acontecer. Parece que é uma novela que não é pensada. Isso é muito estranho. Eu não estou nem criticando, pode ser uma proposta também. Uma coisa meio seriada, pode ser, por que não? Só que tem que ver como você coloca isso para o público.

20. Você acha que você é lido por esses autores?

Eu acho que sim, porque eu já tive esse feedback várias vezes. Atores, autores, diretores. Às vezes sou bem interpretado, às vezes mal interpretado, lógico tem os dois lados. Por exemplo, tem dois autores que pararam de falar comigo. Eu digo que ser crítico é uma profissão muito ingrata Por que se você fala bem a pessoa que gosta daquilo que você falou bem, que é fã, se você falou bem de uma novela elogia, o fã daquela novela te enaltece, que ser teu amigo de infância. A partir do momento que você falar mal ele passa a te odiar, ele não concorda com você, ele passa a te odiar. No caso dos autores, teve um autor que eu elogiei uma novela dele e na novela seguinte eu não elogiei, ele já me trata diferente. Ah fico pensando, na próxima novela que você fizer e eu elogiar você volta a falar comigo, é isso? É assim que funciona. Provavelmente sim. Se eu tivesse no lugar dele eu acho que faria a mesma coisa, porque aí depende de pessoa para pessoa. Então é muito complicado isso. Agora, por exemplo, lembra de uma série da Globo chamada Na será como antes, que se passava na década de 1950 que era sobre o rádio e a implantação da TV no Brasil, uma crítica que eu fiz foi que ela era apresentada como uma série semanalmente, ela perdia o fui da narrativa dela quando passava na outra semana, por que ela não feita para ser série foi feita para ser uma minissérie. Poderia ter sido exibida diariamente, porque senão as pessoas perdiam o fio da meada da 
história. Ela não era serializada, a narrativa dela não era para ser série era para ser uma novela ou uma minissérie, uma novela curta. E eu escrevi isso na crítica, e o diretor que é o José Villamarin ele me encontrou uma vez na Globo e falou comigo 'eu concordo com você, realmente foi um erro nosso de estratégia, não deveria ter sido exibida semanalmente'. Mas isso é um acordo entre eles, mas a Globo decidiu apresentar como série, provavelmente foi isso que aconteceu. Mas assim, existem os dois lados, sou elogiado quando elogio, mas é tipo elogio de mãe. A mãe sempre vai elogiar o filho. Então eu não me iludo muito com isso. É muito fácil você receber um elogio da pessoa 'ah eu gosto de você, você elogiou meu trabalho'. Eu quero ver você fazer o contrário, você reconhecer uma crítica. Ou para discutir. Porque você pode não concordar comigo, mas se você discutir comigo, nós vamos discutir. Aí existe discussão, aí que é legal, interessante; é levantas a discussão. Não, não concordo com você e ponto final isso não é discussão, isso é fascismo. Intolerância à recepção de crítica. Então tem todas essas questões que a gente avalia. Eu não me iludo muito com quem elogia meu trabalho, por que é complicado, é muito fácil você concordar com a pessoa, 'ah realmente', mas isso não gera discussão. Vai gerar discussão quando você discorda.

21. Você assiste a telenovela com caderninho?

Não, às vezes eu anoto o que acho que vai gerar uma pauta, o que merece ser discutido tomo nota com certeza. Meu caderninho é o Twitter. Às vezes eu faço uma enquete, 'o que você está achando disso', as pessoas me dão ideias. Às vezes eu jogo um verde, para ver se aquilo gera buchicho. O Stycer faz isso também. Quem usa bastante o Twitter faz isso. Eu comecei no meu trabalho nisso, porque eu já tuitava antes de escrever crítica, então eu já estava nesse universo antes de começar a escrever. Diferente da Cristina Padiglione, ela não tuita tanto, Patrícia Kogut menos ainda, ela só divulga os textos dela, o Twitter dela é só isso. Mas eu e o Maurício pelo menos usamos ao nosso favor. Mesmo porque o Maurício como ele também entrou nessa de escrever sobre Tv em geral e sobre novela, ele não tinha esse background, ele até usa isso como um norte para ele mesmo. Talvez ele até vá falar isso.

\section{Maurício Stycer}

Entrevista realizada dia 08/05/2019, na casa do crítico.

1. Como você se iniciou na escrita da crítica de ficção televisiva e há quanto tempo exerce a função profissionalmente?

Tem um preâmbulo que é o seguinte, eu sempre quis ser jornalista cultural. Fui levado por esses meus gostos, meu interesse. Eu consegui começar na área num lugar muito bacana na época, eu estou falando no final de 1985, terminando a faculdade, e que logo ainda estudante, tive a oportunidade de escrever alguns texto pro Caderno B do Jornal do Brasil. E foi justamente no período em que o Zuenir Ventura estava assumindo como editor; então ele meio que me abraçou assim. Ele ainda no final da faculdade começou a me pedir textos, e gostou de coisas que eu escrevi. E logo que eu me formei fui contratado como repórter do Caderno B do Jornal do Brasil. Que era tipo uma glória, 
para alguém ali no Rio, recém-formado. E aí eu me deparei como repórter fazendo tudo, reportagens de todas as áreas, na área do caderno B. Muitos anos depois eu guardei esses recortes de jornal, e mais recentemente eu estava olhando, eu já tenho ali críticas de televisão, em 1986 eu escrevi a crítica de Ti Ti Ti, escrevei a crítica de outra novela das oito da época. Ele me botou de interino da colunista de Tv um período, o colunista saiu. Então já tinha ali um gosto. Eu sempre vi televisão, e me arrisquei ali muito jovem não são bons textos, mas tem ali uma vontade de escrever sobre isso. Acho isso interessante, então isso é um preâmbulo. Minha atual de dedicação, ela começa em 2008, quando eu fui trabalhar no segundo semestre no portal IG, foi meu primeiro trabalho numa empresa de internet. Eu fui contratado para ser repórter especial do portal, ainda tinha pouca intimidade com internet, e eu pergunte: vem cá, esse negócio de blog..., 'você quer um blog? A gente vai te dar um blog também'. E me deram um blog em paralelo com meu trabalho de repórter. E eu comecei a experimentar nunca tinha feito blog. Era moda blog, blogueiro. Era visto como uma coisa muito pessoal. E eu comecei a usar o blog como complemento do trabalho de repórter. Então, por exemplo, eu fazia uma reportagem especial, fiz uma série sobre adoção, no dia que a reportagem ia ser publicada eu ia no blog e fazia uns bastidores da notícia, um post contando os detalhes dos bastidores da reportagem que eu tinha feito. E assim eu comecei a fazer o blog, e aí eu via um filme e fazia um post, eu via uma exposição fazia um post, eu via um programa de Tv que achava interessante eu fazia um post. E aí eu comecei a escrever e começou a ter repercussão. Nesse processo que eu fiquei escrevendo esse blog no Ig, um ano e meio que foi o período que eu trabalhei lá. Quando eu escrevia sobre Televisão tinha mais repercussão sobre qualquer outra coisa, quase sempre. Mesmo um filme ou bastidor de uma matéria, escrevia sobre televisão, aí tinha muito comentário. E em algum momento - isso é uma história que eu estou tentando resgatar, até procurei uma menina que trabalhou comigo na época, ela também não lembra, que eu queria lembrar quem foi em algum momento (por que eu entrei no Ig se eu não me engano em agosto de 2008) - em janeiro de 2009 alguém chegou para mim e perguntou: 'você não quer fazer uma coluna para mim sobre o BBB 2009? Escrever sobre o BBB?' Eu falei eu topo! Eu já tinha assistido as oito edições anteriores do BBB, tinha assistido como espectador, algumas eu assisti bastante e outras assisti mal, mas eu conhecia o programa tinha uma curiosidade, embora tivesse muito preconceito. Não tenho mais. Então, eu aceitei fazer essa coluna e teve muita repercussão, foi um negócio assim... Tanto para mim, mesmo lá na Globo, foi surpreendente eu tivesse feito essa coluna, para todo mundo. Que eu tratei aquilo com um olhar, ainda que muito crítico, levei a sério aquilo. Eu lancei um olhar sério sobre aquilo, e chamou muita atenção. E desde o início não foi uma coisa muito pensada, mas depois eu elaborei intuitivamente sobre três questões no BBB: a edição, a atuação do diretor e a atuação do apresentador. Eu evitei falar dos participantes, desde muito tempo eu sempre evito falar dos participantes; só falo deles quando tem a ver com esses três aspectos que eu procurei olhar. $O$ diretor que era o Boninho, a edição eu criei um neologismo, 'mister edição', sempre as matérias assim: "ah a edição fez isso, a edição mostrou aquilo', a edição é alguém, não sei quem é? Dai eu passei a chamar de mister edição logo nesse primeiro ano. É um elemento crucial no negócio e a interação do Bial com os participantes que também era crucial para a forma como as pessoas percebiam o programa. A maneira como o programa é empacotado que eu achei que era uma coisa interessante. Acho que merecia ser entendido, por que ele fazia tanto sucesso, por que ele era muito bem empacotado por esses três elementos. Comecei a escrever sobre isso, fiz essa coluna fez muito sucesso, o Bial me citou no BBB 9 ao vivo, numa interação com uma participante, ele fez um comentário: 'Não, por que tem um brother meu escrevendo sobre o BBB, ele criticou isso...', então teve muita repercussão. Então, esse é um ponto 
de partida. Passei no blog a falar mais sobre televisão, novelas, séries, sobre programas, apresentadores, ao longo de todo ano de 2009 em paralelo ao trabalho de repórter. E no final de 2009, teve uma mudança na direção do IG, as pessoas que tinha me chamado saíram, e veio uma equipe nova e eu esperei. Deu um mês e não rolou uma empatia, não senti que tivesse interesse pelo meu trabalho. Não aconteceu nada na verdade, nem eu fui demitido nem nada. Mas eu não senti que aquelas pessoas novas tinham interesse no meu trabalho, aí eu entrei em contanto com a diretora de conteúdo do UOL, que era uma conhecida minha de muitos anos que é a Marian Strecker, ela tinha sido minha editora na Ilustrada na Folha quando eu trabalhei na Folha em 1988, depois eu voltei como colunista em 2012, mas fiquei na Folha de 1988 a 1997. Quem me levou para lá foi a Marian Strecker. Final de 2009 eu a procurei, e a gente se encontrou e eu falei: 'a situação é essa no IG', contei um pouco isso que estou te contando, e falei essas palavras para ela: 'você não quer fazer um negócio, botar para quebrar de televisão no UOL?' Aí ela falou, 'eu quero'. Ela me pediu um dia para ver as condições de salário e tal. Um dia a gente almoçou e no dia seguinte ela me ligou: 'vem'. Eu comecei logo em janeiro, dia 04 de 2010, acho. Não lembro dia que sai do IG, foi uns 20 e tantos de dezembro. Aí já foi para escrever sobre televisão. Ainda que eu tenha outras coisas nesses quase dez. anos, eu também entrei como repórter fiz parte de várias coberturas, copa, olimpíada, conferência da ONU, fiz um monte de coisa. Eleições eu atuei e ajudei como repórter, mas realmente meu foco principal foi escrever sobre televisão e fazer programas de TV sobre televisão, esse foi o foco. E aí enfim, já tem nove anos que eu estou lá fazendo isso. Eu gosto e procuro mentalizar, refletir, tentar renovar, tem uma tendência a repetição em todo trabalho.

2. Qual sua relação com a televisão, especificamente com a telenovela?

Eu tenho uma interrupção nesse meu processo. Tenho essa relação afetiva de infância com a TV, realmente é uma coisa muito presente na minha vida nos anos 1960 e 1970. Via tudo, quando criança programas infantis, Capitão Asa que era Xuxa da época, eu era fã. As séries infanto juvenis, todas que passavam na minha época. Eu sou da época de Nacional kids, Bat masterson, Família Waltons, todas essas séries americanas que as TVs comparavam e muitas outras. A Tv mais ou menos a partir - eu sou de 1961 - minha memória lembra de coisas de 1967 e 1968. Final dos anos de 1960 comecei a ver novela também. Minha mãe não deixava inicialmente eu ver novela das oito, era tarde, eu lembro de brigar com ele porque queria ver novela. Depois passei a ver e continuei como telespectador normal, não como telespectador obsessivo, nunca fui um telespectador obsessivo de tv, tenho uma lembrança boa era uma coisa que eu gostava, mas não era uma coisa prioritária na minha escala de atividades. Já no final da adolescência, no início que começava a estudar para a universidade, não girava em torno da televisão a minha vida, mas sempre estava presente, sempre vi, sempre me interessei, mas não sou um rato de televisão. Tem períodos sobretudo anos 1990, que eu vejo às vezes reprise de novelas eu lembro que eu via, mas não assistia todo dia, muita novela. Eu via, sabia. A novela, a televisão, sempre esteve no meu radar. Sabia o que estava acontecendo era uma coisa que me interessava, mas não sentava também todo dia diante da televisão horas para ver nesse período, sobretudo anos de 1980 a 1990, teve um afastamento.

3. Que critérios você leva em consideração para escrever suas críticas? 
Primeiro as estreias, eu procuro ver todas as coisas novas em TV aberta. Esse meu trabalho no UOL ele é focado sobretudo em TV aberta. O UOL é quase uma televisão em termos de público que entra, um público muito grande, de todas as faixas econômicas é muito grande, é um tráfego de internet enorme. Então eu percebo que quem procura ali o meu blog são pessoas que assistem TV aberta. Então eu me preocupo em saber tudo o que está acontecendo em TV aberta em todas as estreias, em todas as áreas. Então esse é o primeiro ponto. O segundo, no caso específico de novelas, pela especificidade desse formato, eu procuro assistir todas sempre. Procuro assistir, não que eu consiga. Saber tudo o que está acontecendo, por que desde sempre as novelas tiveram um papel superimportante no cotidiano das pessoas, por tratarem de temas do cotidiano delas, levantarem assuntos, levantarem questões, discutirem problemas. Tem uma tradição no Brasil, da novela se tornar um assunto fora da novela, e isso é uma das coisas mais interessantes que tem na maneira brasileira de fazer o folhetim televisivo. Então eu acho importante saber sempre o quê que as novelas estão falando e como as pessoas estão reagindo a ela. E com a internet isso se tornou mais fácil. As redes sociais repercutem mais as novelas, então se um assunto é tratado em determinado capítulo se ele chama atenção para bem ou para o mal rapidamente reverbera, se transforma numa discussão e vira uma pauta.

4. Você acompanha as discussões e comentários acerca de telenovelas? Como? Em que meios?

Até o ano passado, 2018, eu aprovava todos os comentários do blog. Eu era o mediador. O UOL sempre me ofereceu moderar os comentários do meu blog e eu sempre recusei, porque desde o início eu percebi que ali na caixa de comentários, aquilo ali era, primeiro, uma usina de pautas para mim, e segundo me ajudava a sentir a temperatura dos assuntos. Seja quando enfurecia demais os leitores, seja quando eles se empolgavam demais. Isso me ajudou a modelar o meu texto muitas vezes. Lendo os comentários, as respostas, por obrigação que eu me impus de moderar, eu perdia muito tempo com isso sempre. Eu parei em 2019, porque o UOL instalou um sistema que eles chamam lá de inteligência artificial, para moderar, eu resolvi abrir mão; então esse é o primeiro ano que eu não estou fazendo. $O$ que eu queria dizer com os comentários, não sei se te interessa, mas para mim foi muito educativo algumas coisas. Uma em especial que eu aprendei a entender que eu devo sempre dizer para o espectador, leitor, por que que determinado programa é ruim, mesmo eu sabendo que ele gosta do programa. Mas eu tenho que ter o cuidado de não o ofender com isso. Isso é uma coisa muito delicada, quer dizer que eu aprendi somente vendo os comentários no início. Talvez por eu adotar um tom um pouco alto em relação a algumas críticas, vi uma reação que praticamente o leitor estava ofendido pelo fato de eu estar dizendo que aquilo era ruim. Porque eu estava atingindo diretamente o gosto dele. Então isso me fez pensar da importância de eu modular a minha crítica. Quer dizer eu estar dizendo tudo o que penso, explicando para ele por que que essa novela que ele ama tanto é horrível, na minha opinião. Mas sem que ele se sinta ofendido por isso. Isso eu aprendi lendo os comentários. Eu não mudei a minha opinião, mas muitas vezes eu mudei o tom. Esse ano eu fiz um texto por exemplo que é muito raro eu fazer atualmente que eu já fiz muito mais no passado, que é um texto que eu escrevi assim: 'Por que Tamanho Família é o pior programa da Globo', mas se você reparar muito por conta dessa experiência toda eu tive o cuidado - embora meu blog seja um blog de opinião e é a minha opinião sempre, isso é claro - eu escrevi : 'uma opinião bem pessoal:', coloquei isso no título justamente para tentar amortecer, que eu sabia que isso ia ofender muita gente dizer isso, mas é um texto que me lembrou uma experiência mais inicial do blog. Que eu era mais enfático talvez, um pouco mais duro 
em relação a algumas críticas. Hoje eu faço essas mesmas críticas, mas com outras palavras.

Sobre a utilização do Twitter

É muito interessante realmente essa conversa. Eu entrei no Twitter em 2008, não por coincidência justamente quando eu estava começando no $I G$, porque foi sugestão de alguém do IG para eu abrir uma conta no Twitter. E desde o início eu percebi esse diálogo, essa experiência que é incrível de você assistir televisão como se você estivesse numa sala com várias pessoas ao mesmo tempo. Todo mundo vendo a mesma coisa. Isso realmente é uma experiência incrível. Então o Twitter é uma ferramenta muito importante para o meu trabalho. Aprendo, recebo dicas, ouço reprimendas, corrijo coisas em função de comentários, já muitas vezes ocorreu, apontando erros, imprecisões. O Detetive Vê TV surgiu de sugestões de leitores, eu criei o termo, mas o fato de eu ser muito ativo no Twitter, discuti e dialogar com as pessoas que se comunicam comigo, isso criou uma relação. Então as pessoas se sentiram a vontade para começar a me sugerir coisas, 'ah por que você não escrever sobre não sei o quê?', 'Por que você não faz não sei o quê?', até que começaram: 'você viu não sei o quê?', apontando erros. De fato, o blog é uma experiência de processo colaborativo real, desde o início foi e ainda é. E eu sempre cito quem colaborou as pessoas amam. Pergunto antes por que as vezes a pessoa é anônimo não quer falar. Quando posso citar e eu cito as pessoas ficam radiantes.

5. Na sua opinião, qual é o papel da crítica de telenovela?

Esse é um tema daqui ["Adeus, Controle Remoto"] tema importante. Eu trato desse assunto nesses textos aqui. A crítica de TV, em específico de novela, naturalmente ela é feita a posteriori, porque novela é escrita com alguma antecedência a gente está sempre vendo um capítulo que foi escrito há duas, três, quatro semanas antes. Você não interfere como crítico, mesmo que você aponte problemas, embora seja uma obra aberta e seja possível corrigir, mudar rumos, acho que o crítico afeta muito pouco esse processo de criação. Mas eu acho que ele tem uma importância enquanto ajuda ao espectador para entender o que ele está vendo. Eu penso muito mais no telespectador. Acho que dá para gente como crítico, justamente, ajudar o espectador entender por que que ele está gostando ou não está gostando de determinada novela. O que que ele está vendo às vezes tem significados não está evidente, não tão óbvios. O crítico pode ajudar neste sentido, mostrar às vezes uma intenção oculta, mostrar uma intenção subjacente do que está aparecendo. Dar contexto, isso eu acho muito importante. Um tema que eu tenho repetido muito, em todas as conversas que eu participa que é a importância do contexto de uma novela, de uma situação numa novela, de uma programa de TV em relação ao mundo que a gente tá vivendo, em relação a história da teledramaturgia, o lugar que aquela telenovela ocupa dentro da obra do autor, dentro do horário. Porque esse assunto está chamando atenção agora ou em que momento esse assunto já chamou antes, ou como foi recebido em outros momentos. Então eu acho a preocupação em contextualizar eu tenho desde o início que eu escrevo sobre TV. Busco, tento ter pelo menos. Eu estou sempre ligado nisso. E mostrar entre aspas os truques dos autores, quando eu falo em intenções ocultas, truques que o espectador não está vendo, as repetições, como que a novela está seduzindo o espectador com coisas que são absurdas, irreais e inverossímeis. Tenho certa preocupação com isso, porque as novelas quase todas se pretendem realistas, então acho que elas ficam um pouco sujeitas a essa crítica, a questão da verossimilhança, da possibilidade de realmente disso estar acontecendo. Você falou que um dos casos que 
você está estudando é Salve Jorge uma novela que abusou disso; e é interessante você ver que sempre a defesa que a Glória Perez fez foi 'não, mas eu tenho uma história assim de uma pessoa que fez isso'.

Eu fui um pouco voz dissonante em Verdades Secretas, todo mundo gostou, mesmo os críticos a maioria gostaram. Eu também achei interessante o enredo, eu escrevi algumas coisas. Tem uma coisa, uma vontade de chocar no texto, que é provocar a emoção do espectador da forma mais bruta, que no fundo é pobre, mas que explica um pouco a razão do sucesso dele. Mesmo Verdades Secretas eu escrevi sobre isso também, se for buscar meus textos eu não lembro agora, mas tem algumas vezes que eu critiquei no meio o problema de alguns textos.

6. Quais seriam os requisitos para ser um bom crítico de telenovela?

Um eu já falei, acho que é a questão do contexto, isso eu acho essencial. Acho que você precisa ser didático, claro. Tem um lado do trabalho do crítico que é difícil explicar, eu chamo que é um pouco a sensibilidade, que é sua relação subjetiva que você tem ali, com o assunto, com a interpretação, que comove a uns e não comove a outros, atinge alguns e não atinge outros. E saber comunicar isso para o leitor também, deixar claro que às vezes determinado assunto, determinada interpretação, determinado ator, está transmitindo algo diferente, mesmo que ele não esteja vendo isso. Mas é uma carga de subjetividade. Aí é um terreno pantanoso. Por exemplo, Meu Pedacinho de Chão, é um trabalho difícil você explicar por que que essa novela é boa. É um exercício complicado, difícil. Tem uma, essa eu até gostei de brigar com as pessoas, foi Além do Horizonte. Eu não achava uma novela boa, mas tinha ali uma vontade de fazer uma novela diferente. Ali eu encontrei um argumento para defender a novela, e foi uma bandeira minha, só eu falei. Não precisa ser mais do mesmo sempre, existe uma atitude conformista do espectador, está ligado ao hábito, a novela reconforta o espectador de uma maneira. E ele tem expectativas diferentes, a Globo acostumou o espectador a ver novelas de acordo com o horário. Então quando vem uma novela que foge completamente ao padrão do horário, então eu falei que bom! Eu quis chamar a atenção disso para pessoas: 'olha, mesmo que a novela não seja boa é legal que você esteja vendo algo que é diferente do que você espera; então acho isso um pouco a função do crítico. Meu Pedacinho do Chão eu achei a mesma coisa, mas essa eu a achei magnífica, figurinos de plástico, celofane, supercolorido, mágico, um sonho na verdade na novela; enfim, no último capítulo ele explicita isso era o sonho do menino, aquilo tudo era o menino contando o sonho dele, magnífico. É um requisito, respondendo a sua pergunta, é mostrar muitas vezes o que não está na aparência. Tentar mostrar para o espectador eventualmente o que ele não esteja vendo. Não ter medo de ir contra a corrente, acho isso fundamental. Não ter medo de arriscar as suas opiniões, por exemplo O Sétimo Guardião eu fui a única pessoa que elogiou no início, já de cara todo mundo saiu matando. Eu vi uma coisa ali que me interessou pessoalmente, tentei mostrar para as pessoas. Tentei fazer uma reflexão por que que ele [o autor] está voltando a isso, é um subgênero que está meio morto na teledramaturgia. Achei válido, eu quis dizer isso é uma tentativa de resgatar uma coisa, a novela está em crise já há muitos anos. Mas essa semana eu revi tudo que escrevi e falei olha errei, apostei em uma coisa que não deu certo, a novela foi em outra direção, ele próprio não acreditou nisso, ficou no meio do caminho essa história de realismo mágico, não explorou, era um coisa episódica quando interessava a ele vinha com um pouco de realismo mágico e faz parte. Mas, ele na época ficou felicíssimo, ele republicou meu texto. Publiquei o texto depois de 12 episódios, foi o primeiro texto que eu publiquei. 
O Aguinaldo festejou nas redes sociais dele meu texto. Eu tentei puxar para uma coisa positiva, embora no texto eu fizesse críticas, eu falei que era excesso de narcisismo a novela, que ela era uma espécie de retrospectiva na obra de realismo fantástico dele, resgatava muitas coisas. Mas eu quis puxar para uma coisa positiva no título que era justamente que eu enxergava como uma tentativa de tirar as novelas da crise, não lembro bem as palavras que usei, um resgate, uma alternativa a crise das novelas. E não foi, mas enfim, acho que o papel do crítico é esse também, você tem que se arriscar, tem que dar opiniões que não sejam o que as pessoas estão esperando. Não pode ter medo. Você não tem que buscar o descenso de propósito, quero que fique claro isso. Não sou um cara do contra. Se eu penso algo que eu vejo que não é o que as pessoas estão pensando majoritariamente, isso não me impede, ao contrário, eu tenho que fazer isso, é um pouco minha função arriscar. Mesmo que vá desagradar e as pessoas vão reclamar, protestar. Mesmo que os autores vão ficar furiosos, cabe ao crítico fazer isso.

7. Como é para você a distinção social entre a crítica de teatro e de cinema e a crítica de telenovela? Existe essa distinção? Por quê?

Esse é um dos temas aqui, é o patinho feio da crítica, a crítica de telenovela e de televisão. Primeiro por que a TV aberta entra na casa de $98 \%$ das pessoas de graça. Você não paga, você não fala hoje eu vou sair de casa para ver uma novela. Novela entra na sua casa, você só tem o trabalho de ligar e desligar a televisão, mudar de canal ou não. Então é um tipo de entretenimento, mas democrático que existe. As pessoas assistem desde criança, todo mundo tem repertório de televisão. Grande maioria das pessoas tem repertório, grande maioria tem opiniões sobre televisão. Isso faz com que o trabalho do crítico seja desvalorizado, diferentemente do cinema, do teatro que exige um aprofundamento diferente, que exige uma dedicação diferente. $O$ crítico de televisão tem que ver tudo, assim como o de cinema e o de teatro, tem que ler a respeito assim como de cinema e de teatro. Mas aparentemente existe uma ideia de que é mais fácil por isso. Eu acho que não é verdade que seja mais fácil. Mas tem essa impressão e por isso acho o reconhecimento é menor. É uma atividade menos respeitada, menos valorizada. Não só a crítica mesmo quem estuda na universidade televisão.

8. Quais são os aspectos de sua crítica que, na sua opinião, mais tendem a provocar debate pelo público?

Agora nesse início de 2019 teve uma experiência interessante, eu fiz uma crítica em forma de vídeo de Órfãos da Terra, que eu estou adorando a novela. A crítica teve muita repercussão alguns fãs difundiram a crítica e as autoras também divulgaram a crítica. Realçando uma coisa, assim, não com essas palavras, mas apareceu isso em mais de um dos textos de divulgação da crítica, que era uma crítica muito importante por conta do meu grau de exigência. E isso realmente me satisfaz muito, ser reconhecido como uma pessoa exigente. Fico até um pouco sem graça de falar, mas me dá uma satisfação isso. Não sei se é uma prova, mas é um sinal de que há uma compreensão sobre o que eu estou fazendo. E a compreensão é isso que talvez eu seja rigoroso, exigente e que isso não é gratuito que é uma forma reconhecida como honesta. Acho que sobretudo, o rigor é entendido como honesto, ou seja, está baseado em coisas reais que eu estou vendo. $O$ rigor e o grau de exigência acabam provocando muitas discussões. Junto com isso está a aliado a coisa de não ter medo de emitir uma opinião. Isso é fundamental, porque muitas vezes a gente atenua demais, talvez por medo da repercussão a crítica negativa. 
A minha dedicação exclusiva ao trabalho, não tenho interesse nenhum fora desse meu trabalho. Não sou amigo de nenhum profissional dessa área, embora o Walcyr Carrasco tenha dito que é meu amigo. Uma vez magoado ele falou que eu era amigo dele, na época de amor à Vida quando a gente brigou, ele falou 'você era meu amigo, agora você tá fazendo isso'. A gente trabalhou junto no Estadão em 1997. Ele era colunista, fez uma coluna social lá e eu era repórter do Caderno 2, a gente conviveu na redação algum tempo. Ele evocou a esse período, essa amizade quando eu estava falando mal, muito mal de Amor à Vida. Acho que as pessoas tem essa compreensão que eu sou realmente independente.

9. Como obra aberta, a telenovela permite que você a acompanhe enquanto está sendo feita. Como essa característica molda a sua crítica?

Isso é algo presente o tempo todo. O fato de ser uma obra aberta autoriza os autores a produzirem mudanças muitas vezes drásticas no meio das tramas em função de respostas do público, pesquisa etc. Eu não tenho nada a ver com isso, eu sei que é uma obra aberta, mas a minha função é apontar isso. A reviravolta do personagem, Amor à Vida é uma das novelas que você vai estudar, o personagem ... O Félix teve uma enorme reviravolta, era um personagem dramático virou um personagem de humor; o Nino ... tudo bem é uma obra aberta, não estou proibindo de mudar, agora eu como crítico que estou assistindo aquilo todo dia, não posso deixar de manifestar a minha surpresa com uma reviravolta drástica sem que eu tenha sido preparado para aquilo, sem que eu entenda por que o personagem... sem que o autor tenha dado pistas para você entender por que que o personagem mudou. Então é importante o espectador saber que o personagem era um vilão horrivel e se tornou um personagem cômico, porque estava tendo uma rejeição. Não porque o autor achou que era mais legal, ou porque na lógica da novela fazia mais sentido um personagem que jogou uma criança na caçamba se tornar um clown. Uma pessoa que joga uma criança numa caçamba tem uma trajetória, você imagina que conduza a uma coisa trágica, em algum momento o cara vai morrer, vai ser preso, vai se matar, vai ter uma punição horrível, mas não, ele virou um personagem cômico, que terminou redimido ajudando o pai que era outro canalha também. Tudo bem é do folhetim. Mas se você está assistindo aquilo todo dia, está entrando na casa de milhões de pessoas, acho que você tem que apontar isso. Você vai falar: 'ah legal, deu muito certo, essa virada fez bem'. É, mas faz sentido? Um negócio tão dramático esse início, jogar um bebê numa caçamba, coisa mais dramática que isso, não consigo imaginar, uma das coisas mais dramáticas que eu vi na televisão, um dos gestos mais brutos numa novela que teve nos últimos anos. Eu sei que é uma obra aberta, tem que ter essa consciência, mas isso não pode justificar. Isso justifica para o autor, mas não pode justificar pro crítico o fato de ser uma obra aberta. 'Ah normal, a novela é uma obra aberta isso mesmo, aceita', eu não posso falar isso. O autor pode até estar pensando isso, o público vai aceitar, ele sabe que novela é uma obra aberta. Mas mesmo sendo uma obra aberta acho que tem limites e parâmetros.

10. É de praxe que a primeira crítica acerca de uma telenovela seja logo após ao capítulo de estreia. Quais os parâmetros que você usa para analisar uma obra que está começando?

Órfãos da Terra eu demorei 20 capítulos. Os primeiros três capítulos da novela eu falei: 'isso aqui e maravilhoso, não é possivel que a novela vá continuar assim, como é que vai ser. Mas no início eu achei tão bom que eu fiquei com pé atrás, não é possível que uma 
novela fique tão boa. Eu demorei mais até. Daí eu vi, foi virando uma novela normal, perdeu aquele apuro técnico do início, normal, efeitos especiais e tal. Mas continua muito boa. É tão claro que a Globo tem um cuidado especial com a embalagem do primeiro capítulo, isso é tão evidente, que eu acho que primeiro capítulo é quase uma publicidade estendida de 50 minutos. Um grande comercial, 'olha venha ver essa novela que ela é incrivel'. Cada vez menos tem essa preocupação de apresentar os personagens e mais mostrar como essa novela vai ser encantadora. Acho que eu não preciso dizer isso pro espectador, ele já sabe que o primeiro capítulo tá ali para seduzir. Então eu realmente abri mão. Foi interessante lá no UOL, porque quando eu decidi isso, eu não lembro exatamente em que momento, foi em pouco tempo ali nos dois anos, foi depois que o Nilson começou a escrever, eu não sei que ano. Depois que o Nilson começou a colaborar, eu me senti a vontade de parar quando eu vi que tinha alguém que fazia. Porque tem uma exigência jornalística de fazer, tem a expectativa da audiência desse primeiro texto. Vai para capa do UOL, para capa do jornal, todo mundo quer esse primeiro parecer. Essa minha decisão ela é um pouco anti-jornalística, no sentido mais estrito do texto. Mas como tem outras pessoas escrevendo, eu abro mão de fazer isso.

11. Em sua opinião, o que difere a crítica de telenovela da crítica de programas televisivos como realities, ou de auditório?

Todos são muito diferentes. A novela é uma coisa muito específica, justamente pela duração, fica seis meses no ar. É ficção, depende muito de um autor, depende muito de um diretor, depende de atores, algo incomparável com programas de Faustão, ou mesmo com BBB, são coisas de natureza muito distintas isso não dá para comparar. E acho que é a coisa mais nobre da TV aberta a novela. Acho que exige um cuidado. Ela é importante economicamente para Globo.

12. A telenovela das $21 \mathrm{~h}$ da Globo, é uma das produções mais comentadas na sociedade brasileira. Por isso, a seu ver, a crítica das ficções desse horário, exige mais responsabilidade?

Não, minha não. Mas acho que ela é um produto que para quem faz é o produto mais importante. Eu sei disso, sei do que ela representa. Mas isso não afeta o que eu escrevo. Nem a quantidade do que eu escrevo. Eu vejo democraticamente todas as novelas com a mesma intensidade, escrevo sobre ela quando realmente elas me chamam a atenção para o bem ou para o mal, independente do horário, para mim não afeta em nada. Mas para a emissora sim. Acho que a emissora fique mais preocupada com uma crítica negativa da novela das nove do que a das seis. Para mim não afeta nada.

Quanto às telenovelas serem diferentes das produções de outros países

Eu conheço mais as mexicanas por causa do SBT, mas é bem diferente, é bem melhor a brasileira. Assisti um pouco as turcas quando a Band exibiu, mas elas são mais parecidas com as mexicanas do que com as nossas. Muito close na cara, muita maquiagem. As novelas brasileiras são mais realistas. 
13. Como crítico, o que diferencia a crítica de telenovela da crítica de séries norteamericanas?

Primeiro são produtos muito diferentes, você assiste uma série tem 12 episódios. É mais difícil até de escrever, porque é mais rápido também. E aí é que entra a coisa nova que é realmente o acesso que a gente tem via streaming, então é possível você assistir antes alguns episódios, ter uma ideia mais clara do que é a série e escrever com mais segurança. Eu digo com mais segurança, por que às vezes, o caso que eu contei de $O$ Sétimo Guardião, eu escrevi com base em 12 episódios com uma certa segurança e fui traído pela novela. Uma série é mais difícil isso ocorrer, você consegue assistir três episódios de uma série antes da estreia, por exemplo. Normalmente as empresas têm antecipados para os jornalistas alguns episódios. Se assistiu 3 episódios, você já tem uma ideia já, não vai dar para enganar numa série de 12 episódios. Você já tem uma ideia do que que ela é. Então é mais "fácil" nesse sentido e isso é uma diferença importante hoje.

14. Poderia citar os seus top ten das ficções brasileiras de todos os tempos?

Posso até mandar teria que dar uma pesquisada e te mandar a minha lista. Nunca parei para pensar eu evito, muita gente me pergunta, mas eu evito. Eu posso fazer para você. Mas só o que gostaria de sublinhar em relação a essa coisa de melhores é que eu nesse últimos dez anos, por exemplo, que eu estou olhando profissionalmente para a TV, acho que não é novo é anterior a isso, é o trabalho do Luís Fernando Carvalho como diretor, sempre foi uma coisa que me chamou muito a atenção. Meu Pedacinho de Chão, Velho Chico, Dois Irmãos, uma vontade de explorar novas fronteiras na teledramaturgia. E eu procurei, acompanhando os trabalhos dele, realçar isso também. Porque a Tv por ser muito industrial tende a repetição mesmo. Acho importante sublinhar quando existe um esforço de fugir da repetição. Ele não é o único e como você perguntou de melhores eu me lembrei de Velho Chico e Meu Pedacinho de Chão, que são duas novelas incríveis que justamente apostam, ousam e arriscam. As novelas da Lícia Manzo têm uma característica nova que elas trazem. Quer dizer, nova não, tem muito de novela do Manoel Carlos que é a coisa do diálogo caprichado, da conversa, novela no gogo. Ela, acho que tem uma habilidade incrível, a maneira dela fazer você ficar assistindo 30 a 40 minutos só de pessoas conversando, "sem ação". Acho incrível, é uma coisa muito interessante. As duas novelas dela, que ela fez nos últimos dez anos eu colocaria nessa lista também. A Vida da Gente, Sete Vidas. Um diretor e uma autora que eu acho que são diferenciados. Que fazem coisas que fogem um pouco. Acho que a Maria Adelaide Amaral fez algumas coisas bacanas nesses últimos anos, tipo Sangue Bom acho uma novela legal, adaptação que ela fez de TI TI TI, também acho muito original que ela juntou duas novelas diferentes e fez uma. É muito boa, não sei se estão entre as melhores, mas eu reconheço ali tem um esforço de autoria que é bacana. Que foge do óbvio. Tem alguns exemplos, uma coisa que eu realço, que eu considero qualidade, é o entretenimento com algum grau de inteligência, não só gratuito, um entretenimento que te faz pensar um pouquinho. Que envolve questões para além da exclusiva diversão. Estou pensando para o exemplo, daquela novela Rock Story da Maria Helena Nascimento, divertia, mas ao mesmo tempo você ficava pensando em coisas. Eu gosto desse tipo de coisa. Foge um pouquinho do tradicional. Mas eu sei que estou deixando de citar outras coisas, acho que vou me arrepender depois que eu não lembrei. Mas vou pesquisar mais para te dar uma lista de 10. 
15. Poderia fazer uma análise resumida de como vê a crítica de telenovela no Brasil (pelo menos a que conhece)?

Acho que tem muita gente dando ideias e opiniões, em jornal tem menos no impresso, mas tem ainda. Tem muito na internet que é o meio hoje principal. O que eu questiono um pouco é a seriedade de algumas experiências. A questão essencial para mim na crítica, do trabalho do crítico. Talvez primeiro: é a independência; acho que não existe crítica sem independência total, isso eu acho que é uma limitação em algumas experiências que eu vejo sendo praticadas.

17. Para que serve a crítica de telenovela?

Para mim o mais importante realmente é essa possibilidade de conversar com o telespectador. É um pouco pretensioso esse trabalho, sempre é. Mas eu diariamente confirmo na prática cotidiana que muita gente fica feliz de ouvir pontos de vista diferentes, pontos de vista que complementam sua própria visão sobre a novela que acrescentam sobre a novela ou sobre o programa de televisão. Que acrescentam ponto de vista que eu não tinha pensado. Eu vejo um pouco essa a missão do crítico. Eu vejo hoje, quer dizer tem essa polifonia, tanta gente escrevendo. Pessoas mais atentas conseguem perceber quem está fazendo isso mais seriamente, quem conseguem realmente acrescentar coisas, quem conseguem sugerir coisas novas, visões diferentes, de quem só repete óbvio, copia os outros. Enquanto houver gente interessada em escrever de forma séria, aprofundada e original sobre televisão, eu acho que a atividade vai existir. Pode até num primeiro momento se confundir com o trabalho mais vulgar, que é o trabalho de quem copia, de quem só repete lugares comuns etc. Pode até num primeiro momento se confundir, mas com o tempo o leitor nota quem está fazendo um trabalho, um esforço mais original.

18. Eu percebi que você ler as outras críticas e às vezes você até cita no próprio texto

Leio, todas. Sempre que eu acho necessário, que eu acho que contribui, seja para dizer que eu concordo, seja para dizer que eu discordo. Quando eu discordo nem sempre eu cito, por que às vezes pode soar indelicado. Mas eu acho isso fundamental, quando eu falo de contexto, eu estou falando disso também. Me assusta às vezes ver profissionais que estão - em qualquer área, o que inclui também televisão; profissionais dedicados a uma determinada área, que não tem uma noção completa sobre o que os colegas que estão fazendo a mesmas coisas estão produzindo. Isso é uma obrigação, sem a qual não é possível esse trabalho. Eu leio tudo o que é escrito por pessoas que reconheço que contribuem para esse ofício. Acho essencial. Esse texto dessa semana que eu falei do Sétimo Guardião eu aponto um texto que o Nilson [Xavier] escreveu em março que me abriu os olhos para uma coisa que não estava vendo e me fez ver a novela de outro jeito. Quando eu estou fazendo um balanço eu não vou citar isso? Esse texto contribui para maneira como eu estou vendo a novela, é uma obrigação eu citar isso. E aí eu vou adiante, avanço. E o texto dele me fez pensar sobre outras coisas, fecundou a minha observação. Eu faço isso sempre que eu vejo isso. Às vezes você incorpora sem se dar conta, pode acontecer. Às vezes você sem querer está reproduzindo alguma coisa que você leu, você incorpora e altera a sua maneira de ver, e você passa a ver daquela maneira que a pessoas escreveu, Mas quando é uma coisa muito evidente, que salta os olhos - epifania é um pouco demais a palavra, uma sacada, um grande insight - é 
marcante. O Nilson teve uma sacada em março, e eu falei: 'a gente não gosta de nenhum dos personagens principais da novela, por quê? O Sétimo Guardião tem sete guardiões e a gente não gosta de nenhum, a gente não tem carinho por nenhum, não tem afeto por nenhum, nem raiva, nada', início de março ele fez essa observação sobre os sete e eu achei é mesmo! Então sempre que acontece eu acho importante citar. Bom já que você está falando isso, lamento que meus colegas façam isso pouco. Talvez o próprio Nilson é um crítico que cita também. Respeito muito o trabalho dele, acho um cara muito sério, e ele tem essa característica que eu não tenho que é de pesquisador, ele tem uma bagagem, não é só o que ele viu é o que ele acumulou e registrou que é essencial. Para mim ele é uma fonte importante também, às vezes eu busco o site dele, não o blog, tem muita informação. $O$ Wikipédia copia todo o site dele, todas as novelas que você vai ver que a fonte foi no site dele.

19. Você tem alguma fonte?

Para crítica não. Mas eu como jornalista eu já entrevistei vários autores para discutir as novelas deles. Mas para fazer crítica eu tenho distância total. É que meu trabalho ele é híbrido tem um lado de repórter, então eu faço às vezes entrevistas, reportagens com gente envolvida na produção das novelas. Mas acho que isso não afeta e nunca afetou meu trabalho como crítico.

\section{Patrícia Kogut}

Entrevista realizada no dia 21/08/2019, na redação do Jornal O Globo, Rio de Janeiro

1. Como você se iniciou na escrita da crítica de ficção televisiva e há quanto tempo exerce a função profissionalmente?

Essa coluna que eu faço ela existe a muito anos no jornal e eu herdei ela. E ela não tinha crítica, tá. Era uma coluna de notas, eu ia dizer uma coluna de notas apenas, não é apenas, porque era uma coluna forte num noticiário de televisão importante e continua sendo. Mas os tempos mudaram, quer dizer hoje a internet é muito forte, aquela época a internet não existia. E eu acho, eu vejo assim que a coluna foi acompanhando isso. Então, foi mais ou menos em 2000, que eu resolvi - eu não me lembro a data da primeira crítica - o que tinha na coluna de crítica é a nota 10 e a nota 0, que são a coisa mais forte da coluna. Eu sinto isso pelos leitores, pelas pesquisas, por tudo. Mas aí eu comecei a fazer crítica, e a crítica não é dedicada só as novelas. Eu comecei o negócio da crítica de séries, que ninguém fazia e com isso eu trouxe eu acho (tudo eu estou falando o que que eu acho que é) um leitor, que é um leitor jovem, que é um leitor que estava sem lugar, porque ninguém estava fazendo isso, porque era um assunto que estava chegando no Brasil e tal. Que era a TV a cabo e que hoje é o streaming. A novela ela entra aí, a crítica de novela entra aí. Eu comecei a fazer crítica, eu acho que talvez em 1996, mas era uma coisa eventual, uma estreia. A fazer crítica no Segundo Caderno, porque tinha que ter uma crítica. Eu não era a única crítica de TV do jornal naquela época, mas hoje em dia eu sou a crítica de televisão do jornal, e tem uma estreia de novela eu faço, e é minha obrigação, é meu trabalho mesmo. E houve um momento a gente fazia críticas nas 
estreias e a nota 10 e nota 0 era uma crítica pontual até a novela acabar. E houve um momento que eu comecei a achar que aquilo era injusto, que a novela é uma obra aberta, que ela muda, e que a crítica deveria acompanhar aquilo. Esse negócio da crítica entrar dentro da coluna, tem a ver com esse pensamento. Então quando tem uma cena importante, por exemplo ontem teve a segunda virada da Maria da Paz [protagonista da telenovela A Dona do Pedaço] eu fiz uma segunda crítica. Eu fico atenta a isso, e aí eu escrevo. A crítica de novela ela tem muito mais repercussão do que a crítica de série. A novela é o canhão de audiência, é o produto mais importante da televisão, tenho total consciência disso e procuro ser lida por esse leitor que quer isso.

2. Qual sua relação com a televisão, especificamente com a telenovela?

Acho que a minha relação com a telenovela é a de todos os brasileiros. Sei lá, eu me lembro de telenovela na minha infância. A telenovela é assim, é um pouco que nem aquelas músicas na vida de todo mundo, sei lá... Todos os discos do Caetano que me acompanhava. Todo verão ele lançava um disco, e aquilo para mim acompanhou, trilha sonora da sua vida, a novela tem isso. A novela ela está na tua memória, ela está na tua formação, ela tem esse valor de formação. A gente viu a evolução da novela, a gente se apaixonou por alguns personagens, aquilo está na vida de todos nós, e eu cresci no Brasil, né. Acho que é igual de todo mundo.

3. Que critérios você leva em consideração para escrever suas críticas?

É uma boa pergunta. Tem gente que fala assim: 'ah deve ser tão bom ser você, porque seu trabalho é uma moleza, você fica sentada na frente da televisão, você passa o dia vendo televisão'; e isso não é verdade. A televisão fica ligada aqui sem som, você vê está ligada, eu liguei, eu não estou vendo isso. Eu ligo, mas o meu trabalho não é ficar vendo televisão loucamente. O meu trabalho é ver televisão pontualmente. É escolher o que é importante e comentar o que é importante na televisão. Então, não é ficar zapeando e vendo qualquer coisa irrelevante. Não é. É, às vezes, você enxergar com seu olhar, você procurar uma coisa que não está no mainstreaming, não é campeã de audiência, mas é legal e você apontar aquilo para o seu leitor. Então tem uma coisa de você observar a televisão, mas tem uma coisa de você refletir o que é relevante na televisão. Então, se uma novela está dando um monte de audiência, você pode ignorar aquilo, falar 'ah ...' como um capricho. Eu acho que você tem que ser profissional, refletir a importância que aquilo está tendo para o seu leitor. Então, eu não vejo só o que gosto. Eu vejo o que as pessoas estão vendo e comento o que as pessoas estão vendo. Ai quais são os critérios, o quê que mede isso? Têm as redes sociais que você pode olhar, medir uma temperatura, a audiência, tem o quê que as pessoas estão falando. Tem o meu gosto, tem coisas que eu não gosto. Mas eu não desprezo, não deixo de comentar porque eu não gosto.

Sobre o texto do Walcyr Carrasco

Eu acho assim, tomando o exemplo do Walcyr, é um parazer quando um autor de novelas tem um texto de qualidade, os diálogos são bons e isso não acontece nas novelas dele. Essa é a questão com as novelas dele. Eu acho que o crítico tem obrigação de falar, você não está aqui para ficar aplaudindo para nada disso, você está aqui para contar. Então, falando em quem tem texto bom, as novelas do Miguel Fallabella que talvez não foram 
grandes sucesso de audiência, mas um cara preocupado com diálogo, com o português. É legal isso, eu acho um prazer. O João Emanuel, é espirituoso, ele aposta no ouvido do telespectador. As novelas podem ter um valor educativo, elas não têm obrigação de serem educativas, aquilo é entretenimento. Mas se você puder levantar o nível e fazer uma coisa legal, que não seja um pedregulho na boca do ator. Você dar credibilidade ao texto, você aposta na inteligência do telespectador. O Walcyr, ele é um cara... por exemplo essa novela que está no ar, ele tem uma antena, a novela quando estreou eu falei assim: 'isso é um novelão, isso é um melodrama', tem troca de bebê, tem a filha que trai a mãe, tem não sei quem que é pobre e fica rico e não sei o quê... É legal. Se você gosta de novela, se você respeita o gênero telenovela, você sabe que ele ali está indo fundo naquilo, sem vergonha de ser feliz. Não está fazendo novela envergonhada, fingindo que está fazendo uma série americana. Isso é bom. Essa novela começou bem, eu acho, como estrutura de novela. Mas tem coisas que eu não gosto, tem coisas que eu acho chulas, eu não gosto disso em novela. Tem vários personagens que não fazem nada sem ser a Maria da Paz. Tem aquele núcleo dos invasores, que aquilo não sei para quê que está ali. Tem o negócio do núcleo cômico obrigatório, você leu minhas críticas, você viu, aquilo é pesquisa. Aquilo falam assim 'ah o público quer... '. É uma fórmula, eu não gosto da fórmula. Eu acho que tem dois lados isso o que ele faz, ele é um cara que fala diretamente para o público ninguém pode negar isso, tem muita audiência. Quer dizer, as pessoas estão vendo o que ele faz. Mesmo esse que reclamam, estão gostando porque estão assistindo, estão prestigiando. Mas ele fala muito diretamente, fala para todo mundo, é muita reiteração, é muito diálogo pobre, isso eu falo nas minhas críticas. Eu acho que empobrece o resultado. Eu li uma crítica do Maurício no domingo dizendo que a novela é mal dirigida, eu não acho, eu acho que ela dá uma salvada. Tem um conceito. Ela [Amora Mautner], também embarca na coisa do melodrama, porque tem uma cafonice, digamos estética. Isso é o diretor que escolhe, que é proposital. Ela não está brigando com o texto, ela está acolhendo aquele texto. Mas está fazendo a coisa legal. Mas o texto é o principal de uma novela. Eu acho que você ser popular e não fazer isso. A Glória Perez na Força do Querer, ela falou para o público, ela sabe ser popular, você não ficava ouvindo palavrão, não ficava ouvindo essa coisa chula. Eu não acho que novela tem que ser realista, nem novela nem série, nem nada que é ficção, mas tem que ter credibilidade. Você pode assistir, sei lá The Walking Dead, que o mundo acabou e eles estão lutando contra zombies; e você pode acreditar naquilo tudo, se aquilo for bem feito. Não precisa falar a verdade, a gente não está vendo documentário. Não precisa ter o sotaque, eles têm que tentar aproximar, mas se for mal feito, você não acredita.

4. Você acompanha as discussões e comentários acerca de telenovelas? Como? Em que meios?

Vou ser supre franca com você, eu acho o Twitter meio chato, mas é gosto. Assim, de todas as redes, eu tento; eu tenho muitos seguidores no Twitter, as coisas que eu escrevo no meu site, elas entram no Twitter automaticamente. Eu uso o Twitter para medir temperatura e tal. Mas eu adoro o Instagram, eu adoro. A gente tem o perfil do Facebook da coluna, e tudo isso eu olho muito. O Instagram da coluna eu faço, ele é muito ativo, todo manual, ao contrário do Twitter que é misto. As coisas que entram no meu blog, que hoje em dia a gente chama de site porque ele foi redesenhado, elas entram no Twitter. E eu entro ali para comentar também, mas o Instagram é todo feito a mão. Uma rede que eu uso muito. Eu vejo os comentários de leitores, a gente vê, a gente presta atenção. Às 
vezes a gente precisa de uma nota 0 , falo assim 'vê o quê que os leitores estão dizendo?', aí eu olho o que que os leitores estão dizendo; tem uma dica ali. Aí eu vou e procuro no Youtube para assistir. Então eu uso sim, eu sou superatenta. 'Vamos fazer, vamos entrevistar essa atriz, as pessoas estão interessadas nela' Faço muito, direto.

5. Na sua opinião, qual é o papel da crítica de telenovela?

Eu acho que na nossa cultura brasileira, as pessoas não gostam de crítica. Não gostam, às vezes não entendem, mas tem gente que gosta e que entende. E gente que é do jogo que é criticado, e que recebe isso bem. A crítica - depende da maneira como ela é feita - a intenção dela não é demolir ninguém, é dialogar com aquilo com que ela está criticando. Então muitas vezes eu escrevo uma coisa, depois eu vejo que eles mudaram na novela, sei lá comento uma coisa, eles ouvem e vão lá e mudam, corrigem. Então, esse que é o objetivo da crítica é dialogar com aquilo que está rolando. E ser um pouco também a voz dos leitores. A crítica é perfeita quando você escreve um negócio e você recebe um milhão de e-mails, falando assim 'vocês leem meus pensamentos, era isso que eu queria dizer'. A crítica não é um capricho, não é uma cisma, não é um poderzinho, não é para ser nada disso, ela pode ser. Cismar com uma pessoa, implicar com uma pessoa, ela não é para ser nada disso. Coisa de profissional, fria, e dialogar com a televisão.

6. Quais seriam os requisitos para ser um bom crítico de telenovela?

Ser justo, ouvir, se esforçar. Não fazer uma coisa que você não conhece, falar do que você conhece. Tentar entender como aquilo foi feito, fazer com responsabilidade. E ser uma pessoa que lê, que se informa, essas coisas também muito importantes.

7. Como é para você a distinção social entre a crítica de teatro e de cinema e a crítica de telenovela? Existe essa distinção? Por quê?

Televisão, quando eu comecei nessa área, era totalmente desvalorizada e novela mais ainda. Totalmente. Ninguém queria fazer isso. E aí, hoje, todo mundo quer, todo mundo quer escrever sobre séries; eu não digo nem novela não. É sobre séries. Você vê repórteres de política querendo fazer crítica de série, é uma coisa que não existia isso no jornal. Então tinha mesmo uma hierarquização disso. E a crítica de TV sempre muito associada a fofoca de artista, mas eu acho que isso está mudando. Isso está sendo visto com muito mais respeito. A televisão ganhou uma importância que ela não tinha. É muito bom escrever sobre televisão nesse momento de hoje em que a televisão americana vive essa era de ouro, como se diz. E que tem uma produção tão importante, que os atores de cinema mais importante estão querendo fazer televisão. Tudo isso não tem a ver com novela, tem a ver com série, isso tudo que eu estou te falando, mas o profissional que escreve sobre isso é um só. Então isso está tudo mais valorizado. Acho que a novela acaba entrando nesse balaio. A novela está misturada. Se você é um cara respeitado que escreve sobre televisão, você também está escrevendo sobre novela. Eu acho que ninguém que faz crítica de televisão hoje em dia deveria escrever apenas sobre novela. O mundo está cada vez mais um só. É conteúdo, é tudo misturado. Eu acho que já foi assim, não é mais assim. O leitor é um só, o leitor vê tudo, o cara que está te lendo. A televisão é maior, a televisão é grande, a televisão está importante. A televisão está no 
telefone, está no computador, todo mundo está vendo tudo, você tem que pegar este bonde.

8. Quais são os aspectos de sua crítica que, na sua opinião, mais tendem a provocar debate pelo público?

É sempre a novela, claro. A novela ela é a televisão aberta, ela é a massa, é a maioria esmagadora dos telespectadores brasileiros. Quando eu falo de novela, a repercussão é maior. Primeiro capítulo, cena polêmica, quando eu falo mal de uma coisa que está todo mundo achando, mas a novela insiste, essas coisas.

9. Como obra aberta, a telenovela permite que você a acompanhe enquanto está sendo feita. Como essa característica molda a sua crítica?

A crítica é muito imediata a de novela. Ela reflete esse ritmo, essa dinâmica da obra aberta. Por isso que eu comecei a fazer crítica de novela, porque eu queria refletir isso. Então, o primeiro capítulo das novelas é sempre mais caprichado do que o andamento. É inevitável, é do jogo, não vai aí um demérito. É uma característica. Ninguém consegue fazer todo dia um capítulo hiper caprichado. Acho que isso aconteceu talvez em Avenida Brasil, que foi uma novela que foi uma tempestade perfeita, que tudo deu muito certa e tal. Mas é difícil isso acontecer. Então, a crítica vai refletindo. Você elogia muito um primeiro capítulo que foi incrível, na semana seguinte a novela está ruim. A crítica reflete isso.

Com o Globoplay, você assiste quando passa ou você assiste em outra ocasião?

O Globoplay me salva muitas vezes. Por exemplo, essa cena da Maria da Paz atirando, eu não vi no horário, eu não estava em casa. Eu vi no Globoplay. A internet me libertou dos horários, porque por exemplo, quando o primeiro capítulo eu tenho que assistir, eu tenho que fazer aquela crítica; às vezes sei lá, você tem outras coisas na sua vida, você tem filho, você tem não sei o que, aconteceu um negócio. E aí eu não fico tão presa ao horário, eu tenho o horário que eu tenho que escrever, naquele horário eu tenho que escrever. Mas eu posso assistir daqui mais tarde.

10. É de praxe que a primeira crítica acerca de uma telenovela seja logo após ao capítulo de estreia. Quais os parâmetros que você usa para analisar uma obra que está começando? A crítica tem que ter uma margem, você tem que olhar aquele capítulo. Isso é um pouco de experiência, você não pode decretar, porque se você decreta, às vezes, a novela degringola e você tem que ter coerência na sua crítica. Você pode mudar de opinião, mas não pode ser uma coisa louca. Acontece isso, de você elogiar um primeiro capítulo loucamente e daqui a duas semanas a novela está horrivel, você fala 'Meu Deus'. Ou então, até um ator que você achou ali que foi muito bem e depois aquilo não funciona. Tem que olhar aquilo com um olhar, aquilo é o primeiro dia.

11. Em sua opinião, o que difere a crítica de telenovela da crítica de programas televisivos como realities, ou de auditório?

Abordo, por exemplo eu já escrevi muito sobre BBB. Eu não sou fã pessoalmente de reality, mas ele foi um programa que foi muito pioneiro com o negócio da internet, de 
trazer a internet para dentro da televisão. De você achar que o programa estar no ar fora do horário dele de grade. Isso me encantou, mês fascinou e eu escrevi muito sobre isso. Então, eu presto atenção, tudo o que é importante na televisão. Presto atenção, tenho obrigação de assistir e comentar. Já escrevi sobre todos esses programas de auditório, todos que estão no ar já foram assunto, tudo é assunto da coluna. A coluna é de televisão. É um gênero diferente, mas está na televisão.

12. A telenovela das $21 \mathrm{~h}$ da Globo, é uma das produções mais comentadas na sociedade brasileira. Por isso, a seu ver, a crítica das ficções desse horário, exige mais responsabilidade?

Não, a responsabilidade é igual. O que ela exige é o seguinte, uma novela das nove ela não pode ser ignorada, porque ela está sendo vista, mesmo que ela seja um fracasso, Sétimo Guardião foi um fracasso. Um fracasso de audiência, eu faço um site que surfa também na audiência da televisão, porque é um site de televisão. A novela atual do Walcyr as pessoas estão clicando no meu site, a audiência está lá em cima, todo mundo quer saber o que vai acontecer nas novelas. Mas o Sétimo Guardião as pessoas não clicavam, nem por isso eu posso abandonar uma novela das nove. Mas eu posso me desinteressar e escrever menos sobre aquela novela e isso aconteceu. E às vezes eu me interesso, por exemplo as novelas d a Elizabeth Jhin que eu adoro, a novela das seis Além do Tempo, eu escrevia direto sobre essa novela. As novelas da Licia Manzo que eu adoro, aquela Sete Vidas, eu assisti porque eu sou uma telespectadoras, se eu me interesso tem duas maneiras de você assistir: assistir profissionalmente, quer dizer eu não preciso assistir todo dia, não preciso ser uma enciclopédia de novela, eu preciso ver o que eu sei que vai ser uma virada naquela novela, eu não preciso ver novela das nove todo dia. Eu me interesso sobre aquela novela eu escrevo mais sobre aquela novela. Sendo das nove ou não. Agora sempre com a mesma responsabilidade.

13. Como crítico, o que diferencia a crítica de telenovela da crítica de séries norteamericanas?

Acho que talvez sejam dois leitores. A crítica de novela faz um barulho maior, o público é maior, às vezes eu sinto que é um público mais velho, tem isso também. Porque o público jovem que é leitor da coluna ele está super ligado em série. Eu quero esse leitor. E eu sou uma espectadora de séries muito assídua. A coluna ela tem que ter a minha cara também, ela tem a minha cara. Eu falo ali das séries que eu conheço, que eu vejo, que eu acompanho. Eu acumulei, sei lá, um conhecimento de série tendo assistido um milhão de coisas nos últimos anos porque eu me interessei. Então, a coluna ela é um lugar para esse leitor, ela fez esse lugar. Eu acho legal isso ter acontecido, me reflete e reflete as coisas que eu gosto. Eu acho que ninguém pode mais falar só de uma televisão regional. Eu acho que a televisão é a televisão do mundo. Eu não vejo só série americana, tem série francesa, tem série espanhola. Está tudo aí rolando. Então, é tudo misturado.

14. Poderia citar os seus top ten das ficções brasileiras de todos os tempos?

Avenida Brasil está nesses Top tem, a novela das empreguetes, Cheias de Charme está nesse Top tem, Amores Roubados estaria nesses top tem. Castelo Ra Tim bum foi uma coisa infantil maravilhosa. Vale Tudo, Roque Santeiro, totalmente está nesse Top Tem. No meu livro tem 101. Tem os programas do Chico Anísio, do Jô Soares é uma referência 
para mim... Rei do Gado, Selva de Pedra, as novelas da Janet Clair são referências. Pantanal. TV Pirata vale humor?

15. Poderia fazer uma análise resumida de como vê a crítica de telenovela no Brasil (pelo menos a que conhece)?

Tem pouca gente que faz, mas os meus colegas eu aprecio o trabalho deles, eu leio. Eu leio o Maurício, eu leio a Cristina, eu leio o Nilson. É legal, eu acho eles todos assim, alto nível. Eu acho que aquela crítica que era meio caída, acabou. Que era meio fofoca. Eu acho que tem crítica séria se televisão no Brasil. Acho que a gente está num momento bom.

16. Para que serve a crítica de telenovela?

Essa pergunta que eu acho que já respondi. Eu acho que serve para dialogar com a televisão. Mostrar que a televisão é importante. Ela pontua a importância da televisão, ela não demoli a televisão, como as pessoas que temem a crítica acham. Eu acho o contrário, ela ajuda a construir.

17. O quê que é uma novela moderna?

Então, se você pegar as novelas antigas, assim que sou mais velha que você; por exemplo, o que está passando no Vale a Pena ver de Novo, Por Amor de Manoel Carlos. Por Amor está toda cortada, a gente sabe que está. Tem capítulos de Por Amor que não acontecem nada, mesmo a novela estando cortada. É bom, mas se fosse hoje, eu até escrevi essa semana, eu adoro Por amor, ela me segura no jornal. Às vezes eu estou querendo ir embora, ah não está passando Por Amor eu via e tal. Todos esses elogios à Por amor em que pese ela ter sido mesmo uma novela maravilhosa, está meio protegido pela nostalgia. As novelas modernas, elas não admitem tanta enrolação. As cenas são mais curtas os diálogos, é tudo mais curto. Pode olhar Vale a pena ver de novo. Mesmo Por Amor está protegido pela nostalgia. Porque esse negócio de passa o açúcar e passa o sal, a fulana foi a feira, me diz a lista da feira não sei o quê ... Hoje em dia ninguém admite mais. Tinha um negócio antigamente que o cara estava em casa, com a televisão ligada, não atendia nem telefone porque estava na hora da novela, isso acabou. Não é que as pessoas atendem o telefone, elas entram no computador viajam e veem outra coisa, entram em outra. A novela tem que fazer um esforço gigante para manter a atenção. A disputa pela atenção do espectador multiplicou, não é que triplicou, quadruplicou. Então a novela moderna nesse sentido ela não pega o cara por inércia, não pega. Você não pode dizer 'olha assisti o capítulo e não aconteceu nada', tem que ter um negócio ali rolando. Então mudou. Ficou mais dificil fazer novela.

\section{Cristina Padiglione}

Entrevista realizada no dia 30/09/2019, na padaria Fabrique

1. Como você se iniciou na escrita da crítica de ficção televisiva e há quanto tempo exerce a função profissionalmente? 
Quando eu fui trabalhar no Ferreira Neto, que é um jornalista que já morreu, ele fazia uma coluna na Folha da Tarde, que era sobre televisão. E não tinha coluna de televisão nessa época, tinha tipo a Sônia Abrão no Diário Popular, e tinha o Ferreira Neto que escrevia para 30 jornais, sendo um deles era o Folha da Tarde, aqui em São Paulo, que antecedeu o jornal Agora São Paulo. Eu fui trabalhar lá na produção do programa, ele tinha um programa de política na Record nos anos 90 e tinha uma coluna no jornal. E aí da produção do programa eu pulei para coluna que era sobre televisão e rádio. Comecei a fazer televisão e rádio. Eu não assinava meu nome porque a coluna era dele, a gente era uma equipe de apoio. E aí eu comecei a fazer freelas para Folha da Tarde, nesse assunto que eu estava inserida já que era a televisão. Então isso foi em 1990, comecei a fazer texto para Folha da Tarde. Em 1992 eu assumi uma coluna mesmo de TV no jornal, que foi a primeira, e daí eu não parei mais. Tive acho que um ano só que saí fora disso, que eu fui fazer uma revista de celebridade em 1999, "Chiques e famosos", que era meio a revista Caras, fiquei um ano nas Chiques depois fui pro Estadão. E aí continuei televisão, televisão, televisão.

2. Qual sua relação com a televisão, especificamente com a telenovela?

Na verdade no meu tempo de criança, a minha mãe por exemplo fazia bolo para fora com a minha tia, era minha babá eletrônica a novela. Não tinha essa coisa de hoje dizer que criança não pode ver novela. Elas diziam assim: 'vai lá assistir a novela e depois conta para gente o que aconteceu'. Então, eu tenho uma memória, sei lá, de 'Estúpido Cupido' que eu devia ter sete anos de já estar assistindo novela. Tinha muito pouca diversão, não tinha TV paga, cinema você ia ver os Trapalhões, não tinha uma tonelada de filmes saindo, os filmes demoravam para chegar na televisão. Em casa tinha um hábito muito forte de Globo, não se assistia SBT, minha mãe detestava Silvio Santos, ela dizia 'não suporto a voz desse homem', agora com troféu imprensa todo ano ela vai ficar babando, achar o máximo. Eu adorava ver Domingo no Parque, que passava no domingo, no Silvio Santos, aquela bola gigante que entrava no gol, não é do seu tempo, mas você tinha um programa para criança mesmo de manhã, tinha a história do foguete que é um clássico, a pessoa entrava no foguete e gritava sim ou não, e não ouvia qual era a pergunta $e$ falavam assim 'você trocar a bicicleta por uma bala chupada' e a pessoa respondia 'sim', e perdia a bicicleta. Era um circo divertidíssimo. Aí tinha essa memória minha da novela e um pouco de Domingo no parque especificamente, alguma coisa do 'Qual era a música', mas minha mãe não gostava tinha que mudar logo. E Chacrinha que também tinha uma presença forte em casa. Mas a gente não via muito SBT e tinha uma coisa meio do sinal, o sinal da Manchete era muito bom em casa, então a gente assistia mais Manchete, quando começou também, porque a Manchete começou nos anos 80, e Globo sempre muito Globo. Então era novela. Não tinha vários seriados, tinha Carga Pesada, Plantão de Polícia, que eu não via que não era muito para minha idade. Mas Carga Pesada a gente assistia, tinha Malu Mulher que a minha mãe assistia, mas novela basicamente isso, era nosso parquinho de diversão. Agora quando eu comecei a escrever sobre televisão, você começa a perceber que o interesse maior das pessoas é por novela. $E$ aí eu estou falando dos anos 90 ainda era muito fincado em novela, não saia muito disso. Mesmo as séries e minisséries que era feitas eram só mininovelas a linguagem é a mesma. Então era muito focado nisso mesmo. 
3. Que critérios você leva em consideração para escrever suas críticas?

Recentemente o Silvio de Abreu falou na inauguração dos estúdios novos da Globo que o espectador de novela quer mais emoção que a razão. Eu nunca me pautei por esse critério eu sempre achei que a razão está presente na cobrança do público para assistir uma novela, as pessoas reclamam muito sobre verossimilhança, as lógicas e tal. Eu não acho que seja só sobre emoção. Ao mesmo tempo quando você ver uma audiência como essa da Dona do Pedaço e do O Outro lado do Paraíso, você tem que considerar que realmente as pessoas estão muito interessadas na emoção e pouco na razão, porque ela tem vários furos de lógica ali. Então mais ele [Walcyr Carrasco] entrega o que o público quer, entrega uma coisa maniqueísta. Durante muito tempo eu entrevistei autores que diziam 'não, a gente não está mais nessa pegada maniqueísta mexicana, a gente tem que saber que os vilões tem suas fragilidades, que os mocinhos tem os seus erros e suas falhas; então a gente escreve pessoas com caráter dúbio etc'. Isso caiu completamente. $O$ Walcyr faz coisas muito mastigadas e são grandes sucessos, ao mesmo tempo o João Emanuel Carneiro fez a A favorita e quase deu com os burros n'água. A história não foi uma audiência fraca, porque a Globo ainda era muito hegemônica na época. Mas ele me relatou que tem pessoas que disseram que pararam de falar com ele, que pararam de ver a novela, porque ele invertia no meio da história - que era uma coisa genial e a escalação já tinha uma coisa pronta que era genial, era a Patrícia Pillar que tem cara de boa moça, que era a desgraçada e a Cláudia Raia, que tem cara de biscate que era a pessoa boa da história. Então no meio da história você fica sabendo que realmente, a Patrícia é a bandida e a outra era a pessoa bacana da história. Essa inversão deu um choque no público. Teve muita gente que 'ah fui enganado!' e tal. Na Regra do Jogo ele fez um personagem dúbio que era o Alexandre Nero, que queria ser um cara ruim, mas não conseguia ser ruim. Ele tinha no fundo um bom coração. E morre no fim e foi maravilhoso. A novela foi super mal compreendida e tudo bem, teve lá as bobagens da facção que ele colocou. Eu já conversei sobre isso com o Stycer e ele 'não, mas a parte da facção foi imperdoável'. Pode ser, mas eu acho que as pessoas abandonaram a história porque não sabiam o que pensar daquele cara. Elas ficam querendo resultados prontos, o que se reflete nessa polarização política que se você critica um significa que você está do outro lado. As pessoas estão muito binárias. E aí nesse sentido talvez o Silvio tenha uma razão por que as novelas do Walcyr são super binárias e que só trabalham mais a emoção do que a razão. Agora eu sempre levei em conta a razão. Eu sempre disse o seguinte é ficção, é ficção, mas tem que ter lógica. Harry Potter tem lógica, as pessoas não saem voando de vassoura, mas aquela história toda, a saga de Harry Potter, cada historinha, cada passo do Voldemort, tudo tem um fundamento tem um sentido, tem uma história, tem uma razão de ser. Eles não tiram do nada, tem uma lógica. E aí eu cobro sim um pouco de lógica dentro desse mundo lúdico que pode ser a novela. Eu levo em consideração se ela é panfletária ou não, porque não basta que ela tenha uma boa mensagem social, se ela for panfletária ela é um recado quase perdido. Se você tiver um merchandising social tem que ser uma coisa muito orgânica, paras pessoas se esquecerem que aquilo é um recado e aquilo entra na cabeça, que não seja um comercial, da mesma forma que um comercial tradicional, o cara que vai no banco e aparece em letras garrafais Itaú, me incomoda. A organicidade, pode-se dizer que eu levo em conta essa. Inclusive se os diálogos, se você ouve aquele diálogo e pensa 'nossa isso poderia estar acontecendo do meu lado', eu adoro isso, é uma coisa que me encanta profundamente. Que faz você embarcar numa história. Então eu levo muito na emoção, 
desde que tenha lógica. Não dá para ser um negócio completamente fora de propósito. E a finalização do produto também me interessa muito, não dá para ser um negócio que você ver que é um tapume que vai cair ali se o cara bate na porta e a porta cai. A qualidade estética, a mim interessa a iluminação, a coisa do chamado 'padrão Globo'. Uma vez eu sentei com a minha mãe para assistir uma novela do Lauro César Muniz na Record 'Cidadão Brasileiro', era a primeira novela dele fora da Globo e tinham vários atores que estavam vindo da Globo, e tinha ele que era da Globo. A gente sentou para ver e ela disse 'engraçado, né, você vê que o autor era da Globo, os atores eram da Globo, mas você ver que a novela não é da Globo'. Para mim essa frase é uma lição. Por que não é uma questão de ser da Globo, é uma questão de você comparar aquela embalagem de uma maneira mais sedutora. Quando ela é mais capenga você não compara tanto, ou é uma coisa tipo um Chaves, você compara. Ou Two and a half Man uma comédia de situação, em que o texto é muito forte ou as situações são muito clássicas, aí você entrar na brincadeira e se divertir mas sabendo que aquilo é de mentirinha. A novela eu acho que ela não pode ser de mentirinha, ela tem já há muito tempo uma condição em que ela reflete um pouco da sua vida, do seu comportamento, ou que você possa se espelhar e se identificar com aqueles personagens, ou buscar neles alguma inspiração. Tudo isso torna um espectador com um nível de exigência muito alto. Talvez eu tenha embarcado muito nisso. Estou mal acostumada, pode-se dizer assim pela Globo. Como a gente está mal acostumado hoje pelas séries que vieram de fora, então os diálogos da Globo que eram incríveis passaram a ser também questionados. E você fala 'não, isso não cai bem no ouvido'. E passou-se a ter, por exemplo, uma atenção com outro tipo de texto, que ai é o do João Emanuel, que é o que eu espero que seja o da Manuela Dias, que fez duas séries também super orgânicas, uma delas até de época que era Ligações Perigosas. Mas que você acredito no que está sendo visto, que não é um texto que pareça ensaiado, tudo isso... Ele vem mastigado, você não pensa, é muito chato isso. É que a novela precisa ser didática, ela é um negócio que o cara geralmente está vendo com mais gente. Isso eu levo em conta também, Sempre levo em conta o contexto, ai eu não posso também exigir da novela do SBT e da Record que ela tenha um nível de produção de quem gasta lá 200 mil dólares por capítulo, mas ela não pode ser tão tosca. Essa novela do SBT que tá no ar As aventuras de Polianna, ela tem um tatibitate infantil, mas ela não é uma novela vexatória na produção, ela é um negócio que tá dentro do que ela se propõem. Nesse sentido eu acho que a gente tem que se render, as novela bíblicas da Record também estão dentro do que se propõem. Uma novela das sete como Verão 90 ela parecia quase uma coisa de $H Q$, eu não entendi muito a proposta. Era divertida, era, mas era excepcionalmente tosca na finalização dela. Eu esperava mais. Eu achava que era um pouco demais. Mas é uma pena, porque muita coisa ali era tosco porque era tosco mesmo. Vi o Jesuíta Barbosa mal aproveitado em cena que é um super ator. Parecia uma Malhação na verdade, ela estava fora de seu lugar ali. Eu olhava para aquilo e pensava 'que coisa tosca', entendeu. Tem muito a ver com o contexto que você espera.

4. Você acompanha as discussões e comentários acerca de telenovelas? Como? Em que meios?

Não muito. Uma coisa que cai na minha rede social, sim, eu vou ver e tal. Mas eu não me pauto por isso. Eu tinha alguma coisa no Facebook que é uma página do blog, no Estadão eu tinha muita coisa que vinha como comentário. Algumas coisas eu puxo um fio político, mas tem muita gente que puxa um fio político sem ter havido, acho que o 
retorno fica meio nebuloso, o retorno fica meio contaminado vamos dizer assim. Agora por exemplo tem uma coisa muito hostil com TV Globo, porque tem uma militância bolsonarista contra TV Globo. Então tudo o que você escreve da Globo eles acham que a Globo incentiva casais gays, ou traições ou sexo a três, sabe assim. Parte muito para pauta de costumes, foge um pouco do que eu quero. O Stycer se pauta muito porque tem muita gente que mostra erros de gravação para ele, isso tem bastante. Não é que eu não leia ou evite ler, se cair na minha frente eu leio, mas não é que eu fique atrás.

Primeiro tem as matérias que você faz e tem as críticas. As críticas só podem vir no bojo do que eu vejo, não dá para fazer antes. Às vezes você faz um entrevista uma matéria e sabe que aquilo vai funcionar. A última matéria minha no Estadão foi o primeiro dia de gravação da novela da Maria Adelaide na Globo, aquela A Lei do Amor. Quando eu vi as gravações era com o Gianechini e a Claúdia Abreu no Ibirapuera, eu falei 'nossa, esse casal não tem liga nenhuma'. Na gravação eu falei. Aí criou-se um preconceito já meu que aquilo não ia dar certo, mas ai eu vi o trailer e falei 'nossa, isso aí não tem nenhum...'; se o trailer - que é uma coisa feita para gerar interesse - não conseguia te trazer... Ah gente o trailer é ruim, tomara que a novela seja melhor, e não era. Então algumas coisas você vai muito no preconceito. A Maria Adelaide também não é uma pessoas que só tenha feito coisas ruins. Você vai fazer uma conversa com Gilberto Braga, que é sempre divertido, você sempre está esperando muita coisa. Então tem os preconceitos. Tem o preconceito da crítica. O preconceito do Walcyr, então você já vai achando que vai ser aquele tatibitate, mas eu sempre me lembro que ele fez Verdades Secretas que foi muito boa, e eu sempre acho que ele consegue - naquela história do beijo gay do Félix - criar, ele é bom de criar um ambiente, em que as coisas menos aceitáveis sejam aceitáveis. Isso é muito interessante, muito hábil da parte dele. Mas eu lamento que para isso ele tropece em diálogos tão ruins, em situações ruins. Agora, aquela história do Félix ela é um mérito na história dele, que sabe criar situações. E Verdades Secretas também é. Ele criou um ambiente no primeiro capítulo, eu fiz esse texto, até baseado na história do Félix. É impressionante como ele cria uma justificativa para a menina se prostituir, que você vai comparar a ideia dela daqui a um capítulo. Porque o pai trai a mãe, a avó tá devendo dinheiro, a mãe está numa situação péssima. Ele cria uma situação para você dizer 'ai, está tudo bem, foi ajudar a família e tal'. Você comprou a ideia daquela menina que é uma coitadinha, no fim das contas ela vai continuar com o cara ele sendo casado com a mãe. Ela entra no jogo dele. É muito boa a história, ele é muito hábil em fazer isso. E lá os diálogos não pareciam tão ruins. Talvez porque é das 11 pode dar uma esparramada. Mas você vê, ele faz às seis horas aquele formato Eta mundo bom, Chocolate com Pimenta, Cravo e a Rosa, é tudo igual. Agora Outro Lado do Paraíso em que tudo é mastigado, vilão muito vilão, tem mocinho muito mocinho, entrega mastigado. Então tem os preconceitos assim. Os jornalistas tem uma coisa de antemão de falar bem de Silvio de Abreu e Gilberto Braga, e falar mal de, por exemplo, deixa eu pegar um autor, Glória Perez que tinha um preconceito também. Mas tinha, porque ela é brega e não sei o quê... E aí a gente que se acha muito fino, né... E tem coisas ótimas dela, e na verdade tem coisas geniais dela. Mas a gente precisa ter cuidado com isso. Com a pré ideia do que pode ser o cara, que pode ser genial e tal, e não é. Sempre eu tenho um policiamento de crítica para isso. Me policio para não ficar ai vendo... Ao mesmo tempo o Carlos Lombardi é ao contrário do Walcyr, tem os melhores diálogos do planeta, mas não consegue levar mais do que 10 capítulos que ele se perde. E ele é genial, os diálogos dele são maravilhosos. Agora passou Bebê a Bordo 
no Viva, que foi cortada infelizmente, mas os diálogos eram muito bons. De vez em quando você fala 'não é possível que isso passou há 20 anos atrás', entendeu, porque era muito evoluído. Aí o que eu acho assim, o espectador presta atenção que os diálogos do Lombardi são melhores que o do Walcyr? Eu acho que não, o telespectador médio não presta atenção, mas eu tenho uma pretensão de querer chamar atenção do leitor para esse detalhe. Agora eu fiz uns videozinhos que estão entrando - agora faz duas semana que eu não faço, era para fazer toda semana eu já não entreguei o da semana passada - mas eu fiz uns videozinhos pro meu canal no Youtube que entram também numa plataforma chamada Clicktube que inaugurou aí há um mês. E eu falo sobre Sessão de Terapia, do Globoplay, a nova temporada com o Selton Mello já como terapeuta, e faço uma comparação com o Bom Sucesso. No fim acabei tirando o Bom Sucesso, porque a Globo me cortou o vídeo, suspendeu o vídeo no Youtube porque tinha imagens do trailer da novela, falei 'então não vou falar de Bom Sucesso, mas no vídeo original eu comentei que Sessão de Terapia treina seu ouvido pro o que é um bom diálogo. E você quando vê uma novela das 9, isso dá um choque assim. Porque você vai começar a treinar o seu ouvido para saber o que é um diálogo bom e quando chegar naquilo você vai perceber que tá faltando alguma coisa ali que é legal para você. E que não precisa ser tão ruim, porque Bom Sucesso tem diálogos bons, tem uma boa história, eles conseguem citar Shakespeare no meio da novela, sem ser panfletário. Isso é genial. E a novela vai bem de audiência, porque tem organicidade, entra naquela menina do subúrbio que é costureira, não entra só no cara todo montado na empáfia é o Fagundes. Nossa completamente orgânica, é muito inteligente, muito bem feito, é bem executado. Então não precisa ser sorvete na testa, né. Aí eu quero chamar atenção do leitor para isso. Eu tenho essa pretensão de chamar atenção para um diálogo. Ainda sabendo que esse não é um problema de novela ou de televisão, as pessoas estão realmente muito mais rasas. Ninguém aguenta um texto de dez linhas no Facebook e já chamam de textão, as pessoas não tem paciência de ler, de ir até o fim, elas leem o título, a legenda. Não é o problema da televisão. Agora o Fagundes outro dia falou que Por Amor - que tá em reprise e está muito bem de audiência - tem algumas cenas de 10 minutos com a Regina Duarte, acho que ele exagerou um pouco, são longuíssimas, era coisa de oito páginas, e as pessoas não mudam de canal. Porque se tiver uma boa história, um bom texto, bons atores, as pessoas não mudam de canal. Tem muito preconceito na produção da novela e na gente também, ter expectativas criadas. Quando ele fez a última novela dele Em Família, ela foi mal de audiência mesmo, foi muito mal. Ela foi um tempo antes de Babilônia, a novela de pior audiência da Globo, mas faltava a história, justamente. Em Por Amor você tem a história, então precisa ter as duas coisas. E as figuras, as personagens são muito boas, muito bem construídas, aquela personagem da Suzana é maravilhosa. Aquela história do menino, do Murilo Benício, do filho que não é filho. São muito fortes as personagens. A própria Gabriella Duarte que foi achincalhada que era uma chata, era uma chata mesmo. A Viviane Pasmanter, a história do trio.

5. Na sua opinião, qual é o papel da crítica de telenovela?

Eu acho que é enxergar algumas coisas que o espectador não viu. Para isso não virar uma conversa de botequim. Porque a gente tem a novela, o futebol e a música, são coisas que todo mundo entende um pouco. A gente tem quantos, sei lá, 100 milhões de técnicos de futebol, 100 milhões de autores de novela, todo mundo entende um pouco. Você vai numa reunião de pauta em jornal, ninguém se mete na pauta de economia, ninguém se 
mete quando o crítico de música erudita começa a falar sobre concerto do Verdi que vai chegar no municipal e que vai ser interpretado por ... Mas quando você entra em novela sempre tem alguém para dar um palpite, você em futebol todo mundo tem palpite, quando entra em música popular também é a mesma coisa. Tem algumas coisas que chamam essa conversa de botequim. São coisas que estão presente na sua vida desde que você se entende por gente. Então todo mundo entende um pouco. Artes plásticas, por exemplo, não está presente na sua vida desde o começo. Ninguém sai falando da exposição que vai ter no Masp do Rembrandt não sei das contas... Mas sabe falar sobre novela. E tem o palpite, porque o cara acha que mocinha está muito chata, ou que o autor podia ter feito diferente, ou a Nina como é que não tinha o pendrive. Essas discussões que vão tomando corpo, tornam a conversa de botequim, o que é muito bom para você atrair leitura, para você ter um público para quem falar, mas te obriga a descobrir, revelar coisas que o leitor não viu, o espectador não viu. Ao mesmo tempo, também não posso ser tão, eu tenho que falar alguma coisa que certamente ele se identifique ou que ele não perceba, sei lá, nessa novela que acabou agora Órfãos da Terra, o Herson Capri era um cara tão péssimo, tão mal o personagem dele, que eu acho que ele era grande força da novela. Quando ele morre dá uma esvaziada. É porque ele dava uma raiva daquele sujeito, a audiência de novela também é uma coisa muito feminina, então a gente está neste momento de falar de bandeira femininas, ele sheik que quer casar com outra enquanto tem uma mulher, uma novinha, dá um asco aquilo, mesmo sendo um homem bonito. Mas dá um asco aquele comportamento dele. Que tem uma carga muito grande, você vai ver a novela pelo ódio que você tem daquele sujeito para poder detonar ele. Acho que isso é uma coisa que você pode trazer paras pessoas prestarem atenção. E quando as pessoas falam 'ah o vilão passou a ter mais valor', não passou a ter, sempre foi. A gente sempre viu mais a malévola do que a princesa, né. Sempre foi mais atraente olhar o lobo mal. Eu acho que alguma coisa que você pode falar para desmentir os diretores, desmentir num bom sentido, o Silvio de Abreu quando fala que a pessoas só querem emoção, não, elas querem também razão. Trazer a luz algumas coisas que não estão sendo vistas. E não como verdade, necessariamente. Propor ao leitor 'será que a gente não está vendo essa novela muito mais pelo vilão do que pelos heróis?'. E o sofrimento daquela família que sai da Síria, o Marco Ricca, aquele sofrimento, aquele contexto, aquele cara desgraçado, aí eles perdem o menino, é doloridíssimo na história. E aí você tem aquele sujeito, aí você 'vou assistir porque quero ver aquele cara se dar muito mal'. Então tem uma força catalisadora muito grande. Eu achei isso sobre Aruanas, que é a série que está no Globoplay, em que as meninas são muito muito militantes, mas o vilão que é o Luís Carlos Vasconcelos, ele tem textos iguaizinhos aos do noticiário. Para não falar no própria presidente, que fala na importância de se explorar o nióbio, os terrenos férteis de minério na Amazônia e não sei que lá. Os texto do Luís Carlos, que a gente não sabe o quê que o cara que tá dando entrevista no Jornal Nacional faz nos bastidores, o texto do LC tá igual aquele, e no entanto, nos bastidores, ele é muito cruel. Acho que a grande força da série que as meninas são muito militantes e panfletárias, o que você só engole e se justifica quando você vê com quem elas estão lidando. Então essas coisas assim que eu acho que são fascinantes de você trazer à tona, dar uma luz e tal. Enfim, é isso. Acho que a função da crítica especializada para fugir um pouco da conversa de botequim, é trazer isso à tona.

6. Quais seriam os requisitos para ser um bom crítico de telenovela? 
Primeiro gostar de novela. Eu acho chato o cara que vai escrever sobre isso para ficar procurando os defeitos. Ao mesmo tempo o crítico não pode ser aquele cara - não que não possa ser aquele cara bonzinho, mas ele tá ali justamente para cobrar, trazer a luz. Ou esses efeitos que o texto produz são as falhas, o quê que tem de errado ali, o quê que tem de nocivo ali, tem coisas que são nocivas, essa é a palavra. Podem trazer uma má influência pro espectador. O Nilson chamou a atenção para algumas coisa que tem nessa novela do Walcyr que poderiam ser umas bandeira incríveis mas da forma como são trabalhadas não são. Então, as vezes existe uma falsa ideia de que ele está promovendo uma aceitação de gêneros quando, na verdade, a maneira como aquilo está sendo trabalhado é muito equivocada. Você não pode ser acrítico de achar tudo lindo, a crítica tem que trazer as coisas que estão erradas e o que te incomodam, mas ao mesmo tempo você tem que ir com uma predisposição de quem gosta daquilo. Uma queixa do pessoal que trabalha em novela durante um bom tempo é que os críticos da Folha são pessoas mal humoradas que não gosta de televisão. Então você punha para falar de televisão pessoas que não gostavam de televisão, e daí por princípio falava mal. Eu discordo disso, mas eu conheço gente que ia com uma pré-disposição muito ruim ver uma novela esperando um filme do Fellini, sabe assim. Não é, a proporção não é essa, a gente tá em outro meio, outro contexto, outro olhar, eu não estou ali para cobrar essa erudição toda. Eu quero justamente um negócio que seja bom e que alcance o público, não adianta ser o café filosófico e chegar no popular.

7. Como é para você a distinção social entre a crítica de teatro e de cinema e a crítica de telenovela? Existe essa distinção? Por que?

Eu estava falando que fazia uma aula de crítica de TV na FAAP e tinha um texto ótimo que eu usava no material que era o Artur da Távola, dos anos 1970 eu acho ainda. Em que ele dizia assim 'o teatro ele tá acabado, o livro está acabado, a obra de arte está acabada, a música está acabada, você faz uma crítica de um produto acabado, a crítica de televisão é sobre um produto em andamento, e você faz uma crítica de uma novela que está no ar, de um programa que está no ar, às vezes até de um telejornal, enfim de alguma coisa que está cena, que não se encerrou ali. Diferentemente de uma crítica sobre uma série do streaming que você já assistiu inteira, que já é uma obra fechada. Ou que ela já está toda pronta mesmo que você não tenha assistido, você não interfere naquilo. Mas a crítica da televisão linear você acaba tendo alguma interferência. Eu acho um pouco pretensioso isso, por que eu acho que eles não mudam o processo de produção em função da crítica, ainda mais hoje que eles tem muita ferramenta de pesquisa. Eles não precisam de mim para mexer na novela. Antigamente, ainda presente tem aquela história do grupo de discussão, que eu acho bem discutível, acho que não dá certo aquilo, mas enfim estão há anos fazendo. E hoje eles na Globo principalmente tem um recurso de login com as pessoas, não sei se você já leu sobre isso, eles já falaram algumas vezes; quando você se loga para assistir Globoplay ou ler o Globo, ou uma revista, qualquer coisa que você leia dela é um ID só. Eles mapeiam o comportamento dessas pessoas, eles tem tipo 30 milhões de pessoas mapeadas já. Será que eu estou viajando? E algoritmo, o que esse cara está assistindo, o que ele costuma ver no Globoplay, onde ele procura a Globo, pelo computador eles podem saber isso. O cara que só ver a televisão linear, por exemplo ele não sabe; por exemplo a minha mãe, eles não sabem o que ela está vendo, ela vê televisão pela net, que não passa informação para Globo. A Net tem essas informações e não passa para os canais, pode passar lá no Now o que é mais vistos o que não é, isso eles ficam 
sabendo, mas no linear é uma informação que não chega pros canais. E informação é pode, como você sabe. Então isso fica para eles. Então eles precisam menos disso hoje. Mas de alguma forma a crítica pode não alterar o rumo do programa, mas pode alterar o comportamento do apresentador, pode chamar atenção pro roteirista sobre determinada coisas. Por exemplo, o Maurício citou recentemente, 'poxa a maria da Paz demorou não sei quantos anos para lembrar que tinha duas sobrinhas', eu tenho certeza que isso bate no ouvido do autor. Eu tenho certeza que bate na orelha deles e eles falam 'putz é mesmo, precisamos disfarçar tal coisa'. Nesse sentido, eu acho que ela tem uma interferência. E não é a crítica, é uma avaliação de reação sobre a novela, não é nem se é bom ou se é ruim, uma bola fora, né. Então, nesse contexto ela tem uma interferência e ela é, ao mesmo tempo, muito subjetiva e muito mais frágil, porque ela trata de um produto em andamento. Então, ela é quase uma pesquisa eleitoral, ela vale para aquele momento. Daqui há dois meses o capítulo que você elogiou no começo da novel, pode não valer pro final, normalmente não vale. Daqui a pouco começa um programa novo que está todo mundo de olho, vai assistir, vai fazer uma crítica de um negócio que certamente não está formatado, eles vão jogar um negócio no ar, se jogam já vão jogar para eles mesmos; porque eles vão jogar um monte de coisa no ar para ver o que pega. Então, existe uma fragilidade nesse sentido na crítica de teatro, na crítica de um livro, em que você analisa uma obra acabada. Pro próprio crítico é mais confortável falar disso. E o cinema também, o filme. É engraçado falar disso porque você vê essa reação de Bacurau, ela foi um pouco controversa, né. Teve gente dizendo que 'não, putz, mas o filme é violento, os caras querem tratar de pacificação falando de violência'. Ai quando começou a encher salas de cinema as pessoas começaram a elogiar, acho que o crítico começa a se arrepender e falar 'será que eu não enxerguei o que havia ali?'. Acho que pode pintar isso sabe. Agora no caso da gente que escreve de TV, de repente você fala 'putz, eu elogiei tanto essa novela no começo e ela virou isso', com a internet você tem a chance de voltar ali e falar: 'me enganei, entendeu'. E todo muito fez isso com Órfão da Terra, eu não acompanhei ela exatamente com esse rigor, mas as autoras falaram muito essa necessidade que você ter que escrever cento e tantos capítulos, para uma história que era par ser das 11, era para ter menos de cem capítulos. Então, teve um enxerto ali que elas não souberam lidar. Agora só pelo tema que elas levantaram, de refugiados, eu acho extremamente corajoso, super válido. É frágil pros dois lados, para quem escreve e para quem está fazendo, todo mundo está sujeito a mudar de ideia, dos dois lados.

8. Quais são os aspectos de sua crítica que, na sua opinião, mais tendem a provocar debate pelo público?

Acho que de comportamento mesmo. As emissoras tem chamado muito atenção para isso [as viradas], para dar um re-fôlego, que no meio de uma produção de cento e tantos capítulos chega no capítulo 100 eles promovem umas coisas, avisam a imprensa, e causam um barulho para um negócio, como se tivesse um renascimento na novela, muitos deles adoram usar texto que é assim 'é uma outra novela agora'. Eu acho que são episódios assim, tipo beijo gay, que é uma coisa que sempre dá um bafafar, ou um não beijo. As pessoas que se acarinham o tempo todo e não trocam beijam. Como tinha em Segundo Sol, tinhas as meninas, a Nanda Costa e, esqueci o nome da menina, é uma atriz nova, mas aquilo incomodava muito, era uma relação aparentemente bem resolvida e não trocavam um beijo. A questão de gênero tem chamado muito atenção, como se a gente já tivesse muito calejado de falar quem é bom e quem é mal, quem é ético e quem 
não é ético, então isso não chama mais atenção. O que chama a atenção é a exposição, a materialização ou não de uma relação gay. Teve um tempo que chamava muito atenção cenas de nus, se vai transar ou não vai, acho que a gente superou um pouco isso. Acho que faz parte daquele período pós censura, em que as pessoas estavam experimentando um pouco de tudo. Então, a TV Pirata experimentava piadas politicamente incorretas, as novelas experimentavam cenas de sexo. Isso tudo foi se enxugando depois que a gente foi aprendendo o devido lugar de cada coisa. Mas basicamente isso, acho que a questão do humor, nudez, a questão de gênero, tudo que mexe com isso chama sempre atenção.

9. Como obra aberta, a telenovela permite que você a acompanhe enquanto está sendo feita. Como essa característica molda a sua crítica?

Mas as pessoas estão esperando uma crítica sempre de primeiro capítulo. Acho que tem essa cobrança. E você pode fazer a crítica do capítulo fazendo essa ressalva 'olha, esse é só o primeiro capitulo', como vai ser hoje esse programa, Éramos seis e o programa da tarde, esse Se Joga que vai ter a tarde, que é um programa que é para combater lá a audiência da Record, que ele entra no lugar do Video Show vamos dizer. Esse programa vai ter crítica e ele é tipo a Fátima Bernardes quando nasceu, demorou uns dois anos para aceitar. A mulher saiu de 15 anos na bancada do Jornal Nacional, para precisar sambar juntos com os convidados, não é fácil, né. Então é um negócio que demora para aceitar. Verdade, vou passar o dia assistindo Tv hoje, tem Éramos seis, as pessoas estão esperando uma crítica, ainda mais que é um remake do remake do remake. Acho que é a quinta, teve um inicial que não era diário ainda. A novela não era diária, bem nos anos 50. Daí tem uma versão na Tupi, uma na Record, e uma no SBT, acho que é isso quarta ou quinta versão. Essa daqui é baseado na do SBT, que é um texto do Silvio de Abreu mesmo. Mas as pessoas estão esperando sim uma coisa para primeiro capítulo. Você pode fazer uma ressalva que é primeiro capítulo e não só aquilo pode mudar, mas aquilo tem um cuidado especial de primeiro capítulo O mesmo cuidado que a Record ou a Globo ou o SBT tem com o primeiro capítulo, isso é uma coisa primordial para todos eles, para atrair o telespectador, você tem que ter para olhar aquilo e falar sobre aquilo. É o primeiro capítulo, preciso te contar uma nova história agora. Acho que precisa ser dito que tem uma produção caprichada por ser primeiro capítulo, tem uma coisa precipitada da nossa parte de falar se é bom ou não porque aquilo é só um capítulo de mais de 100, e no mais é você avaliar se o autor foi competente em apresentar os personagens e as tramas daquela história.

10. É de praxe que a primeira crítica acerca de uma telenovela seja logo após ao capítulo de estreia. Quais os parâmetros que você usa para analisar uma obra que está começando?

Mas do que se o texto é bom, se o ator é incrível e tal. Se bem que o Herson Capri me pegou no primeiro capítulo já. E eu falei disso no texto, que era uma coisa muito excepcional, ou se for uma coisa muito fora da casinha você diz 'olha, fulano não se encontrou ainda, tomara que no capítulo seguinte ele tenha alguma noção de quem ele é'. Porque é isso assim, avaliar se as pessoas estão orgânicas, se existe organicidade, se existe organização na síntese de um primeiro capítulo para apresentar aquilo. Isso quem me ensinou isso foi o Negrão, o Walter Negrão, que é um cara muito bom no feijão com arroz, não é um cara de fazer invencionices, é um cara que faz um ótimo feijão com arroz. Primeiro capítulo não é hora de malabarismos, eu tenho que apresentar x personagens, 
quem odeia quem, quem tá afim de quem, quem é pai é mãe, uma arvorezinha genealógica. Mas de uma maneira orgânica, não aquela coisa jogral. É isso que a gente leva em conta. Qual é o fôlego de sedução daquele primeiro capítulo para quem vai ver depois. É uma história que conseguiu me puxar pro segundo capítulo, para uma novela isso é essencial. É isso que tá em jogo ali, ela vai me chamar pro segundo capítulo ou não? Eu tive vontade de ver o segundo capítulo? É meio isso. Eu falei por exemplo de Velho Chico, que eu adorava Velho Chico, ninguém gostava. Os críticos gostavam, mas os meus colegas mais rasos achavam uma chatice, 'era muito lenta'. Na verdade, a novela não é lenta, todos os dias acontece uma coisa e você não está percebendo, todos os dias tinha uma história, só que ela não tinha gancho no final, então eu até comentei depois, comentei até com o Silvio de Abreu, eu assisti a novela porque eu realmente gostei, mas ela não tinha gancho no final, eles não chamavam para o outro dia, ela não terminava com uma cena de suspense. E aí ele tinha uma crítica ao Luís Fernando Carvalho, que resolveu se meter a escrever ou criar a novela, e que o Luís não era autor, era diretor. A filha saiu, lá pro capítulo 30 foi embora, diz que brigou com o diretor, que queria impor as coisas. Parece que era sobrinho dela, também achei que fosse filho e não é, ele é filho da irmã dela. Então é neto, mas não era filho da Edmara, e o menino escrevia muito sobre encomenda dele, do Luís. Isso foi o Silvio que disse não sei se é. Mas o que ele acha que o Luís podia ter feito, quê que foi o Rei do Gado, ele falou 'o Rei do Gado não é uma - ótima novela, é uma ótima novela - então o Luis dirigiu a Edmara também estava escrevendo, porque que não deixou na mão dela? Mas é que na época do Rei do Gado estava o Benedito escrevendo. É que o Benedito sempre estava meio estragado, chegava no meio da novela ele já estava podre. É que o Benedito bebe um pouco, sabe, daí no meio da novela ele sempre tinha uns problemas. Começa dar tilt no organismo, trabalha para cacete e tal, naqueles expedientes longos, ele não tinha colaborador, que era só com filha aquelas coisas. É ele nunca teve colaborador, só que ele botou a filha para escrever com ele. Acho que Pedacinho de Chão já era assim já. Mas assim, enfim, não tinha gancho. Mas era uma novela onde tinha algumas coisas que não eram tão orgânicas, mas tinha frases geniais, todos os capítulos você anotava alguma coisa. E algumas coisas eram muito orgânicas e as touras ficavam meio panfletárias, algumas coisas agressivas de cenas de sexo, que você falava 'ui 9 da noite'

11. Em sua opinião, o que difere a crítica de telenovela da crítica de programas televisivos como realities, ou de auditório?

$O$ reality eu não faço muito crítica. Quando tem esses formatos muito prontos, tipo BBB, A Fazenda, Master Chef eu avalio sempre o elenco, a cada temporada o que muda? Muda o elenco mesmo. A Globo pode fazer dez mil cenários de BBB, mas a história é: toda semana tem um eliminado, um cara vai pro paredão, até ganhar um vencedor. É um formato, né. Então, o que eu sempre levei em conta foi elenco. O que fascina para mim do reality é essa história de o cara ter a capacidade de fazer um elenco que tenhas diferenças. $O B B B 5$, acho que é a maior audiência da Globo, é o do Jean Wyllis que tinha o médico homofóbico, que tinha a Grazi Massafera. Então, era um elenco formidável, porque tinha divergência, tinha gente com o pensamento diferente. Quando você bota um monte de cara lá que não tem nada para fazer em casa, pode até ser advogado, pode até ter uma formação, não precisa ser um I Wanna be Famous, mas 
quando o cara só está ali quando ele quer ser famoso só, é tudo muito igual. Quando você coloca alguém com uma idade mais avançada sempre vira meio chacota, vira o diferente da história nesse sentido. Enfim, a Casa dos Artistas, no SBT, a primeira edição é maravilhosa, Supla com Alexandre Frota, Bárbara Paz. Mas o Frota ali que era uma coisa que a gente não conhecia daquela forma, que cada vez ele é uma surpresa. Mas era impensável juntar o Frota como o Supla, era muito legal, isso que produzia o programa. E que depois nada mais deu certo, é a coisa do elenco. A coisa do BBB 5 é a coisa do elenco. Não tem outro segredo, assim. O Master chef da Band, agora a Globo vai fazer um, eu já vi os chefs eles não têm um pingo de carisma. O Troisgros, que é o apresentador ele é divertidíssimo, o Batista, que é o assistente dele, eles são uma dupla ótima. Mas o trio de jurados, empatia zero. Aí na Band o que que dá certo, são os três chefs, uma apresentadora que sabe conduzir, que dizem que ela é inútil, ela não é, ela costura todas as respostas ali, muito boa. E, você vai ver na Discovery Home and Health, o reality do Master chef é chato para caramba. O do Brasil é maravilhoso. Então não é o formato, é o elenco. Então é muito restrito a isso o reality para mim. Aí á faz um diferença toda para novela. O Boni diz que como o texto dos realities é muito ruim ele prefere assistir um texto de um autor profissional, ele prefere ver novela a ver reality. Porque esses caras nunca tem o que dizer, o texto deles é péssimo. Não tem roteiro, é um programa sem script, como diz aquela categoria de Emmy 'Shows non scrypted', que são os realities, vamos dizer. Mas já é bem diferente. O que existe ai é aquela dificuldade, a gente falou naquele debate de roteiristas. A gente cresceu fazendo muita novela e as minisséries e os seriados eram todos com linguagem de novelas, chegou um momento em que eu mais era conhecedora de novela que de séries internacionais, comecei a ouvir as pessoas reclamarem disso, quem assistia muita série lá fora. Olha as séries feitas no Brasil, são todas uma versão de novela, elas não tem um texto de série. E comecei a me dedicar, tentar entender o que é um texto de série. E quando você começa a ver as coisas de fora você vê uma diferença, e onde tá essa diferença, no diálogo. Basicamente no diálogo, que a gente chama atenção, que a gente descambou aqui. O João Emanuel quando fez a Regra do Jogo, que disse que as pessoas compreenderam mal, e eu acho uma novela muito boa, cada episódio tinha um nome, não sei se você lembra disso. Era como se fosse uma série mesmo. Ele é um autor que está mais ligado, que vem do cinema, que não vem do rádio. Que está mais ligado na coisa do diálogo. Essa sutileza, está por exemplo na Sessão de Terapia, quando você vê já é bem diferente. Ali talvez não conte porque é muito tête a tête o diálogo, então tem que estar muito centrado mesmo no texto. Então você vai olhar e vai falar, isso não é uma novela isso é realmente uma série. Quando você pega, por exemplo, Onde Nascem os Fortes, que o Jorge Moura fez, é uma novela com menos capítulos, com uma densidade enorme em sua essência da história. É uma minissérie que é uma obra fechada. Mas uma série mesmo, como Sob Pressão, por exemplo, não é uma mini novela é uma série. Você percebe no tratamento dos diálogos, no elenco enxuto, ela tem um sequência, que eles namoram, ela engravida, não sei o quê, perde o bebê, aí se separa, tem uma sequência; mas se você assistir a um episódio você não se perde, você tem uma história contada ali.

12. A telenovela das $21 \mathrm{~h}$ da Globo, é uma das produções mais comentadas na sociedade brasileira. Por isso, a seu ver, a crítica das ficções desse horário, exige mais responsabilidade? 
Exige, exige porque é mais caro, você está ali tratando do produto que abastece praticamente a emissora, ainda que você tenha intervalos caros nas seis e nas sete, ou intervalo das nove - na verdade o intervalo mais caro é o do jornal, que é considerado um público mais qualificado. O intervalo do Jornal Nacional é o intervalo mais caro que a novela das nove. Mas jornal Nacional sem a novela das nove vai mal, o próprio diretor de jornalismo fala isso 'a gente está mal agora porque pegamos um periodo ruim de novelas'. Ele está ensanduichado, ele depende das novelas das 7 e das 9. E mesmo a das nove as pessoas ligam para esperar, ou mudam de canal para esperar a novela quando ela tem uma alta expectativa, então influencia bastante. A tensão é maior com a novela das nove em razão disso. Mas hoje que a gente tem o streaming, a gente devia prestar a atenção mais atenção na novela das seis e das sete, realmente. É um erro. A Globo adora dizer que dá a mesma atenção paras três, não é verdade, tem um gasto maior com a novela das nove. Porque efetivamente vai haver um público maior ali, o anúncio custa mais caro, vai ter um número maio de colaboradores, vai ter uma atenção maior com isso. Tudo isso! Se você não tem um projeto muito especial como é o caso agora de Éramos Seis para reservar a Glória Pires, normalmente ela vai estar na novela das nove. Ou como vai ter essa novela do Imperador que tem o Selton Mello, que não faz novela há muito tempo, que está reservado para ele esse papel. Mas fora isso, os medalhões estão todos reservados para a novela das nove.

13. Como crítico, o que diferencia a crítica de telenovela da crítica de séries norteamericanas?

Então tem pouca gente que eu acho que se mistura, que consegue assistir as duas coisas, eu acho isso primeiro assim. O público de série é mais exigente, eu acho que é. E porque que a gente está falando disso também, porque é um público menor, então ele é mais segmentado, por força até do formato. A novela alcança mais gente, a novela é mais para a massa mesmo. E quando você faz uma série, ela já é exibida num horário um pouco mais tarde, só a questão física dela, ou ela está num streaming que é pago, esse espaço que a série ocupa já é um posição que coloca ela numa condição mais segmentada, e, portanto para um público mais exigente. No sentido de que ele escolhe a série que ele vai ver, a novela um pouco assalta quem está no sofá. É uma hora que você fala assim: 'ah eu não tenho nada para fazer, vou ver novela', ou então 'eu não quero pensar em nada', ou eu já vi gente assim: 'a novela é tão ruim que eu adoro ver, porque eu quero não pensar em nada; não quero novela engajada para pensar em coisa nenhum eu quero só sentar e quero tudo mastigado'. Tem isso! Tem esse público que não quer pensar em nada. Então, ele é um pouco assaltado neste sentido. A novela entra muito por inércia, a série é um negócio que o cara vai muito buscar. Ele pode mudar de canal, ele pode desligar, ele pode procurar um filme, ele pode dormir, ele escolheu ver a série. Então, ela é mais escolhida do que escolhe. Eu acho que neste sentido tem um público mais exigente, que está a fim de consumir alguma informação, alguma qualidade, não é tão passivo de conformista como é o público da novela. A gente está falando da média geral, não é que todo mundo veja novela com esse olhar.

14. Poderia citar os seus top ten das ficções brasileiras de todos os tempos?

Meu top tem de novela? A gente já fez essa matéria no Estadão algumas vezes. A gente fez uma vez, quando a novela fez quarenta anos, conversou com vários autores e cada um fez uma lista e eu concordei muito com o que tinha lá, mas assim uma novela que eu 
não vi, olha só, não vi mas eu preciso citar, que ela é um divisor de águas é Beto Rockfeller, porque é onde você começa, todos eles falam isso, quando você começa a ver o anti-herói, a primeira novela com anti-herói que éo Beto Rockfeller, e que você começa a enxergar muito mais um identidade brasileira do que a aquela coisa cubana da Glória Magadan. Então, tem o Beto Rockfeller que eu acho que é extremamente importante, $O$ Bem-Amado, que também traz uma capacidade de crítica que o jornalismo não tinha na época, não tinha condição, o que você tinha na censura você não tinha no Bem Amado, então isso além de ser genial, a novela está posicionada localizada numa época que ela mais incrível ainda. E é uma coisa de microcosmo de Brasil, talvez o primeiro que tenha feito, o coronelismo. Ah e a gente podia citar Irmãos Coragem, que também é uma novela que representa a ascensão da Globo, de hegemonia, de atenção com trilha sonora com a abertura, com tudo isso. Eu gosto muito de O Rei do Gado. Aí eu vou citar aqui já sem cronologia, eu gosto muito de O Rei do Gado, Roque Santeiro... Eu tenho mais de 10 na verdade. É claro que vou citar Avenida Brasil. Adoro Renascer, adoro Renascer, adoro muito. E, eu tenho que citar Pantanal, pelo o que ela representou, menos pela obra e mais pelo o que ela representa depois, porque Renascer só existe por causa de Pantanal. Tem que falar de Guerra dos Sexos que também representa a chegada a consolidação dessa coisa pastelão das sete horas, que é um remake que não deu certo, né? Ai o Silvio um dia me encontrou e falou assim: ' você não gostou da novela? Eu falei: ' eu achei meio datada, tudo o que a gente conversou de ela não ser datada ela ficou datada'; ele falou: 'é, eu percebi que você não falava muito'. Aí que tinha uma coisa, meio que um pudor de falar da nova, por que era uma boa obra, no tempo em que ela foi vista, ela estava fora de contexto. Aí os meninos [filhos de Cristina]tinham, a Manu tinha ... não sei, preciso ver qual foi o ano em que ela foi feita, estava a Manu e um amigo em casaela tá com 17 agora - e ai estava a televisão ligada e aí o menino falou assim: 'o quê que é isso?', dai eu falei 'é uma novela que foi feita nos anos 80 e eles estão refazendo agora, chama Guerra dos Sexos'; e ele falou: 'e quem ganhou?', ai eu falei 'ih', ai eu falei: 'não, na verdade essa coisa de homem disputando com mulher, né, de ter razão, não ter razão'. Ele fez assim para mim, não faz sentido para ele, nenhum. Ficou muito datada mesmo. Eles eram pré adolescentes, era bem interessante isso. Olha como às vezes a gente sai da caixinha, quando você fica ali muito no crítico e tal, aí você pega uma criança fala um negócio desse, ih acho que estava meio datado. Mas a primeira Guerra dos Sexos, então, tá, só para a gente dizer que ela tem uma função. E Vale Tudo claro, como é que eu vou deixar Vale Tudo de fora. Vale Tudo é demais! Mas aí eu citaria também Dancin' Days, sabia? Não sei se pode ter 11, mas é que Dancin' Days é o começo desse tipo de produção. Se você ver Dancin Days no DVD ela é extremamente acelerada, sabia? É dinâmica, né. As outras tudo meio calma, olha não citei uma Janete Clair aí, hein. Ah não, citei Irmãos Coragem. Citei um Dias Gomes, uma Janete Clair, dois Dias Gomes, que é Roque Santeiro. Não citei nenhum Aguinaldo Silvia puro aí. Acho que a novela que eu mais gosto do Aguinaldo é Pedra sobre Pedra, mas pela aquela galeria de personagens, sabe. Jorge Tadeu, Pilar Batista, a história da flor, a história do Osmar Parado que vira lua e que vai embora, tem umas coisas muito legais. Total, é bem realismo fantástico e bem resolvido assim, é bem legal. Mas ela não tá... só citei ela aí porque Roque Santeiro é mais do Aguinaldo que do Dias. Ela é a história do Dias, mas a novela em si que seguiu como um grande sucesso é uma obra do Aguinaldo, então considero que ele esteja presente.

15. Poderia fazer uma análise resumida de como vê a crítica de telenovela no Brasil (pelo menos a que conhece)?

Ah eu acho tão triste a crítica de televisão em geral no Brasil, sabe, acho muito triste. Porque desde que comecei a fazer isso 30 anos atrás, eu tenho que explicar sempre que 
eu faço crítica de televisão e não fofoca. Quando você fala assim, eu escrevo sobre televisão, as pessoas falam assim: 'tipo a Sônia Abrão? Tipo a revista Contigo?'. Revista Contigo tinha muita coisa de novela, mas depois virou meio Revista Caras. Não existe pela crítica de televisão um respeito que existe pela crítica de cinema, entendeu? Quando você fala eu escrevo sobre cinema ninguém fica perguntando se você está interessado na vida dos protagonistas, se faz fofoca do Brad Pitt? Ou mesmo dos ícone nacionais que são praticamente os mesmo da TV. Mas assim, existe uma compreensão imediata de que crítica de cinema é sobre conteúdo e sobre televisão não existe essa concepção, não existe assim. 'Ah ela faz fofoca', entendeu? Isso me entristece bastante e em 30 anos isso não mudou, isso só piorou com a internet, porque existe hoje uma necessidade gigantesca de caçar cliques e o conteúdo em si dá menos audiência do que as fofocas né, evidentemente. Pessoais de quem ficou com quem, quem se separou, quem teve filho... Na disputa entre conteúdo e esse universo de celebridades particular, o que conteúdo perde muito feio, apesar de ter... Desperta interesse? Desperta, é menor, né. Isso me entristece bastante. Acho que é ruim. E a gente não tem tipo um crítico de New York Times aqui, que consegue realmente, pelo o que a gente sabe, afetar e mexer com a televisão. Se tivesse 10 Maurício Stycer seria muito melhor que ter 10 Tv o foco, sabe? Que é um site podre que fica aí fazendo títulos que não correspondem as matérias e chupinhando todo mundo, enfim... Mas não tem. Tem assim... o Stycer ele é um cara depois de anos, assim, eu me coloco nessa questão, o Daniel Castro, o próprio Feltrin, a gente passou o tempo todo fazendo as duas coisas, indo na entrevista e depois fazendo a crítica, entendeu. O Maurício é muito mais crítico do que repórter, ele até tem feito algumas coisas, mas eu acho essencial que um veículo como o UOL banque uma cara para falar para fazer crítica mesmo, e nesse sentido ele é um achado, acho que devia ter 10 dele se fosse bom, mas não existe esse espaço, não existe esse investimento para isso. É uma pena.

16. Para que serve a crítica de telenovela?

Para nada! Acabei com a sua tese. Não serve para nada, só serve para abastecer o ego e a irritação dos profissionais de Tv. Não, eu acho que, primeiro ela tem... As televisão trabalharam durante muito tempo, principalmente a Globo, com a ideia de que a crítica de TV, de novela principalmente, ela mais te ajuda a vender jornal que ajuda a ter audiência, não é como se ela se colocasse numa posição superior a você, sabe? Isso acabou há muito tempo, tem pelo menos duas décadas que a Globo e as outras emissoras já faziam isso, mas a Globo tinha uma certa empáfia, né. A Globo achava sempre que a gente estava correndo atrás deles, e é verdade. É por exemplo assim, a Manchete quando fez, eu comecei a cobrir TV acho que eles estavam fazendo Pantanal, levou um time de jornalista pro Pantanal. Eu fui para Manaus pela Manchete, que eles fizeram uma novela chamada Amazônia. Então, eles tinham uma preocupação, uma necessidade de mostrar o que eles estavam fazendo para abrir espaço nos jornais para eles que eram menores. O SBT sempre fazia ótimos almoços e jantares e não sei o quê lá para lançar novela, agora não mais. Agora só pão de queijo lá na Anhanguera. Mas assim o Nilton Travesso outra vez, quando fez Éramos Seis no SBT, fez Pupilas, tinha sempre uns almoços incríveis no The Place que era um restaurante que eles adoravam lá na Haddock Lobo. E não era uma ostentação era uma necessidade, era tipo assim, a gente precisa de uma isca para chamar esses caras aqui e eles verem o que eles não vão ver espontaneamente. A Globo não, a Globo tinha uma posição de 'ah essas pessoas vão vir atrás da gente, deixa vir, entendeu'. E iam mesmo, sempre foram. Sempre fomos, tenho que dizer isso. 
Eu me lembro quando foi Explode Coração, tem o que quê, vai dar uns 30 anos, é de 92, eu me lembro da Globo fazer um pequeno coquetelzinho aqui em São Paulo e chamar o elenco principal, era um espaço bem pequeno ali na Alameda Santos, no prédio comercial deles, meia dúzia de jornalistas, meia dúzia de atores, o autor e o diretor. Aí a gente começou a ter acesso mais livre ao staff para fazer matérias. E a partir daquilo o negócio começou a crescer e hoje eles fazem um lançamento por semana, leva jornalista pro Rio e não sei o quê lá. Quer dizer, eu acho que não é que eles tenham se dado conta de que eles precisavam da crítica, mas que era melhor eles apresentarem pelas mãos deles as coisas invés de deixar todo mundo correndo atrás do primeiro ator que vai falar e não fala direito. É mais para ter um controle do que vai sair. E, então quando eles fazem as festas lá no Rio fica sempre um assessor cercando os jornalistas mais ferinos, tomando conta da gente. É sério, é sério. Então, isso mudou, essa relação mudou completamente, mas também tem sido muito cortês na medida em que eles oferecem uma passagem, hospedagem, um prato de comida, né entendeu. Não deixa você desesperado. Em compensação, por exemplo, eu cobri o Mapa da mina em São Paulo, gravação; eu ia para porta do hotel onde eles ficavam, eu seguia os carros da Globo, e eu ficava esperando uma chance de fazer a entrevista que eu queria fazer, e isso tornava a coisa muito mais democrática. Eu corria atrás da informação e eu tinha a informação que eu ia buscar. Hoje não. Hoje eu dependo da Globo autorizar a minha entrada no set, entendeu. Eu não chego no set se não estiver autorizado, não existe mais isso. Eu cheguei a pegar uma época que eu me aproximava da Malu Mader e se ela quisesse falar ela falava comigo e pronto. Hoje não, hoje a Globo tem que dar o aval. Tem que fazer uma entrevista com o Fábio Assunção, eles tentaram barrar de todas as formas e ele acabou falando com o Globo. Falei com ele inclusive diretamente que estava a mercê à espera do que a emissora fosse determinar e acabou sendo pro Globo essa entrevista porque era muito delicada, falava da questão pessoal dele numa série que fala de dependência, tudo bem entendeu mas é isso que vai acontecer. Em outros tempo eu teria feito essa matéria. Aí voltando a sua pergunta, para quê que serve a crítica? A pesar desse comportamento que eu não vejo tão benevolente da Globo de mudança de quem se deixava correr atrás, agora controlar a situação, a gente tem alguma interferência do que as pessoas vão ver e como vão ver. Eles tem uma preocupação de como a televisão vai ser lida, por exemplo assim, a televisão - tem uma frase ótima do Gabriel Priolli, que assim a TV cultura, que é uma TV que se faz pesquisa e é a coisa mais admirada em SP, ela não dá nem um ponto de audiência na maior parte do dia, no entanto os paulistanos tem um orgulho danado da TV Cultura, a TV Cultura é uma emissora mais lida do que vista, a gente publica muita coisa da TV Cultura que não é vista, mas que as pessoas tem orgulho daquilo. Tanto que agora alguns problemas muito relevantes tem uma audiência incrível no Youtube, o Roda Viva dependendo do entrevistado ele bomba no Youtube. A do Temer não tá tanto, mas do Glenn Greenwald bombou super no Youtube, do Bolsonaro acho que tem dois milhões de acessos, porque é uma das poucas entrevistas para eleitorais que foi feita. Qual que era outra, a do Frota esse ano foi bem também. A do Glenn esse ano acho que é a maior, espera quem que foi depois do Gleen? teve uma outra... Peraí, teve o Temer, teve o Gleen, semana passada teve uma outra, não teve? Acho que não foi o Temer semana passada. O Temer faz quinze dias já. Bom, enfim... E a Globo, às vezes, pode estar nesta posição mesmo sendo muito vista. Então, eles não querem estar mal na televisão lida, que aquilo pode chamar alguma coisa. Além disso, essa coisa de rede social também, tornou qualquer palavrinha que é dita sobre um programa uma coisa que pode viralizar, que se 
retuita dez mil vezes, entendeu. Então, tem um alcance hoje muito maior que antes, eu acho. Tanto que eles estão fazendo uma divisão, tem uma turma que vai paras coletivas que é chamado pelas assessoria de imprensa e tem uma turma que é chamada por mídia social, mas o Nilson [Xavier] estava na turma das mídias sociais e ele ficava num hotel melhor que o nosso. Porque eles tem uma preocupação de como aquilo vai ecoar, entendeu. Então, eu acho que hoje, duas coisas: uma que eles não tem mais a hegemonia que eles já tiveram, embora eles estejam muito na frente, então eles precisam um pouco disso. E outra que isso viraliza com uma potencial muito maior do que antes, que era muito o jornal impresso, eles não chamavam lá o cara que ia fazer fofoca na televisão, eles chamavam o jornal impresso. Tinha uma meia dúzia que ia muito bem, agora tem,é diminuiu o número de veículos, mas sites e blogs aos montes. O SBT faz coletiva e enche um auditório, eu falo: 'gente onde vocês arrumaram essas pessoas todas. Eu falei: é figuração, não é possível. Aí começa a aparecer: 'ah eu sou do portal... ', não tem portal nenhum, é blog, né. Eu falei assim: 'eu vou começar a chamar o meu de portal', na verdade é um blog no wordpress, mas é que ele tem uma carinha que não é aquele negócio corrido, ele tem uma carinha de site. Mas as pessoas chegam falando em portal, e aparece de tudo, de tudo. Mas é isso assim, acho que tem essa função sim; apesar da gente querer fundamentar este trabalho com preceitos mais antigos, mais clássicos do crítico como ele foi conhecido no jornal impresso mesmo. Não sei se eu posso falar jornal impresso, pode ser. O Rubens Ewald que falava em televisão é um crítico, crítico mesmo. Mas ele tem um preceito mais clássico de ter elementos, ter subsídios, tem informação para a crítica e tudo mais. Essa preocupação atual existe muito por esse nível raso da viralização da internet. Eu acho que é isso.

Quanto à saída do Estadão

Eu sai do Estadão em agosto de 2016 e em outubro eu fundei o blog. Já lancei o blog em outubro de 2016. Você quer ver uma coisa, quando o Domingos Montagner morreu em setembro já, em 2016, é 15 de setembro eu não lembro... Na data do Domingos Montagner eu dei meu primeiro furo no blog, já é anterior a outubro. E as pessoas ficaram malucas porque já falaram: 'nossa, olha ela saiu do estadão e ela já está dando furo porque ela é boa para cacete e tal'. Acho que o Luís Fernando nem sabia que eu tinha saído e acabou falando comigo, ou sabia mas tinha uma confiança porque a gente tinha... Mas ali teve uma sorte por que eu procurei o cara por e-mail, por que eu tenho o celular dele e ele me respondeu meia hora depois. Era a solução da novela, ele morreu na sexta e no sábado de manhã eu troquei o e-mail com o Luís, e ele falou assim: 'eu vou fazer uma câmera que as pessoas olham para ele, as pessoas vão se dirigir a câmera e tal'. E eu fiz esse texto, super bombou. Ai Globo inconformada que ele falou comigo antes, por que ele era um desobediente, fez um texto e distribuiu uma hora depois. Mas estava no meu, assim, primeiro. E é incrível isso como as pessoas olham para aquilo e falam assim: 'não, olha, hoje o poder está nas mãos do jornalista', não dura, na verdade. Não dura isso assim. Você tem um episódio aqui, outro ali e outro lá, mas isso não traz anunciante essa é que é a realidade. Sabe assim, aí dá cliques, dá clique. Aí eu tinha um servidor muito pequeno também e ele começou a cair o site. Por que no começo né, você vai ter um servidor para um milhão de pessoas, não vai, né... A Folha entrou um ano depois. Aí é exatamente isso, em setembro de 2017 entrou a Folha. Tem até no meu Instagram tem a data da entrada na Folha tem uma matéria que saiu e não entrou 
naquele dia. Tinha que entrar mais não entrou, a gente estava com vários problemas de, justamente de servidor, eles não estavam conseguindo tornar compativel. Que mais, aí eu entrei na Folha. Site entrou na Folha em 2017, está lá até agora. Em novembro do ano passado [2018], vai fazer um ano agora, eu entrei no Agora São Paulo para fazer uma coluna de celebs e TV que é Olá e Zapping, o zapping a parte de TV. Eu fundei o Zapping na Folha da tarde em 1992, a primeira assinatura do zapping foi minha. O jornal caiu, o jornal mudou de nome, mas o zapping continua lá com uma proposta bem diferente. Não até eu consigo dar umas puxadas lá, mas eu lembro que eles enchiam menos o meu saco naquele tempo, por que acho que não tinha internet. Então, eu tinha um pouco mais de liberdade para escrever algumas coisas, agora não, 'ah isso é muito elitista e não sei o quê', as vezes tem umas encheções, mas eu passo por cima, finjo que não entendi e está tudo bem. Por que é aquele negócio, isso é uma função do crítico também, se você está vendo que o cara só oferece rabanada na televisão, eu acho que você pode dizer assim: 'que tal, você já experimentou mostrar um concerto no Domingão do Faustão, invés do É o Tchan, pode ter resultado'. E normalmente tem né. Se você souber fazer, você vai lá e bota o Chitãozinho e Xororó com o João Carlos Martins que seja vai, que é um cara popular. O meu amigo crítico de música erudita ia odiar eu falar isso, que ele detesta João Carlos. Mas assim bota os caras mais populares com um orquestra de Las Bachianas, porra formidável, entendeu. Bota a orquestra para tocar Evidências em seguida você toca Bach, entendeu. Funciona assim, né. Mas é, oferece outra coisa, né. Aí quando fica essa coisa na coluna, aí é muito elitista. Um dia tinha uma foto da Madeleine Perrot no Metrópoles, ele achou muito elitista. Ela estava no Serginho Groisman no fiml de semana. Ele não sabe quem é, o meu chefe é inferior ao leitor, na verdade. 'Se sair da redação ninguém sabe quem é', sabe! Falei: 'a menina que tá em cima que dança funk com a Anitta ninguém sabe quem é, e a gente tá dando uma foto gigante dela, por que ela estava de shortinho. Então a gente dá a Madeleine em baixo, é uma maneira de apresentar a Madeleine para quem não conhece, é ótimo, né. Então na Folha da Tarde eu fiz o Zapping em 1992 e fiquei nesse negócio do Ferreira Neto até 1992. Aí eles saíram com o Ferreira Neto da Folha da Tarde, que eles mudaram totalmente o jornal, e ficaram comigo. Foi uma traição mesmo, foi péssima, eu me senti num papel meio ruim na época. Mas, o Flávio Ricco que era o meu chefe na verdade que era o sócio do Ferreira Neto, falou: 'a gente sabe perfeitamente que as coisas funcionam assim ele ia sair de qualquer jeito, então vai ser feliz e tal'. São meus parceiros até hoje, assim adoro. Então foi isso, eu trabalhei todo esse tempo de 1989 a 1992 com o Flávio Ricco, na verdade era com o Flávio Ricco, o Ferreira é só o nome lá do jornalista famoso que também já morreu, depois fui fazer Folha da Tarde. Trabalhei no Jornal da Tarde que foi a melhor equipe que eu peguei de variedades, que eu amava muito e fiquei uma não e meio no JT. Acho que foi um dos períodos mais felizes da vida, assim. Fazia uma coluna de TV mesmo, na época que tinha o Zic como crítico de teatro, o Janine fazia cinema, o Lauro Lisboa música, uma turma assim, impensável. Tá cada um para um lado hoje que o Zic morreu. Aí eu fui para Folha de São Paulo, fiz coluna entre 1997 e 1999, no Outro Canal que não existe mais, que era de informação de TV também. Depois passei um ano em revista de celebridade que era Chics e Famosos e depois fui para o Estadão, fiquei 16 anos. Aí no Estadão fiz o suplemento de TV primeiro, depois fiz, editei suplemento infantil junto com o de TV durante uns 8 anos. Aí em 2010, acho, que eu assumi minha coluna do Caderno Dois. A gente ficou quase dez anos fazendo aquela coluna como uma seção meio perdida no Caderno Dois. A Keila Gimenez assumiu para 
fazer a Coluna mesmo ainda estava editando o Caderno de TV. Em algum momento a Keila foi para a Folha, logo que ela começou a assinar o nome na mão dela lá, ela foi para Folha. E aí eu fiquei com a coluna por que o negócio do Caderno podia não durar e não durou mesmo e acabaram o caderno. Então eu acabei ficando no Estadão, mas na verdade podia ter saído em 2011. Acabei ficando mais cinco anos por causa da coluna, que o caderno de TV acabou e aí eles dispensaram todo mundo, ficou só eu que estava fechando a coluna. E agora hoje é pife aquela cobertura de TV infelizmente, com todo respeito as minhas colegas que estão lá, elas não podem fazer tudo, entendeu. Não dá conta, né. Faz de qualquer jeito. Nesse tempo depois em 2017, eu estava na Folha, não eu estava no blog que foi para Folha, em abril de 2017 eu entrei no programa do Ronnie Von para fazer televisão, para falar de TV, e era conteúdo não era fofoca. E daí esse programa acabou há dois meses. Infelizmente. Adorava. Era uma possibilidade de falar da TV na TV, sabe, por que era a Gazeta. Então, todo mundo falava assim: 'ah mas ele vai para outra emissora e você vai junto", primeiro eu não sei se eu vou junto e segundo que não é a mesma coisa, entendeu. Ele tá em casa agora, estava estudando propostas sei lá do quê. Mas se for assim Rede TV ou Bandeirantes não dá para ficar falando de novela da Globo, entendeu. Aí você tem que entrar no campo da fofoca e eu não sou muito boa nisso mesmo. Então foi um tempo feliz ali de Gazeta, muito feliz. É isso. 